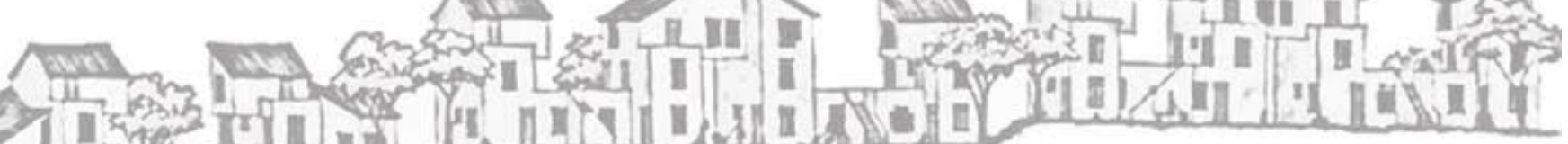

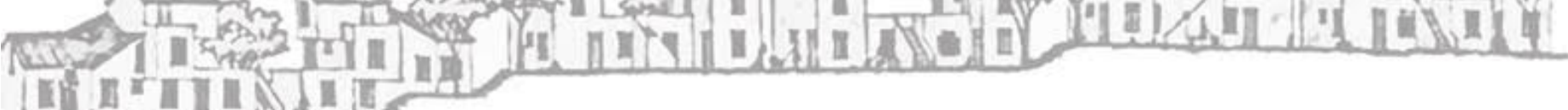

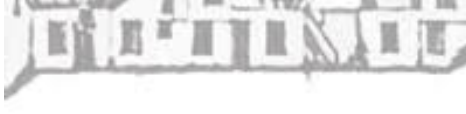

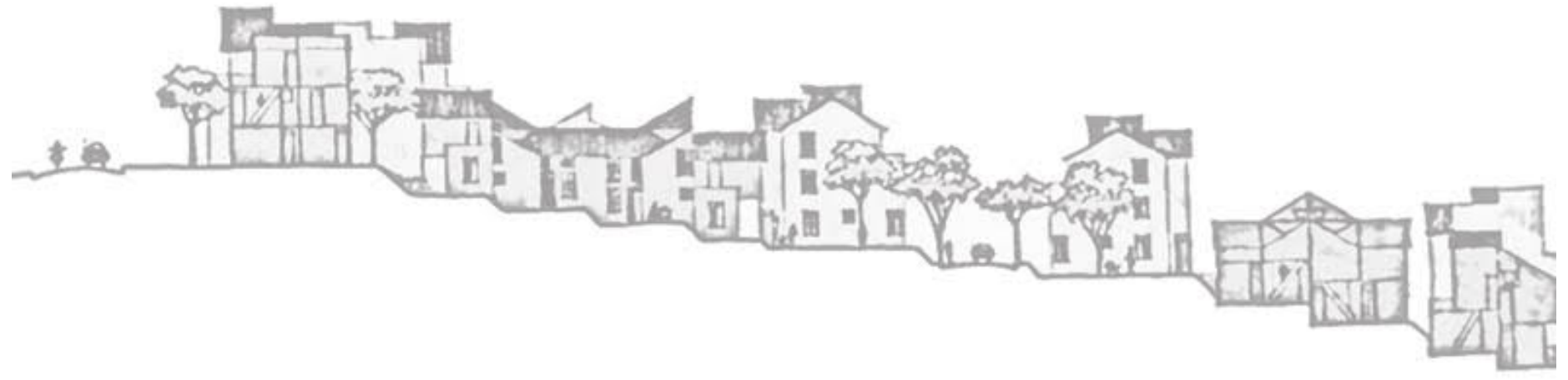

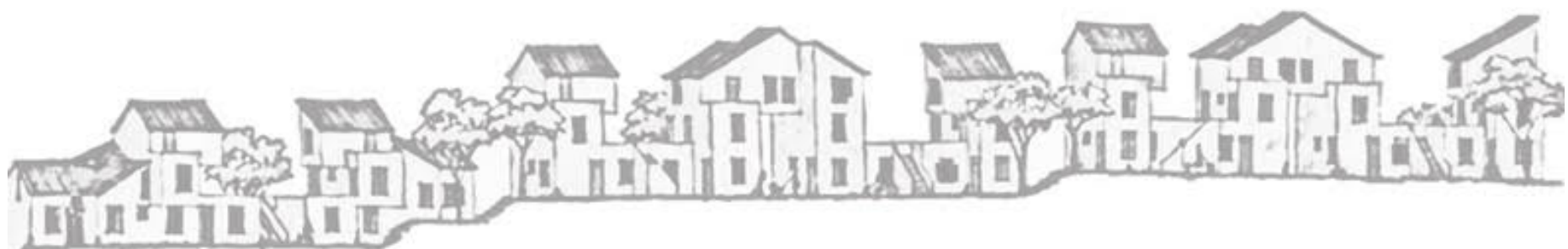

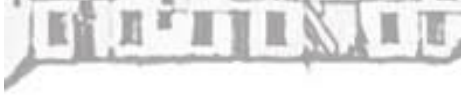

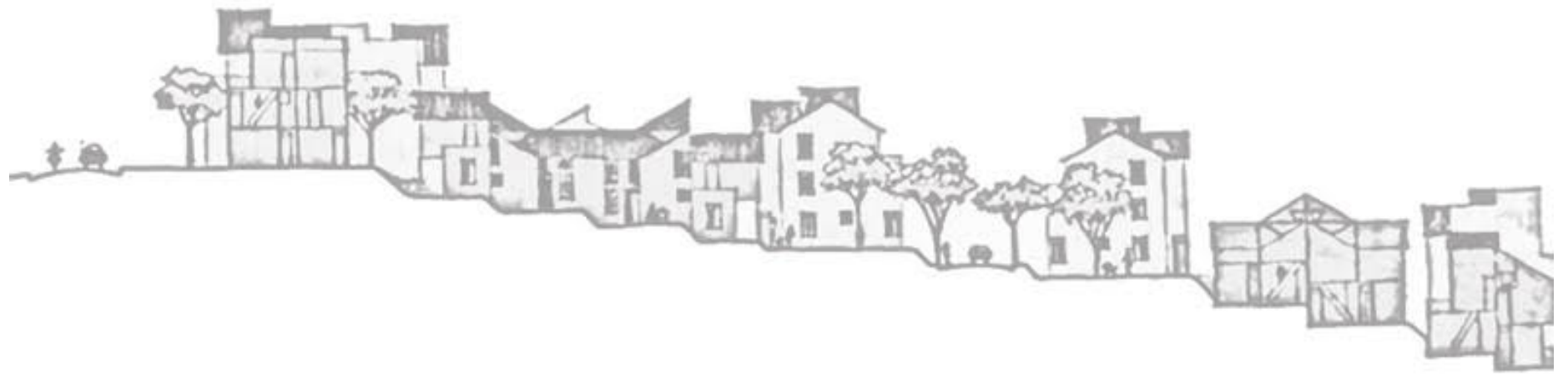

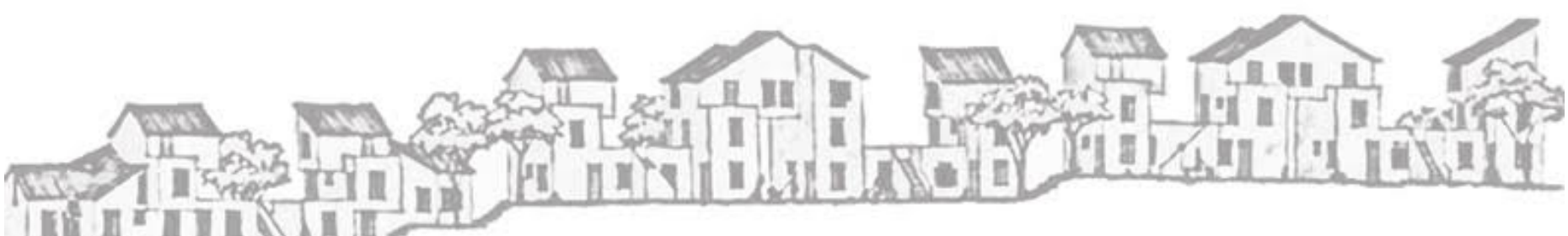

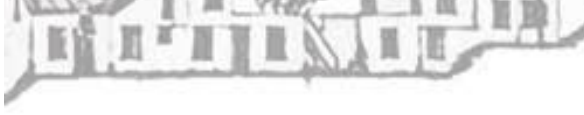

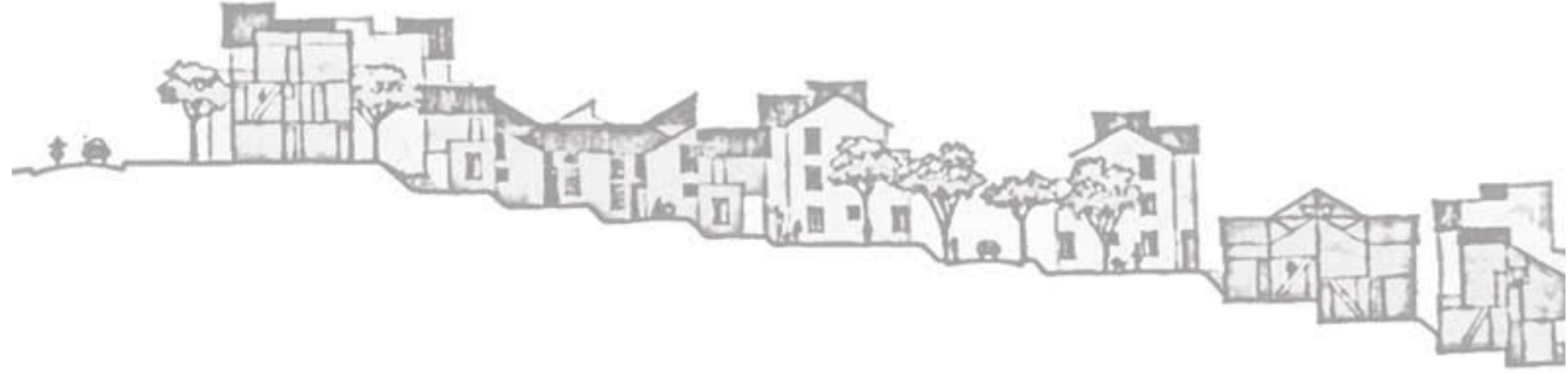




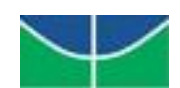

UNIVERSIDADE DE BRASÍLIA

INSTITUTO DE CIÊNCIAS HUMANAS

DEPARTAMENTO DE GEOGRAFIA

PROGRAMA DE PÓS-GRADUAÇÃO EM GEOGRAFIA

\title{
HabitaÇÃo de INTERESSE SOCIAL E GOVERNANÇA URBANa： DESAFIOS, RESISTÊNCIAS E POTENCIALIDADES NA ÁREA METROPOLITANA DE BRASÍLIA
}

\author{
KARLA Christina BATISTA DE FRANÇA \\ MATRÍCULA: 11/0153626
}

Tese apresentada ao Programa de Pós-Graduação em Geografia da Universidade de Brasília - UnB -, como parte dos requisitos para a obtenção do título de Doutora.

Professora Orientadora: Dra. Marilia Luiza Peluso

Eixo Temático: Expansão Territorial da Área Metropolitana de Brasília - RIDE - Brasil Central

Brasília, DF

Setembro-2015 


\section{UNIVERSIDADE DE BRASÍLIA \\ INSTITUTO DE CIÊNCIAS HUMANAS \\ DEPARTAMENTO DE GEOGRAFIA \\ PROGRAMA DE PÓS-GRADUAÇÃO EM GEOGRAFIA}

\section{HABITAÇÃO DE INTERESSE SOCIAL E GOVERNANÇA URBANA： DESAFIOS, RESISTÊNCIAS E POTENCIALIDADES NA ÁREA METROPOLITANA DE BRASÍLIA}

Karla Christina Batista de FranÇA

BRASÍlia, 28 SETEMBRO DE 2015.

\section{Banca examinadora}

Profa. Dra. Marilia Luiza Peluso - Orientadora

Universidade de Brasília - UnB / Departamento de Geografia - GEA

Prof. Dr. Edson Leite Ribeiro

DICT - Secretaria Nacional da Habitação - Ministério das Cidades

Prof. Dr. Fernando Luiz Araújo Sobrinho

Universidade de Brasília - UnB / Departamento de Geografia - GEA

Prof. Dr. Bernardo Alves Furtado

Dirur - Instituto de Pesquisa Econômica Aplicada (Ipea)

Prof. Dra. Rosana Denaldi

Programa de Pós-Graduação em Planejamento e Gestão do Território - UFABC

Profa. Dra. Susan Eghrari - Suplente

Centro UNIUBE/Faculdade de Arquitetura

Brasília,DF 


\section{Ficha Catalográfica}

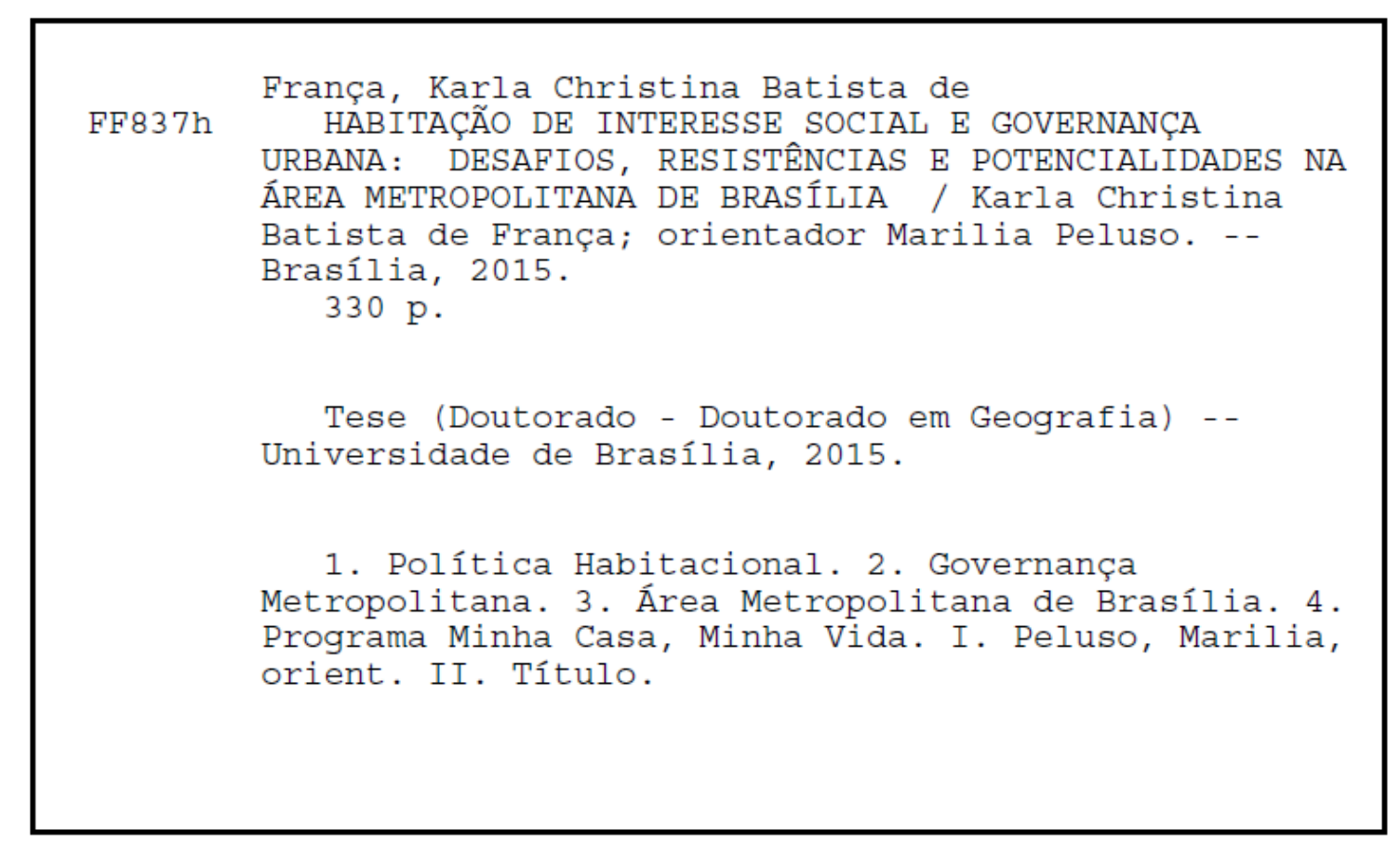


No segundo semestre do ano de 2011 ingressei na primeira turma de Doutorado do Programa de Pós-Graduação em Geografia da Universidade de Brasília. A proposta de projeto apresentada durante a seleção tinha como objetivo central analisar os aspectos epistemológicos do conceito de território. Na etapa de entrevista durante a realização do processo seletivo, fui alertada pelo professor Rafael Sanzio para a necessidade de fazer um recorte empírico para a pesquisa, o que também ao longo da realização das disciplinas do doutorado se repetiu, em especial, nos questionamentos da professora Lucia Cony, uma das responsáveis pela disciplina Metodologia da Ciência em Geografia. Hoje, deixolhes aqui expressos meus agradecimentos, pelo importante questionamento e pelas sugestões.

A definição do recorte e da escolha da função pública de interesse comum, a ser analisada, era recorrente nos diversos espaços de diálogo. Isso ocorria durante a realização das disciplinas, na participação de eventos como congressos nacionais e internacionais, debates realizados no grupo de pesquisas do Laboratório de Análises Territoriais (Later/GEA/UnB) e com a orientadora Marília Peluso, além das conversas sobre governança metropolitana com a então desconhecida Susan Eghrari, hoje minha amiga. Foi a pesquisa de doutoramento da Susan que me atraiu para o tema da governança metropolitana e foi a partir dos aspectos de governança metropolitana que meus objetivos e questionamentos ficaram mais claros, possibilitando encontrar meu recorte espacial e integrá-lo à discussão do território sob a ótica da política habitacional.

A aproximação com a temática de governança metropolitana e da política habitacional teve importantes desdobramentos para a pesquisa de doutoramento e para a minha profissão. No aspecto profissional, foi-me possível apresentar propostas de emendas, estudos e atuação no Congresso Nacional e nos órgãos federais, os quais têm possibilitado o aperfeiçoamento tanto da Lei Federal 13.089/2015 (Estatuto da Metrópole) em vigência quanto do Programa Minha Casa, Minha Vida (PMCMV).

Na trajetória de construção desta tese, contei com a contribuição de inúmeras pessoas, seja nas conversas formais e informais, seja por meio do seu carinho e abraços.

No que diz respeito aos espaços profissionais por onde passei durante a jornada do doutoramento, meus agradecimentos aos técnicos de pesquisa e planejamento e aos bolsistas na DIRUR/Ipea; nos ciclos de reuniões nas esferas dos governos federais, estadual e municipais no meu trabalho na Confederação Nacional de Municípios (CNM), 
aos meus até então professores e depois colegas de profissão, em minhas atividades como professora no Departamento de Geografia na UnB. Destaco as conversas inquietantes com os meus alunos dos cursos de geografia, antropologia, arquitetura e urbanismo e sociologia, durante as aulas de planejamento urbano, geografia humana, geografia rural e geografia econômica, entre outras.

Acerca do período de realização das disciplinas de doutoramento e no dia a dia no PPGEA/UnB, meus agradecimentos especiais aos meus colegas de mestrado ou doutorado: Luis Requião, Marcus Fábio, pelo apoio, carinho e ajuda com os mapas, ao Gilberto Oliveira, pelo apoio, à Ângela Zanelato (Ça va?) e Silvia Leite, pelo apoio e carinho, à Marizangela Bortolo, pelo apoio incondicional e pelo ombro amigo em todas as etapas desta pesquisa, ao Marcelo Miller e aos --professores Neio Campos, pelo carinho de sempre, os almoços e as conversas divertidas, à Lucia Cony, pelas sugestões na qualificação e conversas (lembro-me sempre do seu questionamento: "Karla, você precisa explicar por que a habitação é uma função pública comum”), ao Dante Reis, pelo profundo conhecimento em epistemologia, à Marli Sales, pelo carinho, viagens, almoços, cinemas e as aulas de epistemologia, à Ercilia e ao Valdir, pelas conversas, diversão, apoio, à Nelba Penna, pelo carinho (minha admiração pela sua precisão metodológica), ao Everaldo Costa, pelas conversas sobre teoria urbana, pela oportunidade de dividir uma disciplina contigo, pelo apoio e carinho, à Roselir e à Ruth, pelo apoio e carinho, ao Fernando Sobrinho, pela leveza no trato com a burocracia da UnB, pela simplicidade, sugestões na qualificação, carinho e apoio.

Estendo meus agradecimentos também aos secretários e à equipe de apoio administrativo do PPGEA, Agnelo, Jorge e Simoni, e ao secretariado da GEA/EAD, em especial à Demise e à Elisangela.

Durante minhas atividades profissionais na DIRUR/Ipea pude aprofundar o debate sobre as questões de governança metropolitana e conhecer um outro viés de se trabalhar com planejamento e avaliação de políticas públicas. Meus agradecimentos ao Bernardo Furtado, pelo apoio, conversas, carinho, sugestões, ao Cleandro Krause pelas sugestões, ao Rafael Henrique (Rafa), pelo carinho, conversas e apoio, ao Renato Balbim, pela construção das proposições e argumentações a partir da Geografia, ao Vicente Correia e à Vanessa Nadalin. Aos colegas da sala 320, pelas conversas sempre divertidas, em especial, a Monique Sacardo.

Agradeço pelo apoio e carinho, nas atividades desenvolvidas no projeto governança metropolitana na Codeplan/DF, à Cárita Sampaio e à Giuliana Corrêa. Em especial, à 
Cárita, pela grande ajuda pelo envio de material, contato com os gestores municipais goianos.

Agradeço aos gestores, prefeitos, técnicos pelas entrevistas concedidas. Na SNH, no Ministério das Cidades, às técnicas Izabel Cordeiro, Endyra Russo, Marcia Ishikawa. Na SNAPU, ao Yuri Giustina, pelo comprometimento em realizar a entrevista pouco antes de suas férias. E também a todos os representantes do Conselho Nacional das Cidades, que muito me ajudaram nos debates e lutas pelo direito à moradia e muito me ensinaram sobre as estratégias de lutas cotidianas que jamais os bancos de uma universidade ou as atividades de campo são capazes de compreender.

Ao professor Edson Leite, no Ministério das Cidades, que não mediu esforços para me ajudar em todos os procedimentos que envolveram o contato para as entrevistas e dados relativos ao Programa Minha Casa, Minha Vida na esfera do Ministério das Cidades, além das sugestões durante o processo de qualificação. Na SUDECO/MI, agradeço ao Sérgio Magno Carvalho, pela entrevista e compartilhamento de material. Na CODHAB/DF, à Mara Rosa.

Também deixo aqui meus agradecimentos ao Mauro Ribeiro, pelo apoio, esclarecimentos, paciência em tirar minhas dúvidas sobre o Programa Morar Bem.

Ao professor João Mendes, pelo apoio e ajuda em realizar os contatos com as entrevistas na Sudeco.

Ainda expresso meus agradecimentos pelo apoio e torcida de tantas pessoas na CNM, que no dia a dia, de distintas formas, me apoiaram e entenderam meus momentos de ausências, em especial, agradeço ao Jeconias Rosendo e à Elena Garrido, que, apesar da pouca convivência, foram fundamentais para que eu conhecesse a luta nacional do Movimento Municipalista.

Ao Gustavo Cezário, Edu Stranz e Ignacio, pelo apoio institucional nas capacitações realizadas no exterior e liberação nas atividades de trabalho e o carinho; à Luciane Pacheco (Lu), pela empolgação a cada etapa do doutorado concluída; à Rosângela Silva (Rô ou Mafalda), pelo carinho e apoio, e pelas divertidas andanças comigo pelo Recife; à Tatiane de Jesus e à Vanessa Resende, pelo carinho. E não poderia deixar de agradecer aos membros da minha equipe do Desenvolvimento Territorial, Lauro, Osni, Luma, Claudia, Priscila e Johnny, que tornam divertido o dia a dia do trabalho.

Agradeço à Lorena Guerra, por transformar os dias tensos em que a página do Pages ou do Word ficavam em branco em noites agradáveis e divertidas pela leveza, graciosidade 
e diversão nas aulas de ballet. Ao Fábio, Amanda e Gabriela pelas aulas de Pilates. Agradeço a todos pela paciência nos meus dias de péssimo humor .... e foram muitos.

Aos meus familiares e amigos

Agradeço aos meus amigos de Anápolis, Goiânia, Brasília, São Paulo, Rio de Janeiro, Lisboa e Milão, por compreenderem minhas ausências em momentos importantes de suas vidas.

Agradeço também aos que não mediram esforços em me ajudar com materiais, organização dos gráficos, conversas. Meus agradecimentos especiais à Elaine Lobo, pelo apoio e carinho, à Andrea Princivalli, pela empolgação e torcida, à amiga e professora Regina Maniçoba, pelo apoio e conversas divertidas.

Agradeço aos membros da banca de qualificação, Fernando Sobrinho, Regina Maniçoba e Edson Leite, pelas sugestões durante a definição dos objetivos e metodologia. As sugestões foram fundamentais na construção e finalização da tese. Também deixo aqui registrados meus agradecimentos aos membros da banca de defesa.

Agradeço pela confiança, apoio, puxões de orelha, paciência, carinho da professoraorientadora, Marilia Peluso, minha parceira na trajetória de todos os momentos, desde o dia que resolvi me mudar para Brasília e iniciar o mestrado. Lá se vão nove anos de parceria e de UnB, que, do ponto de vista institucional, na relação aluno-professor, finaliza com a defesa da tese. Mas outras parcerias irão surgir.

Aos meus pais, Maria José e Ivanildo, pelo apoio e amor incondicional, em todos os momentos. Minha eterna gratidão e amor. Vocês são o melhor presente que Deus poderia ter me dado.

Ao meu irmão, Eduardo, sempre pronto a me ajudar e com quem poderei contar para sempre. A vida me abençoou, mandando-lhe para cá antes, para me receber, me ensinar e ser meu melhor amigo.

Aos meus familiares, pelo apoio, almoços, carinhos e compreensão pela ausência no dia a dia familiar. Em especial, ao meu tio Idam, à minha tia Magda, meus/minhas primos(as) Gessika e Diego.

A Deus, pelo eterno aprendizado. 
RESUMO

Habitação de Interesse Social e Governança Urbana: desafios, resistências e potencialidades na Área Metropolitana de Brasília

Esta tese tem por objetivo analisar as assimetrias da política de habitação, em especial da política de habitação de interesse social no nível metropolitano, considerando os seguintes aspectos: a trajetória da política habitacional brasileira e os limites para os arranjos de cooperação metropolitana. Outro aspecto considerado foi a priorização de financiamento habitacional do Programa Minha Casa, Minha Vida (PMCMV), direcionado para os municípios inclusos em regiões metropolitanas e na Ride-DF sem considerar ou incentivar a promoção de estratégias para o enfrentamento do problemas habitacional de forma cooperada. Também se levou em consideração o frágil respaldo dos regramentos nacionais para a promoção da cooperação em territórios metropolitanos e o inconcluso pacto Federativo.

O recorte espacial considerado na investigação limitou-se à Área Metropolitana de Brasília (AMB). Este recorte espacial se revelou um desafio, uma vez que o recorte da AMB não existe institucionalmente, e portanto não tem respaldo na legislação nacional que trata da matéria sobre as regiões metropolitanas. Os procedimentos metodológicos utilizados foram: a) elaboração do banco de dados acerca do volume e das modalidades dos empreendimentos do programa na Área Metropolitana de Brasília, o que permitiu a confecção de mapas inéditos do volume de contratação de unidades habitacionais na Área Metropolitana de Brasília (AMB), vinculadas às faixas de renda, fontes de financiamento, e o cruzamento com o atendimento do déficit habitacional; b) pesquisa bibliográfica e documental das ações de planejamento e ordenamento executadas pelos governos locais e o Distrito Federal e sua interface com as questões metropolitanas; c) a realização de entrevistas com os gestores públicos nas esferas federal, estadual, distrital e municipal, o que foi fundamental para identificar os limites e as potencialidades de arranjos inovadores no território, considerando as diretrizes estabelecidas para a gestão local da política urbana de habitação nos planos de habitação, planos diretores, legislação urbanística e seu nível de incorporação na alocação e hierarquização dos investimentos habitacionais, resultando em importantes modificações na produção do território metropolitano. As entrevistas também possibilitaram identificar em graus diferenciados a necessidade de ações cooperadas ou os impactos da dinâmica metropolitana gerados pela execução de ações habitacionais de outro município na gestão local.

A tese procurou evidenciar a relevância do planejar, executar e gerir estratégias que envolvem as questões habitacionais de forma concertada nos aglomerados metropolitanos. As ações de planejar, executar e gerir a política habitacional se revelaram desafiantes do ponto de vista das materializações de ações, compromissos e corresponsabilidades para a pactuação de Agenda Metropolitana, em anuência aos investimentos estaduais, federais e municipais.

Palavras-chave: Solidariedade Territorial, Política Habitacional, Área Metropolitana de Brasília/Ride-DF 


\section{RÉSUMÉ Logement d'intérêt social et Gouvernance urbaine: défis, résistances et potentialités dans L’Aire Métropolitaine de Brasília}

Cette thèse a pour objetictif d'analyser les asymétries de la politique de logement, en particulier de la politique de logement d'intérêt social au niveau métropolitain, considérant les aspects suivants: la trajectoire de la politique habitationnelle brésilienne et les limites pour les arrangements de coopération métropolitaine. Un autre aspect considéré a été la priorité de financement du logement du Programme Ma Maison, Ma Vie (Minha Casa, Minha Vida - PMCMV), orienté vers les municipalités comprises dans les régions métropolitaines et dans la Ride-DF sans considérer ou encourager la promotion de stratégies pour faire face aux problèmes habitationnels d'une manière coopérative. En outre, il a pris en compte le soutien fragil des réglementations nationales pour la promotion de la coopération dans les territoires métropolitains et le pacte Fédératif inachevé.

La coupure spatiale considérée dans la recherche s'est limitée à L'Aire Métropolitaine de Brasília (Área Metropolitana de Brasília - AMB). Cette coupure spatiale s'est révélée un défi, une fois que la coupure de l'AMB n'existe pas institutionnellement, et donc n'a pas de fondement dans la législation nationale qui traite de la question sur les aires métropolitaines.

Les procédures méthodologiques utilisées ont été: a) élaboration d'une banque de données sur l'ampleur et les modalités des projets du programme dans l'Aire Métropolitaine de Brasília, ce qui a permis la confection de cartes inédites du volume d'embauche d'unités habitationnelles dans l'Aire Métropolitaine de Brasília (AMB), liées aux niveaux de revenus, sources de financement, et le croisement avec la prise en charge du déficit habitationnel; b) recherche bibliographique et documentaire des actions de planification et d'ordres exécutés par les gouvernements locaux et le District Fédéral et son interface avec les questions métropolitaines; c) la réalisation d'entrevues avec les fonctionnaires publics au niveau fédéral, de l'état, du district et de la municipalité, ce qui a été fondamental pour identifier les limites et les potentialités des arrangements novateurs dans le territoire, considérant les directrices établies pour la gestion locale de la politique urbaine du logement, dans les plans du logement, plans directeurs, législation urbaine et son niveau d'intégration dans la destination et l'hierarchie des investissements habitationnels, ce qui entraîne des modifications importantes dans la production du territoire métropolitain. Les entrevues ont également possibilité d'identifier dans des divers degrés la nécessité d'actions coopérées ou les impacts de la dynamique métropolitaine générés par la mise en œuvre d'actions en matière de logement d'une autre municipalité dans la gestion locale.

La thèse a cherché à mettre en évidence l'importance de planifier, exécuter et générer des stratégies qui impliquent des questions de logement de manière concertée dans les agglomérations métropolitaines. Les actions de planifier, exécuter et générer la politique de logement se sont révélées de manière défiante du point de vue des matérialisations d'actions, engagements et coresponsabilités pour le pacte de l'Agenda Métropolitain, en accord avec les investissements des états, fédéraux et municipaux.

Mots-clés: Solidarité Territoriale, Politique du Logement, l' Aire Métropolitaine de Brasília / Ride-DF 


\section{Sumário}

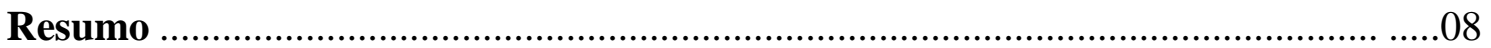

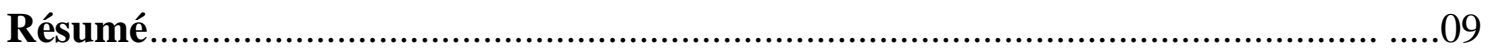

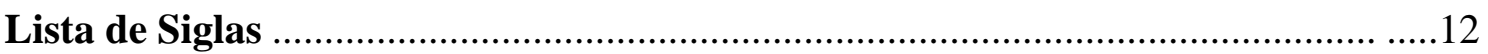

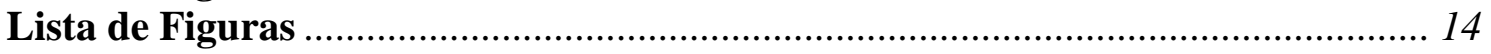

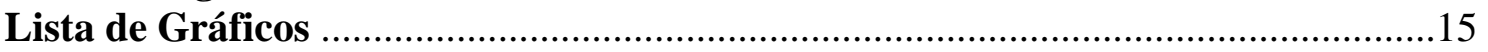

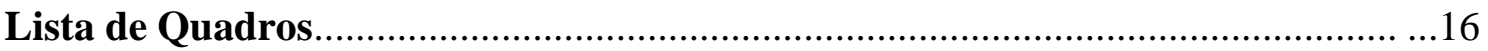

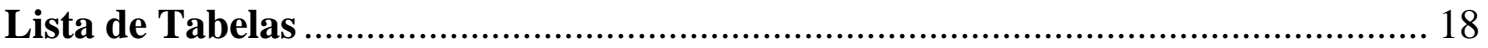

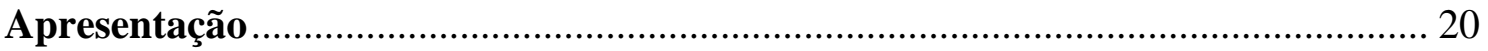

Introdução: Aproximações para a compreensão da habitação como uma questão

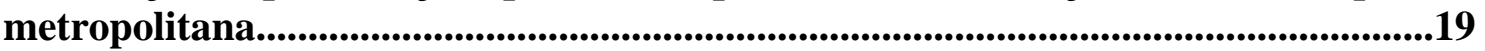

Parte A: Problematização: a habitação como uma função pública de interesse

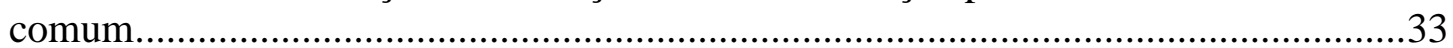

Parte B: O recorte espacial: a Área Metropolitana de Brasília (AMB) .......................42

Parte C: Procedimentos metodológicos ..............................................................47

Capítulo 1 As interfaces entre política habitacional e o território............................54

1.1 Território, metropolização e habitação ..........................................................55

1.2 Evolução, limites e desafios dos arranjos institucionais das Regiões

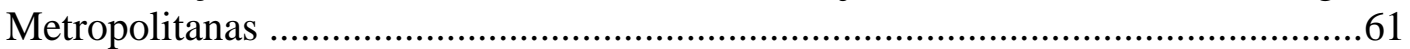

1.3 Dos Institutos de Aposentadorias e Pensões (IAPs) à Fundação da Casa

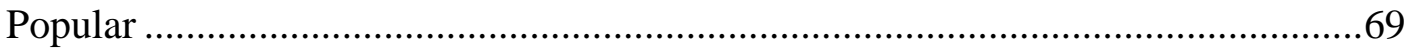

1.3.1 Novos rumos da política habitacional: da criação do Banco Nacional de

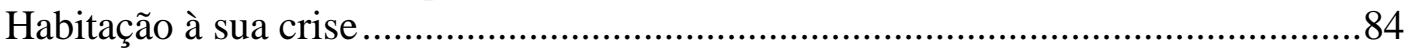
1.3.2 Políticas habitacionais: governo Collor (1990-1992) ao governo Fernando

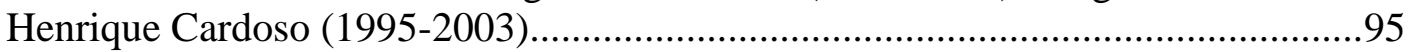
1.3.3 Políticas habitacionais: governo Lula (2003-2010) ao governo de Dilma Rousseff (2011-2014): continuidades e rupturas ................................................ 108

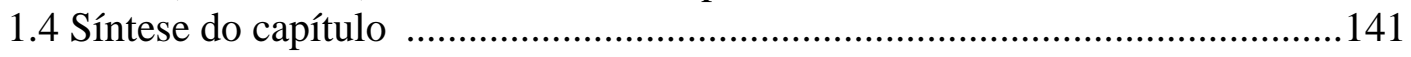

Capítulo 2 Os limites da política habitacional no Distrito Federal ......................145

2.1 Brasília: planejamento e produção do espaço urbano ......................................146

2.1.1 Primeira fase: a construção da capital Brasília (1956-1970) .........................147

2.1.2 Segunda fase: as práticas de gestão e planejamento urbano-regional e as políticas habitacionais 1970-1979 ...................................................................151

2.1.3 Terceira fase: Não tinha teto, Não tinha Nada: de uma política de não oferta habitacional para uma política clientelista: 1980-1995 ......................................158

2.1.4 Política habitacional populista versus planos de ordenamento do território.167

2.2 Investimentos habitacionais e novas configurações metropolitanas - período

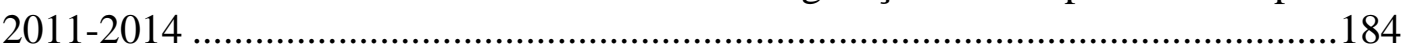

2.2.1 A produção da moradia social para o atendimento das famílias de baixa

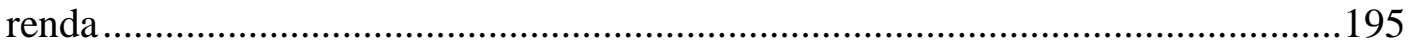

2.2.2 O papel protagonista do setor privado na produção de moradias: o Programa

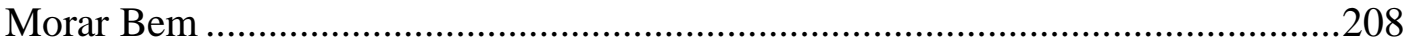

Capítulo 3 A (des)concertação da política habitacional na Área Metropolitana de 
3.1 Caracterização socioeconômica da Área Metropolitana de Brasília.

3.2 Instrumentos de planejamento e gestão urbana na Área Metropolitana de Brasília

237

3.3 Déficit habitacional versus investimentos do Estado de Goiás em municípios vinculados à Área Metropolitana de Brasília.

3.4 A produção habitacional do PMCMV na Área Metropolitana de Brasília: novas

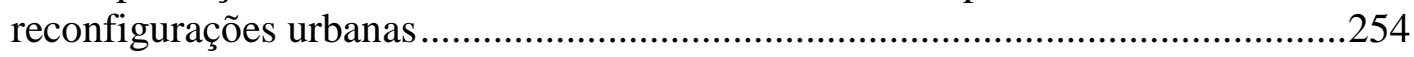

Considerações Finais .................................................................................................281

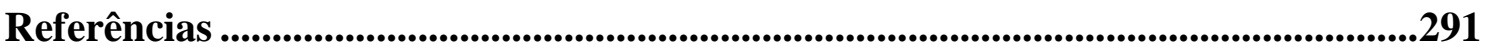

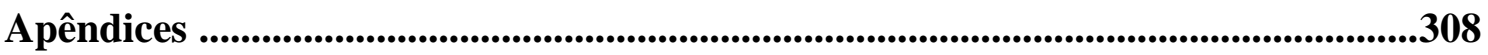

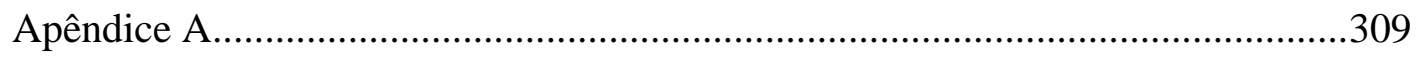

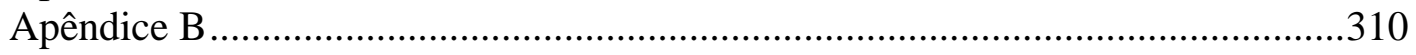

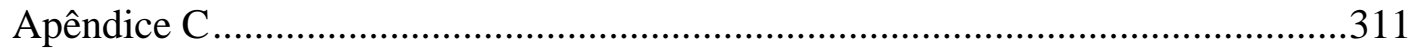

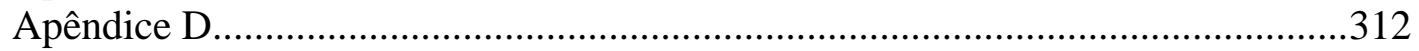

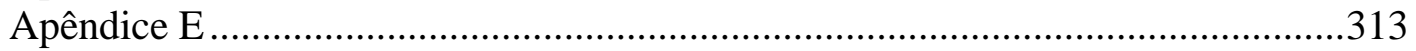

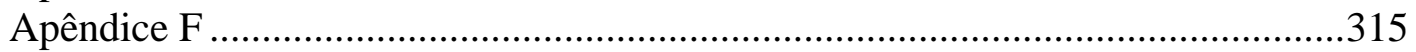

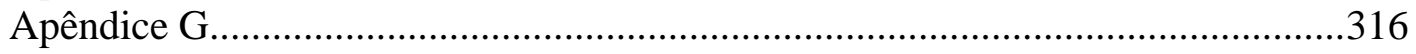

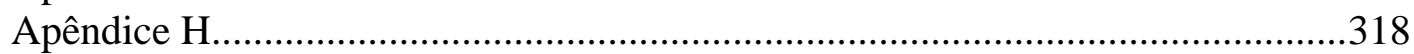

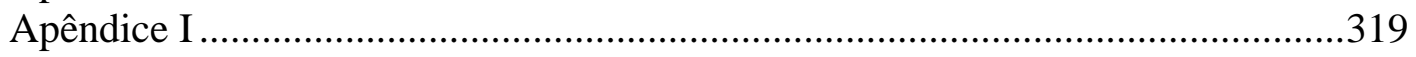

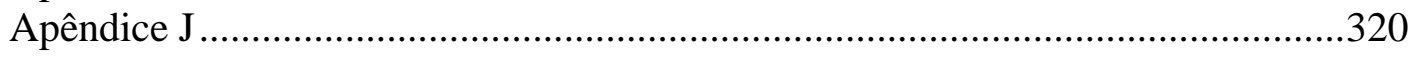

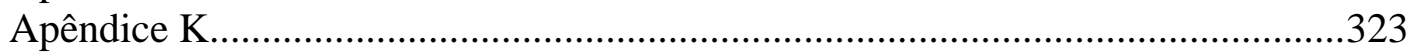

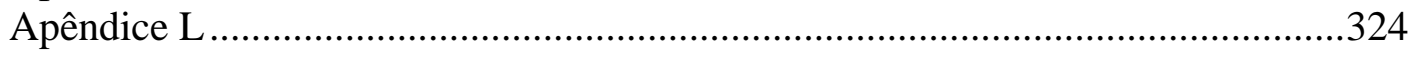

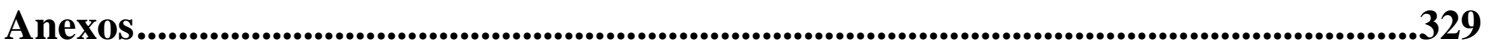

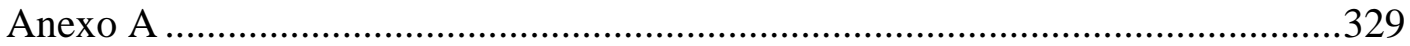

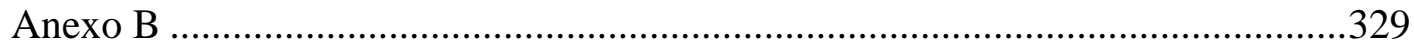

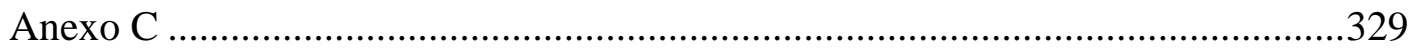

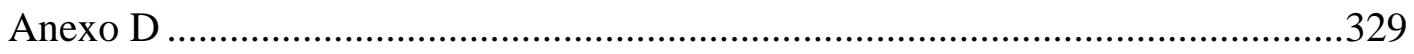

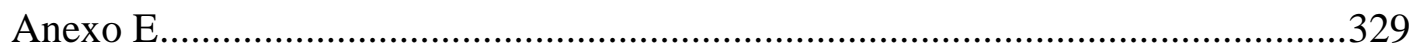

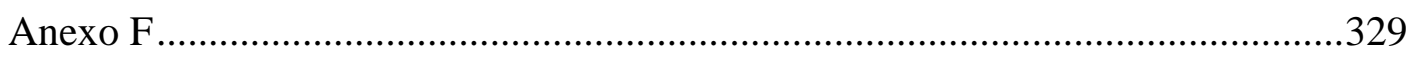

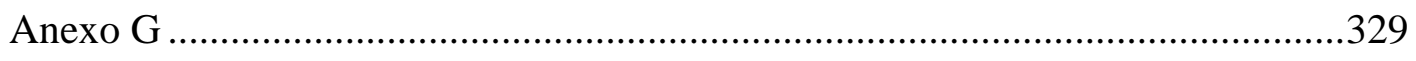

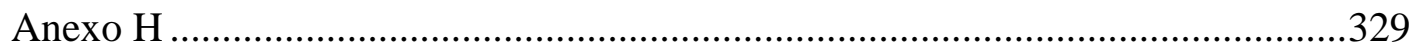

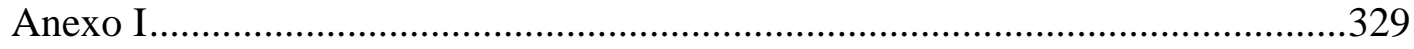

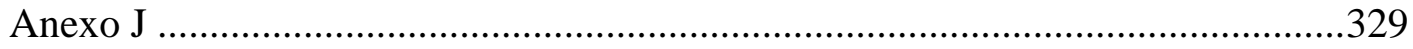




\title{
$\underline{\text { Lista de Siglas }}$
}

\author{
ABECIP - Associação Brasileira das Entidades de Crédito Imobiliário e Poupança \\ AGEHAB - Agência Goiana de Habitação \\ AMB - Área Metropolitana de Brasília \\ BID - Banco Interamericano de Desenvolvimento \\ BNDES - Banco Nacional de Desenvolvimento Econômico e Social \\ BNH - Banco Nacional da Habitação \\ CAESB - Companhia de Saneamento Ambiental do Distrito Federal \\ CBIC - Conselho Brasileiro da Indústria da Construção \\ CCFGTS - Conselho Curador do Fundo de Garantia por Tempo de Serviço \\ CEF - Caixa Econômica Federal \\ CMN - Conselho Monetário Nacional \\ COHAB - Companhia de Habitação \\ CF - Constituição Federal \\ CODHAB - Companhia de Desenvolvimento Habitacional do Distrito Federal \\ CODEPLAN - Companhia de Planejamento do Distrito Federal \\ CONCIDADES - Conselho das Cidades \\ EC - Estatuto da Cidade \\ FAR - Fundo de Arrendamento Residencial \\ FCP - Fundação da Casa Popular
}

FETREN - Financiamento para Sistemas Ferroviários para Transporte Urbano de Passageiros

FGHab - Fundo Garantidor da Habitação

FDS - Fundo de Desenvolvimento Social

FGTS - Fundo de Garantia por Tempo de Serviço

FIMURB - Financiamento para Urbanização

FIPLAN - Financiamento para Planejamento Urbano

FINC - Financiamento para Urbanização de Conjuntos Habitacionais

FINBEC - Financiamento de Equipamento Comunitário de Conjuntos Habitacionais

FJP - Fundação João Pinheiro

FNHIS - Fundo Nacional de Habitação de Interesse Social

FUNDHIS - Fundo de Desenvolvimento de Habitação de Interesse Social

GDF - Governo do Distrito Federal

IAPs - Institutos de Aposentadorias e Pensões

IBGE - Instituto Brasileiro de Geografia e Estatística

IPEA - Instituto de Pesquisa Econômica Aplicada

IPTU - Imposto Predial e Territorial Urbano

ITBI - Imposto sobre Transmissão de Bens Imóveis

LUOS - Lei de Uso e Ocupação do Solo

MCIDADES - Ministério das Cidades

OGU - Orçamento Geral da União

PAC - Programa de Aceleração do Crescimento

PAR - Programa de Arrendamento Residencial

PAEG - Plano de Ação Econômica do Governo

PAIH - Plano de Ação Imediata para Habitação

PLANHAP - Plano Nacional de Habitação Popular 
PLANHAB - Plano Nacional de Habitação

PD - Plano Diretor

PDAD - Pesquisa Distrital de Amostras de Domicílios

PDL - Plano Diretor Local

PDOT - Plano de Ordenamento Territorial do Distrito Federal

PEA - População Economicamente Ativa

PEHIS-GO - Plano Estadual de Habitação de Interesse Social de Goiás

PEOT - Plano Estrutural de Organização Territorial do Distrito Federal

PERGEB - Programa Especial da Região Geoeconômica de Brasília

PIB - Produto Interno Bruto

PEP - Programa de Empréstimo Popular

PLANDHIS - Plano Distrital de Habitação de Interesse Social

PLHIS - Plano Local de Habitação de Interesse Social

PMAD - Pesquisa Metropolitana por Amostra de Domicílio

PMCMV - Programa Minha Casa Minha Vida

PNAD - Pesquisa Nacional por Amostra de Domicílios

PND - Plano Nacional de Desenvolvimento

PNDU - Política Nacional de Desenvolvimento Urbano

PNH - Política Nacional de Habitação

POT - Plano de Ocupação Territorial do Distrito Federal

PRODEPO - Programa Apoio ao Desenvolvimento de Polos Econômicos

POUSO - Plano de Ocupação e Uso do Solo

PPP - Parceria Público-Privada

PROMORAR - Programa de Erradicação da Sub-Habitação

PSH - Programa de Subsídio à Habitação de Interesse Social

RA - Região Administrativa

RIDE DF - Região Integrada de Desenvolvimento do Distrito Federal e Entorno

RM - Região Metropolitana

SFH - Sistema Financeiro de Habitação

SFI - Sistema Financeiro Imobiliário

SBPE - Sistema Brasileiro de Poupança e Empréstimo

SEDHAB - Secretaria de Estado de Habitação: Regularização e Desenvolvimento Urbano

SEDUMA - Secretaria de Estado de Desenvolvimento Urbano, Habitação e Meio

Ambiente

SEGETH - Secretaria de Estado de Gestão do Território e Habitação

SEGPLAN-GO - Secretaria de Estado de Gestão e Planejamento - Goiás

SFH - Sistema Financeiro de Habitação

SNHIS - Sistema Nacional de Habitação de Interesse Social

TERRACAP - Companhia Imobiliária de Brasília

UPT - Unidade de Planejamento Territorial

UH - Unidade Habitacional

ZEIS - Zonas Especiais de Interesse Social

ZEU - Zonas de Expansão Urbana 


\section{$\underline{\text { Lista de Figuras }}$}

Figura 1: Mapa do Território da Ride/DF e da Área Metropolitana de Brasília (AMB)

Figura 2: Escalas de intervenção do PERGEB 1975 ..................................................156

Figura 3: Espacialização dos Empreendimentos Contratados com Financiamento do PMCMV 1 no Distrito Federal: 2009-2010 ................................................................176

Figura 4: Regionalização das Unidades de Planejamento Territorial (UPTs)...............180

Figura 5: Demanda Habitacional por Unidade Territorial de Planejamento (UPT).....187

Figura 6: Áreas definidas no PDOT 2009 para ofertas habitacionais..........................189

Figura 7: Principais áreas delimitadas para ofertas de UHs do Morar Bem.................191

Figura 8: Localização do empreendimento Paranoá Park - Faixa 1............................196

Figura 9: Localização da área de expansão do empreendimento Paranoá Park...........197

Figura 10: Unidades habitacionais entregues Paranoá Park.........................................197

Figura 11: Localização do empreendimento Itapoã Parque........................................198

Figura 12: Projeto do empreendimento do Itapoã Parque.............................................199

Figura 13:Localização do empreendimento Parque do Riacho......................................200

Figura14: Unidades entregues do Parque do

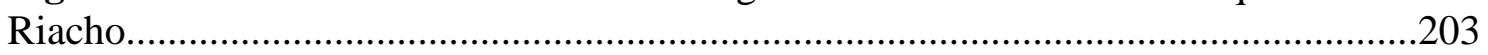

Figura15: Empreendimento Bairro Nacional - RA-São Sebastião............................201

Figura16: Empreendimento Bairro Nacional - RA-São Sebastião................................201

Figura 17: Localização do empreendimento Parque das Bênçãos...............................202

Figura 18: Tipologia do empreendimento Parque das Bênçãos localizado na RA Recanto

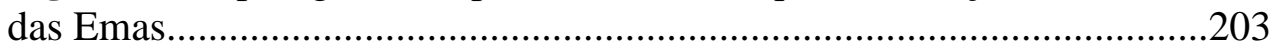

Figura 19: Espacialização dos empreendimentos do PMCMV/FAR no DF ................205

Figura20: Empreendimento Jardins

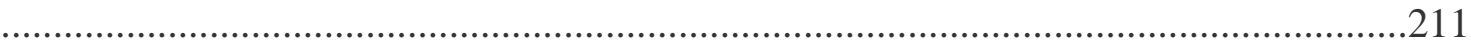

Figura21: Andamento das obras do Jardins

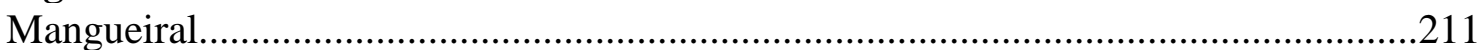

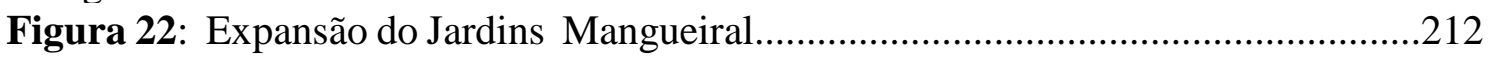

Figura 23: Unidades habitacionais do Parque do Riacho.........................................213

Figura 24: Empreendimento Planaltina Parque..........................................................214

Figura 25: Espacialização do Programa Morar Bem por Faixas de

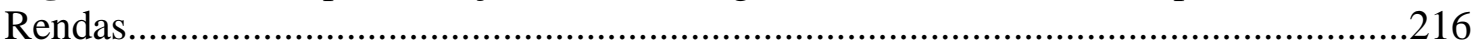

Figura 26: Proposta de Ampliação da Ride-DF...........................................................224

Figura 27: Existência de tipos de instrumentos urbanos nos Municípios da

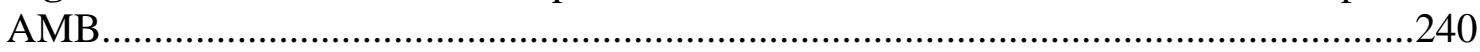

Figura 27: Demanda habitacional por Região de Planejamento do Estado de

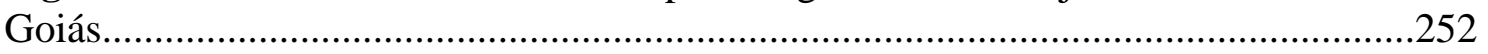

Figura 28: Municípios com principais Investimentos PAC (OGU +FNHIS) em

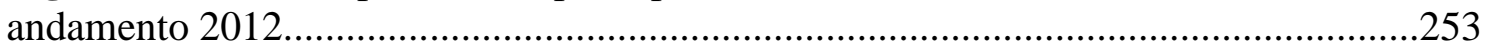

Figura 29: Contratações de unidades habitacionais: fonte de recursos FAR...............258

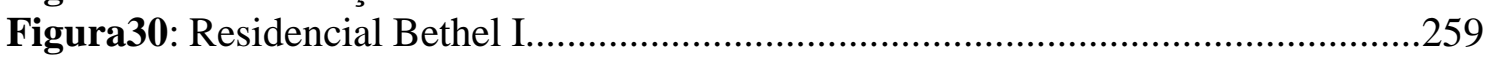

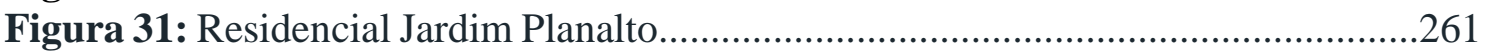

Figura 32:Espacialização da Contratação da UHs faixas 2 e 3 por Município................266

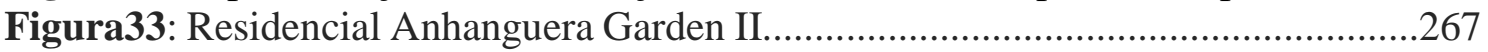

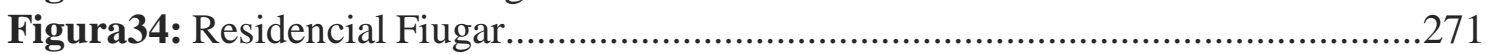




\section{Lista de Gráficos}

Gráfico 1: Valores contratados FGTS e SBPE 2002-2008 ( R\$ milhões).

Gráfico 2: Porcentagem de execução: proponente estadual - Urbanização de

Assentamentos Precários - FNHIS

Gráfico 3: Dados da Pnad ano 2012 versus atendimento das famílias - faixa $1 .$.

Gráfico 4: Contratações do PMCMV (FGTS) por faixa de renda

(PMCMV 1+2)

Gráfico 5: População urbana da AMB por local de trabalho

Gráfico 6: - Variação do déficit habitacional por componente: 2007-2012 


\section{$\underline{\text { Lista de Quadros }}$}

Quadro 1: Tendências de governança metropolitana ..................................................31

Quadro 2: População nos Censos Demográficos 1960-2010.......................................34

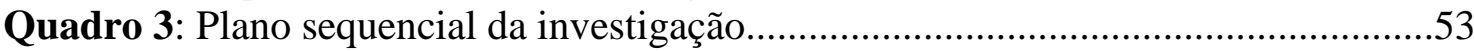

Quadro 4: Características dos planos de financiamento dos IAPs ...............................71

Quadro 5: Produção habitacional dos IAPs e da FCP (1937-1964)...............................73

Quadro 6: Territorialização da produção habitacional dos IAPs e FCP (1937-

1964)

Quadro 7: Distribuição por período dos conjuntos residenciais construídos pelos IAPs e

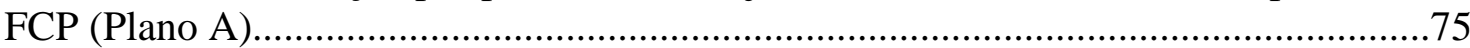

Quadro 8: Produção habitacional FCP por tamanho de municípios - 1946-1960.........80

Quadro 9: Produção habitacional da FCP por região: 1946-1960.................................81

Quadro 10: Produção Habitacional da FCP nos grandes municípios: 1946-

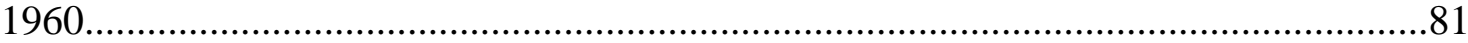

Quadro 11: Financiamentos habitacionais concedidos pelo SFH até 1980...................90

Quadro 12: Financiamentos habitacionais FGTS + SBPE: unidades e valores dos

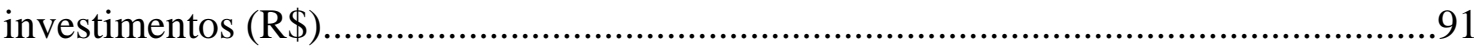

Quadro 13: Financiamento habitacional FGTS e SBPE: 1987-1994_...........................97

Quadro 14: Grupos dos programas habitacionais: governo FHC ...............................100

Quadro 15: Habitar Brasil e Pró-Moradia: síntese da execução dos programas: 19951998.

Quadro 16: Financiamentos de unidades habitacionais/região via PAR - 1999 $2002 .$.

Quadro 17: Modalidades de financiamento do PSH - ano base 2002 .........................103

Quadro 18: Contratações via FGTS/modalidades: 1995-2003 ....................................107

Quadro 19: Programas Habitacionais vinculados ao Ministério das Cidades - ano base $2008-2014$.

Quadro 20: Principais programas habitacionais para produção ou aquisição de unidades novas.

Quadro21: $\quad$ Faixas $\quad$ de $\quad$ renda $\quad$ PMCMV

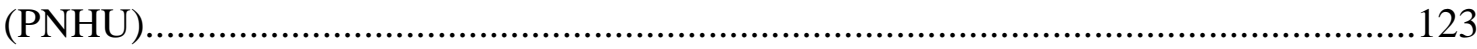

Quadro 22: Modalidades do Programa Nacional de Habitação Urbana - PNHU..........124

Quadro 23: Programa Nacional de Habitação Rural (PNHR)......................................128

Quadro 24: Execução do Programa Minha Casa, Minha Vida 1 (2009-2011)

Quadro 25: Execução do Programa Minha Casa, Minha Vida 2 (2011-

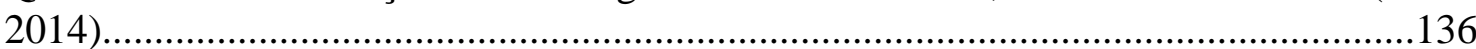

Quadro 26: Contratações do PMCMV - 2 por porte municipal acima de $50 \mathrm{mil} / \mathrm{hab}$. -

faixa 1 (famílias com renda até $\mathrm{R} \$ 1.600,00$ )

Quadro 27: Crescimento populacional DF (1960-1970).........................................151

Quadro 28: Produção habitacional no Distrito Federal até 1979...............................153

Quadro 29: Operações do PAPE no DF: 1982-1985 …..............................................161

Quadro 30: Oferta de lotes pela Terracap: setores de média e alta renda-DF, período 1982-1985

Quadro 31: Quantidade de lotes entregues pelo Programa Socorro Social, período 2002-2006.

Quadro 32: Regiões Administrativas criadas nos governos de Joaquim Roriz. 
Quadro 33: Empreendimentos contratados com financiamento do PMCMV no Distrito Federal: 2009-2010

Quadro 34: Crescimento da demanda habitacional por grupos de renda no DF 2005-

2010 .

Quadro 35: Perfil dos inscritos no Cadastro Habitacional do DF Ano Base 2012 ....186

Quadro 36: Faixas de renda do Morar Bem/PMCMV ...............................................187

Quadro 37: Valor dos empreendimentos do Programa Morar Bem por RA................193

Quadro 38: Projetos em andamento no DF pelo PMCMV - entidades....................... 193

Quadro 39: Densidade demográfica na AMB - 2010 ...............................................226

Quadro 40: Principais aglomerações urbanas na AMB.............................................227

Quadro 41: Crescimento da população urbana na AMB: 1960-

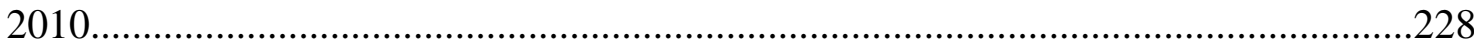

Quadro 42: Distribuição dos domicílios urbanos ocupados por classes de renda domiciliar, segundo os municípios da AMB: 2013 .....................................................232

Quadro 43: Tipo de transporte utilizado pela população urbana da AMB para ida ao

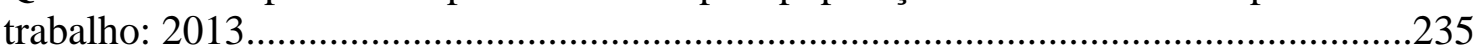

Quadro 44: Componentes do déficti habitacional na AMB - Censo 2010...................251

Quadro 45: Execução do Programa Minha Casa, Minha Vida fases 1 e 2 na Ride-

DF

Quadro 46: Déficit habitacional versus oferta de unidades habitacionais do PMCMV 
xviii

\section{Lista de Tabelas}

Tabela 1: Déficit habitacional total e relativo referente ao total de domicílios particulares permanentes por situação de domicílio, segundo regiões metropolitanas (RM) e regiões integradas de desenvolvimento (Ride) - Brasil - 2010 .............................................. 36

Tabela 2: População urbana e renda per capita por unidades de planejamento Territorial (UPTs) 
Apresentação 
A provisão dos serviços urbanos nos espaços metropolitanos exige uma articulação integrada para que sua oferta e o acesso a eles estejam compatíveis com a dinâmica urbana do conjunto de municípios. Para Cruz, Berg e Marques (2011), a provisão da habitação como serviço de interesse social e sua gestão de forma local em território de complexa dinâmica urbana não pode ser de responsabilidade exclusiva dos governos locais, já que envolvem pesados investimentos em infraestrutura e articulação. Frequentemente o poder local não obtém recursos compatíveis para a escala da demanda e da oferta de habitação de interesse social, sendo necessárias ações cooperadas para uma eficiente provisão desse serviço e dos outros que estão envolvidos, como transporte público, mobilidade urbana, educação e saúde.

As pesquisas têm procurado identificar as dificuldades e as estratégias dos países desenvolvidos e em desenvolvimento, para planejar e implementar ações coordenadas entre os entes governamentais, visando à oferta e ao acesso adequados da população de baixa renda aos serviços urbanos no território metropolitano.

$\mathrm{Na}$ agenda de pesquisa dos espaços acadêmicos e dos organismos internacionais, como a Un-Habitat, por exemplo, indica-se a necessidade de uma articulação metropolitana intergovernamental construída por distintos agentes, a fim de implementar políticas para a oferta de serviços urbanos integrados, tais como transporte urbano, acesso à moradia para a população de baixa renda associada ao conjunto de usos do solo urbano. A inovação de serviços deve gerar renda e emprego com a finalidade de otimizar recursos e integrar econômica e socialmente os territórios metropolitanos.

Destaque-se que alguns países têm apresentado experiências de governança ${ }^{1}$ metropolitana com relativo grau de coesão e participação do governo central ou subnacional. Em Montreal e Toronto, no Canadá, foram instituídas autoridades metropolitanas tanto compulsórias quanto voluntárias para a oferta de serviços urbanos de forma partilhada. Assim, por exemplo, na cidade de Toronto, a criação de bairros em áreas centrais com renda mista traz uma experiência de provisão da moradia social em conjunto com condomínios de classe média. Nesses bairros há tipologias de aluguéis de mercado e aluguéis sociais e, também, há participação dos moradores no planejamento e orçamento dos bairros.

Na Comunidade Metropolitana de Montreal, desde o ano de 2001, todas as municipalidades que pertencem à comunidade metropolitana contribuem com uma cota-

\footnotetext{
${ }^{1}$ Para pesquisas aprofundadas, consultar Collin e Robertson (2007), Hoffmann-Martinot e Sellers (2007)
} e Seixas e Albet (2012). 
parte de imposto calculado de acordo com a capacidade fiscal para o financiamento de programas de habitação social ao nível metropolitano. Vale lembrar que a Comunidade Metropolitana elaborou o Plan d'action métropolitain pour le logement social et abordable (2009-2013), para fortalecer as ações cooperadas e assegurar a ampliação de habitação social no âmbito metropolitano.

Já na região de Île-de-France, na França, a implementação de leis e linhas de financiamento tem fomentado a cooperação intermunicipal, assim como de contínuas políticas que visam integrar uma gestão para o uso do solo cooperada. Destaquem-se a obrigação de um porcentual de $25 \%$ destinados para moradias de interesse social para a aprovação de grandes empreendimentos imobiliários e, no ano de 2013, a aprovação para a elaboração do plano metropolitano para a habitação de Interesse social em andamento.

Também merecem destaque as recentes aprovações de planos para o ordenamento integrado na Espanha. Barcelona, por exemplo, teve, no ano de 2010, seu Plano Territorial Metropolitano regulamentado, o que tem viabilizado, em colaboração com as municipalidades, a ampliação da provisão da habitação social na escala metropolitana. Vale lembrar que a habitação não é uma competência local. O Institut Metropolità de Promoció de Sòl i Gestió Patrimonial - IMPSOL - é uma entidade pública com personalidade jurídica própria que atua na Área Metropolitana de Barcelona com a finalidade de administrar, gerir e explorar o uso do solo e ações de urbanismo, levando em consideração a solidariedade intermunicipal e as estratégias do plano diretor metropolitano.

$\mathrm{Na}$ América Latina, merecem destaque as experiências de cooperação e fortalecimento da gestão nas áreas metropolitanas. Em especial países como Chile e México se destacam na elaboração de estratégias para a provisão habitacional articulada à dinâmica metropolitana. Assinale-se que a problemática urbana desses países e os desafios para a promoção de cooperação se assemelham à realidade brasileira.

No Chile e no México, embora exista uma centralização do governo central e subnacional, são asseguradas as competências para o nível local em consonância com as respectivas Constituições. Existe um papel ativo do governo subnacional em algumas áreas metropolitanas para melhor adesão às políticas habitacionais, a fim de que se reduza a expansão urbana periférica dos empreendimentos voltados para segmentos sociais de baixa renda. 
A política habitacional chilena tem sido apontada como o modelo latinoamericano para o enfrentamento dos problemas urbanos e a implementação de programas habitacionais que assegurem moradias para a população de baixa renda.

O Chile tem se destacado no cumprimento de metas de desenvolvimento global, se comparado aos demais países da América Latina, no que tange ao enfrentamento da ocupação irregular e às soluções habitacionais para a provisão da moradia articulada aos serviços básicos visando à redução das externalidades da urbanização periférica, que em grande parte são aprofundadas em função das formas de ocupação irregulares da moradia e da ausência ou inadequação do acesso aos serviços básicos (DUCCI, 1997).

No México, as ações no campo habitacional resultaram na construção de aproximadamente 600 mil casas por ano, em especial nas áreas metropolitanas. Vale destacar que, diferentemente de no Brasil, no México o acesso a uma moradia social é assegurada somente aos trabalhadores com emprego estável. Nas principais áreas metropolitanas do México, como por exemplo Cidade do México, Guadalajara e Monterey, foram criadas instâncias de coordenação e de planejamento metropolitano, sobretudo nas questões relativas ao uso do solo e da provisão da moradia social.

Essas instâncias têm realizado esforços para uma melhor distribuição da moradia social articulada às bacias de emprego e lazer, a fim de reduzir o enorme número de trabalhadores que abandona a moradia social, adquirida em função da sua localização periférica, o que tem gerado impactos socioeconômicos nas principais áreas metropolitanas mexicanas.

Já no Brasil, o debate sobre a cooperação interfederativa nas regiões metropolitanas é marcado por períodos de centralização e descentralização do Estado. Os anos 1970 marcaram a criação das primeiras regiões metropolitanas pela União, com a Lei Federal no 14 de 1973, a saber: Belém, Fortaleza, Recife, Salvador, Belo Horizonte, São Paulo, Curitiba, Porto Alegre. No ano de 1974, pela Lei Complementar $n^{\circ} 20$, determinou-se a criação da região metropolitana do Rio de Janeiro. A criação das regiões metropolitanas tem como finalidade prover ações compartilhadas de serviços públicos caracterizados como funções públicas comuns (FRANÇA; FURTADO; 2013).

Com a aprovação da Constituição Federal de 1988 e das estratégias de descentralização da Administração Pública, a criação e gestão das regiões metropolitanas passaram a ser competência dos Estados.

Os Estados poderão, mediante lei complementar, instituir regiões metropolitanas, aglomerações urbanas e microrregiões, constituídas por agrupamentos de municípios limítrofes, para integrar a organização, o 
planejamento e a execução de funções públicas de interesse comum. (BRASIL, 1988, Art. 25, § $3^{\circ}$ ).

Também a Constituição de 1988, em seu artigo 43, dispõe acerca da criação, pela União, através de lei complementar, das Regiões Integradas de Desenvolvimento (RIDEs), em um mesmo complexo social e geoeconômico. Para tanto, ações que envolvam municípios localizados em distintas Unidades da Federação são promovidas visando ao seu desenvolvimento e à redução das desigualdades regionais (BRASIL,1988).

A aprovação da Constituição Federal de 1988 elevou o município a uma instância de poder muito particular em relação a outros países federativos. O município foi incorporado como um ente federativo com autonomia. Já em relação à implementação das regiões metropolitanas, esta foi delegada aos Estados, porém a União não estabeleceu normas gerais ou mecanismos que pudessem fortalecer a regulação e gestão das regiões metropolitanas.

Nesse contexto, não houve por parte dos Entes federativos ações que fomentassem a cooperação. Ao contrário, a agenda foi marcada pela guerra fiscal entres os entes. A redução de investimentos em políticas urbanas, dada a austeridade fiscal e os frágeis diálogos com os governos locais, revelou-se problemática para práticas de cooperação em territórios metropolitanos, em um novo período que evocava a gestão local e sinalizava a competência do Ente municipal, para o ordenamento urbano e a gestão do uso do solo.

Assim, as práticas de gestão metropolitana ganharam novos contornos em decorrência das novas nuanças federalistas e também em função da crise econômica e dos reajustes fiscais, que reduziram os investimentos em políticas urbanas. Para Klink (2013), a pauta metropolitana não foi incluída como medida estratégica nos novos pleitos dos prefeitos pós-1988, tampouco marcou uma ação integrada da esfera federal diante das mudanças institucionais e econômicas.

Embora o tema metropolitano, em anos recentes, tenha ganhado espaço na agenda governamental com a retomada de investimentos federal e estadual no setor de desenvolvimento urbano e no campo técnico e de pesquisa, destacam-se importantes ações de governos estaduais repensando o ordenamento e a gestão metropolitana:

a)

O estado de Minas Gerais avançou com a criação de Agência Metropolitana de Belo Horizonte e a aprovação do Plano Metropolitano (2011) e delimitação das Zonas de Interesse Metropolitano (ZIMs); 
b)

O estado de São Paulo tratou da reorganização do planejamento metropolitano do ponto de vista institucional, com a regulamentação de novas regiões metropolitanas. Para isso, elaborou ações de planejamento metropolitano, como o plano habitacional metropolitano para a região metropolitana de São Paulo, que se encontra em andamento, a maioria delas conduzida pela Empresa Paulista de Planejamento Metropolitano (Emplasa). Também foram regulamentadas as atividades da Agência Metropolitana de Campinas (AgemCamp) e da Agência Metropolitana da Baixada Santista (Agem);

c) O estado do Rio de Janeiro está promovendo seminários para a promoção de diretrizes e a proposição de um novo desenho metropolitano para as políticas urbanas articuladas aos grandes eventos internacionais esportivos;

d) O Distrito Federal e o Estado de Goiás estão fomentando estratégias que resultem na construção de uma agenda de cooperação, através de fóruns temáticos, para a discussão de um plano integrado de resíduos sólidos para a Ride-DF. A Companhia de Planejamento do Distrito Federal (CODEPLAN) tem realizado importantes diagnósticos e pesquisas que resultaram na delimitação de uma Área Metropolitana de Brasília (AMB). Essa regionalização da Área Metropolitana de Brasília tem subsidiado consideráveis acordos de cooperação para embasar políticas públicas.

Nesse sentido, observa-se uma retomada de estratégias de planejamento e gestão considerando as múltiplas interfaces do território metropolitano. Em especial, alguns estados se destacam na retomada de estratégias com a reorganização das suas agências de desenvolvimento metropolitano e a elaboração de plano metropolitano, bem como, em certa medida, com ações inovadoras, em decorrência da sua organização e capacidade administrativa, como por exemplo os estados de Minas Gerais e São Paulo.

Ainda assim, observa-se uma fragilidade de inserção do tema metropolitano como uma estratégia prioritária que paute a agenda governamental e que seja objeto de ações 
que induzam pactos cooperativos de serviços em espaços que possuem forte integração de uso de serviços urbanos. Também é frágil a instituição de mecanismos de regulação para o financiamento e a gestão que possibilitem a estados e municípios otimizarem recursos para a implementação de estratégias para o desenvolvimento do território metropolitano.

Na esfera política, a descentralização administrativa tem proporcionado uma série de experiências de cooperação voluntária, porém são eivadas de conflitos. Na esfera econômica, emergem proposições de ações que podem propiciar economias de aglomeração. Contudo, trata-se de ações setorializadas e desintegradas, que fragmentam o tecido metropolitano e potencializam deseconomias de aglomeração, além de gerar entraves ao próprio desenvolvimento.

Por fim, na esfera social, há a necessidade de participação dos segmentos da sociedade, mecanismos de controle social e desenvolvimento econômico articulado a ganhos para a coletividade.

Essas facetas se interconectam e são investigadas a partir de diferentes aportes teóricos e metodológicos, apontando indicativos e proposições sobre o quão necessárias e eficazes podem ser as articulações interfederativas para a gestão metropolitana. A razão disso está no fato de que tais articulações permitem viabilizar a escala ótima para a prestação dos serviços públicos comuns para os cidadãos que vivem nos territórios metropolitanos.

As pesquisas geográficas buscam, considerando o seu instrumental teórico e aplicado, trazer contribuições à promoção de políticas públicas e formas de planejamento que considerem os processos de formação e reprodução espacial.

A Geografia, com o seu instrumental teórico e prático, busca compreender as diferentes formas de como as relações sociais são reproduzidas no território, com indicativos de proposições de mudanças no planejamento e desenho das políticas urbanas. Há casos para os quais a Geografia aponta para verdadeiras revoluções nas formas de organização e produção do Estado, sociedade, território e natureza, que têm marcado a investigação da ciência geográfica.

Nesse sentido, ao defendermos a elaboração da tese sob a perspectiva geográfica, buscamos justificar o contexto da questão metropolitana, utilizando as dimensões espaciais: a) a institucional - permeada pelas mudanças federativas e, sobretudo, das tratativas do enfrentamento de externalidades negativas nos processos de metropolização; 
b) a real - os distintos processos de metropolização que vivenciamos - nas dimensões percebida, concebida e vivida, em interface com as políticas públicas habitacionais.

Ao investigarmos a questão metropolitana sob a ótica da ciência geográfica, estamos adentrando em um mundo de relações sociais que não são lineares, sucessivas ou estáticas; ao contrário, elas são construídas e desconstruídas por subjetividades políticas, econômicas e sociais (MASSEY, 2008).

As subjetividades constroem as espacialidades globais dos fenômenos. Nesse caso, as espacialidades da questão metropolitana são um fenômeno urbano que possui características globais, porém com distintas histórias e territórios, que se conectam aos processos das transições espaciais, tais como: a passagem do fordismo para a acumulação flexível; as reformas da administração pública; os novos mercados de consumo urbano; a polarização dos centros econômicos metropolitanos; a reprodução das relações sociais e os novos direcionamentos do Estado em temporalidades distintas que reproduzem novas formas de urbanização e definem novos rumos da globalização.

A Geografia, ao se propor explicar a (re)produção do espaço metropolitano, utiliza o seu instrumental estratégico, isto é, as possibilidades e limites de analisar o território metropolitano a partir das escalas, das temporalidades e das redes. Nessas condições, o território metropolitano fluido pelas redes informacional, financeira e terciária tem transformado, de forma acelerada, a base material e imaterial do tecido urbano e ampliado a vivência do fenômeno metropolitano em distintos graus (CASTELLS, 1999; HARVEY, 2011).

O entendimento da questão metropolitana passa pela compreensão do conceito de território, do seu caráter relacional e de poder na reprodução das relações sociais e das políticas públicas. Assim, o conceito de território configura-se por meio de práticas materiais e imateriais, sempre em processo de fazer-se (SANTOS, 1999; MASSEY, 2008).

Assim, ganha centralidade o papel decisório dos atores que produzem o território metropolitano e direcionam o desenho e a execução das políticas públicas que transformam o urbano.

A nossa proposição é que a geografia "conte" as estórias metropolitanas e os limites para uma gestão cooperada a partir de diversas possibilidades, e é aí que o território sinalizado por Santos (1999), Massey (2008), Moura (2012), Firkowski (2013) e tantos outros geógrafos ganha essencialidade. 


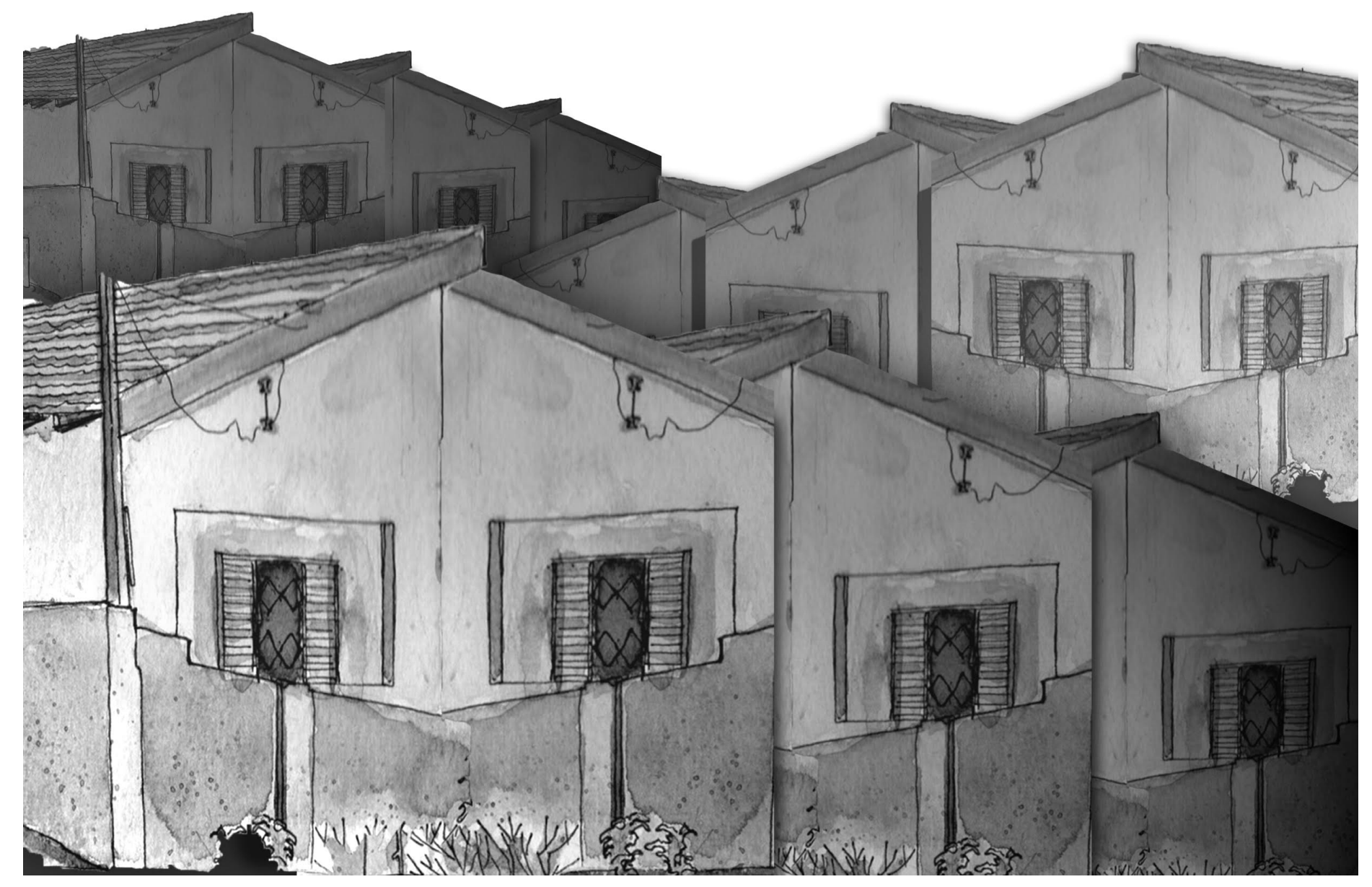




\section{Introducão}

Aproximações para a compreensão da habitação como uma questão metropolitana 
Os territórios metropolitanos concentram o poder de decisão do capital, sobretudo o financeiro. Simultaneamente esses territórios são dotados de uma complexidade que impõe novas estratégias para o desenho e a implementação de políticas públicas eficientes, eficazes e efetivas para o enfrentamento da precariedade urbana neles concentrada e potencializada em graus diversos.

Os territórios metropolitanos são os polos de riqueza e ao mesmo tempo concentram os mais graves problemas urbanos que não estão circunscritos aos limites administrativos, sejam estes municipais ou estaduais. Assim, esses territórios se tornam verdadeiras arenas políticas, onde distintos agentes produzem e reproduzem estratégias em diferentes tempos e escalas, as quais, em sua maioria, se apresentam descasadas e conflitantes com as necessidades coletivas.

Portanto, o planejar, o implementar, o regular e o gerir políticas públicas para a prestação de serviços urbanos comuns requerem negociação, redesenhos, partilhamento de exercício de competências, novas formas de aplicação e arrecadação de investimentos entre os Entes da Federação, sociedade e parceiros privados.

Para Moura e Gorsdorf (2009), nos territórios metropolitanos a prestação de serviços urbanos que exerçam uma forte relação com outros municípios deve ser planejada de forma coordenada. Daí o reconhecimento de que alguns serviços urbanos podem ser caracterizados como "funções públicas de interesse comum”, a depender da sua espacialização no território.

A adoção de estratégias cooperadas para o enfrentamento dos problemas urbanos em territórios metropolitanos tem sido planejada, investigada e proposta mediante os distintos vieses de governança metropolitana. Para Mévellec e Douay (2007), a governança metropolitana comporta, via de regra, três elementos centrais: a mobilização de competências do Estado em induzir políticas integradas, considerando o modelo descentralizado de competências; a fluidez das funções econômicas, em especial, do setor terciário, e por fim, a fluidez do tecido urbano.

No entanto, existem diversas tendências de governança metropolitana. $\mathrm{Na}$ Ciência Política, três tendências se destacam pelos distintos alinhamentos teóricos, sobretudo no que tange ao papel do governo central em induzir e coordenar estratégias cooperadas relacionadas aos conteúdos e às escalas do capitalismo. 


\section{Quadro 1 - Tendências de Governança Metropolitana}

\begin{tabular}{|c|c|c|c|}
\hline Tendências & Período & Características & Formas de Governança \\
\hline Reform School & $\begin{array}{c}\text { Início do século XX } \\
\text { até meados de 1960: } \\
\text { período da } \\
\text { Industrialização }\end{array}$ & $\begin{array}{c}\text { Institucionalização, } \\
\text { governos } \\
\text { metropolitanos } \\
\text { centralizados }\end{array}$ & $\begin{array}{c}\text { Governos/Entes } \\
\text { metropolitanos e } \\
\text { Conselhos Metropolitanos }\end{array}$ \\
\hline Public Choices & $\begin{array}{l}\text { Anos de 1980: pós- } \\
\text { industrialização }\end{array}$ & $\begin{array}{l}\text { Descentralização/ } \\
\text { poder decisório dos } \\
\text { governos locais }\end{array}$ & $\begin{array}{c}\text { Policentrismo/ações } \\
\text { voluntárias }\end{array}$ \\
\hline New Regionalism & $\begin{array}{c}\text { Anos de 1990: estágio } \\
\text { avançado da } \\
\text { globalização }\end{array}$ & $\begin{array}{c}\text { Cooperação } \\
\text { horizontal/vertical }\end{array}$ & $\begin{array}{c}\text { Cooperação } \\
\text { intermunicipal e } \\
\text { participação da sociedade } \\
\text { civil }\end{array}$ \\
\hline
\end{tabular}

Fonte: Adaptado de Yaro; Ronderos (2011).

As transformações do capitalismo mundial no período pós-1970 trouxe mudanças no regime de atuação e gerenciamento do Estado. Assim, as tendências de governança metropolitana apresentadas no Quadro 1 correspondem às transformações no regime de produção capitalista e aos modelos de oferta de serviços públicos pelo Estado. Para Klink (2013), as mudanças no regime de atuação do Estado pós-1970 apresentam a transição dos regimes de gerenciamento para o regime de empresariamento urbano:

No primeiro, os governos municipais limitavam-se à gestão burocrática de
um conjunto pré-definido de serviços urbanos, enraizado em um sistema
relativamente rígido de planejamento e zoneamento compreensivos. O
segundo caracterizava-se por um estilo empreendedor de governança, em um
cenário mundial de turbulências e incertezas, que fazia com que os governos
locais assumissem mais riscos (calculados) e uma postura gerencial de
flexibilidade, em busca de inserção urbana na economia mundial. Lançavam
mão de projetos estratégicos de revitalização urbano-regional (selecionando,
para esse objetivo, corredores industriais, áreas centrais e portuárias
abandonadas, rios poluídos etc.), articulados e implementados no âmbito de
coalizões locais compostas por agentes da sociedade civil e do empresariado.
(KLINK, 2013, p. 89).

No caso brasileiro, ainda segundo Klink (2013), a retração nos anos de 1990 dos investimentos da União em políticas sociais e urbanas e as parcerias com o setor privado para a provisão de infraestruturas acirraram a competitividade e a concorrência fiscal entre Municípios e Estados, o que evidenciou ações desarticuladas de planejamento e gestão do território e dificultou na esfera dos estados a criação e o fortalecimento das agendas regionais integradas de desenvolvimento.

As guerras fiscais envolvendo municípios e estados, para a alocação de investimentos, trouxeram impactos profundos nas diretrizes e estratégias de 
planejamento urbano e na flexibilização, no que diz respeito às leis do uso e ocupação do solo, às leis de expansão do perímetro urbano, para assegurar a alocação de investimentos e a projeção das cidades no cenário regional ou mundial. Diante desse cenário, as ações de cooperação se mostraram frágeis e não foram temas centrais das agendas dos Entes federativos ${ }^{12}$ (KLINK, 2013).

Para Arretche (2010), as desigualdades territoriais, as distintas e por vezes conflitantes relações entre a União, estados, Distrito Federal e municípios são elementos que, em parte, explicam a fragmentação de mecanismos que induziriam os entes e agentes para a formulação e execução de políticas públicas integradas.

Nessas condições, a indução da União para a formulação de diretrizes para a execução de políticas integradas se torna essencial. Isso porque a formulação de diretrizes e as condicionalidades de acesso aos recursos de programas federais orientam e afetam a execução e regulação de políticas públicas para a provisão de serviços urbanos na escala estadual e local.

No Brasil, já é reconhecido que a estrutura das regiões metropolitanas ${ }^{3}$ revela grandes diferenças em capacidade técnica, tributária, administrativa e acesso e oferta de serviços urbanos entre a área-polo e os municípios limítrofes. Somam-se a isso as assimetrias de capacidade e fragilidade de coesão (para não dizer ausência em alguns casos) do planejamento, além da implementação de serviços urbanos de um município que traz impactos negativos nos demais municípios. Isso reafirma a necessidade de mecanismos de cooperação no planejamento e na execução das políticas urbanas, quando um serviço urbano exerce forte relação com outros municípios.

Nesta pesquisa procuramos investigar as assimetrias da atual política habitacional a partir da execução do Programa Minha Casa, Minha Vida, em contexto metropolitano. Trata-se de programa que tem impactado de diversas formas a gestão estratégica e a população e cujas ações para o enfrentamento da problemática metropolitana requerem respostas cooperadas para uma ação efetiva de política pública.

\footnotetext{
${ }^{1}$ A esse respeito, ver: Observatório das Metrópoles (2012); Ipea (2013). As referidas obras trazem contundentes críticas à criação de regiões metropolitanas sem critérios técnicos e, em sua maioria, com recortes que não possuem natureza metropolitana.

${ }^{2} \mathrm{O}$ tema da governança metropolitana tem tido papel de destaque nos principais centros de pesquisas do país, como, por exemplo, nos já citados Observatório das Metrópoles (2012) e Ipea (2013). Merece destaque a recente cooperação técnica firmada entre o escritório da Un-Habitat com o Ministério das Cidades (2013), para o desenvolvimento de metodologia visando à formulação e à implementação de diretrizes para a geração de subsídios, com o propósito de promover um marco legal da política de planejamento e gestão metropolitanos.

${ }^{3}$ Uma análise detalhada sobre a estrutura das regiões metropolitanas é feito por Ribeiro e Santos Junior (2004, 2007) e Observatório das Metrópoles (2012).
} 
Para tanto, tratar como função pública comum a habitação já se apresenta como um desafio para esta pesquisa, sendo necessário problematizar e identificar os processos que permitem reconhecer a habitação como uma função pública de interesse comum. Isso requer, portanto, um exercício colegiado de competências e estratégias para sua provisão na escala metropolitana.

\section{Parte A - Problematização: a habitação como uma função pública de interesse comum}

O processo de reestruturação econômica, de urbanização e de metropolização acelerada no Brasil resultou em uma reorganização e flexibilização do sistema produtivo brasileiro, cada vez mais voltado para as atividades industriais e terciárias, $\mathrm{o}$ que impôs uma também reorganização e tecnificação da produção agrícola. Por sua vez, a reestruturação econômica provocou impactos na estrutura da mão de obra e nos investimentos em políticas sociais, em especial nas políticas redistributivas.

Esse conjunto de fatores condicionou novas configurações urbanas e frentes migratórias direcionadas para a cidade, em decorrência da reorganização da estrutura econômica no país, que se somou ao violento processo de expulsão do camponês do mundo rural, fato que, em certa medida, condicionou sua migração para a cidade.

Assim, o Brasil, nos anos 1970, já alcançava uma população eminentemente localizada em áreas urbanas e, sobretudo, concentrada nas áreas mais dinâmicas - as denominadas regiões metropolitanas. Também merece destaque o crescimento da população urbana nas novas frentes de ocupação, resultante das políticas de interiorização, como ocorreu na região Centro-Oeste, com a implantação da Capital Federal - Brasília. 
Quadro 2 - População nos Censos Demográficos 1960-2010

\begin{tabular}{|c|c|c|c|c|c|c|c|c|c|c|c|c|}
\hline & Urbana & Rural & Urbana & Rural & Urbana & Rural & Urbana & Rural & Urbana & Rural & Urbana & Rural \\
\hline BRASIL & 32.004 .817 & 38.987 .526 & 52.904 .744 & 41.603 .839 & 82.013 .375 & 39.137 .198 & 110.875 .826 & 36.041 .633 & 137.755 .550 & 31.835 .143 & 160.925 .792 & 29.830 .007 \\
\hline $\begin{array}{l}\text { Região } \\
\text { Sudeste }\end{array}$ & 17.818 .649 & 13.244 .329 & 29.347 .170 & 10.984 .799 & 43.550 .664 & 9.029 .863 & 55.149 .437 & 7.511 .263 & 65.441 .516 & 6.855 .835 & 74.696 .178 & 5.668 .232 \\
\hline Região Sul & 4.469.103 & 7.423 .004 & 7.434 .196 & 9.249 .355 & 12.153 .971 & 7.226 .155 & 16.392 .710 & 5.724 .316 & 20.306 .542 & 4.783.241 & 23.260 .896 & 4.125.995 \\
\hline $\begin{array}{l}\text { Região } \\
\text { Centro- }\end{array}$ & 995.171 & 1.683 .209 & 2.358 .218 & 2.271 .422 & 4.950 .203 & 2.053 .312 & 7.648 .757 & 1.763 .485 & 10.075 .212 & 1.541 .533 & 12.482 .963 & 1.575 .131 \\
\hline
\end{tabular}

(*) População recenseada. (**) População residente

Fonte: IBGE, Censos Demográficos de 1960, 1970, 1980, 1991, 2000 e 2010.

A população de migrantes de baixa renda, aqui compreendida em linhas gerais como aquela que recebe até três salários mínimos, em sua maioria, não possui qualificação profissional e parte dela, que se integra ao mercado de trabalho, seja pela via formal ou informal, recebe baixos rendimentos. Essa população enfrenta grandes dificuldades em obter acesso à moradia nas cidades, em especial nas grandes cidades, por conta das pífias ações do Poder Público em assegurar condições mínimas de acesso à moradia digna para esse perfil da população.

As linhas de crédito e os programas habitacionais, quando disponíveis, nem sempre se revelaram adequados ou suficientes para atender à população de baixa renda. Portanto, a ocupação informal muitas vezes foi a via disponível para os cidadãos de se reproduzir na cidade, dada a omissão de uma política habitacional de interesse social, além da ausência de uma política fundiária, seletividade dos critérios e enquadramento de renda dos programas habitacionais e o acesso às fontes de financiamento.

As precárias formas de acesso à moradia e à infraestrutura urbana, somadas às práticas de autoconstrução das moradias na periferia sob a responsabilidade dos trabalhadores, ou o acesso à moradia nos cortiços no centro das cidades, propiciaram uma série de condicionantes, tais como ocupação irregular, carência de serviços urbanos e falta de oportunidades que promovessem a geração de renda e oferta de emprego.

Esses condicionantes, em parte, explicam a expansão segregada e o processo de urbanização perverso nas grandes cidades brasileiras, sem a intervenção adequada de estratégias de fortalecimento ao planejamento urbano e políticas sociais coesas. Assim, as periferias se expandiram, ora pela ocupação irregular, ora pelas práticas adotadas 
pelo Poder Público de retirar os cortiços dos centros, com incentivos à autoconstrução em áreas desprovidas de infraestrutura ou a oferta de provisão da moradia social sem integração urbana.

Portanto, as "escolhas" do local de moradia das famílias de baixa renda são determinadas pelo valor da terra urbana e pelas condições de acesso, aqui compreendidas como o conjunto de ações ou respostas do Poder Público para a obtenção da moradia social. Logo, a espacialização da moradia no território urbano é determinante para o acesso ou a segregação das famílias aos serviços como água, luz, esgoto, educação, oportunidade de emprego e transporte. Portanto, "a habitação não pode ser concebida como mero abrigo, pois ela representa a porta de entrada dos serviços urbanos" (VALLADARES, 1982, p. 30).

A dimensão da segregação ou das dificuldades de acesso à moradia pela população de baixa renda pode ser mensurada em dados. Estima-se, com base nos estudos realizados pela Fundação João Pinheiro em parceria com o Ministério das Cidades, que o déficit habitacional ${ }^{4}$ brasileiro calculado com base no Censo de 2010 apresentava naquele ano uma carência de 6 milhões e 940 mil unidades. Deste total, $85 \%$ estavam em áreas urbanas e $15 \%$ em áreas rurais. No período avaliado, o déficit habitacional urbano relativo às regiões metropolitanas foi estimado, em termos absolutos, em 3 milhões e 299 mil unidades (FJP, 2013).

\footnotetext{
${ }^{4}$ A Fundação João Pinheiro, responsável pelo levantamento do déficit habitacional no Brasil, conceitua-o da seguinte forma: "O conceito de déficit habitacional utilizado está ligado diretamente às deficiências do estoque de moradias. Engloba aquelas sem condições de serem habitadas em razão da precariedade das construções e que, por isso, devem ser repostas. Inclui ainda a necessidade de incremento do estoque, em função da coabitação familiar forçada (famílias que pretendem constituir um domicílio unifamiliar), dos moradores de baixa renda com dificuldades de pagar aluguel e dos que vivem em casas e apartamentos alugados com grande densidade. Incluem-se ainda nessa rubrica a moradia em imóveis e locais com fins não residenciais. O déficit habitacional pode ser entendido, portanto, como déficit por reposição de estoque e déficit por incremento de estoque" (FJP, 2013, p. 13).
} 
Tabela 1 - Déficit habitacional total e relativo ${ }^{5}$ referente ao total de domicílios particulares permanentes por situação de domicílio, segundo regiões metropolitanas $(\mathbf{R M})$ e regiões integradas de desenvolvimento (Ride) - Brasil 2010

\begin{tabular}{|c|c|c|c|c|c|c|}
\hline \multirow{3}{*}{ Especificação } & \multicolumn{6}{|c|}{ Déficit Habitacional Total } \\
\hline & \multicolumn{3}{|c|}{ Absoluto } & \multicolumn{3}{|c|}{ Relativo } \\
\hline & Total & Urbano & Rural & Total & Urbano & Rural \\
\hline RM Manaus & 111.365 & 113.795 & 5.571 & 22.5 & 22.8 & 18.1 \\
\hline RM Belém & 105.976 & 102.740 & 3.236 & 19.1 & 19.1 & 19.4 \\
\hline RN Macapá & 26.253 & 25.565 & 688 & 22.5 & 22.7 & 17.1 \\
\hline RM Grande São Luís & 64.576 & 53.588 & 10.988 & 18.0 & 18.0 & 17.9 \\
\hline RM Sudoeste Maranhense & 19.023 & 14.454 & 4.570 & 20.2 & 18.2 & 31.3 \\
\hline RM Cariri & 19.269 & 16.720 & 2.550 & 12.5 & 13.5 & 8.3 \\
\hline RM Fortaleza & 130.407 & 126.676 & 4.131 & 12.7 & 12.7 & 11.4 \\
\hline RM Natal & 53.501 & 50.520 & 2.981 & 13.7 & 14.3 & 8.4 \\
\hline RM João Pessoa & 21.550 & 18.763 & 2.787 & 10.2 & 11.8 & 5.3 \\
\hline RM Campina Grande & 47.587 & 44.916 & 2.671 & 13.8 & 13.9 & 12.3 \\
\hline RM Recife & 143.235 & 139.706 & 3.530 & 12.9 & 12.9 & 13.5 \\
\hline RM Maceió & 17.092 & 11.925 & 5.166 & 10.5 & 13.0 & 7.3 \\
\hline RM Agreste & 52.470 & 51.516 & 954 & 15.8 & 15.8 & 14.8 \\
\hline RM Aracaju & 34.611 & 33.650 & 961 & 14.2 & 14.1 & 16.2 \\
\hline RM Salvador & 142.255 & 139.888 & 2.367 & 12.6 & 12.6 & 12.1 \\
\hline RM Belo Horizonte & 167.124 & 165.090 & 2.034 & 10.0 & 10.2 & 5.1 \\
\hline RM Vale do Aço & 18.680 & 17.861 & 819 & 10.0 & 10.5 & 5.3 \\
\hline RM Grande Vitória & 57.810 & 57.377 & 434 & 10.8 & 10.9 & 5.5 \\
\hline RM Rio de Janeiro & 387.216 & 386.025 & 1.191 & 9.9 & 9.9 & 6.6 \\
\hline RM São Paulo & 793.048 & 787.552 & 5.496 & 13.0 & 13.1 & 9.0 \\
\hline RM Baixada Santista & 75.769 & 75.587 & 182 & 14.4 & 14.4 & 17.1 \\
\hline RM Campinas & 95.433 & 94.091 & 1.342 & 11.0 & 11.1 & 6.4 \\
\hline RM Curitiba & 87.706 & 80.334 & 5.372 & 8.6 & 8.7 & 7.2 \\
\hline RM Londrina & 22.777 & 21.448 & 1.329 & 8.8 & 8.7 & 11.7 \\
\hline RM Maringá & 19.520 & 18.981 & 539 & 8.8 & 8.9 & 5.4 \\
\hline RM Florianópolis & 31.647 & 30.217 & 1.430 & 9.4 & 9.7 & 5.6 \\
\hline RM Vale do Itajaí & 21.611 & 20.190 & 1.421 & 9.8 & 10.2 & 6.5 \\
\hline $\begin{array}{l}\text { RM Norte/Nordeste } \\
\text { Catarinense }\end{array}$ & 30.267 & 28.542 & 1.724 & 8.9 & 9.2 & 5.6 \\
\hline
\end{tabular}

\footnotetext{
${ }^{5}$ Até 2008 o déficit habitacional relativo era calculado dividindo-se o número de unidades de déficit pelo total de domicílios particulares permanentes. Para o estudo de 2010, esse indicador passou a contabilizar também os domicílios improvisados. Assim, o déficit habitacional relativo passou a considerar no denominador o somatório dos domicílios particulares permanentes e dos domicílios improvisados (FJP, 2013).
} 


\begin{tabular}{lcccccc} 
RM Foz do Rio Itajaí & 20.591 & 20.269 & 322 & 12.0 & 12.3 & 4.8 \\
RM Carbonífera & 12.371 & 11.010 & 1.362 & 7.0 & 7.5 & 4.8 \\
RM Tubarão & 8.199 & 6.844 & 1.355 & 7.1 & 7.5 & 5.6 \\
RM Lages & 10.459 & 8.861 & 1.597 & 9.6 & 9.7 & 8.9 \\
RM Chapecó & 11.511 & 9.583 & 1.927 & 9.1 & 9.4 & 7.8 \\
RM Porto Alegre & 125.803 & 123.510 & 2.293 & 9.4 & 9.5 & 6.0 \\
RM Vale do Rio Cuiabá & 36.935 & 33.922 & 3.012 & 13.1 & 13.0 & 13.8 \\
RM Goiânia & 95.377 & 94.649 & 728 & 13.9 & 14.1 & 5.2 \\
RM Bento Gonçalves & 18.850 & 17.835 & 1.015 & 7.9 & 8.0 & 6.0 \\
RM Pelotas & 17.019 & 16.213 & 806 & 8.6 & 8.8 & 6.1 \\
RM Osório & 7.529 & 7.093 & 436 & 7.8 & 8.5 & 3.4 \\
Ride-DF & $\mathbf{1 6 6 . 8 0 7}$ & $\mathbf{1 6 0 . 5 4 2}$ & $\mathbf{6 . 2 6 5}$ & $\mathbf{1 5 . 1}$ & $\mathbf{1 5 . 4}$ & $\mathbf{1 0 . 0}$ \\
Ride Teresina & 54.037 & 41.253 & 12.784 & 17.4 & 15.1 & 33.9 \\
Ride Petrolina/Juazeiro & 27.101 & 20.434 & 6.667 & 14.5 & 15.3 & 12.5 \\
\hline
\end{tabular}

Fonte: FJP (2013).

Considerando os dados exposto na Tabela 1 se observa que a Ride-DF apresenta o quarto maior déficit habitacional absoluto, na ordem de 166 mil unidades, em comparação com as RMs de São Paulo (793 mil unidades), Rio de Janeiro (387 mil unidades), Belo Horizonte (167 mil unidades). E o déficit relativo é o segundo maior, na ordem de 15,4\%, se comparado com as principais regiões metropolitanas do Brasil, ficando atrás apenas da RM de Belém.

Os resultados dos estudos da Fundação João Pinheiro indicam a gravidade e a especificidade das necessidades habitacionais em municípios localizados nas regiões metropolitanas e na Ride-DF. Os estudos que monitoram o déficit habitacional trazem apontamentos da importância e graus distintos das necessidades habitacionais, sejam elas quantitativas ou qualitativas, que viabilizam e orientam a formulação, o monitoramento e a avaliação de políticas públicas relacionadas à habitação e à promoção de estratégias de planejamento e gestão interfederativa.

Não menos importante, as pesquisas realizadas pelo Observatório das Metrópoles ${ }^{6}$ apontam que as distintas formas e direcionamentos das políticas municipais e estaduais voltadas para a habitação estão gerando externalidades negativas no que tange ao processo de uso e ocupação do solo urbano no conjunto metropolitano. Sublinha-se a fragilidade dos municípios para a implementação dos instrumentos

\footnotetext{
${ }^{6}$ A coletânea de pesquisas publicada pelo Observatório das Metrópoles (2013) traz um diagnóstico sobre a inserção urbana periférica dos empreendimentos habitacionais do Programa Minha Casa, Minha Vida nas regiões metropolitanas. No entanto, não integra a coletânea nenhum estudo sobre a Ride-DF.
} 
urbanos e de estratégias para o fomento a ações compartilhadas de planejamento e gestão no campo habitacional.

Segundo Royer (2013), o exemplo do Plano Nacional de Habitação (PlanHab, 2009) é elucidativo. Nele está expressa a necessidade de cooperação entre os Entes da Federação, para o enfrentamento das necessidades habitacionais em territórios de complexa dinâmica urbana:

\footnotetext{
Nas Regiões Metropolitanas e Aglomerados Urbanos, em se constatando a inexistência de quantidade de terra necessária para atender às necessidades habitacionais de interesse social em cada município isoladamente, o dimensionamento deverá ser feito de maneira articulada, se possível em planos estaduais ou metropolitanos onde se possa ter uma visão do território regional como um todo e planejar o dimensionamento das terras necessárias na região para Habitação de Interesse Social. (BRASIL, 2009, p. 127).
}

Ainda que as diretrizes do PlanHab expressem a necessidade de articulação e apresentem um olhar diferenciado para a gestão habitacional nas regiões metropolitanas, as estratégias políticas adotadas pelos governos em seus vários níveis na esfera habitacional indicam um vácuo de mecanismos de indução de fatores técnicos e orçamentários para a promoção de ações concertadas para o planejamento e gestão na provisão da habitação de interesse social em territórios de complexa dinâmica urbana, como, por exemplo, as Regiões Metropolitanas e Rides.

Para Bonduki (2013), a relação entre políticas habitacionais de interesse social em nível metropolitano revela a necessidade de articulação institucional e estratégias de gestão, controle social, regulação fundiária e desenho do financiamento de forma integrada entre os Entes federados com a participação de um conjunto de agentes e da sociedade civil.

Os problemas enfrentados pelo poder público podem condicionar, ou mesmo induzir, a localização de moradias em outro município com condições de acesso à terra e formas de prestação de serviços que facilitam a ocupação e localização de residências. Isso leva à necessidade de entender o problema das assimetrias e os limites políticos e socioeconômicos para uma gestão habitacional compartilhada em territórios metropolitanos.

Cabe então levantar a hipótese de que as formas de implementação da política habitacional, por meio de programas habitacionais sem estratégias de regime de governança metropolitana, podem estar induzindo o espraiamento urbano e gerando em médio prazo um passivo urbano. A verificação desta hipótese foi possível a partir da 
investigação da execução e gestão das ações no campo habitacional pelos entes da Federação que integram a Área Metropolitana de Brasília (AMB).

Os argumentos expressos nessa tese reafirmam a necessidade de mecanismos de cooperação e pactuação de diretrizes e estratégias que fortaleçam as ações no campo habitacional, dado o entendimento de sua vinculação direta com o uso e a ocupação do solo nas áreas de interesse metropolitano.

Bonduki (2013) exemplifica que um conjunto de ações implementadas de forma isolada por um município metropolitano gera impactos no conjunto de municípios em nível metropolitano. Por exemplo, a revisão das diretrizes de planejamento para novos eixos de ocupação urbana, a alteração nas legislações de uso e ocupação do solo, as ações de ampliação do perímetro urbano, a ineficiência para a provisão de habitações sociais ou a construção de grandes obras públicas geram impactos nos outros municípios metropolitanos.

Verifica-se, então, que o planejamento habitacional no Brasil tem sido pautado pela execução de programas habitacionais vinculados às iniciativas locais, em virtude da redefinição das competências dos entes federados com a aprovação da Constituição Federal de 1988. Também tem sido marcado pela articulação dos interesses dos incorporadores e agentes imobiliários e do governo federal no desenho e execução do orçamento destinado à habitação de interesse social.

\footnotetext{
A habitação é constitucionalmente uma das matérias de competência concorrente, ou seja, que pode ser tratada pelos três entes governamentais. Já a competência da gestão do uso e ocupação do solo é exclusivamente municipal, o que pode gerar dificuldade na articulação entre os entes federados. (ROYER, 2013, p. 157).
}

Em situações de forte integração econômica e social, a dinâmica do mercado habitacional e de seu planejamento não se restringe à gestão setorial das administrações locais. Ao contrário, as dinâmicas urbanas se reproduzem no tecido metropolitano. Nessas condições, a gestão local se mostra incapaz de prover estratégias habitacionais que melhor atendam à coletividade, haja vista que a dinâmica habitacional nesses territórios se estende para além dos limites administrativos, o que provoca externalidades negativas para o conjunto da metrópole.

Esse conjunto de realidades sobrepostas se configura um desafio ao planejamento das necessidades habitacionais, que são reproduzidas e resultantes da reprodução social e econômica no território metropolitano. Mas o rebatimento do ponto 
de vista administrativo ocorre nos municípios. $\mathrm{E}$ as respostas ao problema metropolitano têm sido marcadas por ações fragmentadas das gestões locais.

De um lado os municípios denominados dormitórios ${ }^{7}$ arcam com uma demanda habitacional que não foi gestada em seus limites administrativos e recebem ano a ano cada vez mais fluxo populacional, em decorrência das dinâmicas urbanas perversas, da escassez da terra, em virtude da sua valorização, e ausência de mecanismos de regulação fundiária, que expulsam a população de baixa renda do acesso à terra urbana bem localizada nas áreas-polos das grandes cidades, justamente as que oferecem os empregos.

De outro lado, o mercado de trabalho e consumo se realiza nos grandes complexos econômicos, recolhendo as externalidades positivas do consumir, a arrecadação de impostos, e também atendem massivamente à população dos municípios, sobrecarregando os serviços de saúde, educação, entre outros serviços, dada a baixa infraestrutura dos municípios de moradia da população trabalhadora.

Portanto, o problema de pesquisa se expressa nas ações descasadas dos programas federais destinados à provisão da habitação social, para os quais não foram vinculados mecanismos indutores de solidariedade metropolitana. Isso induz a uma execução pelos governos locais de políticas e programas no campo habitacional sem harmonização com os mecanismos de planejamento urbano e regional, agravando os problemas habitacionais, seja nos números expressivos do déficit habitacional, no preço elevado dos terrenos nas áreas centrais, nas dificuldades de equacionamento das necessidades habitacionais, o que induz a população a residir em outros municípios, muitas vezes condicionadas pela fragmentação das políticas habitacionais locais. Portanto, a tentativa de harmonização e de equacionamento dos problemas habitacionais se coloca como indutor para a integração do território.

Assim, a questão de alocação dos recentes investimentos habitacionais advindos do Programa Minha Casa, Minha Vida e sua execução desarticulada se constituem em importantes subsídios para analisarmos o problema da pesquisa e respondermos aos seguintes questionamentos resultantes dos desdobramentos da pesquisa realizada na Área Metropolitana de Brasília:

\footnotetext{
${ }^{7}$ Trata-se de municípios que, na literatura brasileira, são chamados de municípios-dormitórios, isto é, aqueles que apresentam graves problemas de provisão de infraestrutura urbana e reduzida capacidade de arrecadação e investimento, e são conhecidos como aqueles em que a população trabalha, diferente do local de moradia.
} 
$\checkmark$ Como e em que medida a alocação de investimentos federais em habitação tem fomentado estratégias de articulação interfederativa em territórios metropolitanos?

$\checkmark$ Quais as alternativas possíveis para dimensionar as necessidades habitacionais e as formas e regulação de uso e ocupação do solo de forma coordenada nos territórios metropolitanos em anuência à autonomia municipal?

A construção desse quadro situacional justifica, de um lado, a investigação e a identificação das externalidades negativas resultantes da implementação das políticas de habitação e seus impactos no território metropolitano. Por outro lado, permite trazer elementos que revelem o bônus do planejamento cooperado para ações necessárias na área de habitação de interesse social, quando esta se configure como função pública comum, isto é, um território privilegiado de pactuação interfederativa da política pública.

Destarte, o objetivo geral da pesquisa visa analisar as assimetrias das políticas habitacionais e as possibilidades de implementação de políticas cooperadas para a habitação de interesse social na Área Metropolitana de Brasília.

Ademais, os objetivos específicos que norteiam as inflexões das políticas habitacionais no recorte espacial da Área Metropolitana de Brasília são os seguintes:

Identificar as estruturas e os instrumentos de planejamento e gestão urbana do Distrito Federal e Municípios da Área Metropolitana de Brasília e sua capacidade de responder aos problemas urbanos de forma articulada;

Avaliar o atendimento do déficit habitacional por meio dos empreendimentos contratados ou em andamento do Programa Minha Casa Minha Vida na Área Metropolitana de Brasília; 
Analisar a territorialização dos recursos do programa Minha Casa, Minha Vida destinados à habitação popular na Área Metropolitana de Brasília;

Apontar atributos para a promoção de estratégias concertadas que induzam o planejamento do uso do solo, a fim de trazer desenvolvimento e atendimento às necessidades habitacionais em âmbito metropolitano.

A escolha do recorte espacial da Área Metropolitana de Brasília (AMB) para investigar as assimetrias e necessidade de uma governança para o planejamento habitacional traz algumas especificidades no que tange a sua delimitação e às possibilidades institucionais de ações. Daí a complexidade de investigar e apontar possibilidades de gestão habitacional em um território metropolitano complexo e conflitivo, cuja dinâmica espacial interfere na escala de provisão e gestão de serviços habitacionais.

Nesse sentido, compreender e caracterizar a dinâmica habitacional da Área Metropolitana de Brasília e apontar os entraves para os subsídios de ações cooperadas se revelam um caso sui generis de planejamento metropolitano no Brasil, dada a complexidade da escala institucional, política e econômica.

\section{Parte B: O recorte espacial: Área Metropolitana de Brasília (AMB)}

A delimitação para a investigação do problema de pesquisa, de que as formas fragmentadas de planejamento e gestão dos governos locais para a implementação das políticas habitacionais têm gerado graves problemas sociais e econômicos ao conjunto metropolitano, faz-se a partir da seleção do recorte espacial. O propósito é identificar as assimetrias e possibilidades de interação e coesão habitacional no território na perspectiva dos processos metropolitanos. Assim, é necessário um olhar mais focado nas experiências municipais e distritais na Área Metropolitana de Brasília (AMB). 
(AMB)

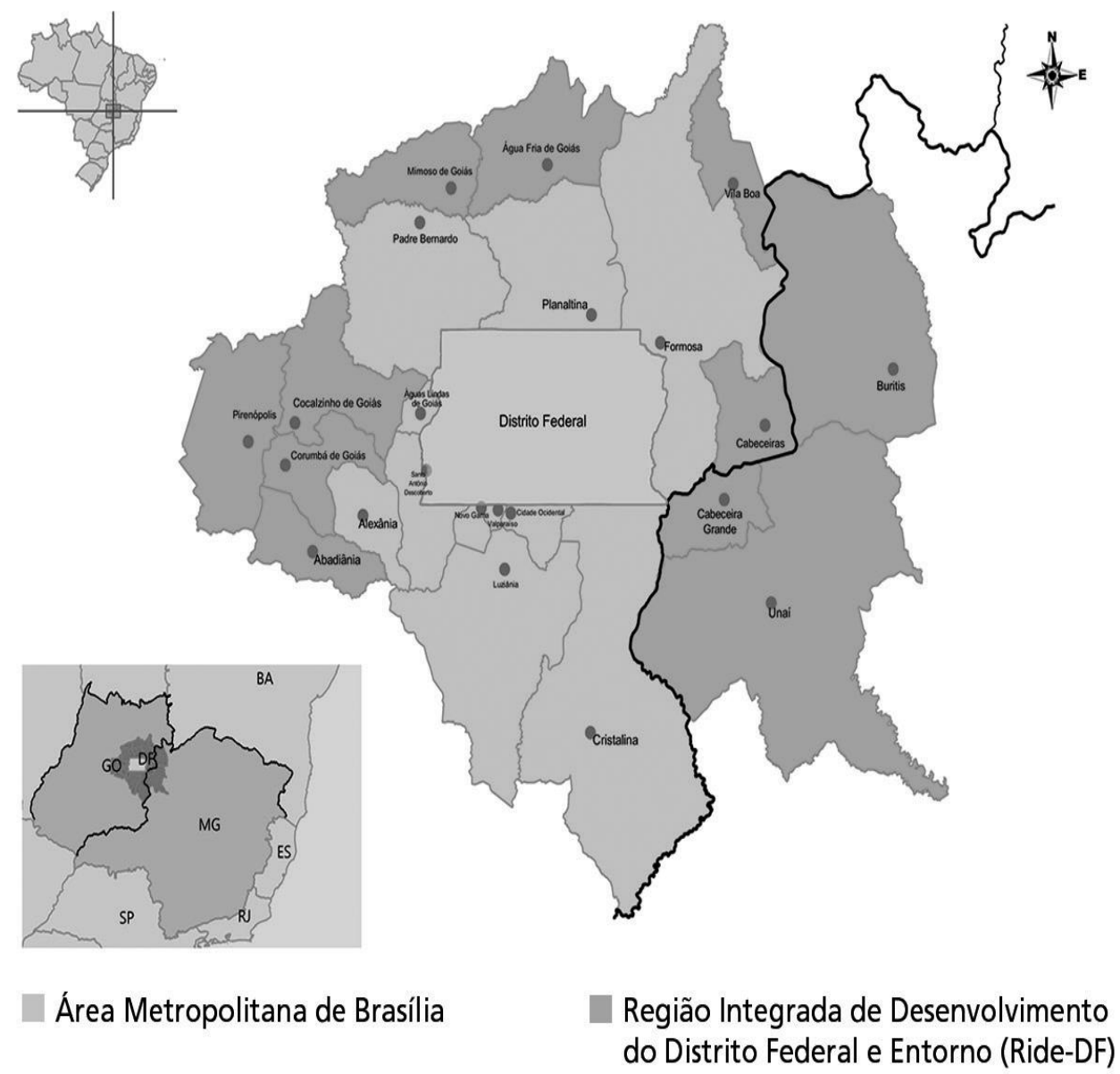

Fonte: Ipea (2013).

A escala de investigação (Figura 1) envolve o Distrito Federal e onze municípios goianos, quais sejam: Águas Lindas de Goiás, Alexânia, Cidade Ocidental, Cristalina, Formosa, Luziânia, Novo Gama, Padre Bernardo, Planaltina, Santo Antônio do Descoberto e Valparaíso de Goiás.

A delimitação dos onze municípios levou em consideração a Pesquisa Metropolitana por Amostra de Domicílios (CODEPLAN/PMAD, 2013) e dois estudos do Instituto Brasileiro de Geografia e Estatística (IBGE): o primeiro intitulado "Região de Influencia das Cidades" e o segundo, "Divisão Urbano-Regional".

Os estudos mostram similaridade na indicação dos municípios que apresentam relações metropolitanas, aqui compreendidas como: fluxos diários da população para o trabalho (commuting), deslocamentos para compras ou para obter serviços, alcance dos meios de comunicação (IBGE, 2008, 2013; CODEPLAN, /PMAD, 2013). 
Vale enfatizar que o recorte da Área Metropolitana de Brasília (AMB) é reconhecido pelo estado de Goiás, pelos governos locais e pelo Distrito Federal nas ações de acordos de cooperação para pesquisas e projetos futuros de ações de infraestrutura.

É preciso ressaltar que a seleção do recorte espacial apresenta especificidades, em comparação aos estudos que visam caracterizar o fenômeno metropolitano nas grandes cidades brasileiras, como São Paulo (ROLNIK, 2002, 2005; PASTENARK, 2009), Rio de Janeiro (RIBEIRO, 2004), Belo Horizonte (MONTE-MÓR, 2012, 2013), que partem da forma institucional da região metropolitana para apreender o fenômeno metropolitano e confrontar a forma institucional à realidade metropolitana.

Entende-se que a forma institucional de região metropolitana é aquela delimitada por lei estadual. No entanto, nem todas as regiões metropolitanas criadas apresentam natureza espacial metropolitana. Isto porque nem todas as unidades institucionalizadas como "região metropolitana" decorrem efetivamente do processo de metropolização. Assim, no Brasil, parte das regiões metropolitanas aproxima-se mais de um recorte regional convencional, sem qualquer evidência de características metropolitanas, resultando no divórcio entre metropolização e região metropolitana, bem como nos seus respectivos processos constitutivos (FIRKOSWKI, 2013).

No caso desta pesquisa, se faz necessário esclarecer que o estudo parte de um recorte que não possui reconhecimento institucional, ou seja, trata-se de recorte espacial que não foi criado e regulamentado por legislação. O recorte da AMB foi instituído pelos órgãos governamentais do Distrito Federal em parceria com os governos locais, para delimitar a influência metropolitana exercida pelos municípios goianos com o Distrito Federal, para melhor identificar as ações necessárias para o enfrentamento dos problemas metropolitanos.

A escolha do recorte da AMB foi fundamentada pelas pesquisas da Codeplan, que apontam a influência metropolitana nesse conjunto de municípios. Também foi constatado que os municípios que integram a AMB foram identificados como os de maior concentração de empreendimentos habitacionais do Programa Minha Casa, Minha Vida (PMCMV), fator relevante para esta pesquisa.

Vale enfatizar que a Companhia de Planejamento do Distrito Federal (CODEPLAN) tem procurado delimitar a real dinâmica metropolitana e os graus de interação dos municípios goianos, na tentativa de induzir estratégias de planejamento integrado. Nesse sentido, é recorrente nos estudos da Codeplan a denominação “Área 
Metropolitana de Brasília” (AMB). Inclusive, no ano de 2013, o órgão realizou pesquisa inédita, através da assinatura de um Acordo de Cooperação Técnica (ACT) com o Estado de Goiás e as prefeituras municipais goianas, para a realização do levantamento sobre o perfil socioeconômico da população e dos domicílios que compõem a Área Metropolitana de Brasília. O propósito era subsidiar ações de planejamento e gestão que potencializassem estratégias concertadas a partir da caracterização e abrangência das dinâmicas socioeconômicas.

Diferentemente, o recorte da Região Integrada de Desenvolvimento do Distrito Federal e Entorno (Ride) tem reconhecimento institucional, por decreto federal. As $\operatorname{Rides}^{8}$ se caracterizam como recortes regionais delimitados exclusivamente pela União, visando ao fortalecimento de estratégias interfederativas de municípios de diferentes unidades federativas, mas que integram o mesmo complexo geoeconômico e as ações de planejamento e insumos produtivos articulados a uma escala de desenvolvimento regional.

A Constituição Federal de 1988, Art. 21, IX, afirma que é atribuição exclusiva da União "elaborar e executar planos nacionais e regionais de ordenação do território e de desenvolvimento econômico e social". Já em seu Art. 43, dispõe: "Para efeitos administrativos, a União poderá articular sua ação em um mesmo complexo geoeconômico e social, visando ao seu desenvolvimento e à redução das desigualdades regionais".

Considerando o texto constitucional, no ano de 1998 foi aprovada a Lei Complementar n. ${ }^{\circ}$ 94, que instituiu a primeira Região Integrada de Desenvolvimento. Trata-se da Ride do Distrito Federal e Entorno, integrada pelos estados de Goiás, Minas Gerais, Distrito Federal, municípios goianos e mineiros e a União. Foi autorizada a criação do Programa Especial de Desenvolvimento do Entorno do Distrito Federal, conforme o Art. $4^{\circ}$ da Lei Complementar n 94/1998: “ouvidos os órgãos competentes, estabelecerá, mediante convênio, normas e critérios para unificação de procedimentos relativos aos serviços públicos, abrangidos tanto os federais e aqueles de responsabilidade dos entes federados".

Sabe-se que a Ride-DF não é reconhecida institucionalmente como uma região metropolitana, uma vez que a sua estrutura territorial integra Entes de distintas Unidades Federativas, quais sejam, os Estados de Goiás, Minas Gerais, municípios

\footnotetext{
${ }^{8}$ Atualmente existem três Rides: a Ride-DF, criada no ano de 1998, a Ride do Polo Petrolina (PE), Juazeiro (BA), e a Ride Grande Teresina (PI), Timon (MA), criadas no ano de 2001.
} 
goianos e mineiros e o Distrito Federal, ao passo que as regiões metropolitanas institucionalizadas possuem caráter eminentemente estadual. ${ }^{9} \mathrm{Ou}$ seja, toda região metropolitana é criada pelo estado no qual se encontram e integram municípios de uma mesma unidade federativa e qualquer ação de cooperação implica estratégias intermunicipais e estadual.

Vale enfatizar que, no ano de 2015, o veto presidencial ao Art. 19 da Lei $n^{\circ}$ 13.089/2015, que aprovou o Estatuto da Metrópole, reafirmou a proibição do Distrito Federal de integrar região metropolitana. Já o Art. $4^{\circ}$ permitiu municípios pertencentes a diferentes estados integrarem regiões metropolitanas, com exceção do DF.

É preciso ressaltar que pesquisas acadêmicas e órgãos de planejamento governamentais têm inserido os municípios goianos pertencentes à $\mathrm{AMB}$ e que integram a Ride-DF na composição dos seus estudos sobre o processo de metropolização e caracterização das regiões metropolitanas. Fatores como alta densidade populacional, elevada concentração populacional e econômica, intensa mobilidade pendular e polarização que a Capital Federal, Brasília, exerce sobre um conjunto de municípios goianos são considerados para a inserção da Ride-DF nas pesquisas (OBSERVATÓRIO DAS METRÓPOLES, 2012).

Portanto, há especificidades na delimitação do recorte desta pesquisa, como, por exemplo: a) a escolha do recorte espacial não apresenta coesão do ponto de vista institucional para o reconhecimento de uma região metropolitana no Brasil; b) a RideDF é o único arranjo interfederativo reconhecido pela Constituição Federal que integra todos os Entes federativos, isto é, municípios, Estados, Distrito Federal e a União; c) o recorte da Ride-DF não apresenta similaridade com a realidade dos processos metropolitanos que se constituem, ou seja, o fenômeno metropolitano está presente na articulação de um conjunto de municípios goianos com a Capital Federal - Brasília. Portanto, a escala metropolitana que denominamos Área Metropolitana de Brasília não existe institucionalmente, mas pauta a agenda de articulação política, econômica e de planejamento integrado do Distrito Federal e governo do Estado de Goiás, podendo ser priorizada nas ações de fomento na esfera da Ride-DF.

\footnotetext{
${ }^{9}$ A partir de 12 de janeiro de 2015, a aprovação do Estatuto da Metrópole permite, em seu Art. $4^{\circ}$, a instituição de região metropolitana ou de aglomeração urbana que envolva mmunicípios pertencentes a mais de um Estado, a ser formalizada mediante a aprovação de leis complementares, pelas Assembleias LegislativasLegislativas de cada um dos Estados envolvidos.
} 


\section{Parte C: Procedimentos Metodológicos}

A metodologia proposta para o desenvolvimento desta pesquisa envolve o arcabouço teórico sobre a crise habitacional e as respostas do Estado para o enfrentamento do problema, considerando, em especial, as respostas para o problema habitacional nos territórios metropolitanos e as conjunturas que trouxeram avanços e inflexões da política habitacional brasileira.

Os procedimentos adotados na elaboração do Capítulo 1 envolveram a contextualização das fases da estruturação das ações governamentais no campo habitacional, o volume de contratações vinculadas às suas respectivas fontes de financiamento e as mudanças na trajetória do financiamento habitacional.

Nessa primeira etapa da metodologia, dividimos em três períodos as ações governamentais no campo habitacional, com a finalidade de captar os momentos de mudanças, crises e avanços no desenho da política habitacional brasileira que viabilizaram a retomada dos investimentos de forma significativa com o lançamento do Programa Minha Casa, Minha Vida (PMCMV).

O primeiro período compreendeu os anos de 1940 a 1964. O estudo abordou a atuação dos Institutos de Aposentadorias e Pensões (IAPs) até a atuação da Fundação da Casa Popular (FCP).

O segundo período engloba os anos de 1964 a 1986. O estudo tratou da estrutura institucional e econômica para a provisão da habitação durante o período militar. Para tanto, optou-se pela focalização do Plano Nacional de Habitação, lançado no ano de 1964, e a instituição do Banco Nacional de Habitação (BNH), do Serviço Federal de Habitação e Urbanismo (SERPHAU) e do Sistema Financeiro de Habitação (SFH), incluindo a produção de unidades habitacionais nesse período e as causas que levaram à extinção do $\mathrm{BNH}$.

O estudo do terceiro período foi dividido em duas subseções. Na primeira, tratase das ações pontuais e fragmentadas do governo federal entre os anos de 1990 e 1998. Destacam-se o lançamento do Plano de Ação Imediata para a Habitação (PAIH), durante a vigência do governo Collor (1990-1992), e a indução da política habitacional, através da análise dos programas Habitar Brasil e Pró-Moradia, na vigência do governo de Fernando Henrique Cardoso (1995-1998).

A segunda subseção compreende os anos de 2003 a 2013. A análise abarcou a criação do Ministério das Cidades, instituído no ano de 2003, e a proposta de 
estruturação do setor habitacional contida no Plano Nacional de Habitação (PlanHab). Acerca desse Plano, interessam a sua regulação, com a criação do Sistema Nacional de Habitação de Interesse Social (SNHIS), e o novo rumo da atuação da política habitacional com o lançamento do Programa Minha Casa, Minha Vida (PMCMV) no ano de 2009.

Também, no terceiro período, procedimentos relevantes foram a identificação e a avaliação dos normativos e dos mecanismos de operacionalização das modalidades do Programa Minha Casa, Minha Vida, especialmente as voltadas para o atendimento da faixa de renda 1 , de baixa renda.

A segunda etapa da pesquisa envolveu a investigação da execução das políticas habitacionais pelo Distrito Federal e pelos governos locais integrantes da Área Metropolitana de Brasília (AMB). As estratégias metodológicas definidas para o desenvolvimento dos Capítulos 2 e 3 dividem-se em escalas de investigação, quais sejam, a escala metropolitana e a escala municipal.

Para a escala metropolitana foram adotados procedimentos que permitiram a confecção de um banco de dados do volume de empreendimentos contratados pelos municípios e pelo Distrito Federal via Programa Minha Casa, Minha Vida, a partir de solicitação aos órgãos, Ministério das Cidades, Caixa Econômica Federal e a Companhia de Desenvolvimento Habitacional do Distrito Federal (CodHab). Destacam-se a dificuldade para a obtenção de dados e o não cumprimento de prazos para o repasse de dados pelo órgão Caixa Econômica Federal ${ }^{10}$ conforme a lei de acesso à informação.

Destacam-se, também, a incongruência de valores e o volume de unidades nos banco de dados repassados pelos órgãos citados anteriormente, o que exigiu a elaboração de um banco de dados próprio, em que apenas os valores e o volume de unidades habitacionais convergentes pudessem ser objeto de análises.

A partir de elaboração do banco de dados foi possível estratificar a distribuição dos empreendimentos vinculados às modalidades do Programa. Esse procedimento permitiu a confecção de mapas inéditos do volume de contratação de unidades habitacionais na Área Metropolitana de Brasília (AMB) vinculado às faixas de renda e fontes de financiamento e o cruzamento com o atendimento do déficit habitacional.

\footnotetext{
${ }^{10}$ No Anexo K encontram-se exemplos de não atendimento das solicitações.
} 
$\mathrm{Na}$ escala municipal e distrital procurou-se identificar a inserção urbana dos empreendimentos selecionados no entorno imediato em relação ao acesso de serviços urbano áreas de lazer, acesso ao transporte público, e quando possível aos padrões de uso e ocupação do solo. Também foi realizada pesquisa bibliográfica e documental, por meio dos planos diretores, dos planos locais de habitação, da legislação urbanística e da capacidade institucional dos governos na continuidade, estruturação e implementação das ações de planejamento e ordenamento executadas pelos governos locais e o Distrito Federal, em articulação às diretrizes das políticas habitacionais.

Vale enfatizar a baixa capacidade dos governos locais e, em certa medida, do Distrito Federal em arquivar documentos relevantes das ações realizadas no campo habitacional anteriores às atuais gestões. É quase inexistente o conhecimento dos gestores municipais das ações no campo habitacional anteriores à atual gestão, o que dificulta a elaboração de estratégias e ações de continuidade entre o término de uma gestão e início de outra.

$\mathrm{Na}$ esfera do governo federal, foram realizadas visitas e entrevistas na Secretaria Nacional de Habitação (SNH) e na Secretaria Nacional de Acessibilidade e Programas Urbanos (SNAPU), vinculadas ao Ministério das Cidades. Na SNH, a entrevista teve como objetivo identificar os desafios da operacionalização do PMCMV nas regiões metropolitanas e na Ride-DF e a viabilidade de aperfeiçoamento nos seus regramentos para uma cooperação metropolitana. Na SNAPU, a entrevista teve como objetivo verificar as estratégias de planejamento integrado voltado para os territórios metropolitanos.

Já na Superintendência de Desenvolvimento do Centro-Oeste (SUDECO), o foco da entrevista foi identificar as estratégias previstas para o fomento ao desenvolvimento da Ride-DF e verificar a existência de estratégias focalizadas para os problemas metropolitanos, bem como, a existência de ações para o tratamento da habitação como uma função de interesse comum.

Também foram realizadas duas visitas à Agência Goiana de Habitação (AGEHAB) e uma visita à Companhia de Desenvolvimento Habitacional do Distrito Federal (CODHAB/DF), vinculada à Secretaria de Estado de Gestão do Território e Habitação do Distrito Federal (SEGETH), para consulta e esclarecimentos aos planos habitacionais de interesse social e entrevistas com o diretor de produção habitacional. $\mathrm{O}$ procedimento de visita aos órgãos governamentais e prefeituras foi necessário, uma vez 
que os planos locais de habitação dos municípios goianos não estavam digitalizados e disponibilizados em versão on-line .

Nas visitas aos órgãos governamentais das Prefeituras foi possível uma aproximação com o dia a dia de trabalho dos gestores, além da possibilidade de identificar a capacidade de estrutura de equipamentos técnicos, o nível de capacidade técnica dos gestores e suas dificuldades. As visitas se limitaram às ações relacionadas ao planejamento urbano, em especial as questões habitacionais relacionadas à execução do Programa Minha Casa, Minha Vida.

Nesta etapa, também, foram realizadas entrevistas in loco com gestores de desenvolvimento urbano ou com prefeitos envolvidos para conhecer as dificuldades e a execução local dos programas habitacionais. Nas prefeituras em que os gestores ou prefeitos demonstraram indisponibilidade para a realização das entrevistas foram realizados cinco contatos telefônicos e contato via e-mail, com envio em formato digital das questões norteadoras das entrevistas, a fim de se obter respostas. A identificação das Prefeituras que concederam entrevistas e das que não retornaram os contatos encontram-se no Apêndice B.

Vale destacar que os resultados das entrevistas e das visitas aos órgãos governamentais serviram como indicativos para a compreensão dos avanços e das dificuldades que marcam as ações de planejamento, gestão urbana e habitacional. Além disso, contribuíram para a construção da avaliação da gestão municipal do desenvolvimento urbano considerando os seguintes aspectos: instrumentos de planejamento e gestão; estrutura da gestão; participação dos cidadãos na gestão e existência de ações compartilhadas como os entes federativos, como, por exemplo, arranjos intermunicipais ou interfederativos no campo da habitação. Para tanto, recorreu-se às consultas e tratamento dos dados referentes ao recorte de pesquisa contido na Pesquisa de Informações Básicas Municipais (Munic/IBGE) do ano de 2012, além de informações expressas nos respectivos PDOT, Plano Estadual de Habitação e no Plano Distrital de Habitação de Interesse Social.

Dada a impossibilidade de visitar todos os empreendimentos habitacionais em andamento nos municípios e no Distrito Federal pertencentes à Área Metropolitana de Brasília (AMB), por conta das questões que envolvem indisponibilidade de tempo, custeamento das visitas realizadas com recursos próprios e a necessidade da tramitação burocrática para a aprovação das autorizações para a realização de visitas aos empreendimentos, optou-se pela realização de visitas ao menos a um empreendimento 
destinado para a faixa 1 em cada município e no Distrito Federal. No entanto, esta estratégia precisou ser modificada, uma vez nem todos os municípios possuíam empreendimentos contratados e em execução para o atendimento da faixa 1.

A lista dos empreendimentos visitados encontra-se no apêndice G. Durante as visitas aos empreendimentos, registra-se que foram coletadas informações complementares com os beneficiários (moradores,) com a finalidade de identificar os pontos positivos e os problemas relacionados à infraestrutura da unidade e ao acesso a serviços urbanos. As principais informações coletadas com os beneficiários encontramse no apêndice $\mathrm{H}$.

Os resultados da aplicação dos procedimentos permitiram a construção de um quadro dos avanços e limites das atuais estratégias habitacionais executadas pelos governos na Área Metropolitana de Brasília (AMB). Também revelaram o descasamento na implementação das estratégias habitacionais que tem impactado no território dos municípios goianos com novos empreendimentos verticalizados para o atendimento de parte da população anteriormente residente no DF, evidenciando uma forte ação metropolitana no campo habitacional das construtoras. Ainda que os governos locais e o Distrito Federal, em graus diversos, reconheçam a relação metropolitana no campo habitacional, pouco se tem avançado em estratégias consorciadas para amenizar as externalidades negativas do descasamento das suas políticas habitacionais.

Assim, as entrevistas com os gestores ou prefeitos também abordaram os efeitos das políticas habitacionais de outro município ou do Distrito Federal e seus graus de dificuldades no planejamento e execução do programa habitacional em seu Município. Essa medida se revelou importante para identificar a capacidade dos gestores e prefeitos em reconhecer ou apontar estratégias de cooperação no campo metropolitano.

Ao final do capítulo foram elaboradas críticas ao descasamento das políticas habitacionais. Também se procurou elencar importantes elementos e ações viáveis para ações cooperadas no campo habitacional e para o enfrentamento da problemática metropolitana, considerando as dificuldades em harmonizar a legislação urbana. Ainda se levaram em consideração as estratégias apontadas pela Secretaria Nacional de Acessibilidade e Programas Urbanos (SNAPU) e da Secretaria Nacional de Habitação (SNH), ambas vinculadas ao Ministério das Cidades. Não menos importante, procurouse identificar as estratégias da Superintendência do Desenvolvimento do Centro-Oeste (Sudeco), que é a responsável pela implementação dos projetos e programas no espaço 
Ride-DF para a promoção da cooperação interfederativa que envolve as ações de melhoramento dos serviços urbanos reconhecidos como funções públicas de interesse comum, como é o caso da habitação.

Nas considerações finais resgatamos a importância das avaliações de políticas públicas relacionadas os programas habitacionais e seus graus distintos de especificidades. Trata-se de programa complexo, com vários objetivos, distintas modalidades e desenho para os territórios que apresentam distintas realidades e formas de operacionalização e consequentemente distintos efeitos e consequências na gestão urbana e na configuração espacial. 


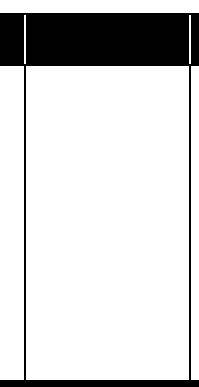

Objetivos

Plano Geral: Quais os entraves políticos e

econômicos para a promoção de estratégias

cooperadas para o planejamento da habitação de

interesse social nos territórios metropolitanos no

Brasil?

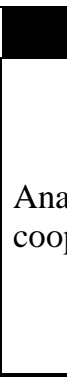

Objetivos

Analisar as assimetrias das políticas habitacionais e as possibilidades de implementação de políticas cooperadas para a habitação de interesse social na Área Metropolitana de Brasília.

\section{Habitação como uma questão metropolitana}

Como e em que medida a alocação de investimentos federais tem proporcionado a articulação interfederativa na área de habitação na AMB?

Quais as alternativas possíveis para dimensionar as necessidades habitacionais e as formas e regulação de uso e ocupação do solo de forma coordenada na AMB?
Identificar as estruturas e os instrumentos de planejamento e gestão urbana do Distrito Federal e municípios e sua capacidade de responder aos problemas urbanos de forma articulada;

Avaliar o atendimento do déficit habitacional por meio dos empreendimentos implementados ou em implementação do Programa Minha Casa Minha Vida na Área Metropolitana de Brasília;

Analisar a territorialização dos recursos do programa Minha Casa, Minha Vida destinados à habitação popular na Área Metropolitana de Brasília;

Apontar atributos para a promoção de estratégias concertadas que induzam o planejamento do uso do solo, a fim de trazer desenvolvimento e atendimento das necessidades habitacionais em âmbito metropolitano. 


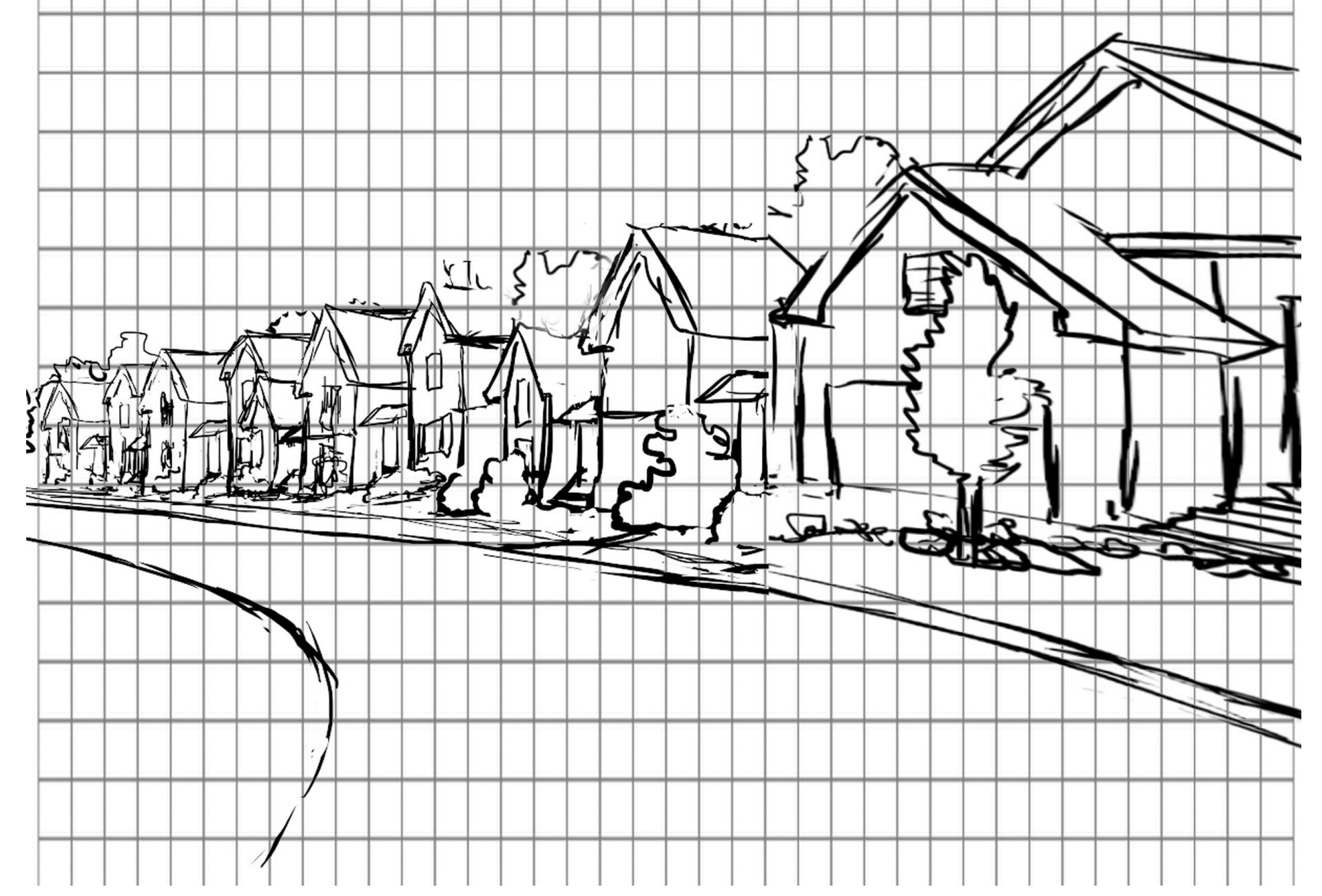




\section{Capítulo 1}

\section{As interfaces entre Política Habitacional e o Território}

\section{Por que habitação?}

Habitação com boas razões é uma das principais reivindicações da população pobre das cidades do país. É o fulcro no qual se apóiam todas as demais atividades da população. Educação, saúde, famílias social e economicamente integradas, amor, sexo e todas as demais necessidades para a fruição da vida saudável dependem da possibilidade de morar decentemente. E a população pobre sabe disso mais do que os melhores textos de sociologia, antropologia, psicologia social e demais disciplinas afins.

Cherkezian; Bolaffi, 1998 


\subsection{Território, Metropolização e Habitação}

Na literatura especializada denominam-se metropolização, em linhas gerais, os processos mais dinâmicos da urbanização. Eles se vinculam ao potencial de capilaridade do capitalismo em articulação com o setor terciário, tecnologias e seu potencial de inovação e criatividade que marcam a produção do espaço urbano.

Esse fenômeno em curso não ocorre de forma homogênea entre os países e suas áreas urbanas. Eles são permeados de diferenças, em virtude dos distintos contextos históricos e territoriais. Além disso, também há de se considerar as diferentes formas de ordenamento do território, escalas da economia e a implementação de políticas públicas, sobretudo as relacionadas à dispersão da moradia e aos investimentos em transporte público.

No entanto é notório o aprofundamento do processo de metropolização nas grandes áreas urbanas dos países, sejam estes desenvolvidos ou em desenvolvimento. A razão disso está no fato de que tais áreas são dotadas de concentração de pessoas, oportunidades e inovação e ao mesmo tempo apresentam significativos problemas urbanos, como escassez de moradia aos segmentos mais baixos, profundos processos de periferização da moradia social, precariedade na cobertura e acesso aos serviços básicos e dificuldade em implementar mecanismos de cooperação para a gestão dos territórios metropolitanos.

Segundo Randolph (2011), os processos de metropolização guardam, em certa medida, a manifestação dos processos de difusão e dispersão, redefinindo as centralidades, o espraiamento urbano e os múltiplos policentrismos. Portanto, a difusão e a dispersão têm distintas origens, mas, em linhas gerais, estão relacionadas à valorização da terra, sobretudo nas áreas centrais, e às ações do poder público em ampliar as redes de infraestrutura voltadas para a mobilidade e escoamento da produção. Assim, essa nova etapa do processo de urbanização - denominada metropolização caracteriza-se pela ampliação das áreas urbanas e pela interação socioeconômica entre as áreas-polos e sua região metropolitana.

Ainda de acordo com o autor, não se pode resumir o fenômeno da metropolização apenas à extensão das dinâmicas metropolitanas para áreas cada vez mais distantes e ao aumento da população, uma vez que o fenômeno da metropolização envolve novas articulações e relações entre o urbano e o rural. 
Para Fresca (2011), as análises mais recentes têm procurado evidenciar o papel que atividades terciárias exercem na produção do espaço metropolitano, articulado à descentralização política e à desterritorialização das atividades, o que tem colaborado para o desenvolvimento de novas escalas de centralidade dos serviços e novas lógicas urbana e de tipologias habitacionais (condomínios fechados estilo Alphaville). Concomitantemente a esse movimento econômico, há severas imposições para o acesso da população de baixa renda à moradia. E quando este segmento tem acesso à moradia, via de regra, sua localização é desprovida de infraestrutura e oferta de serviço de qualidade.

Vale lembrar que as análises acerca da segregação residencial, articulada aos processos capitalistas em contextos urbanos, permeiam uma vasta literatura. Acerca do assunto, Fresca (2011) aponta três lógicas gerais de segregação para as cidades latinoamericanas. Numa delas, predominavam nas áreas centrais a população de alto poder aquisitivo e na periferia a população de baixo poder aquisitivo, sobretudo até meados dos anos de 1850. Em outra, posteriormente até os anos de 1930, inverte-se a localização das moradias, em decorrência das profundas mudanças econômicas, com a implantação das indústrias nas áreas centrais, a implantação de sistemas de transporte e o aumento da oferta de trabalho destinado à classe trabalhadora. Tais elementos foram relevantes para que a população de alto poder aquisitivo substancialmente deixasse de residir nas áreas centrais. A outra lógica corresponde ao período após a década de 1930, em que há uma complexificação das formas urbanas e residenciais.

A América Latina apresentou um intenso processo de urbanização periférica após a década de 1940. A esse processo de urbanização vincula-se um aprofundamento da economia desses países em distintos graus ao processo de industrialização tardia, que reordenou e priorizou as atividades econômicas e por consequência modificou profundamente a forma e os conteúdos das cidades latino-americanas.

Segundo Harvey (1992), as políticas de substituição de importações implementadas nos países latino-americanos resultaram em uma industrialização periférica e competitiva que aprofundou a divisão territorial do trabalho, a concentração de investimentos e os empregos nas grandes áreas urbanas.

Com esse movimento, as cidades latino-americanas cresceram de forma acelerada, e a fragilidade e/ou as respostas inadequadas dos governos na região para enfrentar os problemas urbanos aprofundaram a ocupação informal, e consequentemente ampliaram o déficit habitacional na região nas décadas de 1970-1980. Para Wilson, 
Spink e Ward (2011), o processo de industrialização tardia nos países latino-americanos fomentou a criação de postos de trabalho com baixa qualificação e remuneração, sendo um dos condicionantes do aumento das formas de assentamento precário em áreas periféricas das metrópoles. Além disso, a incapacidade de oferta de trabalho formal, em certa medida potencializada pelos ajustes estruturais econômicos advindos da crise de 1980, contribuiu para a complexificação do fenômeno metropolitano periférico na América Latina.

$\mathrm{Na}$ ausência ou fragilidade de políticas governamentais que assegurassem o acesso à moradia, a ocupação informal, motivada pela ocupação das áreas públicas ou privadas, ou através da aquisição de lotes irregulares, foi a via encontrada pela população para construir sua moradia, em geral em áreas desprovidas de infraestrutura e distantes das bacias de emprego.

Para esse processo típico de urbanização periférica nas áreas urbanas dos países latino-americanos, o Banco Interamericano de Desenvolvimento (BID) estimou, com base em um levantamento realizado no ano de 2012 , que $37 \%$, o que equivale a 54 milhões de latino-americanos, apresentavam alguma carência relacionada ao déficit habitacional. Segundo Bouillon, Medellin e Boruchowicz (2012), há um número significativo de famílias urbanas que está abaixo da linha da pobreza, correspondendo a um quarto desse porcentual. A gravidade da pobreza e da precariedade habitacional torna o acesso e/ou os investimentos em habitação onerosos e desafiadores do ponto de vista da gestão para os governos latino-americanos. Estima-se que um terço da população latino-americana - aproximadamente 57\% dos trabalhadores urbanos - esteja vinculado ao mercado informal (RUPRAH, 2009).

Blanco et al. (2014) dimensionam a gravidade dos países latino-americanos em enfrentar o problema de carência ou inadequação da moradia para a população de baixa renda. Estima-se que, para que esse segmento populacional possa ter acesso a uma moradia de 40 metros quadrados - valor da moradia de US\$ 15 mil, com entrada de $10 \%$ e financiamento por um período de vinte anos com taxas de juros a $6 \%-$, aproximadamente $20 \%$ das famílias latino-americanas comprometeriam mais de $30 \%$ da renda, porcentual não recomendado, segundo a Un-Habitat. Portanto, o acesso ao crédito e os subsídios habitacionais via Estado são necessários para a elaboração e implementação das políticas habitacionais associadas a uma legislação urbana que promova a construção das casas em áreas bem localizadas ou áreas que recebam investimentos produtivos. Dito de outro modo, apenas as políticas e os recursos próprios 
dos governos locais e subnacionais não são suficientes para enfrentar as distintas carências habitacionais, o que somente é possível com a cooperação contínua do Estado ou dos governos centrais e com a adoção de novas formas de financiamento.

No Brasil a acelerada urbanização periférica e as respostas do Estado aos problemas urbanos, sobretudo os habitacionais, levam à necessidade de revisitar a trajetória da política habitacional com suas respostas e limites para o enfrentamento das necessidades habitacionais, articuladas ao desenvolvimento e ordenamento do território.

No jogo dessa relação, analisar as respostas do Estado para o enfrentamento da crise habitacional e seus efeitos no tecido urbano traz indicativos sobre sua eficiência ou apontamentos de que as estratégias adotadas podem ter contribuído para uma complexa fragmentação do tecido urbano, sobretudo o tecido metropolitano. E contribuído, assim, para o aparecimento de distintas e excludentes formas de habitar. É razoável apontar que o percurso das estratégias adotadas pelo Estado na política setorial habitacional se baseou na natureza política e econômica, transformando o solo urbano em um poderoso instrumento de acumulação capitalista e levando o Estado a buscar respostas conflituosas para o enfrentamento da precariedade urbana. Desse modo, o acesso ao direito à moradia digna ficou subordinado às decisões que potencializam o crescimento econômico, descasado dos ideais de desenvolvimento voltados para a redução das desigualdades, em especial aquelas que visam à desconcentração de renda e trabalho e garantia ao acesso com qualidade à moradia popular.

[...] o preço do solo tem impacto determinante na forma como se verificam o crescimento e a transformação das cidades, em cuja dinâmica o Estado exerce papel relevante e o solo urbano assume caráter estratificador. (LOW-BEER; SILVA, 1989, p. 28).

Acerca do papel relevante do Estado, Lojkine (1997) esclarece o importante papel intervencionista do poder estatal no território, uma vez que esta classe controla política e economicamente os aparelhos de Estado, o desenho, o alinhamento, a articulação e a implementação das políticas urbanas que produzem externalidades positivas e negativas à sociedade como um todo. Portanto, através da execução das políticas urbanas, sobretudo a habitacional, o Estado se consolida como um agente intervencionista no território.

Em linhas gerais, o Estado atua de duas formas articuladas, quais sejam: no planejamento e gestão territorial. Através do planejamento, estabelece as 
condicionalidades e o desenho do financiamento habitacional, e os governos subnacionais intervêm no território com a elaboração e implementação de diretrizes para a legislação urbana. Por exemplo, na esfera municipal, para coordenar a ocupação e o uso do solo e, assim, exercer a função reguladora em relação ao ordenamento do território.

A legislação de ordenamento do território, que no Brasil é formada pelo Plano Diretor (PD) e pela Lei do Uso e Ocupação do Solo (LUOS), determina os usos a serem dados às diversas zonas da cidade e acaba definindo ou limitando as condições para o exercício da função social a ser cumprida pela propriedade urbana. Além disso, a intervenção no ordenamento do território a partir das legislações determina as áreas onde a densidade deve ser incentivada ou controlada, ou seja, determina onde deverão ser construídas novas moradias, com base na oferta de infraestrutura, serviços e equipamentos. Também delimita áreas destinadas à habitação de interesse social e, digase de passagem, cada vez menos inseridas nas regiões centrais. Ainda, interfere na regulamentação dos instrumentos urbanísticos e tributários, os quais deveriam induzir o uso dos terrenos vazios ou subutilizados em processo de especulação imobiliária a exercerem sua função social.

O Estado pode intervir flexibilizando até mesmo os índices urbanísticos adotados (lote mínimo, recuos, taxa de ocupação, índice de aproveitamento, entre outros), o que condiciona a produção de uma determinada tipologia de moradias vinculada ao poder aquisitivo de determinada faixa de renda.

Por sua vez, na gestão do território, o Estado define as formas e condicionalidades para a implementação de infraestrutura, serviços ou equipamentos em determinada área em detrimento de outras. Trata-se de diferenciação entre áreas que gera a valorização imobiliária e a diferença de preço.

Diante desse cenário complexo, a tomada de decisão do poder público para o enfrentamento da realidade tem sido marcada, nos últimos anos, por uma gestão por demanda para responder aos problemas mais urgentes, que são muitos nas cidades brasileiras. Para Costa (2013), a gestão por demanda busca responder aos problemas emergenciais, para amenizar as situações cotidianas e cujos efeitos positivos possuem um prazo curto. Isto é, não se enfrentam os problemas, buscam-se soluções, em certa medida imediatistas, a fim de evitar ou reduzir as tensões, como, por exemplo, o caos no transporte urbano, a dificuldade no acesso ao direito de ter direito à moradia digna, pela população de baixa renda. 
Nessas condições, o pensar a gestão quase sempre se reduz a enfrentar os problemas urgentes, com remédio que tenha efeito imediato, preferencialmente no curto prazo para efeitos eleitorais. É evidente que a gravidade dos problemas urbanos deve ser enfrentada de forma rápida, mas o pensar a gestão dos territórios metropolitanos não pode se resumir a proposições de ações e estratégias que amenizem os problemas urbanos cotidianos. Faz-se necessário enfrentar as causas estruturais e repensar os próprios modelos da política habitacional e as várias escalas de gestão estratégica, para o enfrentamento de problemas comuns nos plurais territórios metropolitanos.

A compreensão das respostas do Estado diante da problemática habitacional não pode se dar de forma isolada, mas como expressão das relações com a sociedade, considerando as conjunturas históricas do espaço-tempo. Para Silva (1989), a implementação de uma política social, neste caso a política habitacional, representa uma ação do Estado em articulação aos interesses conflitantes da sociedade e de seus atores integrados ao processo social.

O Estado é percebido como produto das relações sociais, a partir do interior da sociedade civil, apresentando-se, por conseguinte, como uma expressão social histórica. Ao inserir-se no contexto econômico e político é obrigado a adaptar-se às conjunturas. Além de se encontrar a serviço da manutenção da estrutura social, se coloca como uma instância contraditória, e, como tal, assume também funções contraditórias, conforme a correlação das forças sociais presentes na sociedade. (SILVA, 1989, p. 10).

Hirsch (2010), em sua teoria materialista do Estado, afirma que o Estado estabelece relações com todos os estratos de classe e grupos sociais; no entanto, elas são seletivas e conflitivas.

As relações dos aparelhos de Estado com as classes ou grupos sociais não são estáveis, podem sofrer deslocamentos com a alteração das relações de força e das posições dos conflitos sociais. Isso pressupõe certa capacidade de adaptação da aparelhagem estatal em relação às modificações das relações sociais, mas ao mesmo tempo coloca em questão, de forma permanente, a sua unidade relativa e sua capacidade em garantir o conjunto de processos de produção social e desenvolvimento. (HIRSCH, 2010, p. 39).

A partir dessas relações conflitivas e complexas são costuradas a política estatal, a estrutura dos órgãos governamentais e a agenda governamental:

A política estatal resulta desse processo, e o seu conteúdo depende das relações socais de força, tanto da força relativa das classes dominadas como das relações de força no interior do bloco no poder. É por isso que ela pode adquirir diferentes conotações. Mas a sua formulação está sempre submetida a uma seletividade estrutural, sob o imperativo da manutenção do processo de reprodução socioeconômico que funda a garantia de valorização do capital. (HIRSCH, 2010, p. 558). 
Portanto, para balizar o percurso dos investimentos e inflexões da política de habitação de interesse social no Brasil e sua retomada nos últimos dez anos, é necessário considerar a nova articulação de forças e as alianças conflitivas formadas pelos distintos atores e as escalas de intervenção da política. De um lado, a escala nacional com suas diretrizes, a articulação no jogo econômico e a territorialização dos investimentos na rede urbana, bem como suas condicionalidades. De outro lado, a escala local onde a política habitacional se concretiza, em interface ou de forma descontínua com a política urbana e a gestão local, com indicativos de ônus para a estrutura metropolitana.

\subsection{Evolução, limites e desafios dos arranjos institucionais das Regiões Metropolitanas}

As respostas governamentais não foram suficientes para amenizar a gravidade do quadro urbano no Brasil, dada a restrição de investimentos em políticas sociais. Nessas condições a dificuldade dos governos na implementação de políticas voltadas à provisão da habitação social contribuiu para o crescimento das áreas informais e para a expansão urbana desordenada, que ultrapassava os limites administrativos dos municípios. A complexidade da expansão urbana para além dos limites administrativos e a necessidade de provisão de serviços urbanos para o atendimento da população foram fatores que em médio prazo contribuíram para a necessidade de elaboração de estratégias compartilhadas.

Considerando a necessidade de enfrentamento dos problemas urbanos que se estendiam para além dos limites administrativos dos municípios, alguns estados desenvolveram mecanismos de cooperação para o enfrentamento da problemática na tentativa de fomentar estratégias articuladas para a redução da gravidade da crise urbana.

Os estados, em parceria com os municípios, criaram grupos ou organizações dentro das pastas das secretarias para ações de cooperação. Por exemplo, o Estado de São Paulo criou, no ano de 1967, o Grupo Executivo da Grande São Paulo (GEGRAN); no Rio Grande do Sul, os municípios tomaram a frente do processo e, em Belém, a Prefeitura se articulou com o Serviço Federal de Habitação e Urbanismo - SERFHAU para o planejamento metropolitano (GARSON, 2007, p. 92). 
Em meados da década de 1970, a gravidade dos problemas nas grandes áreas urbanas e a centralização do financiamento na esfera do governo federal se constituíram em um importante elemento para a intervenção da União, a partir da regulamentação das regiões metropolitanas. "No período de maior centralização e concentração de poder e de recursos no nível da União, durante a ditadura militar, as Regiões Metropolitanas eram compreendidas como parte de uma estratégia de desenvolvimento nacional" (BALBIM et al., 2012, p. 116).

As principais ações do governo federal para o enfrentamento da crise urbana que viabilizaram pesados investimentos para seu enfrentamento foram articuladas com a criação, no ano de 1964, do Sistema Financeiro da Habitação (SFH), do Banco Nacional da Habitação (BNH) e do Serviço Federal de Habitação e Urbanismo (SERFHAU). Além disso, houve ações de desenvolvimento e estratégias de integração do território nacional contidas nos Planos Nacionais de Desenvolvimento (PNDs).

As primeiras regiões metropolitanas foram criadas em anuência às diretrizes da Constituição Federal de 1967 que, em seu artigo 157, § 10, dispõe sobre a instituição de regiões metropolitanas pela União.

A União, mediante lei complementar, poderá estabelecer regiões
metropolitanas, constituídas por Municípios que, independentemente de sua
vinculação administrativa, integrem a mesma comunidade sócio-econômica,
visando à realização de serviços de interesse comum. (BRASIL, 1967).

As primeiras nove regiões metropolitanas foram regulamentadas pela União através da Lei Complementar $n^{\circ}$. 14/1973, em consonância com o aparato legal da Constituição Federal de 1967, com o objetivo de implementar ações de cooperação de serviços reconhecidos como de interesse comum. As nove primeiras regiões metropolitanas criadas foram: a RM de São Paulo, a de Belo Horizonte, a de Porto Alegre, a de Recife, a de Salvador, a de Curitiba, a de Belém, a de Fortaleza e, em 1974, foi incluída a RM do Rio de Janeiro.

A Lei Complementar também reconheceu como serviços de interesse comum para a cooperação entre os entes os seguintes serviços: saneamento básico (abastecimento de água, esgoto, limpeza pública), uso do solo, transportes, sistema viário, gás canalizado, recursos hídricos e controle da poluição.

Segundo Garson (2007), a estrutura de gestão das regiões metropolitanas era composta pelo Conselho Deliberativo e pelo Conselho Consultivo, que deveriam ser mantidos com recursos do respectivo Estado. Para a composição do Conselho 
Deliberativo os membros eram nomeados pelo governador do Estado que, também, assumia o cargo de presidente do Conselho. O conselho era composto de um representante para o município da capital e um representante que deveria defender os interesses dos demais municípios.

As atribuições do Conselho Deliberativo versavam sobre o desenvolvimento de planos integrados e o estabelecimento de diretrizes para a operacionalização dos planos e programas que fomentassem a implementação de políticas para a prestação cooperada dos serviços comuns.

O Conselho Consultivo era composto de representantes dos municípios, porém a presidência do Conselho era assegurada ao presidente do Conselho Deliberativo, ou seja, o governador do Estado. Nessas condições, os interesses do poder do Ente estadual estavam assegurados, e os municípios tinham pouca margem para defender seus interesses quando estes fossem contrários aos do Estado.

Como atribuições do Conselho Consultivo, conforme estabelecido no Art. $4^{\circ}$ da LC $n^{\circ}$ 14/9173, competia-lhe "opinar, por solicitação do Conselho Deliberativo, sobre questões de interesse da região metropolitana", e sugerir ao Conselho Deliberativo a elaboração de planos regionais e a adoção de providências relativas à execução dos serviços comuns.

A criação das regiões metropolitanas pela União teve um papel fundamental na elaboração de estratégias para o desenvolvimento econômico e a integração do território nacional.

\begin{abstract}
Ao atribuir à União a competência para criar regiões metropolitanas, a Lei Complementar $\mathrm{n}^{\circ} 14$ subordinou as políticas de investimento em infraestrutura urbana ao controle federal, reafirmando o poder da União sobre as áreas mais dinâmicas do país e eliminando canais de representação da sociedade civil. Para isto contava com mecanismos financeiros vigorosos para financiar a infraestrutura e os serviços urbanos. Para o IPEA, do ponto de vista setorial, o Banco Nacional de Habitação era o mais importante instrumento federal. Em estudo apresentado em 1976, apontava que os empréstimos previstos para 1973/75 correspondiam a mais do dobro do orçamento do Estado de São Paulo em 1972 e a 84,0\% do orçamento da União para o mesmo ano. Sua atuação se ampliou, passando do financiamento da habitação para o do saneamento e atuando através de diversos fundos urbanos. (GARSON, 2007, p. 94). ${ }^{11}$
\end{abstract}

Os resultados da implementação das regiões metropolitanas e o repasse de investimentos para o enfrentamento da crise metropolitana viabilizaram vultosos investimentos nas áreas de saneamento básico, transporte e habitação. A instituição das

11 As considerações de Garson (2007) foram baseadas no estudo intitulado Política nacional de desenvolvimento urbano: estudos e proposições alternativas, elaborado pelo IPEA no ano de 1976 e que integra a Série Estudos para o Planejamento, n. 15. 
regiões metropolitanas e as condicionalidades dos acordos cooperados para o repasse de investimentos possibilitaram, em certa medida, ações de planejamento cooperadas e a priorização dos investimentos nas regiões metropolitanas em função, também, da execução do II Plano Nacional de Desenvolvimento (PND).

Segundo Balbim et al. (2012), o II PND reconhece que o Brasil se torna um país urbano e, com isto, vincula a questão urbana a uma estratégia de desenvolvimento e integração nacional.

As metrópoles nacionais, definidas concomitantemente, passam a ser um meio e instrumento da política do Estado central para desenvolver o país, por meio da canalização de investimentos para estes territórios. Além disso, os intensos movimentos migratórios para estas cidades e o crescimento do "milagre econômico" implicavam aumento da demanda por investimentos em infraestrutura social e urbana nestas metrópoles. (BALBIM et al., 2012, p. 117).

Sublinha-se que os estados eram as peças-chave na estrutura da gestão das entidades metropolitanas, pelo fato de serem eles os responsáveis pela definição da alocação dos investimentos. No entanto, os critérios de escolha dos territórios a receberem investimentos pelos estados, em sua maioria, foram permeados pelas disputas e interesses políticos clientelistas que definiam os municípios que seriam pleiteados, ou seja, nem sempre as escolhas eram pautadas nas necessidades coletivas ou prioritárias, o que fragmentava a concretização das obras e investimentos para o desenvolvimento integrado do território. Desse modo, as "escolhas" de alocação dos investimentos eram condicionadas pelas disputas e ganhos políticos, constituindo-se em um importante elemento de barganha para fins políticos.

A crise econômica mundial dos anos de 1980, bem como a crise do regime militar foram fatores impactantes para a gestão das regiões metropolitanas, uma vez que os investimentos em políticas sociais e de infraestrutura foram reduzidos e as estratégias governamentais priorizaram as recomendações dos organismos internacionais, como, por exemplo, a implementação de políticas restritivas aos investimentos em políticas sociais e estratégias de flexibilização do mercado nacional para o capital internacional. Sublinha-se que internamente o governo enfrentava críticas, em função do regime centralista e do aprofundamento da crise econômica.

A redução de recursos para investimentos em habitação, saneamento e infraestrutura bem como as sucessivas políticas setoriais aquém de financiamentos foram fatores que geraram insatisfação dos governos estaduais e municipais. Vale enfatizar que a restrição de investimentos federais e a insatisfação dos governos 
estaduais e municipais em dar continuidade às ações cooperadas impactaram seriamente na estrutura de planejamento das entidades estaduais metropolitanas. Estas foram enfraquecidas e as ações centralistas dos governos estaduais passaram a ser questionadas de forma mais emblemática pelos municípios.

Considerando o contexto econômico dos anos de 1990, pautado na competição fiscal entre os entes da Federação, a gestão metropolitana não se configurou como uma prioridade no planejamento para os estados e municípios. Nessas condições, a estrutura de gestão metropolitana dos anos de 1970, criada pela União e executada pelos estados, sofreu profundas alterações em alguns casos, com uma redução na atuação das entidades metropolitanas.

A partir do momento em que os estados passaram a ser competentes para a criação das regiões metropolitanas, cada um tem adotado diferentes procedimentos para a delimitação de suas regiões metropolitanas e estratégias de gestão distintas. Acerca do assunto, Branco, Pereira e Nadalin (2013) assinalam que não existem na estrutura dos estados brasileiros critérios comuns para a instituição de regiões metropolitanas, o que resulta em uma estrutura metropolitana nacional extremamente heterogênea, dispersa e sem características metropolitanas.

Balbim et al. (2012) denominam este processo "estadualização das RMs" ou "metropolização institucional”. Trata-se da ampliação do número de regiões metropolitanas sem relação com o território metropolitano e com os processos de gestão e regulação metropolitana:

[...] esse descolamento entre o reconhecimento de uma metrópole - ou seja, a identificação e a caracterização do processo de metropolização - e a instituição de uma RM tem se aprofundado, desde as alterações trazidas pela CF de 1988. As metrópoles brasileiras definidas como tal, nos anos 1970, têm seu Estatuto de RM acoplado ao processo histórico que levou à produção do espaço metropolitano. No entanto, diversas aglomerações urbanas e um conjunto expressivo de microrregiões, que sequer apresentam a ocorrência de núcleos urbanos conurbados e que partilhem um conjunto expressivo de funções públicas de interesse comum, possuem o Estatuto de RM, ainda que não constituam territórios reconhecidos como metropolitanos. Estas são regiões metropolitanas sem metrópoles. (BALBIM et al., 2012, p. 115).

No quadro atual, ${ }^{12}$ são reconhecidas institucionalmente 61 Regiões Metropolitanas, que apresentam distintos critérios para sua criação e em sua maioria os instrumentos de gestão criados encontram-se inoperantes.

\footnotetext{
${ }^{12}$ Até a data de março de 2014 consta a regulamentação, por Lei Estadual, de 61 Regiões Metropolitanas.
} 
A aceleração da "metropolização institucional" sem coesão com a agenda de desenvolvimento provoca um esvaziamento das possibilidades de cooperação e corresponsabilidades entre os Entes para o fomento ao planejamento integrado. Por sua vez, a União tem implementado políticas urbanas que, em sua maioria, se apresentam fragmentadas e se distanciam da possibilidade de articular mecanismos ou planos estratégicos que induzam a cooperação. Soma-se a estes fatores a reduzida atuação dos Estados na construção de uma agenda de desenvolvimento territorial.

Ademais, acrescente-se o agravamento dos problemas urbanos em função das questões de rivalidades interterritoriais das legendas da política partidária, impondo desafios para o planejamento territorial integrado, sobretudo na elaboração e implementação dos planos regionais. Essa situação torna ainda mais complexa a adoção de estratégias para a coordenação vertical e horizontal entre os níveis de governo, ficando o planejamento territorial e, em particular, a gestão metropolitana submetidos à lógica político-eleitoral ou a uma ação estratégica dos Estados, como tem ocorrido com os Estados de Minas Gerais, São Paulo e Rio de Janeiro (BALBIM et al., 2012, p. 121 ).

Para Losada (2010), a Constituição Federal de 1988 valorizou a esfera local, favorecendo os governos locais na construção de políticas sociais descentralizadas. Em relação ao planejamento e gestão territorial, a Constituição Federal também valorizou a escala local, sobretudo no que tange às competências das políticas urbanas. Já em relação à promoção de estratégias para uma gestão integrada, a União estabeleceu uma engenharia complexa: ao mesmo tempo em que transferiu a competência de criação das regiões metropolitanas aos Estados, eximiu-se da adoção de um regramento para o estabelecimento de estratégias e corresponsabilidades para a gestão metropolitana.

Nos anos de 1990, têm-se pontuais experiências de cooperação e mecanismos que poderiam induzir a cooperação entre os entes, com destaque para os consórcios públicos e convênios. Esses mecanismos podem ser utilizados para o fomento à cooperação entre os municípios, Estados e União. Sublinha-se que os consórcios e convênios não foram desenvolvidos considerando a problemática metropolitana e a necessidade de cooperação nas regiões metropolitanas, no entanto, podem ser objeto de pactuações para ações consorciadas nas regiões metropolitanas (LOSADA, 2010).

No início dos anos 2000, houve a regulamentação de importantes marcos legais, relacionados à política urbana, com a aprovação da Lei Federal 10.257/2001, conhecida como Estatuto da Cidade, que tornou obrigatórias a elaboração e a aprovação dos planos diretores aos municípios com população superior a vinte mil habitantes. Além disso, 
ainda que timidamente, trouxe uma preocupação com a questão metropolitana, quando tornou obrigatória a elaboração dos planos diretores aos municípios integrantes de RMs.

O Estatuto da Cidade traz a premissa de que as ações e tomadas de decisão do poder local e da sociedade podem trazer desenvolvimento ao município e que este planejamento no caso dos municípios inclusos em RMs necessita considerar a dinâmica metropolitana. $\mathrm{O}$ Estatuto da Cidade trouxe significativos avanços para $\mathrm{o}$ desenvolvimento urbano dos municípios. Contudo, ele não disciplina as possibilidades de implementação de forma cooperada dos instrumentos urbanos para a promoção do desenvolvimento nos territórios metropolitanos.

Vale ressaltar que nos últimos vinte anos houve um reforço nas estratégias de planejamento para a regulamentação das políticas urbanas, sobretudo no que diz respeito à elaboração de planos com condicionalidades ao recebimento de recursos federais. No entanto, a instituição de planos e programas priorizou a escala municipal, em detrimento da escala do planejamento integrado. Ainda que as leis orientem a necessidade do planejamento integrado, a falta de articulação das políticas setoriais e dos programas federais não assegura ou incentiva estratégias para o fomento ao planejamento integrado.

Como exemplo, cite-se que as leis que fixaram, em caráter de obrigatoriedade, a instituição de planos apresentam fragilidade no enfrentamento dos problemas urbanos na escala metropolitana pelos seguintes motivos:

a) $\quad$ A Lei $n^{\circ} 11.124 / 2005$, que versa sobre a elaboração do Plano Local e Estadual de Habitação de Interesse Social, não traz mecanismos de promoção a ações na esfera metropolitana;

b) A Lei $11.445 / 2007$, que instituiu a Política Nacional de Saneamento Básico, expressa que a esfera municipal deverá elaborar até 31 de dezembro de 2015 o Plano Municipal de Saneamento Básico;

c) A Lei $\mathrm{n}^{\mathrm{o}}$ 12.587/2012, que institui a Política Nacional de Mobilidade Urbana, obriga os municípios acima de vinte mil habitantes a elaborarem o plano municipal de mobilidade urbana até 2015;

d) $\quad$ A Lei $n^{\circ} 12.608 / 2012$, que institui a Política Nacional de Proteção e Defesa Civil - PNPDEC -, trata da elaboração dos Planos de Contingência de Proteção e Defesa Civil.

Embora grande parte dos planos sinalize a articulação integrada com o plano diretor, os planos são tratados de forma setorializada na estrutura interna dos municípios 
e também das secretarias do Ministério das Cidades, que estabelecem diretrizes para o repasse de recursos e não preveem ações relacionadas à implementação das políticas urbanas de forma integrada ou que incentivem a integração de políticas em territórios metropolitanos.

$\mathrm{Na}$ tentativa de suprir a lacuna de planejamento e promoção ao desenvolvimento urbano nas regiões metropolitanas, no ano de 2004 tramitou na Câmara dos Deputados o Projeto de Lei 3.460/2004, conhecido como Estatuto da Metrópole. O objetivo do projeto de lei era estabelecer um regramento nacional para a promoção de ações interfederativas nos espaços metropolitanos. O PL foi objeto de inúmeras críticas, como, por exemplo, em relação aos critérios para a definição de regiões metropolitanas, aos frágeis mecanismos de articulação para a gestão e inexistentes mecanismos acerca do financiamento de políticas integradas.

As críticas viabilizaram a realização de oficinas técnicas para melhorar as diretrizes e normas do projeto. Isso viabilizou a elaboração de um Substitutivo e sua aprovação na Câmara dos Deputados de forma célere no ano de 2014, permitindo sua inserção como Projeto de Lei da Câmara (PLC) 5/2014 no Senado Federal, o qual, de forma rápida, tramitou e foi aprovado no Senado ainda em 2014. Em janeiro de 2015, foi sancionado pela Presidente Dilma Rousseff, na Lei 13.089/2015, que institui o Estatuto da Metrópole em vigor desde o dia 13 de janeiro de 2015.

A Lei Estatuto da Metrópole abre um debate importante no cenário brasileiro, o que tem chamado a atenção de importantes setores do governo e entidades de representação dos municípios no que se refere à forma e conteúdo da lei para a promoção de ações cooperadas. Em contrapartida, esse debate não se articula de forma clara com os debates em andamento há mais de vinte anos, pela aprovação e regulamentação da Política Nacional de Desenvolvimento Urbano (PNDU), que traz a dimensão da questão metropolitana articulada ao desenvolvimento urbano.

Apesar de a União ter estabelecido um regramento nacional que versa sobre as regiões metropolitanas e instâncias de gestão partilhada para a promoção do desenvolvimento integrado, a lei não estabeleceu parâmetros e estratégias para a promoção de financiamento e o seu equacionamento, o que fragiliza as ações e pactuações necessárias ao financiamento, fato primordial para a execução partilhada das estratégias.

Em linhas gerais, observam-se pontuais ações, na esfera Legislativa, diante da necessidade de disciplinar as diretrizes nacionais para o enfrentamento dos problemas 
urbanos nos territórios metropolitanos. Na esfera do Judiciário, há o reconhecimento da necessidade de compartilhar ações em serviços que exerçam características comuns. E na esfera do Executivo há recomendações de medidas pontuais para a promoção do planejamento integrado. Ainda que tímido esse esforço das esferas governamentais, chama a atenção para a questão metropolitana e para os desafios visando à adoção de estratégias que viabilizem ações integradas no campo da política urbana.

Nesse sentido, uma revisão da trajetória das políticas habitacionais proposta na seção seguinte visa compreender as mudanças no desenho das políticas desde a criação dos Institutos de Aposentadorias e Pensões (IAPs), que excluiu grande parte da população brasileira ao acesso a uma moradia até a segunda fase do Programa Minha Casa, Minha Vida. O direcionamento das políticas, dos programas e das estratégias revela as respostas do Estado para o enfrentamento da questão habitacional, em especial nos aglomerados metropolitanos, e nos auxilia a entender as atuais escolhas e dificuldades brasileiras nas tentativas de se estabelecer arranjos cooperativos, bem como regramentos nacionais integrados que visem ao compartilhamento de estratégias de interesse metropolitano no campo da habitação.

\subsection{Dos Institutos de Aposentadorias e Pensões (IAPs) à Fundação da Casa Popular}

Os Institutos de Aposentadorias e Pensões foram criados ao longo da década de 1930 durante o governo de Getúlio Vargas (1930-1945) com a finalidade de regulamentar as relações de trabalho e interesses das categorias. Os Institutos também se constituíram em elementos-chave para a expansão do capitalismo, industrialização no Brasil e a intervenção do Estado na questão habitacional.

Entre os anos de 1930 e 1938 foram criados seis IAPs, quais sejam: o IAPM, representando a categoria dos trabalhadores marítimos; o IAPB, representando a categoria dos bancários; o IPAC, representando os comerciários; o IAPI, representando os industriários; o IAPETEC, representando os condutores de veículos e empregados das empresas de petróleo; e por fim o IAPE, representando a categoria dos estivadores. Vale lembrar que cada instituto tinha suas leis específicas e formas de funcionamento (BONDUKI, 2011).

De acordo com Farah (1983) e Bonduki (2011), com a criação dos Institutos todos os empregados e trabalhadores ativos pertencentes a essas categorias teriam de 
destinar-lhe cota-parte compulsória. Os recursos arrecadados pelos institutos eram aplicados em investimentos que garantissem a ampliação do seu fundo.

Os recursos dos IAPs podiam ser investidos na aquisição de títulos da dívida pública e na aquisição de prédios para a instalação da sua sede e serviços de saúde. No entanto, dada a dificuldade de recursos para importantes investimentos nacionais, os recursos advindos dos IAPs se constituíram em fontes alternativas para investimentos no setor estatal, como, por exemplo, na construção da Companhia Siderúrgica Nacional de Volta Redonda-RJ e na construção de Capital Federal - Brasília.

O uso de recursos previdenciários para investimentos sempre foi polêmico. Com a aprovação dos Decretos 19.469/1930 e 1.749/1937, os recursos dos IAPs poderiam ser aplicados em habitação. O primeiro decreto autorizava investimentos para a construção de casas aos associados, e o segundo decreto autorizava os IAPs a criarem suas carteiras prediais e regulamentava que os IAPs poderiam destinar até metade das suas reservas em financiamento para construções.

O decreto [1.749/1937] estabelecia condições de financiamento habitacional
tendentes a ampliar a demanda, com a redução das taxas de juros de $8 \%$ para
$6 \%$ (não existia atualização monetária); ampliação dos prazos de pagamento
de 10 para 25 anos; a elevação do limite máximo de financiamento; e a
autorização para a concessão do benefício para associados que já possuíssem
casa própria. (BONDUKI, 2011, p. 104).

Sabe-se que cada IAP funcionava de maneira distinta, em especial no que tange à operacionalização de recursos para financiamento habitacional e ao atendimento das necessidades dos seus associados de baixa renda para o acesso ao financiamento habitacional. Com a regulamentação do Decreto 1.749/1937 foram asseguradas, pela primeira vez no país, uma redução de taxas de juros e a ampliação dos prazos para os pagamentos relativos à casa própria. Essa medida ampliava a capacidade dos associados dos IAPs pertencentes ao segmento de baixa renda vislumbrarem a aquisição de sua casa própria.

Segundo Farah (1983), Varon (1988) e Bonduki (2011), o modus operandi de todos os IAPs em linhas gerais era estruturado em três carteiras de planos habitacionais. Os planos A e B eram voltados para o atendimento dos associados dos IAPs de baixa renda. $\mathrm{O}$ plano $\mathrm{C}$ tinha uma perspectiva econômica de proporcionar maior rentabilidade aos IAPs, já que não dispunha de nenhum mecanismo voltado para o atendimento do segmento de baixa renda. Os recursos do plano $\mathrm{C}$ eram destinados ao financiamento de construções de indústrias, asilos e edifícios, além do atendimento residencial para as classes média e alta. 


\title{
Quadro 4 - Características dos planos de financiamento dos IAPs
}

\begin{tabular}{|c|l|}
\hline \multicolumn{2}{|c|}{ Planos } \\
\hline Plano A & $\begin{array}{l}\text { Locação ou venda de unidades habitacas } \\
\text { residenciais adquiridos ou construídos pelos institutos, com o } \\
\text { objetivo de proporcionar aos associados moradia digna, sem } \\
\text { prejuízo da remuneração mínima do capital investido. }\end{array}$ \\
\hline Plano B & $\begin{array}{l}\text { Financiamento aos associados para aquisição da moradia ou } \\
\text { construção em terreno próprio. }\end{array}$ \\
\hline Plano C & $\begin{array}{l}\text { Empréstimos hipotecários feitos a qualquer pessoa jurídica ou } \\
\text { física, bem como outras operações imobiliárias que o instituto } \\
\text { julgasse conveniente. }\end{array}$ \\
\hline
\end{tabular}

Fonte: Adaptado de Bonduki (2011).

Considerando as características dos três planos e as escolhas governamentais, observa-se uma priorização de investimentos no plano $\mathrm{A}$, ou seja, a construção de conjuntos habitacionais destinados para a locação dos associados dos IAPs, na contramão de uma política e promessas do governo de Vargas de criar condições para o segmento de baixa renda ter acesso à casa própria.

Para Farah (1983), a priorização pelo Plano A valorizava o patrimônio dos IAPs, uma vez que os IAPs adquiriram uma quantidade de terrenos muito superior ao potencial de construção e disponibilidade de financiamento.

\begin{abstract}
Ao manter a propriedade dos conjuntos habitacionais, os IAPs preservaram e valorizaram um patrimônio que gerava renda de aluguel transformando-se numa espécie de rentistas estatais. [...]. O Plano A pode ser entendido como uma combinação de um programa de habitação social com uma forma de investimento das reservas previdenciárias, estatizando uma atividade - a construção de casas de aluguel - até então rentável e reservada ao setor privado. O Plano B, ao contrário, ao financiar a longo prazo e sem correção monetária a aquisição de imóveis, teria um menor retorno para os institutos. (BONDUKI, 2011, p. 107).
\end{abstract}

A produção de moradias para a população de baixa renda somente era acessível para trabalhadores associados a algum IAPs. Ainda assim, dada a elevada demanda dos associados em acessarem à casa própria, as diferenciações de atuação dos IAPs na seleção dos beneficiários configuravam-se em fatores que tornavam extremamente difícil ao trabalhador de baixa renda associado a um IAP ter acesso à moradia. Sublinha-se que casos de clientelismos marcavam a seleção e aquisição da locação e da compra à casa.

A intervenção do Estado na questão da moradia para o atendimento da população de baixa renda ocorreu a partir da reconversão de recursos dos IAPs para 
subsidiar a provisão da habitação. Entretanto, a política habitacional era fragmentada, isto é, apenas atendia, ainda que parcialmente, à problemática de trabalhadores ativos vinculados a algum IAPs. Os demais cidadãos tinham enormes dificuldades de obter algum tipo de financiamento, haja vista que o enquadramento da sua renda não permitia acesso a financiamento governamental.

Ao mesmo tempo, os financiamentos dos IAPs destinados para o Plano C foram essenciais para novas configurações urbanas, em especial na ampliação dos produtos imobiliários verticalizados e na provisão de infraestrutura urbana. Nesse sentido, observa-se nesse período uma priorização do Estado em destinar as terras urbanas bem localizadas para a produção dos empreendimentos vinculados ao Plano C. Por sua vez a produção de moradia de baixa renda nas áreas bem localizadas era quase inexistente.

Durante os 27 anos de atuação dos IAPs foram produzidas mais de 123 mil unidades habitacionais considerando os Planos A e B. Essa produção habitacional se concentrou, sobretudo, nas grandes áreas urbanas. Considerando que a atuação dos IAPs na provisão de moradias ocorreu até os anos de 1964, na época do censo de 1960 a população rural brasileira era mais numerosa que a população urbana.

Bonduki (2011) registra que no ápice de maior produção habitacional dos IAPs, isto é, a década de 1950, a estrutura populacional brasileira era formada por apenas 16,2 milhões pessoas localizadas em área urbana e um pouco mais da metade, isto é, 8,7 milhões, localizado em cidades com população superior a cinquenta mil habitantes, onde o problema habitacional assumia contornos dramáticos, como a ampliação de favelas e ocupação informal, sobretudo em municípios dos estados do Rio de Janeiro, São Paulo, Minas Gerais. 


\section{Quadro 5 - Produção Habitacional dos IAPs e da FCP (1937- 1964)}

\begin{tabular}{|lccc|}
\hline Órgão & Plano A & Plano B & Subtotal* \\
\hline IAPB & 5.511 & 12.347 & 17.858 \\
IAPC & 11.760 & 16.219 & 27.979 \\
IAPETC & 3.339 & 2.917 & 6.256 \\
IAPFESP & 742 & 25.053 & 25.795 \\
IAPI & 19.194 & 17.219 & 36.413 \\
IAPM & 882 & 2.451 & 3.333 \\
IPASE & 6.361 & & 6.361 \\
Subtotal & & & \\
IAPs & 47.789 & 76.206 & 123.995 \\
FCP & & & 18.132 \\
Total & & & 142.127 \\
\hline
\end{tabular}

*Não incluem a produção do Plano C Fonte: Bonduki (2011).

Com base nos dados gerais, sem as variações dos períodos, afirma-se que a partir dos anos de 1950 houve uma centralização de recursos no Plano B, ou seja, a produção da moradia, em vez da locação de imóveis. Essa última havia marcado fortemente a atuação dos IAPs nos anos de 1930. Vale enfatizar as dificuldades de obter dados quantitativos da produção do Plano C. Contudo, a literatura aponta que os investimentos e a produção habitacional do Plano C foram superiores aos dos Planos A e B de forma conjunta.

Os dados relevam que, com base na trajetória da habitação no país, os anos de operação dos IAPs viabilizaram a maior produção estatal de moradias destinadas para locação. Não menos importante, esses dados revelam a importância das primeiras intervenções estatais voltadas para a habitação no Brasil. Já em relação à territorialização da produção habitacional dos IAPs, observa-se, no quadro a seguir (Quadro 6), uma focalização da produção nos estados da região Sudeste. 


\section{Quadro 6 - Territorialização da Produção Habitacional dos IAPs e FCP (1937- 1964)}

\begin{tabular}{|lcccccc|}
\hline \multicolumn{1}{c}{ Órgão } & RJ & SP & MG & Brasília & Outros & Total \\
\hline IAPs - Plano & & & & & & \\
A & 26.504 & 8.950 & 1.742 & & 10.593 & 47.789 \\
IAPs - Plano & & & & & & \\
B & 21.187 & 16.478 & 6.635 & 7.315 & 24.621 & 76.206 \\
FCP & 3.993 & 2.959 & 4.248 & 1.520 & 5.412 & 18.132 \\
Total & 51.684 & 28.387 & 12.625 & 8.835 & 40.626 & 142.627 \\
$\%$ & 36.3 & 20 & 8.9 & 6.2 & 28.6 & 100 \\
\hline
\end{tabular}

Fonte: Bonduki (2011).

Com base no Quadro 6, verifica-se que existe uma concentração de investimentos em dois estados, quais sejam, Rio de Janeiro e São Paulo. Brasília se destaca, sendo a única cidade fora do eixo Sudeste que teve financiamento habitacional dos IAPs destinado à construção de casas.

Outro dado que se destaca é o ápice dos financiamentos e ações voltadas para a habitação nos anos de 1950 durante o período de atuação dos IAPs (1937-1964). O ápice da produção habitacional na década de 1950 pode ser explicado pelo crescimento vertiginoso da população urbana no país. Ao mesmo tempo, os anos de 1950 marcaram o período de maior disponibilidade de recursos dos IAPs destinados à habitação. Vale lembrar que os IAPs não se constituíam em um órgão governamental com finalidade específica para a execução da política habitacional, visto que o órgão dividia sua atuação como instituto previdenciário com a atribuição de intervir na problemática habitacional. 

Quadro 7 - Distribuição por período dos conjuntos residenciais construídos
pelos IAPs e FCP (Plano A)

\begin{tabular}{|l|c|c|c|c|}
\multicolumn{1}{|c|}{ Órgão } & $\mathbf{1 9 3 7 - 4 5}$ & $\mathbf{1 9 4 6 - 5 0}$ & $\mathbf{1 9 6 1 - 6 4}$ & Total * \\
\hline IAPB & 98 & 2.325 & 2.679 & 5.102 \\
\hline IAPC & 1.178 & 998 & 897 & 3.073 \\
\hline IAPETC/IAPE & & & 742 & 742 \\
\hline IAPFESP & 4.749 & 12.976 & 1.427 & 19.152 \\
\hline IAPI & 400 & 1.348 & 4.047 & 5.795 \\
\hline IAPM & 6.626 & 19.670 & 11.429 & 37.725 \\
\hline IPASE & 8.265 & 9.817 & 18.082 \\
\hline $\begin{array}{l}\text { Subtotal IAPs - } \\
\text { Plano A }\end{array}$ & & 27.935 & 21.246 & 55.807 \\
\hline FCP & 11.9 & 50 & 38.1 & 100 \\
\hline $\begin{array}{l}\text { Total (em } \\
\text { conjuntos com } \\
\text { data conhecida) }\end{array}$ & 6.626 & & & \\
\hline $\begin{array}{l}\text { Porcentagem por } \\
\text { período }\end{array}$ & 1.48 & 10.2 & 2.73 & \\
\hline $\begin{array}{l}\text { Média de } \\
\text { unidades por ano } \\
\text { em cada período }\end{array}$ & 736 & 5.587 & 1.517 & 1.973 \\
\hline $\begin{array}{l}\text { Porcentagem } \\
\text { média por ano em } \\
\text { cada período }\end{array}$ & & & & \\
\hline
\end{tabular}

*Não está inclusa a produção dos Planos B e C por período.

Fonte: Azevedo; Andrade (1982).

Em análise dos Quadros 5, 6 e 7, é possível notar a priorização dos investimentos e escolhas do Estado em intervir na problemática habitacional, em especial na região Sudeste.

Bonduki (2011) chama a atenção para a diferenciação na estrutura dos IAPs e o acesso a informações que facilitaram algumas categorias a acessar financiamentos habitacionais e a escolher as unidades habitacionais em detrimento de outras categorias.

[...] os bancários, por exemplo, eram uma categoria privilegiada, que recebia salários médios muito superiores aos demais trabalhadores e, em consequência, seu instituto, o IAPB, proporcionava um melhor atendimento habitacional para os seus associados. (BONDUKI, 2011, p. 110).

Em linhas gerais, os conjuntos produzidos através do Plano A destinavam-se para locação e apresentavam uma qualidade de construção e urbanística superior aos conjuntos produzidos a partir dos financiamentos vinculados ao Plano B. Portanto, os conjuntos do Plano A interessavam aos associados que pertenciam ao topo da pirâmide 
dos IAPs, e para a obtenção de um imóvel eram corriqueiras as práticas clientelistas. Já os conjuntos destinados ao Plano $\mathrm{B}$ não interessavam prioritariamente à classe média $\mathrm{e}$ alta, em decorrência da sua localização e qualidade urbanística. Por sua vez, esses conjuntos eram destinados aos segmentos de associados dos IAPs de classe de renda mais baixa (VALLADARES, 1982; FARAH, 1983; BONDUKI, 2011).

A crise dos IAPs ocorreu especialmente em função dos conflitos internos em destinar suas reservas para o financiamento habitacional. Essa destinação, para parte dos associados não deveria ser a prioridade do órgão. Por isso, ao longo de sua história, os conflitos entre a perspectiva atuarial e a necessidade de intervir na crise habitacional marcaram a história dos IAPs. A assertiva de Bonduki (2011) resume os conflitos que caracterizaram os IAPs:

Financiar ou alugar moradias abaixo do custo, sem dispor de recursos para dar continuidade à ação, não se configurava uma política social com objetivos de curto prazo, [...], uma política habitacional deveria estabelecer critérios de investimentos que dirigissem os subsídios para quem de fato tinha necessidade, definindo a origem dos recursos a serem financiados para que não houvesse depreciação de seus fundos. (BONDUKI, 2011, p. 108).

Somam-se aos conflitos internos as disputas políticas e os interesses corporativos dos IAPs, que inviabilizaram a unificação dos IAPs, vislumbrada pelo governo federal com a finalidade de ampliar a atuação dos órgãos e fortalecer o financiamento habitacional. O objetivo do governo federal em parte foi atendido com a aprovação do Decreto 7.536/1945, que criou o Instituto de Serviço Social Básico (ISSB) e trouxe a necessidade de unificar os IAPs, além de criar um órgão habitacional cuja responsabilidade seria de gerir as carteiras prediais. Caberia aos ISSB a execução das questões previdenciárias. Tal iniciativa indicava a necessidade de mudanças e a relevância de um órgão com atribuição específica para tratar da questão habitacional no país.

A unificação dos recursos dos IAPs era vislumbrada como uma possibilidade para ampliar a atuação dos órgãos no território brasileiro, assim como para aumentar o volume e a dimensão de suas construções. Um motivo de resistência à unificação dos Institutos era a diferença existente entre os recursos acumulados pelas diferentes carteiras prediais das classes trabalhadoras. (ALMEIDA, 2007, p. 78).

Ainda que os IAPs destinassem importantes recursos para o financiamento habitacional, diga-se de passagem que a atuação dos IAPs marcou a história do Estado, como a primeira ação de envergadura nacional para dispor de financiamento, ainda que o acesso ao financiamento fosse exclusivo para os associados. A estrutura de financiamento revelou-se frágil e sem viabilidade de uma ação contínua para os 
investimentos em longo prazo no setor habitacional. A fragilidade (para não dizer ausência) no estabelecimento de critérios e de retorno dos recursos destinados aos financiamentos foi um dos fatores que contribuíram para a extinção dos financiamentos habitacionais advindos dos IAPs e ao, mesmo tempo, para que o novo governo de Dutra reformulasse as ações no campo habitacional (BONDUKI, 2011).

Ademais, a crise econômica dificultou aos associados manter o pagamento das parcelas do financiamento e cumprir com o pagamento dos aluguéis em função dos reajustes. Ao mesmo tempo, os investimentos com novas produções demandavam novos custos aos IAPs relativos à construção civil. Acrescente-se o baixo retorno dos financiamentos destinados ao Plano B, em que foi estabelecido para pagamento das parcelas um prazo longo com juros baixos, o que ocasionou uma depreciação dos fundos dos IAPs e provocou uma grave crise e cortes em novos financiamentos habitacionais (BONDUKI, 2011).

Considerando este contexto de crise e as mudanças no quadro político ${ }^{13}$ foi criada a Fundação da Casa Popular (FCP), através do Decreto n 9.218/1946. A FCP (1946-1964) se constituía no primeiro órgão nacional com atribuição exclusiva para tratar das questões relativas à habitação social no país.

Caberia à Fundação da Casa Popular (FCP) unificar as fontes de recursos e a gestão da habitação no país. Assim, o planejamento habitacional deveria estar articulado com as questões de desenvolvimento urbano. Logo, as atribuições da FCP eram grandiosas, se comparadas com as ações pontuais e fragmentadas que marcaram a atuação dos IAPs. Isso sem contar que o novo órgão era responsável por todas as operações que estavam em andamento pelos IAPs relativas à questão da moradia. Isto é, todas as operações imobiliárias e cartas prediais deveriam ser transferidas para a FCP.

Entretanto, desde a criação do órgão nacional para planejar e gerir os recursos habitacionais houve forte oposição dos IAPs. Os IAPs eram contra as transferências dos recursos para a FCP. Também o setor da construção civil se posicionou dessa forma, pelo fato de o novo desenho de gestão habitacional ser centralizado pelo Estado, o que poderia provocar dificuldades no segmento para a construção de moradias privadas. Segundo Bonduki (2011), o temor da indústria da construção civil tinha relação com a dificuldade de o segmento privado obter material de construção ou mesmo haver falta

\footnotetext{
${ }^{13}$ A Fundação da Casa Popular foi criada no governo do presidente Eurico Gaspar Dutra (1946-1950).
} 
de material em virtude da operacionalização do novo órgão, o que poderia afetar a atividade lucrativa da produção de moradia de média e alta renda no país.

No projeto de criação da FCP estavam previstas diversas fontes de recursos. Acerca do assunto, Azevedo e Andrade (1982, p. 22) explicam:

\begin{abstract}
O dispositivo legal de sua criação previa, além de recursos tradicionais como doações, contribuições e transferências do Tesouro, empréstimo compulsório de pessoas físicas que adquirissem terreno de valor superior a 200 mil cruzeiros ou que construíssem edificações de área acima de $200 \mathrm{~m}^{2}$. Os primeiros estariam obrigados a empréstimo igual a $0,5 \%$ do preço da compra do terreno; os últimos, a 15 cruzeiros por metro quadrado construído. O prazo de resgate era superior a 30 anos, equivalendo, na realidade, a um imposto disfarçado. A intenção era nitidamente redistributiva: adquirentes de imóvel mais bem aquinhoados estariam subsidiando os menos favorecidos, mediante o financiamento da Fundação da Casa Popular.
\end{abstract}

No entanto, dada a força política dos setores de oposição nas atribuições e operacionalizações previstas para a atuação da FCP, houve mudanças significativas nas obrigações e fonte de recursos para a execução dos projetos a ela vinculados. Entre os aspectos que fragilizaram a criação da FCP, foi decisiva a quase inexistência de recursos de origem não orçamentária. Isso sem contar a inviabilização das medidas de unificação das carteiras prediais e a transferência de suas operações e recursos. Coube à FCP se contentar com recursos de outras fontes (BONDUKI, 2011).

Em relação às outras fontes de recursos previstas, foi implementada a contribuição obrigatória de $1 \%$ sobre o valor do imóvel adquirido cujos valores ultrapassem cem mil cruzeiros. No entanto, a criação dessa fonte se revelou pouco efetiva. Segundo Azevedo e Andrade (1982), dois fatores contribuíram para a fragilidade da arrecadação da contribuição obrigatória, quais sejam: a) o contribuinte dispunha de fortes incentivos para falsear o valor real, de modo que ficava isento de pagar a contribuição obrigatória; b) competia aos Estados cobrar a contribuição obrigatória e repassá-la à Fundação da Casa Popular -, mas nem sempre isso era feito, e quando a cobrança era realizada, não era repassada à Fundação.

Nessas condições, o novo órgão foi criado com enormes demandas e poucos meios e recursos para atender às demandas relativas à questão habitacional e de desenvolvimento urbano. Para a questão habitacional, foram direcionados recursos e ações que incentivassem a população de baixa renda a adquirir a casa própria. De acordo com Azevedo e Andrade (1982), a priorização da população a ser atendida pela FCP incluía o seguinte público:

a) trabalhadores em atividades particulares; 
b) servidores públicos ou das autarquias;

c) outras pessoas;

d) candidatos cuja renda familiar não excedesse a 60 mil cruzeiros anuais e que tivessem sob sua dependência econômica um mínimo de cinco pessoas.

Diferentemente das ações dos IAPs, que enquadravam somente associados para o atendimento à locação ou à aquisição de uma casa, a FCP incorporou trabalhadores e servidores. Esse enquadramento do perfil de pessoas se revelou um avanço significativo no atendimento da população de baixa renda nas ações de acesso à moradia. No entanto, observa-se que durante a vigência da FCP não houve uma priorização do quesito renda no desenho das ações da FCP, ou seja, a renda não foi um quesito definidor para o perfil de beneficiários.

Ao estabelecer o critério de renda máxima, a FCP flexibilizou o acesso de parcelas da população com renda de até 12,8 salários mínimos mensais ao enquadramento na parcela prioritária a ser atendida pela FCP, o que desvirtualizava o perfil de atendimento prioritário à população de baixa renda. Sobre o enquadramento da renda, Azevedo e Andrade (1982, p. 28) afirmam que "o número de dependentes tornava-se, pelo menos em teoria, o fator determinante na classificação e escolha dos candidatos".

Em relação à operacionalização dos projetos desenvolvidos pela $\mathrm{FCP}$, a unidade habitacional dos conjuntos habitacionais era padronizada: uma unidade de até $70 \mathrm{~m}^{2}$ para os projetos habitacionais de um piso e unidade habitacional de $60 \mathrm{~m}^{2}$ para os projetos de dois pisos. Em linhas gerais, os projetos integravam de dois a três quartos por unidade, dado o atendimento do critério de famílias numerosas (AZEVEDO; ANDRADE, 1982).

Já em relação ao papel do município, caberia a doação do terreno e sua responsabilidade de provisão de infraestrutura básica, como, por exemplo, água, luz e esgoto, conforme os termos contratuais estabelecidos entre o município e a Fundação da Casa Popular.

No que diz respeito à localização e priorização das unidades habitacionais construídas pela FCP, observa-se que majoritariamente os recursos e a produção de unidades foram destinados para as grandes cidades, onde os problemas habitacionais eram agravados em função da expansão urbana informal, da dificuldade de a população de baixa renda ter acesso à casa própria. Vale lembrar que a FCP foi o primeiro órgão 
no país a disponibilizar recursos para a população de baixa renda, o que ampliava a demanda da população pela possibilidade de ter acesso à casa própria e gerava graves dificuldades no atendimento a esta demanda. Vale assinalar que a FCP operava com parcos recursos para atender à enorme demanda das necessidades habitacionais da população de baixa renda.

\section{Quadro 8 - Produção Habitacional FCP por Tamanho de Municípios - 1946-1960}

\begin{tabular}{|lcccc|}
\hline $\begin{array}{l}\text { Tamanho dos } \\
\text { Municípios }\end{array}$ & $\begin{array}{c}\text { Unidades } \\
\text { Construídas }\end{array}$ & $\begin{array}{c}\text { Porcentagem } \\
(\%)\end{array}$ & $\begin{array}{c}\mathbf{N}^{\mathbf{0}} \text { de } \\
\text { conjuntos } \\
\text { construídos }\end{array}$ & $\begin{array}{c}\text { Porcentagem } \\
(\%)\end{array}$ \\
\hline Até 5 mil/hab. & 836 & 5 & 22 & 15 \\
De 5 a 10 mil/hab. & 914 & 5 & 24 & 17 \\
De 10 a 20 mil/hab. & 1.109 & 7 & 22 & 15 \\
De 20 a 50 mil/hab. & 2.586 & 15 & 35 & 25 \\
De 50 a 100 & 2.157 & 13 & 19 & 13 \\
mil/hab. & 9.362 & 55 & 21 & 15 \\
Mais de 100 & 16.964 & 100 & 143 & 100 \\
mil/hab. & & & \\
Total & & & & \\
\hline
\end{tabular}

Fonte: Azevedo; Andrade (1982).

Conforme os dados do Quadro 8, observa-se que foram construídas 11.519 unidades habitacionais em municípios com população superior a cinquenta mil habitantes. E que a produção habitacional em municípios com cem mil habitantes foi maior que das outras classes de tamanho populacional, com um total de 9.362 unidades. Assinale-se que a produção da FCP, apesar de reduzida, concentrou-se nos municípios com população superior a 100 mil habitantes. Sublinha-se também que a produção em municípios com população até cinquenta mil habitantes foi significativa, totalizando 5.445 unidades.

Com base na relação entre quantidade de conjuntos habitacionais e porte municipal, observa-se que em municípios de até cinquenta mil habitantes a quantidade de conjuntos habitacionais produzidos pela FCP foi maior que a produção em grandes municípios, totalizando $72 \%$. Esse fato pode ser explicado pelas características urbanísticas dos empreendimentos aprovados, tamanho do conjunto e atendimento da demanda habitacional. Azevedo e Andrade (1982) destacam também o fator espacial, isto é, quanto maior a quantidade de municípios atendidos pela ação, maior a expectativa em dividendos políticos. 
Já os Quadros 9 e 10 demonstram a espacialização das unidades habitacionais. O Quadro 9 revela a espacialização por regiões e o Quadro 10, a produção habitacional nos maiores municípios brasileiros.

Quadro 9 - Produção Habitacional da FCP por Região: 1946-1960

\begin{tabular}{|l|r|r|r|r|}
\hline \multirow{2}{*}{\multicolumn{1}{c}{ Regióes }} & \multicolumn{2}{c}{ Número de Casas } & \multicolumn{2}{c|}{ Número de Conjuntos } \\
\cline { 2 - 6 } & \multicolumn{2}{c|}{ Construídas } & \multicolumn{1}{c|}{$\%$} & \\
\hline Norte & & & 31 & 22 \\
\hline Nordeste & 2.317 & 14 & 10 & 7 \\
\hline Centro-Oeste & 1.860 & 11 & 84 & 60 \\
\hline Sudeste & 11.837 & 70 & 18 & 11 \\
\hline Sul & 950 & 5 & 143 & 100 \\
\hline Total & 16.964 & 100 & & \\
\hline
\end{tabular}

Fonte: Azevedo; Andrade (1982).

Quadro 10 - Produção Habitacional da FCP nos Grandes Municípios: 19461960

\begin{tabular}{|l|c|c|c|c|}
\hline \multicolumn{1}{|c}{ Municípios } & \multicolumn{1}{c}{$\begin{array}{c}\text { Número de } \\
\text { Unidades } \\
\text { Habitacionais } \\
\text { Construídas }\end{array}$} & $\begin{array}{c}\text { \% Total das } \\
\text { Construções } \\
\text { da FCP }\end{array}$ & $\begin{array}{c}\text { Número de } \\
\text { Conjuntos } \\
\text { Habitacionais }\end{array}$ & $\begin{array}{c}\text { \% Total } \\
\text { dos } \\
\text { Conjuntos } \\
\text { da FCP }\end{array}$ \\
\hline Rio de Janeiro & 3.993 & 24 & 5 & 3 \\
\hline $\begin{array}{l}\text { Brasília (Distrito } \\
\text { Federal) }\end{array}$ & 1.520 & 9 & 4 & 3 \\
\hline Belo Horizonte & 1.109 & 7 & 3 & 2 \\
\hline Recife & 588 & 3 & 1 & 1 \\
\hline Fortaleza & 456 & 3 & 1 & 1 \\
\hline Salvador & & & & \\
\hline São Paulo & & & & \\
\hline Porto Alegre & 7.666 & 46 & 14 & 10 \\
\hline Total & & & & \\
\hline
\end{tabular}

Fonte: Azevedo; Andrade (1982)

Os dados revelam que $70 \%$ das unidades construídas se concentram na região Sudeste, sobretudo nos municípios de Belo Horizonte e Rio de Janeiro. Vale dizer que, na época em que a FCP operou, o município de São Paulo não foi contemplado por financiamento habitacional da FCP. Esse fato demonstra a gravidade na priorização do atendimento dos problemas habitacionais e a influência política dos governantes de Minas Gerais na obtenção de financiamentos. Ao mesmo tempo se observa que a 
recente Capital Federal - Brasília - ocupa a segunda posição em comparação aos demais municípios que mais receberam financiamento habitacional da FCP.

Esse fato pode ser explicado pela transferência da Capital para o Centro-Oeste e pela demanda por moradias dos servidores públicos transferidos do Rio de Janeiro para a recente Capital.. Nessas condições, parte desta população foi atendida com recursos da FCP. Registre-se que os recursos e a quantidade de unidades habitacionais construídas foram aquém da demanda em todos os estados e no Distrito Federal. Vale ressaltar, que os recursos da FCP direcionados para o Distrito Federal minoritariamente atenderam a população de baixa renda, sobretudo os cidadãos que vieram construir a Capital e ali permaneceram, sem efetivamente os governantes terem estruturado estratégias para o atendimento desse segmento de renda.

Ao se considerar o déficit habitacional no período dos anos de 1950-1960 - na ordem de três milhões de unidades - e a produção habitacional aquém das necessidades habitacionais, conclui-se que a FCP não teve uma atuação abrangente para o enfrentamento da questão habitacional do país. No entanto, Azevedo e Andrade (1982), assim como Bonduki (2011), afirmam que as atuações dos IAPs e da FCP foram importantes e significativas em determinados períodos e regiões.

No período de 1937-1964, juntos os IAPs e a FCP produziram aproximadamente 143 mil unidades habitacionais destinadas para o segmento de baixa renda, o que equivale, segundo Azevedo e Andrade (1982), a 5,3 mil/unidades produzidas em média por ano. Ao correlacionarmos esse volume de produção com a quantidade de população urbana em municípios com população acima de 50 mil habitantes $-8,7$ milhões de habitantes nos anos de 1950 -, pode-se sublinhar que nessa categoria de cidades localizava-se a maior problemática habitacional e concentração do déficit habitacional. Os autores citados estimam que $10 \%$ da população localizada nos grandes centros urbanos foram atendidas pelas políticas habitacionais dos IAPs ou da FCP.

Ainda assim a atuação da FCP foi inexpressiva e seu papel foi limitado, diante do que se esperava de um órgão nacional de habitação e de desenvolvimento urbano com perspectivas de fomentar estratégias de infraestrutura urbana para melhorar as condições urbanas do país.

Por conseguinte, os reduzidos recursos orçamentários, a falta de diversidade de fontes de financiamento e a dificuldade institucional de gerir os recursos de forma estratégica em momentos de elevação da inflação, que impactava na redução de pagamento das prestações pelos beneficiários, contribuíram para o agravamento da crise 
de gestão na FCP. Uma das saídas para a crise foi a tentativa de criar mecanismos que proporcionassem o reinvestimento do capital, como, por exemplo, a criação de cartas hipotecárias (BONDUKI, 2011.)

Nesse sentido, buscava-se a adoção de novas estratégias de reorganização na estrutura e atuação da FCP, com a criação de um Banco Hipotecário e um Instituto Brasileiro de Habitação (IBH) - um novo órgão para substituir a FCP. Ao banco caberiam a execução da política e a decisão sobre as diretrizes e destino do orçamento; ao Instituto, o papel normativo.

Ainda que a carta de estratégias afirmasse a necessidade de uma reorganização dos rumos da política habitacional, sendo inclusive reiteradas no Plano de Assistência Habitacional, elas não foram implementadas para reorganizar as ações da FCP. Se tivessem sido implementadas na época, tais estratégias teriam marcado os rumos da política habitacional pós-década de 1964 no país, embora muito daquelas ideias permeiem as atuais decisões da política habitacional.

As principais estratégias contidas no Plano de Assistência Habitacional foram: a) a centralização da normatização do planejamento habitacional, isto é, estados e municípios deveriam se orientar pelos aspectos normativos para acessarem recursos; b) no que tange aos recursos, previam-se dotações orçamentárias, arrecadação advinda da renda de patrimônio, previsão de empréstimos internacionais, além de estratégias como a contribuição de um quinto sobre as folhas do trabalhador destinado à habitação, destinação de taxas relativas a contrato de imóveis aos investimentos habitacionais e; c) em relação às prestações das casas financiadas, essas seriam corrigidas anualmente de acordo com um índice a ser criado pelo governo.

No entanto, as estratégias não foram implementadas, e a partir dos anos de 1964 novos rumos políticos definiram as estratégias no campo habitacional. Com o golpe de 1964, a FCP foi extinta, pois representava uma estratégia clientelista e pouco efetiva para enfrentar o problema habitacional e, em seu lugar, foram implementados novos marcos no desenho e financiamento da política habitacional. 
1.3.1 Novos rumos da política habitacional: da criação do Banco Nacional de Habitação (BNH) à sua crise

O Banco Nacional de Habitação (BNH) foi criado em um contexto de golpe militar e diante da incapacidade dos órgãos anteriores como os IAPs e a FCP de enfrentarem a problemática da moradia em nível nacional, num cenário de ampliação dos problemas urbanos.

A problemática social vivenciada nas grandes cidades e também no meio rural era um elemento que evidenciava a necessidade de uma intervenção do Estado para o enfrentamento dos distintos níveis de problemas relacionados à moradia. Nesse contexto, a resposta do governo militar foi a elaboração de uma nova política habitacional centrada em uma nova estrutura de crédito habitacional que marcou significativamente as propostas habitacionais pós-governo militar.

O governo militar implementou a Lei Federal 4.380/1964, que instituiu o Banco Nacional de Habitação (BNH), o Serviço Federal de Habitação e Urbanismo (SERFHAU) e o Sistema Financeiro de Habitação (SFH), marcando uma nova fase de intervenção estatal na problemática habitacional, sobretudo com a criação de mecanismos financeiros que ampliaram a articulação entre o Estado e o setor privado. A articulação do Estado com o setor privado estabelecida na estrutura do BNH constituiuse em um fator determinante na provisão da habitação social no país.

Em linhas gerais, cabia ao BNH disciplinar o sistema financeiro e estabelecer as condições gerais em relação às aplicações do Sistema Financeiro da Habitação, quanto a garantias, juros, prazos, limites de risco e valores máximos de financiamento e de aquisição dos imóveis financiados no âmbito do Sistema Financeiro da Habitação. Ao SERPHAU cabia a elaboração de pesquisas e de estudos relativos ao dimensionamento do déficit habitacional no país, além do fomento a estratégias concernentes ao planejamento urbano e prestação de assistência técnica a programas regionais e municipais de habitação de interesse social (BRASIL, 1964).

A nova estruturação de provisão habitacional no país representou uma ruptura com as ações anteriores. Acerca do assunto, Azevedo e Andrade (1982) apontaram três elementos que elucidam os aspectos inovadores dos rumos da questão habitacional no país pós 1964:

Primeiro, trata-se de um banco, ao contrário das soluções anteriores, baseadas na Fundação da Casa Popular e órgãos previdenciários. Segundo, os financiamentos concedidos prevêem um mecanismo de compensação 
inflacionária - a correção monetária - que reajusta automaticamente os débitos e prestações por índices correspondentes às taxas da inflação. Terceiro, constitui um sistema em que se busca articular o setor público (na função de financiador principal) com o setor privado, a quem compete, em última análise, a execução da política habitacional. (AZEVEDO; ANDRADE, 1982, p. 61, grifo nosso).

A principal fonte financiadora para a provisão habitacional com a criação do $\mathrm{BNH}$, nos anos iniciais, advinha da porcentagem de $1 \%$ sobre o salário e, também, das letras imobiliárias que integravam a carteira de financiamento do banco, destinada aos locadores de imóveis com área superior a 160 metros quadrados, além dos recursos dos institutos de previdência, o Sesc, Sesi e Caixas Econômicas.

No entanto, essa fonte inicial de recursos foi insuficiente para atender aos objetivos da nova estrutura da política habitacional. Nessas condições, no ano de 1966 foi promulgada a Lei 5.107, que criou o Fundo de Garantia de Tempo de Serviço (FGTS). O FGTS é constituído pelo conjunto das contas vinculadas, cujos recursos são aplicados com correção monetária e juros, de modo a assegurar a cobertura de suas obrigações, cabendo sua gestão ao Banco Nacional de Habitação. Em relação ao montante de recursos que compõem o fundo, esses são provenientes conforme explicitado no Art. $2^{\circ}$ da referida Lei:

Para os fins previstos nesta Lei todas as empresas sujeitas à Consolidação das Leis do Trabalho (CLT) ficam obrigadas a depositar, até o dia 30 (trinta) de cada mês, em conta bancária vinculada, importância correspondente a $8 \%$ (oito por cento) da remuneração paga no mês anterior, a cada empregado, optante ou não, excluídas as parcelas não mencionadas nos arts. 457 e 458 da CLT. (BRASIL, 1966).

Com a criação do FGTS, foi expressivo o aumento do volume de recursos para a execução da política habitacional. De acordo com Aragão (1999) e Royer (2009), os recursos destinados ao $\mathrm{BNH}$ tinham caráter reembolsável e um custo financeiro não inferior a $5 \%$ por ano para o FGTS e de $8,5 \%$ para as cadernetas de poupança e letras imobiliárias.

O cumprimento dessas novas obrigações exigiria, naturalmente, que as aplicações do BNH e SFH como conjunto tivessem uma rentabilidade média suficiente para cobrir os custos financeiros e operacionais e assegurar um mínimo de reservas técnicas destinadas a compensar o risco de eventuais inadimplências dos tomadores dos empréstimos concedidos pelas entidades financiadoras. (ARAGÃO, 1999, p. 98).

A nova estruturação financeira segmentava a origem dos recursos a depender da faixa de renda do beneficiário. Além disso, conforme a faixa de renda e tipologia do produto foi estabelecida uma divisão dos agentes públicos e privados na 
operacionalização da política habitacional. Ou seja, o financiamento para a provisão de moradia social era segmentado para famílias enquadradas com renda mensal de um a três salários mínimos, cujo financiamento advinha de recursos do Fundo de Garantia do Tempo e Serviço (FGTS), que regulamentou a obrigatoriedade de recolhimento de $8 \%$ sobre as folhas dos empregados, por parte do empregador.

Os recursos do FGTS representaram a principal fonte de investimentos para habitação social pelo Estado. Cabia às Companhias Habitacionais (COHABs), que são órgãos federais autônomos, a execução da política habitacional destinada para a população de baixa renda com vistas à construção de unidades habitacionais e a melhorias habitacionais. Também foi previsto o atendimento do segmento econômico daquelas famílias enquadradas com rendimento superior a três e até seis salários mínimos. $\mathrm{O}$ atendimento a esse segmento coube às cooperativas habitacionais profissionais.

Já para a provisão da moradia para as famílias de classe média, entendidas como aquelas com renda superior a seis salários mínimos, os recursos advinham do Sistema Brasileiro de Poupança e Empréstimo (SBPE). O SBPE é o "responsável pela captação de recursos voluntários, através dos depósitos das cadernetas de poupança e venda de letras imobiliárias" (SILVA, 1989, p. 53). Para esse segmento de renda, a provisão habitacional estava a cargo dos agentes privados. Não havia participação direta de agências estatais como as Cohabs, que contam com estrutura de execução de habitação social.

A nova política habitacional foi estruturada em dois planos, Plano A e Plano B, que orientavam as linhas de financiamento do BNH. No Plano A, composto com recursos do FGTS, caberiam as ações de urbanização de favelas e fomento à produção de moradias para a classe baixa. Sublinha-se que nas novas diretrizes da política habitacional que regulamentou a operacionalização do BNH foram criados mecanismos de correção monetária em relação às parcelas dos financiamentos.

No Plano A, os reajustes das prestações eram baseados conforme a elevação do salário mínimo. Já no Plano $\mathrm{B}$, composto com recursos do SBPE para a provisão de moradia para a classe média, o reajuste ocorria a cada trimestre, considerando o valor da Unidade Padrão de Capital (UPC).

Azevedo e Andrade (1982) explicam que o cálculo relativo ao saldo devedor de ambos os planos ocorria trimestralmente tendo como base a UPC. No caso do Plano B já era utilizada a UPC para reajustar as prestações e o saldo devedor. Assim, o prazo 
devedor finalizava com o tempo de contrato. No caso do Plano A, as prestações eram ajustadas com base no aumento do salário mínimo, porém o saldo devedor era reajustado com base na UPC.

\begin{abstract}
Em termos teóricos, esse prazo poderia encurtar-se ou alongar-se, dependendo da relação entre a elevação do salário mínimo, que iria afetar a correção das prestações, e o reajustamento da UPC,fator determinante da atualização do saldo devedor. Somente na hipótese de os salários crescerem a taxas substancialmente mais elevadas que as da correção monetária é que se poderia abreviar o prazo de pagamento. Isso porque, fosse o salário elevado a taxas iguais ou ligeiramente superiores à da UPC, não se conseguiria compensar a diferença entre a correção trimestral do saldo devedor e a atualização anual das prestações. (AZEVEDO; ANDRADE, 1982, p. 69).
\end{abstract}

De acordo com assertiva de Azevedo e Andrade (1982), o reajuste das prestações no Plano A vinculava-se à elevação do salário mínimo, o que viabilizava a provisão habitacional e a correção das prestações evitando a depreciação dos financiamentos. Entretanto, o mecanismo de reajuste do saldo devedor significativamente estendia o prazo sem uma normatização de um prazo final máximo. Nessas condições, o BNH regulamentou a Resolução 01/1977, que estabeleceu um Fundo de Compensação das Variações Salariais (FCVS). Com a regulamentação desse fundo, as maiores alterações ocorreram nos reajustes relativos ao plano A. Vale lembrar que o Plano B recebeu nova denominação - Plano de Correção Monetária (PCM) -, e o Plano A passou a ser denominado Plano de Equivalência Salarial (PES), estendendo sua atuação para os mutuários do mercado econômico e médio.

\footnotetext{
A principal inovação do PES, em relação ao plano A, é a fixação do número de prestações a serem pagas pelos adquirentes. O mutuário pelo PES não tem motivo para se preocupar com o saldo devedor, já que a sua dívida é dada por um número de prestações constantes, expressa em função do maior salário mínimo vigente no país. O Fundo de Compensação das Variações Salariais assume a responsabilidade pelo saldo devedor dos financiamentos contratados. Na verdade, com a adoção do PES, o BNH assume o risco de subsidiar, uma vez terminado o prazo estipulado pelo contrato, não só parte das dívidas reais dos mutuários populares, mas também dos diversos setores da classe média, visto que estes últimos têm agora condições de utilizar esse plano. (AZEVEDO; ANDRADE, 1982, p. 70).
}

O objetivo da implementação do FCVS era atenuar o descasamento entre as prestações e o saldo devedor, em especial dos financiamentos destinados à moradia social. Royer (2009) explica que, ao final do contrato, se houvesse um saldo devedor e o contrato estivesse coberto pelo FCVS, caberia ao fundo restituir o restante do saldo devedor ao agente financeiro, de forma que o mutuário não arcaria com a diferença. Refere ainda Royer (2009, p. 52): 
O FCVS daria segurança para operações de longo prazo e era alimentado por contribuições dos próprios tomadores de financiamento imobiliário. Seria uma importante garantia para cobrir as eventuais distorções ocorridas ao longo de uma operação de crédito imobiliário de 10 a 15 anos, que era a média de tempo dos financiamentos à época. No entanto, o que se viu ao longo dos anos seguintes à sua implementação foi a utilização do FCVS para cobrir passivos contratuais criados por problemas dos índices de correção de prestações e de saldo devedor que superavam e muito a sua condição e mesmo o seu objetivo inicial. A inflação pós-choque dos juros americanos de 1979 disparou os valores das prestações e dos saldos devedores e fulminou o FCVS. Atualmente o FCVS detém um passivo de mais de 60 bilhões de reais, cujo devedor final é a União, e seus títulos são ainda utilizados por instituições financeiras para comprovar sua atuação na área habitacional.

As mudanças na composição dos recursos, os ajustes na forma de correção monetária das prestações e a operacionalização dos empreendimentos habitacionais setorializadas entre o poder público e o privado marcaram a primeira fase de estruturação e funcionamento do BNH.

Já na segunda fase, houve mudanças na atuação do Banco. Azevedo e Andrade (1987), Aragão (1999) e Royer (2009) denominam a segunda fase como a fase em que o BNH se transformou em um banco de segunda linha. Ou seja, por ser um banco era necessário criar mecanismos de remunerar o capital investido. No entanto, o atraso de pagamento e o abandono dos imóveis impactavam no volume de recursos do banco e por sua vez reduziam a capacidade de retroalimentação de investimento na política. Uma das saídas para transferir o ônus era repassar os créditos concedidos aos agentes, bem como a responsabilidade pelas operações. Acerca do assunto, Royer (2009, p. 55) explica o contexto da transformação do BNH em banco de segunda linha:

Em 1971, o BNH inicia uma importante mudança institucional culminando com a sua formatação em empresa pública (e não mais em autarquia) em 1973. Começa a operar como banco de segunda linha, ou seja, exerce o controle e a fiscalização das operações sem operar diretamente com o público. Alguns autores identificam nessa mudança uma busca pela eficácia no retorno dos investimentos bem como uma resposta às críticas por conta do péssimo desempenho do programa Mercado de Hipotecas.

A partir da operação do BNH como repassador de crédito para a busca de retorno à lucratividade e redução da liquidez, nota-se que a maioria dos créditos transferidos advinha das operações vinculadas à produção habitacional até a faixa de três salários mínimos, isto é, a produção de moradia social. Registre-se que o BNH não repassou esses créditos às Cohabs, que eram as operadoras dos programas de moradia social, em função de o BNH vislumbrar maior rentabilidade ao transferir o crédito para o setor privado. 
O repasse de créditos para o segmento de atuação privada significou, em certa medida, a operacionalização do privado na provisão de habitação social. No entanto, o repasse não evidenciou uma redução na inadimplência e um retorno dos investimentos. Acerca do assunto, Azevedo e Andrade (1987, p. 79) assinalam as dificuldades de operacionalização da habitação social via mercado privado:

\begin{abstract}
O problema habitacional para essa faixa de renda da população não pode ser simplesmente inserido no bojo de atividades das entidades do SBPE sem o forte e conveniente subsídio governamental, não apenas financeiro, que é indispensável, mas o subsídio inclusive sobre o aspecto de apoio logístico, desencadeado através de mecanismo que só o governo tem condições de movimentar. Os problemas de infraestrutura, no plano físico, e os problemas de educação, de policiamento, de mobilidade populacional, de perda de renda, no plano humano, não podem ser resolvidos apenas com soluções financeiras, de diferenciais de juros, altos ou baixos
\end{abstract}

Durante a atuação do BNH como um banco de segunda linha, foi criada uma série de programas habitacionais. Também o BNH passou a financiar uma diversidade de programas vinculados ao desenvolvimento urbano ampliando o leque de atuação. Por exemplo, no ano de 1973 foram criados os Fundos Regionais de Desenvolvimento Urbano. Já em 1974 foram criados os seguintes programas: Financiamento para Urbanização (FIMURB), Financiamento para Sistemas Ferroviários para Transporte Urbano de Passageiros (FETREN) e o Financiamento para Planejamento Urbano (FIPLAN); e no ano de 1975, foi criado o Programa Apoio ao Desenvolvimento de Polos Econômicos (PRODEPO) (MARICATO, 1987; ROYER, 2009).

$\mathrm{O} \mathrm{BNH}$ começou a disponibilizar financiamento para as obras complementares basicamente voltadas para a infraestrutura dos conjuntos habitacionais, com destaque para os seguintes programas: Financiamento para Urbanização de Conjuntos Habitacionais (FINC), Financiamento de Equipamento Comunitário de Conjuntos Habitacionais (FINBEC) e Financiamento de Lotes Urbanizados (PROFILURB) (MARICATO, 1987; ROYER, 2009).

Esses programas, em função de sua diversidade e objetivo, podem ser inseridos em três grandes linhas de atuação do BNH: a) provisão de habitação e obras de infraestrutura urbana vinculada aos conjuntos habitacionais; b) apoio a grandes obras de infraestrutura desvinculada de uso residencial e; c) apoio a obras de infraestrutura produtiva em nível regional e nacional, como, por exemplo, usinas hidrelétricas e aeroportos.

Outro fator importante desse período foi o lançamento, no ano de 1973, do Plano Nacional de Habitação Popular (PLANHAP) e do Sistema Financeiro de Habitação 
Popular (SIFHAP). A criação no ano de 1973 de um plano e sistema voltados para a habitação popular é o reconhecimento de que, desde a criação do BNH no ano de 1964 até a década de 1970, a política habitacional não estava atendendo de forma prioritária o segmento de renda baixa, e por sua vez caberia ao PLANHAP recorrigir os rumos da política habitacional. Com o lançamento do PLANHAP, observam-se, a partir do ano de 1975, resultados significativos na provisão habitacional para a classe popular. Os dados da ABECIP revelam a elevação da produção habitacional para o segmento de baixa renda pós-ano de 1975.

Quadro 11 - Financiamentos Habitacionais concedidos pelo SFH até 1980

\begin{tabular}{|l|r|r|}
\hline \multicolumn{1}{|c|}{ Segmento } & $\begin{array}{l}\text { Quantidade de } \\
\text { Unidades } \\
\text { Financiadas }\end{array}$ \\
\hline Mercado Popular* & 1.004 .884 & 35 \\
\hline Mercado Econômico ** & 627.824 & 21.8 \\
\hline Mercado Médio & 1.241 .175 & 43.2 \\
\hline Total & 2.873 .883 & 100 \\
\hline
\end{tabular}

* Cohabs e habitações construídas diretamente pelo BNH para população de baixa renda; ** Cooperativas habitacionais, Institutos, Mercado de Hipotecas;

*** SBPE e Recon;

Fonte: Azevedo; Andrade (1982). 
Quadro 12 - Financiamentos Habitacionais FGTS + SBPE: Unidades e Valores dos Investimentos $(\mathbf{R} \$)$

\begin{tabular}{|c|c|c|c|c|c|c|}
\hline \multirow[b]{2}{*}{ Ano } & \multicolumn{2}{|c|}{ FGTS } & \multicolumn{2}{|c|}{ SBPE (Cardeneta) } & \multicolumn{2}{|c|}{ Total $(\mathrm{SFH}=$ FGTS +SPBE) } \\
\hline & $\begin{array}{l}\text { Unidades } \\
\text { construídas }\end{array}$ & $\begin{array}{l}\text { Investimento } \\
\text { acumulado }\end{array}$ & $\begin{array}{l}\text { Unidades } \\
\text { construídas }\end{array}$ & $\begin{array}{l}\text { Investimento } \\
\text { acumulado }\end{array}$ & $\begin{array}{l}\text { Unidades } \\
\text { construídas }\end{array}$ & $\begin{array}{l}\text { Investimento } \\
\text { acumulado }\end{array}$ \\
\hline 1970 & 73.144 & 363.358 & 84.086 & 222.192 & 157.230 & 585.550 \\
\hline 1971 & 59.059 & 422.417 & 58.531 & 280.723 & 117.590 & 703.140 \\
\hline 1972 & 47.804 & 470.221 & 76.685 & 357.408 & 124.489 & 827.629 \\
\hline 1973 & 61.178 & 531.399 & 96.623 & 454.031 & 157.801 & 985.430 \\
\hline 1974 & 35.937 & 567.336 & 60.268 & 514.299 & 96.205 & 1.081 .635 \\
\hline 1975 & 77.417 & 644.753 & 64.512 & 578.811 & 141.929 & 1.223 .564 \\
\hline 1976 & 164.353 & 809.106 & 109.410 & 688.221 & 273.763 & 1.497 .327 \\
\hline 1977 & 209.709 & 1.018 .815 & 58.004 & 746.225 & 267.713 & 1.765 .040 \\
\hline 1978 & 279.516 & 1.298 .331 & 58.133 & 804.358 & 337.649 & 2.102 .689 \\
\hline 1979 & 274.238 & 1.572 .569 & 108.985 & 913.343 & 383.223 & 2.485 .912 \\
\hline 1980 & 366.808 & 1.939.377 & 260.534 & 1.173 .877 & 627.342 & 3.113 .254 \\
\hline 1981 & 198.514 & 2.137 .891 & 266.884 & 1.440 .761 & 465.398 & 3.578 .632 \\
\hline 1982 & 282.384 & 2.420 .275 & 258.745 & 1.699 .506 & 541.129 & 4.119.781 \\
\hline 1983 & 32.685 & 2.452 .960 & 44.562 & 1.744 .068 & 77.247 & 4.197.028 \\
\hline 1984 & 43.551 & 2.496 .511 & 42.807 & 1.786 .875 & 86.358 & 4.283.386 \\
\hline 1985 & 25.005 & 2.521 .516 & 34.652 & 1.821 .527 & 59.657 & 4.343 .043 \\
\hline $1986^{*}$ & 44.350 & 2.565 .866 & 62.312 & 1.883 .839 & 106.662 & 4.449.705 \\
\hline
\end{tabular}

Fonte: ABECIP, 2003.

Conforme os dados expressos nos quadros se depreende a forte concentração dos financiamentos destinados para as faixas de renda média e alta. Isso porque aproximadamente 64\% dos financiamentos de provisão de habitação do BNH (19701986) se concentraram nas faixas de renda média e alta, ao passo que para a faixa de renda baixa o porcentual foi de aproximadamente 35\% (AZEVEDO; ANDRADE, 1982; ROYER, 2009).

Nesse período, foram financiadas cerca de 400 mil unidades habitacionais por ano. Entre novas unidades e melhorias, o quantitativo foi significativo, porém insuficiente em comparação com a elevação do déficit habitacional - por volta de 8 milhões de moradias no ano de 1974. Durante a existência do BNH, ou seja, entre os anos de 1964 e 1986, foram construídas 4,3 milhões de unidades novas, sendo que 4 milhões financiadas com recursos do FGTS, para o setor popular, não necessariamente para a população de renda até três salários mínimos, e 1,9 milhão com recursos do Sistema Brasileiro de Poupança e Empréstimo (SBPE), ou seja, para a habitação voltada ao segmento do mercado (IPEA, 2010). 
Azevedo e Andrade (1982, p. 121), em análise dos recursos financiados pelo $\mathrm{BNH}$ por estratos de renda, constataram que:

[...] os mutuários com rendimentos mensais até 5,85 salários mínimos captam apenas 23,68\% dos recursos do Sistema Financeiro da Habitação. Dentro desse setor popular chamam atenção os estratos mais pobres, com renda até 3 salários mínimos, que não chegam a usufruir de $10 \%$ das aplicações.

Corrobora, com a análise dos autores, o fato de que o FGTS concentrava no período de 1979 quase $42 \%$ dos recursos do $\mathrm{BNH}$, índice que era insuficiente à provisão da moradia para a faixa de renda até três salários mínimos. Para Azevedo e Andrade (1982), a faixa salarial de um a três salários, marco da criação do BNH para assegurar a provisão da moradia para as classes mais baixas, não representou, na trajetória de todo o $\mathrm{BNH}$, o segmento prioritário de atuação do banco. Ao contrário, o foco da atuação do BNH se concentrou nas faixas mais altas, com valor superior a três salários mínimos.

Vale lembrar também que um número considerável de mutuários enquadrados na clientela das Cohabs se encontrava acima do limite de renda legal definido para as Cohabs. Ou seja, parte considerável dos mutuários das Cohabs se concentrava significativamente na faixa acima de três salários mínimos e, em função dessa elevação de renda, os conjuntos habitacionais construídos pelas Cohabs, que a princípio deveriam priorizar o segmento de renda até três salários mínimos, atendiam cada vez mais faixas de renda mais elevada.

Quando interpeladas sobre as causas da "elitização" de seus conjuntos, as Cohabs reagem de várias maneiras. Por um lado, afirmam que esta é a única forma de garantir um desempenho financeiro satisfatório. Além disso, apontam a validade social dessa estratégia, já que os setores beneficiados (três a cinco salários) são também pobres. Outras vezes, também encaram o fenômeno como uma decorrência estrutural que escapa aos seus raios de ação enquanto instituição. Segundo essa lógica, como o crescimento acelerado das metrópoles e cidades médias nos últimos anos não foi acompanhado por uma adequada oferta de novas habitações, ocorreu um processo de especulação imobiliária em larga escala. Nesse sentido, as cooperativas, que em princípio deveriam atender a baixa e a média classe média, são pressionadas por pessoas de estratos mais altos de renda para atendê-los. Aqueles setores preteridos por essas agências, e sem alternativas no mercado, pressionam por sua vez as Cohabs. (AZEVEDO; ANDRADE, 1982, p. 126).

No contexto nacional, as inúmeras críticas em relação à falta de aderência da política habitacional do $\mathrm{BNH}$ em atender à faixa de renda baixa explicam o contexto de crise e extinção do BNH. Além disso, somam-se outros, como, por exemplo, a elevação da inflação nos anos de 1980, o acelerado crescimento urbano atrelado ao espraiamento de moradias informais em todas as grandes cidades brasileiras, o aumento do 
desemprego, a baixa arrecadação do FGTS, as retiradas de investimentos das cadernetas de poupança, a incompatibilidade da renda das famílias e o reajuste das prestações dos contratos firmados com recursos do BNH. Em relação ao descasamento entre os reajustes das prestações e a elevação da inadimplência, Royer (2009, p. 59) assim explica:

\begin{abstract}
O recrudescimento da inflação, o reajuste das prestações feito com $80 \%$ da variação do salário mínimo (uma das opções oferecidas aos mutuários), índice sem relação com o que foi aplicado aos saldos devedores, gerou um descasamento importante entre o ativo e o passivo do financiamento. Em 1985 , os saldos devedores foram corrigidos em $246 \%$, creditado aos detentores de contas de poupança e do FGTS, enquanto as prestações foram reajustadas em 112\%. [...] Em 1986, por conta do Plano Cruzado, as prestações foram convertidas para a moeda então criada, o cruzado, pelas médias aritméticas das prestações dos seis ou doze meses anteriores a março de 1986, atingindo a totalidade dos contratos.
\end{abstract}

Outros fatores que contribuíram para a extinção do $\mathrm{BNH}$ foram a crise enfrentada pelo regime militar e as estratégias de mudança na estrutura política e econômica do país. Sublinha-se que a criação do BNH no regime militar contribuiu para a legitimação do fortalecimento político e econômico do governo militar.

A política habitacional foi duramente atingida no seu duplo aspecto de constituição. De um lado, a crise econômica acarretava altas taxas de inadimplência e diminuição do nível de empreendimento, pela escassez do financiamento público e pela progressiva queda do poder aquisitivo da população. De outro, as políticas do BNH, por estarem diretamente ligadas ao regime, uma das fontes de sua legitimação, passaram a ser questionadas juntamente com ele, tornando-se símbolo do passado que se queria enterrar. (ROYER, 2009, p. 59).

O BNH foi extinto no ano de 1986 e o crédito habitacional passou a ser regulamentado pelo Banco Central e pelo Conselho Monetário Nacional. E o agente financeiro passou ao comando da Caixa Econômica Federal.

\begin{abstract}
Após a extinção do BNH, o então Ministério de Desenvolvimento Urbano e Meio Ambiente ficou com a incumbência de formular a política habitacional e de desenvolvimento urbano. O Conselho Monetário Nacional, CMN, e o Banco Central do Brasil, BACEN, tornaram-se os órgãos controladores do sistema, cabendo ao primeiro as funções de orientar, disciplinar e controlar e ao segundo a fiscalização das instituições financeiras integrantes do sistema. À Caixa Econômica Federal coube a gestão do FGTS e a administração dos contratos ativos e passivos, bem como dos bens móveis e imóveis e do quadro de pessoal do BNH. (ROYER, 2009, p. 61).
\end{abstract}

Com a extinção do $\mathrm{BNH}$, os recursos destinados aos financiamentos habitacionais foram reduzidos e a atuação do governo federal priorizou os investimentos voltados para o atendimento da faixa de mercado. Nessas condições, a política 
habitacional voltada para o segmento de baixa renda ficou desestruturada e a atuação do Estado no que se refere à formulação de políticas e programas revelou um alto grau de fragmentação, em decorrência da alocação da "pasta" habitação sofrer alta volatilidade nos vários órgãos governamentais.

Vale lembrar que o contexto de desarticulação da política habitacional nos anos de 1980 coincidiu com a abertura da democratização no país e a aprovação da Constituição Federal de 1988, que regulamentou um capítulo sobre a política urbana no país e reconheceu a autonomia do Ente municipal.

Essas mudanças foram determinantes para as escolhas do Estado nos novos rumos do planejamento da política habitacional nos anos de 1990 e no modo de vida urbano pautado numa agenda estratégica de empreendedorismo. É nesse contexto que os rumos da política habitacional se vinculam às ações empreendedoras do poder público em parceria com o segmento privado.

Assim, o acesso à casa própria surge como oportunidade para enfrentar a crise e ampliar a acumulação do capital. É nesse contexto que, na seção a seguir, analisam-se as respostas do Estado no período do governo Collor (1990-1992). Durante seu governo, foi apresentado o Plano de Ação Imediata para a Habitação (PAIH), com a meta de construir, de forma célere, 245 mil unidades habitacionais em 180 dias a cargo da iniciativa privada, meta não cumprida. Também se analisa a recomposição dos fundos de financiamento habitacional durante o governo de Fernando Henrique Cardoso, que contribuíram para a ampliação de recursos, proporcionando a consolidação da operacionalização do mercado privado na provisão da habitação social. Além disso, analisam-se os ajustes realizados durante do governo de FHC, que viabilizaram a reestruturação da política habitacional pós-2003. 
1.3.2 Políticas habitacionais: do governo Collor (1990-1992) ao governo Fernando Henrique Cardoso (1995-2003)

Após a extinção do BNH e a fragmentação das ações do governo federal em planejar em médio e longo prazo estratégias que melhorassem as ações governamentais para o enfrentamento da questão habitacional, nota-se nos anos de 1990 uma ação fragmentada e pontual da esfera governamental no campo habitacional.

Acerca do assunto, Cláudio Hamilton M. Santos (1999) assinala que, em um período de apenas quatro anos, o então Ministério do Desenvolvimento Urbano e Meio Ambiente (MDU), criado no ano de 1985, transformou-se em Ministério da Habitação, Desenvolvimento Urbano e Meio Ambiente (MHU), depois em Ministério da Habitação e Bem-Estar Social (MBES) e, finalmente, foi extinto no ano de 1989, quando a questão urbana voltou a ser atribuição do Ministério do Interior.

\begin{abstract}
As atribuições na área habitacional do governo, antes praticamente concentradas no $\mathrm{BNH}$, foram pulverizadas por vários órgãos federais, como o Banco Central (que passou a ser o órgão normativo e fiscalizador do SBPE), a Caixa Econômica Federal (gestora do FGTS e agente financeiro do SFH), o ministério urbano do momento (formalmente responsável pela política habitacional) e a então chamada Secretaria Especial de Ação Comunitária, a responsável pela gestão dos programas habitacionais alternativos. (SANTOS, C. H. M., 1999, p. 19).
\end{abstract}

Os programas habitacionais pós-extinção do BNH se resumiram basicamente a programas alternativos para atender à faixa de renda baixa e amenizar a gravidade da crise da moradia.

O dinamismo dos programas alternativos da época voltados às classes de renda mais baixa contrasta, entretanto, com o desmanche da área social do SFH ocorrido no período em questão. O fato é que os programas alternativos eram voltados para a mesma clientela do segmento social do SFH, ou seja, as populações com renda inferior a três salários mínimos, e ofereciam unidades habitacionais em condições muito mais favoráveis do que este último (dado que eram altamente subsidiados). Além disso, as COHABs, principais responsáveis pelo atendimento às demandas sociais do SFH até então, tiveram seus financiamentos bastante restringidos pelo governo central, a pretexto de contribuir para a diminuição do endividamento de estados e municípios com a União. Tal fato fez que as COHABs passassem de agentes promotores (tomadores de empréstimos do FGTS e executores de obras) a meros órgãos assessores, diminuindo assim a capacidade de atuação dos estados e municípios na questão habitacional. (SANTOS, C. H. M., 1999, p. 20).

No governo de Fernando Collor (1990-1992) foi lançado o Plano de Ação Imediata para a Habitação (PAIH), cujo financiamento advinha dos recursos do FGTS. O plano estruturava-se em três linhas programáticas: a) urbanização de áreas de 
regularização fundiária (Produrb-Habitação); b) habitação popular cujos agentes promotores eram as Cohabs, Prefeituras e cooperativas (PROHAP) e; c) o segmento de mercado Empresário Popular (PEP) (ROYER, 2009).

O PAIH tinha como meta prioritária a construção de 245 mil unidades habitacionais no prazo máximo de cento e oitenta dias. Caberia à iniciativa privada a construção das unidades. No entanto, o prazo estipulado não foi cumprido. Os cento e oitenta dias se transformaram em dezoito meses e ao final foram construídas 210 mil unidades, cujo custo médio da unidade habitacional foi superior ao previsto, ou seja, não foram seguidas as orientações do Conselho Curador do FGTS, o que agravaria os problemas na recomposição do FGTS.

O governo Collor foi o primeiro a ser eleito democraticamente em um contexto de orientação de abertura econômica do país. Nesse sentido, as ações no campo da habitação em sua grande maioria foram executadas pelas empreiteiras, e quando executadas em parceria com as Cohabs e prefeituras eram fortemente vinculadas aos preceitos do mercado privado. Desse modo, o mercado privado ampliou sua atuação na provisão da habitação social nos anos de 1990.

As ações direcionadas para a habitação durante o período do governo Collor foram marcadas por forte setorialização no que tange às estratégias de planejamento. Os programas habitacionais de cunho social desse período focalizavam a construção da unidade habitacional, desvinculada de obras de infraestrutura urbana e qualidade urbanística (ROYER, 2009).

Ainda de acordo com Royer (2009), o financiamento habitacional era composto basicamente do FGTS, em um contexto de recessão econômica, altos índices de desemprego, elevação de saques, além da redução do montante de recursos nos depósitos. Esses fatores afetaram de forma significativa a capacidade de investimentos no setor habitacional.

Ao mesmo tempo, a retomada dos investimentos em habitação com recursos do FGTS sem o atendimento das orientações do Conselho Curador contribuiu para o agravamento da continuidade dos investimentos em habitação. Acerca do assunto Gonçalves (1997, p. 27) afirma:

A efetiva retomada das operações com recursos do FGTS voltou a ocorrer nos anos de 1990 e 1991, quando foram contratadas cerca de 526 mil unidades, sendo 360 mil somente no ano de 1991. O volume de operações contratadas nesses dois anos, no entanto, comprometeu o orçamento dos anos seguintes, impedindo a realização de novas operações. Neste aspecto, merece 
ser destacado que boa parte das 526 mil unidades visaram a atender objetivos políticos e muitas delas apresentaram problemas de comercialização, sendo que no final de 1996 mais de 50 mil delas não haviam sido comercializadas, sendo que um número expressivo ainda não tinha sua construção concluída. Boa parte delas, inclusive, só teve sua comercialização viabilizada por valor de bem inferior ao custo incorrido em sua produção, demonstrando que sua contratação não observou os critérios técnicos requeridos.

Segundo Royer (2009), a aplicação dos recursos do FGTS majoritariamente estava concentrada nos programas PAIH, PEP e PROHAP (público e privado) e nas cooperativas, com porcentual de aproximadamente 94\%, totalizando 432.142 .924 de Unidades Padrão de Financiamento (UPFs) contratadas. Para dimensionar o volume de unidades habitacionais contratadas com recursos do FGTS, o quadro a seguir traz a evolução de contratação de unidades habitacionais entre os anos de 1987 e 1994 . Nesse intervalo, observa-se que nos anos de 1990-1991, durante a vigência do PAIH, houve um desproporcional número de contratações com recursos do FGTS, se comparados ao final do ano de 1992.

\section{Quadro 13 - Financiamento Habitacional FGTS e SBPE: 1987-1994}

\begin{tabular}{|r|r|r|r|r|r|r|}
\hline \multirow{2}{*}{ Ano } & \multicolumn{2}{c|}{ FGTS } & \multicolumn{1}{c|}{ SBPE (Cardeneta) } & \multicolumn{1}{l|}{ Total (SFH= FGTS +SPBE) } \\
& $\begin{array}{l}\text { Unidades } \\
\text { construídas }\end{array}$ & $\begin{array}{l}\text { Investimento } \\
\text { acumulado }\end{array}$ & $\begin{array}{l}\text { Unidades } \\
\text { construídas }\end{array}$ & $\begin{array}{l}\text { Investimento } \\
\text { acumulado }\end{array}$ & $\begin{array}{l}\text { Unidades } \\
\text { construídas }\end{array}$ & $\begin{array}{l}\text { Investimento } \\
\text { acumulado }\end{array}$ \\
\hline 1987 & 99.227 & 2.665 .093 & 132.005 & 2.015 .844 & 231.232 & 4.680 .937 \\
\hline 1988 & 98.249 & 2.763 .342 & 181.834 & 2.197 .678 & 280.083 & 4.961 .020 \\
\hline 1989 & 31.617 & 2.794 .959 & 68.089 & 2.265 .767 & 99.706 & 5.060 .726 \\
\hline 1990 & 165.617 & 2.960 .576 & 74.993 & 2.340 .760 & 240.610 & 5.301 .336 \\
\hline 1991 & 359.719 & 3.320 .295 & 41.050 & 2.381 .810 & 400.769 & 5.702 .105 \\
\hline 1992 & 43.801 & 3.364 .096 & 64.869 & 2.446 .679 & 108.670 & 5.810 .775 \\
\hline 1993 & 4.256 & 3.368 .352 & 53.708 & 2.500 .387 & 57.964 & 5.868 .739 \\
\hline 1994 & & 3.368 .352 & 61.384 & 2.561 .771 & 61.384 & 5.930 .123 \\
\hline
\end{tabular}

Fonte: ABECIP (2003).

O governo Collor se destacou pela retomada das contratações com financiamento do FGTS após três anos desde a extinção do BNH. No entanto, a forma não planejada e com finalidade política comprometeu a continuidade de investimentos em habitação. Também a parceria na produção da habitação social via mercado privado, sem mecanismos de fiscalização eficientes, viabilizou a atuação do setor privado com uso de material de má qualidade, visando à minimização dos custos e à elevação da margem de lucro, fatores esses que contribuíram para a péssima qualidade da moradia. 
Acerca do assunto, Freitas (2004) traz um diagnóstico da produção habitacional e da inserção dos conjuntos habitacionais no tecido urbano durante o período do governo Collor e conclui:

\begin{abstract}
Os conjuntos habitacionais do período Collor foram concebidos, em "zonas de fronteira", limitados pela área rural e separados do tecido urbano por rodovias, vales (cursos d'água) ou vazios urbanos. Desta maneira, a moradia representava apenas um bem de consumo para os promotores habitacionais da época. As zonas de fronteira, além dedificultarem a acessibilidade do morador aos serviços básicos, são indutoras do processo de degradação do bairro. $\mathrm{O}$ isolamento diminui as possibilidades desurgimento da vida urbana, que poderia se dar tanto na diversidade e animação das ruas, com usos diversos, quanto nas áreas destinadas ao uso comercial. $\mathrm{O}$ resultado foi a formação das periferias mal construídas, cujas unidades habitacionais apresentam péssima qualidade construtiva. As construtoras que executaram estes conjuntos habitacionais realizaram as obras da forma mais econômica para atingir maiores lucros. (FREITAS, 2004, p. 120).
\end{abstract}

Os investimentos direcionados para o setor habitacional foram objeto de investigações, assim como outras operações financeiras que se apresentavam em desconformidade com a lei. Tais desdobramentos provocaram pela primeira vez na história da América Latina a aprovação do impeachment de um presidente. No ano de 1992, o presidente Collor renunciou ao cargo e esse passou a ser ocupado provisoriamente pelo então vice-presidente Itamar Franco.

Considerando a gravidade da crise política e econômica, os programas habitacionais foram redesenhados, e o então presidente Itamar Franco implementou mecanismos de controle social através da instituição de conselhos locais. Os programas habitacionais foram reformulados, por exemplo, com programas destinados à população de baixa renda. Merecem destaque o programa Habitar Brasil, voltado para as cidades médias e grandes, e o programa Morar Município, para as cidades pequenas.

Os recursos para a operacionalização dos programas advinham do Orçamento Geral da União (OGU) e do então Imposto Provisório sobre Movimentações Financeiras (IPMF). Também, durante o governo de Itamar Franco foram implementados mecanismos para a conclusão das obras não concluídas com recursos do FGTS durante a vigência do governo Collor.

Nesse período foi extinto o Plano de Equivalência Salarial (PES) e foram reformulados os mecanismos de correção monetária das prestações através de medidas para a amortização vinculada à renda. No entanto as mudanças não foram suficientes para reverter o quadro da crise no setor de habitação e viabilizar a retomada dos investimentos (SANTOS, C. H. M., 1999; FERREIRA, 2009). 
Para Cariello Filho (2011), o governo de Itamar Franco (1992-1994) foi marcado pela limitação e pela crise herdada do seu antecessor. Em relação aos programas habitacionais, esses ficaram restritos à utilização de recursos do FGTS para a provisão da moradia popular.

Com a vitória de Fernando Henrique Cardoso à presidência, nota-se um redesenho no Sistema Financeiro Habitacional que viabilizou a operacionalização da política habitacional aos preceitos do mercado e Estado.

Segundo Royer (2009), no primeiro governo de Fernando Henrique Cardoso (1995-1998), coube ao Ministério do Planejamento e Orçamento, em especial à Secretaria de Política Urbana, o novo desenho da política habitacional com a meta de reajustar a operacionalização da política com recursos do FGTS e recursos da caderneta de poupança para a retomada da política habitacional.

Durante o primeiro governo de FHC foi realizado um diagnóstico da capacidade de investimentos na provisão da habitação com recursos do FGTS e da caderneta de poupança, o que viabilizou o lançamento do Plano Nacional de Habitação, no ano de 1996. Esse plano tratava a questão da terra urbana vinculada a sua função social e, para tanto, reconhecia a cidade ilegal e informal, além de propor medidas que viabilizassem a integração dos assentamentos informais à cidade legal, bem como o reconhecimento por parte do governo federal da urgência em implementar uma carta diversificada de programas habitacionais operados de forma descentralizada (SANTOS, C. H. M., 1999).

As ações no campo habitacional durante o primeiro governo de FHC podem ser divididas em três grupos. 


\section{Quadro 14 - Grupos dos Programas Habitacionais: Governo FHC}

Primeiro grupo: desenvolvimento de programas que visavam à melhoria do funcionamento do mercado privado de habitações, voltados para as faixas de renda superiores a doze salários mínimos. Os mecanismos adotados, nesse sentido, foram a reformulação da legislação e o apoio ao desenvolvimento institucional e tecnológico do setor imobiliário e da construção civil. Também, em cumprimento ao acordo assinado pelo Brasil na Habitat II, foi criado o Programa Brasileiro da Qualidade e Produtividade do Habitat (PBQP-H).

$-$

Segundo grupo: desenvolvimento de programas destinados ao financiamento para a recuperação de áreas habitacionais degradadas, ocupadas principalmente por população com renda até três salários mínimos, por meio de melhoria ou de construção de unidade habitacional e de infraestrutura. Nessa linha, foram aperfeiçoados os programas Pró-Moradia e Habitar Brasil.

Terceiro grupo: desenvolvimento de linhas de financiamento acessível diretamente ao mutuário final, com a implementação, por exemplo, dos programas: Programa Carta de Crédito, operacionalizado com os recursos do FGTS e do SBPE, e o programa Apoio à Produção, cujo financiamento era concedido direto ao produtor privado e também era operacionalizado com recursos do FGTS.

Fonte: Adaptado de Santos C. H. M. (1999) e Shimbo (2012).

Considerando os três grupos, observa-se que os programas do segundo grupo, como o Pró-Moradia e o Habitar Brasil, apresentaram um desenho e operacionalização semelhantes. Cláudio Hamilton M. Santos (1999, p. 23) explica a operacionalização dos programas:

Em ambos [os programas] cabe aos estados e municípios apresentarem projetos às instâncias federais que, então, decidem sobre a liberação ou não do financiamento, levando em conta, entre outras variáveis, a disponibilidade de recursos, a qualidade técnica do projeto, sua relação custo-benefício, sua adequação aos objetivos dos programas etc. Ao receber o financiamento, o poder público local realiza então as melhorias nas comunidades escolhidas (geralmente caracterizadas por elevado grau de informalidade) e legaliza a 
situação das famílias beneficiadas. Na maioria dos casos, o poder público local não exige qualquer tipo de contrapartida à população beneficiada, mesmo porque não há nada no desenho dos programas que o obrigue a cobrar pelas melhorias efetuadas. É importante notar, portanto, o caráter assistencialista desses programas, cujo público-alvo são áreas habitacionais degradadas, caracterizadas pela extrema pobreza de seus habitantes e que, justamente por isso, necessitam de ações emergenciais do poder público. A relativa escassez de recursos para esses programas, aliada à despreocupação quanto à recuperação dos custos, fazem que seu escopo seja necessariamente limitado. Essa conclusão é reforçada quando se nota que esses programas não visam principalmente a construção de novas unidades habitacionais (ainda que contemplem essa possibilidade em alguns casos), e sim à melhoria das unidades existentes. Assim, atua-se muito mais na redução do déficit habitacional qualitativo do que no quantitativo.

Uma das diferenças entre os programas refere-se à fonte de financiamento e sua recomposição. O programa Pró-Moradia é operacionalizado com recursos do FGTS, que devem ser restituídos em médio e longo prazo. Portanto, os programas operacionalizados com recursos do FGTS trazem exigências e normas de acesso aos estados e municípios com base na sua capacidade de pagamento e endividamento. Já no caso do Habitar Brasil, cuja base de financiamento dos recursos advém do Orçamento Geral da União, ou seja, do OGU, esses não precisam ser repostos, por isso a denominação financiamento a "fundo perdido". Ainda que tenham um desenho e operacionalização semelhantes, o acesso e o volume de recursos destinados à habitação são superiores no FGTS, em comparação com os recursos do OGU. Em função da fonte de financiamento, o desempenho dos programas apresenta diferenças no que tange ao volume de recursos e à sua territorialização.

Com base nas diferentes capacidades institucionais e administrativas dos estados e municípios, o volume de recursos do FGTS foi acessado em linhas gerais pelos estados e municípios localizados nas regiões Sudeste, Sul e Centro-Oeste, ao passo que os municípios das regiões Norte e Nordeste tiveram reduzido acesso aos recursos do FGTS, dada a sua baixa capacidade financeira.

\section{Quadro 15 - Habitar Brasil e Pró-Moradia: Síntese da Execução dos Programas: 1995-1998}

\begin{tabular}{|lcrrrrr|} 
Programas & $\begin{array}{l}\text { Investimentos } \\
\text { (R\$ Milhões) }\end{array}$ & $\begin{array}{l}\text { Famílias } \\
\text { atendidas }\end{array}$ & $\begin{array}{l}\text { Empregos } \\
\text { gerados }\end{array}$ & $\begin{array}{l}\text { Municípios } \\
\text { atendidos }\end{array}$ & $\begin{array}{l}\text { Obras } \\
\text { realizadas }\end{array}$ \\
\hline Pró-Moradia & 1072 & 285.000 & 102.235 & 630 & 1.175 \\
Habitar-Brasil & 1090 & 437.524 & 103.314 & 2.546 & 4.241 \\
\hline
\end{tabular}

Fonte: Santos, C. H. M. (1999). 
Também no governo de FHC foi implementado, no ano de 1999, o Programa de Arrendamento Residencial (PAR) para as famílias com renda de até seis salários mínimos, com contratos de até quinze anos. O PAR era uma espécie de leasing, isto é, o mutuário optava pelo arrendamento residencial e ao final do contrato o mutuário poderia comprar o imóvel, optar pela continuidade da locação ou devolver o imóvel. A diferença do PAR, em comparação aos demais programas, é que a sua finalidade não era o financiamento diretamente para a aquisição do imóvel e sim para o arrendamento residencial. Trata-se de um dos poucos programas nacionais que não tinham como foco direto o acesso à casa própria.

O imóvel, durante o período de arrendamento, permanece na posse da Caixa Econômica Federal e o contrato pode ser rescindido quando ocorrer descumprimento de cláusula ou quando ferir alguma condição estabelecida: falsidade das declarações prestadas pelo arrendatário, transferência ou cessão de direitos do contrato ou uso inadequado do imóvel, isto é, quando não obedecer ao uso estritamente residencial. (CARMO, 2006, p. 137).

Para o funcionamento do PAR, o governo implementou o Fundo de Arrendamento Residencial (FAR), composto de várias fontes de recursos onerosos e não onerosos. Vale lembrar que, majoritariamente, o FAR era composto pelos recursos do FGTS e tinha como foco de atuação as regiões metropolitanas.

Quadro 16 - Financiamentos de Unidades Habitacionais/Região via PAR - 19992002

\begin{tabular}{|c|c|c|c|c|c|}
\hline Região & 1999 & 2000 & 2001 & 2002 & Total \\
\hline Centro-Oeste & & 3.147 & 864 & 1.677 & 5.688 \\
\hline Nordeste & 3.854 & 12.280 & 5.151 & 6.297 & 27.582 \\
\hline Norte & & 884 & 622 & 1.656 & 3.162 \\
\hline Sudeste & 3.104 & 11.307 & 11.280 & 16.749 & 42.440 \\
\hline Sul & & 3.387 & 2,398 & 3.892 & 9.677 \\
\hline Total & 6.958 & 31.005 & 20.315 & 30.271 & 88.549 \\
\hline
\end{tabular}

Fonte: Carmo (2006).

A meta do PAR era produzir cerca de duzentas mil unidades habitacionais nas regiões metropolitanas. No entanto, o custo do terreno, da infraestrutura e do padrão de construção nas regiões metropolitanas valorizou os empreendimentos e dificultou a operacionalização do programa. O valor inicial de cada unidade habitacional era de $\mathrm{R} \$$ 15.400,00, no entanto, com a valorização dos empreendimentos, o custo médio por unidade habitacional elevou-se para $\mathrm{R} \$ 22.400,00$, sendo que o valor máximo podia chegar a R\$35.000,00. O Programa PAR produziu, até o ano de 2002, 88.549 mil 
unidades habitacionais com valor médio acima de R\$24.000,00. Sublinha-se que a maioria dos recursos do PAR era composta pelo FGTS, cujo investimento deveria retornar ao fundo. Conclui-se que grande parte dos investimentos do PAR tenha se concentrado no atendimento das faixas de renda acima de três salários mínimos (CARMO, 2006; SHIMBO, 2012).

No final do governo de FHC, foi implementado o Programa de Subsídio à Habitação de Interesse Social (PSH), com a finalidade de subsidiar os financiamentos para famílias com renda de até três salários mínimos. O PSH era operado com recursos provenientes do Orçamento Geral da União (OGU) e contava, ainda, com o aporte de contrapartida proveniente dos estados, DF e municípios, sob a forma de complementação aos subsídios oferecidos pelo programa.

Segundo Carmo (2006), no ano de 2002 o investimento do PSH alcançou aproximadamente R \$ 138 milhões, correspondendo em média a 17.000 operações de crédito. O PSH focalizou o atendimento das famílias de baixa renda, conforme se depreende da afirmação do citado autor: “[...] esta fonte financiou contratos com o menor valor médio (alcançando $\mathrm{R} \$ 8.150,00$ por operação - compatível com a renda da população na base da pirâmide)" (CARMO, 2006, p. 147). O quadro a seguir detalha as modalidades de financiamento do PSH no ano de 2002.

Quadro 17 - Modalidades de Financiamento do PSH - Ano Base: 2002

\begin{tabular}{|lc|}
\hline \multicolumn{1}{|c|}{ Modalidades } & $\begin{array}{l}\text { Quantidade de } \\
\text { Operações de } \\
\text { Crédito }\end{array}$ \\
\hline Aquisição de Imóvel Novo & 171 \\
Aquisição de Terreno e Construção & 15 \\
Construção & 249 \\
Imóvel na Planta & 9.938 \\
Imóvel Rural & 2.012 \\
Material de Construção & 4.587 \\
\hline Total & 16.972 \\
\hline Fonte: Carmo (2006).
\end{tabular}

Já em relação aos programas do primeiro e terceiro grupo das ações desenvolvidas durante o governo de FHC, conforme destacado no Quadro 14, nota-se a inclusão de mecanismos inovadores na forma de acessar os recursos financeiros destinados à habitação. No primeiro grupo, o objetivo dos programas era melhorar a performance do mercado privado, com a adoção de medidas visando ajustes na qualidade e produtividade dos materiais da construção civil. Para tanto, foram 
implementados mecanismos de modernização tecnológica e gerencial, o que contribuiu para a redução dos custos e ampliação da escala de produção, como, por exemplo, a criação do Programa Brasileiro da Qualidade e Produtividade do Habitat (PBQP-H).

Ainda, no primeiro grupo, destaca-se a criação do Sistema Financeiro Imobiliário (SFI) regulamentado pela Lei $\mathrm{n}^{\circ}$. 9.514/1997, com o objetivo de ampliar e diversificar a captação de recursos em longo prazo para o setor habitacional.

O SF capta fundos em um mercado secundário de títulos de créditos e recebíveis imobiliários. Por isso, exige instrumentos financeiros que façam a conexão entre o setor imobiliário e o mercado de capitais. Alguns foram instituídos com o SFI, como os Certificados de Recebíveis Imobiliários (CRI), as Cédulas de Crédito Imobiliário (CCI) e as Letras de Crédito Imobiliário (LCI). Outros foram modificados, como as Debêntures, as Letras Hipotecárias e as Cédulas de Crédito Bancário. (FIX, 2011, p. 180).

A criação do SFI trouxe para a política habitacional uma forte vinculação com o mercado e ampliou a lógica da moradia como um produto a ser consumido. Segundo Royer (2009, p. 132), a criação do SFI foi o mecanismo institucional que estruturou "o mercado imobiliário no Brasil, livre das amarras do setor público e do direcionamento do crédito por critérios de natureza política".

O SFI procura construir, dessa forma, um sistema financeiro que dê segurança aos agentes envolvidos no processo do crédito imobiliário, especialmente aos investidores, ponto central da lógica do funcionamento do sistema, procurando fomentar um mercado de crédito imobiliário baseado, a princípio, na lei da oferta e da procura. (ROYER, 2009, p. 95).

A criação do SFI, em certa medida, consolidou a inserção do setor privado e agentes imobiliários na provisão da moradia em conexão ao mercado imobiliário, visto que regulamentou mecanismos de segurança, o que por sua vez ampliou o volume de investimentos privados para a financeirização da cidade. Vale destacar que a criação do SFI e a ampliação do volume de recursos não se vinculam diretamente ao enfrentamento do déficit habitacional ou à melhoria habitacional para a população de baixa renda. Assinale-se que a criação do SFI trouxe importantes mudanças no setor público e privado na provisão habitacional, assim como viabilizou novas nuanças do Poder Público para o planejamento estratégico no campo do desenvolvimento urbano com a finalidade de atrair novos investimentos para fortalecer a competitividade entre os atores privados e públicos.

Nesse contexto, a cidade brasileira transforma-se em uma ordem e desordem de novas configurações urbanas, vinculadas a uma elevada valorização da terra urbana, 
resultando principalmente em novos eixos de valorização e expansão urbana. A esse processo, soma-se a incorporação de áreas até então periféricas como áreas de potencial interesse do capital imobiliário para a criação de novas centralidades urbanas, o que resultou em um processo de expulsão da população de baixa renda para áreas mais distantes dessas novas centralidades ocasionando o espraiamento das periferias. Configuram, assim, novas conurbações, que vão além dos limites administrativos municipais, cuja lógica do mercado imobiliário é ser parceiro dos governos locais para a flexibilização das legislações urbanas locais, viabilizando a instalação dos novos produtos imobiliários. Dessa forma, a periferia se estende para as fronteiras dos limites institucionais da administração local.

Outro fator que contribuiu para as novas configurações urbanas refere-se aos financiamentos habitacionais destinados diretamente ao mutuário final, isto é, os programas vinculados ao terceiro grupo (vide Quadro 14). O crédito disponibilizado diretamente à pessoa física é uma inovação na política habitacional na gestão de FHC, com a implementação, por exemplo, do programa Carta de Crédito. O programa Carta de Crédito subdividia-se em duas modalidades: a modalidade individual, que financiava diretamente o mutuário final, e a modalidade associativa, que financiava grupos de mutuários organizados por instituições (empresas de construção, incorporadoras, Companhias de Habitação, sindicatos, cooperativas) que, por sua vez, eram responsáveis pela solicitação de crédito aos agentes financeiros (SHIMBO, 2012).

\footnotetext{
$\mathrm{O}$ crédito direto ao consumidor garantiria maior liberdade de escolha para o cidadão, que poderia optar por uma série de alternativas que vão desde a compra de imóveis prontos novos ou usados (no modelo anterior o financiamento era concedido apenas para a compra de imóveis novos) até a compra de terrenos ou de materiais de construção. (SANTOS, C. H. M., 1999, p. 25).
}

Cláudio Hamilton M. Santos (1999) explica, resumidamente, o funcionamento do programa para que o mutuário, aqui compreendido como pessoa física com renda de até doze salários mínimos, possa obter diretamente acesso ao financiamento para aquisição de imóvel, reforma de imóveis ou compra de materiais de construção. De acordo com o autor, o financiamento direto ao mutuário final é composto com os recursos do FGTS, o que significa que deve ser reposto em médio e longo prazo. Os critérios para o cidadão ter acesso ao crédito vinculavam-se ao enquadramento da faixa de renda até o limite do programa, ou seja, até doze salários mínimos, não ser proprietário de imóvel e a prestação do financiamento não ultrapassar $30 \%$ da renda familiar. 
O volume de recursos nessa modalidade foi superior a todos os programas habitacionais desenvolvidos no primeiro governo de FHC. O programa Carta de Crédito-FGTS “financiou cerca de US\$ 5 bilhões no período de janeiro de 1995 até junho de 1998 (mais do que o dobro do Habitar Brasil e do Pró-Moradia somados)" (SANTOS, C. H. M., 1999, p. 24) e beneficiou aproximadamente 265 mil famílias, além de gerar cerca de 145 mil empregos.

O Programa Carta de Crédito, apesar de procurar atender, originalmente, faixas de renda mais baixas, acabou sendo o principal instrumento de financiamento para os setores de renda média, entre os anos 1990 até o presente momento. Mais do que isso, a modalidade associativa do programa foi, na prática, o mecanismo pelo qual a incorporação imobiliária privada pôde captar recursos do FGTS para a produção de unidades habitacionais novas. Se no SFH, o mercado imobiliário acessava diretamente apenas os recursos do SBPE, no governo FHC ele passa a acessar também o FGTS, com juros menores que aqueles praticados pelo mercado, tornando-se uma fonte de recursos mais barata para esses agentes. (SHIMBO, 2012, p. 71, grifo nosso).

Considerando o programa Carta de Crédito e a criação do SFI, observa-se uma forte parceria do Estado com o mercado na provisão da habitação. A lógica de operacionalização do programa Carta de Crédito abriu caminho para o enfrentamento dos problemas habitacionais pelo cidadão, e o papel do Estado se reduziu a ser um facilitador do processo. Nesse contexto, não somente as construtoras tiveram papel fundamental na articulação com o Estado na provisão da habitação, mas também os bancos - no caso a Caixa Econômica Federal -, atuando como atores relevantes nesse novo desenho da política habitacional. 
Quadro 18 - Contratações via FGTS/Modalidades: 1995-2003 ${ }^{14}$

\begin{tabular}{|c|c|c|c|c|c|}
\hline \multirow{3}{*}{\multicolumn{2}{|c|}{ Programa/Modalidade }} & & & \multicolumn{2}{|c|}{ Quantidade de Valor } \\
\hline & & \multicolumn{2}{|c|}{ Valor Contratado Valor } & \multirow{2}{*}{$\begin{array}{l}\text { Unidades } \\
\text { Habitacionais } \\
\text { (Mil) }\end{array}$} & \multirow{2}{*}{$\begin{array}{l}\text { Porcentual de } \\
\text { U.Hs por } \\
\text { modalidade }\end{array}$} \\
\hline & & (RȘ milhões) & Contratado (\%) & & \\
\hline \multicolumn{2}{|c|}{ PAR } & 2.344 & 10.53 & 106 & 6.32 \\
\hline \multicolumn{2}{|c|}{ Pró-Moradia } & 884 & 3.97 & & \\
\hline \multicolumn{2}{|c|}{ Apoio à Produção } & 55 & 0.25 & 4 & 0.24 \\
\hline \multicolumn{2}{|c|}{ Carta de Crédito Associativa } & 4.109 & 18.45 & 180 & $10 ; 74$ \\
\hline \multirow{5}{*}{ Carta de Crédito Individual (C.C.I) } & Imóvel Usado & 9.284 & 41.68 & 523 & 31.21 \\
\hline & M. Construção & 2.095 & 9.40 & 567 & 33.83 \\
\hline & Imóvel Novo & 1.418 & 6.36 & 74 & 4.42 \\
\hline & Outros & 2.086 & 9.36 & 222 & 13.24 \\
\hline & Total C.C.I & 14.883 & 66.80 & 1.386 & 82.70 \\
\hline \multicolumn{2}{|c|}{ Total } & 22.775 & 100 & 1.676 & 100 \\
\hline
\end{tabular}

Fonte: Cariello Filho (2011).

Considerando os dado de aplicações do FGTS por programa relativo ao período de 1995-2003 expostos no Quadro 18, observa-se que o predomínio do programa Carta de Crédito no governo de FHC está associado à primazia da lógica bancária e ao redirecionamento dos recursos do FGTS para o financiamento quase exclusivo da habitação das camadas sociais de melhor situação econômica, seguindo tendência crescente desde o BNH.

Vale destacar, que o período ultrapassa o final do governo de FHC, porém o perfil e os números da ação governamental em 2002, último ano de seu mandato, e em 2003, primeiro ano do governo de Lula da Silva, são bastante próximos respectivamente, $\mathrm{R} \$ 3,02$ bilhões de investimentos para a produção de 197 mil unidades, e R $\$ 2,83$ bilhões para 185 mil unidades, com quedas significativas apenas nas aplicações minoritárias com recursos do OGU e do Fundo de Amparo ao Trabalhador (FAT) (CARIELLO FILHO, 2011, p. 181, com adaptações).

Conclui-se, então, que no governo de FHC observou-se a reestruturação da política habitacional pós- extinção do $\mathrm{BNH}$, com a retomada nos investimentos habitacionais com recursos do FGTS, SBPE e a ampliação dos mecanismos de mercado. O governo não interveio diretamente na provisão habitacional. Em linhas gerais coube aos programas Habitar Brasil e Pró-Moradia a provisão da moradia ao segmento de

14 No quadro 18 foi considerando o volume total de contratações durante o período de 1995-2003. Não foi possível obter dados desagregados. 
baixa renda cujos parceiros para a estruturação dos programas foram os estados e municípios. Nesse caso, merecem destaque a estrutura de fiscalização e o andamento das obras nos estados e municípios condicionados aos repasses de recursos por parte da Caixa Econômica Federal, o que fortaleceu o gerenciamento dos recursos (ROYER, 2009; SHIMBO, 2012).

No entanto, os programas foram insuficientes para a redução do déficit habitacional qualitativo e quantitativo da população de baixa renda. Ao mesmo tempo, evidenciavam que o acesso aos recursos do FGTS atendia aos segmentos de renda superior a três salários mínimos.

\subsubsection{Políticas habitacionais: do governo Lula (2003-2010) ao governo de Dilma Rousseff (2011 -2014) - continuidades e rupturas}

No ano de 2000, o então candidato à Presidência da República Luís Inácio Lula da Silva, membro sócio do Instituto Cidadania, uma organização não governamental, havia elaborado, em parceria com movimentos sociais, acadêmicos e especialistas em política habitacional, o Projeto Moradia.

A finalidade do Projeto Moradia era a criação de um Sistema Nacional de Habitação, composto pelos três entes da Federação, que atuariam de forma interfederativa no controle e gestão financeira e territorial da política habitacional.

A confirmação da vitória de Lula à Presidência no ano de 2003 vislumbrou a implementação de um arcabouço institucional para a criação de um sistema nacional de habitação de interesse social. Para tanto, no ano de 2003 foi criado o Ministério das Cidades, principal agente coordenador e gestor na estruturação de uma nova política de desenvolvimento urbano, cuja finalidade era a implementação da Política Nacional de Desenvolvimento Urbano (PNDU). Sublinha-se que a PNDU não foi implementada na gestão do governo Lula e atualmente pouco se tem avançado para a sua regulamentação e implementação.

No ano de 2004 foi aprovada, pelo Conselho das Cidades, a Política Nacional de Habitação (PNH), que estabeleceu a criação do Sistema Nacional de Habitação de Interesse Social (SNHIS) e a elaboração do Plano Nacional de Habitação (PlanHab).

O Sistema Nacional de Habitação foi regulamentado pela Lei Federal 11.124/2005 segmentado por dois subsistemas. O primeiro, o Subsistema de Habitação de Mercado (SHM), compõe-se de recursos financeiros do Sistema Brasileiro de 
Poupança e Empréstimo (SBPE) e do Sistema Financeiro Imobiliário (SFI), com ênfase na ampliação do fomento à habitação para a iniciativa privada. Nesse âmbito de atuação, o objetivo é atender à demanda da população de classe média aos financiamentos públicos. O segundo, o Subsistema Nacional de Habitação de Interesse Social (SNHIS), compõe-se de fundos públicos para atender à demanda habitacional pela população de baixa renda (SHIMBO, 2012; FRANÇA, 2013).

O Subsistema de Habitação de Interesse Social foi regulamentado pela Lei 11.124/2005, que instituiu o Sistema Nacional de Habitação de Interesse Social (SNHIS). O SNHIS deveria centralizar e gerir todos os programas habitacionais destinados à urbanização de assentamentos precários e de moradia social. A operacionalização dos recursos financeiros para os programas sociais de habitação deveria ser via Fundo Nacional de Interesse Social (FNHIS).

A composição de recursos do FNHIS advém do Orçamento Geral da União (OGU) e do Fundo de Apoio ao Desenvolvimento Social (FAS), de contribuições e doações de pessoas físicas ou jurídicas, entidades e organismos de cooperação nacionais ou internacionais, e de receitas de operações realizadas com recursos do FNHIS (SHIMBO, 2012).

A adesão ao SNHIS era condição para estados e municípios acessarem recursos do FNHIS. A adesão deveria atender aos requisitos previstos na Lei 11.124/2005, isto é, criação de um fundo e conselho local, além da elaboração do plano local de habitação. A criação do SNHIS atendia aos preceitos do Projeto Moradia, embora com algumas modificações que ocasionaram o enfraquecimento do Sistema Nacional de Habitação.

Bonduki (2013, p. 36) aponta que a aprovação do FNHIS como fundo orçamentário, em vez de ser um fundo financeiro, atuou com "uma dotação orçamentária gerida por um Conselho gestor com participação da sociedade, reduzindo enormemente seu potencial financeiro". O autor também destaca que os estados e municípios que aderiram ao SNHIS e instituíram os fundos estaduais e locais não apresentam articulação para as transferências inter e intrafundos. $\mathrm{O}$ funcionamento interfederativo inter e intrafundos era um das metas no desenho original do SNHIS que não se encontra em funcionamento.

Bonduki chama a atenção para os mecanismos de adesão. Na ideia original, os entes poderiam ser enquadrados em adesão parcial ou integral. A adesão parcial condicionava o repasse de recursos do FNHIS à aprovação de projetos apresentados 
pelos municípios, ao passo que a adesão integral significava o repasse de recursos via fundo para os estados e municípios de forma autônoma para implementação de sua política.

\begin{abstract}
Ao eliminar a concepção original de transferência fundo a fundo e o conceito de adesão integral, a nova PNH fragilizou enormemente o papel e a importância do plano local de habitação, instrumento fundamental à concessão da "maioridade" para os entes federativos em termos de política habitacional. Esperava-se que os planos locais de habitação demonstrassem a capacidade do município para equacionar, "com as próprias pernas institucionais", seu problema habitacional, de modo que necessitasse, sobretudo, de recursos financeiros. Essa proposta partia do pressuposto de que apenas os municípios mais estruturados - onde, aliás, se concentra a maior parte do déficit habitacional - lograriam a adesão integral. (BONDUKI, 2013, p. 46).
\end{abstract}

A implementação do SNHIS no ano de 2005 vislumbrava a articulação aos objetivos do Plano Nacional de Habitação, sobretudo no que diz respeito ao atendimento da população de baixa renda e ao enfrentamento do déficit habitacional qualitativo e quantitativo, por meio de uma diversidade de ações e programas.

Shimbo (2012) destaca que cada recurso no SNHIS está vinculado a uma operação. Por exemplo, os recursos do FGTS vinculam-se aos financiamentos onerosos, isto é, àqueles que precisam ser repostos. No entanto, para a habitação social, a taxa de juros apresentava índices menores e combinava recursos de outros fundos. Já os recursos não onerosos, caso do FNHIS, vinculam-se ao repasse aos agentes promotores públicos, isto é, estados, Distrito Federal, municípios ou empresas públicas locais; e os casos dos demais fundos, quais sejam, FDS, FAR, FAT, estão vinculados à cobertura de outros programas, como é o caso do PAR e do Programa Crédito Solidário.

Embora o governo Lula tenha estabelecido novos marcos com a Política Nacional de Habitação, sublinha-se que parte dos programas habitacionais, em sua gestão, foi baseada nos programas habitacionais do governo anterior, ou seja, do governo de FHC, e por sua vez foi reformulada no então governo do PT. Acerca do assunto, Shimbo (2012) destaca que o Ministério das Cidades deu uma nova roupagem aos programas PAR, Carta de Crédito Associativo, Habitar Brasil/BID, Pró-Moradia, PSH e "Apoio à Produção" e criou novos programas, como, por exemplo, o Programa Crédito Solidário.

Os recursos do FNHIS foram destinados ao atendimento das famílias com renda de até três salários mínimos. Para tanto, foram criados os seguintes programas: Programa da Ação Provisão Habitacional de Interesse Social; Programa Urbanização, 
Regularização e Integração de Assentamentos Precários; e Apoio à Produção Social da Moradia (SHIMBO, 2012).

No primeiro governo Lula (2003-2006) foram investidos mais de $\mathrm{R} \$ 6$ bilhões em recursos não onerosos e quase $\mathrm{R} \$ 30$ bilhões em recursos onerosos, focalizados na produção e aquisição de moradias, programas de urbanização de favelas, aquisição de material de construção, reforma e ampliação de unidades habitacionais, produção de lotes urbanizados e requalificação de imóveis para uso habitacional. Desse total, R $\$ 2,5$ bilhões foram recursos do FGTS para subsídios (IPEA, 2013).

Também houve elevação nos recursos do SBPE em função das medidas de segurança jurídica e econômica regulamentadas pelo governo, o que viabilizou a ampliação do setor privado no campo habitacional com a utilização dos recursos públicos.

\section{Gráfico 1 - Valores Contratados FGTS e SBPE 2002-2008 (R\$ milhões)}

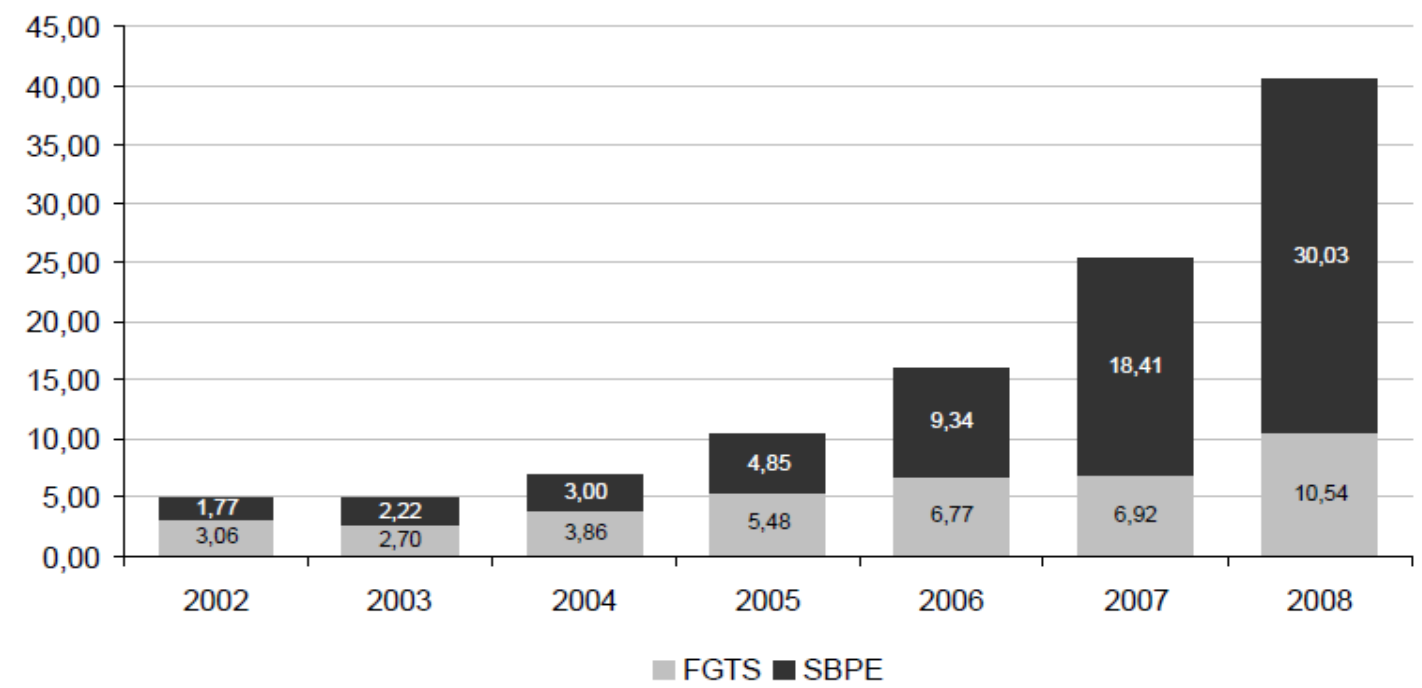

Fonte: Shimbo (2012).

Com base no levantamento das características dos programas habitacionais implementados durante o governo Lula e com vigência ainda no período atual é possível observar a ampla inserção do setor privado nesses programas, não apenas nos programas destinados para a classe média, mas também nos programas destinados para habitação social, que possuem significativo subsídio governamental e deveriam ser desenhados prioritariamente de forma interfederativa, evidenciando o protagonismo dos entes estadual e local. 
O quadro a seguir identifica os programas destinados à provisão, melhoria e assistência técnica da habitação, vinculados ao Ministério das Cidades, com identificação do proponente e vinculação de fonte de recursos.

Quadro 19 - Programas Habitacionais Vinculados ao Ministério das Cidades - Ano Base 2008-2014

\begin{tabular}{|c|c|c|c|}
\hline Necessidade & Programação/Ação & Proponente & Fonte \\
\hline \multirow{8}{*}{ Construção de Habitações } & $\begin{array}{l}\text { Apoio à Provisão } \\
\text { Habitacional de } \\
\text { Interesse Social }\end{array}$ & $\begin{array}{l}\text { Poder público, } \\
\text { executivo } \\
\text { municipal, } \\
\text { estadual e DF }\end{array}$ & \begin{tabular}{|l} 
Fundo \\
Nacional de \\
Habitação de \\
Interesse \\
Social \\
(FNHIS) \\
\end{tabular} \\
\hline & $\begin{array}{l}\text { Carta de Crédito } \\
\text { Individual }\end{array}$ & Pessoa física & $\begin{array}{l}\text { Fundo de } \\
\text { Garantia do } \\
\text { Tempo de } \\
\text { Serviço } \\
\text { (FGTS) } \\
\end{array}$ \\
\hline & $\begin{array}{l}\text { Carta de Crédito } \\
\text { Associativo }\end{array}$ & $\begin{array}{l}\text { Pessoas físicas } \\
\text { organizadas em } \\
\text { entidade associativa }\end{array}$ & FGTS \\
\hline & $\begin{array}{l}\text { Apoio à Produção } \\
\text { de } \\
\text { Habitações }\end{array}$ & $\begin{array}{l}\text { Pessoa jurídica: } \\
\text { empresa do ramo da } \\
\text { construção civil }\end{array}$ & FGTS \\
\hline & Pró-Moradia & $\begin{array}{l}\text { Poder público, } \\
\text { executivo } \\
\text { municipal, } \\
\text { estadual e DF } \\
\end{array}$ & FGTS \\
\hline & $\begin{array}{l}\text { Programa de } \\
\text { Arrendamento } \\
\text { Residencial (PAR) }\end{array}$ & $\begin{array}{l}\text { Pessoa jurídica: } \\
\text { empresa do ramo da } \\
\text { construção civil }\end{array}$ & $\begin{array}{l}\text { Fundo de } \\
\text { Arrendamento } \\
\text { Residencial } \\
\text { (FAR) } \\
\end{array}$ \\
\hline & $\begin{array}{l}\text { Programa Crédito } \\
\text { Solidário }\end{array}$ & $\begin{array}{l}\text { Pessoas físicas } \\
\text { organizadas em } \\
\text { entidade associativa }\end{array}$ & $\begin{array}{l}\text { Fundo de } \\
\text { Desenvolvi- } \\
\text { mento Social } \\
\text { (FDS) }\end{array}$ \\
\hline & $\begin{array}{l}\text { Subsídio à } \\
\text { Habitação de } \\
\text { Interesse Social - } \\
\text { PSH }\end{array}$ & $\begin{array}{l}\text { Poder público, } \\
\text { executivo } \\
\text { municipal, } \\
\text { estadual e DF e } \\
\text { Associações Rurais }\end{array}$ & FNHIS \\
\hline
\end{tabular}




\begin{tabular}{|c|c|c|c|}
\hline \multirow{5}{*}{$\begin{array}{c}\text { Aquisição de } \\
\text { Habitação Nova }\end{array}$} & $\begin{array}{l}\text { Apoio à Provisão } \\
\text { Habitacional de } \\
\text { Interesse Social }\end{array}$ & $\begin{array}{l}\text { Poder público, } \\
\text { executivo } \\
\text { municipal, } \\
\text { estadual e DF }\end{array}$ & FNHIS \\
\hline & $\begin{array}{l}\text { Carta de Crédito } \\
\text { Individual }\end{array}$ & Pessoa física & FGTS \\
\hline & $\begin{array}{l}\text { Carta de Crédito } \\
\text { Associativo }\end{array}$ & $\begin{array}{l}\text { Pessoas físicas } \\
\text { organizadas em } \\
\text { entidade associativa }\end{array}$ & FGTS \\
\hline & $\begin{array}{l}\text { Programa de } \\
\text { Arrendamento } \\
\text { Residencial (PAR) }\end{array}$ & $\begin{array}{l}\text { Pessoa } \\
\text { física/jurídica: } \\
\text { proprietário de } \\
\text { imóvel }\end{array}$ & FAR \\
\hline & $\begin{array}{l}\text { Subsídio à } \\
\text { Habitação de } \\
\text { Interesse Social - } \\
\text { PSH }\end{array}$ & $\begin{array}{l}\text { Poder público, } \\
\text { executivo } \\
\text { municipal, } \\
\text { estadual e DF e } \\
\text { Associações Rurais }\end{array}$ & FNHIS \\
\hline \multirow{4}{*}{$\begin{array}{c}\text { Aquisição de } \\
\text { Habitação Usada }\end{array}$} & $\begin{array}{l}\text { Apoio à Provisão } \\
\text { Habitacional de } \\
\text { Interesse Social }\end{array}$ & $\begin{array}{l}\text { Poder público, } \\
\text { executivo } \\
\text { municipal, } \\
\text { estadual e DF }\end{array}$ & FNHIS \\
\hline & $\begin{array}{l}\text { Carta de Crédito } \\
\text { Individual }\end{array}$ & Pessoa física & FGTS \\
\hline & $\begin{array}{l}\text { Programa de } \\
\text { Arrendamento } \\
\text { Residencial (PAR) } \\
\end{array}$ & $\begin{array}{l}\text { Pessoa } \\
\text { física/jurídica: } \\
\text { proprietário de } \\
\text { imóvel }\end{array}$ & FAR \\
\hline & $\begin{array}{l}\text { Subsídio à } \\
\text { Habitação de } \\
\text { Interesse Social - } \\
\text { PSH }\end{array}$ & $\begin{array}{l}\text { Poder público, } \\
\text { executivo } \\
\text { municipal, } \\
\text { estadual e DF e } \\
\text { Associações Rurais }\end{array}$ & FNHIS \\
\hline $\begin{array}{l}\text { Conclusão, } \\
\text { Ampliação, } \\
\text { Reforma ou } \\
\text { Melhoria de } \\
\text { Unidade } \\
\text { Habitacional }\end{array}$ & $\begin{array}{l}\text { Apoio à Melhoria } \\
\text { das } \\
\text { Condições de } \\
\text { Habitabilidade de } \\
\text { Assentamentos } \\
\text { Precários }\end{array}$ & $\begin{array}{l}\text { Poder público, } \\
\text { executivo } \\
\text { municipal, } \\
\text { estadual e DF }\end{array}$ & FNHIS \\
\hline
\end{tabular}




\begin{tabular}{|c|c|c|c|}
\hline & $\begin{array}{l}\text { Carta de Crédito } \\
\text { Individual }\end{array}$ & Pessoa física & FGTS \\
\hline & $\begin{array}{l}\text { Programa Crédito } \\
\text { Solidário }\end{array}$ & $\begin{array}{l}\text { Pessoas físicas } \\
\text { organizadas em } \\
\text { entidade associativa }\end{array}$ & FDS \\
\hline \multirow{3}{*}{$\begin{array}{l}\text { Aquisição de } \\
\text { Material de } \\
\text { Construção }\end{array}$} & $\begin{array}{l}\text { Apoio à Melhoria } \\
\text { das } \\
\text { Condições de } \\
\text { Habitabilidade de } \\
\text { Assentamentos } \\
\text { Precários }\end{array}$ & $\begin{array}{l}\text { Poder público, } \\
\text { executivo } \\
\text { municipal, } \\
\text { estadual e DF }\end{array}$ & FNHIS \\
\hline & $\begin{array}{l}\text { Carta de Crédito } \\
\text { Individual }\end{array}$ & Pessoa física & FGTS \\
\hline & $\begin{array}{l}\text { Programa Crédito } \\
\text { Solidário }\end{array}$ & $\begin{array}{l}\text { Pessoas físicas } \\
\text { organizadas em } \\
\text { entidade associativa }\end{array}$ & FDS \\
\hline \multirow[t]{2}{*}{$\begin{array}{c}\text { Aquisição de FNHIS } \\
\text { Lote(s) } \\
\text { Urbanizado(s) }\end{array}$} & $\begin{array}{l}\text { Apoio à Provisão } \\
\text { Habitacional de } \\
\text { Interesse Social }\end{array}$ & $\begin{array}{l}\text { Poder público, } \\
\text { executivo } \\
\text { municipal, } \\
\text { estadual e DF }\end{array}$ & FNHIS \\
\hline & $\begin{array}{l}\text { Carta de Crédito } \\
\text { Individual }\end{array}$ & Pessoa física & FGTS \\
\hline \multirow{2}{*}{$\begin{array}{l}\text { Produção de } \\
\text { Lotes } \\
\text { Urbanizados }\end{array}$} & $\begin{array}{l}\text { Apoio à Provisão } \\
\text { Habitacional de } \\
\text { Interesse Social }\end{array}$ & $\begin{array}{l}\text { Poder público, } \\
\text { executivo } \\
\text { municipal, } \\
\text { estadual e DF }\end{array}$ & FNHIS \\
\hline & $\begin{array}{l}\text { Carta de Crédito } \\
\text { Associativo }\end{array}$ & $\begin{array}{l}\text { Pessoas físicas } \\
\text { organizadas em } \\
\text { entidade associativa }\end{array}$ & FGTS \\
\hline \multirow{2}{*}{$\begin{array}{l}\text { Requalificação de } \\
\text { Imóveis Urbanos }\end{array}$} & $\begin{array}{l}\text { Apoio à Provisão } \\
\text { Habitacional de } \\
\text { Interesse Social }\end{array}$ & $\begin{array}{l}\text { Poder público, } \\
\text { executivo } \\
\text { municipal, } \\
\text { estadual e DF }\end{array}$ & FNHIS \\
\hline & $\begin{array}{l}\text { Carta de Crédito } \\
\text { Associativo }\end{array}$ & $\begin{array}{l}\text { Pessoas físicas } \\
\text { organizadas em } \\
\text { entidade associativa }\end{array}$ & FGTS \\
\hline $\begin{array}{l}\text { Urbanização de } \\
\text { Assentamentos } \\
\text { Precários }\end{array}$ & $\begin{array}{l}\text { Programa de } \\
\text { Arrendamento } \\
\text { Residencial (PAR) }\end{array}$ & $\begin{array}{l}\text { Pessoa jurídica: } \\
\text { empresa do ramo da } \\
\text { construção civil }\end{array}$ & FAR \\
\hline
\end{tabular}




\begin{tabular}{|c|c|c|c|}
\hline & $\begin{array}{l}\text { Apoio à Produção } \\
\text { de } \\
\text { Habitações }\end{array}$ & $\begin{array}{l}\text { Pessoa jurídica: } \\
\text { empresa do ramo da } \\
\text { construção civil }\end{array}$ & FGTS \\
\hline & $\begin{array}{l}\text { Apoio à Melhoria } \\
\text { das } \\
\text { Condições de } \\
\text { Habitabilidade de } \\
\text { Assentamentos } \\
\text { Precários }\end{array}$ & $\begin{array}{l}\text { Poder público, } \\
\text { executivo } \\
\text { municipal, } \\
\text { estadual e DF }\end{array}$ & FNHIS \\
\hline \multirow{6}{*}{$\begin{array}{l}\text { Desenvolvimento } \\
\text { Institucional }\end{array}$} & $\begin{array}{l}\text { Intervenções em } \\
\text { Favelas }\end{array}$ & $\begin{array}{l}\text { Poder público, } \\
\text { executivo } \\
\text { municipal, } \\
\text { estadual e DF }\end{array}$ & $\mathrm{OGU}$ \\
\hline & Pró-Moradia & $\begin{array}{l}\text { Poder público, } \\
\text { executivo } \\
\text { municipal, } \\
\text { estadual e DF }\end{array}$ & FGTS \\
\hline & $\begin{array}{l}\text { Intervenções em } \\
\text { Favelas }\end{array}$ & $\begin{array}{l}\text { Poder público, } \\
\text { executivo } \\
\text { municipal, } \\
\text { estadual e DF }\end{array}$ & OGU \\
\hline & Pró-Moradia & $\begin{array}{l}\text { Poder público, } \\
\text { executivo } \\
\text { municipal, } \\
\text { estadual e DF } \\
\end{array}$ & FGTS \\
\hline & $\begin{array}{l}\text { Apoio à Elaboração } \\
\text { de Planos } \\
\text { Habitacionais de } \\
\text { Interesse Social } \\
\end{array}$ & $\begin{array}{l}\text { Poder público, } \\
\text { executivo } \\
\text { municipal, } \\
\text { estadual e DF }\end{array}$ & FNHIS \\
\hline & $\begin{array}{l}\text { Apoio à Provisão } \\
\text { Habitacional de } \\
\text { Interesse Social - } \\
\text { Modalidade } \\
\text { Assistência Técnica }\end{array}$ & $\begin{array}{l}\text { Poder público, } \\
\text { executivo } \\
\text { municipal, } \\
\text { estadual e DF }\end{array}$ & FNHIS \\
\hline
\end{tabular}

Fonte: Brasil (2007); Guia básico dos programas habitacionais. Adaptado de Shimbo (2010). 
Já o Quadro 20 detalha os principais programas habitacionais destinados à produção de unidades habitacionais novas ou à aquisição de unidades novas. De acordo com Shimbo (2010), a partir do mapeamento dos programas observa-se o papel protagonista do setor privado na figura de proponente ou de forma indireta, isto é, via concessão de financiamento a pessoas físicas ou nas chamadas operações vinculadas a entidades. 
Quadro 20 - Principais Programas Habitacionais para Produção ou Aquisição de Unidades Novas

\begin{tabular}{|c|c|c|c|c|}
\hline Programas & Ano & $\begin{array}{l}\text { Breve descrição do } \\
\text { Programa }\end{array}$ & Proponente & $\begin{array}{l}\text { Limite do enquadramento de renda } \\
\text { dos beneficiários }\end{array}$ \\
\hline Pró-Moradia & 1994 & $\begin{array}{c}\text { Concessão de } \\
\text { financiamentos ao poder } \\
\text { público para promover o } \\
\text { acesso à moradia adequada } \\
\text { à população em situação de } \\
\text { vulnerabilidade social }\end{array}$ & $\begin{array}{l}\text { Estados, DF } \\
\text { e Municípios }\end{array}$ & Até RS 1.395,00 \\
\hline $\begin{array}{l}\text { Carta de } \\
\text { Crédito } \\
\text { Individual }\end{array}$ & 1995 & \begin{tabular}{|c} 
Concessão de \\
financiamentos a pessoas \\
físicas para as modalidades \\
contidas no Programa. Os \\
interessados devem \\
procurar diretamente os \\
Agentes Financeiros \\
habilitados a operar os \\
programas do FGTS
\end{tabular} & $\begin{array}{l}\text { Pessoas } \\
\text { Físicas }\end{array}$ & $\begin{array}{c}\text { Até R } \$ 4.300,00 \text {, admitida elevação } \\
\text { até R } \$ 5.400,00 \\
\text { nos casos de imóveis situados em } \\
\text { municípios } \\
\text { integrantes de regiões metropolitanas } \\
\text { ou equivalentes, municípios-sede de } \\
\text { capitais estaduais, ou municípios com } \\
\text { população igual ou superior a } 250.000 \\
\text { (duzentos e cinquenta mil) habitantes. }\end{array}$ \\
\hline
\end{tabular}




\begin{tabular}{|c|c|c|c|c|}
\hline $\begin{array}{c}\text { Carta de } \\
\text { Crédito } \\
\text { Associativo }\end{array}$ & 1995 & $\begin{array}{c}\text { Concessão de } \\
\text { financiamentos a pessoas } \\
\text { físicas, associadas em } \\
\text { grupos formados por } \\
\text { condomínios, sindicatos, } \\
\text { Cohabs ou empresas do } \\
\text { setor de construção civil, } \\
\text { para as modalidades } \\
\text { contidas no Programa }\end{array}$ & $\begin{array}{l}\text { Grupo de } \\
\text { pessoas } \\
\text { físicas ou } \\
\text { empresas do } \\
\text { setor da } \\
\text { construção } \\
\text { civil }\end{array}$ & $\begin{array}{c}\text { Até R } \$ 4.300,00 \text {, admitida elevação } \\
\text { até R\$ 5.400,00 } \\
\text { nos casos de imóveis situados em } \\
\text { municípios } \\
\text { integrantes de regiões metropolitanas } \\
\text { ou equivalentes, municípios-sede de } \\
\text { capitais estaduais, ou municípios com } \\
\text { população igual ou superior a } 250.000 \\
\text { (duzentos e cinquenta mil) habitantes. }\end{array}$ \\
\hline $\begin{array}{l}\text { Apoio à } \\
\text { Produção }\end{array}$ & 1998 & $\begin{array}{c}\text { Concessão de } \\
\text { financiamento direto ao } \\
\text { setor privado para a } \\
\text { produção de habitações } \\
\text { cujos valores não } \\
\text { ultrapassem R\$ } 130 \text { mil, } \\
\text { nas regiões metropolitanas, } \\
\text { e R\$ } 100 \text { mil nas demais } \\
\text { regiões } \\
\end{array}$ & $\begin{array}{l}\text { Empresas do } \\
\text { setor da } \\
\text { construção } \\
\text { civil }\end{array}$ & Até $\mathrm{R} \$ 4.900,00$ \\
\hline $\begin{array}{l}\text { Programa de } \\
\text { Arrendamento } \\
\text { Residencial } \\
\text { (PAR) }\end{array}$ & 1999 & $\begin{array}{l}\text { Acesso à moradia pela } \\
\text { população de baixa renda, } \\
\text { sob a forma de } \\
\text { arrendamento residencial } \\
\text { com opção de compra }\end{array}$ & $\begin{array}{l}\text { Empresas do } \\
\text { setor da } \\
\text { construção } \\
\text { civil }\end{array}$ & Até $\mathrm{R} \$ 1.800,00$ \\
\hline
\end{tabular}




\begin{tabular}{|c|c|c|c|c|}
\hline $\begin{array}{l}\text { Programa de } \\
\text { Subsídio à } \\
\text { Habitação de } \\
\text { Interesse Social } \\
\text { (PSH) }\end{array}$ & 2002 & $\begin{array}{c}\text { Financiamento por } \\
\text { intermédio da concessão de } \\
\text { subsídios aos cidadãos } \\
\text { organizados em grupos, } \\
\text { pelos governos dos estados, } \\
\text { DF ou municípios, e, } \\
\text { excepcionalmente, em áreas } \\
\text { rurais }\end{array}$ & $\begin{array}{c}\text { Entidades } \\
\text { privadas sem } \\
\text { fins } \\
\text { lucrativos }\end{array}$ & Até R\$1.245,00 \\
\hline $\begin{array}{l}\text { Programa de } \\
\text { Crédito } \\
\text { Solidário }\end{array}$ & 2004 & $\begin{array}{c}\text { Concessão de } \\
\text { financiamento habitacional } \\
\text { a famílias de baixa renda } \\
\text { organizadas em } \\
\text { associações, cooperativas, } \\
\text { sindicatos ou entidades da } \\
\text { sociedade civil organizada } \\
\text { para a construção de } \\
\text { moradia sob os regimes de } \\
\text { autoconstrução, mutirão e } \\
\text { autogestão }\end{array}$ & $\begin{array}{c}\text { Cooperativas } \\
\text { habitacionais } \\
\text { ou mistas, } \\
\text { associações } \\
\text { e demais } \\
\text { entidades } \\
\text { privadas sem } \\
\text { fins } \\
\text { lucrativos }\end{array}$ & $\begin{array}{l}\text { Até } \mathrm{R} \$ 1.125,00 \text {, entre } \mathrm{R} \$ 1.125,01 \mathrm{e} \\
\mathrm{R} \$ 1.900,00 \text {, limitadas às seguintes } \\
\text { situações: a) } 10 \% \text { do grupo associativo } \\
\text { ou, b) } 35 \% \text { em regiões metropolitanas }\end{array}$ \\
\hline $\begin{array}{l}\text { Programa à } \\
\text { Provisão } \\
\text { Habitacional de } \\
\text { Interesse Social }\end{array}$ & 2007 & $\begin{array}{l}\text { Apoio ao poder público no } \\
\text { acesso da população de } \\
\text { baixa renda à moradia } \\
\text { digna dotada de serviços } \\
\text { públicos, em localidades } \\
\text { urbanas ou rurais }\end{array}$ & $\begin{array}{c}\text { Estados, DF } \\
\text { e municípios }\end{array}$ & Até R\$1.600,00 \\
\hline
\end{tabular}




\begin{tabular}{|c|c|c|c|c|}
\hline $\begin{array}{c}\text { Programa de } \\
\text { Urbanização, } \\
\text { Regularização e } \\
\text { Integração de } \\
\text { Assentamentos } \\
\text { precários }\end{array}$ & 2007 & $\begin{array}{l}\text { Apoio ao poder público nas } \\
\text { intervenções necessárias à } \\
\text { regularização fundiária, } \\
\text { segurança, salubridade e } \\
\text { habitabilidade da população } \\
\text { localizada em área } \\
\text { inadequada à moradia ou } \\
\text { em situações de risco }\end{array}$ & $\begin{array}{l}\text { Estados, DF } \\
\text { e municípios }\end{array}$ & Até $\mathrm{R} \$ 1.600,00$ \\
\hline $\begin{array}{c}\text { Apoio à } \\
\text { Produção Social } \\
\text { da Moradia }\end{array}$ & 2008 & $\begin{array}{c}\text { Apoio às entidades no } \\
\text { desenvolvimento de ações } \\
\text { integradas e articuladas que } \\
\text { resultem em acesso à } \\
\text { moradia, situada em } \\
\text { localidades urbanas ou } \\
\text { rurais, com envolvimento } \\
\text { das comunidades nas ações } \\
\text { de autoconstrução e } \\
\text { mutirão }\end{array}$ & $\begin{array}{c}\text { Entidades } \\
\text { privadas sem } \\
\text { fins } \\
\text { lucrativos } \\
\text { vinculadas } \\
\text { ao setor } \\
\text { habitacional }\end{array}$ & Até $\mathrm{R} \$ 1.125,00$ \\
\hline
\end{tabular}

Fonte: Shimbo (2010). 
No segundo governo Lula (2007-2010), houve a ampliação dos recursos destinados à habitação e também foi priorizado que estes investimentos habitacionais não estivessem articulados ao SNHIS. No ano de 2007, o governo lançou o Programa de Aceleração e do Crescimento (PAC). Vinculado ao PAC, foi lançado o programa habitacional Urbanização de Assentamentos Precários. De acordo com o $10^{\circ}$ balanço do PAC relativo ao programa Urbanização de Assentamentos Precários seleção 2007-2008, incluso no PAC 1, foram contratados 296 empreendimentos em 26 estados e em 131 municípios, totalizando o investimento com recursos OGU na ordem de $\mathrm{R} \$ 13,25$ bilhões. Em relação à execução das obras, estima-se que $99 \%$ foram iniciadas, porém o ritmo de execução gira em torno de $68 \%$. Os empreendimentos vinculados ao Programa Urbanização de Assentamentos Precários com recursos do FNHIS no PAC 1 totalizaram 2.195, em 1.549 municípios, com investimentos na ordem de R \$2,05 bilhões, sendo $98 \%$ das obras iniciadas e $75 \%$ em execução

\section{Gráfico 2 - Porcentagem de Execução Proponente Estadual - Urbanização de Assentamentos Precários - FNHIS}

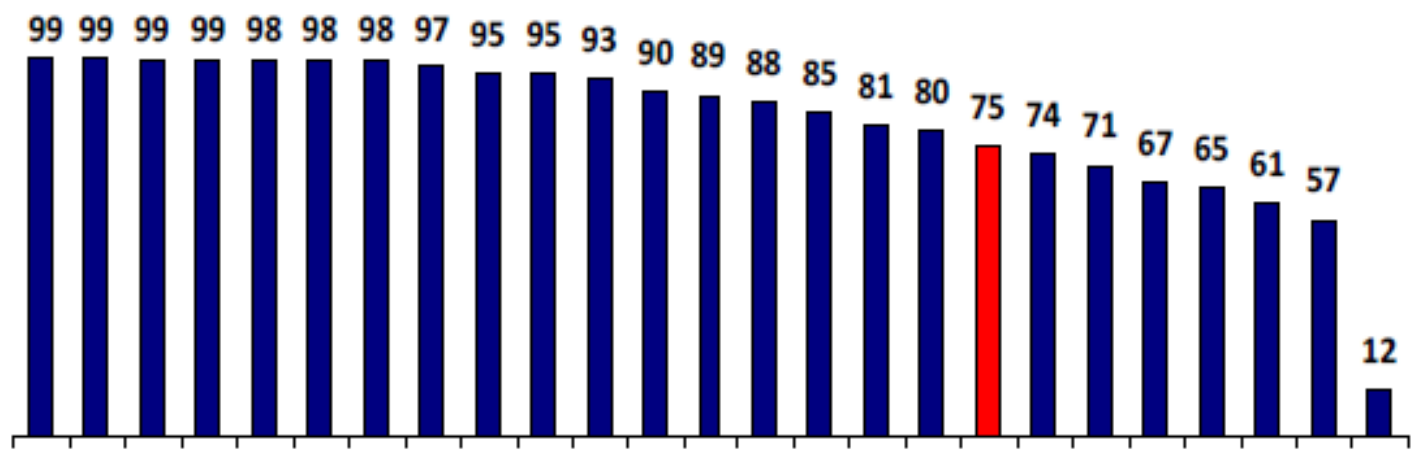

AMMSTOAL RRFNMGACMI PI PBCOPRSCMAPASEERCE RJPERSSP BAAP

Fonte: DUAP/SNH/MCIDADES (2013). Balanço referente ao mês de maio de 2013.

A transição do primeiro para o segundo governo Lula foi marcado pelo lançamento do PAC 1 no ano de 2007 e pela crise econômica internacional no ano de 2009. Para Cardoso e Aragão (2013), a crise dos títulos de hipoteca do mercado norteamericano conhecida como subprime trouxe efeitos em todo o mercado financeiro globalizado. A resposta do governo brasileiro para amenizar o efeito da crise no Brasil foi a expansão de créditos pelos bancos - o Banco do Brasil, o BNDES e a Caixa Econômica -, com a finalidade de amenizar a retração de investimentos do setor privado. 
Uma das alternativas encontradas pelo governo foi a ampliação do crédito habitacional acessível à iniciativa privada.

Considerando o cenário de crise internacional, a baixa execução das obras do PAC 1, como, por exemplo, o baixo ritmo de execução dos programas vinculados à urbanização de favelas. Somam-se a esses fatores a pressão dos setores do segmento da construção civil, que demandavam ao governo a necessidade de ampliação do crédito habitacional e de reformulação dos programas habitacionais mais aderentes à iniciativa privada. Esse conjunto de fatores respaldou do ponto de vista econômico o lançamento do Programa Minha Casa, Minha Vida (PMCMV).

Acerca do assunto, Dias (2012) explica que a tomada de decisão do governo federal, em parceria com o mercado privado, viabilizou o lançamento do Programa Minha Casa, Minha Vida (PMCMV) no ano de 2009:

\begin{abstract}
Dada essa situação de crise e pressão do segmento da construção civil, o presidente da República optou em 2009 por uma política anticíclica de construção em massa de moradias, o PMCMV. As construtoras passam, então, a ter um papel que ultrapassa a edificação em si, atuando também na elaboração de projetos habitacionais de cunho social e na sua viabilização, em parceria com Estados, prefeituras e entidades pró-moradia. A Caixa Econômica Federal, além de sua tradicional função de financiadora, torna-se a grande facilitadora dos projetos, responsável pela coordenação das ações públicas e privadas nos empreendimentos. O PMCMV, com volume inédito de subsídios, alçaria a política habitacional, que crescia e se reestruturava, a um novo patamar. (DIAS, 2012, p. 133).
\end{abstract}

Já Shimbo (2012) chama a atenção, sobre o lançamento do Programa Minha Casa, Minha Vida, para o fato de que este não pode ser encarado como uma surpresa e caracterizado como um rompimento com as premissas da Política Nacional de Habitação e do Plano Nacional de Habitação (PlanHab). Para a autora, o "pacote" Minha Casa, Minha Vida regulamentou a ampliação da provisão privada da habitação, em especial da habitação social. Sublinha-se que as medidas regulatórias aprovadas no primeiro governo Lula fortaleceram os investidores privados e deram-lhes segurança. assim como viabilizaram a criação do Programa Minha Casa, Minha Vida em seu segundo mandato.

As premissas e as motivações iniciais da "nova" política de habitação, formulada em 2004 pelo mesmo governo Lula, já vinham sendo deslocadas e ganhava relevo a atuação privada tanto no Subsistema de Habitação de Interesse Social, como naquele de Habitação de Mercado. Ao mobilizar um conjunto de medidas de estímulo à produção habitacional, mantendo o desenvolvimento dos setores imobiliário e da construção civil, o pacote foi apresentado como uma das principais ações do governo em reação à crise econômica internacional e também como uma política social de grande escala. Justificado por atender esses dois imperativos econômicos e sociais - 
por um lado, a criação de empregos no setor da construção, e, por outro, aprovisão de moradias - o MCMV vem corroborar a ampliação do mercado para o atendimento da demanda habitacional de baixa renda. (SHIMBO, 2012, p. 93).

O Programa Minha Casa, Minha Vida foi regulamentado pela Lei no 11.977/2009 e há uma série de resoluções, portarias e decretos que o normatizam. O programa apresenta três grandes linhas de ações, quais sejam: a) ações de urbanização em assentamentos precários; b) financiamento habitacional pelo Sistema Brasileiro de Poupança e Empréstimo (SBPE) e; c) provisão de unidades habitacionais. No que tange à operacionalização, o programa é constituído pelas seguintes modalidades: Programa Nacional de Habitação Urbana (PNHU); Programa Nacional de Habitação Rural (PNHR); Programa Minha Casa, Minha Vida - Entidades e Programa Minha Casa, Minha Vida Oferta Pública de Recursos (BRASIL, 2010).

Quadro 21 - Faixas de Renda PMCMV (PNHU)
\begin{tabular}{|cll|}
\hline Fase & Faixa de Renda & Renda Familiar Mensal \\
\hline \multirow{2}{*}{ Fase 1 } & Faixa 1 & Até $\mathrm{R} \$ 1.395,00$ \\
& Faixa 2 & De $\mathrm{R} \$ 1.395,01$ a $\mathrm{R} \$ 2.790,00$ \\
& Faixa 3 & De $\mathrm{R} \$ 2.790,01$ a $\mathrm{R} \$ 4.650,00$ \\
& Faixa 1 & Até $\mathrm{R} \$ 1.600,00$ \\
Fase 2 & Faixa 2 & De $\mathrm{R} \$ 1.600,01$ a $\mathrm{R} \$ 3.100,00$ \\
& Faixa 3 & De $\mathrm{R} \$ 3.100,01$ a $\mathrm{R} \$ 5.000,00$ \\
\hline
\end{tabular}

Fonte: Elaboração própria. Informações colhidas no sítio do Ministério das Cidades (2014). 
Quadro 22: Modalidades do Programa Nacional de Habitação Urbana - PNHU

\begin{tabular}{|c|c|c|c|c|c|c|c|}
\hline Modalidades & $\begin{array}{c}\text { Enquadramento } \\
\text { Renda }\end{array}$ & Objetivo & Abragência & Como funciona & Meta & Especificação do Empreendimento & Valor das Unidades Habitacionais \\
\hline $\begin{array}{l}\text { PMCMV } \\
\text { Empresas }\end{array}$ & $\begin{array}{c}\text { Até R\$1.600,00 } \\
\text { (Faixa 1) }\end{array}$ & $\begin{array}{c}\text { Aquisição pelo } \\
\text { Fundo de } \\
\text { Arrendamento } \\
\text { Residencial } \\
\text { (FAR), de } \\
\text { projetos de } \\
\text { empreendimen } \\
\text { tos } \\
\text { apresentados } \\
\text { por empresas } \\
\text { do setor da } \\
\text { construção civil }\end{array}$ & \begin{tabular}{|c|} 
Capitais \\
estaduais e \\
respectivas \\
regiões \\
metropolitanas, \\
região \\
metropolitana de \\
Campinas/SP e \\
Baixada \\
Santista/SP, \\
Distrito federal e \\
municípios com \\
população igual \\
ou superior a 50 \\
mil?Hab. \\
Respeitados \\
alguns critérios \\
também pode \\
ser \\
implementadas \\
operações de \\
aquisição de \\
imoveis nos \\
municípios com \\
população entre \\
20 e 50 mil/hab
\end{tabular} & $\begin{array}{c}\text { União estabelece metas de aplicação dos } \\
\text { recursos por Unidade da Federação (UF), } \\
\text { com base no déficit habitacional. Estados } \\
\text { e Municípios, a partir do seu cadastro } \\
\text { habitacional, realizam o enquadramento } \\
\text { das famílias nos critérios de priorização } \\
\text { definidos para o Programa e inserem no } \\
\text { Cadúnico, se for o caso. empresas do } \\
\text { setor da construção civil apresentam } \\
\text { projetos à Caixa Econômica Federal ou } \\
\text { Banco do Brasil. Após análise, a Instituição } \\
\text { Financeira contrata a operação, } \\
\text { acompanha a execução da obra e libera } \\
\text { recursos conforme o cronograma. } \\
\text { Concluído o empreendimento, a } \\
\text { Instituição Financeira providencia a } \\
\text { alienação das unidades para as famílias } \\
\text { selecionadas. Durante a execução das } \\
\text { obras e após a entrega das UHs, o trabalho } \\
\text { social é realizado sob a responsabilidade } \\
\text { dos Estados e Municípios. Beneficiário } \\
\text { paga mensalmente prestação equivalente } \\
\text { a } 10 \% \text { da renda ou mínima de R\$ } 50,00, \\
\text { durante } 10 \text { anos. Estados e Municíios } \\
\text { podem aportar contrapartidas sob a forma } \\
\text { de recursos financeiros, terreno ou } \\
\text { servicos. }\end{array}$ & $\begin{array}{l}\text { Contratação } \\
\text { de } 860 \text { mil } \\
\text { unidades } \\
\text { habitacionai } \\
\text { s até } \\
\text { dezembro } \\
\text { de } 2014 .\end{array}$ & $\begin{array}{l}\text { casas ou apartamentos de acordo } \\
\text { com especificações técnicas } \\
\text { mínimas, contendo, no mínimo, sala, } \\
2 \text { quartos, cozinha, banheiro e a'rea } \\
\text { de serviço, adaptáveis ao uso por } \\
\text { famílias de que façam parte pessoas } \\
\text { com deficiência. Quantidade } \\
\text { máxima d } 300 \text { Uhs por condomínio. }\end{array}$ & $\begin{array}{l}\text { O limite máximo de aquisição das } \\
\text { Uns é de R\$ } 65 \text { mil e varia de } \\
\text { acordo com a UF/localidade e a } \\
\text { tipologia. Este limite compreende } \\
\text { os custos de terreno, edificação, } \\
\text { infraestrutura interna, legalização } \\
\text { e trabalho. }\end{array}$ \\
\hline
\end{tabular}




\section{Cont. Quadro 22}

\begin{tabular}{|c|c|c|c|c|c|c|c|}
\hline Modalidades & $\begin{array}{c}\text { Enquadramento } \\
\text { Renda }\end{array}$ & Objetivo & Abragência & Como funciona & Meta & Especificação do Empreendimento & Valor das Unidades Habitacionais \\
\hline $\begin{array}{l}\text { PMCMV } \\
\text { Entidades }\end{array}$ & Até $\mathrm{R} \$ 1.600,00$ & \begin{tabular}{|c|} 
Produção e \\
aquisição de \\
unidades \\
habitacionais \\
mediante \\
concessão de \\
financiamentos \\
para famílias \\
organizadas de \\
forma \\
associativa em \\
cooperativas \\
habitacionais \\
ou mistas \\
associações, \\
sindicatos e \\
demais \\
entidades \\
privadas sem \\
fins lucrativos \\
por meio da \\
transferencia \\
de recursos ao \\
Fundo \\
deDesenvolvim \\
ento Social \\
(FDS).
\end{tabular} & $\begin{array}{c}\text { Território } \\
\text { Nacional: áreas } \\
\text { urbanas }\end{array}$ & $\begin{array}{l}\text { União aloca recursos por meio da } \\
\text { transferência de recursos do FDS; } \\
\text { Entidades habilitadas pelo Mcidades } \\
\text { desenvolvem projetos e apresentam à } \\
\text { Instituição Financeira que analisa os } \\
\text { projetos e o enquadramento dos } \\
\text { beneficiários; Entidade e beneficiários } \\
\text { fazem o acompanhamento da obra; } \\
\text { Beneficiário paga mensalmente prestação } \\
\text { equivalente a } 10 \% \text { da renda ou mínima de } \\
\mathrm{R} \$ 50,00 \mathrm{~m} \text { durante } 10 \text { anos. }\end{array}$ & \begin{tabular}{|} 
Contratação \\
de 60 mil \\
unidades \\
habitacionai \\
s até \\
dezembro \\
de 2014.
\end{tabular} & $\begin{array}{c}\text { casas ou apartamentos de acordo } \\
\text { com especificações técnicas } \\
\text { mínimas, contendo, no mínimo, sala, } \\
2 \text { quartos, cozinha, banheiro e a'rea } \\
\text { de serviço, adaptáveis ao uso por } \\
\text { famílias de que façam parte pessoas } \\
\text { com deficiência. Quantidade } \\
\text { máxima d } 300 \text { Uhs por com }\end{array}$ & $\begin{array}{l}\text { O limite máximo de aquisição das } \\
\text { Uhs é de } R \$ 65 \text { mil e varia de } \\
\text { acordo com a UF/localidade e a } \\
\text { tipologia. Este limite compreende } \\
\text { os custos de terreno, edificação, } \\
\text { infraestrutura interna, legalização } \\
\text { e trabalho. }\end{array}$ \\
\hline
\end{tabular}


Cont. Quadro 22

\begin{tabular}{|c|c|c|c|c|c|c|c|}
\hline Modalidades & $\begin{array}{c}\text { Enquadramento } \\
\text { Renda }\end{array}$ & Objetivo & Abragência & Como funciona & Meta & Especificação do Empreendimento & Valor das Unidades Habitacionais \\
\hline $\begin{array}{l}\text { PMCMV Oferta } \\
\text { Pública }\end{array}$ & Até $\mathrm{R} \$ 1.600,00$ & $\begin{array}{c}\text { Apoiar Estados e } \\
\text { Municííios para } \\
\text { produção ou } \\
\text { reposçãão de } \\
\text { unidades } \\
\text { habitacionais por } \\
\text { meio da oferta } \\
\text { pública de recursos } \\
\text { a instituições } \\
\text { financeiras ou } \\
\text { agentes financeiros } \\
\text { autorizados pelo } \\
\text { BACEN e MCidades. }\end{array}$ & $\begin{array}{l}\text { Municípios com } \\
\text { até } 50 \mathrm{Mil} / \mathrm{Hab} \text { - } \\
\text { áreas urbanas }\end{array}$ & $\begin{array}{l}\text { União realiza oferta pública destinada à } \\
\text { Instituições e Agentes Financeiros } \\
\text { habilitados;Os proponentes, Estados e } \\
\text { Municípios, apresentam propostas de } \\
\text { projetos que são selecionadas pelo } \\
\text { MCidades; Instituições ou Agentes } \\
\text { Financeiros fazem a análise de viabilidade } \\
\text { técnica, jurídica e documental das } \\
\text { propostas e firma Termo de Acordo e } \\
\text { Compromisso com os proponentes; Os } \\
\text { Proponentes selecionam beneficiários } \\
\text { que após enquadrados, firmam contrato } \\
\text { com as Instituições ou Agentes } \\
\text { Financeiros. }\end{array}$ & $\begin{array}{c}\text { Contratação } \\
\text { de } 220 \text { mil } \\
\text { unidades } \\
\text { habitacionai } \\
\text { s até } \\
\text { dezembro } \\
\text { de } 2014\end{array}$ & \begin{tabular}{|} 
Unidades habitacionais \\
unifamiliares isoladas ou em \\
conjunto, de acordo com \\
especificações técnicas mínimas, \\
contendo, no mínimo, sala, 2 \\
quartos, cozinha, banheiro e a'rea \\
de serviço, adaptáveis ao uso por \\
famílias de que façam parte pessoas \\
com deficiência. Quantidade \\
máxima d 300 Uhs por condomínio.
\end{tabular} & $\begin{array}{l}\text { O valor da subvenção para a } \\
\text { produção da unidade habitacional } \\
\text { é de } \mathrm{R} \$ 25 \text { mil. }\end{array}$ \\
\hline Modalidades & $\begin{array}{c}\text { Enquadramento } \\
\text { Renda }\end{array}$ & Objetivo & Abragência & Como funciona & Meta & Especificação do Empreendimento & Valor das Unidades Habitacionais \\
\hline $\begin{array}{c}\text { Financiamento } \\
\text { Habitacional }\end{array}$ & Até $R \$ 3.100,00$ & $\begin{array}{l}\text { Subvenção a pessoa } \\
\text { física na contratação } \\
\text { de financiamento } \\
\text { habitacional com } \\
\text { recursos do FGTS, } \\
\text { para aquisição de } \\
\text { imóvel novo ou } \\
\text { construção de } \\
\text { imóvel }\end{array}$ & $\begin{array}{c}\text { Território } \\
\text { Nacional: áreas } \\
\text { urbanas }\end{array}$ & $\begin{array}{l}\text { Ao contratar um financiamento } \\
\text { habitacional o beneficiário tem acesso } \\
\text { aos seguintes benefícios: subsídio } \\
\text { complemento - aporte financeiro direto } \\
\text { variando em função da renda, modalidade } \\
\text { e UF?localidade; Subsídio Equilibrio - } \\
\text { visando à redução da taxa de juros do } \\
\text { financiamento; Acesso ao fundo } \\
\text { Garantidor da Habitação FGHab - garante } \\
\text { benefícios adicionais de redução de } \\
\text { custos de seguro, além de } \\
\text { refinanciamento de parte das prestações } \\
\text { em caso de perda da renda ou } \\
\text { desemprego. }\end{array}$ & $\begin{array}{c}\text { Contratação } \\
\text { de } 600 \text { mil } \\
\text { unidades } \\
\text { habitacionai } \\
\text { saté } \\
\text { dezembro } \\
\text { de } 2014\end{array}$ & $\begin{array}{l}\text { Imóveis com habite-se de até } 180 \\
\text { dias e cujo valor de avaliação se } \\
\text { enquadre nos limites máximos de } \\
\text { financiamento. }\end{array}$ & $\begin{array}{l}\text { Subvenção de até } \mathrm{R} \$ 23 \text { mil, } \\
\text { variando de acordo com a renda da } \\
\text { família e UF/Localidade. }\end{array}$ \\
\hline
\end{tabular}




\section{Cont. Quadro 22}

\begin{tabular}{|c|c|c|c|c|c|c|c|}
\hline Modalidades & $\begin{array}{c}\text { Enquadramento } \\
\text { Renda }\end{array}$ & Objetivo & Abragência & Como funciona & Meta & Especificação do Empreendimento & Valor das Unidades Habitacionais \\
\hline $\begin{array}{c}\text { Financiamento } \\
\text { Habitacional }\end{array}$ & $\begin{array}{c}\text { entre } R \$ 3.100,00 \\
\text { a } R \$ 5.00,00\end{array}$ & $\begin{array}{l}\text { Subvenção a pessoa } \\
\text { física na contratação } \\
\text { de financiamento } \\
\text { habitacional com } \\
\text { recursos do FGTS, } \\
\text { para aquisição de } \\
\text { imóvel novo ou } \\
\text { construção de } \\
\text { imóvel }\end{array}$ & $\begin{array}{c}\text { Território } \\
\text { Nacional: áreas } \\
\text { urbanas }\end{array}$ & $\begin{array}{l}\text { Ao contratar um financiamento } \\
\text { habitacional o beneficiário tem acesso ao } \\
\text { Fundo Garantidor da Habitação FGHab - } \\
\text { garante benefícios adicionais de redução } \\
\text { de custos de seguro, além de } \\
\text { refinanciamento de parte das prestações } \\
\text { em caso de perda da renda ou } \\
\text { desemprego. }\end{array}$ & $\begin{array}{c}\text { Contratação } \\
\text { de } 200 \text { mil } \\
\text { unidades } \\
\text { habitacionai } \\
\text { s até } \\
\text { dezembro } \\
\text { de } 2014\end{array}$ & $\begin{array}{l}\text { Imóveis com habite-se de até } 180 \\
\text { dias e cujo valor de avaliação se } \\
\text { enquadre nos limites máximos de } \\
\text { financiamento. }\end{array}$ & $\begin{array}{l}\text { O valor máximo de avaliação dos } \\
\text { imóveis financiados varia de } \\
\text { acordo com UF/Localidade }\end{array}$ \\
\hline
\end{tabular}




\section{Quadro 23 - Programa Nacional de Habitação Rural (PNHR)}

\begin{tabular}{|c|c|c|c|c|c|c|c|c|}
\hline $\begin{array}{l}\text { Linha do } \\
\text { Programa }\end{array}$ & Modalidades & $\begin{array}{c}\text { Enquadramento } \\
\text { da Renda }\end{array}$ & Objetivo & Abrangência & Beneficiário & Subsídios & Como Funciona & $\begin{array}{l}\text { Comprometi } \\
\text { mento da } \\
\text { Renda }\end{array}$ \\
\hline $\begin{array}{l}\text { Programa } \\
\text { Nacional de } \\
\text { Habitação } \\
\text { Rural } \\
\text { (PNHR) }\end{array}$ & PNHR G I & $\begin{array}{l}\text { Famílias com } \\
\text { renda a nual } \\
\text { bruta de até } \mathrm{R} \$ \\
15 \mathrm{mil}\end{array}$ & $\begin{array}{l}\text { Subsidiar } \\
\text { a } \\
\text { produção } \\
\text { ou } \\
\text { reforma de } \\
\text { imoveis, } \\
\text { por meio } \\
\text { de repasse } \\
\text { de } \\
\text { recursos } \\
\text { do } \\
\text { orçamento } \\
\text { geral da } \\
\text { União }\end{array}$ & $\begin{array}{l}\text { Território } \\
\text { Nacional: } \\
\text { áreas rurais }\end{array}$ & $\begin{array}{l}\text { Agricultores } \\
\text { familiares e } \\
\text { trabalhadores } \\
\text { rurais; os } \\
\text { beneficiários } \\
\text { deverão estar } \\
\text { organizados } \\
\text { de forma } \\
\text { associativa } \\
\text { por uma } \\
\text { Entidade } \\
\text { Organizadora } \\
\text { (EO), } \\
\text { cooperativas, } \\
\text { associações, } \\
\text { sindicatos , } \\
\text { ou Poder } \\
\text { Público Pado }\end{array}$ & 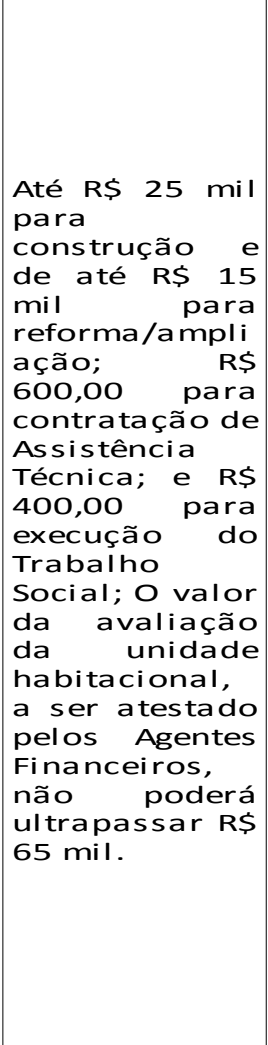 & $\begin{array}{l}\text { A Entidade } \\
\text { Organizadora (EO) } \\
\text { apresenta o projeto } \\
\text { de engenharia, de } \\
\text { Trabalho Social e } \\
\text { documentação } \\
\text { juridíca do } \\
\text { empreendimento, ao } \\
\text { Agente Financeiro } \\
\text { Caixa ou Banco do } \\
\text { Brasil; O Agente } \\
\text { Financeiro analisa e } \\
\text { aprova o projeto } \\
\text { para a contratação } \\
\text { do financiamentos } \\
\text { com os } \\
\text { beneficiários; A EO } \\
\text { inicia o Trabalho } \\
\text { Social e institui a } \\
\text { Comissão de } \\
\text { Acompanhamento de } \\
\text { Obra (CAO) e de } \\
\text { representantes dos } \\
\text { beneficiários, que } \\
\text { presta conta aos } \\
\text { demais } \\
\text { beneficiários; } \\
\text { Conforme o } \\
\text { andamento e as } \\
\text { medições da obra, os } \\
\text { recursos são } \\
\text { repassados à EO; O } \\
\text { Trabalho Social } \\
\text { finaliza a pós a } \\
\text { conclusão e } \\
\text { ocupação das UHs. }\end{array}$ & $\begin{array}{l}\text { Beneficiário } \\
\text { retorna } \\
\text { equivalente a } \\
4 \% \text { do valor } \\
\text { repassado em } \\
4 \text { pagamentos } \\
\text { anuais. }\end{array}$ \\
\hline
\end{tabular}


Cont, Quadro 23

\begin{tabular}{|c|c|c|c|c|c|c|c|c|}
\hline $\begin{array}{l}\text { Linha do } \\
\text { Programa }\end{array}$ & Modalidades & $\begin{array}{c}\text { Enquadramento } \\
\text { da Renda }\end{array}$ & Objetivo & Abrangência & Beneficiário & Subsídios & Como Funciona & $\begin{array}{l}\text { Comprometi } \\
\text { mento da } \\
\text { Renda }\end{array}$ \\
\hline $\begin{array}{l}\text { Programa } \\
\text { Nacional de } \\
\text { Habitação } \\
\text { Rural } \\
\text { (PNHR) }\end{array}$ & PNHR G 2 & $\begin{array}{l}\text { Famílias com } \\
\text { renda anual } \\
\text { bruta entre R\$ } \\
15.00,01 \text { e RS } \\
30 \mathrm{mil}\end{array}$ & $\begin{array}{l}\text { Subsidiar } \\
\text { a } \\
\text { produção } \\
\text { ou } \\
\text { reforma de } \\
\text { imoveis, } \\
\text { por meio } \\
\text { de repasse } \\
\text { de } \\
\text { recursos } \\
\text { do FGTS }\end{array}$ & $\begin{array}{l}\text { Território } \\
\text { Nacional: } \\
\text { áreas rurais }\end{array}$ & $\begin{array}{l}\text { Agricultores } \\
\text { familiares e } \\
\text { trabalhadores } \\
\text { rurais; os } \\
\text { beneficiários } \\
\text { deverão estar } \\
\text { organizados } \\
\text { deforma } \\
\text { associativa } \\
\text { por uma } \\
\text { Entidade } \\
\text { Organizadora } \\
\text { (EO), } \\
\text { cooperativas, } \\
\text { associações, } \\
\text { sindicatos, } \\
\text { ou Poder } \\
\text { Público }\end{array}$ & \begin{tabular}{|l} 
Financiamento \\
habitacional \\
com \\
subvenção de \\
R\$ 7 mil para \\
edificaçãoou \\
reforma da \\
unidade \\
habitacional; \\
R\$ 6Oo,Oo \\
para \\
contratação de \\
Assistência \\
Técnica; RS \\
4OO,OO para \\
execução do \\
Trabalho \\
Social; O valor \\
máximo de \\
avaliação dos \\
imoveis \\
financiados \\
varia de \\
acordo coma \\
UF/Localidade
\end{tabular} & $\begin{array}{l}\text { A Entidade } \\
\text { Organizadora (EO) } \\
\text { apresenta o projeto } \\
\text { de engenharia, de } \\
\text { Trabalho Social e } \\
\text { documentação } \\
\text { juridíca do } \\
\text { empreendimento, ao } \\
\text { Agente Financeiro } \\
\text { Caixa ou Banco do } \\
\text { Brasil; O Agente } \\
\text { Financeiro analisa e } \\
\text { aprova o projeto } \\
\text { para a contratação } \\
\text { do financiamentos } \\
\text { comos } \\
\text { beneficiários; A EO } \\
\text { inicia o Trabalho } \\
\text { Social e institui a } \\
\text { Comissão de } \\
\text { Acompanhamento de } \\
\text { Obra (CAO) e de } \\
\text { representantes dos } \\
\text { beneficiários, que } \\
\text { presta conta aos } \\
\text { demais } \\
\text { beneficiários; } \\
\text { Conformeo } \\
\text { andamento e as } \\
\text { mediçoses da obra, os } \\
\text { recursos são } \\
\text { repassados à EO; O } \\
\text { Trabalho Social } \\
\text { finaliza após a } \\
\text { conclusão e } \\
\text { ocupação das uHs. }\end{array}$ & $\begin{array}{l}\text { Até } 30 \% \text { da } \\
\text { renda familiar } \\
\text { bruta limitada } \\
\text { à capacidade } \\
\text { de pagamento } \\
\text { do } \\
\text { beneficiário. }\end{array}$ \\
\hline
\end{tabular}


Cont. Quadro 23

\begin{tabular}{|c|c|c|c|c|c|c|c|c|}
\hline $\begin{array}{l}\text { Linha do } \\
\text { Programa }\end{array}$ & Modalidades & $\begin{array}{c}\text { Enquadramento } \\
\text { da Renda }\end{array}$ & Objetivo & Abrangência & Beneficiário & Subsídios & Como Funciona & $\begin{array}{l}\text { Comprometi } \\
\text { mento da } \\
\text { Renda }\end{array}$ \\
\hline \begin{tabular}{|l|} 
Programa \\
Nacional de \\
Habitação \\
Rural \\
(PNHR)
\end{tabular} & PNHR G 3 & $\begin{array}{l}\text { Famílias com } \\
\text { renda anual } \\
\text { bruta entre } R \$ \\
30.000,01 \text { até } \\
\text { R\$ } 60 \text { mil }\end{array}$ & $\begin{array}{c}\text { Subsidiar } \\
\text { a } \\
\text { produção } \\
\text { ou } \\
\text { reforma de } \\
\text { imoveis, } \\
\text { por meio } \\
\text { de repasse } \\
\text { de } \\
\text { recursos } \\
\text { do FGTS }\end{array}$ & $\begin{array}{l}\text { Território } \\
\text { Nacional: } \\
\text { áreas rurais }\end{array}$ & $\begin{array}{l}\text { Agricultores } \\
\text { familiares e } \\
\text { trabalhadores } \\
\text { rurais, } \\
\text { organizados } \\
\text { ou não de } \\
\text { forma } \\
\text { associativa } \\
\text { por uma } \\
\text { Entidade } \\
\text { Organizadora } \\
\text { - } \\
\text { Cooperativaa } \\
\text { s, } \\
\text { Associações, } \\
\text { Sindicatos, ou } \\
\text { Poder Público }\end{array}$ & $\begin{array}{c}\text { Financiamento } \\
\text { habitacional } \\
\text { com taxas de } \\
\text { juros reduzida; } \\
\text { O valor } \\
\text { máximo de } \\
\text { avaliação dos } \\
\text { imóveis } \\
\text { financiados } \\
\text { varia de } \\
\text { acordo coma } \\
\text { UF/Localidade }\end{array}$ & $\begin{array}{l}\text { Da mesma forma que } \\
\text { os Grupos } 1 \text { e } 2 \\
\text { quando os } \\
\text { beneficiários } \\
\text { estiverem } \\
\text { organizadoes de } \\
\text { forma associativa } \\
\text { por EO; O } \\
\text { beneficiário pode } \\
\text { também, } \\
\text { individualmente, } \\
\text { contratar } \\
\text { financiamento } \\
\text { habitacional junto à } \\
\text { I.F. }\end{array}$ & $\begin{array}{c}\text { Até } 30 \% \text { da } \\
\text { renda familiar } \\
\text { bruta limitada } \\
\text { à capacidade } \\
\text { de pagamento } \\
\text { do } \\
\text { beneficiário. }\end{array}$ \\
\hline
\end{tabular}


A Caixa tem um papel importante na aprovação dos projetos e na gestão do PMCMV, uma vez que ela é o agente operador do PMCMV, isto é, possui o papel de gestora operacional e financeiro do PMCMV. Dentre as suas atribuições, destacam-se as relacionadas à aprovação e acompanhamento das obras que englobam a realização de vistorias nas obras. Portanto, caberia à Caixa melhorar seus procedimentos relativos à aprovação de projetos e vistoria das obras, uma vez que cabem a ela, também, importantes ações na formulação e operacionalização dos programas e crédito habitacional.

A aprovação de projetos habitacionais (PMCMV) na Caixa está alinhada à provisão de infraestrutura e de existência de equipamentos sociais (escolas, creches, postos de saúde e postos policiais) próximos à região que tenha a capacidade de atender à nova demanda. É o que se observa nas diretrizes disponibilizadas pela Caixa relativas à produção habitacional do PMCMV.

No período de análise dos empreendimentos, a área de Engenharia da CAIXA
analisa o entorno para verificar se os equipamentos sociais existentes - escolas,
creches, postos de saúde e postos policiais - são suficientes para atender à nova
demanda. Caso não sejam suficientes, verifica-se junto à prefeitura se há
terreno disponível para a construção desses equipamentos e disposição do
poder público municipal para mantê-los após concluídos.
Essa é uma condição essencial para a aprovação do projeto. Em caso positivo,
ou seja, existindo terreno e disposição da prefeitura em manter os
equipamentos, a União disponibiliza recursos necessários para sua construçãa,
o que ocorre simultaneamente à produção das unidades habitacionais. (CAIXA
ECONÔMICA FEDERAL, 2014).

É fundamental considerarmos o papel da Caixa, ainda que se admita que não lhe cabe a regulação do uso e ocupação do solo, uma vez que a instituição não é executora direta da política habitacional. Royer (2013) alerta para o papel da Caixa e de outras instituições financeiras serem definidoras na produção do espaço. As instituições financeiras, em especial a Caixa, são as responsáveis pelo maior volume de concessão de crédito habitacional e de aprovação de projetos habitacionais vinculados às linhas programáticas destinadas ao empreendedor imobiliário privado. 
Cada faixa salarial possui o seu produto habitacional correspondente: famílias da faixa 1 adquirem a moradia por meio dos recursos do Fundo de Arrendamento Residencial (FAR), ou, caso estejam reunidas em uma entidade organizadora (EO), por meio do Fundo de Desenvolvimento Social (FDS). As famílias da faixa 2 e 3 têm acesso às linhas de financiamento habitacionais da Caixa Econômica Federal que foram agrupadas ao MCMV e cujos recursos financeiros têm como origem o Fundo de Garantia por Tempo de Serviço (FGTS). Os produtos habitacionais podem ser subdivididos também nos destinados às pessoas físicas $(\mathrm{PF})$ ou à pessoa jurídica $(\mathrm{PJ})$ : no primeiro caso os financiamentos habitacionais são contratados diretamente pelo mutuário nas agências da Caixa. O segundo caso, diferentemente, envolve operações de créditos destinadas às construtoras, cujo recurso financeiro pode ser oriundo do FAR, do FDS ou do FGTS. Adicionalmente, para os empreendimentos das faixas 2 ou 3, há ainda o financiamento feito pela Caixa à pessoa física, e para a faixa 1 a participação da prefeitura que cadastra e sorteia as famílias que poderão adquirir a moradia pelo MCMV. Se o empreendimento se destina a uma entidade organizadora (EO) da faixa 1, não há participação da prefeitura, pois é a EO quem seleciona e indica as famílias que serão beneficiadas pelo programa - na prática, as próprias famílias participantes da entidade. (MARQUES; RODRIGUES, 2013, p. 161).

Os subsídios e as regras do PMCMV vinculam-se ao enquadramento das famílias às faixas de renda. Por exemplo, as famílias enquadradas na Faixa 1, com renda de até $\mathrm{R} \$$ 1,6 mil/mês, podem ter subsídios de até $96 \%$ do valor do imóvel pelo governo federal, com isto as famílias beneficiadas podem ter suas parcelas divididas em até 120 meses, taxas de juros reduzidas e iniciam o pagamento do imóvel a partir da sua entrega. Para as famílias desta faixa, o valor da parcela do financiamento não deve ultrapassar 5\% da renda mensal familiar, sendo que o pagamento mínimo é de $\mathrm{R} \$ 25,00$ por dez anos. Já a faixa de renda 2, no máximo, pode obter subsídio do governo federal de até $\mathrm{R} \$ 25$ mil e está sujeita à aprovação e condições de pagamento determinadas pela instituição financeira. Para a faixa 3, não existe subsídio do governo federal em relação ao pagamento do imóvel. O que existe são juros diferenciados e descontos relativos aos seguros obrigatórios.

Considerando as modalidades e o enquadramento da faixa de renda observa-se o forte papel das construtoras e bancos, em especial da Caixa, na aprovação dos projetos e consequentemente da localização dos terrenos para a execução dos empreendimentos. Registre-se que, majoritariamente, os recursos públicos são alocados no desenho do programa na produção direta, ou seja, priorizando as empresas construtoras. Em nível nacional, o programa, em sua primeira fase (2009-2011), contratou em todas as modalidades 1.093 .249 e entregou 928.024 unidades habitacionais. 
Quadro 24 - Execução do Programa Minha Casa, Minha Vida 1 (2009-2011)

\begin{tabular}{|c|c|c|c|c|}
\hline \multirow{2}{*}{ Renda } & \multirow{2}{*}{ Modalidade } & \multirow{2}{*}{ Contratadas } & \multicolumn{2}{|c|}{ Estágio de Execução } \\
\hline & & & Concluídas & Entregues \\
\hline \multirow{5}{*}{ Faixa 1} & Empresas (FAR) & 404.128 & 373.279 & 350.865 \\
\hline & Entidades (FDS) & 8.024 & 5.199 & 2.930 \\
\hline & Município < 50 mil (OPR) & 63.772 & 49.037 & 40.002 \\
\hline & Rural & 6.817 & 6.535 & 6.518 \\
\hline & FGTS até R\$ $1.600^{*}$ & 107.424 & 106.541 & 88.121 \\
\hline Faixa 2 & $\begin{array}{l}\text { FGTS de R\$ } 1.600 \text { até R\$ } \\
3.275\end{array}$ & 375.764 & 366.968 & 333.531 \\
\hline Faixa 3 & $\begin{array}{l}\text { FGTS de R\$ } 3.275 \text { até R\$ } \\
5.000\end{array}$ & 146.623 & 124.188 & 87.637 \\
\hline & Total & 1.112 .552 & 1.031.747 & 909.604 \\
\hline
\end{tabular}

* Contratação Pessoa Física

Fonte: DUAP/SNH/MCIDADES. Balanço referente ao mês de dezembro de 2014.

Com base nos balanços da primeira fase do programa, no que se refere à meta de contratação o programa atingiu pouco mais de um milhão de unidades habitacionais. No entanto se observa que o ritmo de entregas das unidades habitacionais, no segmento da faixa 1, é mais lento, se comparado ao ritmo de entrega das unidades habitacionais para as faixas de renda 2 e 3, o que corresponde a $88 \%$ de unidades já entregues.

A literatura que analisa os efeitos territoriais do programa e seus problemas para a viabilização da moradia para a população de baixa renda, em linhas gerais, tem apontado os seguintes problemas do programa em sua primeira fase: a) localização periférica dos empreendimentos e o alto custo da terra nas capitais, em cidades com população superior a 50 mil habitantes e inseridas em regiões metropolitanas, o que tem provocado uma expansão urbana para áreas rurais e periurbanas e baixa inserção urbana dos empreendimentos; b) a baixa capacidade dos governos locais e estaduais em articular a contratação dos empreendimentos com a implementação dos instrumentos da política urbana; c) a territorialização dos empreendimentos por faixas de renda nas capitais e municípios integrantes de regiões metropolitanas apresenta distorções em relação ao atendimento do déficit habitacional; d) o monopólio das empresas construtoras na execução dos empreendimentos (BONDUKI, 2009; CARDOSO, 2013).

Com a continuidade do programa, dada a vitória da candidata à Presidência Dilma Rousseff, a segunda fase do Programa Minha Casa, Minha Vida foi implementada pela 
Lei $n^{\circ} 12.424 / 2011$. Em sua segunda fase observa-se uma reformulação de normativos, para amenizar os problemas identificados na primeira fase, além da ampliação de unidades habitacionais para o atendimento do déficit habitacional das famílias enquadradas na faixa 1; e também a ampliação do subsídio. Em sua primeira fase, o programa focalizou $40 \%$ das unidades para a faixa 1, por sua vez, na segunda fase houve um incremento que atingiu 60\%. Além disso, houve uma elevação das exigências em relação às especificações mínimas para a construção das unidades habitacionais na tentativa de aumentar a qualidade construtiva e urbanística dos imóveis (DUAP/SNH/MCIDADES, 2013).

Outro ponto de melhoria refere-se à construção dos empreendimentos "condomínios". Na fase 1 as construtoras, para otimizar a divisão das grandes glebas periféricas, utilizaram-se do efeito proximidade para a construção de vários empreendimentos. Segundo Marques e Rodrigues (2013), esses empreendimentos são tratados como "condomínios fechados" e geraram uma série de externalidades negativas no que tange aos custos de infraestrutura e gestão no pós-morar. $\mathrm{Na}$ segunda fase do programa, os empreendimentos com mais de mil e quinhentas unidades habitacionais ficaram condicionados à análise técnica da Secretaria Nacional de Habitação, vinculada ao Ministério das Cidades, acerca da concepção urbanística e da viabilidade de equipamentos e serviços urbanos. Ou seja, cabe ao corpo técnico do Ministério das Cidades, em reuniões conjuntas com gestores locais e construtoras, a avaliação dos empreendimentos com grande número de unidades habitacionais.

$\mathrm{Na}$ esfera nacional, em sua segunda fase (2011-2014) o programa contratou em todas as modalidades 2.902 .906 e entregou 1.334 .259 unidades habitacionais, totalizando preliminarmente um investimento na ordem de $\mathrm{R} \$ 154,65$ bilhões. 
Quadro 25 - Execução do Programa Minha Casa, Minha Vida 2 (2011-2014)

\begin{tabular}{|c|c|c|c|c|}
\hline \multirow{2}{*}{ Renda } & \multirow{2}{*}{ Modalidade } & \multirow{2}{*}{ Contratadas } & \multicolumn{2}{|c|}{ Estágio de Execução } \\
\hline & & & Concluídas & Entregues \\
\hline \multirow{6}{*}{ Faixa 1} & Empresas (FAR) & 869.058 & 273.206 & 159.585 \\
\hline & Urbanização (FAR) & 48.757 & 12.629 & 5.506 \\
\hline & Entidades (FDS) & 45.858 & 12.188 & 2.116 \\
\hline & Município < 50 mil (OPR) & 103.093 & 24.209 & 17.908 \\
\hline & Rural & 159.839 & 68.560 & 68.292 \\
\hline & FGTS até R\$ $1.600^{*}$ & 144.435 & 139.515 & 139.207 \\
\hline Faixa 2 & FGTS de R\$ 1.600 até R \$ 3.275 & 1.224 .714 & 1.013 .908 & 842.274 \\
\hline Faixa 3 & FGTS de R\$ 3.275 até R $\$ 5.000$ & 307.152 & 155.646 & 99.371 \\
\hline & Total & 2.902 .906 & 1.699 .861 & 1.334 .259 \\
\hline
\end{tabular}

O PMCMV, em suas duas etapas, contratou mais de 3,7 milhões de unidades habitacionais, sendo 1,7 milhões para as famílias enquadradas na faixa de renda 1 e mais de 2 milhões de moradias para as faixas de renda 2 e 3 . Ao verificarmos a adesão do PMCMV, vinculado ao atendimento da população de baixa renda enquadrada na faixa 1 , observa-se que em sua maioria a renda máxima das famílias foi de até $\mathrm{R} \$ 800$, ainda que a renda média das famílias seja de $\mathrm{R} \$ 650$. 
Gráfico 3 - Dados da Pnad no Ano 2012 Versus Atendimento das Famílias Faixa 1

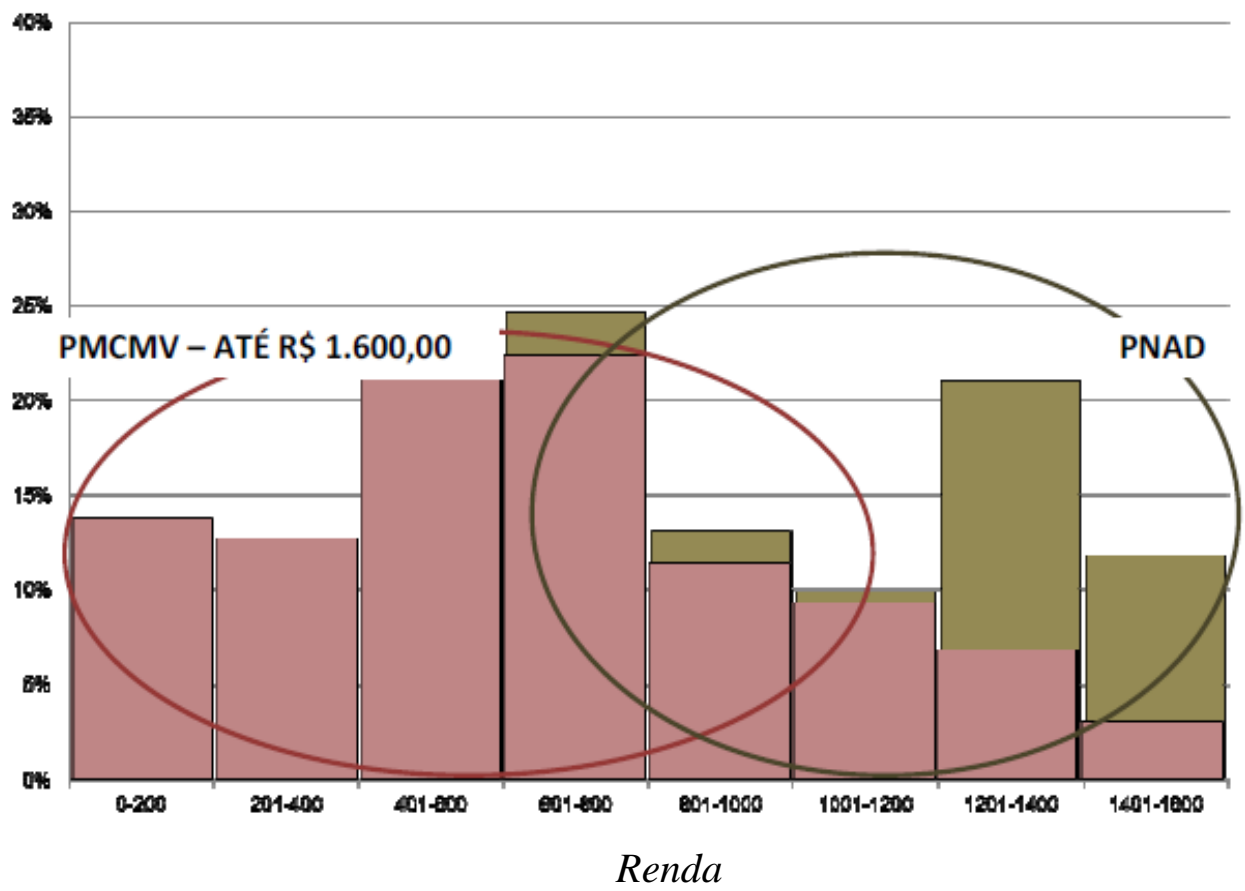

Fonte: DUAP/SNH/MCIDADES, 2012.

Com base nos dados do Gráfico 3, observa-se que o programa tem focalizado no atendimento das famílias com menor renda. Entretanto, ao comparar o volume de contratações para o atendimento das famílias enquadradas na faixa de renda 1 , cujo financiamento advém do FGTS, nota-se uma retração na participação das famílias. 
Gráfico 4 - Contratações do PMCMV (FGTS) por Faixa de Renda (PMCMV 1+2)

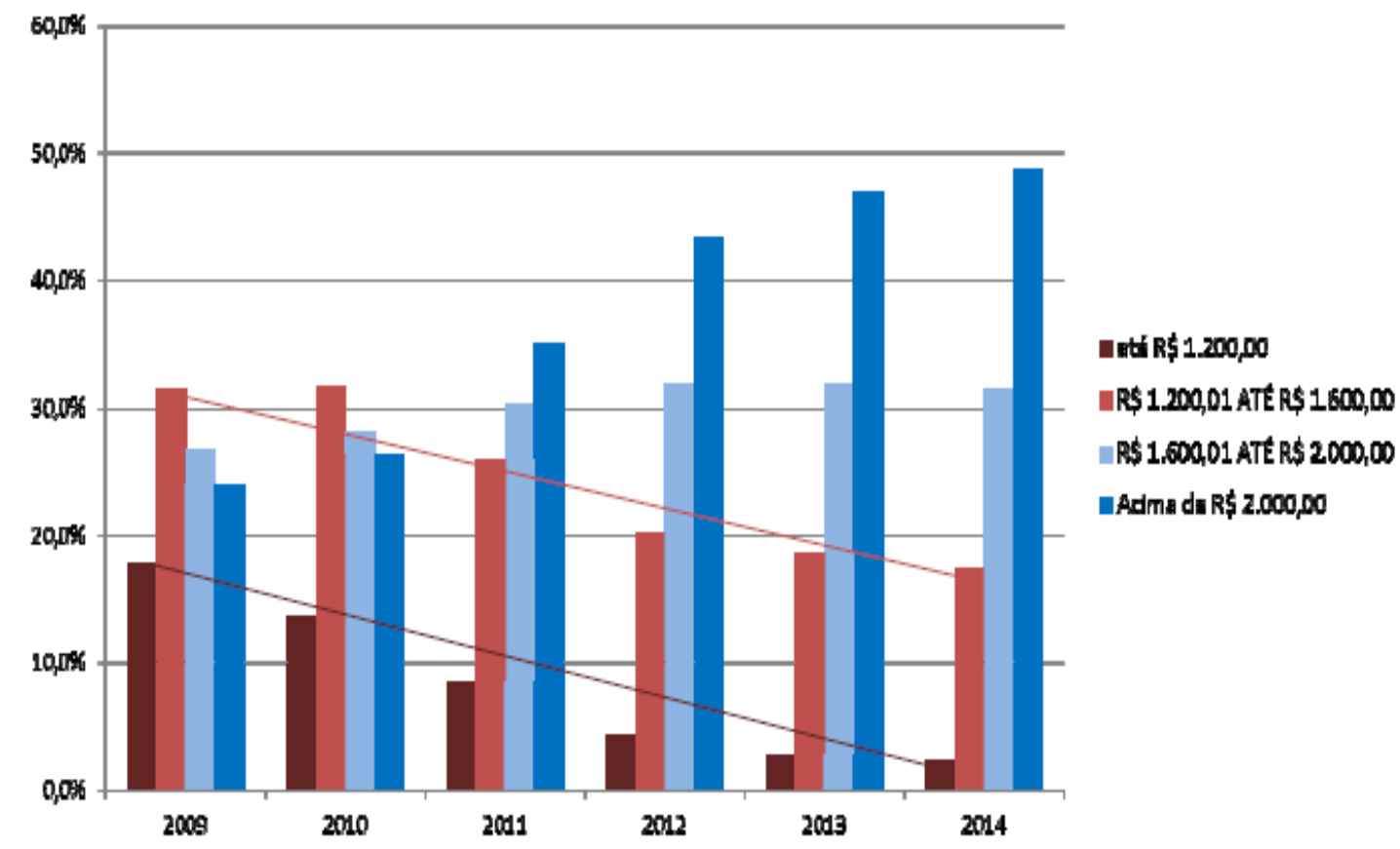

Fonte: DUAP/SNH/MCIDADES (2014).

Os dados do Gráfico 4 nos permitem afirmar que na primeira etapa do PMCMV (2009-2010) as famílias enquadradas na faixa de renda 1 tinham prioridade na participação do programa para as contratações de unidades habitacionais. No entanto, na segunda fase do programa é notória a redução de contratações de unidades habitacionais vinculadas ao FGTS para o atendimento da faixa 1, reduzindo de percentuais superiores a $30 \%$ para percentuais inferiores a $20 \%$. Ou seja, os financiamentos vinculados ao FGTS na segunda etapa do programa não priorizaram o atendimento das famílias de renda mais baixa. Ao contrário, na segunda etapa observa-se uma aceleração das contratações de unidades habitacionais para famílias com renda superior a $\mathrm{R} \$ 1.600,00$.

Apesar da ampliação dos investimentos e das melhorias implementadas na segunda fase do programa, ainda se constituem em desafios a priorização das contratações para o atendimento das famílias enquadradas na faixa 1. Além disso, a localização dos empreendimentos destinados a famílias de baixa renda são, em geral distantes, dispersos e desconectados da malha urbana. É notória a dificuldade de obtenção de terrenos com boa localização nas grandes capitais e nos municípios integrantes de regiões metropolitanas para a produção de moradias para a faixa 1.

Essa segmentação no financiamento impôs limites à produção, decorrentes dos valores máximos para cada unidade habitacional. Considerando o preço da terra enquanto variável determinante para escolha da localização do empreendimento pela iniciativa privada (em função das margens de lucro 
projetadas), o que vem sendo identificado é uma progressiva periferização da produção voltada para as famílias de baixa renda. O mercado busca terrenos mais baratos, o que acaba direcionando os empreendimentos para áreas na margem das áreas urbanizadas, e geralmente carentes de infraestrutura e serviços básicos. (CARDOSO; NUNES Jr., 2013, p. 6).

Com a elevação de crédito habitacional, houve um aumento no preço dos terrenos e na lógica do mercado, com os terrenos mais bem localizados destinados para a produção habitacional para o atendimento das faixas 2 e 3 . Por sua vez, a ausência de aplicação de instrumentos da política urbana que assegurem a delimitação de áreas para a produção de habitação de interesse social, assim como a criação de um banco de terras públicas que poderiam assegurar áreas providas de centralidade à construção de moradias destinadas para a população de baixa renda.

Em linhas gerais, a produção habitacional de interesse social nas grandes metrópoles segue a lógica de regionalização para o atendimento da população de baixa renda. Nota-se, assim, uma concentração significativa de unidades habitacionais em determinadas áreas ou bairros da cidade. Em geral, nos limites das áreas urbanas verificase um adensamento e uma expansão urbana com frágeis elementos de inserção urbana, ao passo que as áreas próximas aos bens e serviços estão sendo destinadas para a produção habitacional visando ao atendimento das faixas de renda 2 e 3.

\section{Quadro 26 - Contratações do PMCMV-2 por Porte Municipal Acima de 50 Mil/Hab. - Faixa 1 (Famílias com Renda até R\$ 1.600,00)}

\begin{tabular}{|c|c|c|c|c|c|}
\hline Recorte & $\begin{array}{c}\text { Déficit } \\
\text { Urbano - } \\
\text { Faixa } 1\end{array}$ & $\begin{array}{c}\text { UHs } \\
\text { Contratadas } \\
\text { OGU (Área } \\
\text { Urbana) Faixa } \\
1\end{array}$ & $\begin{array}{c}\text { UHs } \\
\text { Contratadas - } \\
\text { FGTS (Ára } \\
\text { urbana) Faixa } \\
1\end{array}$ & $\begin{array}{l}\text { Total da UHs } \\
\text { Contratadas }\end{array}$ & $\begin{array}{c}\text { Desempenho } \\
\text { de } \\
\text { contratação } \\
\text { sobre o } \\
\text { déficit }\end{array}$ \\
\hline$>100 \mathrm{mil} / \mathrm{hab}$ & 826.963 & 272.363 & 56.518 & 328.881 & $40 \%$ \\
\hline & 504.594 & 159.278 & 21.866 & 181.144 & $36 \%$ \\
\hline Capitais & 1.238 .247 & 204.221 & 32.364 & 236.585 & $19 \%$ \\
\hline $\begin{array}{l}\text { RM da Capital (sem } \\
\text { a capital) }\end{array}$ & 725.090 & 179.459 & 78.268 & 257.727 & $36 \%$ \\
\hline
\end{tabular}

Fonte: DUAP/SNH/MCIDADES - Dados de contratações utilizadas até 30 março de 2014 - apenas contratações via Caixa. 
No Quadro 26 observa-se a concentração do déficit habitacional nas capitais e municípios integrantes de regiões metropolitanas. Por sua vez onde o programa deveria empreender maiores esforços é notório seu desempenho reduzido no atendimento ao déficit em comparação com o desempenho do programa em outros recortes territoriais.

Também se nota que nas capitais e em regiões metropolitanas há um porcentual significativo de famílias que não se enquadram nas três faixas de rendas e, consequentemente, têm dificuldade de obter acesso ao financiamento habitacional. Tratase das famílias que possuem renda entre $\mathrm{R} \$ 1.448$ e $\mathrm{R} \$ 2.112$. Isto é, o teto limite de renda de até $\mathrm{R}$ \$ 1.600,00 nas capitais e regiões metropolitanas dificulta a inserção de famílias na obtenção de subsídio. Para tanto, uma das propostas na terceira fase do programa, com lançamento previsto para o segundo semestre de 2015, seria a criação de uma faixa intermediária, conhecida provisoriamente como "a faixa $1 \frac{1}{2}$ ".

Vale dizer que a produção habitacional tem sido realizada em parceria com o setor privado. Este, por sua vez, tem obtido importantes e aceleradas aprovações dos seus projetos nas GIDURs (Caixa) e articulado relevantes "flexibilizações", nas legislações urbanas locais, para a execução de empreendimentos em terrenos no limiar do perímetro urbano. Isso tem viabilizado uma produção dos empreendimentos com (má) localização, fomentando a segregação social e reforçando os problemas sociais e a geração de externalidades negativas para a população.

Os custos para os governos locais são imensos para essa produção distante e desconectada, dada a necessidade de implantação de equipamentos, infraestrutura e prestação de serviços urbanos, tais como saneamento, energia, coleta de lixo, transporte, educação, segurança, lazer.

Em determinadas localidades nota-se uma produção habitacional superior ao déficit habitacional. Evidencia-se, assim, que essa produção poderá estar atendendo à demanda de outro município e configurando uma estratégia territorial das construtoras para assegurar a produção habitacional na faixa 1 com terrenos baratos e em sua maioria periféricos. Por sua vez, tal fato evidencia a necessidade de planejar e gerir as políticas habitacionais considerando as dinâmicas dos mercados imobiliários e socioeconômicas das regiões metropolitanas.

A produção habitacional e o atendimento do déficit habitacional necessitam de ações consorciadas entre gestões locais e estaduais em territórios de alta complexidade, como no caso das regiões metropolitanas. Por sua vez, historicamente, as políticas públicas habitacionais não viabilizaram desenhos e programas voltados para a 
problemática metropolitana e que poderiam, em certa medida, fomentar os governos locais e estaduais a viabilizarem de forma coordenada ações consorciadas para uma melhor gestão do uso e ocupação do solo.

Em um período de redesenho do PMCMV mais aderente ao atendimento do déficit habitacional nos territórios metropolitanos, em virtude dos baixos resultados obtidos no enfrentamento do déficit habitacional, tem-se a oportunidade de adotar estratégias concertadas para a promoção de programas habitacionais para além da produção de casas. Tais programas precisam articular a oferta da habitação social à promoção econômica, com resultados no território oriundos de empreendimentos compactos, conectados e coordenados às dinâmicas metropolitanas.

\subsection{Síntese do Capítulo}

Como síntese da produção de habitações sociais no país, a discussão apontou que a produção da habitação social inicialmente era segmentada e atendia a grupos de trabalhadores vinculados aos IAPs. As primeiras ações do Estado para o enfrentamento da crise da moradia não vislumbraram o atendimento de grande parte da população que necessitava de moradia, população essa que historicamente apresenta enormes dificuldades para obtenção de subsídios via governo. Nota-se que a habitação, em especial a habitação social, não era uma prioridade na agenda governamental, tampouco para os segmentos da construção civil.

A elaboração de uma política habitacional para o atendimento da população de baixa renda passou a ser um dos principais pleitos ao Estado no momento em que se nota uma aceleração do crescimento urbano, com forte pressão da população de baixa renda por acesso à moradia. Assim, a questão da moradia tornou-se pauta dos governantes e dos vários segmentos da sociedade. Ao mesmo tempo as cidades brasileiras reconfiguravam seu território, em função das novas atividades econômicas, sobretudo as atividades industrial e comercial.

Nos anos de 1940, como resposta governamental para a crise habitacional criouse a Fundação Casa Popular (FCP), um dos mais ambiciosos projetos para o enfrentamento da crise habitacional. No entanto, a Fundação produziu poucas moradias, e o reduzido financiamento não permitiu o atendimento em ampla escala da sociedade. Mas vale destacar que a criação da FCP marca o reconhecimento do governo federal em estruturar políticas habitacionais para a sociedade, sobretudo para o segmento de baixa renda, marcando a necessidade de produção da habitação social. 
Nesse bojo, a questão habitacional ganha relevância, especialmente na década de 1960, com a criação do Banco Nacional de Habitação (BNH). A atuação do BNH para a produção habitacional no país é um marco, em virtude da estruturação dos mecanismos de financiamentos e dos subsídios governamentais, pois ampliou de forma significativa a produção habitacional no país. Ainda que neste capítulo tenha-se levantado a falta de adesão das políticas do $\mathrm{BNH}$ em atender de forma prioritária à classe de renda de até três salários mínimos, não se pode ignorar o avanço da produção habitacional, no que diz respeito à estruturação na esfera governamental no que tange às fontes de recursos e diretrizes para a intervenção do Estado na provisão da habitação social. Nesse sentido, as políticas habitacionais durante a atuação do BNH representaram uma ruptura do Estado em planejar e implementar políticas públicas voltadas para a habitação, sobretudo a habitação social, se comparadas à forma segmentada e excludente das ações governamentais na época dos IAPs e FCP.

Com o fim do BNH em meados dos anos de 1986, verificaram-se a fragmentação institucional, de planejamento e financiamento no campo habitacional, bem como o agravamento da expansão urbana desordenada, em parte fruto da omissão ou ações inadequadas dos governos em responder às demandas da sociedade em relação às necessidades habitacionais.

Nos anos de 1990, em especial durante o governo de FHC, observa-se um estreitamento do mercado privado com o Estado no campo habitacional. Esse estreitamento é mais bem compreendido no contexto do neoliberalismo, e a provisão da habitação passa a ser entendida como um serviço e, portanto, necessitando de uma reestruturação para melhor adequação aos preceitos de mercado. No governo de FHC observam-se a ampliação do setor privado na produção habitacional e a atuação do Estado como um agente financiador.

O fortalecimento da parceria mercado e Estado nos anos de 1990 marcou de forma significativa o desenho das políticas habitacionais em andamento no país, aproximandoo dos modelos de políticas dos países em desenvolvimento e, em certa medida, desenvolvidos com a presença necessária do mercado privado para a execução dos programas habitacionais, especialmente os de habitação social.

Ao mesmo tempo, essa parceria, com frágeis mecanismos de gestão e cooperação, contribuiu para novas configurações urbanas, acentuando as graves desigualdades que marcam as cidades latino-americanas. São exemplos as regiões metropolitanas, cujos serviços cada vez mais se apresentam concentrados no que denominamos "espaços 
luminosos", e a moradia, sobretudo a moradia social, desintegrada fisica e socialmente da rede de transporte, bacias de empregos e serviços.

Os anos 2000 revelaram uma reestruturação dos mecanismos de financiamento e planejamento habitacional, desde novos regramentos nacionais, como a aprovação do Estatuto da Cidade (10.257/2001), a regulamentação do Sistema Nacional de Habitação de Interesse Social (11.124/2005) e pela primeira vez a criação em nível interfederativo de um Fundo Nacional de Habitação de Interesse Social (FNHIS). Também se observa uma ampliação de subsídios para o acesso à casa própria e uma ampliação do mercado privado no acesso ao crédito habitacional, o que tem influenciado as diretrizes de planejamento e gestão da política habitacional.

A revisão da literatura revela que as respostas do Estado para o enfrentamento da questão habitacional e historicamente a priorização de políticas e programas habitacionais voltados para a aquisição da casa própria, como o modelo principal para o atendimento das necessidades habitacionais e interesses econômicos. Ao mesmo tempo, observa-se que, apesar dos avanços na aprovação de uma legislação nacional para o melhoramento dos mecanismos e implementação de instrumentos urbanos, as estratégias se apresentaram frágeis do ponto de vista de cooperação interfederativa, para o enfrentamento da problemática habitacional nos territórios de complexa dinâmica urbana.

Historicamente, observa-se uma priorização dos investimentos e produção de moradias nos grandes centros urbanos, apresentando, em certa medida, consonância com a concentração do déficit habitacional. Contudo, esses recursos e a localização da produção das unidades podem não estar sendo alocados no município detentor de maior déficit, em decorrência do valor da terra urbana, ou mesmo de sua escassez e dos interesses de elevação de lucro das construtoras e incorporadores, priorizando a produção nas áreas centrais para as faixas de renda mais elevadas.

A fragilidade de mecanismos de cooperação ou programas voltados para o fomento a uma gestão cooperada do uso e ocupação do solo contribuiu para um desinteresse do Estado para o enfrentamento dos problemas metropolitanos, ao desvincular o planejamento da regulação e da fiscalização metropolitana da pauta das agendas transversais do governo federal com os estados e municípios.

No caso da política habitacional que se insere de forma mais ampla na regulação do uso e ocupação do solo, historicamente as agendas de planejamento e implementação dos programas habitacionais não se encontraram. Disso resulta a dificuldade do Estado em amenizar os problemas urbanos, em nível metropolitano, que trazem externalidade na 
economia, com a concentração de oferta de serviços em determinadas áreas das cidades, reforçando a lógica segregacionista e o modelo urban sprawl e, por sua vez, fragmentando o planejamento habitacional, a gestão do uso do solo urbano em articulação à rede de transporte público.

Nesse sentido, as respostas para o enfrentamento dos problemas habitacionais em território metropolitano podem se revelar insuficientes quando planejadas e geridas sem interlocução com os demais Entes federativos.

Disso resulta a necessidade de investigar, como apresentado no capítulo seguinte, os impactos das ações governamentais na esfera da política habitacional em um território de complexa dinâmica urbana, para identificarmos as assimetrias e os avanços que têm modificado a estrutura urbana do território, nesse caso, a Área Metropolitana de Brasília. Ao mesmo tempo, busca-se identificar as ações públicas no campo habitacional e seus graus de influência no território metropolitano. 


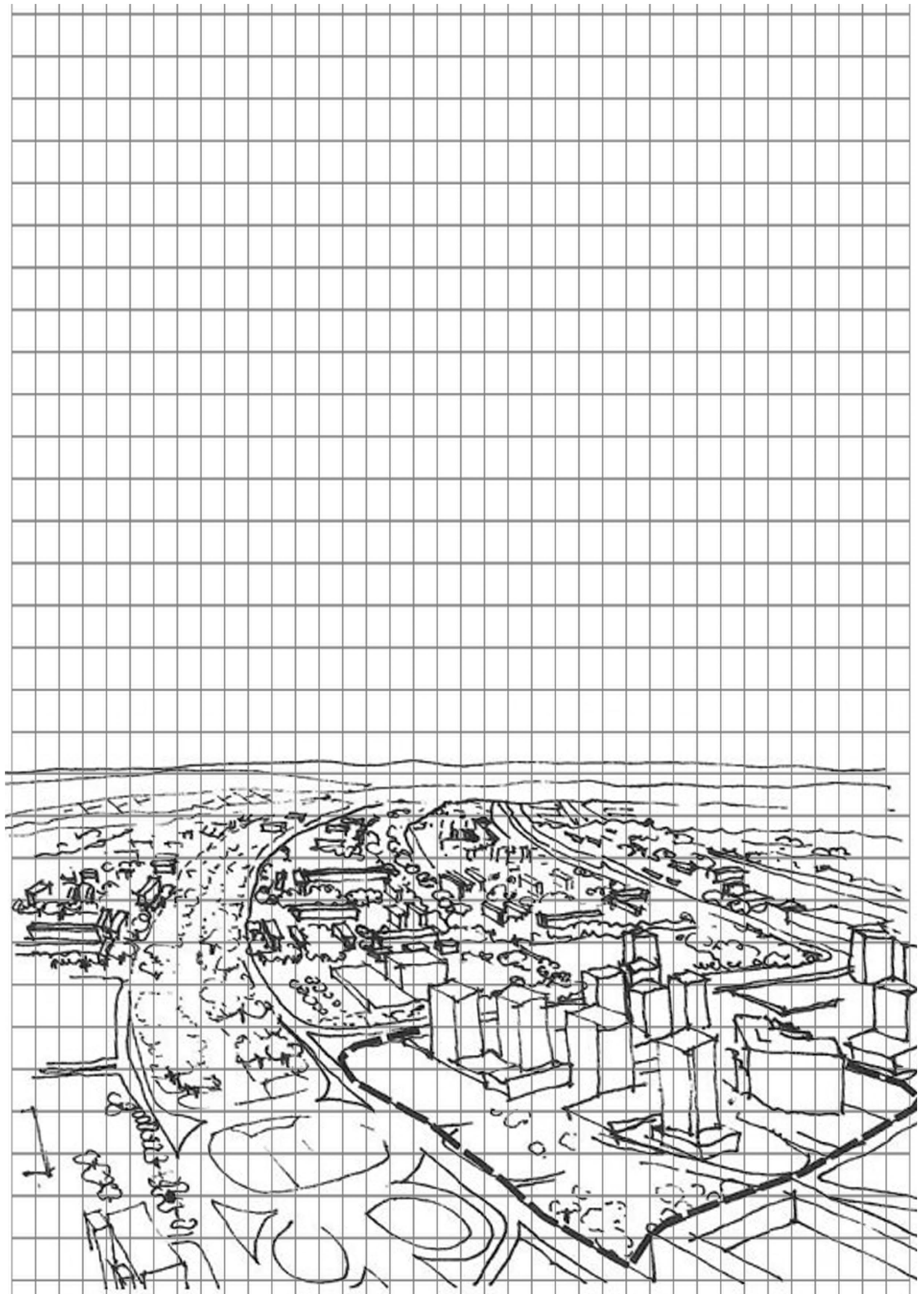




\section{Capítulo 2}

Os limites da política habitacional no Distrito Federal 


\subsection{Brasília: planejamento e produção do espaço urbano}

Ao longo dos 55 anos de Brasília verificaram-se mudanças no enfrentamento da problemática habitacional. Desde o processo de criação da nova Capital Federal - Brasília -, as respostas para a falta de moradia foram influenciadas fortemente pela adoção de estratégias que induziram a oferta de programas, incentivando a população de baixa renda a retornar às suas cidades de origem, assim como por ações de erradicação dos assentamentos e favelas e, em menor grau, pela oferta de lotes em áreas periféricas ou mesmo em municípios goianos próximos a Brasília.

A partir das mudanças na Constituição e da eleição direta para cargo de governador no DF, observam-se ações fragmentadas de apoio à oferta de lotes e moradias para a população de baixa renda.

Antes mesmo da inauguração oficial de Brasília, já existiam demanda habitacional no DF e uma série de medidas e estratégias de ordenamento territorial que ora restringiram o processo de ocupação e a provisão de habitação social, ora induziram o processo de adensamento de outras áreas, nem sempre acompanhadas de provisão de infraestrutura. Assim, o padrão de ocupação de Brasília nos anos iniciais foi marcado por um forte nucleamento, e as áreas distantes do Plano Piloto destinaram-se para as políticas de habitação social, em sua maioria periféricas e com graves problemas de precariedade de serviços urbanos.

As periferias foram se modificando em função das novas estratégias de ordenamento territorial e, sobretudo, das políticas habitacionais, que transformaram os usos e o padrões de ocupação do solo, além das novas infraestruturas instaladas, como serviços, transporte público, comércio e bacia de empregos. Portanto, se no início da criação de Brasília as Regiões Administrativas eram vistas como locais periféricos e desprovidos de infraestrutura, com os investimentos advindos do governo e do setor privado imobiliário transformaram-se em novas frentes de expansão imobiliária, contribuindo para o processo de metropolização do DF.

Para analisarmos as respostas recentes para o enfrentamento do problema habitacional em Brasília e seu rebatimento no território metropolitano se faz necessário revistar as ações no campo do planejamento, gestão urbana e das políticas habitacionais, implementadas pelo governo do Distrito Federal, para identificarmos as assimetrias e os avanços que têm modificado a estrutura urbana do território metropolitano. 


\subsubsection{Primeira fase: a construção da capital - Brasília (1956-1970)}

Brasília começou a ser construída no ano de 1956 e foi inaugurada em abril de 1960. Trata-se de período que denominamos primeira fase, que é a fase de construção da Capital - Brasília.

A transferência da capital do país para a região Centro-Oeste se configurou como um dos elementos relevantes para a interiorização e integração do território brasileiro. Isso a despeito de reconhecer as teorias que abordam a transferência da capital considerando a sua posição estratégica, em consonância aos anseios de defesa do território brasileiro, teorias essas vinculadas, portanto, à perspectiva geopolítica. No entanto, nesta tese é a vertente socioeconômica que pauta as análises da construção de Brasília e a produção do seu território em articulação ao planejamento urbano em interface com as políticas habitacionais e os interesses do Estado.

Brasília, projetada nos princípios modernistas da Carta de Atenas, com base nos elementos funcionalistas das cidades-jardins e do zoneamento, foi concretizada no desenho da proposta vencedora de Lucio Costa e Oscar Niemeyer, a partir do Edital do Concurso Nacional para a construção da nova capital do país.

A premissa que pautou a construção da nova capital foi de novos ideais para o país, para que o espaço pudesse ser vivenciado por todos e cujos princípios do urbanismo e do planejamento urbano poderiam contribuir para uma melhor gestão do espaço, em um contexto de oposição às formas e conteúdos das cidades brasileiras, que revelavam a expansão urbana desordenada, a periferização e a segregação social.

Assim, Brasília foi projetada para uma população de até quinhentos mil habitantes, onde diferentes faixas de renda poderiam habitar espaços próximos e os padrões e zoneamentos urbanos contidos no projeto evitariam a "desordem" tão característica das demais cidades brasileiras. Acerca do assunto, Peluso (1998, p. 43) afirma que a transferência da capital para o Centro-Oeste enfrentou resistência:

\footnotetext{
Para vencer as resistências, um discurso nacional-desenvolvimentista acoplado ao populismo elaborou imagens mitificadas de um Brasil grandioso que, enfim, alçara vôo em direção à era da máquina. $\mathrm{O}$ discurso oficial construiu imagens de Brasília como ponto culminante de um processo de interiorização da civilização e da cultura.
}

Considerando a assertiva da autora, os signos do progresso foram essenciais para legitimar a transferência e a construção da nova capital e, também, para omitir a desconexão de um projeto modernista, inserido em um contexto urbano brasileiro e 
marcado por graves problemas socioeconômicos, pobreza e escassez da moradia e inexistência de uma política nacional de habitação social.

Os primeiros anos da construção de Brasília foram marcados pela chegada de trabalhadores em caminhões vindos de todas as regiões do país, em especial da região Nordeste, para a construção das grandes obras. Trabalhadores que foram submetidos a um regime de trabalho extremamente rígido, além do forte controle da Guarda Especial de Brasília (GEB). Após a construção da capital estava previsto o retorno dos migrantes, visto que a capital não previa espaços de moradias para os candangos ${ }^{15}$ e nem para a população de baixa renda, que migrava para a capital em busca de novas perspectivas de emprego e melhoria na qualidade de vida.

Para dimensionarmos a forte migração em direção a Brasília nos anos de sua construção, vale considerar o que afirma Barbosa Ferreira (1985), segundo a qual no ano de 1957 a população era de 12.700 habitantes e no ano de 1960 elevou-se para 127 mil habitantes.

Paralelo à construção da cidade planejada também ocorreu a construção dos primeiros acampamentos provisórios e das cidades-satélites construídas antes da inauguração da capital. Os acampamentos estavam previstos para atender às necessidades provisórias de "moradia" dos trabalhadores. Em geral esses espaços provisórios de moradias localizavam-se nas proximidades aos canteiros das obras, o que facilitava o controle das construtoras quanto ao ritmo de produção. Sublinha-se que esses espaços seriam extintos após a finalização das obras.

Já as cidades-satélites estavam previstas, no projeto de construção da capital, somente quando a população chegasse a quinhentos mil habitantes. No entanto, a criação de parte delas ocorreu antes mesmo da inauguração da capital, em função da permanência dos trabalhadores e do forte contingente migratório. (PELUSO,1998)

Dentre os acampamentos provisórios que se formavam próximos aos canteiros, três deles dariam lugar às cidades-satélites: a) os acampamentos provisórios criados para a construção do Eixo Monumental e de suas edificações, que ao todo somavam vinte e dois e dariam lugar à Vila Planalto (1957); b) a Candangolândia, que foi o primeiro acampamento construído no ano de 1956 pela Novacap, para abrigar as equipes técnicas, administrativas e trabalhadores; somente no ano de 1989 a Candangolândia se tornou oficialmente uma cidade-satélite e; c) os acampamentos da Cidade Livre, também criados

\footnotetext{
${ }^{15}$ Nome com que se designam os trabalhadores comuns que colaboraram na construção de Brasília.
} 
no ano de 1956 como um núcleo provisório para os construtores da capital (PELUSO, 1998)

A denominação de Cidade Livre pode ser explicada em função da isenção de taxas e impostos das atividades comerciais em uma tentativa de atrair serviços. A Cidade Livre era o suporte técnico e administrativo para a construção da capital, e sua remoção estava prevista após a finalização das obras. Entretanto, em função da resistência da população, tornou-se cidade-satélite no ano de 1961, com a denominação de Núcleo Bandeirante (PELUSO, 1998).

A lógica de construção dos acampamentos próximos aos locais de construção da capital, além de ter facilitado o controle social, foi a opção encontrada pelos gestores responsáveis pelas obras pois as cidades goianas próximas à capital, como Planaltina, Luziânia e Brazlândia, não apresentarem condições de infraestrutura para alocarem os trabalhadores, o que inviabilizaria a fluidez dos trabalhadores para os canteiros de obras.

Os acampamentos, com toda a ordem de precariedade, tornaram-se as primeiras formas de moradia para a população de baixa renda na capital. Ademais, o fato de que os trabalhadores se posicionaram contra e resistiram às práticas adotadas pelo GDF, de derrubar os acampamentos, em uma tentativa de induzir o retorno da população para as cidades de origem, somado às ações de erradicação e remoção das famílias para locais distantes e sem infraestrutura, marcaram a criação das primeiras cidades-satélites.

\footnotetext{
Além dos dois municípios consolidados e então existentes no quadrilátero destinado à implantação do Distrito Federal: Brazlândia e Planaltina, surgiram o Núcleo Bandeirante, destinado a ter uso exclusivamente comercial residencial provisório e de serviços; Taguatinga, fundada em 5 de junho de 1958 a oeste de Brasília; a Vila Paranoá, criada em janeiro de 1957, com a chegada dos primeiros trabalhadores para as obras da Barragem do Paranoá; e São Sebastião, que surgiu em 1957, onde existiam várias olarias que supriam a demanda da construção civil por materiais. Posteriormente foi criado o Guará, em maio de 1967, para abrigar funcionários públicos do Governo do Distrito Federal (GDF), posteriormente foram criadas as cidades-satélites do Gama (1960), de Sobradinho (1960) e do Paranoá (1964). Em 1969, com apenas nove anos de fundação, Brasília já possuía 79.128 favelados, que moravam em 14.607 barracos. (MOURA, 2015, p. 203, com adaptações).
}

A remoção dos acampamentos da área central de Brasília para a Vila IAPI, que com os acampamentos e as invasões da Vila Tenório, da Esperança, de Bernardo Sayão, do Colombo, do Morro do Urubu, da Placa da Mercedes se constituía num dos maiores aglomerados de favelas de Brasília, abrigavam aproximadamente 82 mil moradores e cerca de 12 mil barracos. Sublinha-se que a Vila IAPI foi objeto por parte da Novacap de ações de erradicação de favelas (GOUVEA, 1995). 
A Vila IAPI se constituiu em um dos exemplos mais marcantes de resistência da população contra as ações do GDF. Registre-se que sua remoção para uma área distante e sem infraestrutura localizada a trinta quilômetros da área central de Brasília, ocorreu contra a vontade dos moradores (GOUVEA, 1995; COSTA; PELUSO, 2013).

A resposta do Estado para preservar as características do projeto urbano da nova capital e conter o acelerado crescimento urbano foram a segregação e a periferização dos locais de moradia destinados à população de baixa renda. Uma vez que a posse da terra era de origem pública da Novacap, ficaram facilitados o planejamento e a gestão urbana controlada da população de baixa renda.

No ano de 1962, foi fundada a Sociedade de Habitações Econômicas de Brasília (SHEB), com a finalidade de promover a construção de moradias para os funcionários administrativos do governo e também atender à população dos acampamentos. Em mais de dois anos de existência, a SHEB construiu apenas 99 moradias na região de Sobradinho. Assinale-se que a SHEB foi substituída pela Sociedade de Habitações de Interesse Social (SHIS) no ano de 1964.

Coube à SHIS a elaboração e execução do Plano Nacional de Habitações no Distrito Federal, alinhado à recente estrutura federal concebida a partir da criação do Banco Nacional de Habitação (BNH). Também, nos anos de 1960, mais precisamente em 1968, foi criada a Comissão de Supervisão dos Núcleos Habitacionais Provisórios (CSNHP), com a missão de remover os acampamentos e favelas da área central e próximas ao Plano Piloto de Brasília.

Considerando-se o período de criação de Brasília até meados dos anos de 1970, observam-se ações fragmentadas e divergentes no que tange às ações governamentais para a provisão da moradia para a população de baixa renda. Em linhas gerais, a SHIS, nos anos 1960, não promoveu a construção de moradias sociais, e as ações mais prementes do governo foram as remoções de favelas e acampamentos, revelando a face autoritária e violenta das políticas habitacionais no DF.

As formas de habitação para a população realocada ou que permaneceu nos acampamentos eram precárias e não havia uma política pública desenvolvida para o atendimento da população de baixa renda. Pelo contrário, a política de gestão urbana era pautada na erradicação dos acampamentos e no descompromisso com infraestrutura urbana nas recentes cidades-satélites.

Ao mesmo tempo, a lógica adotada pelo Estado marcaria o ordenamento territorial do Distrito Federal, em núcleos urbanos polinucleados e distantes dos centros 
e com baixa capacidade de oferta de emprego e lazer. Ações essas que ainda são reproduzidas na implementação dos projetos urbanos e habitacionais na atualidade.

\subsubsection{Segunda fase: as práticas de gestão e planejamento urbano-regional e as políticas habitacionais do período de 1970-1979}

A política habitacional, até meados da década de 1970, no Distrito Federal, foi marcada pelas práticas de erradicação de favelas. Entre os anos de 1970 e 1976 foram removidas aproximadamente 118 mil pessoas de áreas adjacentes à área central de Brasília (Plano Piloto) para as recém-criadas cidades-satélites. Estima-se que entre os anos de 1970 e1976 houve um incremento de 44 mil lotes. Para dimensionar as fortes ações de erradicação nesse período, note-se que o número de favelas e acampamentos foi reduzido para 17 mil pessoas que abrigavam-se em favelas na área central de Brasília (GOUVEA, 1995).

\section{Quadro 27 - Crescimento Populacional DF (1960-1970)}

\begin{tabular}{|c|c|c|c|c|}
\hline Ano & $\begin{array}{l}\text { População } \\
\text { do DF } \\
\text { (Mil) }\end{array}$ & $\begin{array}{l}\text { Crescimento } \\
\text { do DF (\%) }\end{array}$ & $\begin{array}{l}\text { População } \\
\text { do Brasil } \\
\text { (milhões) }\end{array}$ & $\begin{array}{l}\text { Crescimento da } \\
\text { População do } \\
\text { Brasil (\%) }\end{array}$ \\
\hline 1960 & 140.165 & & 66.302 .271 & - \\
\hline 1970 & 537.492 & 283,47 & 93.139 .037 & 40,47 \\
\hline
\end{tabular}

Nos anos de 1970 a capital iniciou o processo de consolidação, com a transferência dos órgãos governamentais do Rio de Janeiro para o DF, e também nota-se o acelerado processo de ocupação e crescimento demográfico, impondo ao governo a necessidade de controlar e evitar o avanço de áreas informais. Para tanto, no ano de 1973, a Novacap foi transformada em empresa pública autônoma, denominada Companhia Imobiliária de Brasília (Terracap), e consolidou o seu papel de detentora das terras públicas do Distrito Federal.

Segundo a Lei Federal no 5.861/1972, que autorizou a criação da Terracap e estabeleceu suas responsabilidades, cabia à Terracap: “[...] gerir o patrimônio imobiliário do Distrito Federal, mediante utilização, aquisição, administração, disposição, incorporação, oneração ou alienação de bens" (BRASIL, 1972).

Segundo Gouvea (1995), a Terracap, nos anos de 1973-1985, trabalhou com quatro modalidades de alienação de imóveis: a) licitação pública (leilão) - para imóveis 
com todas as destinações e localizados em todos os núcleos urbanos, o comprador tinha trinta meses para construir ; b) venda direta - para entidade com fins lucrativos ou entidades governamentais com receita própria, o preço equivalia a $10 \%$ do valor de mercado; e para as entidades sem fins lucrativos ou com receita própria, o preço equivalia a 50\% do valor de mercado; c) regularização - com cessão de direitos, comércio de terras, o preço era de $70 \%$ do valor de mercado residência; d) doação - para uso da União ou do Governo Federal.

A política da Terracap priorizou a oferta de terras para o atendimento da população de alta e média renda, o que acelerou a construção e ocupação das áreas centrais, em função do dispositivo jurídico que obrigava o comprador a construir em até trinta meses para não perder o imóvel. Nesse sentido, observam-se ações por parte do governo para a construção e ocupação de moradias na área central de Brasília pela população de classe alta e média.

Já as ações de moradias destinadas para a população de baixa renda ficaram a cargo da SHIS. Nos anos de 1970, as práticas habitacionais resumiam-se a políticas de remoção de favelas e acampamentos e oferta de lotes e moradias nas cidades-satélites em regime de concessão de uso. Isto é, o morador não tinha direito à propriedade, de modo que a venda ou o repasse ficavam proibidos, e em alguns casos pagava-se pela concessão de uso. (PELUSO,1998)

Já as moradias sociais ofertadas pela SHIS em regime de aquisição do imóvel próprio somente eram destinadas aos estratos de renda capazes de pagar pelas prestações, razão por que só uma minoria da população de baixa renda teve acesso a elas.

Nos anos de 1974 a 1979 a SHIS produziu aproximadamente 53 mil moradias, grande parte delas com recursos do $\mathrm{BNH}$ destinadas paras as famílias com renda entre três e cinco salários mínimos. 
Quadro 28 - Produção Habitacional no Distrito Federal até 1979

\begin{tabular}{|crr|}
\hline Ano & & Quantidade de UHs construídas \\
\hline & 1960 & $1.520^{*}$ \\
$1962-1973$ & & 17.192 \\
& 1974 & 2.706 \\
& 1975 & 4.634 \\
& 1976 & 2.090 \\
& 1977 & 13.869 \\
& 1978 & 14.474 \\
& 1979 & 15.474 \\
\hline \multicolumn{2}{|c|}{ Total } & 71.959 \\
\hline *Produção habitacional no período da Fundação Casa Popular (FCP). \\
** Na década de 1970, a produção habitacional foi pela SHIS. \\
Fonte: Adaptado de Colela (1991) e Gouvea (1995).
\end{tabular}

A produção de moradias destinadas para a população carente - famílias com renda abaixo de três salários mínimos - era quase inexistente. Sublinha-se que é nessa faixa de renda que grande parte da população removida das favelas a assentamentos se enquadrava.

A lógica das primeiras ofertas de habitações sociais no DF pautou-se na periferização, lógica que poderia ser amenizada visto que grande parte da terra urbana no DF ser de propriedade estatal, o que poderia ensejar um planejamento e oferta habitacional mais equânime.

Considerando esse contexto, nas análises sobre a produção do espaço urbano em Brasília é mister considerar o papel estratégico que o governo exerce nas formas de planejamento segregacionista, em especial o papel da Terracap como um dos principais agentes imobiliários. Acerca do assunto, Penna (2000) explica que entre as décadas de 1960 e meados de 1980 as ações do Estado para ordenar o território da capital ocorreram em consonância com as ações de remoção das favelas e ocupação das cidades-satélites.

[...] as ações do Estado para consolidar e organizar a cidade ocorriam incrementalmente, ligadas à personalidade dos governantes. Os conflitos entre o projeto do Plano Piloto e o planejamento da ocupação do território deixam abertas grandes lacunas, proporcionando as opções para compor os interesses no estabelecimento de uma estratégia política de ocupação do território. Estas lacunas vão ao encontro das transformações das relações políticas, sociais, territoriais que se impunham para fortalecer e legitimar os novos interesses políticos e econômicos do país durante essas décadas. Assim, inicialmente o GDF determina estrategicamente a organização polinucleada da periferia, localizando as cidades-satélites distantes do Plano Piloto e entre si, fragmentando a terra, porém mantendo o domínio absoluto sobre esse processo, por intermédio do planejamento burocrático e centralizado. (PENNA, 2000, p. 116). 
A criação e expansão das áreas urbanas nas recém-criadas cidades-satélites no Distrito Federal, somadas à ocupação periférica e à informalidade da terra nos municípios goianos próximos à capital, revelaram um forte processo de ocupação periférica. Tratase de um processo condicionado pelas formas de moradias precárias para a população de baixa renda, desprovida da posse do terreno (título da propriedade privada), e pela deficiência na oferta e acesso aos serviços públicos, em decorrência do baixo grau de desenvolvimento da economia, do frágil mercado de consumo e da ausência de potencial de inovação nos municípios goianos (PENNA, 1991).

Até então, a estrutura produtiva dos municípios goianos era baseada na pecuária e agricultura de subsistência, de modo que o processo de instalação da nova capital Brasília - provocou grandes alterações no uso e ocupação do solo nas áreas urbanas e rurais e no modus vivendi de rural para urbano.

Para Ferreira (2010), Brasília como polo de desenvolvimento no Centro-Oeste inaugurou uma nova fase de ocupação do território. A nova capital representou novas premissas no planejamento urbano, novas relações sociais e a implantação da modernização conservadora.

Por sua vez, os baixos níveis de industrialização, a reduzida capacidade administrativa dos municípios goianos próximos à capital, além do acelerado crescimento da população urbana, dissociada de oferta de emprego e planejamento urbano, evidenciaram a falta de uma estrutura produtiva capaz de gerar benefícios econômicos e sociais de promoção ao desenvolvimento regional (CAVALCANTI, 2009).

A realidade urbana de Brasília nos anos 1970 evidenciava a emergência de ações para ordenar o acelerado processo de ocupação da capital federal em interface com a sua região de influência. Isso se devia à forte contradição entre a região core-Brasília, com funções planejadas, e a periferia, territorialmente fragmentada e desarticulada em relação à inovadora matriz produtiva da região core (FERREIRA, 2010).

As novas relações urbanas demandavam uma resposta do Estado. A intervenção governamental para enfrentar a problemática urbana de Brasília ocorreu por meio de ações e investimentos priorizando a escala regional e de ações específicas para conter o processo de metropolização (CAVALCANTI, 2009). Tratava-se de uma tentativa de dinamizar a economia regional, diversificar o perfil das economias municipais e evitar a forte dependência da população residente nos municípios goianos em busca de emprego no Distrito Federal. 
A primeira grande ação do governo federal para promover infraestrutura e dinamizar a estrutura produtiva dos municípios goianos e integrá-los ao processo de modernização ocorreu no ano de 1966, com a regulamentação do Art. 209 do DecretoLei $n^{\circ} 82 / 1966$.

A implementação do Decreto viabilizou a criação do Fundo de Desenvolvimento Econômico do Distrito Federal (FUNDEPE), com a finalidade de apoiar financeiramente obras de infraestrutura urbana, para diversificar as atividades econômicas e sociais na escala regional para o fomento às economias conectadas aos polos de desenvolvimento regional. O Decreto também estabelecia que, para as ações de investimentos na região, $20 \%$ advinham da receita tributária anual arrecadada no DF e "dos dividendos percebidos pelo Distrito Federal de suas ações no Banco Regional de Brasília S.A., da Companhia de Desenvolvimento do Planalto Central e das demais empresas de cujo capital participe” (BRASIL, 1966).

Como o Fundo foi criado e coordenado pelo Distrito Federal, grande parte das ações e receitas foi investida na promoção de infraestrutura do próprio Distrito Federal. Cavalcanti (2009) chama a atenção para o fato de que a implantação do FUNDEPE ampliou o faturamento das empresas com investimentos que propiciaram a modernização e o aumento do número de postos de empregos. Ressalva, porém, que a maioria das ações se restringiu ao parque produtivo do Distrito Federal.

As ações do FUNDEPE já nos anos de 1970 revelavam a necessidade emergencial de coordenação interfederativa e mecanismos de fiscalização para que as ações pudessem ser promovidas na escala regional.

No ano de 1972, sob a matriz desenvolvimentista do I Plano Nacional de Desenvolvimento (PND), havia proposições para a criação do Programa para a Região Geoeconômica de Brasília (PERGEB). Entretanto, somente no II PND (1975-1979) é que foram definidas e implementadas as estratégias de ação para o Programa da Região Geoeconômica de Brasília.

O PERGEB (Figura 2) definiu cinco áreas-programas para a estruturação da rede urbana regional, abrangendo 87 municípios, sendo 74 goianos e 13 mineiros, além do Distrito Federal. O PERGEB apresentava os seguintes objetivos:

- Minimizar o impacto dos fluxos migratórios que demandam a capital da república, através da abertura de novas oportunidades de emprego na Região Geoeconômica de Brasília, notadamente nos pontos estratégicos da trajetória dos migrantes; - Atenuar as pressões sobre o equipamento urbano de Brasília através da melhoria de infraestrutura social dos principais núcleos urbanos da região; - Preservar as funções político-administrativas e cultural da Capital 
Federal, canalizando os esforços produtivos de maior vulto para o quadro mais amplo da região; - Integrar a área ao processo de desenvolvimento regional através do fortalecimento dos núcleos urbanos e da infraestrutura da região; Valorizar a economia da região com vistas à integração ao processo de desenvolvimento nacional e ao abastecimento de Brasília através do estímulo às atividades agropecuárias e industriais. (CAVALCANTI, 2009, p. 44).

A finalidade do PERGEB era gerar maior integração das áreas-programas com as demais regiões brasileiras, ou seja, propor estruturas econômicas, especialmente baseadas no agronegócio, para alavancar e diversificar as matrizes econômicas dos municípios goianos e mineiros. Essa medida poderia reduzir a demanda por serviços urbanos no Distrito Federal e proteger as características político-administrativas da capital. No ano de 1977, o PERGEB introduziu metas de ordenamento territorial, segundo escalas de atuação regional.

Figura 2 - Escalas de intervenção do PERGEB 1975

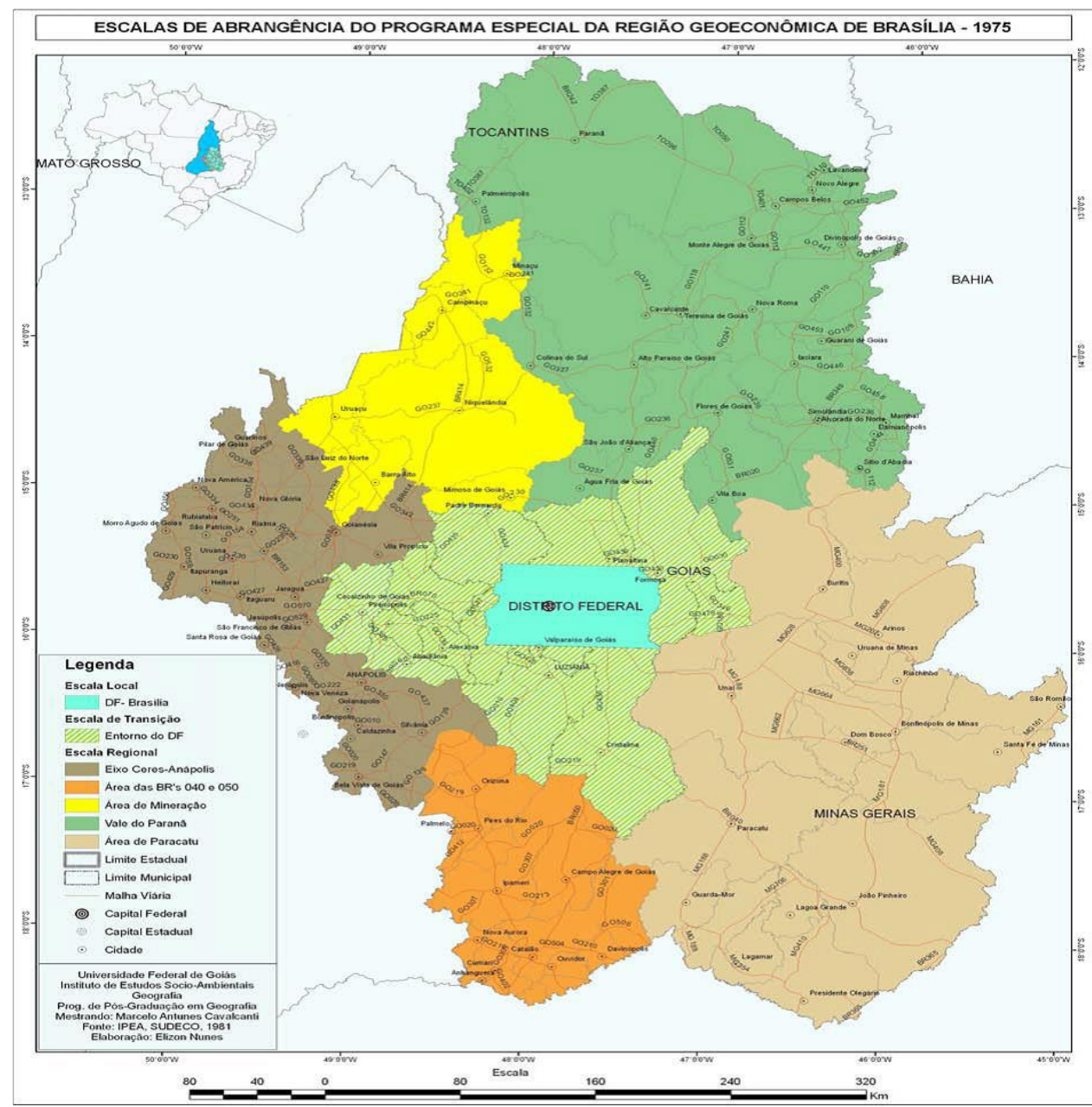

Fonte: Adaptado de Cavalcanti (2009). 
De acordo com as propostas do programa, seriam três escalas de intervenção: a escala local (área de contenção), constituída pelo território do Distrito Federal; a segunda, a escala de transição (área de controle), constituída pelos municípios goianos adjacentes ao Distrito Federal; e a terceira, a escala regional, correspondente à área de dinamização composta por eixos goianos - Ceres e Anápolis, municípios sob a influência da BR-040 e da BR-050, Vão do Paranã - e por Minas Gerais - municípios com vocação para mineração, em especial na área do Paracatu.

A delimitação das escalas de atuação do PERGEB no ano de 1975 consolida-se como uma das primeiras tentativas institucionalizadas de ordenar o território metropolitano da capital federal através de escalas de intervenção, sobretudo a escala local e de transição. Os objetivos apontados no programa para o ordenamento no Distrito Federal se articulavam à escala de transição que corresponderia, em certa medida, a uma regionalização governamental para o enfrentamento dos problemas metropolitanos.

$\mathrm{Na}$ escala do GDF ocorreram as primeiras grandes ações de ordenamento do território, com a criação do Plano Estrutural de Organização Territorial para o Desenvolvimento do DF (PEOT-DF), no ano de 1977. O PEOT é considerando um dos mais importantes instrumentos da política urbana no estabelecimento de diretrizes e propostas de ocupação do território do DF de modo a reduzir a expansão urbana . Nesse sentido, o PEOT restringiu a ocupação nas áreas livres próximas à bacia do Paranoá, com estratégias de preservação ambiental, em especial dos recursos hídricos. Indicou como eixos para o processo de ocupação o quadrante sudoeste do DF, áreas que já eram marcadas por acentuados processos de ocupação, sobretudo os vetores próximos ao Gama (BR-040), Núcleo Bandeirante (BR 060) e Taguatinga.

Os resultados do PERGEB na escala regional e do PEOT na escala local foram insuficientes. O PERGEB estava previsto para ser finalizado em dois anos, mas se estendeu até 1984. De acordo com França e Peluso (2008), as atuações das autoridades ficaram voltadas para a escala local (de contenção), considerando Brasília como o centro hegemônico e seus interesses como dominantes. A visão "de dentro do Distrito Federal", que procurava conter a elevada migração, dificultou ações cooperadas para atingir os objetivos de dinamização propostos na promoção de oportunidades endógenas para a população.

Na escala local, as ações do PEOT, ao restringir a ocupação nas áreas próximas à bacia do Paranoá e direcionar o processo de ocupação para o eixo sudoeste, evidenciou uma estratégia de preservação das características urbanísticas do Plano Piloto e, também, 
uma forte preocupação em conter o crescimento urbano e a ocupação irregular. Essas ações de restrição e direcionamento dos eixos de ocupação sem articulação com outras políticas sociais e urbanas como de promoção às moradias sociais evidenciaram uma forte crise urbana por acesso à moradia no DF, pela população de baixa renda, devido à fragilidade de investimentos públicos voltados aos segmentos sociais e à ausência de mecanismos para conter o elevado preço da terra urbana.

É nesse contexto que há uma simbiose entre as ações de planejamento e de políticas urbanas no DF, ao se adotar uma legislação urbana restritiva e também uma política de restrição ao acesso à moradia social, induzindo o acesso à moradia ainda que precária nos municípios goianos próximos ao DF. Os fatores que explicam a migração da população para estabelecer moradia nos municípios próximos ao DF referem-se às fragilidades de regulamentações da legislação urbana, preços mais baratos da terra e condições de pagamento mais acessíveis de compra de lote tanto em área urbana quanto rural. No caso de compra em área rural, posteriormente os usos foram modificados para urbano nos municípios.

\subsubsection{Terceira fase: "Não Tinha Teto, Não Tinha Nada"16". De uma política de não oferta habitacional para uma política clientelista (1980-1995)}

No início dos anos de 1980, na tentativa de conter a migração para o DF, uma das estratégias adotadas pelo GDF foi a redução da política de oferta de lotes e unidades habitacionais. Essa ação já havia sido adotada nos anos de 1970, para induzir o retorno da população aos locais de origem.

No final do ano de 1979, o governador do DF, Aymeé Lamaison, indicado pelo então presidente Figueiredo, entendia que os altos índices de migração da população de baixa renda pelo DF se deviam à oferta, por parte do governo, de lotes e moradias para a classe popular, o que o levou a proibir tal iniciativa (COLELA, 1991).

Estima-se que entre os anos de 1979 e 1983 o governo construiu apenas 169 unidades habitacionais para a população de baixa renda. No entanto, a expansão da ocupação informal, a sublocação de cômodos, a compra e venda no mercado informal se

\footnotetext{
16 O Trecho do título do tópico "Não tinha teto, Não tinha nada" pertence a música "A Casa", de autoria de Vinícius de Moraes e Toquinho e também foi utilizado na pesquisa que envolveu identificar os "Desafios à Efetividade dos Direitos Fundamentais" vinculado ao Projeto Pensando o Direito, disponível em http://pensando.mj.gov.br/2014/04/25/direito-urbanistico-comeca-a-pesquisa-nao-tinha-teto-nao-tinhanada/
} 
estabeleceram como as principais opções e condições para a população de baixa renda ter acesso a um lugar para residir, ainda que precário e em desconformidade com a legislação.

Para Colela (1991), a suspensão quase que total de moradias populares durante esses quatro anos (1979-1982) provocou o encarecimento dos preços de venda e dos aluguéis. Essa medida contribuiu para a proliferação de "invasões", o aumento da sublocação no interior dos lotes e também o crescimento rápido das cidades goianas próximas ao DF. Acerca do assunto, Paviani (1989, p. 43) explica:

O esquema relativamente fechado de terras públicas para usos urbanos e o mecanismo imobiliário ensejaram um movimento de empurrão para além dos limites do Distrito Federal de considerável contingente de população de baixa renda, sejam em terremos legalizados pelo esquema especulativo, seja em terras "invadidas" - as favelas.

Sublinha-se que a estrutura de planejamento e ordenamento urbano dos municípios goianos próximos ao DF era quase inexistente, o que contribuiu para um processo de ocupação formal e informal sem intervenção de estratégias de ordenamento territorial. Também o processo de compra de lote ou casa + construção de moradias, sobretudo, ocorreu majoritariamente pelo processo de autoconstrução. Assinale-se que a maioria das terras dos municípios goianos nessa época enquadrava-se na categoria de uso rural, porém seu uso foi modificado para urbano de forma célere, para atender aos ensejos dos loteadores e especuladores.

Em meados de 1982, o DF apresentava graves problemas no campo da habitação, como, por exemplo, grande número de ocupações irregulares, ausência de políticas de promoção de moradias populares e uma organização da população que dificultava a tomada de ações autoritárias, como ocorreu em períodos anteriores de remoção das ocupações informais.

Também se destaca no cenário nacional que o início dos anos de 1980 apresentava uma organização da sociedade que demandava dos governantes reformas e havia pesadas críticas ao governo militar. Assim, na esfera nacional foram anunciadas novas estratégias de negociação, a fim de evitar o conflito com as classes populares. No campo habitacional, na esfera nacional, observa-se que as políticas de habitação do BNH enfocavam a urbanização das favelas, ao invés de práticas de remoção.

$\mathrm{Na}$ escala do DF, no governo de Ornellas foram iniciadas as primeiras ações de urbanização de favelas. Trata-se de uma resposta, ainda que tímida, de reconhecimento e urbanização das favelas e, também, da retomada das políticas de construção de moradias sociais. 
As ações de intervenção de melhorias em áreas de favelas foram realizadas, sobretudo, pelo programa federal Promorar, ${ }^{17}$ lançado nacionalmente em 1979. Vale lembrar que este programa não foi implantando inicialmente no $\mathrm{DF}$, em função da paralisação da SHIS. Destaca-se que o Promorar iniciou suas operações no DF apenas no ano de 1982 e recebeu o nome de Programa de Assentamento Populacional de Emergência (PAPE).

Para a operacionalização do PAPE foi criado o Grupo Executivo para Assentamentos de Favelas e Invasões (GEPAFI), vinculado na época à Secretaria de Serviços Sociais. De acordo com Penna (2000), a implementação do PAPE possibilitou ações de intervenção em melhorias de infraestruturas urbanas, como água, luz e esgoto nas moradias localizadas na Candagolândia, no Itamaracá (Gama) e na QE 38 (Guará).

O objetivo do PAPE era ampliar a oferta de moradia compreendida como a provisão de unidades habitacionais, a oferta de lotes, provisão de infraestrutura e acessibilidade, uma vez que o aumento da oferta de habitação levaria à estabilização dos preços de compra e venda e dos aluguéis, o que condicionaria o acesso a melhores condições de moradia. Portanto, cabia ao GDF não apenas produzir habitações, como também estimular a produção via iniciativa privada e das famílias (GEPAFI, 1983; GOUVEA, 1995).

Já Colela (1991) destaca que o PAPE estabeleceu duas linhas de atendimento de operação, quais sejam: a) a urbanização da "invasão", desde que atendesse às condições técnicas e legais e em consonância com o interesse dos moradores e; b) a transferência da população para uma área próxima, inserida na malha urbana onde estivesse localizada. Sublinha-se que essas linhas de atendimento não contemplavam a urbanização e fixação de favelas na área do Plano Piloto.

Durante os anos de operacionalização do PAPE 1982-1985, em três anos foram construídas 8.328 unidades habitacionais, o que viabilizou o atendimento de

\footnotetext{
${ }^{17}$ PROMORAR - Programa de Erradicação de Sub-Habitação. Dos programas reformistas, o PROMORAR representou a versão mais acabada da nova política habitacional que acompanhou o processo de abertura política do regime militar. Instituído em 1979 pelo recém-empossado presidente Figueiredo, o PROMORAR objetivava "erradicar sub-habitações" a partir de intervenções visando à melhoria dos núcleos habitacionais de favelas, sem implicar, portanto, a remoção dos moradores. É com o PROMORAR que a produção de habitações populares nos moldes de programas alternativos atinge o recorde histórico em termos quantitativos. As COHABs produziram no período 1979-1982 mais de 600 mil unidades, das quais quase um quarto pelo PROMORAR, ou seja, cerca da metade do número de habitações produzidas no período 1964-1986 (MELO, 1979, p. 39).
} 
aproximadamente 41 mil famílias de baixa renda (até três salários mínimos), conforme se pode visualizar no quadro a seguir.

\section{Quadro 29 - Operações do PAPE no DF: 1982-1985}

\begin{tabular}{|c|c|c|c|c|c|}
\hline Projetos & Local & $\begin{array}{l}\text { Período de } \\
\text { Execução } \\
\text { das Obras }\end{array}$ & $\begin{array}{l}\text { Quantidade } \\
\text { de UHs }\end{array}$ & $\begin{array}{l}\text { Quantidade } \\
\text { de Pessoas } \\
\text { Atendidas }\end{array}$ & Tipologia \\
\hline $\begin{array}{l}\text { Projeto Vila São } \\
\text { José I }\end{array}$ & Brazlândia & 1982 & 536 & 2.680 & $\begin{array}{l}\text { Módulo pré- } \\
\text { fabricado }\end{array}$ \\
\hline $\begin{array}{l}\text { Projeto Urbanização } \\
\text { Vila Itamaracá }\end{array}$ & Gama & Nov. 83 & 452 & 2.260 & $\begin{array}{l}\text { Módulo pré- } \\
\text { fabricado }\end{array}$ \\
\hline Projeto Sobradinho & Sobradinho & Out. 84 & 177 & 885 & $\begin{array}{l}\text { Módulo pré- } \\
\text { fabricado }\end{array}$ \\
\hline $\begin{array}{c}\text { Projeto V. São José } \\
\text { II }\end{array}$ & Brazlândia & Jan. 84 & 536 & 2.680 & $\begin{array}{l}\text { Módulo pré- } \\
\text { fabricado }\end{array}$ \\
\hline Guará QE 38 & Guará II & $\begin{array}{l}\text { Ago.-out. } \\
1984\end{array}$ & 528 & 2.640 & $\begin{array}{c}\text { Casa de alvenaria } \\
\text { isolada }\end{array}$ \\
\hline Expansão QNL & Taguatinga & $\begin{array}{l}\text { Out. 1984- } \\
\text { mar. 1985 }\end{array}$ & 2.683 & $14.315^{*}$ & $\begin{array}{c}\text { Casa de alvenaria } \\
\text { geminada }\end{array}$ \\
\hline Candangolândia & $\begin{array}{c}\text { Núcleo } \\
\text { Bandeirante }\end{array}$ & $\begin{array}{l}\text { Fev.-jun. } \\
1985\end{array}$ & 2.236 & $11.180^{*}$ & $\begin{array}{c}\text { Casa de alvenaria } \\
\text { geminada }\end{array}$ \\
\hline Vila Buritis I e II & Planaltina & Fev.-jul. 1985 & 1.000 & $5.000 *$ & $\begin{array}{c}\text { Madeirit }-1.701 \\
\text { alvenaria }- \\
6.627\end{array}$ \\
\hline Total & & & 8.328 & $41.640 *$ & \\
\hline
\end{tabular}

Fonte: Gouvea (1995).

Em linhas gerais, entre os anos de 1979 a 1985 observam-se dois distintos direcionamentos das ações no campo de habitação. O primeiro direcionamento refere-se às estratégias de não oferta habitacional na tentativa de conter o acelerado processo migratório no DF, o que ocasionou a construção de novas relações de produção e reprodução dos espaços do DF com os municípios goianos e, posteriormente, uma nova estratégia de intervenção no campo habitacional. Ou seja, houve uma retomada ainda que tímida de oferta habitacional para a população de baixa renda e o reconhecimento da necessidade de urbanizar as áreas de favelas.

Para Gouvêa (1995), essas ações ocasionaram o reconhecimento de novas cidades-satélites e também uma mudança na curva de oferta de moradias. Houve uma priorização da oferta e urbanização voltada para o atendimento da população de baixa 
renda, em detrimento da oferta para os setores de classe média e alta renda, como se pode observar na oferta de lotes destinados à população de média e alta renda.

\section{Quadro 30 - Oferta de Glebas pela Terracap: Setores Média e Alta Renda - DF， Período 1982-1985}

\begin{tabular}{|c|cccc|}
\hline Localidade & $\mathbf{1 9 8 2}$ & $\mathbf{1 9 8 3}$ & $\mathbf{1 9 8 4}$ & $\mathbf{1 9 8 5}$ \\
\hline Brasília & 31 & 155 & 255 & 121 \\
Guará/SHCE & 13 & s. i. & s.i. & s.i. \\
Núcleo Bandeirante & s. i.* & 1 & 10 & s.i. \\
Gama & s.i. & 3 & 22 & 12 \\
Taguatinga & s.i. & 6 & 340 & 196 \\
Ceilândia & 2 & 5 & 1 & 8 \\
Brazlândia & 5 & 14 & 42 & 15 \\
Sobradinho & s.i. & 3 & s.i, & 2 \\
Planaltina & s.i. & 4 & 6 & 2 \\
\hline
\end{tabular}

*s.i.= sem informação. Fonte: Adaptado de Gouvea (1995).

De um lado, a oferta de moradias para população de baixa renda não pode ser analisada deslocada da implantação de políticas sociais e de acesso ao emprego para a garantida da permanência da população de baixa renda nas respectivas moradias. Por outro lado, a oferta de habitação social não deve ser a única faixa de renda a ser atendida pela política habitacional, embora ela deva ser a prioritária. Nesse sentido, as ações do GDF, quando reduziu drasticamente as ações para o atendimento da demanda habitacional da classe média e alta, provocaram uma demanda por moradias pela classe média, o que resultou na substituição dos moradores contemplados pelos programas de moradia social, em função da implantação de uma política social de moradias descolada de políticas sociais. Assim, a venda dos imóveis, a valorização da terra e a dificuldade da população de baixa renda em permanecer nas moradias, dado o custo de vida, o pagamento dos impostos e o preço da terra urbana elevado em algumas cidades-satélites, dificultou a permanência dos mais pobres, o que ocasionou um processo de migração para áreas mais baratas no DF ou para os municípios goianos.

Com os processos de abertura política na escala nacional no ano de 1985, somados aos interesses políticos em função da abertura do processo eleitoral e da nova Constituição, a pauta habitação e política urbana tornou-se um importante elemento para angariar votos. Ao mesmo tempo, nos anos 1980 os movimentos de luta pela moradia 
passaram a exercer um papel importante na reivindicação de políticas urbanas e habitacionais na escala nacional.

No DF, no ano de 1985 foi indicado, pelo presidente Figueiredo, José Aparecido de Oliveira para exercer o cargo de governador do DF. Sua gestão foi marcada pela reduzida provisão de habitação e estratégias para restringir o fluxo migratório para o DF. Acerca do assunto, Colela (1991) aponta as principais intervenções no campo habitacional no governo de José Aparecido: a) expansão do setor M Norte de Taguatinga, com provisão de quinhentas unidades habitacionais em regime de mutirão de um dia; b) remoção da Vila Guarani e da favela da SQN 309/10 para a QE 38 (Guará II); c) construção de 2.986 unidades habitacionais em Ceilândia e Samambaia e; d) aprovação do Decreto de fixação das Vilas Planalto e Paranoá.

Já Penna (2000) destaca que, ao contrário de programas de urbanização de favelas, que marcou a gestão de Ornellas, na gestão de Aparecido foi implantada uma rígida política de controle e erradicação de favelas com objetivo de reduzir o fluxo migratório para o DF. Também a Secretaria de Serviços Sociais implantou programas para incentivar o retorno dos migrantes ao local de origem.

Foram realizados, principalmente, dois programas gerenciados pela Secretaria de Serviços Sociais: "Programa Retorno com Dignidade" - que oferecia recursos para o migrante retornar com sua família para seu lugar de origem e o "Programa Entorno com Dignidade" - que assentava o migrante em assentamentos fora do DF, principalmente em Brasilinha de Goiás (atualmente Planaltina de Goiás), e Santo Antônio do Descoberto, também em Goiás, realizadas em parceria com as prefeituras municipais. (PENNA, 2000, p. 119, grifo nosso).

É no governo de Aparecido que, de forma mais clara, se observa uma cooperação entre o GDF e as prefeituras goianas na esfera da habitação. O DF, preocupado em conter o crescimento e a expansão urbana, sobretudo, gerada pela população de baixa renda, adotou programas restritivos e incentivou a alocação da moradia nos municípios goianos. Estes, vislumbrando um possível crescimento econômico, em função da migração e desenvolvimento de atividades comerciais, adota flexibilizações na legislação urbana para acelerar a alocação de moradias ainda que precárias e desprovidas de infraestrutura urbana.

Outro fator que contribuiu para a expansão urbana nos municípios goianos foi a elaboração pelo governo distrital no ano de 1985 do Plano de Ocupação Territorial (POT). Este foi modificado pelo Plano de Ocupação e Uso do Solo (POUSO), de 1986, que estabelecia estratégias de preservação ambiental e restrição à ocupação nas áreas 
próximas às bacias hidrográficas. Também nesse período o crescimento populacional acelerado e as novas formas urbanas foram elementos que contribuíram para a elaboração do projeto Brasília Revisitada, elaborado por Lucio Costa nos anos de (19851987). Esses planos de ordenamentos e projetos trouxeram uma série de recomendações para preservar as características do Plano Piloto e reorientar os eixos de crescimento ordenado no DF.

No final dos anos de 1980, as estratégias de planejamento procuraram traçar estratégias para todo o território do DF, considerando as cidades-satélites e seus eixos de expansão. Tais ações, também, se devem ao reconhecimento de Brasília como Patrimônio Histórico da Humanidade no ano de 1987, o qual criou uma série de restrições e proibições de modificação no uso e formas urbanas nas áreas do Plano Piloto e áreas do Lago Sul e Norte.

As restrições de uso e ocupação foram regulamentadas pelos planos de ordenamento e das recomendações advindas do tombamento, o que gerou uma onda de interesse dos empreendedores imobiliários em desenvolver novos produtos, como prédios residenciais e escritórios comerciais nas cidades-satélites próximas ao Plano Piloto que não estavam condicionadas às restrições do tombamento. Nesse sentido, as terras urbanas das cidades-satélites passaram por uma elevada valorização e com isso houve a substituição dos mais pobres por segmentos sociais menos vulneráveis da classe média, que passou a buscar novos locais de moradias acessíveis em cidades-satélites consolidadas e com preço da terra mais barato, tais como Guará, Taguatinga, Sobradinho.

No ano de 1988, assumiu o mandato de governador no DF Joaquim Roriz (indicado pelo Presidente da República). Vale lembrar que Roriz posteriormente tornouse o primeiro governador eleito pela população do DF no ano de 1991. Na primeira gestão de Roriz (1988-1990), houve uma mudança significativa no que tange à restrição e políticas rígidas de ocupação de áreas no DF. As estratégias do então governador Roriz foram de desenvolver políticas de construção de moradias e entrega de lotes de forma ampla, em comparação com as gestões anteriores. Nessa fase, as políticas habitacionais no DF se configuraram como populistas e assistencialistas. Acerca do assunto, Penna (2000, p. 122) afirma:

Desde 1988, o governador passou a desenvolver uma política de doação de lotes às famílias desabrigadas (moradoras de áreas invadidas no Plano Piloto e Cidades-Satélites), que também está relacionada ao aumento do número de migrantes na região, em busca de melhores condições de vida. (PENNA, 2000, p. 122). 
Em sua primeira gestão, Roriz criou o Programa Assentamento de População de Baixa Renda, com a finalidade de remover as famílias das áreas públicas centrais para áreas das cidades-satélites consolidadas. Segundo Gonçalves (1998) e Silva (2007), o programa dividia-se em três etapas, quais sejam: a) cadastramento e seleção da população residente em ocupações informais e população de baixa renda, como inquilinos, por exemplo; b) remoção e assentamento nos locais destinados para a população, como a RA Samambaia, especialmente; c) consolidação de novos assentamentos.

Na prática os critérios para a seleção das famílias não foram aplicados. A escolha baseava-se em fortes relações clientelistas e interesses eleitorais. Também a oferta de lotes era baseada em termos de compromissos validados entre os moradores e a Terracap, que destinava o lote a uso residencial e cobrava uma taxa pela ocupação. Destaca-se que o governador Roriz proibiu a cobrança de taxas vislumbrando interesses eleitorais (COLELA, 1991).

Em sua segunda gestão (1991-1995), Roriz deu continuidade à oferta de moradias e lotes sem infraestrutura, o que condicionou uma expansão urbana do DF descontrolada e também o reconhecimento de novas cidades-satélites, ${ }^{18}$ como Samambaia, Santa Maria, São Sebastião, Recanto das Emas, Riacho Fundo.

Nos municípios goianos próximos ao DF, os anos de 1990 representaram uma forte onda de crescimento populacional e a ampliação do número de municípios em função dos interesses políticos, além de uma aproximação das elites locais das prefeituras goianas com o governo distrital.

Registra-se nos anos de 1990 uma significativa fragmentação territorial nos municípios goianos próximos ao DF. O município de Luziânia deu origem aos municípios de Padre Bernardo (1963), Santo Antônio do Descoberto (1982), Cidade Ocidental (1993), Novo Gama (1997), Valparaíso de Goiás (1997) e Vila Boa (1992); Formosa deu origem a Cabeceiras (1958), Águas Frias de Goiás (1989) e Planaltina de Goiás (1991). Os municípios desmembrados também se multiplicaram em outros. Por exemplo, Santo Antônio do Descoberto deu origem, em 1997, a Águas Lindas de Goiás e Padre Bernardo

\footnotetext{
${ }^{18}$ O Decreto $\underline{n}^{\circ} 19.040$, de 18 de fevereiro de 2001, proibiu a utilização da expressão "cidade-satélite" para designar as cidades situadas no território do Distrito Federal, nos documentos oficiais e outros documentos públicos no âmbito do GDF. Atualmente, as cidades-satélites são denominadas Regiões Administrativas.
} 
originou Mimoso de Goiás (1999). No total, nos anos de 1990 foram criados onze novos municípios na região do Entorno de Brasília (FRANÇA, 2009).

Os fatores que levaram à fragmentação territorial passam por interesses de agentes políticos locais e pela especulação imobiliária. Ao se emanciparem, os municípios passam a ter direito às fontes de repasse constitucionais do Estado e da União, o que também revela os interesses de investimentos a ficarem submetidos aos interesses das elites locais.

Sublinha-se que essas emancipações foram potencializadas, sobretudo, pelas elites locais, que vislumbravam a possibilidade de a ocupação de terras goianas gerar novas receitas municipais. Nesse sentido, se de um lado o DF, nos anos de 1990, possuía uma legislação urbana que procurava restringir a ocupação das áreas centrais e ao mesmo tempo estabeleceu novos eixos de ocupação, que eram próximos dos limites administrativos dos municípios goianos, por sua vez as elites locais goianas facilitaram a atuação dos empreendedores imobiliários , quando não criaram ou flexibilizaram mecanismos de regulamentação e o cumprimento das regras para o uso e ocupação do solo. Assim, os empreendedores imobiliários passaram a atuar no entorno, suprindo a demanda habitacional reprimida no DF, mediante, por exemplo, a venda de loteamentos populares com preços mais baixos e em número maior de parcelas para o pagamento.

Outro fator que contribuiu para a emancipação dos municípios foi o financiamento habitacional advindo do BNH nos anos de 1980, o que viabilizou a construção de três conjuntos habitacionais com aproximadamente 4.500 unidades, com prestações variando de um a dois salários mínimos no município de Luziânia. Ainda segundo Caiado (2004), os nomes desses três conjuntos habitacionais deram origem aos municípios de Cidade Ocidental, Valparaíso de Goiás e Novo Gama.

Nesse sentido, a ocupação das terras goianas também revelou perfis diferenciados de renda da população e tipologias diferentes de unidades habitacionais. Isso evidencia que a incorporação de terras e padrões de ocupação dos municípios goianos não ocorreu de forma homogênea e de forma exclusiva pela população de baixa renda. Acerca do assunto, Caiado (2004) explica que as diferentes formas de incorporação de terras à periferia por sua vez provocam diferentes perfis populacionais em função da capacidade e possibilidade financeira de aquisição de imóveis.

Assim, de um lado, territorializam-se os espaços a serem ocupados em função do poder aquisitivo, o que explica melhor o padrão das tipologias habitacionais dos municípios originados de conjuntos habitacionais e perfil populacional. De outro lado, 
revelam-se o padrão loteamento popular + autoconstrução + precariedade de infraestrutura e serviços para a população de baixa renda. Em concomitância, as ações dos empreendedores imobiliários e os interesses do GDF e dos governos locais tiveram papel importante na formação periférica habitacional com os regramentos urbanos (ou sua ausência) e os eixos de expansão urbana periférica.

\subsubsection{Política Habitacional Populista versus Planos de Ordenamento do Território}

Durante a gestão do governador Roriz (1991-1995) constatam-se importantes regramentos, como a aprovação no ano de 1993 da Lei Orgânica do Distrito Federal, resultante do processo da Constituinte 1988. Vale ressaltar que na Lei Orgânica do DF consta um capítulo sobre a política urbana. Também, no campo urbanístico, destaca-se a aprovação do Plano Diretor de Ordenamento Territorial (PDOT), em 1992, que incorporou nuances dos planos anteriormente desenvolvidos, como o PEOT, o POT, o POUSO e o documento Brasília Revisitada.

Segundo Silveira (1992), o PDOT-1992 reforçou o polinucleamento e evidenciou os dois principais polos urbanos do DF, isto é, Plano Piloto e Taguatinga. No PDOT-1992 foi possível a realização de parcelamento de solo pela iniciativa privada. De acordo com a autora, para a realização de parcelamento do solo foi criada uma estrutura de planejamento e regulamentações:

\footnotetext{
O sistema de planejamento criou o Instituto de Planejamento Territorial e Urbano do Distrito Federal - IPDF, o Conselho de Planejamento Territorial e Urbano do Distrito Federal - CONPLAN, os conselhos locais e as gerências de planejamento nas Regiões Administrativas. [...] Também, o PDOT reconheceu a obrigatoriedade da elaboração do zoneamento ecológicoeconômico, fortaleceu a atuação da Secretaria de Meio Ambiente, assim como tornou obrigatória a elaboração de Estudos de Impacto Ambiental com respectivo Relatório de Impacto Ambiental para todos os parcelamentos do solo, criou o sistema de informações territoriais e urbanas, e estabeleceu a feitura de documentos básicos [...] e estabeleceu como unidades básicas de planejamento as microbacias e, além disso, confirmou as unidades de conservação do DF, definidas pela legislação vigente. SILVEIRA, 1999, p. 158).
}

Também merecem destaque a tendência de concentração urbana e a forte interação metropolitana entre o DF e os municípios goianos, evidenciadas nas estratégias do PDOT-92 a partir das diretrizes para o crescimento urbano estruturadas focalizando as linhas de transporte público e as linhas do metrô. Dito de outro modo, as diretrizes e políticas focalizadas para o eixo de expansão e descentralização das RAs, 
como Guará, Taguatinga, Ceilândia e Samambaia, foram reforçadas pela linha do metrô e dos novos eixos de urbanização com a criação de Águas Claras.

Outro destaque foi o direcionamento da expansão urbana para a região sul e sudoeste do DF, como, por exemplo, na direção das RAs Samambaia, Recanto das Emas, Gama, Santa Maria, reafirmando uma forte conurbação com os municípios goianos de Valparaiso de Goiás, Luziânia, Novo Gama, Cidade Ocidental.

Essas diretrizes de ocupação e descentralização das políticas e orientações dos planos do DF, implementadas sem políticas federais, distritais e municipais concertadas, desencadearam um processo de periferização da habitação, marcado pela característica de lotes semiurbanizados, baixa qualificação no processo de construção, infraestrutura urbana precária e espaços desprovidos de bacias de empregos e equipamentos comunitários.

Portanto, a questão da moradia é um dos principais condicionantes no processo de periferização e pari passu um fator estrutural do processo de migração intrametropolitana. Ademais, Caiado (2004) destaca outro condicionante resultante dessa periferização, que é a possibilidade de auferir renda no campo informal da economia nesses municípios, em virtude do elevado contingente populacional e da inserção do setor terciário na maioria das vezes informal.

Estima-se que a criação do Programa Habitacional de Assentamentos de Baixa Renda durante a gestão de Joaquim Roriz (1988-1995) distribuiu aproximadamente 109 mil lotes residenciais em núcleos já existentes ou lotes em novos núcleos que posteriormente deram origem às novas regiões administrativas, como Samambaia, Riacho Fundo, Santa Maria e Recanto das Emas. (CAIADO, 2004).

No ano de 1997 ocorreu o processo de revisão do PDOT-92 na gestão do então governador Cristovam Buarque (1995-1999). Nesse processo de revisão, foram mais uma vez mantidas as ações de expansão no quadrante sudoeste e ao mesmo tempo estabeleceram-se as diretrizes para a expansão no eixo nordeste. Ressalte-se que no eixo nordeste localiza-se grande parte dos loteamentos irregulares. Dentre os objetivos do PDOT 1997 destaca-se a necessidade de descentralização das atividades, ou seja, adotar estratégias de novas centralidades de emprego articuladas aos núcleos urbanos, numa tentativa de gerar renda, estimular novos usos dos núcleos urbanos e instituir mecanismos para reduzir a dependência e concentração de atividades na área do Plano Piloto.

Como estratégia, foi explicitada na Lei Complementar 17/1997 (Lei do PDOT1997) a constituição de centros regionais na confluência das cidades de Taguatinga, 
Samambaia e Ceilândia, bem como um conjunto de ações e programas para a gestão do território.

Somente com a aprovação do PDOT-1997 as ocupações informais pela primeira vez passaram a constar nos mapas, documentos oficiais de planejamento e ordenamento do território. Anteriormente, os assentamentos informais eram desconsiderados dos documentos de planejamento oficiais do GDF.

Sublinha-se que as áreas informais não são exclusivamente resultantes de um processo de ocupação pela população de baixa renda, mas, ao contrário, são também áreas onde se localizam os condomínios irregulares de classe média. Gonzáles (2010) ressalta que a delimitação no PDOT-1997 da Zona Urbana de Dinamização, ao sul do DF, na verdade se trata de uma imensa zona rural de domínio particular onde estão situados os condomínios irregulares, que são objetos de regularização fundiária pela classe média. A autora ainda ressalta que em outras áreas de ocupação irregular pela população de baixa renda a mesma estratégia não foi adotada.

Segundo Varizo Cavalcante (2009), duas ações para a promoção da descentralização das atividades e dos empregos são claras no PDOT-1997 visando à constituição de novas centralidades. A primeira que já constava nos vários planos de ordenamento do DF diz respeito à consolidação do Plano Piloto como centro regional e nacional e à necessidade de ações para a revitalização das atividades. Saliente-se que as ações direcionadas para o Plano Piloto caminharam no sentido de preservá-lo e evitar o processo de expansão urbana em sua proximidade. Já a segunda ação tem como fator indutor a consolidação de um centro econômico regional entre Taguatinga-SamambaiaCeilândia, a fim de fortalecer as ações de desenvolvimento no quadrante sudoeste. Esse fator de indução ocorrerá com a disseminação de novos projetos comerciais, como shoppings, escolas, projetos de moradia e a implantação do Centro Metropolitano Administrativo, cuja construção encontra-se em andamento, e a primeira etapa do projeto está prevista para o segundo semestre do ano de 2015.

Na gestão de Cristovam Buarque as ações no campo habitacional se concentraram na promoção de infraestrutura urbana, em vez da oferta de casas e lotes. Em decorrência das ações da gestão anterior, isto é, do antigo governador Roriz, ficou praticamente inviabilizada a contratação de projetos habitacionais para a construção de moradias pelo governo que o sucederia - a gestão de Cristovão Buarque.

Acerca do assunto, Gouvea (1999) explica que Roriz atrelou grande parte da terra urbana de valor comercial como garantia aos bancos para as obras do metrô. Ou seja, a 
quantidade de terra urbana para a oferta de lotes e casas era inexistente em função dessa manobra. Outro fator relevante foi a forte oposição do governo federal em relação ao governo do partido de oposição do então governador Buarque, dificultando o acesso a financiamento federal para as obras distritais.

Outro problema enfrentado logo do início foi a total desestruturação do órgão
encarregado da organização da política de habitação. Com efeit, nos últimos
anos, a Sociedade Habitacional de Interesse Social (SHIS), atual IDHAB
(Instituto de Desenvolvimento Habitacional), praticamente funcionou como
distribuidora da Terracap (Companhia Imobiliária de Brasília - gestora das
terras do DF), e teve seu antigo quadro de técnico espalhado por outros órgãos
do GDF. A SHIS, como as outras Cohabs, havia perdido o aporte financeiro e
a condição de grande construtora de casas populares após a extinção do BNH,
em 1986 . Assim falida, foi extinta, e criado o IDHAB, a autarquia que
sucederia a SHIS na organização do setor habitacional. O Instituto, nos anos
de 1995 e 1996, nada recebeu para desenvolver qualquer política habitacional.
(GOUVEA, 1999, p. 256).

Em linhas gerais as ações do governo Buarque no campo da habitação se resumiram à entrega de 367 lotes na RA Sobradinho, à regularização de grande parte dos lotes entregues pelo governo anterior, uma vez que a maioria dos lotes não apresentava desconformidade com a Lei Federal 6.766/1979 para a sua regularização. E, sobretudo, às ações de infraestrutura urbana nos loteamentos e casas de baixa renda. Destaca-se, também, ações de provisão de infraestrutura nos condomínios regularizados ocupados para classe média. Ademais, a regularização de setores era uma estratégia importante para a arrecadação de impostos, como o IPTU, por exemplo. No campo de provisão habitacional, as ações foram tímidas e se resumiram à construção de cem unidades habitacionais.

No retorno de Joaquim Roriz, eleito governador do Distrito Federal entre os anos de 1999 e 2006, este assumiu o compromisso de melhoramento da qualidade de vida da população. O Decreto 24.628/2004 versava sobre as ações de melhoria na qualidade de vida considerando os princípios norteadores do PDOT-1997, como a ocupação ordenada do solo urbano, melhoria da infraestrutura urbana e das condições habitacionais e gestão democrática (SILVA MIRANDA, 2007).

Um dos grandes destaques durante a gestão Roriz foi a criação, no ano de 2000, do Programa Socorro Social e Atendimento Emergencial voltado para as famílias de baixa renda para a aquisição de lote semiurbanizado. Cabia às famílias se inscrever no Cadastro Geral de Interessados (CIDHAB). Os critérios do programa sofriam alterações constantes em função dos interesses políticos, o que em parte gerava insatisfação da 
população, uma vez que a cada mudança de critério as famílias inscritas e que não atendiam aos novos critérios eram excluídas do cadastro.

Segundo Miranda Silva (2007), o programa concedia a entrega do lote sem nenhuma capacitação técnica e subsídios financeiros para as famílias construírem sua moradia, o que acentuava a gravidade da qualidade urbanística e o atendimento das necessidades sociais das famílias que apresentavam graves situações de vulnerabilidade social.

A autora também ressalta que as constantes mudanças nos critérios e a falta de fiscalização no atendimento dos critérios permitiam o acesso a lotes de famílias não enquadradas em situações de pobreza. Entre os anos de 2002 e 2006 foram entregues 223 lotes. Observa-se no quadro a seguir uma oferta de lotes com fortes variações entre os anos. A regionalização da política de entrega de lotes ficou concentrada nas regiões administrativas de Santa Maria, Samambaia, Recanto das Emas e Riacho Fundo II.

\section{Quadro 31 - Quantidade de Lotes Entregues pelo Programa Socorro Social: Período de 2002 a 2006}

\begin{tabular}{|l|c|}
\hline Ano & Quantidade de Lotes Entregues \\
\hline 2002 & 66 \\
2003 & 3 \\
2004 & 110 \\
2005 & 16 \\
2006 & 28 \\
Total & 223 \\
\hline
\end{tabular}

Fonte: Miranda Silva (2007).

Na gestão Roriz observa-se a continuidade das políticas anteriormente implementadas nos anos anteriores em que estava no poder, ou seja, políticas marcadas por fortes práticas clientelistas. Destacam-se nesse período a retomada de entregas de lotes seminurbanizados pelo programa Socorro Social e intervenções em melhoria e aquisição de moradias em parceria com a Caixa Econômica Federal e o Banco Interamericano de Desenvolvimento (BID), com recursos advindos do Programa de Arrendamento Residencial (PAR), isto é, o acesso a financiamento para atender às necessidades habitacionais da população com até cinco salários mínimos. Outro destaque foi a elaboração do projeto da Vila Varjão visando à melhoria e aquisição de moradias com financiamento do programa federal Habitar Brasil. 
No caso do PAR, as dificuldades prementes de o mutuário comprar o imóvel ocorreu em função do alto preço da terra urbana no DF e da ausência na implementação de instrumentos urbanísticos que poderiam viabilizar o acesso à terra urbana. As intervenções desse programa viabilizaram entre os anos de 2004-2005 a conclusão de 1.152 unidades habitacionais, destas, 784 no ano de 2004 e 386 no ano de 2005.

De acordo com Silva Miranda (2007), o Projeto Vila Varjão consistiu na construção de 298 unidades habitacionais. No entanto, apenas 228 foram contratadas e estas não chegaram a ser concluídas na gestão de Roriz, em função do embargo, no ano de 2006, efetuado pelo Ibama, pelo fato de tais construções apresentarem desconformidades com a legislação ambiental no que tange às áreas de sensibilidade ambiental.

Conclui-se que na gestão Roriz houve a implementação de importantes ações no campo da habitação, entretanto, nem sempre essas ações convergiam com o regramento de uso e ocupação das áreas disciplinadas pelo Plano de Ordenamento Territorial e os princípios do acesso à moradia digna. Sublinha-se que na gestão de Roriz foi criada ou reconhecida a maior quantidade de Regiões Administrativas - Samambaia (RA XII), Recanto das Emas (RA XV), Itapoã (RA XXVIII), Vila Estrutural incluída no Setor Complementar de Indústria e Abastecimento (RA XXV), São Sebastião (RA XIV), Vila Roriz incluída em Planaltina (RA VI) - desprovida de planos urbanísticos e infraestrutura urbana. 


\section{Quadro 32 - Regiões Administrativas Criadas nos Governos de Joaquim Roriz}

\begin{tabular}{|l|r|}
\hline Região Administrativa & Data de criação \\
\hline RA XIII - Santa Maria & $10 / 02 / 1993$ \\
RA XIV - São Sebastião & $25 / 06 / 1993$ \\
RA XV - Recanto das Emas & $22 / 09 / 1993$ \\
RA XVI - Lago Sul & $17 / 03 / 1994$ \\
RA XVII - Riacho Fundo & $17 / 03 / 1994$ \\
RA XVIII - Lago Norte & $17 / 03 / 1994$ \\
RA XIX - Candangolândia & $17 / 03 / 1994$ \\
RA XX - Águas Claras & $06 / 05 / 2003$ \\
RA XXI - Riacho Fundo II & $06 / 05 / 2003$ \\
RA XXII - Sudoeste/Octogonal & $06 / 05 / 2003$ \\
RA XXIII - Varjão & $06 / 05 / 2003$ \\
RA XXIV - Park Way & $29 / 12 / 2003$ \\
RA XXV - SCIA* & $27 / 01 / 2004$ \\
RA XXVI - Sobradinho II* & $27 / 01 / 2004$ \\
RA XXVII - Jardim Botânico & $31 / 08 / 2004$ \\
RA XXVIII - Itapoã & $27 / 06 / 2005$ \\
RA XXIX - SAI & $14 / 07 / 2005$ \\
\hline
\end{tabular}

*Criadas no governo interino de Maria de Lourdes Abadia.

Fonte: SEDHAB (2015), com adaptações.

Na gestão de José Roberto Arruda, ${ }^{19,20}$ (2007-2010) observa-se a elaboração de estratégias para a resolução do problema da obra embargada na Vila Varjão, bem como a replicação do projeto da Vila Varjão em outras regiões administrativas, como, por exemplo, Ceilândia e Samambaia, que também deveriam incluir moradores da Vila Varjão que não tiveram suas casas entregues em função do embargamento. Essas ações resultaram na construção de 150 unidades habitacionais para o atendimento das famílias da Vila Varjão.

Outro ponto de destaque na gestão de Arruda refere-se à assinatura de decretos que impulsionaram a retomada de financiamento habitacional no DF. Cinco decretos destinaram 3 mil lotes para a construção de casas ou apartamentos através das associações ou cooperativas de moradia. O governador também assinou outros três decretos, que destinaram 2 mil lotes para a política habitacional nas regiões administrativas de Ceilândia (1,5 mil), Samambaia (200) e Riacho Fundo II (300). E mais outros dois decretos estabeleceram para as cooperativas dez projeções habitacionais

\footnotetext{
${ }^{19}$ Note-se que, entre 31 de março de 2006 e 31 de dezembro de 2006, o cargo de governador do DF foi ocupado pela vice-governadora eleita, Maria de Lourdes Abadia, que assumiu após a saída do cargo de Joaquim Roriz.

${ }^{20}$ José Roberto Arruda foi eleito e teve seu mandato cassado no ano de 2010.
} 
em Santa Maria e outras dez em Samambaia. Isso representa aproximadamente a construção de quinhentas moradias em cada uma dessas dez projeções*.

Essas ações iniciais foram fundamentais, uma vez que o GDF disponibilizou lotes ou projeções habitacionais às cooperativas. A essas caberia a responsabilidade pela construção das casas ou apartamentos. Vale sublinhar que a oferta dos lotes foi possível em função de a Lei distrital 3.877 de 2006 ter estabelecido a política habitacional no DF. Esta lei regulamentou que $40 \%$ dos lotes em projetos habitacionais deveriam ser direcionados às cooperativas, $40 \%$ para os inscritos na Secretaria de Habitação e $20 \%$ aos demais projetos do governo. ${ }^{21}$

Outra ação da gestão Arruda foi o desenvolvimento de projetos habitacionais específicos para o atendimento dos servidores públicos com financiamento para a aquisição de casas ou apartamentos nas RAs Gama e Sobradinho e a implantação do Setor Mangueiral, localizado entre o Jardim Botânico e São Sebastião, planejado na gestão de Arruda, projeto este voltado para o atendimento dos servidores públicos. O Projeto do Setor Mangueiral tinha como previsão a construção de oito mil unidades habitacionais. Assinale-se que a contratação para a execução desse projeto ocorreu apenas no ano de 2012 durante a gestão de Agnelo Queiroz.

Com o lançamento do Programa Minha Casa, Minha Vida em âmbito federal, em sua primeira fase (2009-2011), não houve nenhuma contratação de projeto habitacional com financiamento federal direcionado para a faixa 1 , ou seja, destinado para a população de menor poder aquisitivo no DF. Durante a gestão do governador Arruda, foram contratados empreendimentos habitacionais enquadrados nas faixas de renda 2 e 3 , em especial, na faixa 3. Em sua maioria, os empreendimentos estão localizados nas Unidades de Planejamento Oeste e Sul, sobretudo nas RAs Gama, Ceilândia, Samambaia e Santa Maria, que se enquadram nas submodalidades do FGTS, de apoio à produção ou imóvel na planta e com origem jurídica. ${ }^{22}$

\footnotetext{
${ }^{21}$ As informações contidas neste parágrafo foram consultadas no site do Sindireta-DF. Disponível em: $\langle$ http://www.sindireta.org.br/habitacional.asp $>$. Acesso em: 18 jan. 2015.

22 Os empreendimentos habitacionais podem ser contratados por meio de pessoa física (meio de financiamento direto) ou pessoa jurídica (financiamento para empreendedores ou que reúne os beneficiários por meio de uma E.O).

*projeção - unidade imobiliária peculiar do Distrito Federal que constitui parcela autônoma de parcelamento, definida por limites geométricos e caracterizada por possuir, no mínimo, três de suas divisas voltadas para área pública e taxa de ocupação de cem por cento de sua área.
} 
Figura 3 - Espacialização dos Empreendimentos Contratados com Financiamento do PMCMV 1 no Distrito Federal: 2009-2010

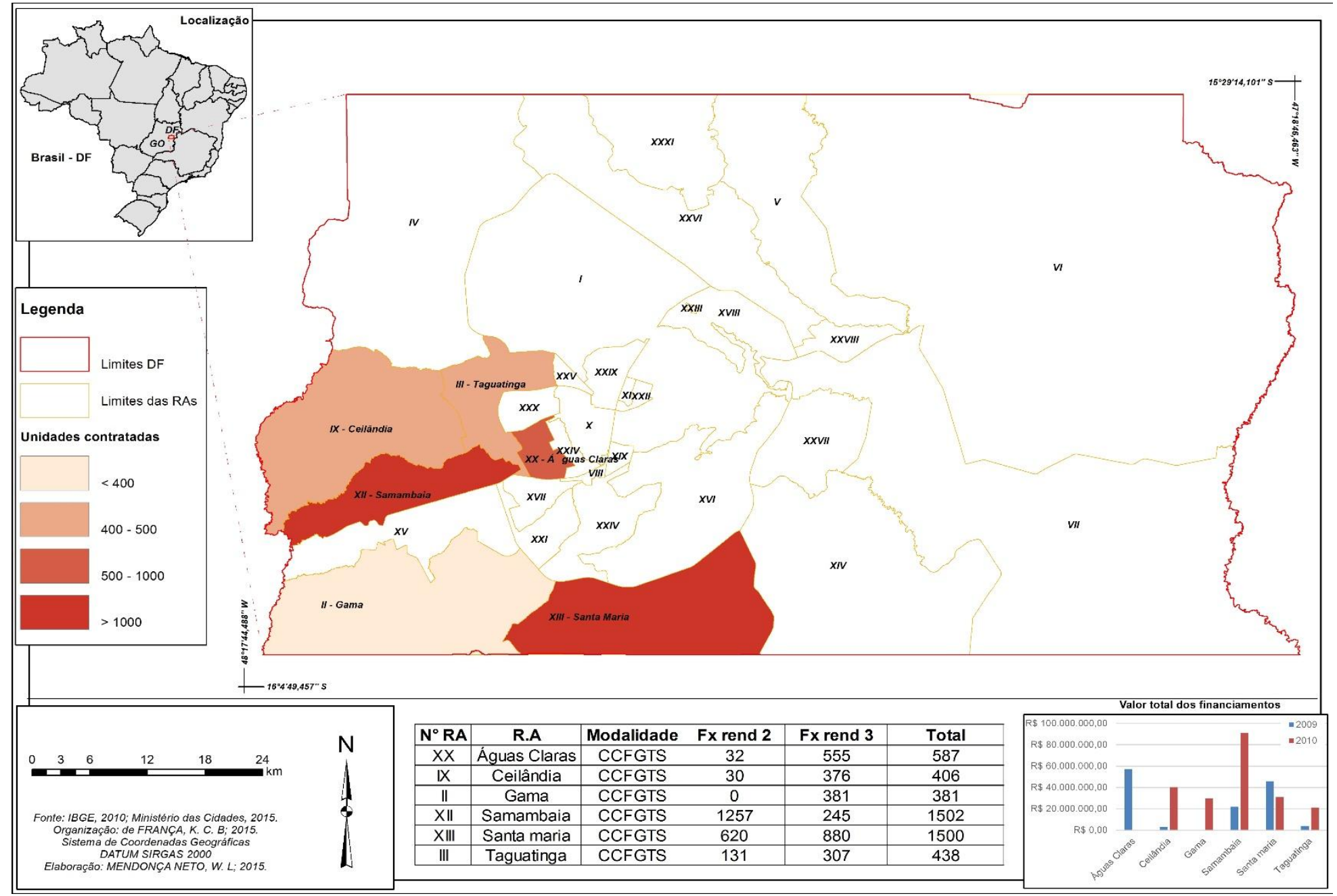


Quadro 33 - Principais Empreendimentos Contratados com Financiamento do PMCMV 1 no Distrito Federal - 2009-2010

\begin{tabular}{|c|c|c|c|c|c|}
\hline $\begin{array}{c}\text { Nome do } \\
\text { Empreendimento }\end{array}$ & Faixa & $\begin{array}{c}\text { Data de } \\
\text { Assinatura do } \\
\text { Contrato }\end{array}$ & \begin{tabular}{|} 
Unidades \\
Habitacionai \\
$\mathbf{s}$ \\
Contratadas
\end{tabular} & $\begin{array}{l}\text { Valor Total } \\
\text { Contratado } \\
\quad(\mathbf{R} \$)\end{array}$ & $\begin{array}{c}\text { Unidades } \\
\text { Habitacionais } \\
\text { Entregues }\end{array}$ \\
\hline Altos de Taguatinga I & $\begin{array}{l}\text { Faixa } \\
3\end{array}$ & $26 / 05 / 2010$ & 96 & 7.749 .766 & 36 \\
\hline Coimbra & $\begin{array}{l}\text { Faixa } \\
3\end{array}$ & $07 / 04 / 2010$ & 44 & 4.532 .103 & 44 \\
\hline Espaço Verde & $\begin{array}{l}\text { Faixa } \\
3\end{array}$ & $24 / 03 / 2010$ & 280 & 17.480 .000 & 24 \\
\hline Essencial I & \begin{tabular}{|l} 
Faixa \\
2
\end{tabular} & $21 / 10 / 2010$ & 88 & 4.400 .000 & 45 \\
\hline Essencial III & $\begin{array}{l}\text { Faixa } \\
2\end{array}$ & $29 / 11 / 2010$ & 88 & 4.400 .000 & 84 \\
\hline Imprensa V & $\begin{array}{l}\text { Faixa } \\
3\end{array}$ & $10 / 02 / 2010$ & 61 & 7.312 .000 & 38 \\
\hline Liverpool Residence & $\begin{array}{l}\text { Faixa } \\
2\end{array}$ & $18 / 12 / 2009$ & 32 & 3.158 .072 & - \\
\hline $\begin{array}{l}\text { MBigucci-Águia } \\
\text { Nobre/American }\end{array}$ & $\begin{array}{l}\text { Faixa } \\
2\end{array}$ & $30 / 12 / 2010$ & 79 & 2.303 .089 & - \\
\hline Maison Personalisée & \begin{tabular}{|l|} 
Faixa \\
3
\end{tabular} & 05/06/2009 & 195 & 16.765 .053 & 4 \\
\hline QNN 11 Engemasa & $\begin{array}{l}\text { Faixa } \\
3 \\
\end{array}$ & 08/12/2009 & 64 & 3.200 .000 & 64 \\
\hline Real Panoramic & $\begin{array}{l}\text { Faixa } \\
3\end{array}$ & 08/09/2009 & 360 & 37.372 .000 & 360 \\
\hline $\begin{array}{l}\text { Residencial Borges } \\
\text { Landeiro - Módulo I }\end{array}$ & $\begin{array}{l}\text { Faixa } \\
3\end{array}$ & $15 / 10 / 2010$ & 312 & 38.274 .000 & - \\
\hline $\begin{array}{l}\text { Residencial Le Grand } \\
\text { Orleans Tower }\end{array}$ & \begin{tabular}{|l|} 
Faixa \\
2 \\
\end{tabular} & $10 / 08 / 2010$ & 100 & 11.686 .078 & - \\
\hline Rio Verde & $\begin{array}{l}\text { Faixa } \\
3\end{array}$ & 28/04/2010 & 54 & 4.110 .426 & 54 \\
\hline San Pietro & $\begin{array}{l}\text { Faixa } \\
2\end{array}$ & $20 / 07 / 2010$ & 36 & 1.800 .000 & 27 \\
\hline Spazio 43 & \begin{tabular}{|l} 
Faixa \\
2
\end{tabular} & $13 / 08 / 2010$ & 30 & 2.036 .214 & 20 \\
\hline $\begin{array}{l}\text { Spazio Boulevard } \\
\text { Taguatinga }\end{array}$ & $\begin{array}{l}\text { Faixa } \\
3\end{array}$ & $29 / 03 / 2010$ & 40 & 5.200 .000 & 30 \\
\hline Taguaville & $\begin{array}{l}\text { Faixa } \\
3\end{array}$ & $22 / 01 / 2010$ & 192 & 9.600 .000 & 192 \\
\hline Total Ville I & $\begin{array}{l}\text { Faixa } \\
3\end{array}$ & 28/09/2009 & 368 & 20.236 .479 & 243 \\
\hline Total Ville II & $\begin{array}{l}\text { Faixa } \\
3\end{array}$ & 20/11/2009 & 256 & 12.800 .000 & 118 \\
\hline Total Ville III & $\begin{array}{l}\text { Faixa } \\
3\end{array}$ & $11 / 12 / 2009$ & 256 & 12.800 .000 & 212 \\
\hline
\end{tabular}




\begin{tabular}{|c|c|c|c|c|c|}
\hline Total Ville IV & \begin{tabular}{|l} 
Faixa \\
2
\end{tabular} & $23 / 07 / 2010$ & 310 & 15.500 .000 & - \\
\hline Total Ville V & \begin{tabular}{|l} 
Faixa \\
2
\end{tabular} & $24 / 09 / 2010$ & 310 & 15.500 .000 & - \\
\hline Unique & \begin{tabular}{|l|} 
Faixa \\
2 \\
\end{tabular} & $08 / 04 / 2010$ & 32 & 1.791 .725 & 27 \\
\hline Viena & \begin{tabular}{|l|} 
Faixa \\
2 \\
\end{tabular} & $22 / 10 / 2010$ & 40 & 2.000 .000 & 22 \\
\hline Villa Borghese & $\begin{array}{l}\text { Faixa } \\
2\end{array}$ & $18 / 08 / 2010$ & 260 & 13.000 .000 & 189 \\
\hline Villa Splendore & $\begin{array}{l}\text { Faixa } \\
2\end{array}$ & $04 / 12 / 2009$ & 109 & 5.450 .000 & 86 \\
\hline \multicolumn{3}{|c|}{ Total } & 4.092 & $\begin{array}{l}\mathrm{R} \$ \\
280.457 .006\end{array}$ & 1.919 \\
\hline
\end{tabular}

Fonte: MCidades (2014 ), com adaptações. 
Um dos fatores que podem explicar a elevada concentração de unidades habitacionais nas faixas de renda 2 e 3 , conforme entrevista realizada na Codhab tem a ver com o alto preço da terra urbana no DF e a dificuldade de encontrar construtoras interessadas em operacionalizar o programa na faixa de renda 1. No entanto, verifica-se que o desinteresse em implementar instrumentos que viabilizariam a contratação de empreendimentos para o atendimento das necessidades habitacionais das famílias enquadradas na faixa de renda 1, pode ser melhor compreendido considerando as recentes ações de infraestrutura urbana desvinculadas das diretrizes inseridas no planos de ordenamento territorial. Vale assinalar, nesse sentido, que grande parte das terras pertence ao Distrito Federal o que, em certa medida, facilitaria à promoção de ações para a provisão de habitação social.

Ademais é preciso considerar que antes da operacionalização do PMCMV no DF, já existia uma significativa dinâmica imobiliária direcionada para a população com enquadramento de renda situada nas 3 e 4 do PMCMV/Morar Bem. Ademais, são essas construtoras que anteriormente já operavam a produção habitacional na esfera privada que atuam no segmento econômico do PMCMV/Morar Bem no DF. Apenas, adaptaram sua carteria de projetos para operacionalizar os projetos vinculados ao atendimento da faixa de renda 2 , que tem se revelado lucrativo para o mercado privado.

Outra ação importante realizada na gestão de Arruda foi a revisão do Plano de Ordenamento Territorial (PDOT-2009) no ano de 2012 à luz do Estatuto da Cidade. O processo de revisão do PDOT foi permeado por conflitos, frágil participação popular e divergências, apesar de referenciar o Estatuto da Cidade e a Lei federal n ${ }^{\circ} 11.977 / 2009$, ao diferenciar o processo de regularização fundiária de interesse social e de interesse específico.

A legislação do DF colocou em patamares semelhantes essas duas modalidades de regularização, com princípios, procedimentos, licenciamentos e índices urbanísticos e ambientais equivalentes, ou seja, tratou as diferentes modalidades como iguais. Esse fato, além de possibilitar a violação de direitos na regularização fundiária, acabou por privilegiar os segmentos de maior renda, cujo poder de pressão e influência política e de organização são maiores, o que corrobora para aprofundar as desigualdades sociais e, também, retroalimentar o ciclo da informalidade urbana.

Apesar dos conflitos, merecem destaque os avanços em termos de política habitacional e de regularização fundiária contidas no PDOT de 2009 e em sua revisão no 
ano de 2012. Um dos aspectos positivos, resultantes da estratégia de regularização fundiária, foi a delimitação dos setores habitacionais destinados para a regularização para além de áreas estritamente destinada a usos monofuncionais. Por exemplo, apenas para habitação, foi estabelecida a incorporação de usos diversos e compatíveis com o uso do morar e com variações de tipologias. Também houve a oferta de unidades imobiliárias voltadas a diferentes rendas, assim como a articulação com as demais áreas consolidadas e a estruturação de espaços abertos a partir de sistema de circulação viária, transporte, praças e equipamentos comunitários públicos.

Ainda merecem destaque as mudanças que a aprovação da revisão do PDOT-2009 estabeleceu para as ações de planejamento urbano no DF. Azevedo et al. (2014, p. 9) assim explicam:

Até 2007, a legislação de planejamento territorial no DF era composta por um Plano Diretor de Ordenamento Territorial (PDOT) e por Planos Diretores Locais (PDLs) para cada RA, em conformidade com os preceitos do Estatuto da Cidade (EC). No entanto, apenas sete RAs do DF tiveram seus planos aprovados, sendo estes coordenados pelo órgão de gestão do desenvolvimento urbano à época, com a participação de técnicos das Administrações Regionais (AR) e da população. No entanto, em virtude do grande número de RAs, quase a metade delas criadas nos últimos dez anos, e diante das condições de planejamento existentes, entendeu-se que o planejamento urbano do DF deveria se dar apenas por um plano diretor.

Com o novo PDOT-2009, os Planos Diretores Locais (PDLs) ${ }^{23}$ foram substituídos pelos Planos de Desenvolvimento Local (PDLs), definidos para cada uma das Unidades de Planejamento Territorial (UPTs). Registre-se que cada UPT abrange um conjunto de RAs reunidas em razão da poligonal tombada, que envolve o Conjunto Urbanístico de Brasília, os limites das regiões administrativas, proximidade física, principais corredores de transporte, morfologia urbana e características econômicas semelhantes.

\footnotetext{
${ }^{23}$ As RAs do DF que possuem PDLs são Taguatinga, Ceilândia, Samambaia, Guará, Sobradinho, Gama e Candangolândia.
} 
Figura 4 - Regionalização das Unidades de Planejamento Territorial (UPTs)

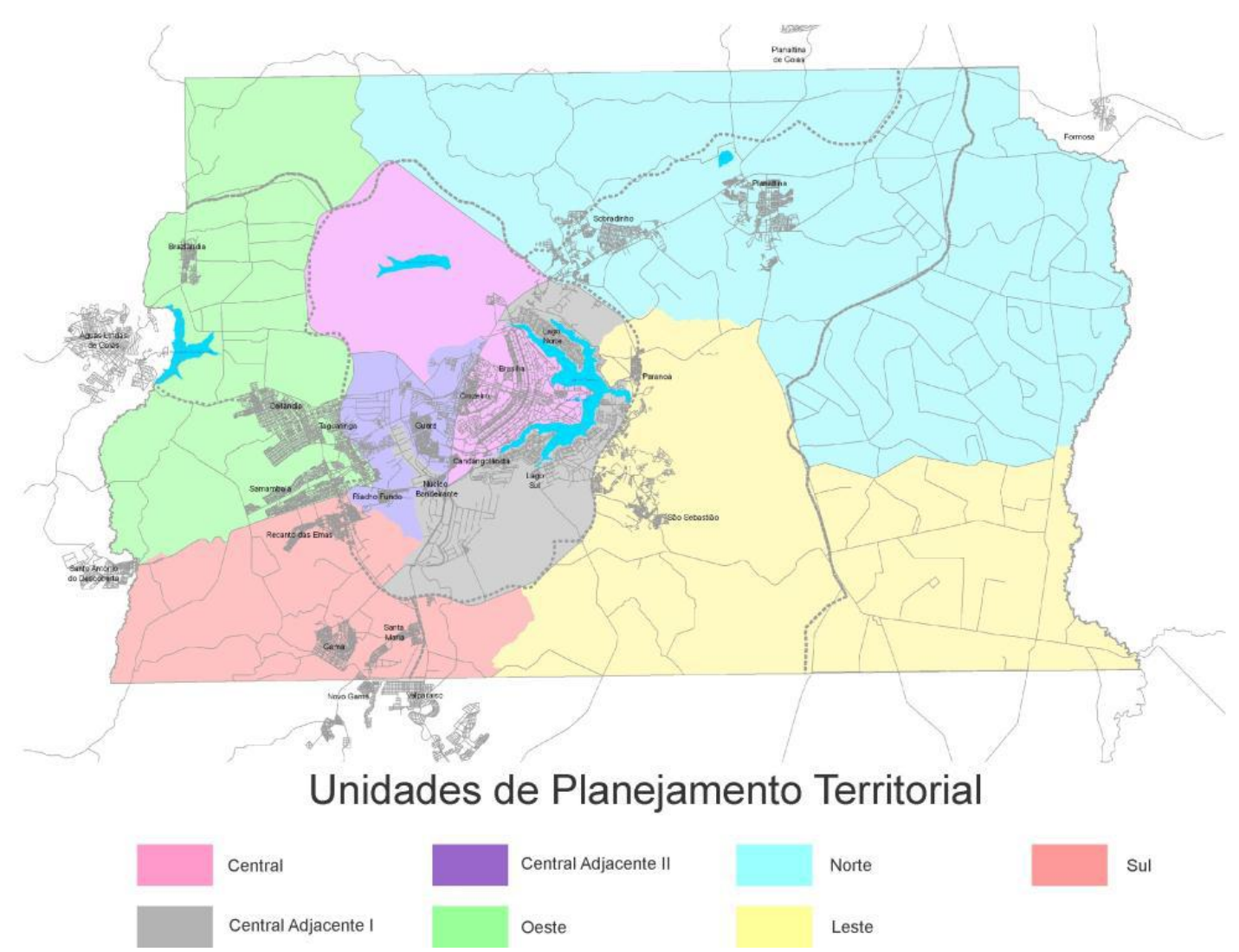

Fonte: PDOT (2009). *UPT Central: Brasília, Candangolândia, Cruzeiro, Sudoeste/Octogonal; UPT Central Adjacente I: Lago Sul, Park Way, Lago Norte e Varjão; UPT Central Adjacente II: SIA, Guará, Riacho Fundo, Águas Claras, SCIA, Núcleo Bandeirante e Vicente Pires; UPT Oeste: Taguatinga, Brazlândia, Ceilândia e Samambaia; UPT Norte: Sobradinho, Planaltina e Sobradinho II; UPT Leste: Paranoá, Itapoã, Jardim Botânico e São Sebastião; UPT Sul: Gama, Santa Maria, Recanto das Emas e Riacho Fundo II.

Estas UPTs apresentam características diferenciadas em relação às demandas habitacionais, contingente de população urbana e distribuição de renda, conforme se observa na tabela a seguir. 
Tabela 2 - População Urbana e Renda per capita por Unidades de Planejamento Territorial (UPTs)

\begin{tabular}{|c|c|c|c|}
\hline $\begin{array}{l}\text { Unidades de } \\
\text { Planejamento } \\
\text { Territorial }\end{array}$ & Região Administrativa & $\begin{array}{l}\text { População } \\
\text { Urbana }\end{array}$ & $\begin{array}{l}\text { Renda } P e r \\
\text { Capita R\$ } \\
\text { (Mensal) }\end{array}$ \\
\hline \multirow{4}{*}{ Central } & Plano Piloto & 216.00 & $4.451,87$ \\
\hline & Sudoeste/Octogonal & 52.300 & $6.144,17$ \\
\hline & Cruzeiro & 32.200 & $2.532,13$ \\
\hline & Candangolândia & 16.900 & $1.114,19$ \\
\hline \multirow[b]{4}{*}{ Central Adjacente I } & Lago Sul & 30.650 & $6.510,10$ \\
\hline & Lago Norte & 34.200 & $4.558,40$ \\
\hline & Park Way & 19.750 & $4.871,39$ \\
\hline & Varjão & 9.300 & 501,91 \\
\hline \multirow{7}{*}{ Central Adjacente II } & Guará & 119.950 & $2.279,91$ \\
\hline & Núcleo Bandeirante & 23.700 & $1.500,18$ \\
\hline & Riacho Fundo & 37.600 & $1.346,09$ \\
\hline & Águas Claras & 118.850 & $3.158,29$ \\
\hline & Vicente Pires & 72.400 & $2.075,47$ \\
\hline & SIA & 2.000 & $1.500,84$ \\
\hline & Estrutural & 35.100 & 367,50 \\
\hline \multirow[b]{4}{*}{ Oeste } & Taguatinga & 212.850 & $1.635,12$ \\
\hline & Samambaia & 228.350 & 765,32 \\
\hline & Ceilândia & 452 & 720,49 \\
\hline & Brazlândia & 51.100 & 818,30 \\
\hline \multirow{4}{*}{ Sul } & Gama & 134.950 & $1.103,93$ \\
\hline & Santa Maria & 122.750 & 708,50 \\
\hline & Recanto das Emas & 139.000 & 662,28 \\
\hline & Riacho Fundo II & 39.450 & 759,93 \\
\hline \multirow[b]{4}{*}{ Leste } & Paranoá & 46.250 & 741,71 \\
\hline & Itapoã & 59.700 & 726,93 \\
\hline & São Sebastião & 98.900 & 764,05 \\
\hline & Jardim Botânico & 25.300 & 4.132,91 \\
\hline \multirow{4}{*}{ Norte } & Sobradinho & 63.700 & $1.594,26$ \\
\hline & Sobradinho II & 97.450 & $1.518,41$ \\
\hline & Fercal & 8.400 & 574,31 \\
\hline & Planaltina & 185.400 & 728,72 \\
\hline Total & & 2.786 .800 & $1.459,57$ \\
\hline
\end{tabular}

Fonte: Codeplan (2015); PDAD-DF (2013). *Os valores de renda mensal equivalem aos últimos treze meses.

Observa-se que a UPT Oeste é a mais populosa do DF. Ela comporta um terço da população distrital, correspondente a 960 mil habitantes. Nesta UPT encontra-se a maioria das RAs mais populosas do DF, sendo elas Ceilândia, Taguatinga e Samambaia. A segunda mais populosa UPT é a Sul, com 450 mil habitantes, equivalendo a 15,7\% da população do DF. Já em relação à renda domiciliar per capita, observa-se que os valores 
mais elevados ocorrem nas regiões Central, Central Adjacente I e II, revelando uma desproporcionalidade em relação aos índices mais elevados de população. As UPTs Central, Adjacente II e Oeste concentram 70\% da renda do DF, o que demonstra uma espacialização da renda concentrada. Nota-se que a UPT Oeste apresenta uma significativa concentração de renda em função do volume populacional (CODEPLAN, 2015).

Ainda segundo Azevedo et al. (2014), os Planos de Desenvolvimento Local têm como objetivo a promoção do desenvolvimento sustentável e integrado às questões urbanas e rurais. Considerando as especificidades das UPTs e também a elaboração dos planos, devem atender ao conteúdo mínimo, ou seja, devem contemplar projetos especiais de intervenção urbana, e as prioridades e metas das ações devem ser executadas com previsão orçamentária. No entanto, observam-se dissonâncias, ao se integrarem em uma mesma UPTs RAs com características bem distintas ${ }^{24}$. A partir da delimitação das UPTs e dos estudos que subsidiaram a elaboração do Plano Distrital de Habitação de Interesse Social (PLANDHIS), foi possível estimar a demanda habitacional, o que corresponde ao déficit habitacional mais a demanda futura por unidades habitacionais para as sete UPTs.

De um lado, a demanda habitacional regionalizada auxilia os gestores a elaborarem políticas e programas focalizados nos territórios prioritários para $\mathrm{o}$ atendimento da política habitacional. Por outro lado, a delimitação da demanda a partir das UPTs homogeneíza a demanda habitacional, sem estabelecer o escalonamento de projetos prioritários vinculados ao atendimento da faixa de renda por RAs e, ao mesmo tempo, fragmenta a articulação da sociedade civil em participar de forma efetiva no desenho das políticas e dos planos na escala das RAs. Assim, a atual escala dos PDLs dificulta a participação efetiva da sociedade na propulsão dessas novas perspectivas de planejamento e desenvolvimento, estruturadas a partir da escala dos PDLs.

\footnotetext{
${ }^{24}$ Destaca-se que nenhum plano de desenvolvimento foi elaborado até a elaboração desta tese.
} 
Figura 5 - Demanda Habitacional por Unidade Territorial de Planejamento (UPT)

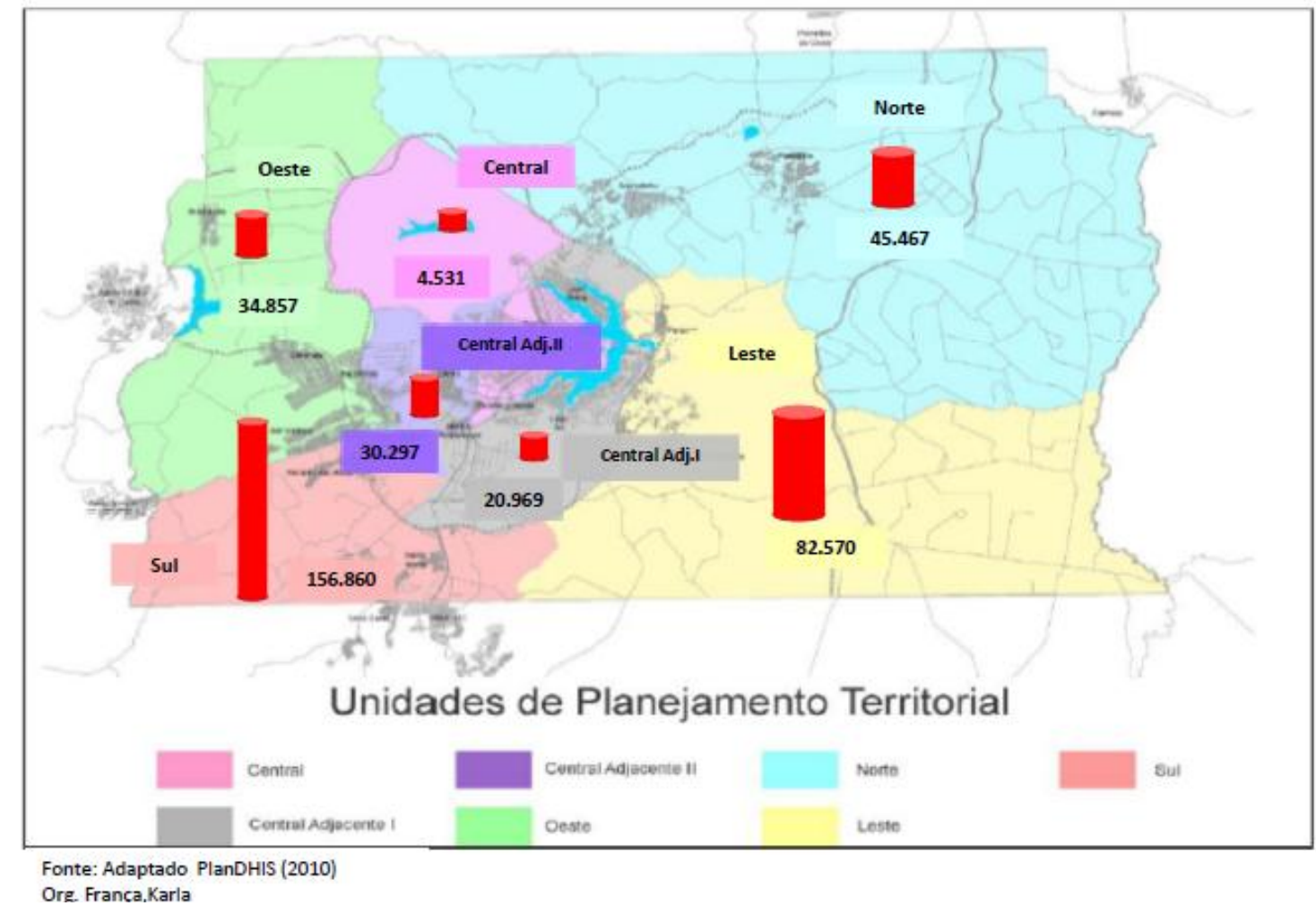

Fonte: Adaptado de PlanDHIS (2010). Organizado por Karla França.

Durante a gestão de Arruda, nota-se uma retomada dos investimentos em habitação e urbanização com financiamento distrital e federal atrelado às mudanças de legislação do PDOT. Também ficaram estabelecidos vetores de expansão urbana associados à contratação de empreendimentos habitacionais, que valorizaram as terras urbanas em áreas de regiões administrativas anteriormente destinadas à população de menor renda. Isso provocou novas configurações territoriais no tecido urbano do DF e, também, nos municípios goianos que integram a Área Metropolitana de Brasília - RideDF.

Após a cassação do mandato de José Arruda no mês de abril de 2010, houve uma sucessão de governadores temporários para exercer a função. O primeiro que assumiu foi o vice-governador Paulo Otavio, que renunciou ao cargo, passando-o em caráter interino para Wilson Lima e posteriormente para Rogério Rosso. Durante esse período as estruturas dos órgãos governamentais se mantiveram semelhantes às do governo Arruda. Deflagrado o processo eleitoral, Agnelo Queiroz foi eleito governador e realizou mudanças na operacionalização da política habitacional do DF. 


\subsection{Investimentos habitacionais e novas configurações metropolitanas no período 2011-2014}

Com a vitória nas urnas de Agnelo Queiroz, este passou a assumir o cargo de governador entre 2011 e 2014. No período da gestão de Agnelo, observa-se a maior contratação de investimentos habitacionais no DF. Esta fase coincide com a segunda etapa do programa federal Minha Casa, Minha Vida (PMCMV2).

A ampliação do desenvolvimento de projetos habitacionais configurou novos vetores de expansão de atuação do mercado imobiliário, abrindo um leque de novas oportunidades para as construtoras poderem implementar projetos habitacionais em regiões administrativas como Taguatinga, Samambaia, Ceilândia, Riacho Fundo, Samambaia, Santa Maria e Paranoá.

A partir da elaboração do PLANDHIS, foi quantificada a necessidade de 262 mil moradias a serem construídas (reposição), 191 mil moradias que demandariam ações de regularização fundiária e 126 mil unidades habitacionais que necessitariam de programas de requalificação de moradia. Já as pesquisas do Ipea estimaram um déficit habitacional de reposição no DF, no ano de 2007, de 96,2 mil unidades habitacionais. Em 2012, o número se elevou para 116 mil unidades (SEDHAD-DF, 2012; IPEA, 2013a).

Já a demanda habitacional é compreendida como a diferença do estoque de habitações entre os períodos de tempo. Ou seja, a demanda habitacional representa a quantidade a mais de domicílios que existirá em relação a determinado período, abarcando tanto as moradias novas que precisam ser construídas pelo mercado imobiliário quanto as que reclamam por reforma (MOURA, 2015).

No DF, os estudos que estimaram a demanda habitacional mais recente ocorreram a partir das projeções do Estudo da Demanda Habitacional (EDH) realizada no ano de 2005, considerando o período de 2000-2010. Neste estudo, observa-se que as projeções da demanda habitacional para o período de 2005 e 2010, efetuadas pelo EDH-DF, correspondem a 96.882 moradias novas. 


\section{Quadro 34 - Crescimento da Demanda Habitacional por Grupos de Renda no DF: 2005-2010}

\begin{tabular}{|c|c|c|c|c|c|c|c|c|c|}
\hline \multirow{3}{*}{$\begin{array}{c}\text { Grupo de } \\
\text { Renda } \\
\text { Domicilia } \\
\text { r por } \\
\text { Salário } \\
\text { Mínimo }\end{array}$} & \multicolumn{8}{|c|}{ Domicílios Permanentes e Improvisados por Ano } & \multirow[b]{2}{*}{$\begin{array}{l}\text { anda } \\
\text { nal 2000- } \\
10\end{array}$} \\
\hline & \multirow[t]{2}{*}{2000} & \multirow[t]{2}{*}{2005} & \multirow[t]{2}{*}{2010} & \multicolumn{2}{|c|}{$\begin{array}{c}\text { Demanda } \\
\text { Habitacional } \\
\text { 2000-2005 }\end{array}$} & \multicolumn{2}{|c|}{$\begin{array}{c}\text { Demanda } \\
\text { Habitacional } \\
2005-2010\end{array}$} & $\begin{array}{r}\text { Dem } \\
\text { Habitaci } \\
20\end{array}$ & \\
\hline & & & & Abs & $\%$ & Abs & $\%$ & Abs & $\%$ \\
\hline Até $3 \mathrm{SM}$ & 145.860 & 171.713 & 197.677 & 25.853 & 28.63 & 25.853 & $26.8 \%$ & 51.817 & 27.68 \\
\hline $\begin{array}{l}\text { De } 3 \text { a } 5 \\
\text { SM }\end{array}$ & 81.957 & 96.521 & 111.115 & 14.564 & 16.13 & 14.594 & 15.06 & 29.158 & 15.58 \\
\hline $\begin{array}{l}\text { De } 5 \text { aa } \\
10 \text { SM }\end{array}$ & 113.881 & 134.084 & 154.359 & 20.203 & 22.37 & 20.775 & 20.93 & 40.478 & 21.62 \\
\hline $\begin{array}{l}\text { De } 10 \text { a } \\
20 \mathrm{SM}\end{array}$ & 90.763 & 106.852 & 123.009 & 16.089 & 17.82 & 16.157 & 16.68 & 32.246 & 17.23 \\
\hline $\begin{array}{l}\text { Mais de } \\
20 \mathrm{SM}\end{array}$ & 111.734 & 131.548 & 151.440 & 19.814 & 21.94 & 19.892 & 20.53 & 39.706 & 21.21 \\
\hline Total DF & 550.414 & 640.718 & 737.600 & 90.304 & $\begin{array}{c}100 \\
\%\end{array}$ & 96.882 & $100 \%$ & 187.186 & $100 \%$ \\
\hline
\end{tabular}

Fonte: Adaptado de PDOT (2009) e PlandHis (2012).

Em seu primeiro ano de gestão, Agnelo lançou o Programa Morar Bem, com financiamento do Programa Minha Casa, Minha Vida. Este programa atende famílias com renda bruta de até doze salários mínimos, o que equivalia em 2015 a $\mathrm{R} \$ 9.456,00$. Cabe à Secretária de Habitação e Regularização Fundiária (Sedhab) o planejamento do programa Morar Bem e à Companhia de Desenvolvimento Habitacional do DF (Codhab) o cadastramento das famílias e a execução do programa.

Considerando a demanda por unidades habitacionais a partir do perfil dos inscritos no novo cadastro habitacional do DF até o ano de 2013, obtém-se o montante de 375.960 inscritos que informaram a necessidade de adquirir uma moradia. 


\section{Quadro 35 - Perfil dos Inscritos no Cadastro Habitacional do DF}

Ano Base: 2012

\begin{tabular}{l|cccc}
\multicolumn{1}{c}{ Faixa de Renda } & $\begin{array}{c}\text { Quantidade } \\
\text { por Faixa } \\
\text { de Renda }\end{array}$ & Entidades* & $\begin{array}{c}\text { Total por } \\
\text { Faixa }\end{array}$ & $\begin{array}{c}\text { Porcentual } \\
(\%)\end{array}$ \\
\hline Faixa 1: até R\$ 1.600,00 & 263.039 & 38.369 & 301.408 & 80.20 \\
Faixa 2: R\$ 1.601,00 a R\$ & 39.804 & 9.941 & 49.745 & 13.20 \\
3.100,00 & 15.444 & 3.635 & 19.079 & 5.10 \\
Faixa 3: 3.101,00 a $\mathrm{R} \$ 5.000,00$ & 4.728 & 1.000 & 5.728 & 1.50 \\
Faixa 4: Acima de $\mathrm{R} \$ 5.001,00$ & 323.015 & 52.945 & 375.960 & 100 \\
Total &
\end{tabular}

* Os inscritos na modalidade Entidades correspondem às famílias organizadas em cooperativas habitacionais ou mistas, associações ou demais entidades privadas sem fins lucrativos, visando à produção, aquisição ou requalificação de imóveis urbanos. As prioridades são as famílias com renda mensal de até $\mathrm{R} \$ 1.600,00$.

Fonte: Dados fornecidos em visita à antiga SedHab realizada em 2015.

Embora com dados parciais e não atualizados, verificou-se que a maior demanda para o atendimento das necessidades habitacionais encontra-se na faixa 1, o que equivale, em termos porcentuais, a 80,2\% dos inscritos no cadastro. Ao acrescentarmos a demanda da faixa 2, totalizam-se $93 \%$ da demanda por uma unidade habitacional, o que nos permite afirmar que no DF o déficit habitacional está concentrado nas faixas 1 e 2.

Sublinha-se que o total de usuários inscritos no cadastro habitacional reflete $o$ número de interessados em receber atendimento do GDF em ter acesso a uma unidade habitacional e não necessariamente o número de pessoas que precisam da intervenção do Estado para equacionar sua necessidade habitacional.

$\mathrm{O}$ indicativo de inscritos tem como finalidade apontar as convergências de elementos que auxiliam na priorização de ações governamentais para o atendimento das necessidades habitacionais, em especial políticas de novas moradias prioritárias para as famílias enquadradas na faixa 1 . Também se enfatiza que o atendimento das necessidades habitacionais requer ações diversificadas que não são supridas apenas por políticas de construção de novas unidades. Conforme sinalizado no PlandHis, no DF existe uma demanda significativa de moradias que necessitam de ações de regularização fundiária e de programas de requalificação de moradia.

Enfatiza-se que, nos últimos levantamentos, acerca da identificação dos

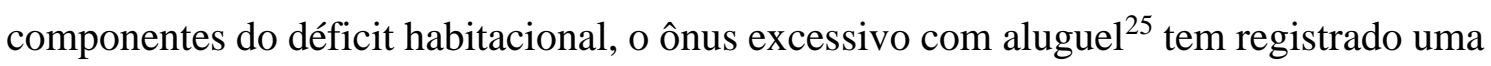

\footnotetext{
${ }^{25} \mathrm{O}$ ônus excessivo com aluguel refere-se ao comprometimento pelas famílias de mais de $30 \%$ da renda domiciliar com aluguéis. O índice de 30\% é considerado o limite para se gastar com as despesas de um imóvel seja para alugar ou para as prestações nos financiamentos habitacionais.
} 
alta de 30\% no período de 2007-2011. De acordo com a pesquisa Síntese de Indicadores Sociais, divulgada pelo Instituto Brasileiro de Geografia e Estatística (IBGE) no ano de 2014, o componente aluguel afetou 5,2\% do total de domicílios urbanos, o que equivale a 55,8 milhões de domicílios urbanos no país. O Distrito Federal ocupa a primeira posição nacional de maior índice de ônus excessivo com o aluguel, atingindo a marca de 9,5\% e entre os alugados, 29,1\%. Demanda esta que não tem sido foco de políticas habitacionais em âmbito nacional e distrital.

Conforme consta nos documentos oficiais do Programa Morar Bem, sua finalidade é zerar o déficit habitacional (reposição) do Distrito Federal, construindo 100 mil $^{26}$ unidades habitacionais até o ano de 2014, dentro do conceito de moradia plena. Trata-se de moradias completas, com infraestrutura urbana (abastecimento de água, esgoto sanitário, energia elétrica, iluminação pública, instalações telefônicas, redes de drenagem de águas pluviais, pavimentação asfáltica) e equipamentos públicos, como escolas, postos de saúde e de polícia. Além de área de comércio que gere emprego e renda à população local (MORAR BEM, 2014).

Sublinha-se que o Programa Morar Bem se diferencia do programa federal Minha Casa, Minha Vida no que tange às faixas de renda, visto que o programa federal opera nacionalmente com três faixas de renda, no Distrito Federal, e o programa Morar Bem opera com quatro faixas de renda.

\begin{tabular}{|cl|}
\hline Quadro 36 - Faixas de Renda do Morar Bem/PMCMV \\
\hline Faixa & Especificidade da Renda \\
\hline Faixa 1 & Até $\mathrm{R} \$ 1.600,00$ \\
Faixa 2 & $\mathrm{R} \$ 1.601,00$ a $\mathrm{R} \$ 3.100,00$ \\
Faixa 3 & $\mathrm{R} \$ 3.101,00$ a $\mathrm{R} \$ 5.000,00$ \\
Faixa 4 & Acima de $\mathrm{R} \$ 5.001,00$ até $\mathrm{R} \$ 9.456,00$ \\
\hline
\end{tabular}

Fonte: CodHab (2014).

Segundo entrevista realizada na Codhab para esta pesquisa, a operacionalização do programa Morar Bem em quatro faixas de renda ocorre para atender às necessidades habitacionais do DF. A justificativa apresentada é que a renda per capita elevada no DF não permitia a inserção de famílias na estrutura nacional do PMCMV, sendo necessária a instituição de outra faixa de renda, isto é, a 4. Vale destacar que a faixa de renda 4 não

\footnotetext{
${ }^{26}$ Para a construção de 100 mil unidades habitacionais para zerar o déficit consideraram-se as estimativas anteriores ao ano de 2012, uma vez que a elaboração do PlanDHis utilizou dados do período de 2006-2011.
} 
recebe nenhum tipo de subsídio federal ou distrital e a fonte de financiamento vincula-se aos recursos do Sistema Brasileiro de Poupança e Empréstimo (SBPE), dirigida às operações que envolvem o setor privado. Uma das medidas adotadas pelo governo distrital nesta faixa de renda é a doação de terrenos para a execução dos empreendimentos. Por sua vez a doação de terrenos públicos para as operações traz uma redução do valor do imóvel, barateando o valor das prestações aos mutuários finais.

Para a implementação do Programa Morar Bem, foi necessário planejar a oferta de novas áreas destinadas à habitação social. Em seu escopo técnico, o programa traz essas áreas habitacionais a serem ofertadas em consonância com as áreas previstas no PDOT. 
Figura 6 - Áreas Definidas no PDOT 2009 para Ofertas Habitacionais

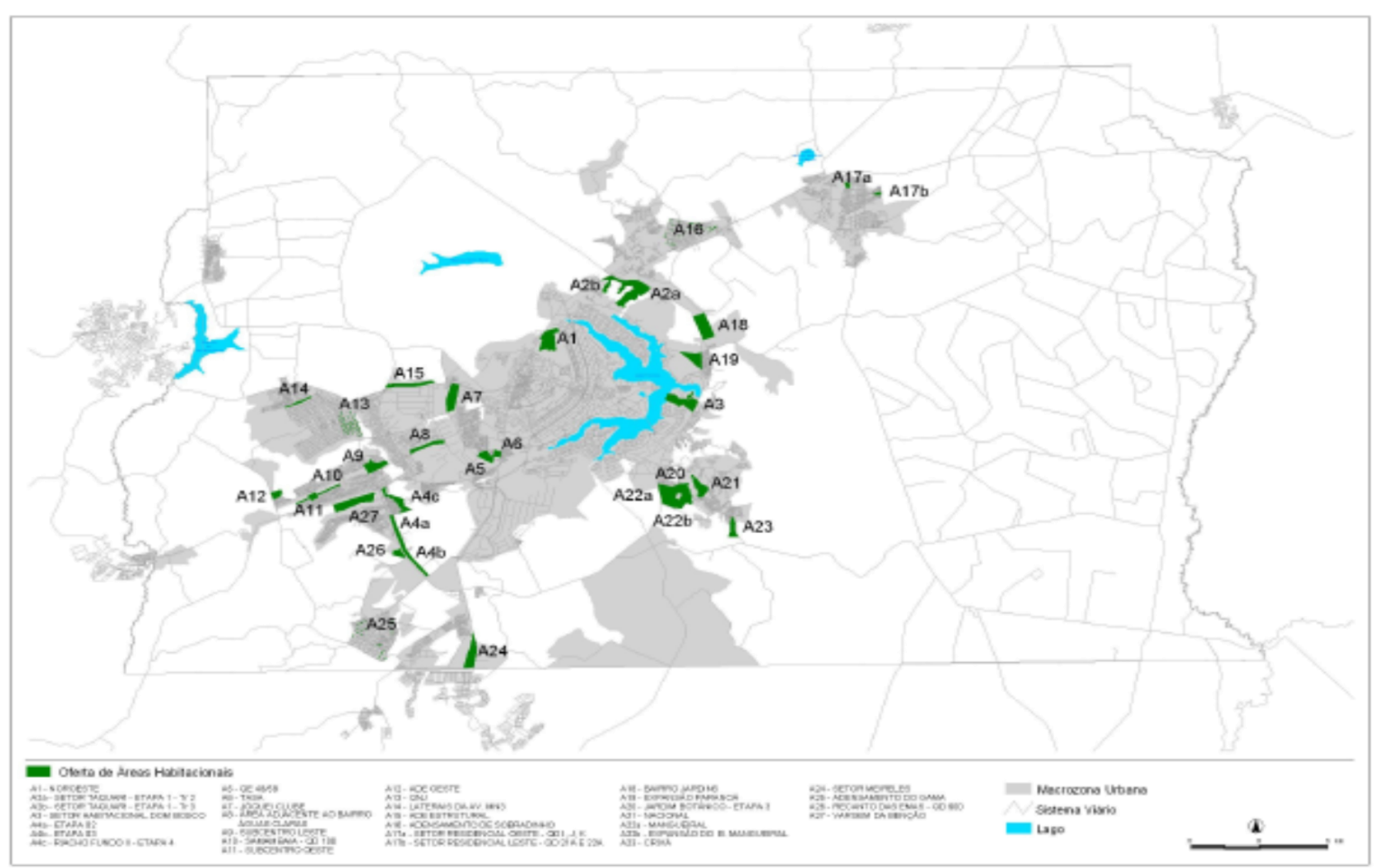

Fonte:PDOT; SEDHAB (2009). 
Segundo Moura (2015), essas novas áreas e o adensamento de áreas habitacionais previstas no PDOT e detalhadas no Relatório Técnico do PDOT (2009) preveem o atendimento de 318.718 habitantes com a oferta de lotes destinados à baixa renda em Planaltina, Samambaia e Paranoá, e para média renda em Taguatinga, Ceilândia, Águas Claras, Sobradinho, Gama, Paranoá e Riacho Fundo visando ao atendimento de 135.379 habitantes.

De acordo com o PDOT, a oferta de novas áreas habitacionais prioriza a ocupação dos vazios intraurbanos e a ocupação de áreas próximas aos núcleos urbanos consolidados, onde haja oferta de serviços, comércios e equipamentos comunitários. Nas entrevistas realizadas na CODHAD foi ressaltado que boa parte dos empreendimentos possui equipamentos públicos ou está em um raio de $2,5 \mathrm{~km}$, onde já existem equipamentos públicos desta natureza, conforme preveem os normativos. Ademais, foi unânime a posição da CODHAB em afirmar que na atual gestão há o empenho em evitar a repetição de construir bairros residenciais desprovidos de comércio, escolas, postos de saúde, como ocorreu em todo o país.

A oferta de novas áreas habitacionais previstas no PDOT 2009 traz duas tipologias: novas áreas habitacionais; e áreas a serem adensadas com projetos habitacionais. Essas áreas sinalizadas levaram em consideração a disponibilidade hídrica.

Em sua maioria os empreendimentos do Morar Bem/PMCMV estão localizados, ou em fase de contratação, nas UPTs Norte, Leste, Oeste e Sul, com destaque para a oferta de áreas nas regiões administrativas de Samambaia, Gama, Itapoã, Paranoá, Planaltina, Recanto das Emas, Riacho Fundo II, Santa Maria, São Sebastião I e II, Crixá e Bairro Nacional e Sobradinho. 
Figura 7 - Principais áreas delimitadas para ofertas de UHs do Morar Bem

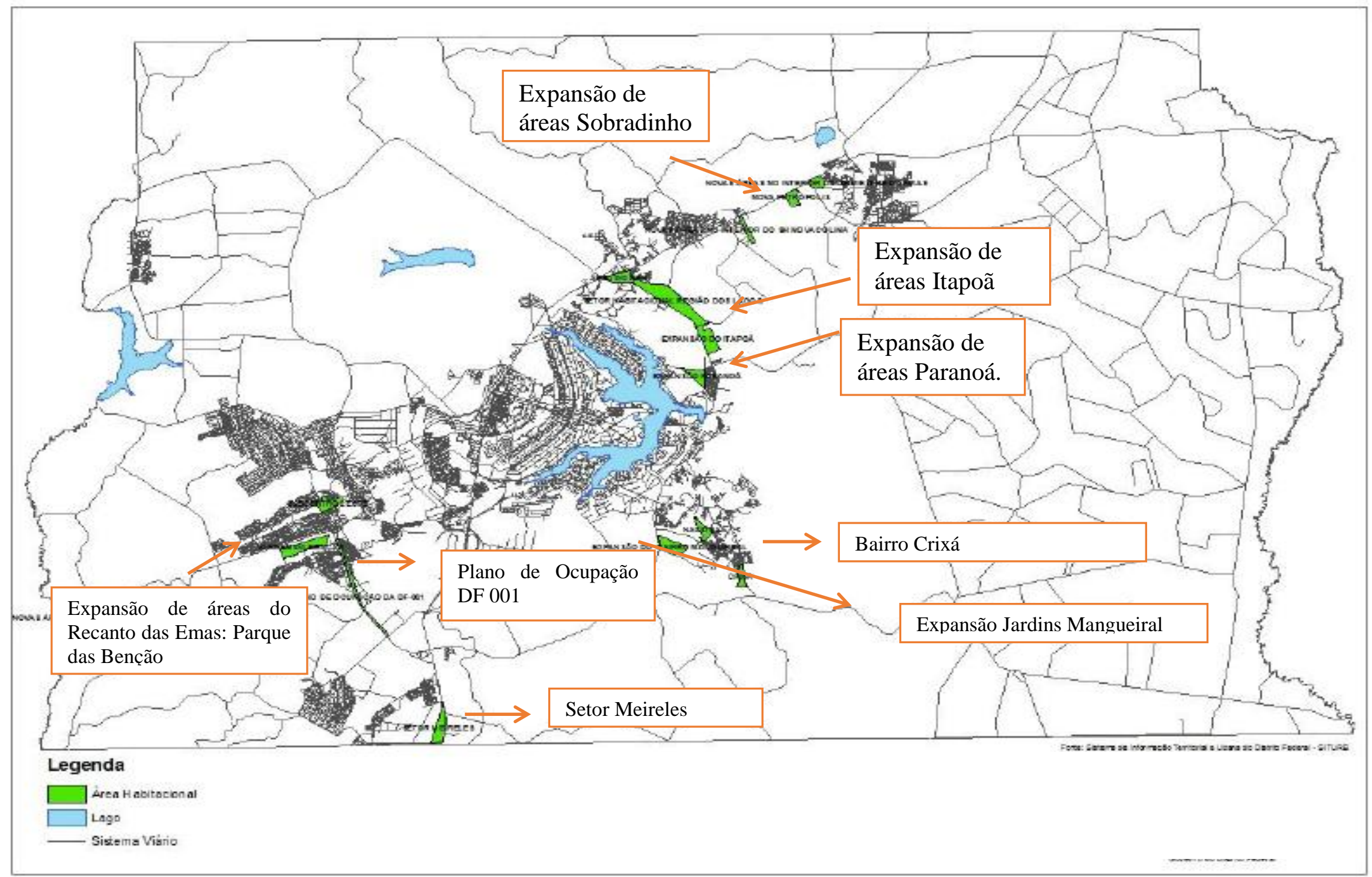

Fonte: PlanDHIS (2012). Adaptado por Karla França (2015) 
Outro fator destacado no PDOT-2009 na delimitação dessas novas áreas é a preocupação com o uso misto, ou seja, a provisão de habitação coletiva e oferta de unidades individuais voltadas a diferentes faixas de renda. Dentre as novas áreas disponibilizadas no PDOT, destinadas para programas habitacionais, são citados, por exemplo, a localização, os tipos de usos e a priorização de contratação para o atendimento das famílias de renda baixa ou média, sem fazer alusão ao limite máximo de renda ou porcentuais de atendimento por faixas de renda nas áreas delimitadas para a provisão habitacional.

Para o atendimento das necessidades habitacionais vinculadas às faixas de renda, o Programa Morar Bem delimitou a tipologia dos empreendimentos e seu preço conforme a localização. O Quadro 37 apresenta o panorama dos imóveis em andamento ou a serem contratados e as fontes de recursos. Observa-se que em sua maioria foi incluso o atendimento da faixa de renda 1, no entanto, em sua operacionalização verificou-se que a porcentagem de unidades destinadas para a faixa 1 é minoritária. 


\begin{tabular}{|c|c|c|c|c|}
\hline Empreendimento & Faixa Salarial (R\$) & Preço/Tipologia & $\begin{array}{l}\text { Fonte de } \\
\text { Recursos }\end{array}$ & $\begin{array}{c}\text { Construtora Responsável pela } \\
\text { execuçãa }\end{array}$ \\
\hline Paranoá Parque & De $R \$ 0$ a $1.600,00$ & $\mathrm{R} \$ 65.000,00$ - apartamentos de 2 quartos & FAR & Direcional Engenharia \\
\hline Recanto das Emas & De $\mathrm{R} \$ 0$ a $1.600,01$ & $\mathrm{R} \$ 85.240,05$ - apartamentos de 2 quartos & FAR & Em licitação \\
\hline \multirow[b]{2}{*}{ Recanto das Emas no Parque das Bênçãos } & \multirow[b]{2}{*}{ De 0 a $5.000,00$} & $\mathrm{R} \$ 76.000,00$ - apartamentos de 2 quartos & FAR & \multirow[b]{2}{*}{ Mendes Júnior } \\
\hline & & $\mathrm{R} \$ 85.000,00$ - apartamentos de 3 quartos & FGTS & \\
\hline Riacho Fundo II $-3^{\mathrm{a}}$ etapa & De $\mathrm{R} \$ 0$ a $1.600,00$ & $\mathrm{R} \$ 85.000,00$ - apartamentos de 2 quartos & FAR/FDS & $\begin{array}{l}\text { Consórcio Prefisan, } \\
\text { Marka/CWP/Socienge }\end{array}$ \\
\hline \multirow[b]{2}{*}{ Riacho Fundo II - Parque do Riacho } & \multirow[b]{2}{*}{ De $R \$ 1.600,01$ a $3.275,00$} & $\mathrm{R} \$ 75.000,00$ - apartamentos de 2 quartos & \multirow[b]{2}{*}{ FGTS } & \multirow[b]{2}{*}{ JC Gontijo } \\
\hline & & $\mathrm{R} \$ 85.000,00$ - apartamentos de 3 quartos & & \\
\hline \multirow[b]{2}{*}{ Santa Maria } & \multirow[b]{2}{*}{ De $\mathrm{R} \$ 1.600,01$ a $8.136,00$} & $\mathrm{R} \$ 123.000,00$ - apartamentos de 2 quartos & \multirow[b]{2}{*}{ FAR/FGTS } & \multirow[b]{2}{*}{ Carvalho Accioly } \\
\hline & & $\mathrm{R} \$ 147.000,00$ - apartamentos de 3 quartos & & \\
\hline \multirow[b]{3}{*}{ São Sebastião - Jardins Mangueiral } & \multirow[b]{3}{*}{ De $R \$ 2.488,00$ a $8.136,00$} & $\mathrm{R} \$ 109.000,00$ - casa de 2 quartos & FGTS & \multirow{3}{*}{$\begin{array}{l}\text { Jardins Mangueiral Empreendimentos } \\
\text { Imobiliários } \\
\end{array}$} \\
\hline & & $\mathrm{R} \$ 122.200,00$ - casa de 3 quartos & FGTS & \\
\hline & & $\mathrm{R} \$ 146.000,00$ - apartamentos de 2 quartos & SBPE & \\
\hline Setor Crixá & De 0 a $1.600,00$ & $\mathrm{R} \$ 76.000,00$ - apartamentos de 2 quartos & FAR & Direcional Engenharia \\
\hline Setor Nacional & De 0 a $1.600,00$ & $\mathrm{R} \$ 76.000,00$ - apartamentos de 2 quartos & FAR & Direcional Engenharia \\
\hline \multirow[b]{2}{*}{ Gama } & \multirow[b]{2}{*}{ De $R \$ 1.600,01$ a $8.136,00$} & $\mathrm{R} \$ 152.000,00$ - apartamentos de dois quartos & FGTS & \multirow[b]{2}{*}{ Em licitação } \\
\hline & & $\mathrm{R} \$ 170.003,57$ - apartamentos de 3 quartos & SBPE & \\
\hline \multirow[b]{2}{*}{ Samambaia } & \multirow[b]{2}{*}{ De $\mathrm{R} \$ 1.600,01$ a $8.136,01$} & $\mathrm{R} \$ 107.500,00$ - apartamento de 2 quartos & FGTS & Não informado \\
\hline & & $\mathrm{R} \$ 133.300,00$ - apartamento de 3 quartos & SBPE & Não informado \\
\hline \multirow[b]{2}{*}{ Sobradinho } & \multirow[b]{2}{*}{ De $R \$ 1.600,01$ a $8.136,00$} & $\mathrm{R} \$ 143.683,43$ - apartamento de 2 quartos & FAR/FGTS & Em licitação \\
\hline & & $\mathrm{R} \$ 161.674,40$ - apartamentos de 3 quartos & SBPE & Em licitação \\
\hline Sobradinho II & De 0 a $R \$ 1.600,00$ & $\mathrm{R} \$ 65.000,00$ - casa de 2 quartos & FAR & Em licitação \\
\hline \multirow{2}{*}{$\begin{array}{c}\text { Itapoã } \\
\text { Itapoã Parque }\end{array}$} & \multirow[b]{2}{*}{ De 0 a $R \$ 5.000,00$} & $\mathrm{R} \$ 76.000,00$ - apartamentos de 2 quartos & FAR & \multirow[b]{2}{*}{ JC Gontijo } \\
\hline & & $\mathrm{R} \$ 83.219,83$ - apartamento de 3 quartos & FGTS/SBPE & \\
\hline Planaltina - Mestre D'Armas & De 0 a $1.600,00$ & $\mathrm{R} \$ 76.000,00$ - apartamentos de 2 quartos & FAR & Não informado \\
\hline Planaltina - Planaltina Parque & De 0 a $R \$ 3.275,00$ & $\mathrm{R} \$ 80.284,92$ - apartamentos de 2 quartos & FAR & Direcional Engenharia \\
\hline Planaltina - Planaltina Parque & De 0 a $R \$ 3.275,01$ & $\mathrm{R} \$ 86.621,07$ - apartamentos de 3 quartos & FGTS & Direcional Engenharia \\
\hline
\end{tabular}




\begin{tabular}{|c|c|c|c|c|}
\hline Nova Petrópolis & De 0 a $1.600,00$ & $\mathrm{R} \$ 82.00,00$ - casa de 2 quartos & FAR & Em licitação \\
\hline Nova Planaltina & De 0 a $1.600,00$ & $\mathrm{R} \$ 76.000,00$ - casa de 2 quartos & FAR & Em licitação \\
\hline \multirow[b]{2}{*}{ Recanto das Emas - Vargem da Bênção } & \multirow[b]{2}{*}{ De $R \$ 0$ a $5.000,00$} & $\mathrm{R} \$ 83.000,00$ - apartamentos de 2 quartos & FAR & Não Informado \\
\hline & & $\mathrm{R} \$ 95.000,000$ - apartamentos de 3 quartos & FAR & Não Informado \\
\hline SCIA Estrutural & De 0 a $1.600,00$ & $\mathrm{R} \$ 65.000,00$ - casa de 2 quartos & FAR & Elmo \\
\hline Varjão & De 0 a $1.600,00$ & $\begin{array}{c}\mathrm{R} \$ 76.000,00 \text { - apartamento (térreo + um pavimento) } \\
\text { ou casa sobreposta com } 2 \text { quartos }\end{array}$ & FAR & Em licitação \\
\hline
\end{tabular}


No PLANDHIS ganharam destaque as áreas destinadas para a oferta de unidades habitacionais do Programa Morar Bem, no entanto não houve prioridades dessas áreas para o atendimento da população de menor renda, uma vez que a política habitacional do DF visa atender à população entre zero e doze salários mínimos de renda familiar. Em linhas gerais, não há garantias para a priorização de áreas e projetos para o atendimento das famílias enquadradas na faixa 1, que é a de menor renda e de maior concentração do déficit e da demanda habitacional no DF.

\subsubsection{A produção da moradia social para o atendimento das famílias de baixa renda}

A partir do cruzamento de informações acerca das novas áreas disponíveis no PDOT para a oferta habitacional e as áreas disponíveis para a execução do Programa Morar Bem, nota-se uma convergência de volume de contratação nas RAs Samambaia, Riacho Fundo II, Santa Maria, Gama e Recanto das Emas, no quadrante sudoeste, principal vetor de adensamento urbano do DF e área prioritária das obras contratadas pelo Morar Bem. Sublinha-se que nos municípios goianos que fazem divisa com essas RAs, também, nos últimos quatro anos houve um boom de contratação de obras do Programa Minha Casa, Minha Vida para o atendimento da faixa 2, o que trouxe mudanças nas tipologias, isto é, de casa para apartamento. Nos últimos quatro anos, tanto nessas RAs quanto nos municípios goianos da AMB próximos às BR-060 e BR-040 observase um acelerado processo de verticalização de empreendimentos habitacionais.

Ao cruzarmos essas novas áreas delimitadas no PDOT destinadas à habitação social com o enquadramento de renda das famílias a partir do volume de contratação do PMCMV e do Programa Morar Bem entre os anos de 2011-2014, nota-se que até o ano de 2014 foram contratadas 16.200 (dezesseis mil e duzentas) e previstas ou em fase de contratação 28.575 (vinte e oito mil, quinhentas e setenta e cinco) unidades habitacionais para o atendimento da faixa 1 através da modalidade Fundo de Arrendamento Residencial (FAR) ${ }^{27}$ sendo que a demanda das famílias enquadradas na faixa de renda 1 , no cadastro habitacional, equivale a $80 \%$ dos inscritos no cadastro.

A contratação de unidades habitacionais com financiamento do PMCMV no Distrito Federal iniciou-se apenas no ano de 2012 para o atendimento das famílias enquadradas na faixa 1 , com valor de $\mathrm{R} \$ 405.600 .000,00$.

\footnotetext{
${ }^{27}$ Unidades Habitacionais financiadas para famílias com rendimentos de até $\mathrm{R} \$ 1.600,00$ (faixa 1).
} 
O primeiro empreendimento contratado exclusivamente para o atendimento da faixa 1 foi o Paranoá Parque (RA Paranoá), com 6.240 (seis mil e duzentas e quarenta) unidades habitacionais na tipologia apartamento. De acordo com os dados mais recentes da Codhab, foram entregues 1.846 unidades habitacionais do empreendimento Paranoá Parque e a previsão é que sejam entregues 4.384 unidades até dezembro de 2015.De acordo com as estimativas da Codhab serão beneficiadas 19.968 pessoas..

\section{Figura 8 - Localização do Empreendimento Paranoá Parque - Faixa 1}

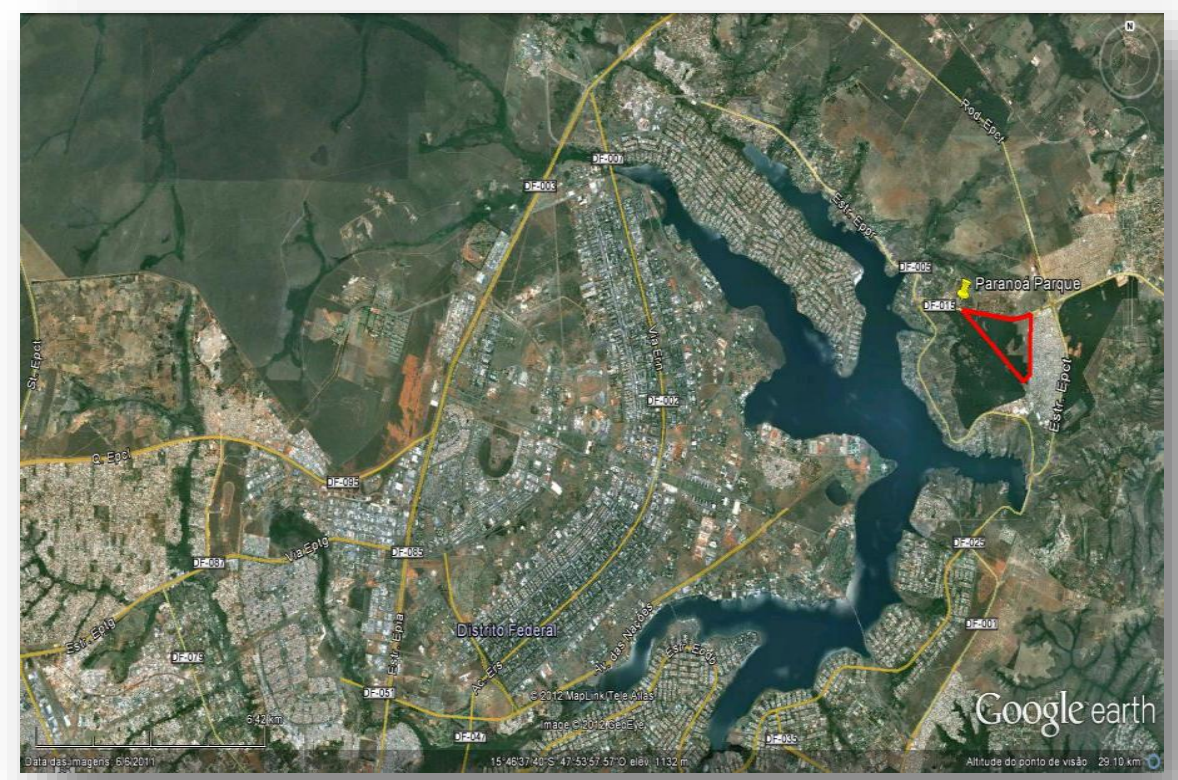

Fonte: SedHab (2014). 
Figura 9 - Localização da Área de Expansão do Empreendimento Paranoá Parque

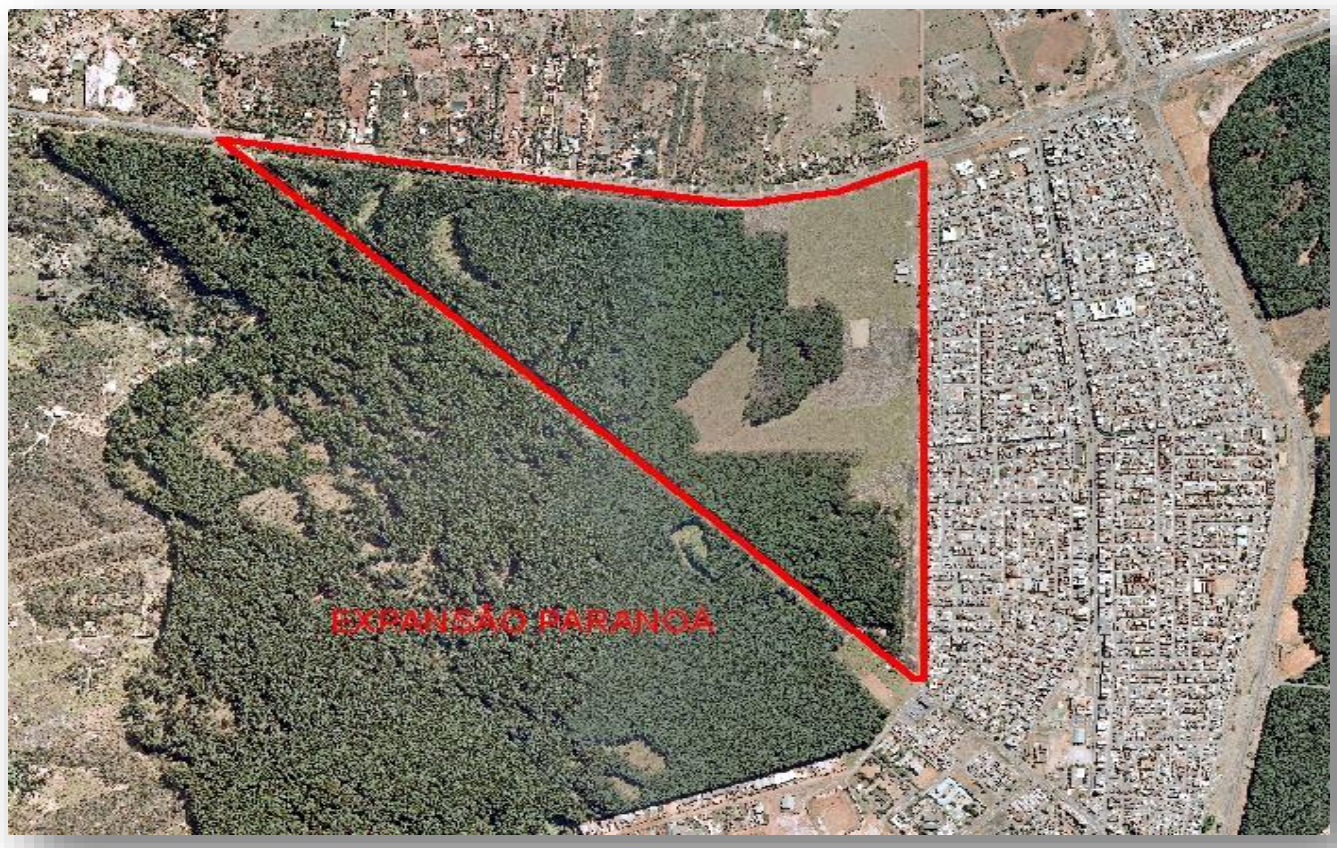

Fonte: SedHab (2014).

Figura 10 - Unidades Habitacionais entregues: Paranoá Parque

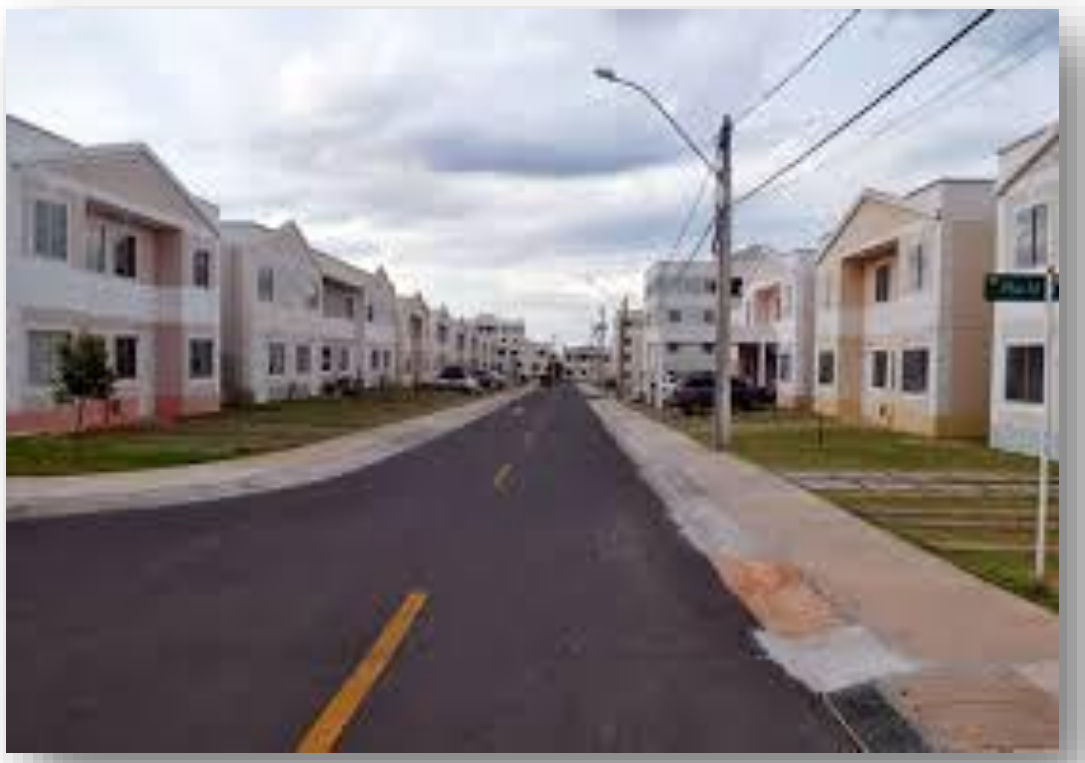

* o empreendimento Paranoá Parque está dividido em 390 blocos de quatro pavimentos, conforme consta no memorial descritivo do projeto.

Fonte: SedHab (2014). 
No ano de 2013 foram contratados mais dois projetos para o atendimento da faixa 1 na RA Itapoã, sendo eles Itapoã Parque Trecho 1, com 6.624 unidades (seis mil, e seiscentas e vinte e quatro) e o Itapoã Parque Trecho 2, com 3.312 (três mil e trezentas e doze) unidades. Em sua maioria esses empreendimentos seguem uma tipologia dividida em blocos e pavimentos. Até o ano de 2015, os dados oficiais de medições fornecidos em entrevista na Coddhabapontavam que menos de $15 \%$ das obras estavam executadas no Itapoã Parque.

\section{Figura 11 - Localização do Empreendimento Itapoã Parque}

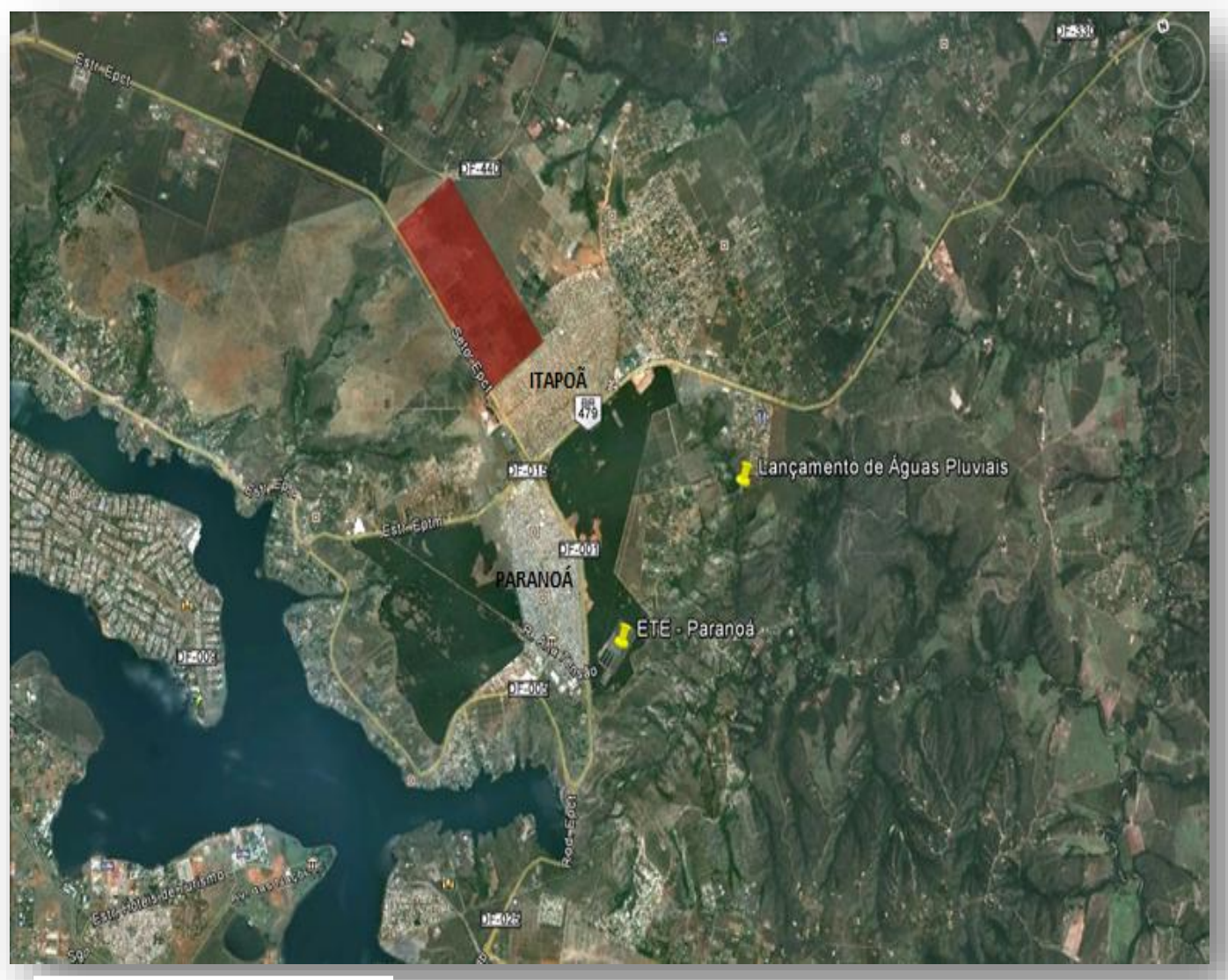

Fonte: SedHab (2014). 
Figura 12 - Projeto do Empreendimento do Itapoã Parque

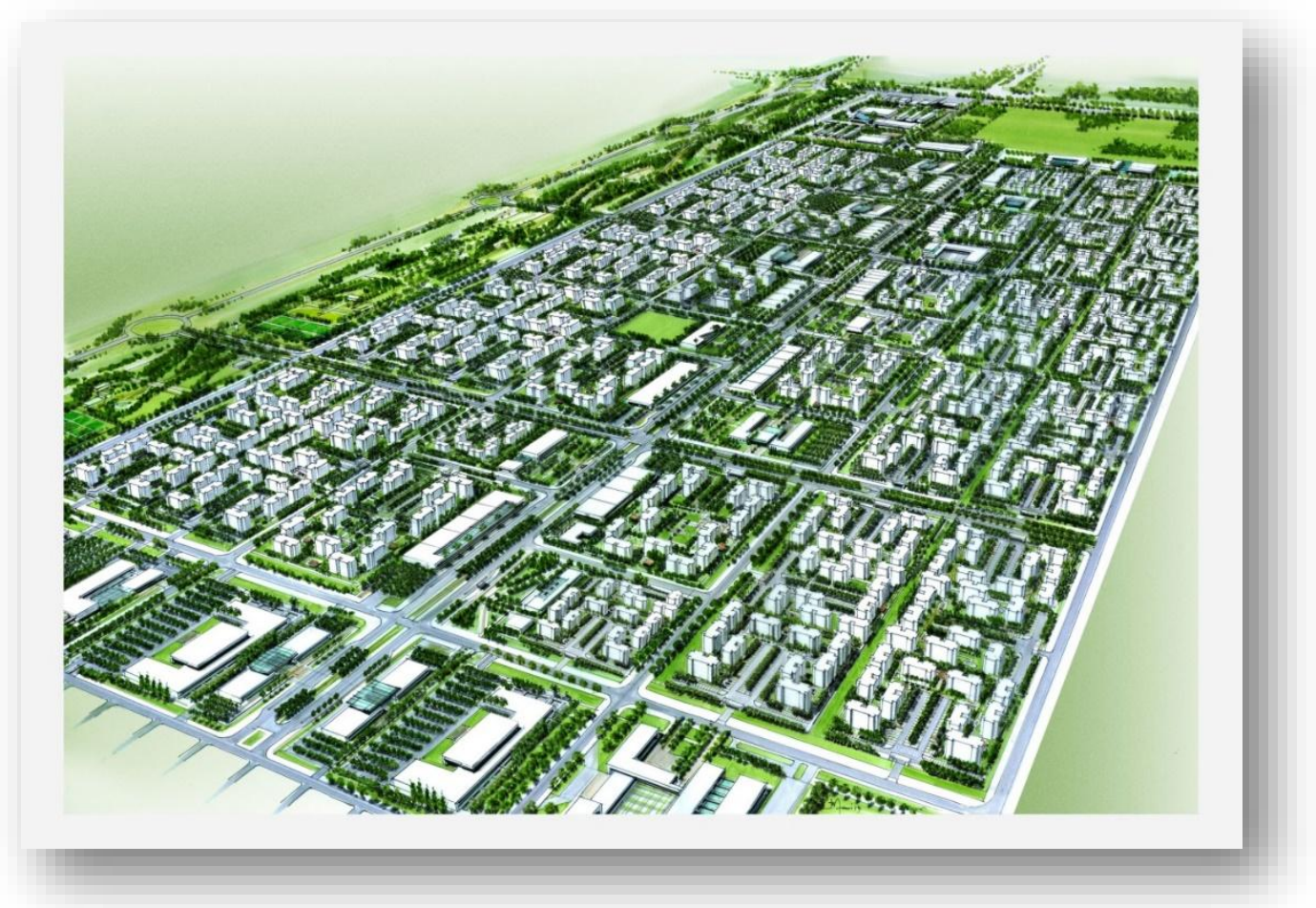

Fonte: SedHab (2014).

Na RA Riacho Fundo II, localiza-se o empreendimento Parque Riacho, dividido em cinco etapas. Para o atendimento da faixa de renda 1, em sua terceira etapa foram contratadas 1.800 (um mil e oitocentas) unidades para o atendimento das famílias com renda até $\mathrm{R} \$ 1.600,00$. Em sua quinta etapa, estão em construção 5.089 (cinco mil e oitenta e nove) unidades habitacionais, sendo que 4.071 (quatro mil e setenta e uma) unidades para o atendimento da faixa 1 e 1.018 (mil e dezoito) unidades para o atendimento da faixa 2. Sublinha-se que os valores das unidades habitacionais variam conforme a quantidade de dormitórios. Para os apartamentos de dois quartos, o valor máximo é de $\mathrm{R} \$ 75$ mil por unidade, e para os apartamentos com três quartos o valor máximo é de R \$ 85 mil por unidade. Esses valores, conforme resolução nacional do PMCMV, referem-se aos valores máximos das unidades habitacionais localizadas em Regiões Metropolitanas. 
Figura 13 - Localização do Empreendimento Parque do Riacho

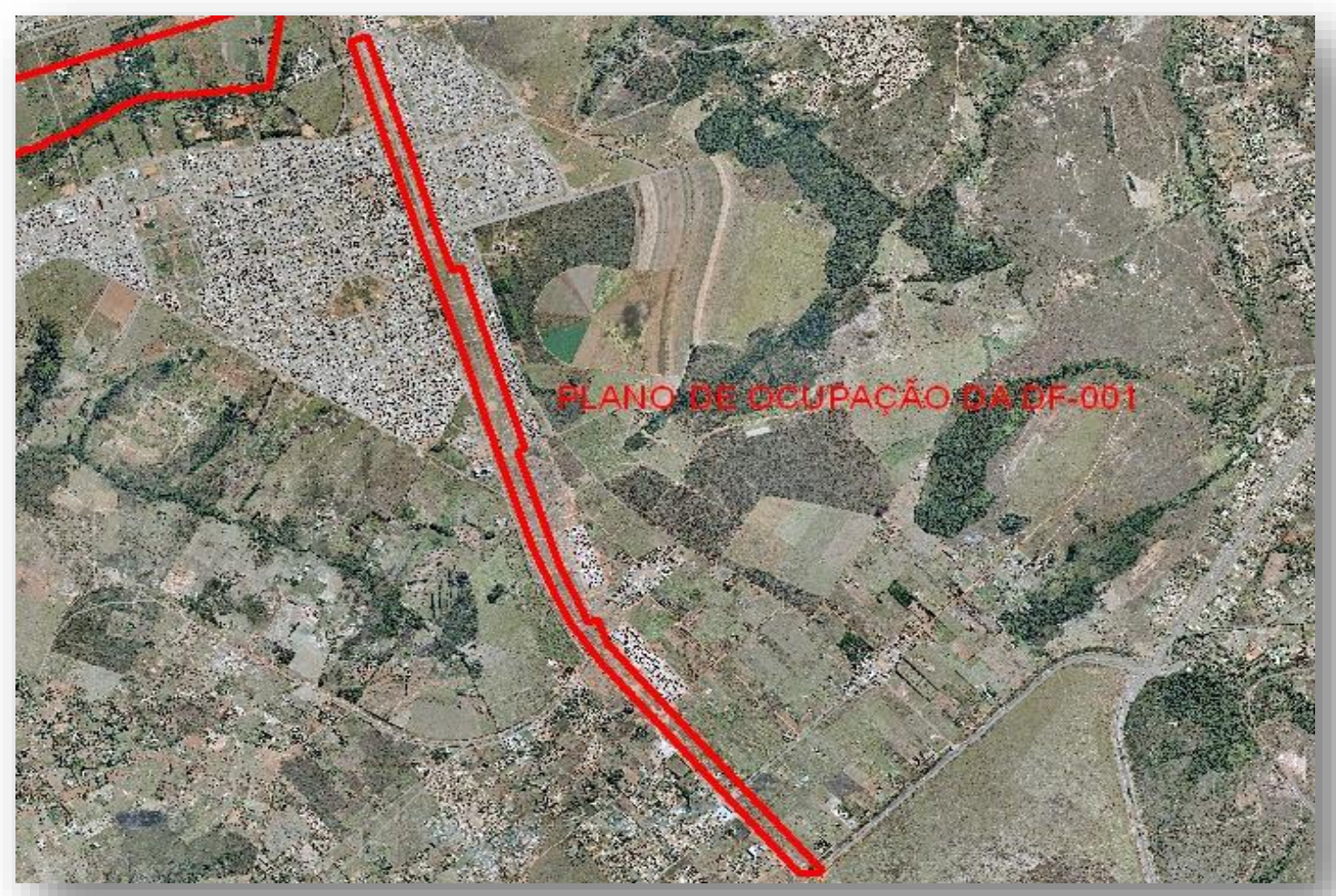

Fonte: SedHab (2014).

Figura 14 - Unidades Entregues Parque do Riacho

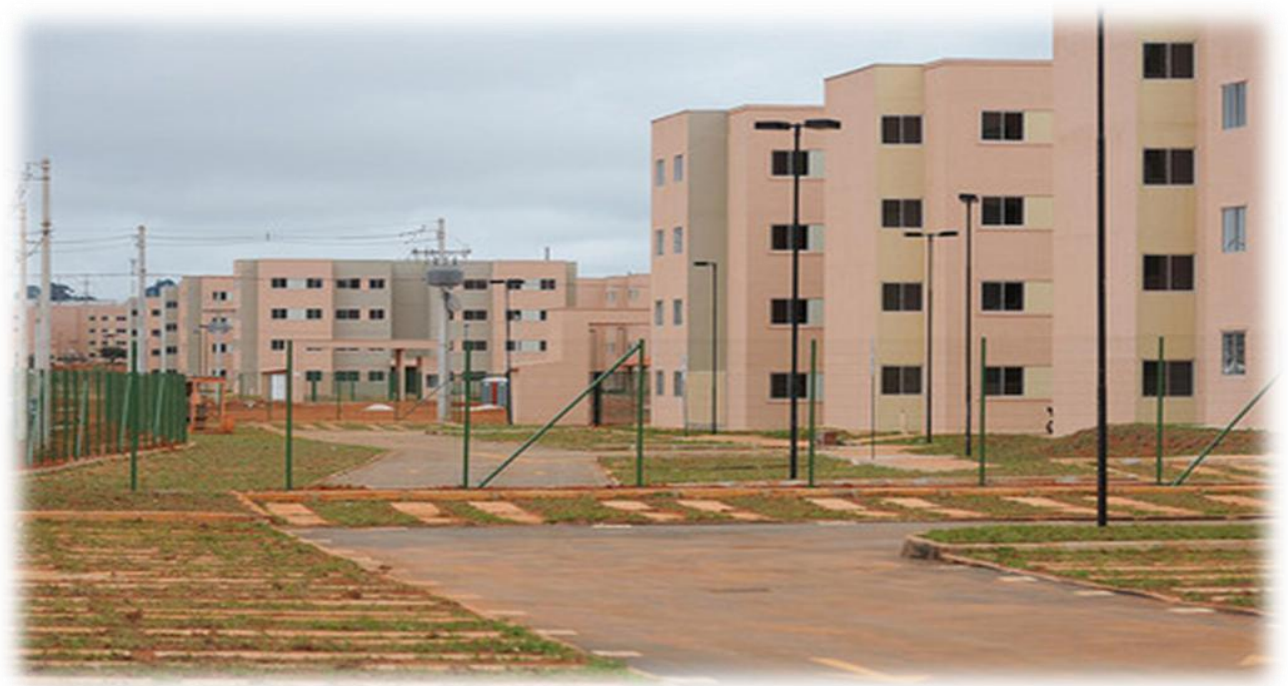

Fonte: GDF (2015). 
Os empreendimentos dos bairros Crixá e Nacional, ambos localizados na RA São Sebastião, encontravam-se, no ano de 2014, em fase de aprovação dos respectivos projetos urbanísticos. No Bairro Crixá serão construídas 2.960 (duas mil novecentas e sessenta) unidades habitacionais para as famílias enquadradas na faixa de renda 1 . No empreendimento Bairro Nacional, serão contratadas 3.872 (três mil oitocentas e setenta e duas) unidades habitacionais para a faixa de renda 1.

\section{Figura 15 - Empreendimento Bairro Crixá - RA-São Sebastião}

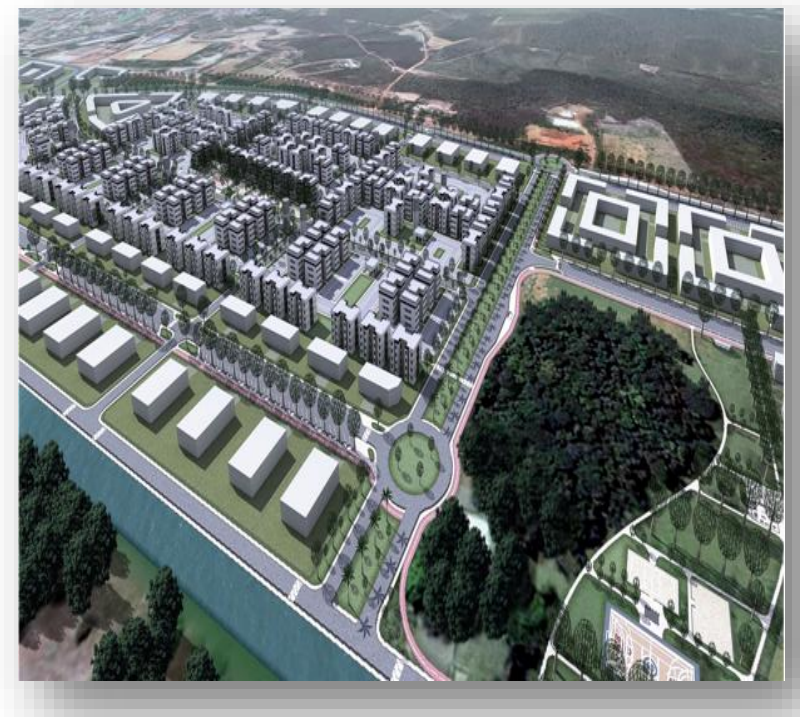

Figura 16 - Empreendimento Bairro Nacional - RA-São Sebastião

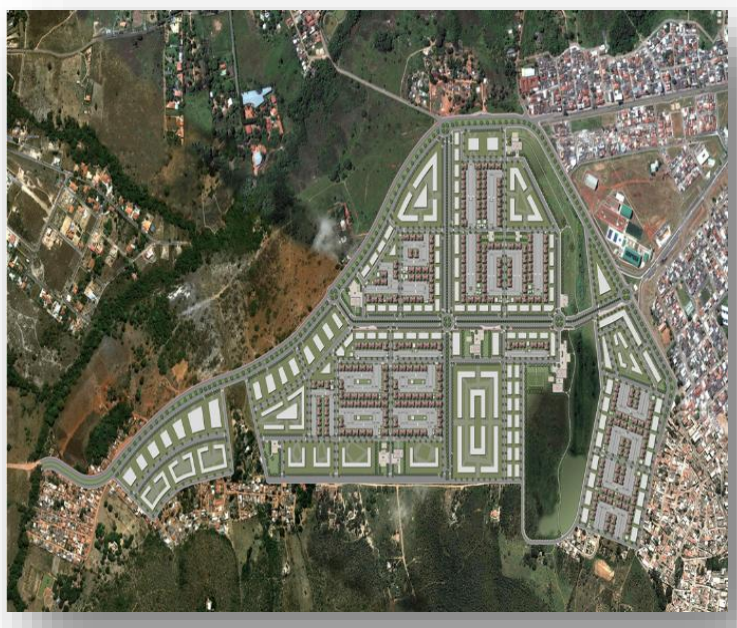

Fonte: SedHab (2014).

Outro empreendimento contratado para atender às famílias enquadradas na faixa 1 foi o Planaltina Parque, localizado na região do Mestre D’Armas na RA Planaltina, totalizando 4.608 (quatro mil seiscentas e oito) unidades habitacionais, sendo que 3.686 (três mil seiscentas e oitenta e seis) unidades destinadas às famílias de faixa renda 1 e as outras 400 (quatrocentas) unidades habitacionais para o atendimento das famílias enquadradas na faixa 2.

Segundo informações da SEDHAB, este empreendimento encontra-se na fase de aprovação do Estudo de Impacto Ambiental e Relatório de Impacto Ambiental - 
EIA/RIMA -, dependendo da autorização da EMBRAPA para que a equipe de topografia da TERRACAP realize o levantamento (SEDHAB, 2014).

Também, no ano de 2014, foram contratadas 1.736 (mil setecentas e trinta e seis) unidades habitacionais para as famílias com renda até $\mathrm{R} \$ 1.600,00$ (faixa 1) nas Quadras 117 e 118 da RA Recanto das Emas. A tipologia desse empreendimento é do tipo casa/loteamento.

A contratação do empreendimento Nova Colina, localizado na RA Sobradinho, prevê a construção de 2.500 (duas mil e quinhentas) unidades habitacionais, sendo que 2.000 (duas mil) unidades destinadas ao atendimento das famílias enquadradas na faixa renda 1 e as outras 500 (quinhentas) unidades para as famílias enquadradas na faixa de renda 2.

No ano de 2014, houve a contratação do Projeto de Expansão Urbana Setor Oeste (COER), localizado na Região Administrativa de Sobradinho, para a construção de 33 (trinta e três) unidades para o atendimento da faixa 1, modalidade casa/loteamento. Outras 286 (duzentas e oitenta e seis) unidades foram contratadas na RA Estrutural para o atendimento das famílias enquadradas na faixa 1.

$\mathrm{Na}$ sequência houve a aprovação preliminar do empreendimento Parque das Bênçãos (RA Recanto das Emas) com 20.128 (vinte mil cento e vinte e oito) unidades habitacionais para o atendimento da faixa 1 e 4.512 (quatro mil e quinhentas e doze) unidades habitacionais para o atendimento das faixas 2 e 3 .

Figura 17 - Localização do Empreendimento Parque das Bênçãos

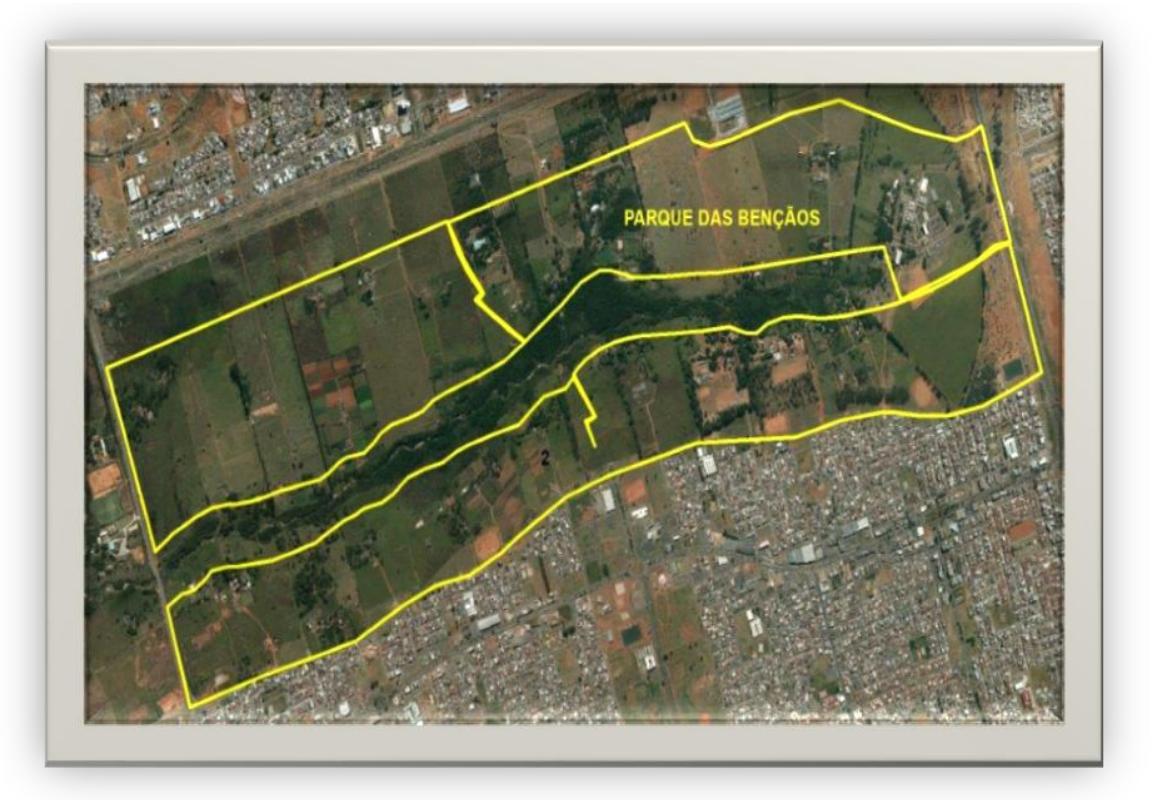

Fonte: SedHab (2014). 


\section{Figura 18 - Tipologia do Empreendimento Parque das Bênçãos Localizado na RA Recanto das Emas}

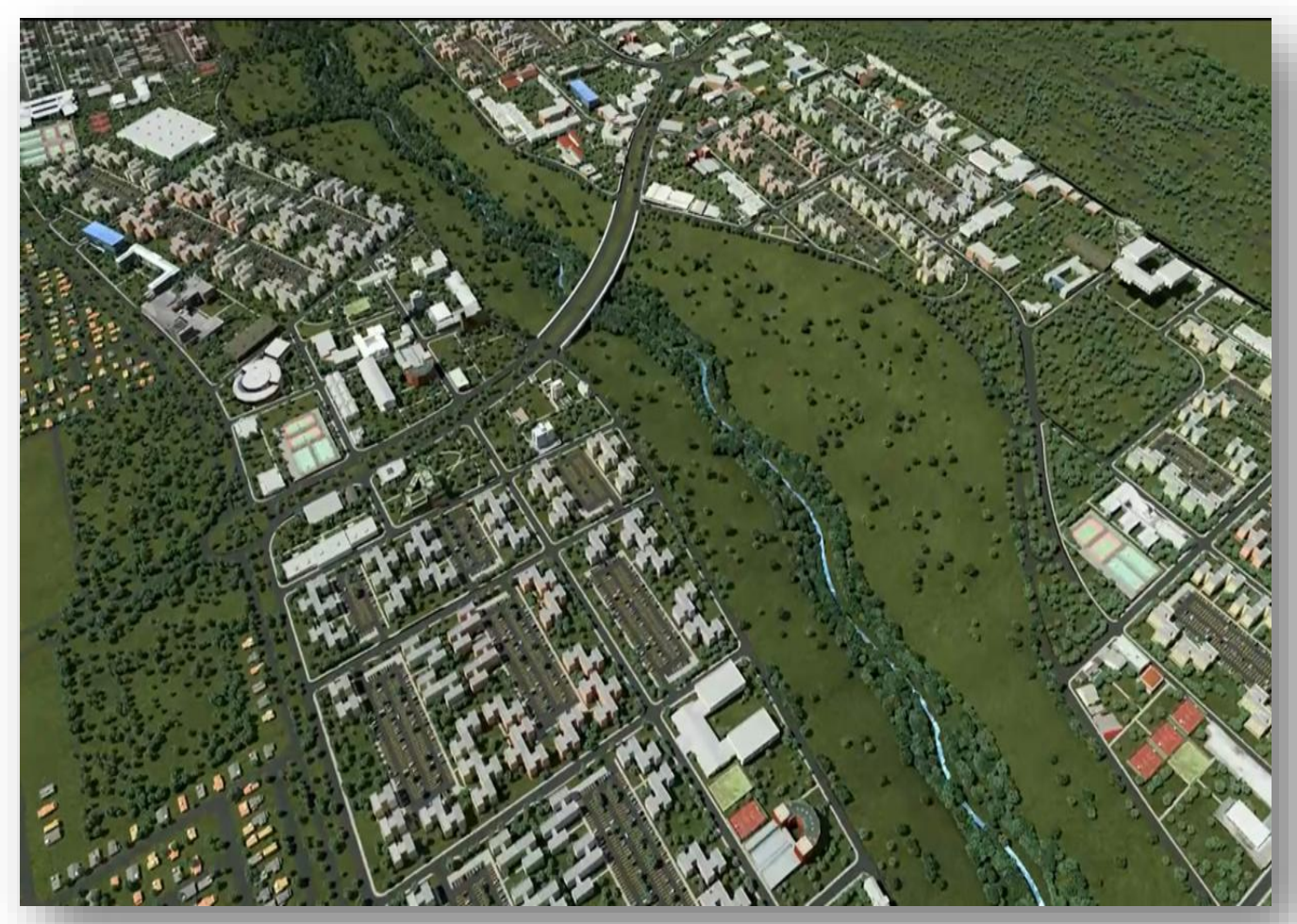

Fonte: SedHab (2014).

Registre-se que o empreendimento Parque das Bênçãos está localizado entre as RAs Samambaia e Recanto das Emas, em uma área de 700 hectares. Trata-se do maior empreendimento no Brasil em volume de unidades contratadas. ${ }^{28} \mathrm{O}$ Parque das Bênçãos está dividido em quatro etapas. Da área do parcelamento para a execução das etapas $1 \mathrm{e}$ 2, 50\% já foram aprovadas no cartório de imóveis. Já as etapas 3 e 4 ainda se encontram em fase de análise na Secretaria de Gestão de Território e Habitação (SEGETH). ${ }^{29}$

Registre-se que dos empreendimentos analisados em sua maioria a data para conclusão e entrega dos empreendimentos não foi fornecida pela instituição financeira, a Caixa Econômica Federal, sob a alegação de que o balanço do ciclo do Programa

\footnotetext{
${ }^{28} \mathrm{O}$ maior empreendimento habitacional para o atendimento da faixa 1 contratado pelo Programa Minha Casa Minha Vida (PMCMV), com a entrega das 5.384 unidades, era o Residencial Viver Melhor 2, localizado no município de Manaus, AM. O empreendimento recebeu investimento total de R\$ 313,39 milhões, com recursos do Fundo de Arrendamento Residencial (FAR).

${ }^{29}$ A partir da gestão de governador Rodrigo Rollemberg (2015), a Secretaria de Habitação e Regularização Fundiária (Sedhab) passa a se chamar Secretaria de Gestão de Território e Habitação (SEGETH).
} 
encontra-se em andamento e por esse motivo os dados necessitam ser conferidos antes de torná-los públicos. No entanto, estima-se, a partir da entrevista realizada na Codhab, que entre $50 \%$ e $75 \%$ dos empreendimentos do Paranoá Parque e do Projeto de Expansão Urbana na RA Sobradinho estejam com medições de obras em andamento.

No entanto, sabe-se que, por causa das contratações recentes e do ritmo de construção, o prazo para conclusão e entrega dos empreendimentos será de aproximadamente dois anos. Acrescentem-se os trâmites de contratação e construção dos empreendimentos, somados às etapas de medições para a liberação dos recursos dos empreendimentos enquadrados na faixa 1, que são diferentes dos trâmites dos empreendimentos para o atendimento das famílias com faixa de renda 2 e 3 .

Todos os empreendimentos habitacionais contratados pelo FAR, são firmados de contratos (Termo de Adesão), entre o poder público estadual, distrital ou municipal com a Caixa, a partir dos procedimentos legais cabe a Caixa receber as propostas de projetos, analisar, aprovar, contratar e acompanhar a execução das obras pela construtora. Posteriormente, a Caixa adquire os empreendimentos, uma vez adquiridos, cabe ao poder público a seleção e indicação dos beneficiários e cumprimento da provisão de infraestrutura. Portanto, a gestora do programa da modalidade FAR é a Caixa e caberia ao Distrito Federal o protagonismo em selecionar os projetos adequados a sua realidade. Na prática, as construtoras já apresentam aos governos municipais e distritais projetos padronizados, diminuindo sobremaneira o pontencial do poder público de interferir nos projetos. Na entrevista realizada na Codhab, observa-se que o governo local tem realizado sugestões nos projetos para melhorar a qualidade criando mecanismos de concorrentcia entre as construtoras, diferentemente da realidade e pouca capacidade técnica dos municípios goianos inclusos na AMB. 
Figura 19: Espacialização dos empreendimentos do PMCMV/FAR no DF

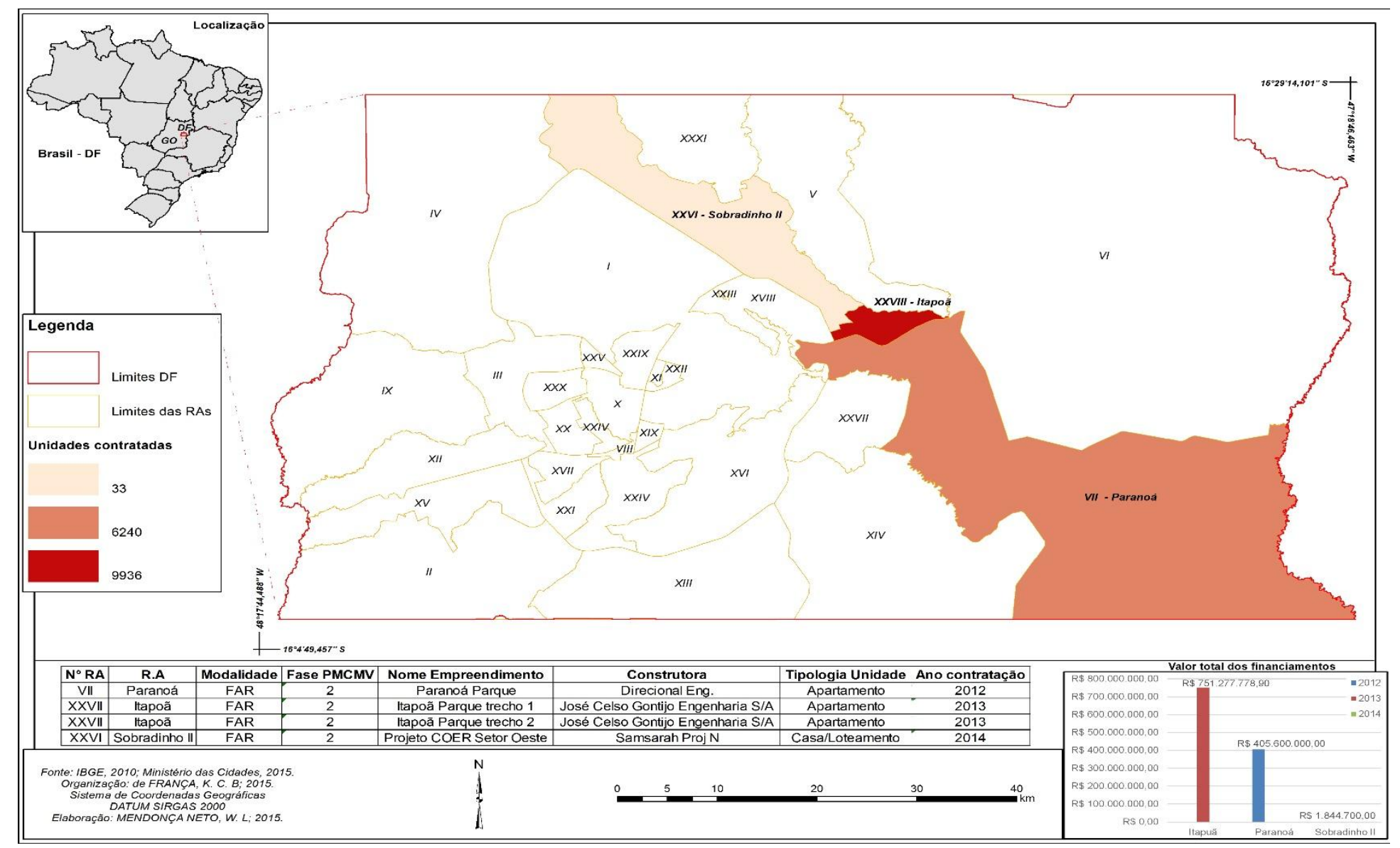


A espacialização do volume de empreendimento por faixa de renda permite concluir que as Regiões Administrativas com maior volume de contratação na faixa 1 foram o Itapoã, seguido do Paranoá. Totalizando os empreendimentos contratados nas duas RAs, chega-se ao valor aproximado de 16.200 unidades habitacionais produzidas com recursos do FAR, para atendimento das famílias de menor baixa renda vinculada à faixa 1 do Programa Morar Bem.

As contratações dos empreendimentos habitacionais com financiamento do FAR deveriam colocar o poder público como protagonista das ações, o que abarca desde a escolha do terreno, a indicação dos beneficiários e as contrapartidas firmadas nos contratos de sua responsabilidade. No entanto, dado o poder estratégico das poucas construtoras que operam na produção da Faixa 1, na prática é limitado o poder de protagonista do poder público para conseguir alterações nos projetos para atender as necessidades locais. Sabe-se que há dificuldades, dada a pouca capacidade institucional e de planejamento do poder local em delimitar áreas com boa localização para a contratação dos empreendimentos enquadrados na faixa 1.

No Distrito Federal essa dificuldade poderia ser reduzida, visto que a terra, em sua maioria, é pública e com forte regulação da Terracap. Entretanto, os fortes interesses imobiliários e a fragilidade na implementação de uma política habitacional de priorização de terras com boa localização para a contratação de empreendimentos que visem ao atendimento das famílias enquadradas na faixa 1 provocam um cenário de baixa contratação de empreendimentos para esta faixa de renda. Acrescente-se que os que se encontram em andamento apresentam problemas de inserção urbana e atrasos na construção das obras de esgotamento, água e luz. É o que ocorre, por exemplo, com parte do empreendimento do Paranoá Parque, que possui unidades concluídas, mas que não são entregues em função da ausência de conclusão de obras de saneamento básico, esgotamento, luz e dos equipamentos comunitários.

Também vale destacar que nas visitas a campo realizadas no empreendimento Paranoá Parque, foi possível notar o número reduzido de linhas e horários de ônibus para atender à nova população residente, além de reclamações acerca da baixa capacidade da rede de energia elétrica, no período noturno acarretando pequenas interrupções semanalmente e também qualidade da água para consumo. Nesse quesito houve inúmeros relatos da possível contaminação da água, problemas de saúde advindos da qualidade da água. Já em relação, a presença de comércio e escolas, observa-se que nas áreas próximas do empreendimento, há a presença de comércio variado. 
Ainda assim o Distrito Federal destaca-se no cenário nacional no que tange às contratações de empreendimentos para a faixa 1 em relação a sua capacidade de tornar os empreendimentos atrativos e promover a competividade entre as empresas interessadas. O Governo do Distrito Federal tem inovado nos editais de chamamento público para as empresas, estabelecendo contratações mistas nos empreendimentos e critérios mínimos para o atendimento dos empreendimentos conforme as normativas federais. No entanto, o GDF estimula a competitividade das construtoras, ao adicionar pontuações extras para as empresas que apresentarem projetos superiores aos critérios mínimos. Isso se deve ao fato de o governo ter estabelecido contrapartidas de mercado para oferecer uma melhoria na execução dos empreendimentos. Atualmente, as principais construtoras que estão operando empreendimentos na faixa 1 no DF são a Direcional Engenharia e a Gontijo Engenharia, nos empreendimentos com contratação de unidades superior a três mil, já a construtora COER e a construtora Samsaram Pro operam os empreendimentos com volume menor de contratações.

Os empreendimentos contratados para atender às famílias enquadradas nas faixas de renda 2 e 3 são fortemente influenciados pelas construtoras. É dela o papel de protagonista. No caso do poder público local, seu papel se reduz a agente de fiscalização, no que diz respeito ao atendimento das normas de uso e ocupação do solo, bem como nas aprovações dos projetos por meio da emissão dos alvarás e, posteriormente, para a emissão do habite-se.

Para Royer (2013), a diferença de operacionalização do desenho e participação do poder público provoca enormes dificuldades para que o poder público local exerça uma gestão habitacional efetiva, uma vez que em sua maioria os governos locais têm dificuldades prementes para induzir ações que assegurem o atendimento da coletividade, além de praticamente se ausentar na busca de soluções para gerenciar os conflitos entre atores, intervir na escolha dos instrumentos adequados e mediar interesses divergentes que envolvem a disputa pelos melhores terrenos. Assim, o empreendedor privado acaba tendo um papel mais destacado do que deveria, ao assumir parte das funções técnicas que caberiam ao poder local ou influenciar o papel do poder público.

Resultado disso é a elevação do preço da terra urbana, como pode ser notado nas regiões administrativas, em função dos interesses imobiliários em promover a construção de empreendimentos habitacionais destinados para a classe média. Em tais casos, fatores como o adensamento urbano, acesso ainda que precário ao transporte público e infraestrutura já existente têm transformado a paisagem dessas RAs em verdadeiros 
canteiros de obras, para estimular o sonho do imóvel próprio acessível para a classe média.

Como justificativa para a liberação dos empreendimentos pelo GDF, o governo tem defendido a ideia de que, ao permitir o adensamento, há uma indução de oportunidades para a geração de novos negócios para as RAs localizadas na porção sudoeste do DF, o que gera uma melhor otimização dos investimentos públicos. Conforme exposto na entrevista do então diretor técnico da Terracap, Luiz Antônio Reis, "nos locais populosos, temos mais disponibilidade de infraestrutura, de água e de ligação com o metrô. Há ainda importantes vazios que podem ser ocupados". ${ }^{30}$

Essas ações têm acentuado uma produção mercadológica de habitação, o que dificulta a provisão de moradias para a população de baixa renda em terrenos com boa localização e tem se tornado uma das maiores dificuldades nessa área. Ao mesmo tempo esses investimentos produzem novas configurações urbano-metropolitanas, produzindo cada vez mais uma paisagem verticalizada, com graves problemas de infraestrutura urbana, o que amplia a escala dos problemas.

Também se nota a criação de novos setores ou verdadeiras cidades, como é o caso do empreendimento Parque das Bênçãos, maior empreendimento brasileiro em volume de unidades habitacionais em fase de contratação. A priorização de novos setores ou novas áreas para os empreendimentos voltados para a faixa 1 distante das áreas consolidadas demonstra a fragilidade em otimizar infraestrutura instalada, induz a expansão urbana e contribui para o aumento dos custos de instalação de infraestrutura e de serviços para a população de baixa renda, localizada em áreas distantes do seu local de trabalho, ampliando as dificuldades e desafios da mobilidade urbana.

\subsubsection{O papel protagonista do setor privado na produção de moradias: o Programa Morar Bem}

O ritmo de contratação e a localização dos empreendimentos habitacionais enquadrados na faixa 1 para o atendimento às famílias de baixa renda evidenciam as dificuldades do GDF em articular os investimentos habitacionais com as diretrizes de planejamento e gestão habitacional, considerando a implementação dos instrumentos urbanísticos para a promoção de subsídios, a localização dos empreendimentos em áreas

\footnotetext{
${ }^{30}$ Trecho da entrevista concedida ao jornal Correio Braziliense publicado na data de 19 de dezembro de 2012, em sua versão on-line. Disponível em: <http://unb.br/noticias/unbagencia/cpmod.php?id=93372>.
} 
com boa inserção urbana. Isso evitaria uma demanda de serviços urbanos nem sempre computada nos orçamentos, bem como a instalação desses novos empreendimentos gerados no conjunto urbano-metropolitano, o que reduziria os graves problemas de mobilidade, emprego e lazer, em virtude do atraso ou da ausência na implementação dos equipamentos públicos e serviços urbanos.

As contratações de unidades habitacionais com financiamento do FGTS para o atendimento das famílias enquadradas na faixa 2, 3 e 4 (SBPE) têm se mostrado lucrativas para o mercado privado e também para o governo distrital. Na segunda etapa do programa até o final de 2014, foram contratados 101 empreendimentos para o atendimento das famílias enquadradas na faixa 2 com origem de pessoa jurídica, o que equivale à contratação de 18.609 unidades habitacionais, totalizando um valor de contratação na ordem de $\mathrm{R} \$$ 1.026.933.693,96. Já as contratações com origem de pessoa física para a faixa 2 somam 3.734 unidades habitacionais, correspondendo ao valor de R\$ $399.550 .616,62$.

Para o atendimento da faixa 3 foram realizados dezenove contratos com operação jurídica, totalizando 2.465 unidades com investimento de $\mathrm{R} \$ 189.022 .405,12$. Já as contratações com origem de pessoa física somaram 93 operações, com a construção de 1.438 unidades, totalizando um investimento de $\mathrm{R} \$ 144.891 .748 .66$. A soma dos investimentos contratados para o atendimento das faixas 2 e 3 no DF somente na fase 2 é bem superior aos investimentos contratados para o atendimento da faixa 1 .

Ressalte-se que apenas o Distrito Federal operacionaliza quatro faixas de renda. A faixa 4 visa ao atendimento das famílias com rendimentos entre $R$ \$ 5.001,00 e R\$ 9.456,00. Para operacionalizar o Programa Morar Bem e atender às famílias enquadradas na faixa $4,{ }^{31}$ o GDF estabelece parcerias com o setor privado, em especial através da concessão de terrenos com boa localização para a execução dos empreendimentos para o atendimento desta faixa de renda.

A concessão do terreno pelo governo distrital é um tipo de subsídio, pois gera uma redução do valor da construção dos empreendimentos, uma vez que os custos de aquisição do terreno não são computados. Dessa forma, existe uma redução no valor das prestações para o mutuário final, em comparação com os empreendimentos executados

\footnotetext{
${ }^{31}$ O GDF não oferece nenhum subsídio financeiro, por se tratar de faixa não prevista para receber subsídios federais do Programa Minha Casa, Minha Vida, em função dos elevados valores. Em linhas gerais, os investimentos para o atendimento desta faixa de renda advêm do Sistema Brasileiro de Poupança e Empréstimo (SBPE), operacionalizado pelo mercado privado.
} 
com financiamento do SBPE, em que o terreno é adquirido pelo processo de compra pelo setor privado.

Em nenhuma base de dados ou relatórios da CodHab e Sedhab consta o volume de contratações já realizadas ou em andamento para o atendimento da faixa 4. Até a elaboração desta pesquisa, constava apenas o empreendimento Jardins Mangueiral, com unidades habitacionais concluídas e entregues para as famílias enquadradas na faixa 4, porém sem ser informado pelos respectivos órgãos o volume de unidades ${ }^{32}$.

Dentre os vários empreendimentos habitacionais para o atendimento das faixas 2, 3 e 4, o mais valorizado, em decorrência da sua localização e pelo fato de atender prioritariamente às faixas 2, 3 e 4, é o setor Jardins Mangueiral. Este empreendimento foi fruto da primeira Parceria Público-Privada (PPP) habitacional do país, realizada pelo GDF.

A PPP é uma concessão administrativa. O terreno foi cedido pelo GDF, por meio de Concessão de Direito Real de Uso Resolúvel, ao Consórcio Jardins Mangueiral. Esse Consórcio foi vencedor da licitação de $\mathrm{R} \$ 1.076$ bilhões, com valores de contraprestações de consórcio de $\mathrm{R} \$ 8.933$ milhões mensais, pelo prazo inicial de quinze anos, posteriormente reduzido para cinco anos, por termo aditivo em análise no TCDF (GDF, 2014).

Além da construção das unidades habitacionais, o consórcio é responsável pela manutenção das vias públicas e áreas verdes, mediante contraprestação ao DF, pelo prazo de cinco anos. Todos os beneficiários estão sendo indicados pelo GDF, após análise e validação dos candidatos segundo as regras da política habitacional local (MANGUEIRAL, 2014).

A tipologia das unidades compreende casa de dois quartos $\left(53,4 \mathrm{~m}^{2}\right)$ e de três quartos $\left(68 \mathrm{~m}^{2}\right)$, além de apartamentos com dois dormitórios $\left(46,4 \mathrm{~m}^{2}\right)$, ocupando uma área de 200 hectares, onde estão sendo construídas oito mil unidades habitacionais, distribuídas por quinze quadras (MANGUEIRAL, 2014).

Este empreendimento localiza-se na RA São Sebastião, com contratação inicial de 8.000 (oito mil) unidades habitacionais ofertadas às famílias de faixas salariais 2 e 3 e 4. Para a faixa 2 foram contratadas 1.600 (mil e seiscentas) unidades e para a faixa 3 e 4 foram contratadas 6.4000 (seis mil e quatrocentas) unidades. 32 Sublinha-se que as principais construtoras responsáveis pelas obras habitacionais que visam ao
atendimento das faixas 2 e 3 são Gontijo, Apex, Carvalho Accioly e Ipê. 
Figura 20 - Empreendimento Jardins Mangueiral

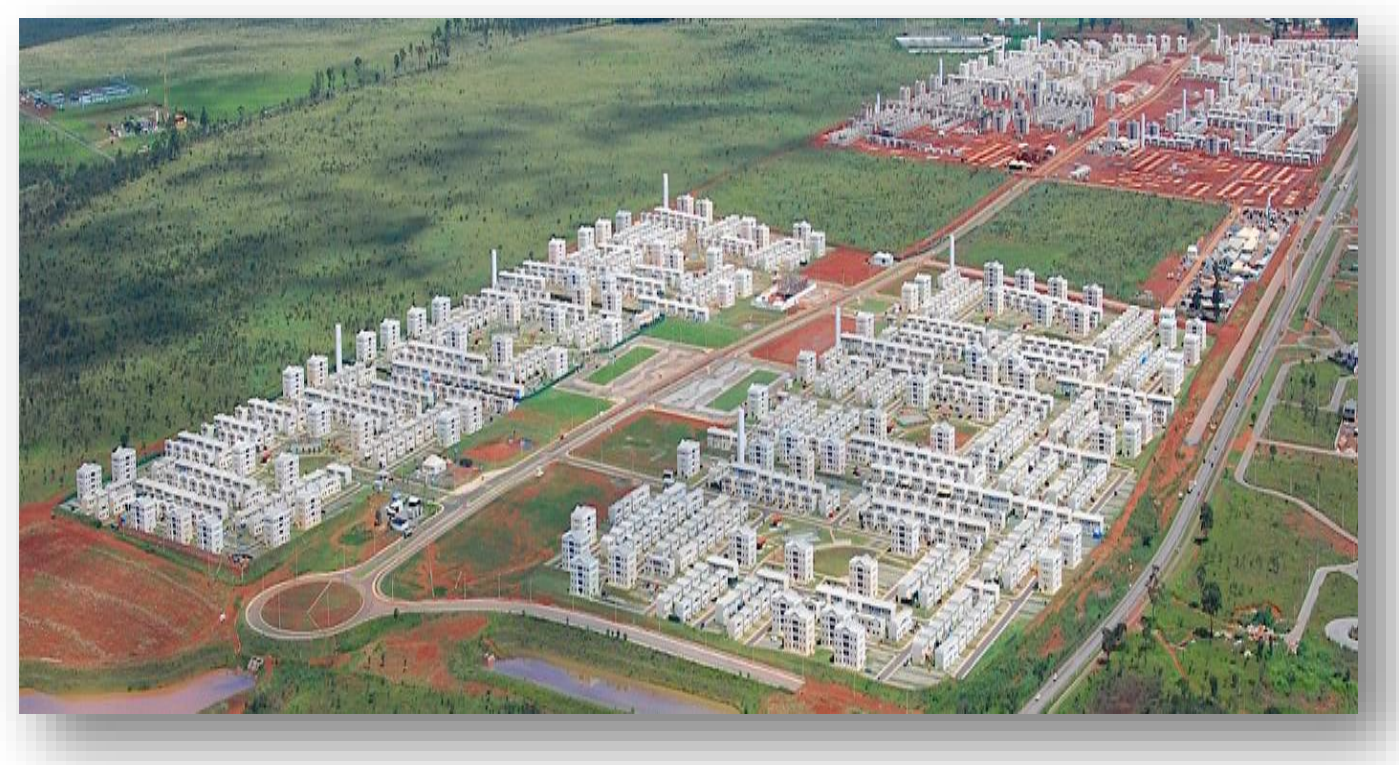

Fonte: SedHab (2014).

Figura 21 - Andamento das obras do Jardins Mangueiral

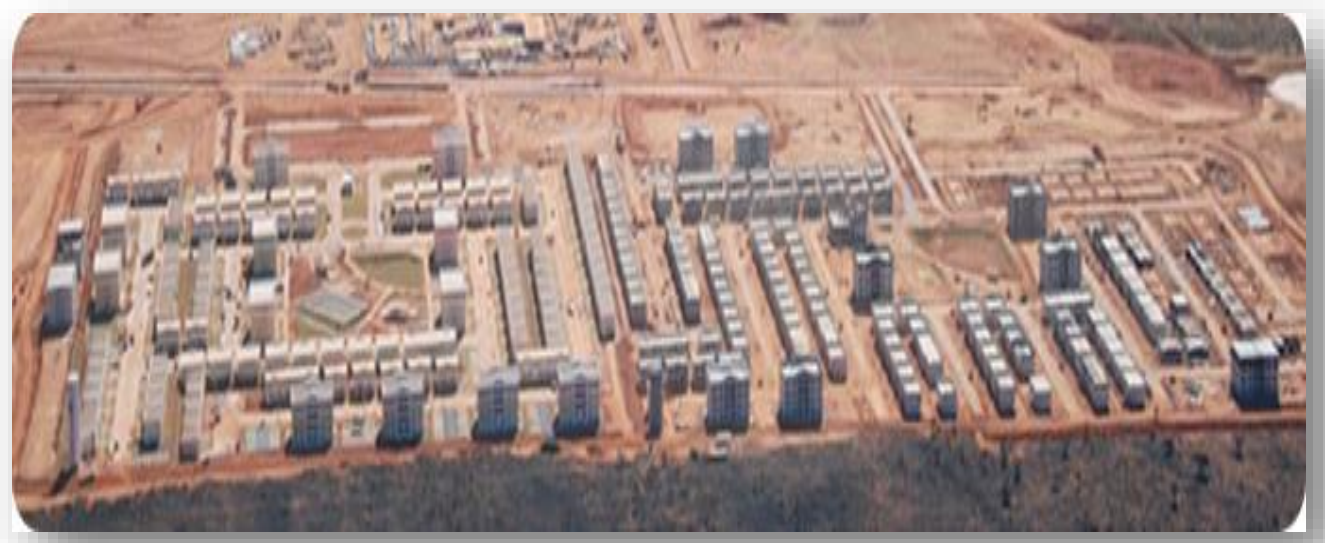

Posteriormente, a Sedhab encomendou estudos técnicos para a expansão do setor Jardins Mangueiral. A partir de um aditivo houve a contratação de mais 1.502 (mil quinhentas e duas) unidades. Para a faixa 2 foram ofertadas 300 (trezentas) unidades e para as faixas 3 e 4 a contratação de 1.202 (mil duzentas e duas) unidades. Este é um dos 
principais investimentos em que foi priorizado em $80 \%$ o volume de unidades para o atendimento das faixas 3 e 4 .

\section{Figura 22 - Expansão do Jardins Mangueiral}

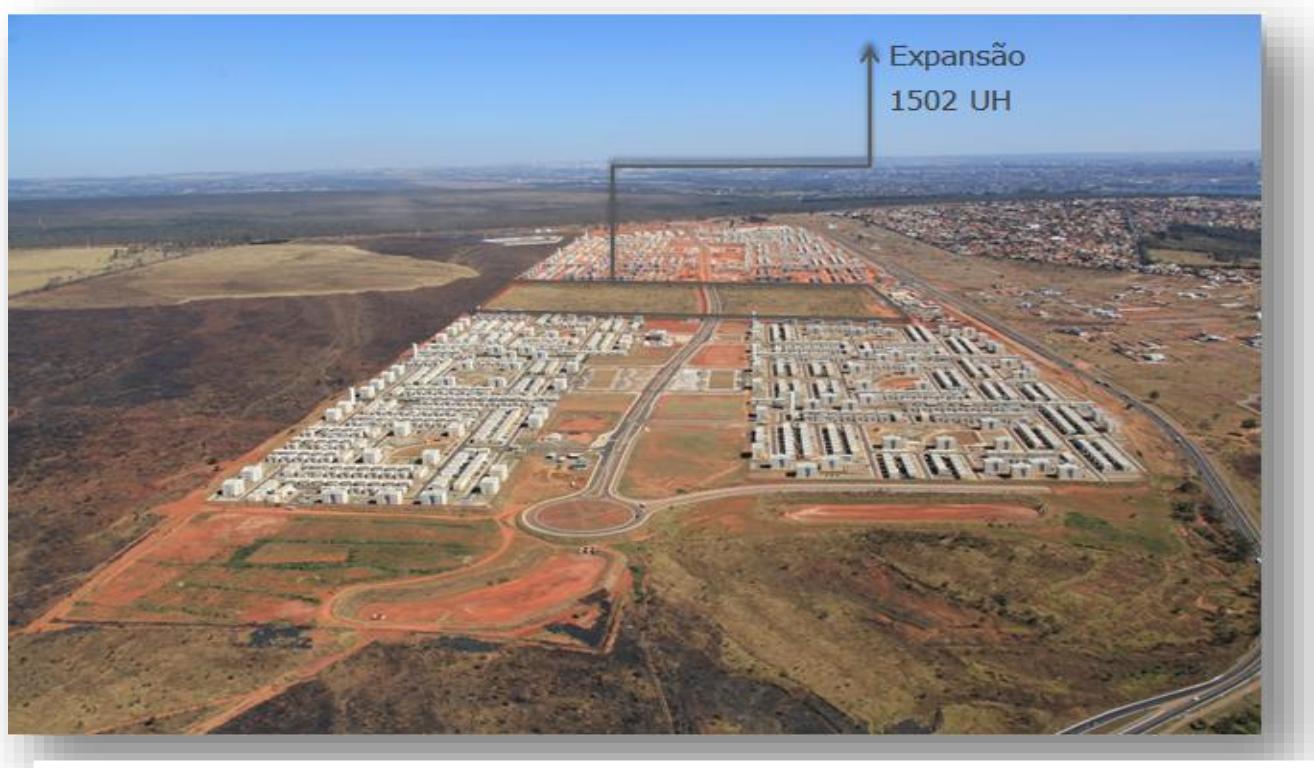

*Localizado dentro do Empreendimento Jardins Mangueiral na Região Administrativa de São Sebastião.

Fonte: SedHab (2014).

No entanto, conforme o zoneamento do PDOT-2009, revisado no ano de 2012, o sítio do empreendimento situa-se na Macrozona Urbana do Distrito Federal, mais especificamente na Zona Urbana de Uso Controlado II, composta por áreas predominantemente habitacionais de baixa e média densidade demográfica, com enclaves de alta densidade, sujeita a restrições impostas pela sua sensibilidade ambiental e pela proteção dos mananciais destinados ao abastecimento de água. Classifica-se também no grupo das “Áreas Especiais de Interesse Social”, correspondendo a Zonas Especiais de Interesse Social - ZEIS (MANGUEIRAL, 2014).

Com isso, afirma-se que parte das áreas destinadas no PDOT, bem como no PlandHis para a provisão de moradias de interesse social, quando não delimitados os instrumentos e mecanismos para a definição de faixa de renda, estas áreas com boa localização e valorização em sua maioria são destinadas para os empreendimentos destinados para o atendimento prioritário da faixa 3.

Outro investimento contratado para a construção de 5.904 (cinco mil novecentas e quatro) unidades habitacionais ofertadas às famílias enquadradas nas faixas de renda 2 
e 3 foi o Residencial Parque do Riacho, localizado entre a DF-001 e o Riacho Fundo II, próximo à antiga faixa de domínio do Metrô. Neste empreendimento, foram contratadas 4.723 (quatro mil setecentas e vinte e três) unidades para o atendimento da faixa 2 e 1.181 (mil cento e oitenta e uma) unidades para o atendimento da faixa 3. Segundo dados passados pela instituição financeira Caixa Econômica Federal, até o mês de dezembro de 2014, foram entregues 1.440 (mil quatrocentas e quarenta) unidades, sem discriminar o enquadramento das faixas de renda. Outras 432 (quatrocentas e trinta e duas) aguardam a provisão de infraestrutura básica para a liberação do habite-se, 704 (setecentas e quatro) unidades encontram-se em fase de acabamento e 2.016 estão prontas, porém não foram entregues, em função da falta de recursos para a instalação de esgoto, água e luz e equipamentos públicos, e ainda há previsão de construção de 1.312 unidades habitacionais.

\section{Figura 23 - Unidades Habitacionais do Parque do Riacho}

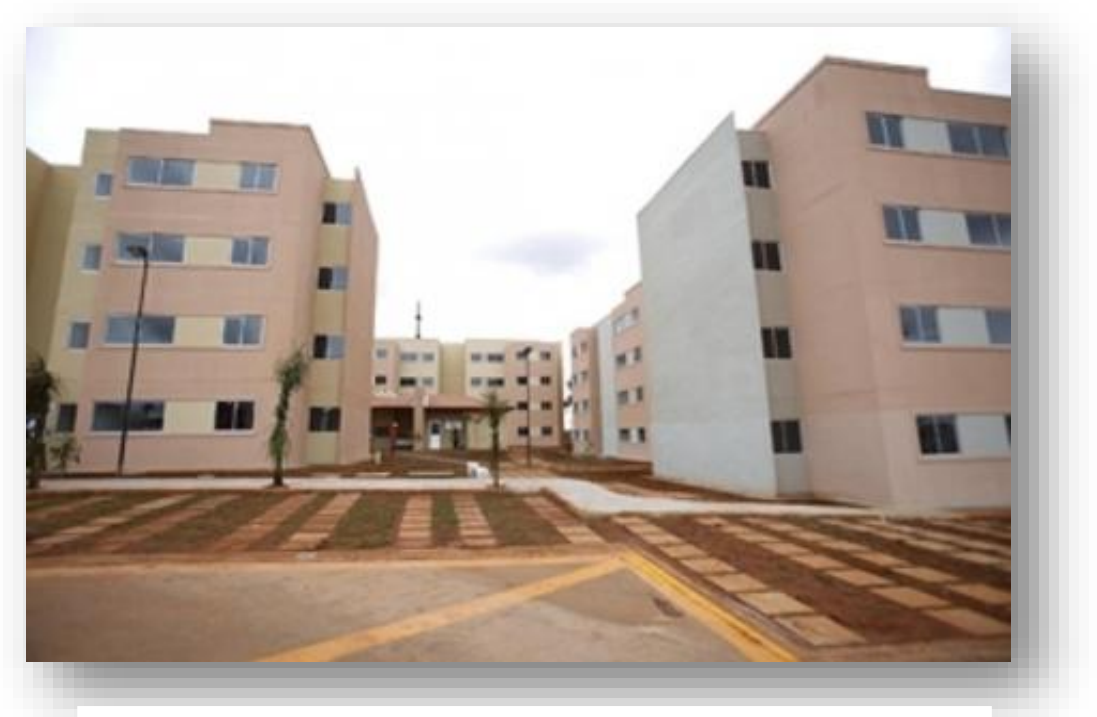

As Unidades Habitacionais compõem os Condomínios 15 e 16. Fonte: SedHab (2014)

Já o empreendimento habitacional Planaltina Parque priorizou o atendimento da faixa 1. Este empreendimento está localizado na RA Planaltina, com previsão de construção de 4.608 unidades, com a finalidade de atender às famílias enquadradas nas faixas de renda 1 e 2 . O volume prioritário de atendimento de $80 \%$ dessas unidades é para as famílias enquadradas na faixa 1 e os outros $20 \%$, isto é, 921 (novecentas e vinte e uma) unidades, para o atendimento da faixa 2. 


\section{Figura 24 - Empreendimento Planaltina Parque}

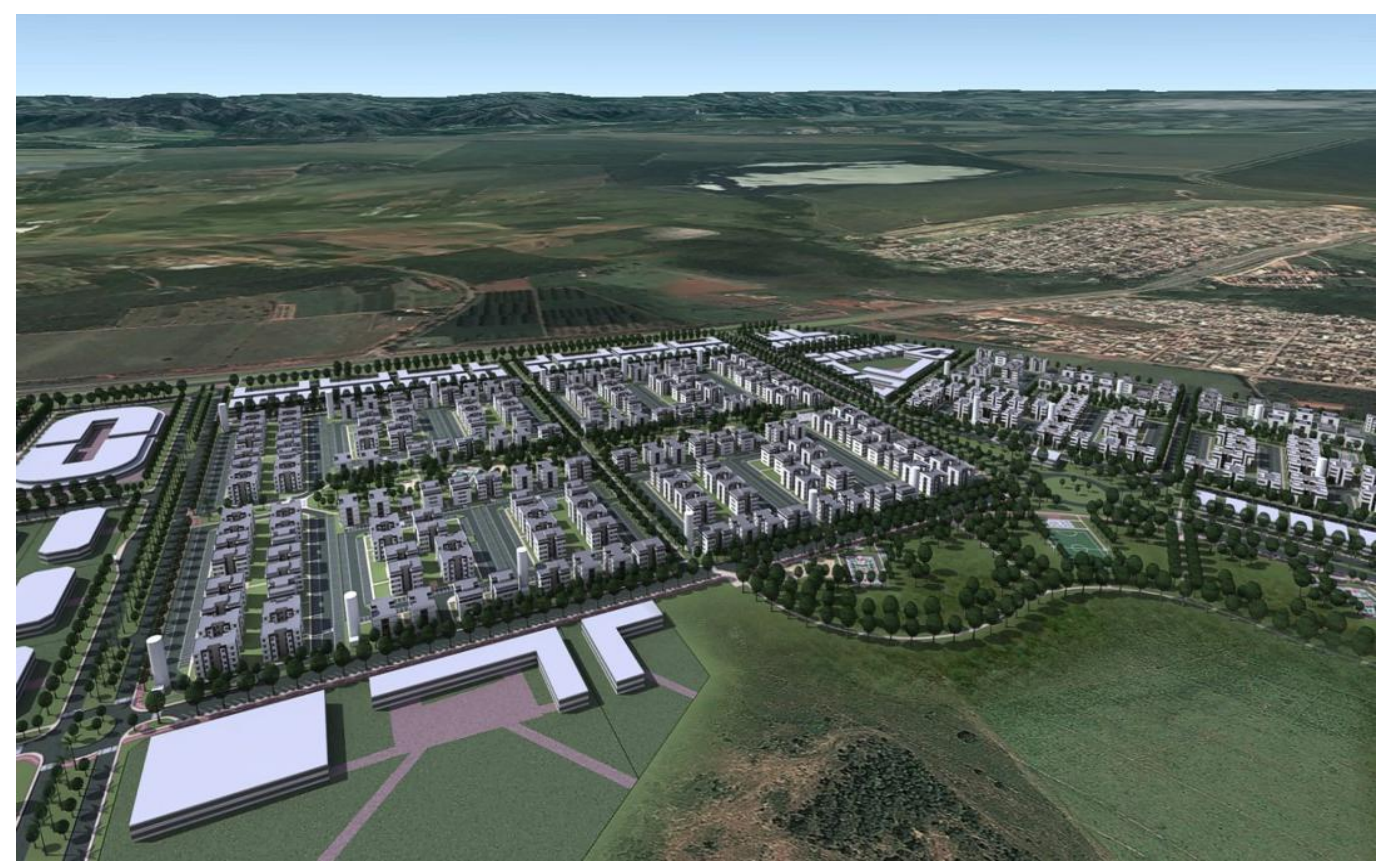

Localizado na região do Mestre D’Armas em Planaltina.

Fonte: SedHab (2014).

Também foi aberto chamamento público para a segunda etapa do empreendimento Planaltina Parque, com previsão de contratação de 4.320 (quatro mil trezentas e vinte) unidades para o atendimento das faixas 1 e 2. No entanto, de acordo com a CodHab, está previsto o relançamento desse empreendimento, uma vez que não houve empresas interessadas na execução das obras do empreendimento, dada a baixa margem de lucro.

Conclui-se que os empreendimentos que apresentam volume maior de contratação pelas construtoras operando no atendimento das faixas 1 e 2 priorizam o maior volume de unidades habitacionais destinados para o atendimento da faixa 2. Quando o volume prioritário é o atendimento da faixa 1 , há dificuldades de contratação, uma vez que na carta de projetos das grandes construtoras são priorizados os empreendimentos para o atendimento das faixas 2 e 3 . Notam-se, também, dificuldades de contratação de empresas para o atendimento das faixas 2 e 3 , quando o volume de construção de unidades habitacionais apresenta-se com um quantitativo reduzido.

Outro empreendimento que se encontra em situação de relançamento é o Varjão do Torto, localizado na RA Varjão, com previsão de contratação de 144 (cento e quarenta e quatro) unidades para o atendimento da faixa 2. De acordo com os dados fornecidos pela CodHab, estima-se que, além das unidades habitacionais a serem relançadas em 
Planaltina e no Varjão, existam aproximadamente outras 4.008 quatro mil e oito) unidades em regiões de Planaltina, Varjão, Riacho Fundo. 
Figura 25 - Espacialização do Programa Morar Bem por Faixas de Renda 2 e 3

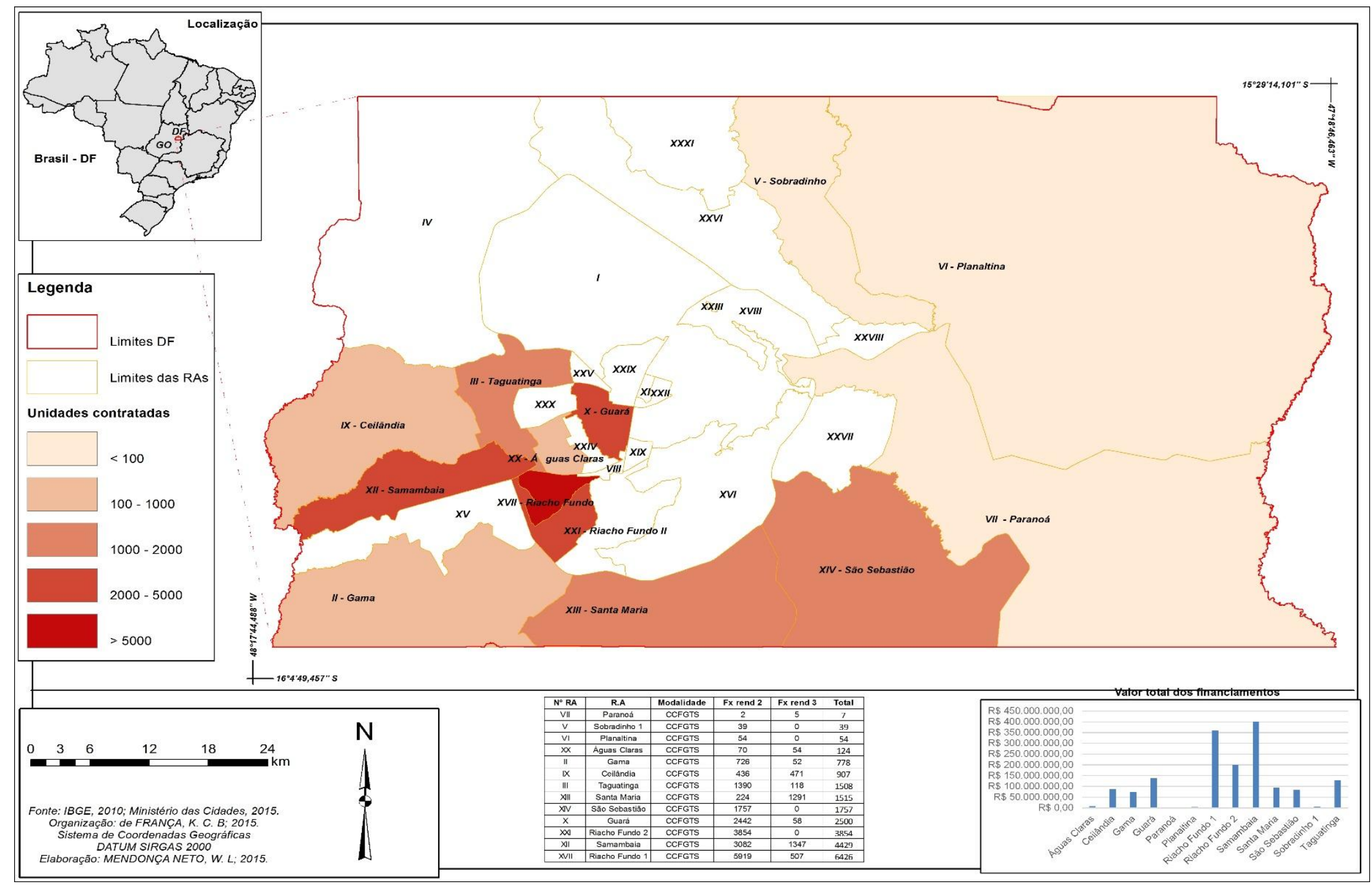

* Não foram incluídos as contratações da PPP- Jardins Mangueiral 
As contratações do Programa Morar Bem para as faixas de renda superior a $\mathrm{R} \$$ 1.600,00 estão concentradas nas Regiões Administrativas de Samambaia, Santa Maria, Riacho Fundo e Taguatinga, que apresentaram o maior volume de empreendimentos vinculados à faixa 2. Também a faixa de renda que concentra grande maioria dos empreendimentos em execução no DF é a faixa de renda 2. Os empreendimentos contratados para o atendimento da faixa de renda 3 apresentam semelhança em termos de localização com os empreendimentos da faixa de renda 2, embora estes empreendimentos tenham um preço superior e projetos diferenciados. Destaca-se que na RA Santa Maria houve um significativo crescimento de empreendimentos direcionados para a faixa de renda 3, com a contratação do empreendimento Total Ville.

A partir desse mapeamento é possível identificar as regiões administrativas que mais concentram unidades habitacionais financiadas pelo Morar Bem e verificar as variações dessa localização e o porcentual de atendimento em função da faixa de renda do beneficiário. Isso permite elencar elementos de acesso aos serviços urbanos e identificar as mudanças significativas na valorização da terra a partir da forte indução da contratação dos empreendimentos com tipologias habitacionais verticalizadas.

Essas novas configurações urbano-metropolitanas foram resultantes da confluência das flexibilidades dos critérios e dos vetores de adensamento urbano estimulados pelo GDF. Somando-se ao volume de investimentos federais em habitação, que pode ser acessado pelo setor privado, viabilizaram-se novos nichos de atuação para a contratação de empreendimentos habitacionais no DF e também nos municípios goianos que têm apresentado um ritmo de produção de moradias priorizando o perfil da classe média.

Sabe-se das inúmeras críticas desse padrão que a produção em massa do Programa Morar Bem tem gerado no tecido urbano do DF, ao entregar unidades habitacionais em localidades desprovidas de equipamentos públicos, como escolas, postos de saúde, delegacias, reproduzindo uma plantação de casinhas e prédios que se tornam verdadeiros depósitos de pessoas. Em todos os empreendimentos do DF cujas etapas já foram concluídas, os equipamentos públicos foram entregues ou estão em fase de conclusão fora do cronograma. Na entrevista realizada na Codhab, a atual gestão reconhece esta problemática e compromete-se a "entregar cidades e não abrigos" com a provisão dos equipamentos públicos.

Para contrapor os resultados alcançados na investigação, que aponta uma forte atuação na contratação de empreendimentos nas faixas 2 e 3, em detrimento da baixa 
operação na faixa 1, e os problemas de inserção urbana dos empreendimentos vinculados à faixa 1, sobretudo os problemas relativos à má qualidade ou ausência de transporte público e a instalação dos equipamentos públicos, a Codhab se posicionou na entrevista concedida para esta pesquisa afirmando que todos os empreendimentos do DF estão próximos de centros urbanos. Como exemplo, foram mencionados "os empreendimentos Crixá e Nacional, encostados a São Sebastião e em áreas centrais do Gama e Sobradinho" .Também não foram relatados problemas de localização de terrenos. Foi ressaltado que, a partir de 2015, haverá concurso público nacional para escolha de projetos de moradias, de escolas e outros equipamentos públicos e sempre será priorizada, na escolha da localização, a disponibilidade de terrenos públicos para construção de empreendimentos.

Uma das justificativas apontadas para a baixa operação do GDF referente ao atendimento da faixa 1 foi a carência de recursos do governo de Brasília. O orçamento apertado compromete a infraestrutura do bairro onde estão localizados os empreendimentos da faixa 1. Além disso, foram citados os seguintes problemas: dificuldades técnicas de aprovação de novos projetos urbanos; a morosidade na tramitação dos procedimentos de obtenção de licença ambiental; quando aprovados os novos projetos urbanos, o cumprimento de medidas mitigadoras e a compensação ambiental exigem altos recursos financeiros, o que traz morosidade no empenho do programa para o atendimento da faixa 1. Como exemplo, cite-se a execução do Parque das Bênçãos, o que em grau menor se repete no faixa 2, no que diz respeito à questão das licenças ambientais e à emissão do Habite-se. Em que pese a informação em entrevista, merece destacar o volume de recursos consideráveis da Terracap e a previsão de transferência não onerosa prevista para a destinação de produção de HIS.

Em linhas gerais, a entrevista realizada na Codhab aponta que na estrutura da política habitacional do GDF não há parâmetros claros ou comitês de força tarefa que procurem intervir nos empreendimentos que apresentam obras em atraso ou fora dos padrões dos projetos aprovados.

Ademais, foi ressaltado que "o corte no orçamento federal, de quase $\mathrm{R} \$ 7$ bilhões destinados ao Programa Minha Casa Minha Vida, deverá frear um pouco a construção de habitações de interesse social“". Não se explicitou claramente se haverá redução ou paralisação dos projetos em andamento.

Essa produção massiva de unidades habitacionais operada pelo mercado privado fortalece o papel dos agentes privados no desenho e execução do Programa Morar Bem, em detrimento do GDF e da inserção da sociedade em participar do desenho da política. 
Evidencia-se, desse modo, a forte atuação do setor privado em induzir o GDF a flexibilizar os mecanismos de regulação do solo e as áreas destinadas para a provisão habitacional. Isso ocorre, em parte, em função da omissão do governo federal em desenhar critérios nacionais que inibem uma produção periferizada e fortaleçam as capacidades institucionais dos governos locais.

Também se acusa o poder público local de ser omisso, incapaz de cumprir com suas funções de regular o uso do solo e de implementar os instrumentos capazes de contribuir para assegurar o direito à moradia para os que mais precisam dela.

Corrobora-se com essas críticas, visto que elas se revelaram convergentes com o funcionamento, a produção e a localização das unidades habitacionais que foram contratadas no DF. No entanto, considera-se, também, que parte desse panorama de produção massiva de conjuntos habitacionais periféricos, desprovidos de qualidade urbanística e de bacias de empregos voltados para o atendimento da classe de baixa renda, somado à indução do mercado privado na operacionalização e execução dos empreendimentos na faixa 2, são os efeitos perversos da falta de uma gestão e governança interfederativa e coletiva da política habitacional vigente no país.

Se não fosse a omissão da escala federal em induzir mecanismos de cooperação, somado a baixa aplicação de instrumentos de recuperação de mais-valias pelos governos locais recuperarem os investimentos em infraestrutura e urbanização dos projetos imobiliários e, também, os normativos federais estimularem o uso de contrapartidas mistas, em vez da atual padronização das contrapartidas, melhores projetos habitacionais e uma melhor eficiência dos investimentos seriam possíveis.

A escala local é a mais frágil e mais influenciável no que tange às manobras das grandes incorporadoras, dos interesses empresariais e dos interesses do mercado privado e dos segmentos da estrutura governamental. No Distrito Federal e em sua área metropolitana, a configuração urbano-metropolitana dos empreendimentos habitacionais revela o quão têm sido modificadas as dinâmicas sociais e urbanas em função dos interesses imobiliários que ultrapassam as fronteiras administrativas para ampliar seus investimentos e atender a demandas habitacionais localizadas em outra unidade federativa. Assim, os graves problemas urbanos que estão ocorrendo no recorte espacial objeto desta pesquisa em função da má localização dos empreendimentos, da falta de aplicação dos instrumentos urbanísticos, do impacto dos empreendimentos em outro município, quando lançadas hipóteses da causa desses problemas e as responsabilidades, em sua grande maioria elas são atribuídas ao poder municipal ou distrital. Essas análises 
são importantes, porém parciais, por não articularem a problemática dos interesses privados, do capital imobiliário e das estruturas de planejamento e gestão do território aos processos de descentralização do pacto federativo inconclusa, que contribuem para o desarranjo no planejamento da habitação.

É fundamental reconhecer o papel significativo das instituições financeiras que regulam o acesso e as formas de financiamento, o volume de financiamento no país e que, também em parte, induzem a produção massiva de conjuntos habitacionais populosos, quando liberam o financiamento cientes de que o projeto nem sempre apresenta qualidade que induziria uma melhoria na qualidade de vida nas cidades. Assim, a lógica de contratação de empreendimentos passa a ser mais prioritária do que a demanda habitacional e a qualidade do projeto, uma vez que estas devem ser supridas posteriormente.

Assim, evidencia-se que pouco se tem avançado na esfera federal sobre o seu papel em induzir diretrizes interfederativas acopladas aos atuais mecanismos de financiamento para melhorar o desenvolvimento urbano e habitacional no país, em especial nas áreas com fortes dinâmicas metropolitanas.

O foco deste capítulo foi mostrar como a provisão da habitação por meio do Programa Morar Bem tem se convertido em uma frente de investimento importante, transformando a dinâmica imobiliária do DF e agravando os problemas de uso e gestão do solo na escala urbana e metropolitana.

Para tanto, foram analisados neste capítulo os meandros das estruturas de planejamento e ações no campo habitacional do Distrito Federal, que territorializam a política habitacional de forma segregada, o que acirra a competitividade pelo acesso à terra urbana, sobretudo com boa localização. Por sua vez, os grandes empreendedores imobiliários têm voltado seus empreendimentos para a escala metropolitana e incorporado ao processo de mercado as áreas urbanas na escala ampliada da área metropolitana. Configuram-se, assim, novos nichos de mercado e novas configurações territoriais nos municípios goianos, resultantes da ação da política habitacional no DF, conforme se analisa no capítulo a seguir. 


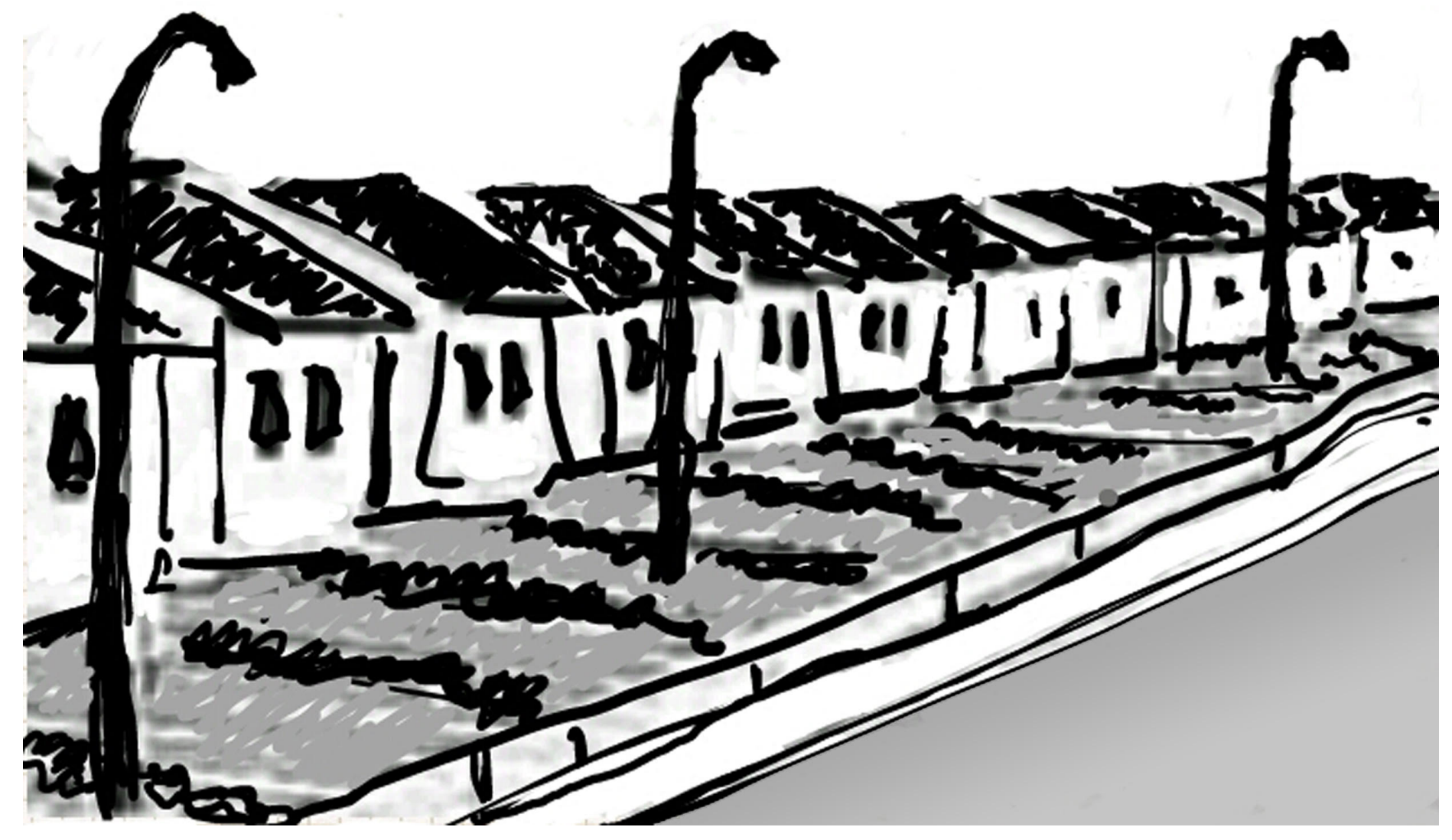




\section{Capítulo 3}

\section{A (des)concertação da Política Habitacional na Área Metropolitana de Brasília}

O que é Brasília?

Brasília é o avião do Plano Piloto, ou a Borboleta de Lúcio Costa, É a Esplanada dos Ministérios (espaço fora do cotidiano da maioria dos brasilienses),

É o Congresso Nacional, são os Palácios do Governo, é a Catedral, é

o Lago Paranoá.

Brasília é a Superquadra, é o Comércio Local,

É o espaço livre dos blocos sob os pilotis,

É o horizonte e muito céu, Haja espaço!

Brasília é o eixão, os eixinhos, as tesourinhas, os balões,

Haja carro!

Brasília são os Setores, as Entrequadras,

Os núcleos rurais (cada vez menos) e os Condomínios (cada vez

mais),

Mas também as Chácaras, os cerrados,

Haja verde!

Brasília é a Vila Planalto, a Vila Varjão, o Vale do Amanhecer, a Agrovila, agora Cidade, São Sebastião, é o Paranoá. É o Acampamento da Telebrasília, é a Estrutural, o Itapoã,

É a Candagolândia, o Cruzeiro, Planaltina e Brazlândia.

É Taguatinga, Ceilândia, Samambaia, Riachos Fundos e Recanto das

Emas.

É Sobradinho, Gama, Guará, Santa Maria.

Haja gente!

Brasília também é o Entorno,

Goiano e mineiro, fora do DF (cada vez menos),

Que fazem e refazem (cada vez mais), essa Brasília Metropolitana

(Benny Schvasberg, 2011 p. 253) 


\subsection{Caracterização socioeconômica da Área Metropolitana de Brasília}

A Área Metropolitana de Brasília (AMB) compreende o Distrito Federal e onze municípios goianos que integram a Ride-DF. São os seguintes: Águas Lindas de Goiás, Alexânia, Cidade Ocidental, Cristalina, Formosa, Luziânia, Novo Gama, Padre Bernardo, Planaltina, Santo Antônio do Descoberto e Valparaíso de Goiás.

Segundo estimativas do IBGE, no ano de 2013 a população dos Municípios goianos que integram a AMB foi de aproximadamente 1.071.583. Incluindo o Distrito Federal, a população da AMB atinge 3,5 milhões de habitantes.

A proximidade geográfica dos municípios goianos que integram a AMB e a relação estabelecida entre seus habitantes e os serviços disponíveis nas duas unidades da federação (DF e GO) envolvidas requerem a formulação e implementação de políticas públicas cooperadas. Trata-se de uma área que exerce e sofre influência direta da Capital Federal em diversos aspectos, afetando suas políticas públicas de transporte, trabalho, habitação entre outras.

Sabe-se que o Estado de Goiás, desde o plano plurianual de 2004-2007, instituiu as Regiões de Planejamento do Estado. Ao todo, são dez regiões, mas apenas uma dessas regiões é reconhecida como metropolitana - a Região Metropolitana de Goiânia. Para o desenvolvimento de estratégias de planejamento e ordenamento do território, o governo goiano criou uma secretaria metropolitana para tratar dos assuntos de ordem metropolitana no âmbito da Região Metropolitana de Goiânia.

No caso dos dezenove municípios goianos próximos ao Distrito Federal e que integram a Ride-DF, o Estado de Goiás criou a região de planejamento denominada “Região do Entorno do Distrito Federal”. Logo, do ponto de vista do planejamento do Estado de Goiás, as políticas públicas e os projetos de intervenção nestes municípios são pautados em estratégias de desenvolvimento estabelecidas para a Região do Entorno do Distrito Federal.

Não há ações ou projetos que demandem ações conjuntas com o DF ou que reconheçam a forte dinâmica metropolitana exercida entre os municípios goianos que integram a Região do Entorno do Distrito Federal nas diretrizes e nas estratégias de planejamento metropolitano do estado de Goiás. Em linhas gerais, o discurso governamental de Goiás sobre os assuntos que envolvem a Região do Entorno são de responsabilidades da Secretaria de Estado de Gestão e Planejamento (Segplan) o 
desenvolvimento de projetos de apoio a arranjos produtivos para potencializar o desenvolvimento da região.

Na última década houve uma aproximação para o fomento de ações entre o DF, os gestores municipais e estaduais goianos para ampliar o debate com foco em ações de desenvolvimento regional, em especial conduzidas pela Sudeco. As questões metropolitanas que envolvem os municípios goianos e o DF tiveram seu debate mais bem qualificado por meio de estudos técnicos a partir das ações realizadas pelo poder executivo do Distrito Federal. Desde o ano de 2003, através da Companhia de Planejamento do Distrito Federal (Codeplan) e da Secretaria de Planejamento do GDF, são realizadas pesquisas domiciliares e definidos perfis socioeconômicos dos municípios do Entorno. A finalidade é identificar os níveis de interação dos municípios goianos com o Distrito Federal, além de indicar os principais vetores e inserção da população no que se refere ao mercado de trabalho, estudo, equipamentos públicos e relações comerciais para a promoção de políticas públicas.

Também a Codeplan realizou, ao longo da última década, importantes estudos acerca do processo de formação da área de influência de Brasília e formulou propostas para melhor organização e planejamento integrado da região.

Nos últimos três anos, destacou-se a revisão dos estudos que tiveram como foco a proposta de ampliação da escala da Ride-DF. Trata-se da inserção de mais 37 municípios na Ride-DF, totalizando 59, com a finalidade de propor a criação de duas escalas de planejamento - a regional e a metropolitana -, ou seja, uma escala que potencialize estratégias para o desenvolvimento regional e outra que procure atuar nos problemas metropolitanos de forma integrada e articulada. 


\section{Figura 26 - Proposta de Ampliação da Ride-DF}

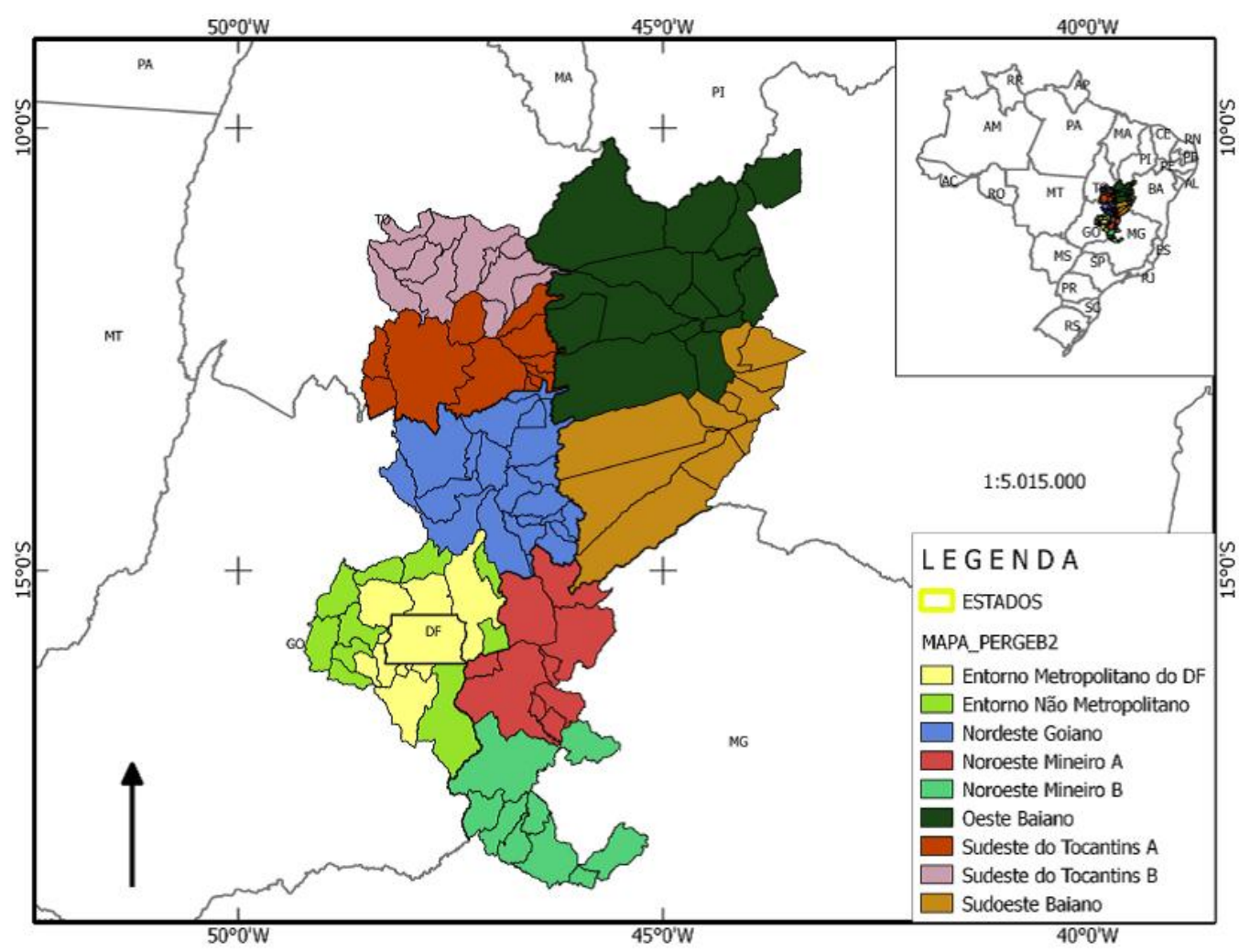

Fonte: PAZ et al. (2001). Elaboração: FARIAS (2013). Organização: Karla França.

A proposição de ampliação da Ride-DF, no entanto gera conflitos, uma vez que a atual composição de 22 municípios é precária do ponto de vista de gestão e planejamento. Portanto, uma ampliação do número de municípios sem uma melhor qualificação de projetos de desenvolvimento e estratégias partilhadas e com corresponsabilidades tornaria ainda mais fragilizadas as ações e ampliaria as dificuldades de pactuação entre os difusos interesses políticos.

$\mathrm{Na}$ tentativa de fortalecer as capacidades institucionais para melhor intervir nos problemas urbanos resultantes da interação exercida entre o DF e o conjunto de municípios goianos do Entorno, o Governo do Distrito Federal criou em sua estrutura de planejamento uma secretaria exclusiva para dialogar e estabelecer diretrizes de forma partilhada entre o Estado de Goiás e municípios goianos, a fim de melhor planejar e gerir os graves problemas urbanos. Assim, consta na estrutura de planejamento e gestão do DF, a partir do Decreto $\mathrm{n}^{\circ}$ 32.716/2011, a Secretaria de Desenvolvimento da Região Metropolitana do Distrito Federal. Esta Secretaria trabalha oficialmente com o recorte da 
Área Metropolitana de Brasília (AMB), em que reconhece onze municípios goianos que possuem interação metropolitana com o DF. No entanto, foi verificado na pasta que não há nenhum projeto implementado ou em andamento que incentive à promoção à de ações ou propostas entre o DF e os gestores estaduais e municipais do estado de Goiás.

Considerando as análises presentes na Nota Técnica $\mathrm{n}^{\circ} 1$, elaborada pela Codeplan, no ano de 2014, verificou-se que um dos critérios utilizados para a identificação desses onze municípios como prioritários para intervenção metropolitana foi a identificação dos fluxos de transporte semiurbano ((até $75 \mathrm{~km}$ de distância). A partir dos dados dos fluxos foi identificada a forte polarização exercida por Brasília como destino desses fluxos, contabilizando-se 89 milhões de passageiros em 551 linhas (CODEPLAN, 2015).

A pesquisa identificou também que seis municípios (Águas Lindas de Goiás, Novo Gama, Santo Antônio do Descoberto, Planaltina, Cidade Ocidental e Valparaíso) possuem intensos fluxos de passageiros com o Distrito Federal e fluxo moderado com Luziânia.

Outro critério utilizado para a identificação dos municípios que exercem forte interação com o DF foi o de atendimento à saúde à população dos municípios goianos, nos hospitais do DF, isto é, da rede pública de saúde. Verificou-se que os municípios que mais acessam a rede pública de saúde do DF coincidem com os de maior fluxo no transporte semiurbano com o Distrito Federal.

Ao correlacionar os indicadores de porte populacional e adensamento populacional, observa-se que seis municípios apresentaram os maiores índices de adensamento populacional e quatro municípios apresentaram índices de adensamento superior a 100 hab $/ \mathrm{km}^{2}$ - Valparaíso de Goiás, Cidade Ocidental, Águas Lindas de Goiás e Novo Gama. 
Quadro 39 - Densidade Demográfica na AMB: 2010

\begin{tabular}{|l|c|c|}
\hline \multicolumn{1}{|c|}{ Município } & População & $\begin{array}{l}\text { Densidade } \\
\text { Demográfica } \\
\text { (hab/km² }\end{array}$ \\
\hline Distrito Federal & 3.724 .181 & 65.99 \\
\hline Águas Lindas de Goiás & 159.378 & 846.00 \\
\hline Alexânia & 23.814 & 28.09 \\
\hline Cidade Ocidental & 55.915 & 143.38 \\
\hline Cristalina & 46.580 & 7.56 \\
\hline Formosa & 100.085 & 17.22 \\
\hline Luziânia & 174.531 & 44.06 \\
\hline Novo Gama & 95.018 & 487.30 \\
\hline Padre Bernardo & 27.671 & 8.81 \\
\hline Santo Antônio do Descoberto & 63.248 & 66.99 \\
\hline Valparaíso de Goiás & 132.982 & $2.165,48$ \\
\hline Planaltina de Goiás & 81.649 & 32.10 \\
\hline
\end{tabular}

Fonte: CODEPLAN (2015). Adaptado por Karla França. Base de dados: IBGE (2010).

Ao agregar a taxa de urbanização observa-se que novamente os municípios inclusos na $\mathrm{AMB}$ apresentaram as maiores taxas de urbanização. ${ }^{33}$ Esta soma de indicadores reafirma que os onze municípios, em graus do forte ao moderado, exercem interações metropolitanas com o Distrito Federal. Outro fator importante foi a presença de aglomerações urbanas relevantes não apenas nas respectivas sedes municipais. A pesquisa da Codeplan identificou quatro municípios com distritos ou localidades isoladas com populações urbanas expressivas.

${ }^{33}$ Um detalhe metodológico foi ressaltado pela Codeplan. Trata-se das exceções dos municípios de Padre Bernardo e Cocalzinho de Goiás, que apresentam grande parte da população efetivamente urbana, mas contabilizada como residente em setores censitários rurais. 


\section{Quadro 40 - Principais Aglomerações Urbanas na AMB}

\begin{tabular}{|l|cc|}
\multicolumn{1}{|c}{$\begin{array}{c}\text { Município/Distrito ou } \\
\text { Localidade Urbana }\end{array}$} & $\begin{array}{c}\text { População Urbana } \\
\text { (2013) }\end{array}$ & (\%) \\
\hline Padre Bernardo & 25.514 & 100 \\
Sede & 13.006 & 51 \\
Monte Alto & 12.508 & 49 \\
& & \\
Cristalina & 43.024 & 100 \\
Sede & 35.877 & 83.4 \\
Campos Lindos & 7.147 & 16.6 \\
& & \\
Cidade Ocidental & 68.502 & 100,00 \\
Sede & 57.481 & 83.9 \\
Jardim ABC & 11.021 & 16.1 \\
\hline & & \\
Luziânia & 177.501 & 100 \\
Sede & 105.324 & 59.3 \\
Jardim Ingá & 72.177 & 40.7 \\
\hline
\end{tabular}

Fonte: CODEPLAN (2015). Base de dados: IBGE (2010).

Esses distritos em geral são localidades urbanas mais próximas ao DF. O distrito de Campos Lindos e a localidade urbana de Monte Alto localizam-se na divisa com o Distrito Federal. O acesso às vias do DF são mais próximas. Além disso, tal proximidade com o DF agrega interesses no que tange ao preço da terra urbana (CODEPLAN, 2015).

Considerando-se os onze municípios que integram a AMB sem o Distrito Federal, verificou-se uma população de 100 mil habitantes na década de 1970. Essa população duplicou em cada uma das três décadas seguintes, alcançando mais de 750 mil habitantes em 2000, evoluindo para 1,07 milhão de residentes urbanos apurados em 2013 pela PMAD, que somados à população rural atinge um total de 1,13 milhão de habitantes (CODEPLAN, 2015). 


\section{Quadro 41 - Crescimento da População Urbana na AMB: 1960-2010}

\begin{tabular}{|l|c|r|r|r|r|r|}
\hline \multirow{2}{*}{ Município } & \multicolumn{6}{c|}{ População Urbana } \\
\hline \multirow{2}{*}{ Distrito Federal } & 1960 & 1970 & 1980 & 1991 & 2000 & 2010 \\
\cline { 2 - 8 } & 88.334 & 516.007 & 1.138 .994 & 1.515 .889 & 1.961 .499 & 2.483 .574 \\
\hline Águas Lindas de Goiás & - & - & - & - & 105.583 & 159.265 \\
\hline Alexânia & 463 & 2.642 & 6.218 & 9.500 & 15.935 & 19.701 \\
\hline Cidade Ocidental & - & - & - & - & 34.465 & 43.124 \\
\hline Cocalzinho de Goiás & - & - & - & - & 6.000 & 6.448 \\
\hline Cristalina & 3.810 & 5.612 & 10.459 & 17.652 & 27.569 & 38.430 \\
\hline Formosa & 11.036 & 12.859 & 29.618 & 49.659 & 69.285 & 92.035 \\
\hline Luziânia & 5.068 & 9.604 & 75.977 & 194.345 & 130.165 & 162.835 \\
\hline Novo Gama & - & - & & & 73.026 & 92.019 \\
\hline Padre Bernardo & & 1.771 & 7.233 & 9.311 & 13.272 & 10.794 \\
\hline $\begin{array}{l}\text { Santo Antônio do } \\
\text { Descoberto }\end{array}$ & - & - & & & & \\
\hline Valparaíso de Goiás & - & - & - & - & 94.856 & 127.405 \\
\hline Planaltina de Goiás & 512 & 582 & 9.275 & 37.499 & 70.127 & 77.192 \\
\hline
\end{tabular}

Fonte: PMAD (2014).

A PMAD, ao verificar o local de trabalho das 470.956 pessoas empregadas na AMB, constatou que 211.993 pessoas, ou seja, 45,03\%, exercem atividade no Distrito Federal e 251.980 pessoas exercem atividades no município de residência, o que equivale ao porcentual de $53,54 \%$ do total. A pesquisa demonstra que esses municípios goianos apresentam um dos mais elevados índices de exercício de atividades trabalhistas em localidade diferente da localidade em que residem. 


\section{Gráfico 5 - População Urbana da AMB por Local de Trabalho}

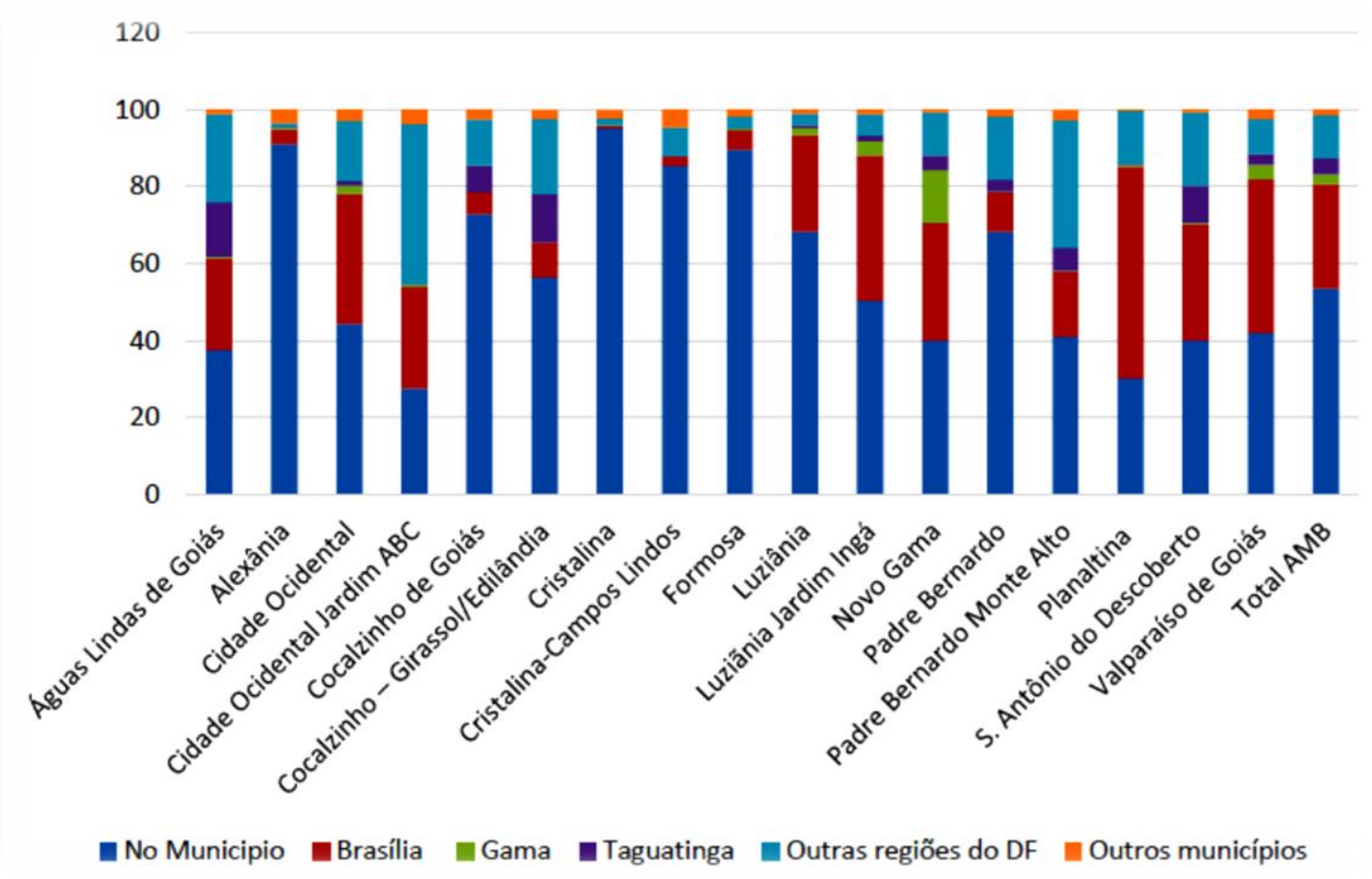

Fonte: PMAD (2014).

Conforme pode ser observado no Gráfico 5, seis municípios possuem porcentuais de pessoas que trabalham no DF acima de 50\%. Destaca-se Planaltina, com 69,53\%, seguida pelo município de Águas Lindas de Goiás, com 61,32\%; Santo Antônio do Descoberto, com 59,38\%; Novo Gama, com 59,34\%; Valparaíso de Goiás, com 55,57\% e o município de Cidade Ocidental, com 52,90\% (PMAD, 2014).

Em outros três municípios, o porcentual dos que trabalham no DF enquadra-se entre $25 \%$ e $30 \%$. São eles: Luziânia, com 30,75\%; Padre Bernardo, com 29,81\%, e Cocalzinho de Goiás, com 24,64\%. Já os municípios de Formosa, Cristalina e Alexânia apresentaram um porcentual reduzido de pessoas que exercem atividade no DF, visto que as atividades da agroindústria se encontram em significativos estágios de desenvolvimento. Em Formosa o porcentual dos que trabalham no DF foi de apenas 8,65\%; já em Alexânia, apenas 5,38\%, e Cristalina apresentou o índice mais reduzido: 2,63\% (PMAD, 2014).

No panorama da situação da população economicamente ativa foi observado que os municípios de Planaltina (55,30\%), Formosa (54,88\%), Valparaíso de Goiás (53,30\%), Cristalina (52,45\%) e Luziânia (52,07\%) apresentaram os mais elevados índices na PEA.

Já a população em situação de desemprego apresentou as taxas mais elevadas nos municípios de Águas Lindas de Goiás (11,40\%), Luziânia (10,40\%), Santo Antônio do 
Descoberto (9,51\%), Padre Bernardo (9,48\%), Novo Gama $(9,11 \%)$, Formosa $(8,46 \%)$, Valparaíso de Goiás (7,24\%) e Cidade Ocidental (6,70\%).

No quesito relativo à ocupação das atividades econômicas verificou-se uma ampla concentração das pessoas que exercem atividades no setor terciário, equivalente a $80 \%$ dos postos de trabalho. Destaque para as atividades relacionadas ao comércio $(25,9 \%)$, serviços gerais $(12,23 \%)$ e serviços domésticos $(7,88 \%)$. Os municípios que apresentaram as maiores taxas de ocupação no setor comercial foram Planaltina de Goiás (37,36\%), Novo Gama (30,54\%), Cidade Ocidental (29,40\%) e Águas Lindas de Goiás (27,03\%).

Já a taxa de ocupação relativa à administração pública totalizou 10,13\% . Essa população em geral encontra-se alocada na administração pública municipal, estadual, distrital ou federal. Já em relação ao setor secundário, é a construção civil o motor de contratação das pessoas, alocando aproximadamente $15,08 \%$ do total ocupado. A indústria de transformação apresentou reduzido número de empregados, apenas 4,88\% do total. Já o setor primário se revelou pouco importante, ${ }^{34}$ com apenas $2,70 \%$ do total de pessoas ocupadas nas atividades agropecuárias, com destaque para o município de Cristalina.

Observa-se que a construção civil tem papel importante no setor secundário, com destaque nos municípios de Planaltina (37,36\%), Novo Gama (30,54\%), Cidade Ocidental $(29,40 \%)$, Águas Lindas de Goiás $(27,00 \%)$ e Alexânia $(25,81 \%)$, o que é resultado das obras habitacionais no âmbito do programa Minha Casa, Minha Vida em andamento nesses municípios.

Já em relação às regiões administrativas em que predomina a concentração das pessoas que residem na AMB e exercem atividades no Distrito Federal, foi observada alta concentração na RA I (Brasília/Plano Piloto), destino de 60,24\% das pessoas. Em segundo lugar, o destino de trabalho é a RA Taguatinga, com 9,34\%, e em terceiro a RA Gama, com 5,57\% do total de pessoas que se deslocam dos municípios da AMB para exercerem atividade laboral em uma dessas RAs. As demais RAs somam juntas 24,85\% das pessoas que residem em algum município da AMB e exercem atividade trabalhista no DF (CODEPLAN, 2015).

\footnotetext{
${ }^{34}$ Cabe desacatar que a pesquisa se restringiu à área urbana, razão por que não foi computada a população rural que, provavelmente, dedica-se a esta atividade.
} 
No quesito renda média mensal, os municípios da AMB apresentaram uma renda média mensal de aproximadamente $\mathrm{R} \$ 2.043,35^{35}$ e a renda média per capita mensal de $\mathrm{R} \$ 703,61$. Outro dado relevante é a distribuição dos domicílios segundo a classe de renda domiciliar. Entre os que declararam renda, predomina a faixa de renda entre dois e cinco salários mínimos (SM), o que equivale a 45,78\% dos domicílios da AMB; em segundo lugar, enquadram-se os que recebem de um a dois salários mínimos, o que equivale a $29,48 \%$ dos domicílios; e em terceiro, os domicílios com rendimento de até um salário mínimo, 29.764, correspondendo a 11,99\%. Em linhas gerais, a população da AMB apresenta uma renda mensal baixa, uma vez que mais de $85 \%$ da população recebe entre um e cinco salários mínimos. Já os domicílios com rendimento acima de cinco salários mínimos representam $12,75 \%$ do total, sendo que 10,34\% com rendimento entre cinco e dez salários mínimos; apenas 2,10\% entre dez e vinte salários mínimos e ínfimos 0,31\% com mais de vinte salários mínimos.

A pesquisa também identificou os municípios com os menores e maiores porcentuais de renda. Os municípios com renda mais baixa de até dois salários representam 41,47\% do total de domicílios da AMB, com destaque para Padre Bernardo (58,21\%), Santo Antônio do Descoberto (50,71\%) e Alexânia (50,46\%). Vale sublinhar que os municípios de Cocalzinho de Goiás $(48,21 \%)$ e Águas Lindas de Goiás $(46,56 \%)$ se aproximaram bastante do enquadramento de renda baixa. Já os municípios de Planaltina de Goiás (29,72\%), Valparaíso de Goiás (8,84\%), Cidade Ocidental (33,30\%) e Formosa $(36,45 \%)$ apresentam um menor porcentual de domicílios nas faixas de menor rendimento.

\footnotetext{
${ }^{35} \mathrm{O}$ valor do salário mínimo vigente na época da pesquisa era de $\mathrm{R} \$ 678,00$, conforme regulamentação do Decreto Federal 7.872/2012.
} 
Quadro 42 - Distribuição dos domicílios urbanos ocupados por classes de renda domiciliar, segundo os municípios da AMB: 2013

\begin{tabular}{|c|c|c|c|c|c|c|c|c|c|}
\hline \multirow[b]{2}{*}{ Município } & \multirow[b]{2}{*}{ Total } & \multicolumn{8}{|c|}{ Classe de Renda } \\
\hline & & 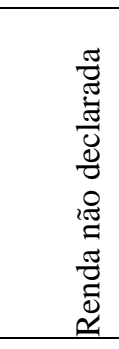 & $\begin{array}{l}\bar{\pi} \\
0 \\
0 \\
0 \\
0 \\
0\end{array}$ & 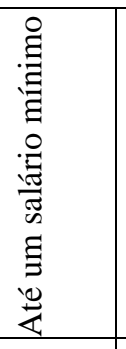 & 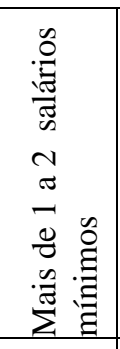 & 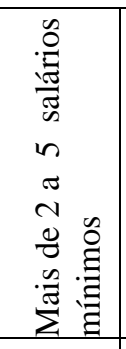 & 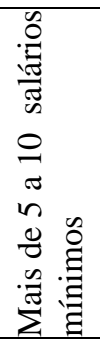 & 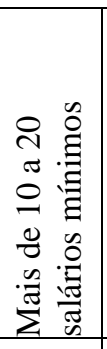 & 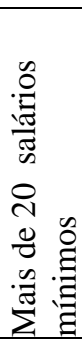 \\
\hline Águas Lindas de Goiás & 55.374 & 9.253 & 46.120 & 6.380 & 15.097 & 21.039 & 3.311 & 292 & 0 \\
\hline Alexânia & 7.010 & 997 & 6.012 & 941 & 2.093 & 2.374 & 435 & 169 & 0 \\
\hline Cidade Ocidental & 19.427 & 1.681 & 17.746 & 1.368 & 4.541 & 8.451 & 2.500 & 859 & 28 \\
\hline Cidade Ocidental - Sede & 16.483 & 1.634 & 14.848 & 1.136 & 3.490 & 7.009 & 2.327 & 859 & 28 \\
\hline Cidade Ocidental -- Jardim ABC & 2.945 & 47 & 2.898 & 233 & 1.050 & 1.442 & 173 & 0 & 0 \\
\hline Cocalzinho de Goiás & 5.462 & 213 & 5.249 & 945 & 1.586 & 2.156 & 507 & 43 & 12 \\
\hline Cocalzinho de Goiás - Sede & 2.771 & 80 & 2.691 & 480 & 856 & 1.010 & 302 & 31 & 12 \\
\hline Cocalzinho de Goiás - Girassol/Edilândia & 2.691 & 133 & 2.559 & 465 & 730 & 1.147 & 205 & 12 & 0 \\
\hline Cristalina & 12.775 & 3.491 & 9.284 & 1.457 & 2.694 & 3.967 & 933 & 118 & 115 \\
\hline Cristalina - Sede & 10.484 & 3.065 & 7.420 & 1.198 & 2.094 & 3.134 & 806 & 92 & 115 \\
\hline Cristalina - Campos Lindos & 2.291 & 427 & 1.864 & 259 & 620 & 833 & 127 & 25 & 0 \\
\hline Formosa & 30.430 & 10.320 & 20.110 & 2.556 & 4.774 & 9.259 & 2.556 & 868 & 96 \\
\hline Luziânia & 52.916 & 11.641 & 41.274 & 4.784 & 14.097 & 19.007 & 3.133 & 254 & 0 \\
\hline Luziânia - Sede & 32.300 & 6.435 & 25.865 & 2.752 & 9.186 & 12.065 & 1.736 & 127 & 0 \\
\hline Luziânia - Jardim Ingá & 20.616 & 5.207 & 15.409 & 2.032 & 4.911 & 6.943 & 1.397 & 127 & 0 \\
\hline Novo Gama & 29.160 & 1.185 & 27.975 & 3.121 & 8.258 & 13.197 & 2.884 & 474 & 40 \\
\hline Padre Bernardo & 7.983 & 399 & 7.584 & 1.676 & 2.739 & 2.619 & 478 & 73 & 0 \\
\hline Padre Bernardo - Sede & 4.152 & 83 & 4.069 & 874 & 1.484 & 1.356 & 324 & 30 & 0 \\
\hline
\end{tabular}




\begin{tabular}{|c|c|c|c|c|c|c|c|c|c|}
\hline Padre Bernardo - Monte Alto & 3.831 & 316 & 3.515 & 802 & 1.254 & 1.263 & 154 & 43 & 0 \\
\hline Planaltina & 26.861 & 2.268 & 24.593 & 1.512 & 5.797 & 13.503 & 3.637 & 144 & 0 \\
\hline Santo Antônio do Descoberto & 17.905 & 2.297 & 16.608 & 2.159 & 5.756 & 6.614 & 1.052 & 28 & 0 \\
\hline Valparaíso de Goiás & 47.071 & 20.749 & 26.593 & 2.864 & 5.729 & 11.415 & 4.233 & 1.881 & 470 \\
\hline Total da AMB & 312.371 & 64.225 & 248.149 & 29.764 & 73.161 & 113.602 & 25.650 & 5.202 & 761 \\
\hline
\end{tabular}

Fonte: PMAD (2014). 
Já os municípios que apresentaram os maiores porcentuais de domicílios com rendimento acima de cinco salários mínimos foram: Valparaíso de Goiás $(24,76 \%)$, Cidade Ocidental $(19,09 \%)$, Formosa $(17,51 \%)$ e Planaltina de Goiás $(15,38 \%)$. Os domicílios que têm rendimento acima de dez salários mínimos são Valparaíso de Goiás (8,84\%), Cidade Ocidental (5,00\%) e Formosa (4,80\%).

Já no quesito tipo utilizado de transporte para ir ao trabalho, as pessoas residentes na AMB utilizam de forma expressiva o transporte público (ônibus) para se locomoverem para o DF. A pesquisa apontou que quase a metade dos ocupados, isto é, 47,18\%, utilizam o ônibus. Em segundo lugar, 23,79\% utilizam o automóvel/utilitário. Um dado expressivo foi o quantitativo de pessoas que utilizam a modalidade andar a pé para ir ao trabalho $(15,98 \%)$, de bicicleta $(5,48 \%)$ e também de motocicleta $(5,62 \%)$. 
Quadro 43: Tipo de transporte utilizado pela população urbana da AMB para ida ao trabalho: 2013

\begin{tabular}{|c|c|c|c|c|c|c|c|c|c|}
\hline Mmicípio & Total & Ônibus & Automóveis & $\begin{array}{l}\text { Transport } \\
\text { Utilitários }\end{array}$ & $\begin{array}{c}\text { es Utilizados/ } \\
\text { Motocicleta }\end{array}$ & $\begin{array}{l}\text { alor Absol } \\
\text { Bicicleta }\end{array}$ & $\begin{array}{l}\text { Anto } \\
\text { A pé }\end{array}$ & Outros & Não Sabe \\
\hline Águas Lindas de Goiás & 82.890 & 51.088 & 11.250 & 49 & 2.727 & 2.776 & 14.123 & 877 & 0 \\
\hline Alexânia & 9.145 & 1.349 & 2.739 & 478 & 745 & 1.278 & 2.290 & 267 & 0 \\
\hline Cidade Ocidental & 29.122 & 15.837 & 5.733 & 96 & 931 & 372 & 5.393 & 760 & 0 \\
\hline Cidade Ocidental - Sede & 24.516 & 12.660 & 5.208 & 83 & 831 & 332 & 4.682 & 720 & 0 \\
\hline Cidade Ocidental - Jardim ABC & 4.606 & 3.177 & 525 & 13 & 100 & 40 & 711 & 40 & 0 \\
\hline Cocalzinho de Goiás & 7.125 & 2.071 & 1.356 & 79 & 581 & 660 & 2.302 & 104 & 24 \\
\hline Cocalzinho de Goiás - Sede & 3.657 & 640 & 813 & 12 & 369 & 394 & 1.361 & 55 & 12 \\
\hline Cocalzinho de Goiás - Girassol/Edilândia & 3.518 & 1.430 & 543 & 66 & 211 & 266 & 941 & 48 & 12 \\
\hline Cristalina & 18.974 & 2.595 & 5.421 & 274 & 1.626 & 3.494 & 4.690 & 808 & 69 \\
\hline Cristalina - Sede & 15.830 & 1.221 & 4.908 & 253 & 1.383 & 3.088 & 4.262 & 645 & 69 \\
\hline Cristalina - Campos Lindos & 3.144 & 1.372 & 513 & 20 & 244 & 406 & 427 & 163 & 0 \\
\hline Formosa & 49.045 & 4.099 & 18.374 & 193 & 6.269 & 9.404 & 9.115 & 1.350 & 241 \\
\hline Luzînia & 79.162 & 34.543 & 20.404 & 466 & 6.096 & 2.413 & 13.589 & 1.355 & 296 \\
\hline Luziânia-Sede & 47.497 & 17.822 & 12.869 & 381 & 5.038 & 1.482 & 9.440 & 339 & 127 \\
\hline Luziânia - Jardim Ingá & 31.665 & 17 & 7.535 & 85 & 1.058 & 931 & 4.149 & 1.016 & 169 \\
\hline Novo Gama & 43.345 & 30.701 & 7.231 & 119 & 1.383 & 158 & 3.240 & 316 & 198 \\
\hline Padre Bernardo & 9.598 & 2.810 & 2.127 & 62 & 755 & 1.230 & 2.380 & 204 & 30 \\
\hline Padre Bernardo - Sede & 5.169 & 625 & 1.273 & 45 & 482 & 1.025 & 1.552 & 136 & 30 \\
\hline Padre Bernardo - Monte Alto & 4.428 & 2.184 & 853 & 17 & 273 & 205 & 828 & 68 & 0 \\
\hline Planaltina & 40.256 & 24.125 & 8.858 & 36 & 1.368 & 972 & 4.609 & 288 & 0 \\
\hline Santo Antônio do Descoberto & 25.820 & 15.027 & 4.068 & 0 & 886 & 360 & 4.871 & 526 & 83 \\
\hline Valparaíso de Goiás & 76.144 & 37.879 & 22.189 & 342 & 3.078 & 2.651 & 8.465 & 941 & 599 \\
\hline Total da AMB & 470.675 & 222.121 & 109.749 & 2.193 & 26.445 & 25.767 & 75.065 & 7.794 & 1.540 \\
\hline
\end{tabular}

Fonte: Codeplan (2013) 
Para Sampaio (2014), a forma acelerada do crescimento e adensamento populacional, somados à velocidade em que são realizados os parcelamentos de terras nos municípios goianos, tem relação intrínseca com o crescimento da demanda de polos geradores de tráfego para o Distrito Federal. Isso se deve ao fato de o DF concentrar os polos de emprego, prestar atendimento à saúde à população que reside nos municípios goianos e se locomove diariamente para o DF.

Ao verificar a composição e estrutura socioeconômica dos municípios da AMB, contatou-se uma composição heterogênea em relação à concentração de renda. Em especial, as maiores rendas concentram-se nos municípios localizados no quadrante sudoeste e próximos ao DF, com exceção de Formosa. Os demais municípios apresentaram uma composição de renda baixa. Esses fatores apontam a forte relação de emprego e serviços com o DF. Esse fator impacta na formulação e intervenção das políticas públicas setoriais, sobretudo no que diz respeito às políticas e estratégias que envolvem o parcelamento de terras, os tipos de uso e ocupação do solo, as atividades de fiscalização para coibir ocupações em áreas não previstas. Impacta também nas ações que envolvem as políticas de planejamento urbano como elemento importante para amenizar a gravidade dos problemas urbanos, ou acentuá-los quando as ações de gestão e planejamento são executadas sem considerar a interação da população que reside nos municípios goianos da AMB e sua influência nas atividades socioeconômicas no DF.

Para tanto, conhecer as estruturas de planejamento e ações dos governos locais no campo do planejamento urbano é fundamental para identificar os objetivos, as estratégias, os projetos prioritários e os níveis de adesão à questão metropolitana. Ou seja, é fundamental identificar a capacidade de respostas das diretrizes e estratégias em execução no campo do planejamento nesses territórios e seu potencial de adesão para melhorar os serviços urbanos, ou suas fragilidades que podem acirrar os problemas metropolitanos. 


\subsection{Instrumentos de planejamento e gestão urbana na Área Metropolitana de Brasília}

A estrutura das configurações de planejamento urbano das agências estadual e dos órgãos municipais é importante para a identificação das estratégias, desafios ou seus fatores limitantes para uma gestão municipal eficaz e que esteja articulada às dinâmicas metropolitanas.

O mapeamento e a avaliação da estrutura de planejamento urbano dos municípios da AMB foram realizados a partir da existência das legislações básicas de planejamento urbano, tais como: leis de uso e ocupação do solo, zoneamento urbano, delimitação de perímetro urbano; a existência e regulamentação dos instrumentos urbanos previstos no plano diretor; a situação dos municípios no Sistema Nacional de Habitação de Interesse Social (SNHIS) e; a articulação do plano habitacional com os projetos de produção de moradias via PMCMV.

Assinale-se que todos os municípios inseridos na AMB devem obrigatoriamente cumprir as legislações e implementar os instrumentos urbanos disciplinados nos Art. 182 e 183 da Constituição. Esses artigos, em especial, foram regulamentados pelo Estatuto da Cidade, que trouxe uma série de diretrizes voltadas para uma gestão social do uso do solo urbano, instituindo, para tanto, o plano diretor como instrumento básico da política de desenvolvimento urbano.

Os municípios da $\mathrm{AMB}$ possuem população acima de 20 mil habitantes e, portanto, devem necessariamente seguir as diretrizes do Estatuto da Cidade, a fim de implementar um conjunto de normas e instrumentos de intervenção urbana voltados para "regular o uso da propriedade urbana em prol do bem coletivo" (BRASIL, 2001).

A realização do diagnóstico dos instrumentos urbanos se releva importante para verificar a adesão ao objetivo específico desta tese, que é identificar os instrumentos urbanísticos, jurídicos e tributários (Estatuto da Cidade) utilizados pelo Distrito Federal e Municípios que possibilitam o desenvolvimento urbano do território. Assim, sempre que possível, procura-se correlacionar a incidência desses instrumentos articulados à promoção da habitação social e, também, a existência de articulações da legislação e planejamento com a questão metropolitana.

No ano de 2001, a Secretaria do Planejamento e Desenvolvimento do Estado de Goiás, em parceria com a Agência Goiana de Desenvolvimento Regional (AGDR/GO), firmou um termo de cooperação técnica com os municípios goianos integrantes da RideDF para apoiar a elaboração do plano diretor, por meio da contratação de uma empresa 
de consultoria. Os municípios integrantes da AMB possuem plano diretor vigente, porém em sua maioria são defasados, uma vez que não foram revisados em conformidade com o prazo legal ou adequados à nova dinâmica urbana.

Nas visitas aos órgãos de planejamento dos respectivos municípios foi identificado que Valparaíso de Goiás, Águas Lindas de Goiás, Luziânia e Santo Antônio do Descoberto revisaram o plano diretor entre os anos de 2012 e 2013. Contudo, em sua maioria os instrumentos aprovados nos respectivos planos não foram regulamentados e implementados.

O mapeamento dos instrumentos de gestão urbana local, existentes nos municípios, para promover o fortalecimento da participação e do controle social se revelou frágil. Em cinco municípios foi verificado que não existem conselhos de políticas urbanas locais, e em outros sete municípios onde existem, eles não se reuniram nos últimos doze meses, o que aponta a fragilidade da inserção dos canais de participação ativa da sociedade em reivindicar seus direitos na construção de políticas urbanas coesas à realidade.

Observou-se, também, que houve indução do poder local e dos agentes sociais em retomar as atividades dos conselhos locais de política urbana em virtude da $5^{\text {a }}$ Conferência Nacional das Cidades, realizada no ano de 2013. No entanto, a pesquisa in loco nos municípios constatou dificuldades na retomada dos conselhos locais pós-conferência, em especial no que diz respeito ao desinteresse do poder público em debater nos conselhos as ações e investimentos em prol do desenvolvimento urbano junto à comunidade. Também não houve resposta em nenhum dos municípios sobre a articulação dos conselhos com as prefeituras para as demandas e prioridades a serem elencadas e a organização de infraestruturas para as audiências locais.

Na maioria das vezes, a compreensão dos gestores municipais é que as reuniões com a comunidade deveriam ser realizadas para apresentar as ações, e não necessariamente para pactuar junto com a sociedade as estratégias para a alocação de investimentos e ações prioritárias das políticas urbanas.

Em relação à existência das leis urbanísticas básicas, como por exemplo lei de perímetro urbano e a lei de parcelamento do uso e ocupação do solo, verificou-se que em oito municípios a lei de zoneamento ou uso e ocupação do solo se apresentaram como parte integrante do respectivo plano diretor. Os demais possuem a lei, porém esta não se apresenta como integrante do plano diretor. Também foram constatadas mudanças recentes na lei de perímetro urbano dos municípios, para ampliar a área urbana e 
favorecer o parcelamento para fins urbanos, em função dos recentes empreendimentos habitacionais.

A integração da lei de zoneamento ou do uso e ocupação do solo ao Plano Diretor deve-se mais ao momento de elaboração do primeiro plano diretor - meados de 20042006 -, visto que oportunamente os municípios incorporaram parte das leis urbanísticas até então inexistentes nos municípios ao Plano Diretor. Essa estratégia relaciona-se mais à otimização de elaboração de instrumentos do que à indução de ações cooperadas de zoneamento e ampliação do perímetro urbano, integradas às diretrizes estabelecidas nos respectivos planos diretores.

No que tange à existência dos instrumentos urbanísticos mais recorrentes nos respectivos planos diretores locais, constatou-se a predominância dos seguintes instrumentos: transferência do direito de construir (4 Municípios), Solo Criado ou Outorga Onerosa do Direito de Construir (8 Municípios), contribuição de melhoria (10 Municípios), aplicação do Imposto Predial e Territorial Urbano Progressivo (9 Municípios), aplicação do Parcelamento, Edificação ou Utilização Compulsórios (5 Municípios), Estudo de Impacto de Vizinhança (5 Municípios), instrumento de Desapropriação com Pagamento em Títulos (1 Município), aplicação do Direito de Preempção (2 Municípios) e previsão de operação consorciada (1 Município). 
Figura 27 - Existência de tipos de instrumentos urbanos nos Municípios da AMB

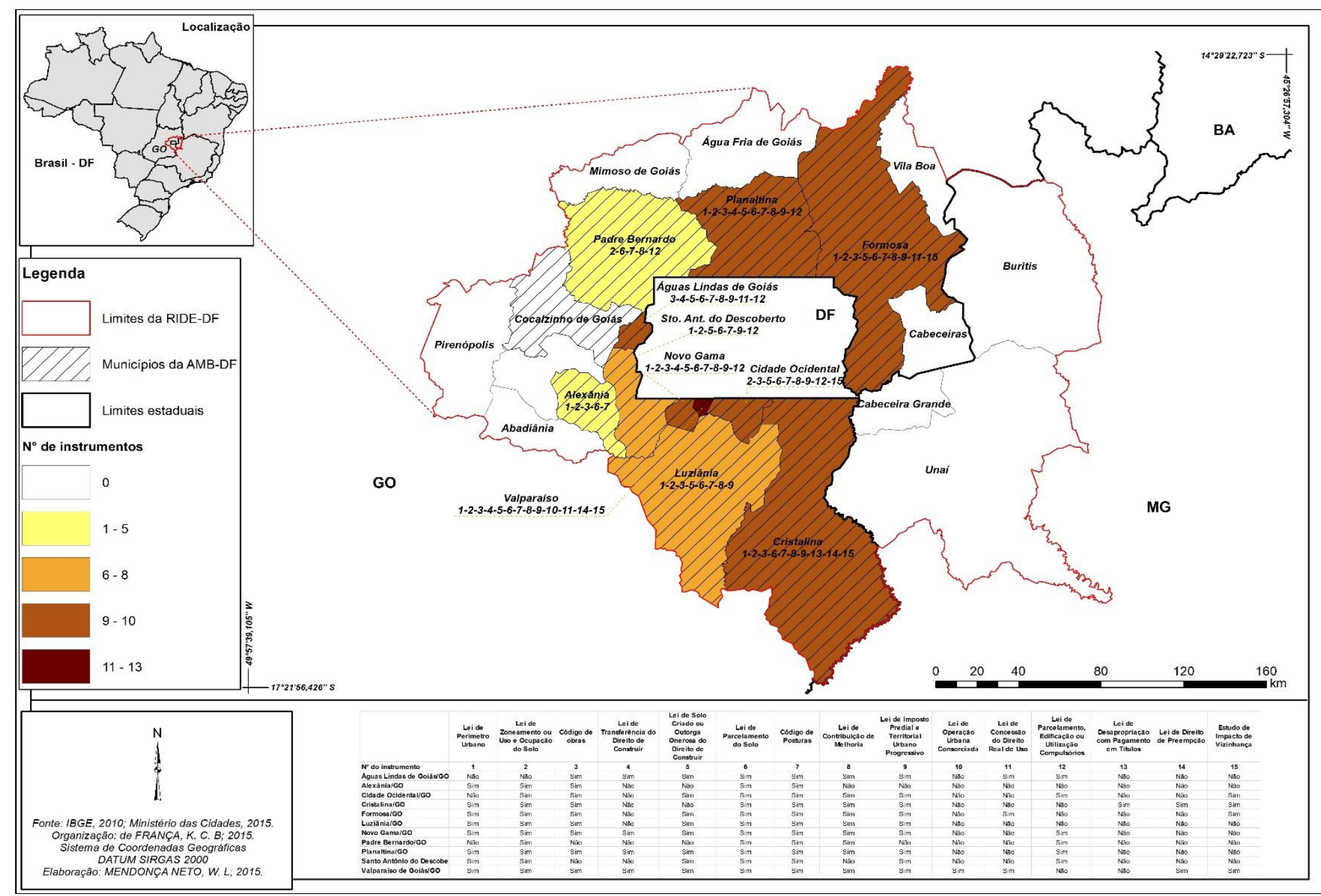


Também foi constatada a existência de cadastro imobiliário e de cobrança do IPTU em todos os municípios. Em relação às isenções do IPTU, verificou-se que em oito municípios há isenção parcial do IPTU e em sete municípios há isenção total do IPTU para alguns tipos de imóveis como igrejas, por exemplo. No entanto, não foi verificada nenhuma ação municipal de tarifas diferenciadas para os empreendimentos habitacionais voltados para o atendimento das famílias enquadradas na faixa de renda 1 do Programa Minha Casa, Minha Vida (PMCMV).

Outra estratégia adotada pelos Municípios para atrair empresas e investimentos externos refere-se à aplicação de mecanismos de incentivo à implantação de empreendimento (11 Municípios). Por exemplo, em quatro municípios é utilizada cessão de terrenos e em outros sete a doação de terrenos.

Sublinha-se que a doação de terreno, além de estar inserida como uma estratégia de atração de investimentos, também é apontada pelo poder público para a contratação de empreendimentos habitacionais para a população de baixa renda em menor escala, ainda que em nenhum plano diretor tenham sido delimitadas as áreas objetos de intervenção de projetos voltados à habitação social, a tipologia dos empreendimentos e a faixa de renda.

Em todos os planos diretores está presente a necessidade de incorporação do instrumento - Zonas de Interesse Social -, para a promoção da habitação social e para fins de regularização fundiária. No entanto, verifica-se que o tipo mais recorrente nos planos diretores é a existência de ZEIS ocupada. Essa foi uma estratégia adotada pela grande maioria dos municípios para facilitar as ações posteriores de regularização fundiária. Já as ZEIS do tipo áreas vazias destinadas para fins de habitação social não são recorrentes. Ainda que os planos diretores sinalizem a necessidade, estas não foram delimitadas, nem implementadas, e não consta o limite de renda do perfil da população, além de inexistirem projetos.

O mapeamento e a análise dos instrumentos urbanos permitem identificar a existência dos instrumentos nos Municípios e as desarticulações nas estratégias de planejamento urbano. Para ilustrar, nos municípios que afirmaram a existência de cobrança do IPTU progressivo, verifica-se a falta de articulação e regulamentação do instrumento anterior, isto é, do instituto do parcelamento, edificação ou utilização compulsórios (Peuc). Vale sinalizar que sem a regulamentação do instituto do PEUC é deficitária a presença do IPTU progressivo no plano diretor. Ou seja, não se aplicam o IPTU progressivo e a desapropriação com pagamento em títulos, se antes não houve o descumprimento pelo proprietário do imóvel do instituto do Peuc. 
Por sua vez, a engenharia para que os municípios possam regulamentar a aplicação do PEUC + IPTU progressivo + desapropriação necessita estar articulada à definição dos coeficientes de aproveitamento que caracterizam e identificam os imóveis ou terrenos vagos, não utilizados ou subutilizados, bem como a atualização da planta venal. Em nenhum Plano Diretor ou em lei específica municipal foram apresentadas as regras, isto é, as condições previstas para a aplicação desses instrumentos.

Este fato denota que, em grande parte dos instrumentos existentes na lei do plano diretor, além de não serem autoaplicáveis, as diretrizes não foram regulamentadas por lei específica e ao mesmo tempo não existe ações de monitoramento da gestão dos instrumentos e de que forma a aplicação dos instrumentos tem gerado efeitos positivos no enfrentamento da questão habitacional. Nas entrevistas com os gestores locais, foi ressaltada a falta de capacidade técnica e de gerenciamento no decorrer do tempo da aplicação do instrumento. Além disso, faltam programas federais que incentivem a capacitação, modernização e assistência técnica e o melhoramento da estrutura de desenvolvimento urbano local foram destacadas pelos gestores.

A ausência na delimitação das ZEIS vazias pelo poder público local fragiliza as ações de enfrentamento à especulação imobiliária e a implementação da habitação de interesse social bem localizada. As ZEIS vazias são um importante instrumento para garantir a construção e o controle social da política urbana, bem como a criação de banco de terras que se articulem às políticas habitacionais existentes nos municípios.

Em termos de gestão pública e capacidade administrativa, há enormes discrepâncias na estrutura de planejamento e gestão urbana dos municípios que integram a $\mathrm{AMB}$, o que traz enormes dificuldades em ações consorciadas, uma vez que os níveis e a capacidade de adoção e estratégias conjuntas para o desenvolvimento urbano implicam acordos e corresponsabilidades de todos os entes.

Pode-se reforçar as lacunas de capacidade do poder público local em implementar os instrumentos urbanos para fomentar o acesso à terra urbanizada e assegurar a função social. Ainda que o poder local tenha a sua parcela de responsabilidade, a reversão desse processo, isto é, de não aplicação efetiva dos instrumentos urbanos, é um grande desafio para esses municípios, haja vista que estes, em sua maioria, tornaram-se municípios em pouco mais de vinte anos, resultado dos processos de desmembramento ou emancipação, além de terem sua estrutura urbana modificada em função da dinâmica urbana de Brasília. 
Portanto, a fragilidade da existência e aplicação da legislação urbana básica elaboração de planta cadastral -, a implementação de leis de zoneamento, a delimitação do perímetro urbano, a legislação para especificar os tipos de uso e ocupação do solo, essenciais para o ordenamento do território, em sua maioria não são efetivas e trazem graves problemas na estrutura de planejamento urbano, sobretudo habitacional.

A falta de clareza que a ausência de aplicação da legislação urbanística traz à dinâmica urbana é notável em todas as prefeituras visitadas, com distintos graus. Para ilustrar, inexistem atividades de avaliação das políticas urbanas municipais e de efetividade da aplicação dos instrumentos previstos no Plano Diretor para subsidiar uma revisão e recomposição de instrumentos urbanos aderentes à realidade local. Outro ponto que chamou atenção diz respeito às recentes alterações realizadas nas leis de perímetro urbano ou na lei de uso e ocupação do solo. Os novos zoneamentos propostos parecem não ter viabilizado o acesso à terra urbanizada. Em vez disso, em geral foram objetos de pressão política dos empreendedores imobiliários para modificar o uso rural em urbano, ampliando a zona urbana periférica para a construção de novos empreendimentos habitacionais.

Contata-se a inexistência, em todos os planos diretores, de diretrizes e estratégias que estejam correlacionadas à dinâmica metropolitana e às consequências desse processo nas estruturas local e regional. O único documento governamental que reconhece a questão metropolitana e aponta a necessidade de ações integradas é o PDOT-DF.

No PDOT-DF, um dos objetivos de planejamento é a promoção de uma gestão compartilhada entre os setores públicos, privados e sociedade civil, envolvendo os municípios limítrofes ao Distrito Federal, de modo a viabilizar a integração das ações de planejamento e gestão do território, diante da concentração não somente de empregos, mas também de serviços e de equipamentos públicos.

Para tanto, o PDOT-DF reconhece a necessidade de integração da política de ordenamento territorial com as demais políticas setoriais que tenham reflexo no processo de planejamento e gestão do território do Distrito Federal e de seus municípios limítrofes. O PDOT-DF, também, recomenda a criação de novas institucionalidades, embora não mencione quais seriam estas institucionalidades.

Também reconhece a necessidade de concertação entre as iniciativas de políticas públicas setoriais do Distrito Federal em articulação às ações promovidas pelo Estado de Goiás e dos governos locais, na medida em que se percebe a conformação de uma área metropolitana de Brasília, incluindo a complexidade de fatores e agentes envolvidos na 
dinâmica do território. No entanto, nenhum instrumento ou estratégia foi proposta no PDOT para o fomento a institucionalidades integradas.

Sublinha-se que as estratégias de ações integradas para o enfrentamento dos problemas urbanos entre o DF e os municípios goianos são reconhecidas nos recentes planos distrital, estadual e municipais de habitação social. Nesses planos foi sinalizada a necessidade de formulação de estratégias para o ordenamento territorial e do planejamento habitacional integrado, mas novamente sem apontamentos de diretrizes ou instrumentos a serem utilizados.

A exigência de elaboração de planos municipais de habitação é uma ação recente no país, uma vez que esta obrigatoriedade vincula-se à adesão dos Municípios, Distrito Federal e Estados ao Sistema Nacional de Habitação de Interesse Social (SNHIS) com um dos requisitos para acessar recursos federais vinculados ao FNHIS.

No Estado de Goiás, observam-se uma forte indução e apoio institucional aos municípios no que diz respeito à elaboração dos respectivos planos municipais de habitação, por meio da Agência Goiana de Habitação (AGEHAB).

No Plano Estadual de Habitação de Goiás (PEHIS-GO), se reconhece, pela primeira vez, em documentos governamentais, a dinâmica metropolitana em duas regiões de planejamento do estado, quais sejam, a Região Metropolitana de Goiânia e a Região Entorno do Distrito Federal, cujo polo está em outra Unidade Federativa, ou seja, no Distrito Federal. Ambas as regiões se destacam como as áreas de maior necessidade de políticas habitacionais voltadas para a produção de moradias, em especial para o atendimento da população de baixa renda.

Todos os municípios goianos que integram a AMB aderiram ao SNHIS. Apenas dois municípios - Águas Lindas de Goiás e Luziânia - não haviam elaborado o plano de habitação até a finalização desta pesquisa. O Município de Águas Lindas de Goiás executou o distrato do termo e devolveu os recursos recebidos. Vale destacar que ambos os municípios receberam recursos federais vinculados ao FNHIS de apoio à elaboração do plano local de habitação. A prefeitura de Luziânia firmou convênio com o Ministério das Cidades entre 2010 e 2014 e recebeu aproximadamente R\$ 35 mil. A prefeitura de Águas Lindas de Goiás fírmou convênio entre 2008 e 2012, tendo recebido aproximadamente $\mathrm{R} \$ 58$ mil do governo federal para apoio à elaboração do plano local. Nas entrevistas realizadas nas prefeituras foi sinalizado que as ações de elaboração dos planos estavam em andamento, porém não foi possível identificar o prazo e o tipo de 
ações de envolvimento com a comunidade, assim como o prazo para a finalização dos respectivos planos locais de habitação.

É a primeira vez que esses municípios elaboraram de forma específica um diagnóstico local da problemática habitacional. Em linhas gerais, os planos trazem um diagnóstico do setor habitacional dos últimos dez anos. Os municípios procuraram evidenciar a importância do planejamento e acesso a recursos federais para a produção de novas moradias, a fim de reduzir ou zerar o déficit habitacional para a população de zero a três salários mínimos.

O foco de zerar o déficit habitacional mostra-se prioritário nas estratégias apontadas em todos os planos habitacionais, mas inexistem recursos ou clareza nas ações para o enfrentamento das necessidades habitacionais relacionadas à ações efetivas de regularização fundiária, ações proativas de prevenção a informalidade e a favelização. Nesse aspecto os planos diretores e de habitação parecem não incorporarem diretrizes ou potencializarem de forma adequada tais ações ao planejamento territorial.

A maioria dos planos habitacionais apresentou uma estrutura programática e de eixos semelhantes. Por exemplo, foram destacados os princípios e objetivos alinhavados com a Política Nacional de Habitação, a necessidade de adoção de estratégias para garantir o direito universal à moradia, a fim de assegurar a função social da cidade com participação democrática da sociedade civil na gestão da política urbana municipal.

As linhas programáticas dos planos locais de habitação em sua maioria se resumem à necessidade de produção de novas moradias. Raros são os planos que estabelecem ações e áreas de intervenção para estratégias de promoção para a regularização fundiária em interface com os instrumentos urbanos contidos nos respectivos planos diretores, como delimitação das áreas para a construção de moradias de interesse social.

No quesito governança metropolitana, em todos os planos de habitação há o reconhecimento da necessidade de articulação intermunicipal com o DF para a promoção de consórcios e o tratamento integrado da questão habitacional, em especial "colocando em pauta o debate sobre habitação, cidade e região". Contudo, em nenhum deles se propuseram algum mecanismo, ação ou diretriz.

Já no Plano de Habitação do Distrito Federal (PLANDHIS-DF) é destacada a necessidade de articulação regional-metropolitana com os municípios goianos mais próximos do Distrito Federal, uma vez que a demanda habitacional desses municípios pressiona o planejamento e gestão habitacional do DF. Por exemplo, o plano distrital 
aponta casos de municípios goianos vinculados a AMB que não chegaram a executar nem a metade de sua necessidade habitacional vinculada à produção de moradias.

Há casos de municípios que contrataram mais do que o dobro de unidades habitacionais, superando, inclusive, seu déficit habitacional, o que traz indicativos de que parte da população residente no DF pode estar equacionando sua necessidade habitacional a partir da aquisição de unidades habitacionais localizadas nos municípios goianos que exercem forte relação metropolitana com o DF.

Portanto, as estratégias setoriais de planejamento, ordenamento e gestão habitacional implantadas pelos governos distritais e municipais, somadas à ausência de clareza dos mecanismos que viabilizem uma articulação habitacional, têm impactado de forma negativa no que tange à efetivação dos objetivos e diretrizes estabelecidas em todos os planos habitacionais. Por sua vez, as novas relações metropolitanas resultantes desse processo de produção de casas têm se intensificado, sobrecarregando as redes de infraestrutura e serviços urbanos existentes ou estabelecendo a necessidade de ampliação ou planejamento de novas redes de infraestruturas nem sempre planejadas em concomitância ao período de contratação e execução dos empreendimentos.

Os planos habitacionais locais realizaram uma importante ação de mapear as deficiências e prioridades para o atendimento das necessidades habitacionais, muito embora esse mapeamento, em linhas gerais, se resumiu a diagnósticos e comparação das necessidades dos indivíduos inscritos nos cadastros habitacionais, o que não equivale à real demanda das necessidades habitacionais do município. Por sua vez, os planos destacaram majoritariamente como origem de recursos o Programa Minha Casa, Minha Vida como fonte de aporte para o atendimento das necessidades habitacionais locais, porém raros foram os planos habitacionais que apresentaram programas locais utilizandose de recursos próprios e federais na tentativa de estruturar uma política local de habitação, como Padre Bernardo e Cocalzinho de Goiás, por exemplo. Em nenhum plano local de habitação analisado foi constatada a elaboração de uma política local de habitação diversificada e articulada com os instrumentos do plano diretor para a promoção de moradias integradas à cidade, criação de programas de regularização fundiária em diálogo com as necessidades da sociedade civil.

É muito frágil a relação estabelecida nos planos habitacionais e a articulação com os planos diretores, seja para dimensionar ou delimitar as áreas do Plano Diretor prioritárias para o atendimento das necessidades habitacionais da comunidade local. 
Nas entrevistas e visitas, ficou constatada a inexistência de mapeamento e levantamento das áreas em que foram ofertadas unidades habitacionais e sua relação com as áreas objeto de intervenção de zonas de interesse social, uma vez que estas, em sua grande maioria, não estão delimitadas. Também é inexistente a criação de banco de terras para novas áreas a serem vinculadas com os investimentos em habitação.

Um exemplo elucidativo é o caso do município de Valparaíso de Goiás. Em entrevista, a prefeita informou que o Ministério das Cidades cobra a realização do que foi proposto uma vez que o município não tem contratado obras habitacionais para o atendimento das famílias enquadradas na faixa de renda 1.

A prefeita, por sua vez, explicou que o município não possui terra urbana disponível para realizar as contratações e critica a revisão realizada no plano diretor na gestão anterior, que não delimitou ZEIS em áreas vazias. Também foi destacado pela prefeita que $100 \%$ das terras do município de Valparaíso de Goiás são urbanas. Logo não se pode alterar o uso rural para urbano e assim ampliar o perímetro urbano, uma vez que, do ponto de vista legal, o município não possui área rural.

Este exemplo é emblemático, pois, ao mesmo tempo em que não há terras disponíveis para a produção de moradia social, verifica-se um aquecimento da contratação de obras habitacionais no município de Valparaíso. Essa produção tem ocorrido em área privada, a partir da compra e venda de terras particulares de forma antecipada pelos incorporadores imobiliários às construtoras, na expectativa de aumento de lucros com a operacionalização do Programa Minha Casa, Minha Vida.

Nessa arena de interesses, a liberação de terras mais baratas, articulada ao processo empreendedor do capital imobiliário em produzir moradias lucrativas incorporou em suas estratégias novos eixos territoriais e tipologias de produção de moradia, como os condomínios e a verticalização para atrair um perfil de renda localizado no Distrito Federal.

Essa ação, em graus de entendimento diferenciados, é reconhecida pela atual gestão de Valparaíso. A prefeita reconheceu que essas moradias contratadas pelo Programa Minha Casa, Minha Vida para o atendimento das faixas 2 e 3 não são acessíveis para a população prioritária das políticas habitacionais locais em Valparaíso. Conforme destacado pela prefeita, "essa produção privada descontrolada traz externalidades negativas ao município, que precisa responder às demandas da população com pesados 
investimentos em infraestrutura, tais como mobilidade urbana, saneamento e esgotamento". 36

Outras entrevistas foram realizadas com prefeitos ou gestores, embora em nenhuma delas tenha se expressado com o grau de clareza como na entrevista realizada em Valparaíso de Goiás. Foi recorrente nas entrevistas o entendimento de que esta produção de moradias nos atuais municípios goianos não tem respondido às necessidades habitacionais locais. Por sua vez, ao serem questionados sobre as responsabilidades dos governos locais, estes não souberam expressar os caminhos possíveis para a reversão da situação e revelaram que os gestores municipais se sentem pressionados para aprovar projetos que impactarão na gestão e desenvolvimento urbano municipal.

Outros gestores acreditam que atraindo empresas para operacionalizar empreendimentos e um perfil de população com maior poder aquisitivo poderá melhorar a situação econômica do município. Quando questionados se a ausência ou carência de infraestrutura urbana não poderá gerar novos problemas sociais e o fato de uma população com maior poder aquisitivo poderá pressionar os gestores locais por melhorias de infraestrutura. Em linhas gerais, sinalizaram que as condições dos novos empreendimentos estão localizados nas principais linhas de acesso ao DF e que, existe melhora na infraestrutura urbana local não indicando de forma específica quais seriam. Ademais, mencionaram o projeto ainda na fase de debate da instalação do Trem de transporte de passageiros de Luziânia (GO) - Brasília (DF) conduzido pela ANTT que trará melhorias no transporte público e na infraestrutura urbana na Área Metropolitana de Brasília.

A investigação demonstrou a ineficiência na utilização dos instrumentos urbanísticos articulados à gestão habitacional, apontando desde a ausência de delimitação de ZEIS tipo áreas vazias ou a delimitação de ZEIS tipo áreas vazias, caso do GDF, utilizadas para a contratação de empreendimentos que não estão voltados para a faixa de renda faixa 1 .

A ausência e efetividade de implementação dos instrumentos para a gestão urbana e habitacional e a limitada capacidade de gestão administrativa municipal parecem emperrar o desenvolvimento de parcerias para a contratação dos empreendimentos habitacionais para o atendimento das famílias enquadradas na faixa 1. Acrescente-se a essa problemática o desenho das atuais políticas federais e estaduais, que não prioriza a

\footnotetext{
${ }^{36}$ Trecho da entrevista realizada com a Prefeita de Valparaíso de Goiás na data de 5 de janeiro de 2015 em Brasília, DF.
} 
aplicação dos instrumentos urbanos e não articula a política habitacional ao melhoramento da gestão urbana local, o que favorece e amplia a atuação dos investidores privados e influencia a distribuição de unidades habitacionais produzidas nestes municípios.

\subsection{Déficit habitacional versus investimentos do Estado de Goiás em municípios vinculados à Área Metropolitana de Brasília}

O conceito de déficit habitacional que pauta o desenvolvimento de políticas habitacionais em âmbito nacional é desenvolvido pela Fundação João Pinheiro (FJP) em parceria com o Ministério das Cidades. Desde os anos de 1990 a Fundação tem aperfeiçoado a metodologia para quantificar, qualificar e dimensionar o déficit habitacional brasileiro.

Atualmente, o déficit habitacional é calculado a partir da soma de quatro componentes ${ }^{37}:\left(1^{\circ}\right)$ domicílios precários; $\left(2^{\circ}\right)$ coabitação familiar; $\left(3^{\circ}\right)$ ônus excessivo com aluguel urbano; e $\left(4^{\circ}\right)$ adensamento excessivo de domicílios alugados. Os estudos que estimam o déficit habitacional da FJP auxiliam os gestores públicos em todas as esferas da Federação para a elaboração e aperfeiçoamento das políticas habitacionais.

Nos estudos mais recentes englobando o período de 2007 a 2012, a FJP estimou a variação do déficit habitacional por componente e apontou uma redução do déficit habitacional em termos absolutos.

\footnotetext{
${ }^{37}$ De acordo com a FPJ (2014), estes componentes são calculados de forma sequencial, na qual a verificação de um critério está condicionada à não ocorrência dos critérios anteriores. Essa forma garante que não há dupla contagem de domicílios, exceto pela coexistência de algum dos critérios e uma ou mais famílias conviventes secundárias que desejem constituir novo domicílio.
} 
Gráfico 6: - Variação do déficit habitacional brasileiro por componente: 2007-2012

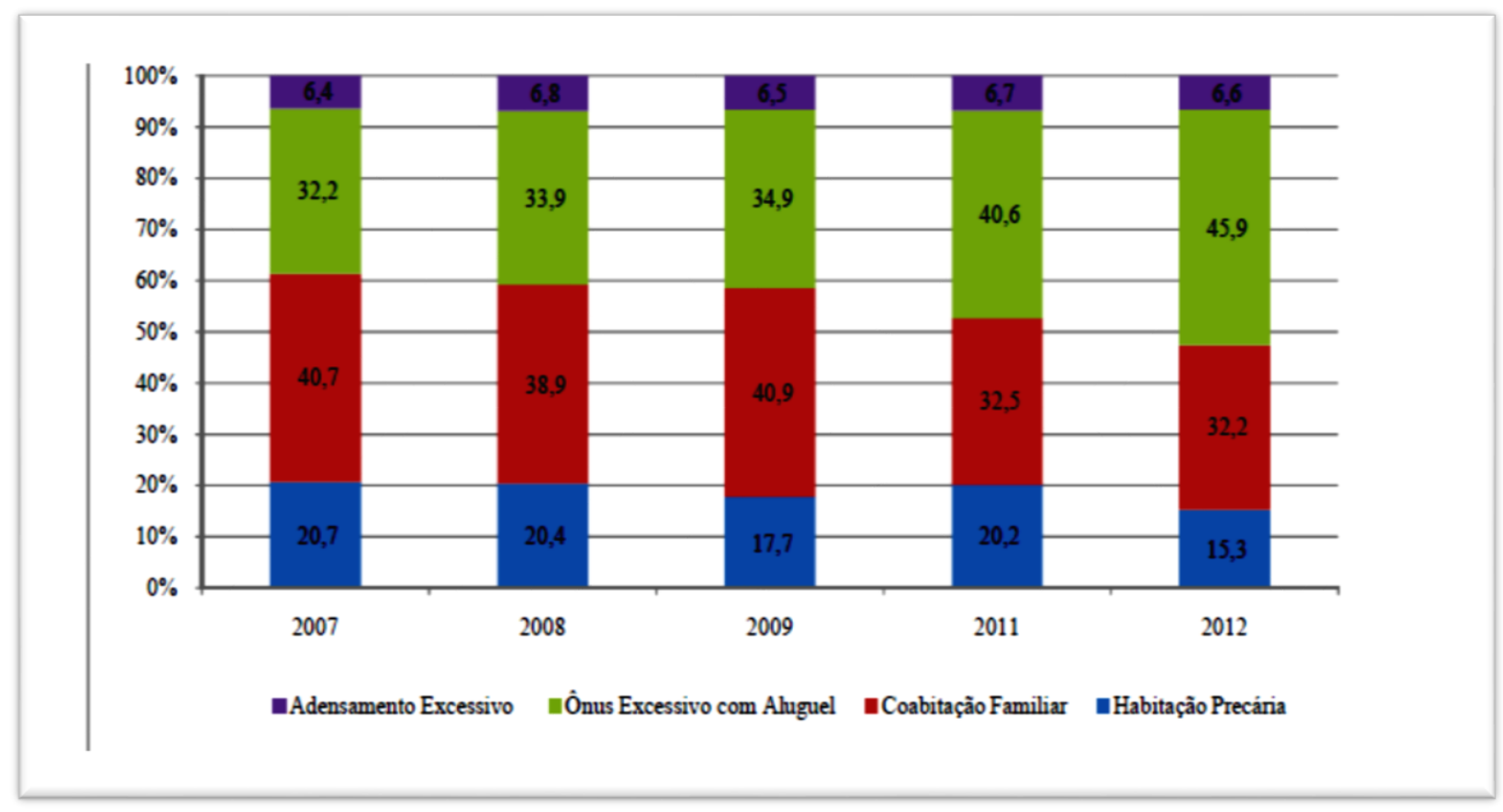

Fonte: FJP (2014).

No ano de 2007, o déficit habitacional estimado era de aproximadamente 6.102 milhões de unidades habitacionais. Já no ano de 2012 observa-se uma queda para 5.792 milhões de unidades. No entanto, ao longo do período analisado observa-se uma variação entre queda e elevação do déficit em termos absolutos. Já em relação aos componentes do déficit habitacional, verifica-se uma queda mais expressiva dos componentes habitação precária e coabitação familiar. Já o componente adensamento excessivo em domicílios alugados apresenta-se constante. No que diz respeito ao componente de participação do ônus excessivo com aluguel nota-se uma elevação significativa nos últimos três anos. Ao se estratificar a composição do déficit habitacional por faixa de renda, constata-se que mais de $70 \%$ estão concentrados na faixa de renda até três salários mínimos.

Ao analisarmos a distribuição dos componentes do défictit habitaiconal na Área Metropolitana de Brasília nota-se que os componentes de maior impacto são a coabitação familiar e o excedente de aluguel, respondendo por, respectivamente, 47,7\% e 37,2\% do total do déficit da AMB. 
Quadro 44 - Componentes do Déficti Habitacional na AMB: Censo 2010

\begin{tabular}{|c|c|c|c|c|c|c|c|c|c|c|c|c|}
\hline Nome do município & Déficit & Precárias & Coabitação & $\begin{array}{l}\text { Excedente } \\
\text { de aluguel }\end{array}$ & $\begin{array}{l}\text { Adensamento } \\
\text { de aluguel }\end{array}$ & Rústico & $\begin{array}{l}\text { Improvisa } \\
\text { dos }\end{array}$ & Cômodos & Conviventes & $\begin{array}{l}\text { Número de } \\
\text { domicilios }\end{array}$ & $\begin{array}{c}\text { População } \\
2010\end{array}$ & $\begin{array}{c}\text { Proporção } \\
\text { domicílios } \\
\text { com } \\
\text { déficit }\end{array}$ \\
\hline Novo Gama & 3.588 & 179 & 2.144 & 884 & 579 & 132 & 46 & 1.020 & 1.168 & 26.543 & 95.013 & $13,52 \%$ \\
\hline Valparaíso de Goiás & 5.071 & 111 & 2.362 & 2.113 & 852 & 50 & 61 & 772 & 1.592 & 39.570 & 132.947 & $12,82 \%$ \\
\hline Águas Lindas de Goiás & 5.304 & 571 & 2.925 & 1.140 & 1.055 & 401 & 170 & 1.123 & 1.856 & 44.386 & 159.505 & $11,95 \%$ \\
\hline Cidade Ocidental & 1.858 & 306 & 974 & 443 & 201 & 295 & 11 & 279 & 702 & 15.935 & 55.883 & $11,66 \%$ \\
\hline Cristalina & 1.568 & 361 & 685 & 481 & 126 & 112 & 249 & 126 & 566 & 13.773 & 46.568 & $11,39 \%$ \\
\hline Planaltina & 2.453 & 235 & 1.367 & 647 & 345 & 205 & 30 & 233 & 1.133 & 23.065 & 81.612 & $10,63 \%$ \\
\hline Luziânia & 5.335 & 395 & 2.892 & 1.634 & 691 & 334 & 61 & 658 & 2.256 & 50.673 & 174.546 & $10,53 \%$ \\
\hline Formosa & 3.136 & 496 & 1.374 & 1.089 & 252 & 226 & 270 & 37 & 1.337 & 30.593 & 100.084 & $10,25 \%$ \\
\hline Santo Antônio do Descoberto & 1.736 & 81 & 884 & 533 & 303 & 34 & 47 & 104 & 794 & 18.021 & 63.166 & $9,63 \%$ \\
\hline Alexânia & 612 & 30 & 354 & 196 & 48 & 21 & 9 & 86 & 269 & 7.502 & 23.828 & $8,15 \%$ \\
\hline Padre Bernardo & 648 & 270 & 300 & 54 & 32 & 204 & 66 & - & 300 & 8.197 & 27.689 & $7,91 \%$ \\
\hline Cocalzinho de Goiás & 341 & 92 & 179 & 53 & 20 & 88 & 4 & 44 & 135 & 5.321 & 17.391 & $6,41 \%$ \\
\hline Brasília & 116.601 & 8.642 & 54.769 & 46.184 & 13.923 & 7.859 & 783 & 14.954 & 40.169 & 785.733 & 2.562 .963 & $14,84 \%$ \\
\hline Total & 148.251 & 11.768 & 71.207 & 55.450 & 18.427 & 9.961 & 1.807 & 19.436 & 52.277 & 1.069 .312 & 3.541 .195 & $139,69 \%$ \\
\hline
\end{tabular}

Fonte: IPEA (2012). Organizado por Karla França. 
Merece destaque que o componente excedente por aluguel é significativo nos Municípios de Luziânia, Valparaíso de Goiás e em Brasília, ao passo que a coabitação é mais elevada em Brasília, Águas Lindas de Goiás, Luziânia, Valparaíso de Goiás e Novo Gama. Vale lembrar que o PMCMV não foi desenhado visando ao enfrentamento significativo na redução do componente excedente do aluguel, sendo necessária a elaboração de políticas alternativas para a redução deste componente, que tem se mostrado elevado, em especial, nas áreas metropolitanas.

Em consonância aos estudos apontados pela FJP, o Plano Estadual de Habitação de Goiás reconhece que os municípios que integram a Região de Planejamento do estado de Goiás - "Região do Entorno do DF" - detêm de 5\% a 10\% do déficit habitacional do estado. Considerando as informações registradas no cadastro do Programa Moradia Digna, sob a coordenação da AGEHAB (GO), confirma-se que a região do entorno do DF detém uma demanda habitacional de $8 \%$ a $12 \%$, sendo considerada a terceira região do estado com maior demanda para a construção de casas e também em construção em terreno próprio cujo enquadramento de renda é majoritariamente até um salário mínimo. Assinale-se que os dados da demanda habitacional representam as necessidades habitacionais espontâneas registradas no cadastro de habitação, diferentemente do déficit habitacional, pautados nos dados da FJP e do Censo 2010.

\section{Figura 27 - Demanda Habitacional por Região de Planejamento do Estado de Goiás}

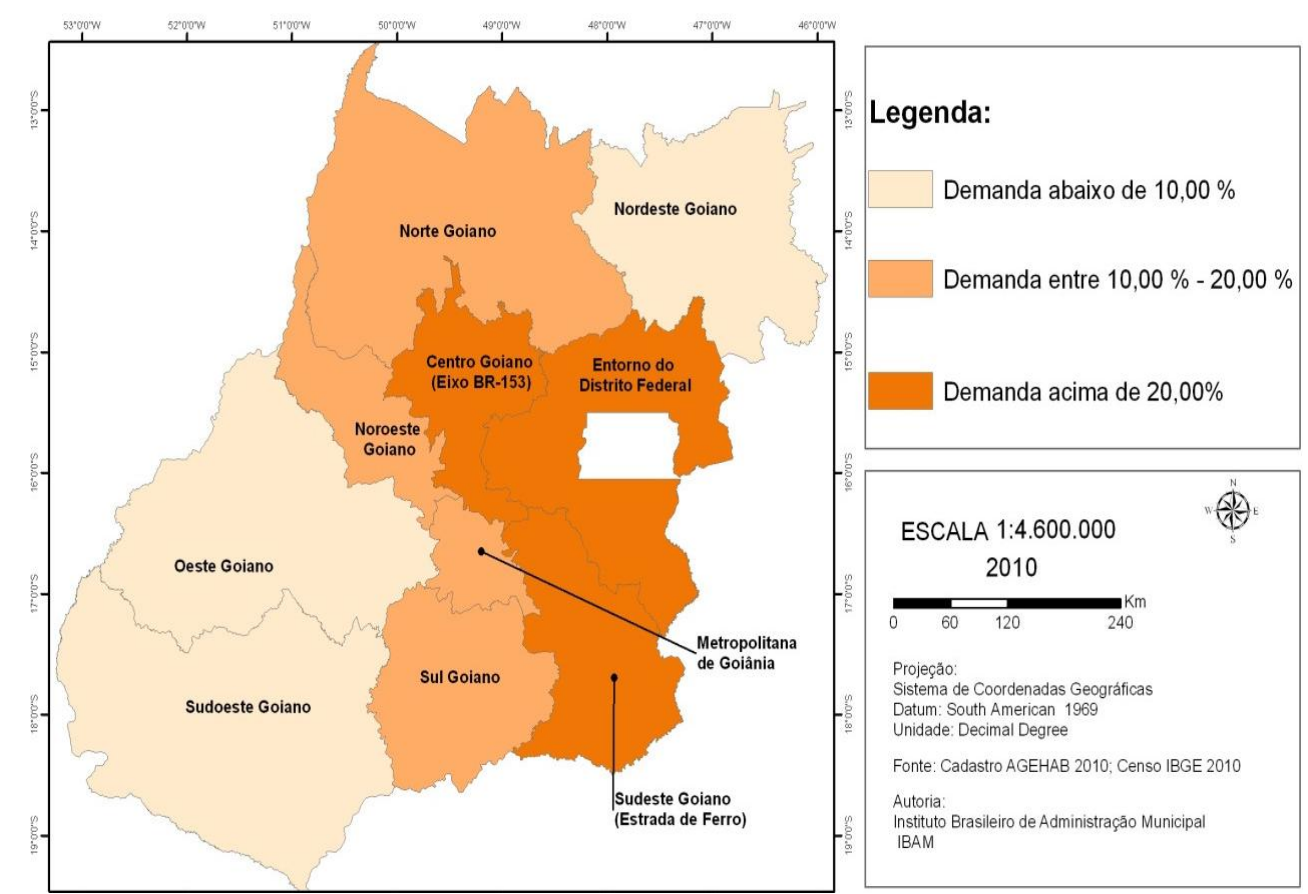

Fonte: PEHIS-GO (2012). 
Uma das metas do Plano Estadual de Habitação para a provisão de moradia social foi verificar a quantidade de terra pública do Estado nos Municípios disponíveis por regiões de planejamento, para induzir a construção de unidades habitacionais. Ao total, foi verificada a quantidade de 41 áreas disponíveis, sendo que sete delas foram identificadas na Região de Planejamento "Entorno do DF”. Nestas sete áreas o Plano Estadual apresentou a proposta de construir 1.265 (mil duzentas e sessenta e cinco) novas unidades habitacionais com recursos do FAR (faixa 1). No entanto, nas entrevistas realizadas nas Prefeituras não foi identificada a localização dessas áreas, assim como não foi possível ver se estas de fato estão sendo utilizadas para a construção de unidades habitacionais destinadas para as famílias de mais baixa renda.

Já em relação aos investimentos do Estado destinados para a urbanização de assentamentos precários, realizados por meio do PAC, 39,3\% destes recursos foram destinados a obras e investimentos em municípios localizados no Entorno do Distrito Federal.

Figura 28- Municípios com principais Investimentos PAC (OGU +FNHIS) em andamento: 2012
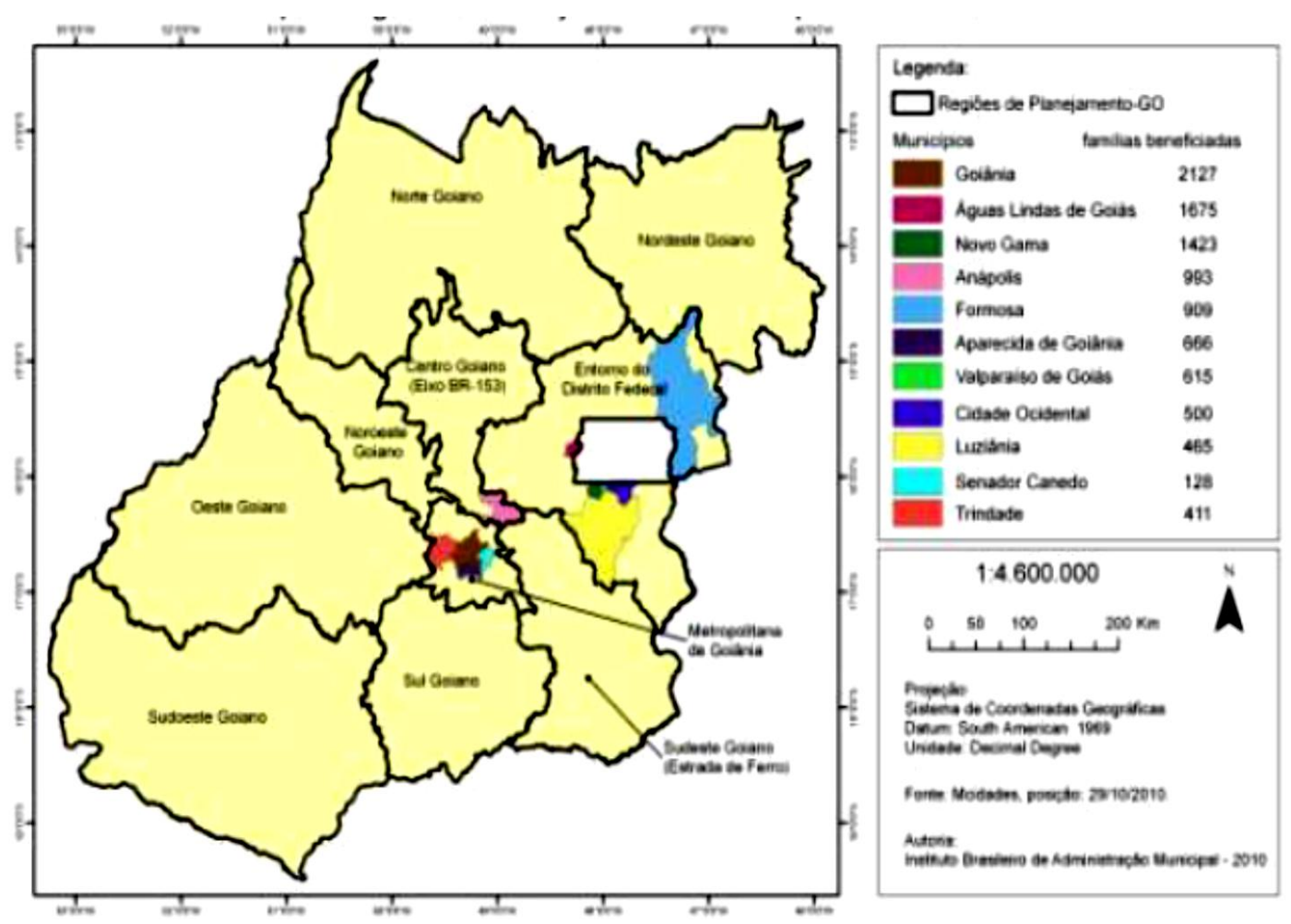

Fonte: PEHIS-GO (2012). 
Os investimentos em urbanização de favelas na Região do Entorno do DF ficaram atrás apenas dos investimentos aportados na Região Metropolitana de Goiânia, que atingiu 46\% dos R\$ 161 milhões de recursos contratados pelo Estado até o ano de 2012. O volume de famílias atendidas com os investimentos se revelou superior na região do Entorno do DF (56,4\%), se comparado à Região Metropolitana de Goiânia $(33,6 \%)$ (PEHIS-GO, 2012).

Nota-se que, dos investimentos aportados pelo Estado de Goiás na Região do Entorno do DF, os principais municípios contemplados foram aqueles que apresentaram forte dinâmica metropolitana com o DF, a saber: Águas Lindas de Goiás, Luziânia, Cidade Ocidental, Novo Gama e Valparaíso de Goiás.

Ao analisarmos os convênios firmados na área de habitação entre o Ministério das Cidades e os Municípios integrantes da Área Metropolitana de Brasília verifica-se que todos os municípios (Ver Apêndice L) firmaram convênios visando melhorar obras de infraestrutura urbana, melhoria das condições de habitação para população de baixa renda.

Nota-se que Águas Lindas de Goiás, Novo Gama, Cidade Ocidental e Luziânia foram os municípios integrantes da AMB que firmaram um elevado número de convênios em termos quantitativos e de recursos orçamentários. Nas entrevistas e visitas a campo nos respectivos municípios os gestores locais não souberam informar a localização e situação das obras objetos desses convênios.

\subsection{A produção Habitacional do PMCMV na Área Metropolitana de Brasília: novas reconfigurações urbanas}

Esta seção tem por finalidade verificar a distribuição e os recursos do programa Minha Casa, Minha Vida e seus impactos na reconfiguração urbana na Área Metropolitana de Brasília.

Os procedimentos metodológicos adotados para a identificação e mapeamento dos empreendimentos habitacionais na Área Metropolitana de Brasília dividem-se em três etapas. A primeira etapa foi de identificação do volume de empreendimentos habitacionais financiados pelo Programa Minha Casa, Minha Vida a partir dos dados oficiais fornecidos pelo Ministério das Cidades, Caixa Econômica Federal e a AGEHAB. A segunda etapa foi de tratamento dos dados, comparação do volume de contratação, 
identificação das faixas de renda e fonte de financiamento envolvidos nas contratações. Outro procedimento adotado foi a espacialização desses empreendimentos nos municípios, sobretudo a partir dos endereços fornecidos pelo Ministério das Cidades e, em alguns casos, pelos Municípios e pela AGEHAB. Nesta etapa, houve dificuldades ${ }^{38}$, uma vez que a Caixa e o Ministério das Cidades não encaminharam os dados georreferenciados ou o endereço de todos os empreendimentos. Para identificar a localização aproximada dos empreendimentos, para a obtenção dessas informações realizaram-se entrevistas com os gestores públicos, que em sua maioria apenas sinalizavam o bairro o que dificultou a elaboração de mapas com localização georreferenciada. Na terceira etapa foram realizadas entrevistas com os agentes do poder público municipal. Essas entrevistas auxiliaram na compreensão do funcionamento dos chamamentos públicos e da abertura de processo para habilitação de empresas que se interessassem em apresentar os projetos.

As entrevistas e visitas aos empreendimentos ${ }^{39}$ também contribuíram para a compreensão da produção habitacional e sua relação com a questão metropolitana. Nessas visitas foram realizadas observações acerca da infraestrutura dos empreendimentos, conversas informais com a comunidade relatando as principais dificuldades de inserção urbana e social dos empreendimentos.

Cabe assinalar que, nesta pesquisa, entende-se inserção urbana como a forma em que as unidades habitacionais se articulam no espaço urbano, considerando a sua localização e suas conexões com as infraestruturas e o atendimento por serviços públicos (ABIKO; ORNSTEIN, 2002).

As contratações do Programa Minha Casa, Minha Vida para o atendimento da faixa 1 com financiamento do FAR ocorreram desde a etapa 1 do PMCMV. O município de Águas Lindas de Goiás foi o primeiro a contratar obras destinadas para o atendimento da faixa 1 no ano de 2009, com 199 unidades habitacionais na tipologia casa/loteamento e execução da construtora Dávila Reis. No ano de 2010, ainda na etapa 1 do PMCMV, ocorreu a contratação de mais 104 unidades habitacionais. Na segunda fase do PMCMV foram contratadas com financiamento do FAR, em toda a AMB, 2.813 (duas mil oitocentas e treze) unidades habitacionais nos municípios de Águas Lindas de Goiás

\footnotetext{
${ }^{38}$ As dificuldades para a obtenção de dados pode ser observada nas respostas institucionais do Ministério das Cidades e Caixa, conforme apêndice J.

${ }^{39}$ A relação dos empreendimentos visitados encontra-se no Apêndice G.
} 
(903), Formosa (723), Luziânia (499) e Planaltina (688). O maior volume de unidades contratadas para o atendimento das famílias enquadradas na faixa 1 ocorreu no município de Águas Lindas de Goiás, respondendo por $42 \%$ do volume de contratação dos municípios que integram a AMB. Todos esses empreendimentos apresentam a tipologia de casa/loteamento, diferentemente dos empreendimentos contratados pelo DF, para o atendimento da faixa 1 , que apresentam um padrão vertical.

Nas análises relacionadas às formas de financiamento e atendimento das necessidades habitacionais da faixa 1, destaca-se a produção habitacional com financiamento do FDS, nos municípios de Planaltina, Formosa e Novo Gama. Na primeira fase do PMCMV, pela modalidade do PMCMV-E, foram contratadas, pelos três municípios na primeira etapa do Programa, 818 unidades habitacionais. Somente no município de Planaltina o PMCMV-E representa 60\% das obras contratadas para o atendimento da faixa 1 .

Já na segunda fase do Programa nota-se uma redução de contratação pela modalidade PMCMV-E, se comparada à fase 1. Na segunda fase houve a contratação de 541 unidades habitacionais em apenas dois municípios - Santo Antônio de Goiás e Luziânia. Santo Antônio de Goiás contratou apenas o empreendimento Loteamento Parque Estrela Dalva XVII, com 149 unidades. Já o município de Luziânia contratou dois empreendimentos, totalizando 392 unidades, distribuídas entre o Residencial Alfa e o Residencial Almirante Vermelho, no Parque Alvorada, com a tipologia casa/loteamento. Vale ressaltar que o Residencial Alfa encontra-se em andamento, com medições entre $25 \%$ e $50 \%$ das obras.

Também para o atendimento da faixa 1, apenas os municípios de Alexânia e Padre Bernardo se enquadram nos requisitos para contratação pela modalidade do PMCMVOferta Pública para o atendimento da faixa 1. Respectivamente, Alexânia contratou 49 UHs e Padre Bernardo 50 UHs na oferta de 2009 e com estimativas de medições entre $75 \%$ e $95 \%$.

Somando todas as modalidades do PMCMV em operação nestes municípios destinadas para o atendimento da faixa 1, os municípios goianos integrantes da AMB/Ride-DF contrataram 5.074 unidades habitacionais. Considerando, o déficit habitacional urbano dos municípios goianos integrantes da AMB é de aproximadamente 30 mil unidades para a faixa de renda 1 e para o recorte da AMB com a inserção do DF é de aproximadamente 102 mil unidades na faixa 1. 
Ao comparar o volume de unidades contratadas na primeira fase do programa em relação a segunda fase para o atendimento da faixa 1 vinculado ao FAR, verifica-se novas frentes de expansão da modalidade. Vale destacar, que somente o município de Águas Lindas de Goiás, contratou pelo FAR na primeira fase do programa. Ao passo, que na segunda fase do programa, nota-se um eixo de contratações nos municípios de Águas Lindas de Goiás/ Luziânia/Planaltina de Goiás/ Formosa. A tipologia dos empreendimentos direcionados para o atendimento das mais de menos baixa renda nos municípios integrantes da Área Metropolitana de Brasília são majoritariamente do tipo casa/loteamento, diferentemente do perfil verticalizado e na forma de condomínio fechado presente no Distrito Federal.

Também, ao comparar as construtoras que operam do PMCMV nos municípios da AMB e no DF que operacionalizam os empreendimentos direcionados para a Faixa 1, nota-se que nos municípios integrantes da AMB são as pequenas e médias construtoras que operam ao passo que no DF são as médias e grandes construtoras. Na primeira e segunda fase do programa nos Municípios da AMB são as pequenas e médias que operam o Programa. Em linhas gerais, são sempre as mesmas construtoras o que demonstra uma forte influências destas em impor seus projetos, suas formas e padrão construtivo e revela a dificuldade do poder público, em especial o municipal de propor mudanças e adequações.

A pesquisa permitiu identificar também a forte relação entre poder público municipal e o grupo de construtoras, na doação de terrenos por parte do poder público e execução dos projetos de forma isolada pelas construtoras. Por outro lado, observa-se que não existe nas Prefeituras um planejamento de projetos antecipados, como ocorre na estrutura do GDF.

Na figura 29, observa-se o volume absoluto das contratações de empreendimentos realizadas na modalidade FAR pelos municípios goianos integrantes a AMB nas duas fases do PMCMV. 
Figura 29 - Contratações de Unidades Habitacionais fonte de recursos FAR -

AMB/RIDE-DF

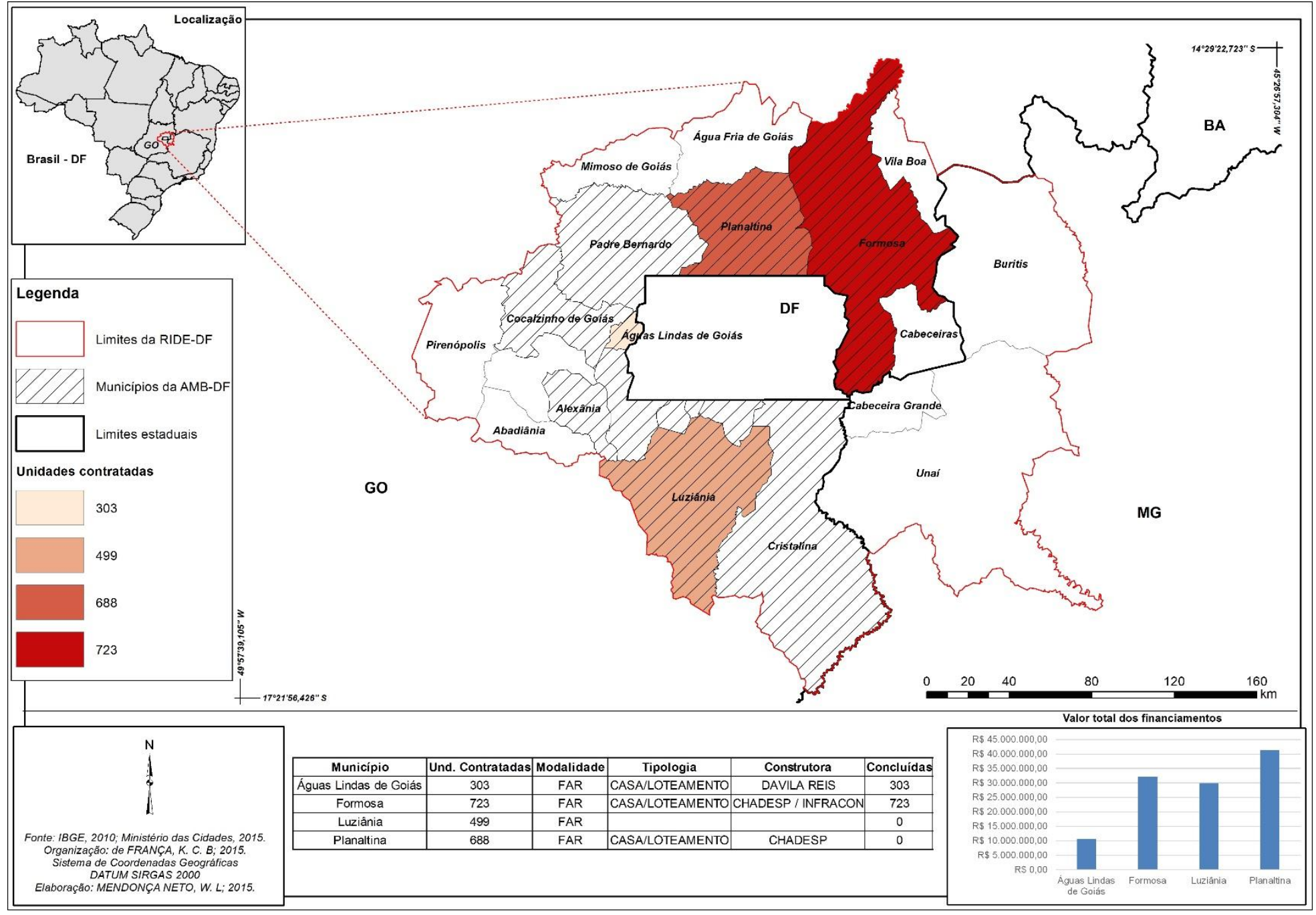


Águas Lindas de Goiás é um dos municípios que mais contrataram empreendimentos para o atendimento da faixa 1 . O primeiro empreendimento contratado ocorreu no ano de 2009, para a construção de 203 unidades habitacionais em duas etapas. O primeiro deles é o Residencial Betel, com 199 (cento e noventa e nove) unidades, no valor total de $\mathrm{R} \$$ 6.657.000,01, e o Residencial Betel II, com 104 (cento e quatro) unidades, no valor total de $\mathrm{R} \$ 4.056 .000,00$. O empreendimento foi executado pela construtora Davila Reis, na tipologia casa/loteamento.

\section{Figura 30 - Residencial Bethel I}

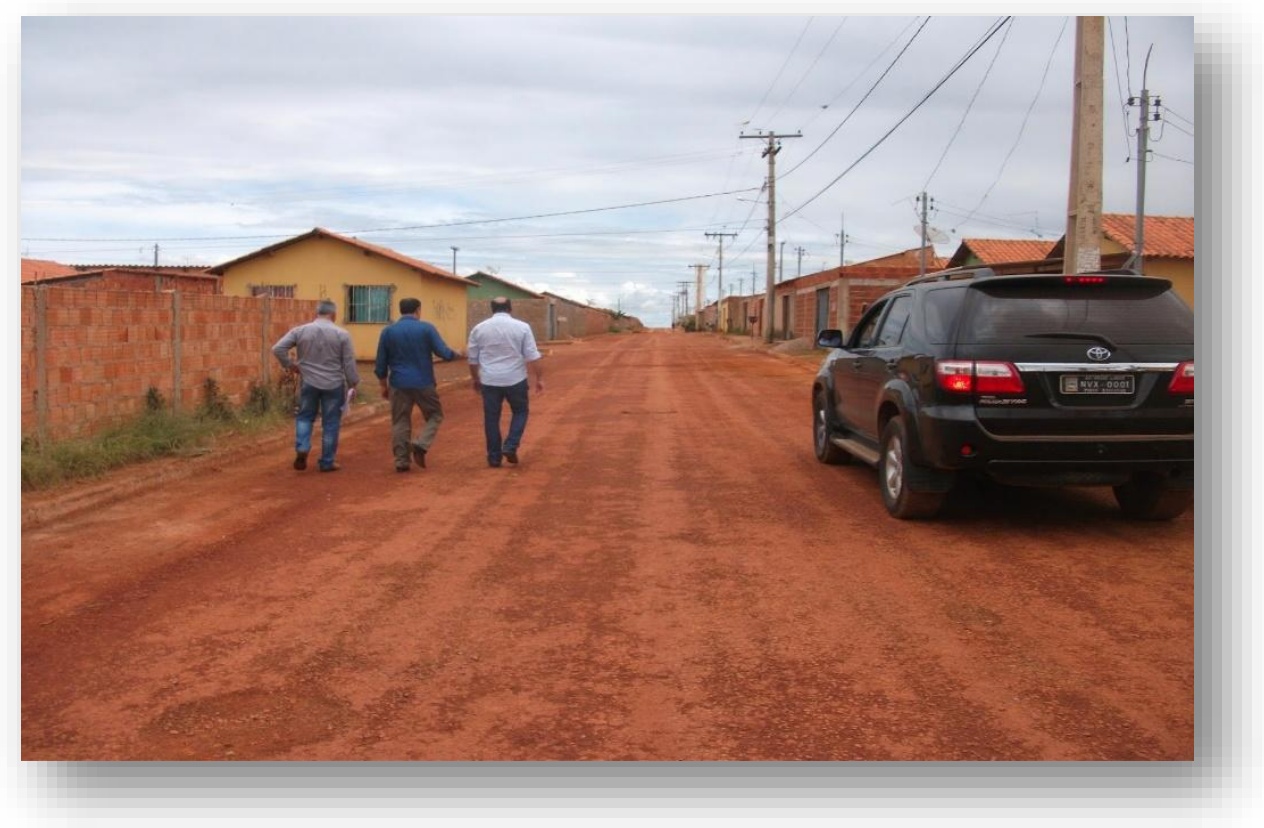

- O TCU recomendou melhoramento da pavimentação, pois esta estava abaixo do aprovado no projeto básico do empreendimento.

Fonte: Assessoria de Imprensa da Prefeitura Águas Lindas (2014).

As visitas em Águas Lindas foram realizadas no empreendimento Residencial Bethel, o que permitiu identificar a tipologia dos empreendimentos, ou seja, o tipo casa (unidade habitacional térrea), e também a inserção urbana do empreendimento, a existência ou não de áreas providas de equipamentos comunitários, comércio e serviços voltados à saúde, educação, segurança, transporte e lazer. O empreendimento está localizado no bairro Jardim Planalto, entre as quadras A e L, apresenta patologias nas construções internas das residências, ausência de comércio, escola e posto de saúde na vizinhança e graves problemas de acesso ao transporte público e mobilidade urbana. Assinale-se que a qualidade da pavimentação está fora dos padrões do projeto. Na visita 
realizada ao empreendimento foi constatada a ausência de pavimentação. Os moradores que concordaram em receber a visita da pesquisadora em seus lares não permitiram a reprodução de fotos.

Outro empreendimento contratado via FAR é o Residencial Vitória Régia, localizado no Bairro Parque da Barragem. O empreendimento apresenta quatro etapas. Essas etapas foram contratadas em 2010 (1 $1^{\text {a }}$ etapa) e as demais no ano de 2013 (em andamento). Observa-se que o Residencial Vitória Régia está em uma área não consolidada, e no entorno do empreendimento constatou-se a ausência de equipamentos e serviços, como escola, creche, unidade básica de saúde, área de lazer. Essas informações confirmaram a desconexão na escolha da localização do terreno e nas diretrizes do Plano Diretor. Nas entrevistas com os gestores municipais, observam-se a fragilidade de ações em delimitar ZEIS em áreas vazias, a inexistência de banco de terras ou ações da administração municipal de adotar taxas diferenciadas para as famílias de baixa renda em relação aos impostos e serviços a serem cobrados. Sobre este último item o gestor entrevistado revelou desconhecimento.

Acerca desse assunto, os moradores do residencial Bethel, nos relatos informais, enfatizaram a dificuldade em realizar o registro do imóvel, pelo fato de as taxas cobradas do ITBI e as outras taxas cartoriais serem elevadas para a sua renda. Também enfatizaram problemas na qualidade das moradias, sinalizando patologias, como vazamentos/infiltrações/rachaduras em paredes, pisos ou tetos, defeitos em janelas e portas e, sobretudo, a falta de pavimentação.

Outro empreendimento visitado e com obras concluídas foi o Residencial Jardim Planalto, localizado na Avenida Flamboyant, setor Bela Vista, município de Formosa. Esse empreendimento foi executado pela construtora Infracon, com a contratação de 496 unidades do tipo casa, com área útil de $38,25 \mathrm{~m}^{2}$, todas divididas em dois quartos, sala, banheiro, cozinha e área de serviço externa. Esse empreendimento recebeu investimento total de R\$23,3 milhões, com recursos do Fundo de Arrendamento Residencial (FAR). 


\section{Figura 31 - Residencial Jardim Planalto}

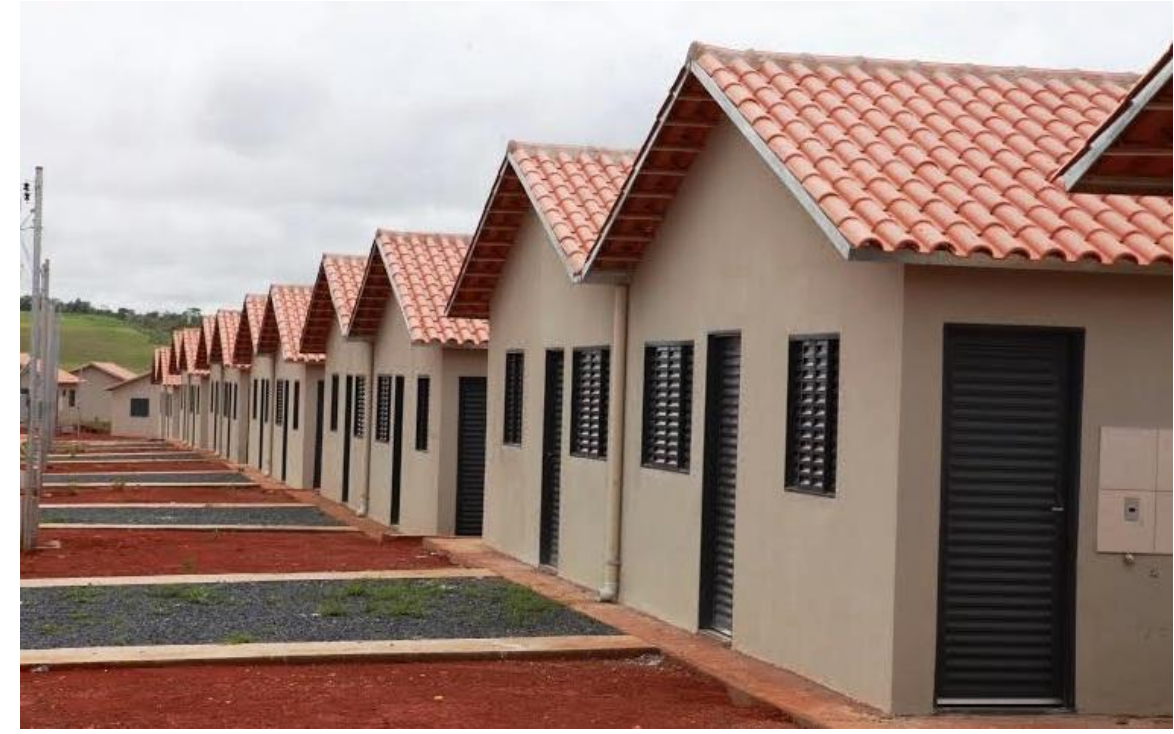

Fonte: Imprensa da Prefeitura de Formosa, GO.

Considerando os aspectos de inserção urbana do empreendimento, observa-se que a localização do terreno ocorreu em área não consolidada, mas apresenta uma melhor inserção, se comparado ao empreendimento Bethel. A qualidade das unidades visitadas apresentaram número menor de patologias relatadas pelos moradores. O Residencial Jardim Planalto encontra-se em um bairro que apresenta oferta de serviços, como supermercado, farmácia, escola, embora em número reduzido.

Em Luziânia, o Residencial Jardim São Paulo, contratado no ano de 2013, encontra-se com as obras em andamento, sendo executadas 499 unidades habitacionais. Trata-se de um novo bairro a ser construído em Luziânia, cuja localização é próxima à BR-040, principal via de ligação com o Distrito Federal. Até a realização desta pesquisa, as obras estavam em estágio inicial, não sendo possível avaliar a construção dos equipamentos urbanos. Sublinha-se que nas proximidades do terreno inexistem equipamentos públicos e serviços urbanos.

No município de Planaltina de Goiás, encontra-se também, em estágio inicial, a execução das obras do Residencial São Francisco, localizado em área próxima ao bairro Jardim das Palmeiras 2. As obras são executadas pela Joares Construtora, e a previsão é que sejam construídas 688 unidades habitacionais para o atendimento da faixa 1. Vale sublinhar que não foi possível ter acesso ao estágio dos empreendimentos do Residencial Jardim São Paulo, em Luziânia, e do Residencial São Francisco, em 
Planaltina de Goiás, pelo fato de os dados do projeto não terem sido detalhados pelas construtoras e prefeitura. Esses empreendimentos mantêm a tipologia casa/loteamento. A ausência dos documentos comprometeu as análises, a inserção do empreendimento e a previsão de infraestrutura acoplada aos empreendimentos.

Nos demais municípios da AMB, não houve contratação do Programa Minha Casa, Minha Vida para o atendimento da faixa de renda 1, por meio do FAR, até a elaboração desta pesquisa.

As visitas aos empreendimentos, o tratamento dos dados e as entrevistas se constituíram em subsídios importantes para confirmarmos a inexistência, por parte das prefeituras, de um mapeamento e diagnóstico da implantação dos empreendimentos, o que traz enormes dificuldades para estratégias de gestão habitacional local. A ausência do mapeamento fragiliza ações de subsídio ao planejamento e políticas públicas para os bairros onde foram construídos os empreendimentos e as ações necessárias de planejamento para o atendimento da demanda por serviços urbanos.

Não há, nas prefeituras, representação gráfica aproximada e marcação de lotes. Esses fatores, atrelados ao não repasse $\operatorname{dos} \operatorname{dados}^{40}$ georreferenciados pela Caixa Econômica Federal, dificultaram uma análise acurada dos impactos da inserção urbana, nem sempre sanados pelas visitas técnicas aos empreendimentos, visto a ausência de informações técnicas dos projetos básicos dos empreendimentos, para estabelecer parâmetros com os empreendimentos entregues.

As visitas aos empreendimentos revelaram a fragilidade de inserção urbana, uma vez que se compreende por inserção urbana de um empreendimento habitacional a sua boa localização na malha urbana, em áreas ou bairros dos municípios providas de infraestrutura instalada e serviços e equipamentos urbanos.

A boa localização do terreno traz benefícios para uma inserção urbana adequada, além de reduzir os custos de infraestrutura e expansão urbana periférica. Corrobora-se com Ferreira (2012, p. 68) quando assinala que:

[...] o empreendimento habitacional bem inserido na cidade deve estar próximo a estabelecimentos de comércio e serviços e de equipamentos de educação, saúde, cultura e lazer. A acessibilidade em tempo adequado a centralidades regionais e locais e a integração à rede de transporte público também são necessárias. Em outras palavras, um empreendimento habitacional bem inserido na cidade é aquele comprometido com processo de urbanização justo e democrático, que garanta qualidade de vida aos moradores e aos demais cidadãos impactados por ele, direta ou indiretamente.

\footnotetext{
${ }^{40}$ Vide apêndice $\mathrm{J}$.
} 
Acerca dos problemas de inserção urbana, o relatório de fiscalização realizado no ano de 2014 pelo Tribunal de Contas da União (TCU), relativo à natureza operacional no Programa Minha Casa, Minha Vida (PMCMV), apontou como uma falha grave desse Programa a reduzida taxa de contratação dos empreendimentos vinculados à modalidade FAR, em especial nos municípios próximos ou integrantes de regiões metropolitanas. $\mathrm{O}$ relatório aponta como elemento conclusivo para a reduzida contratação via FAR a indisponibilidade de terras ou seus preços elevados, o que inviabiliza a contratação do empreendimento para o atendimento da faixa de renda 1.

Como recomendação para assegurar a efetividade de programas habitacionais destinados à população de baixa renda foi destacada, no relatório, a necessidade de medidas para a regulação do acesso à terra, que traria impacto positivo nos terrenos que têm preço elevado. Essa recomendação também foi identificada por $74 \%$ dos respondentes da pesquisa eletrônica, realizada com gerentes de Gidur da Caixa na auditoria realizada pelo TCU.

De acordo com as recomendações do TCU, a regulação e a criação de um banco de terras permitiriam um "estoque" de terras públicas voltadas para as políticas habitacionais de interesse social, em especial as destinadas para famílias de baixa renda. Entretanto aponta-se a dificuldade de capacidade e gestão para a implementação de um banco de terras públicas nos municípios brasileiros, uma vez que é frágil a estrutura de recursos humanos e materiais nas prefeituras, fato este não considerado no relatório do TCU. Portanto, não basta delimitar zonas especiais de interesse social e disponibilizar estoques de terras sem mecanismos indutores presentes no desenho das políticas, financiamento e programas habitacionais.

As entrevistas e visitas nos municípios analisados revelaram a baixa qualificação técnica dos quadros de pessoal na área de habitação. Observa-se, nas visitas realizadas nas prefeituras, a inexistência de secretarias ou órgãos específicos na área de habitação. Em linhas gerais, as questões habitacionais estão vinculadas de forma pulverizada nas áreas de infraestrutura e na área da secretaria de ação social. Basicamente, cabe à secretaria de ação social realizar o enquadramento das famílias. Também se observou a falta de quadro efetivo de profissionais nos municípios para gerenciar e avaliar o programa. 
Também, observa-se a baixa capacidade das Prefeitura em propor alterações nos projetos ou assumir um papel mais protagonista, ainda mais, quando houve doação de terreno público. Nas entrevistas realizadas, em nenhum dos municípios foi constatado alterações de melhorias nos projetos ou uma ação mais estratégica na localização do terreno considerando, por exemplo, os laudos urbanísticos e os impactos da construção do empreendimento em determinada localidade do município.

Ainda que se reconheça as resistências e dificuldades das construtoras de quando poder público municipal solicita adequações nos projetos, uma vez que as construtoras adotam tecnologias padronizadas e não permitem alterações nos projetos. Constata-se por meio das entrevistas que não houve por parte das Prefeituras solicitações de alterações nos projetos ainda que pontuais sob a alegação que poderia elevar o valor do empreendimento.

Em todos os empreendimentos visitados e nas entrevistas com os gestores observa-se o não cumprimento, conforme estipulado, da localização do terreno com acesso a serviços básicos. Os empreendimentos direcionados para o atendimento das famílias de menor baixa renda dos municípios integrantes da AMB/Ride-DF apresentam uma qualidade inferior de infraestrutura, se comparados aos empreendimentos para o atendimento das famílias de menor baixa renda no DF. Também nota-se uma qualidade de unidade habitacional melhor nos projetos contratados pela modalidade PMCMV-E nos municípios goianos, em comparação aos projetos contratados pelo FAR.

Em todos os empreendimentos vinculados ao FAR foi constatado o não cumprimento do poder público municipal dentro do prazo para provimento de infraestrutura nas áreas comuns dos empreendimentos ou no seu entorno. Esses problemas não são exemplos isolados e pontuais identificados nas visitas, dada a sua recorrência nos vários empreendimentos contratados Brasil afora. Diante disso, eles permitem levantar elementos conclusivos de uma omissão dos órgãos federais responsáveis pela gestão e execução do Programa na esfera federal em aperfeiçoar os mecanismos e apontar as soluções quando o poder público local não cumpre as exigências mínimas de instalação de infraestrutura urbana.

Já em relação à produção habitacional acima de $\mathrm{R} \$ 1.600$ ou seja, a contratação de empreendimentos para famílias enquadradas nas faixas de renda 2 e 3 operacionalizada pelo setor privado, verificou-se que todos os municípios goianos inclusos na AMB possuem empreendimentos contratados nessas faixas de renda, totalizando 57.944 unidades habitacionais contratadas, sendo 50.779 unidades para o atendimento das 
famílias enquadradas na faixa 2 e 7.165 unidades contratadas para o atendimento das famílias enquadradas na faixa 3. Os empreendimentos contratados nas faixas 2 e 3 apresentam uma taxa de conclusão que supera os $80 \%$, e majoritariamente os empreendimentos estão vinculados à submodalidade apoio à produção de imóvel novo e apoio à produção. 
Figura 32:Espacialização do PMCMV-1 - faixas de renda 2 e 3 nos Municípios da AMB/Ride-DF

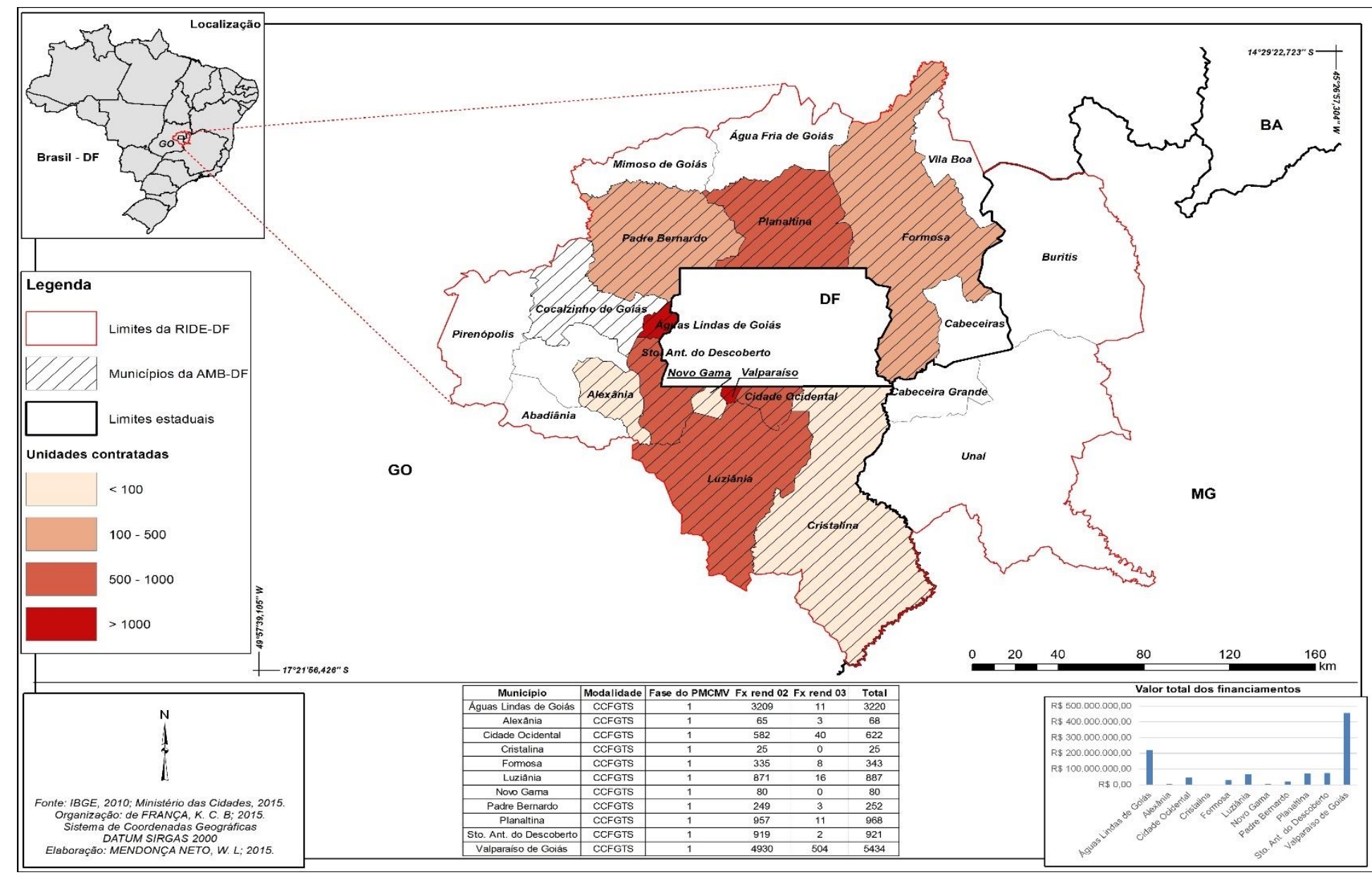


Figura 33:Espacialização do PMCMV-2- faixas de renda 2 e 3 nos Municípios da AMB/Ride-DF

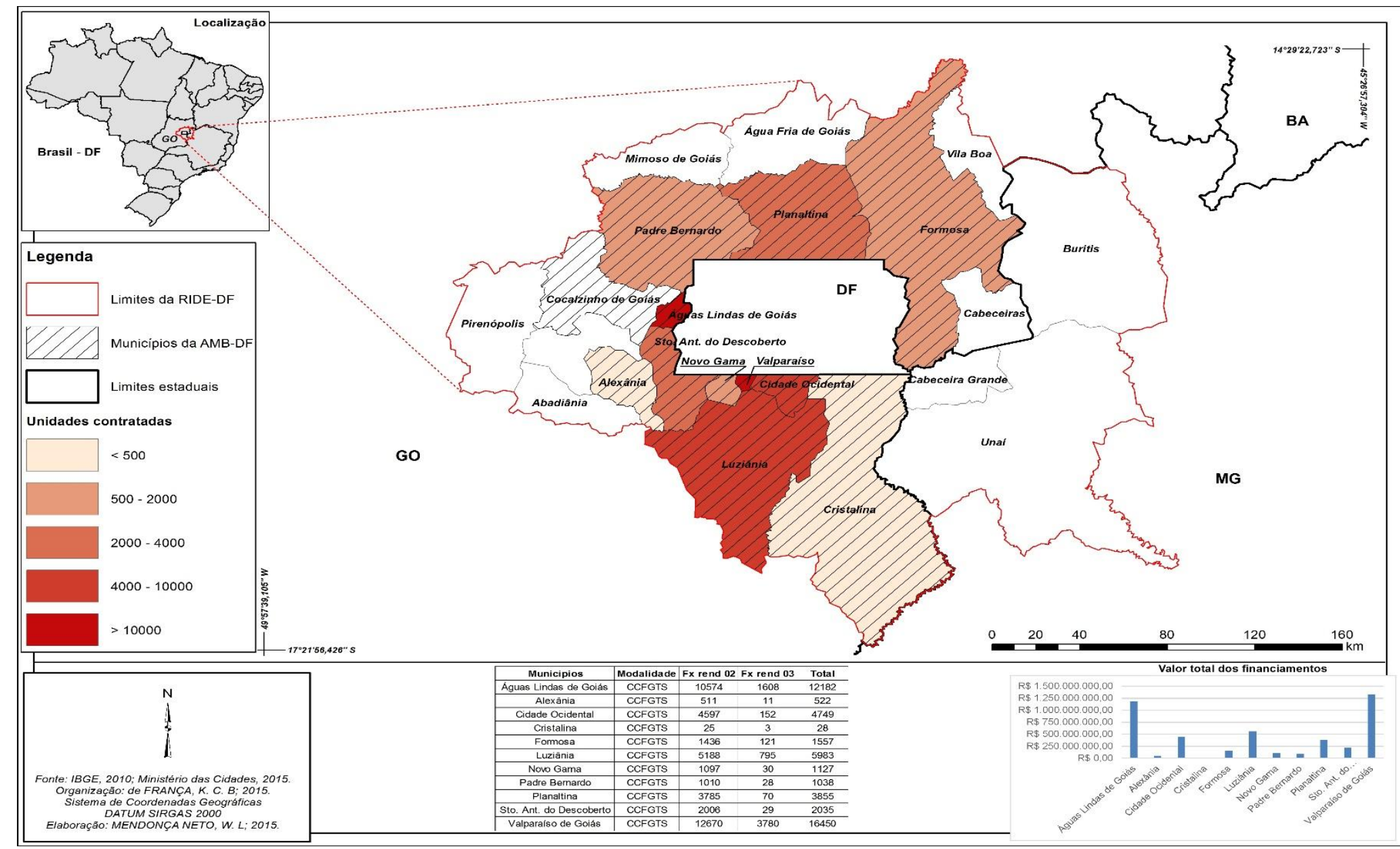


Como se pode visualizar por meio da Figura 33, verifica-se que as unidades habitacionais já contratadas nas faixas de renda 2 e 3 financiadas com recursos do FGTS, em sua maioria, estão localizadas nos municípios de Valparaíso de Goiás (16.450), Águas Lindas de Goiás (12.182), Luziânia (5.983), Cidade Ocidental (4.749), Planaltina de Goiás (3.855), Santo Antônio do Descoberto (2.035), Formosa (1.557), Cocalzinho de Goiás (1.479), Novo Gama (1.127), Padre Bernardo (1.038), Alexânia (522) e Cristalina (28).

No que diz respeito a espacialização do volume de empreendimentos por faixa de renda e fases do programa conclui-se que os municípios com maior volume de contratação foram Águas Lindas de Goiás, Valparaiso de Goiás e Santo Antônio do Descoberto. $\mathrm{O}$ volume de contratação na faixa 2 é superior ao déficit habitacional desta faixa de renda nestes municípios, ${ }^{41}$ em alguns casos superando o total do déficit habitacional municipal (Quadro 47). Em sua maioria, nota-se um volume maior de empreendimentos do PMCMV na faixa 2, em comparação com a contratação na faixa 1, em especial, na segunda fase do programa.

Na segunda fase do programa, nota-se a consolidação de novos empreendimentos contratados em áreas próximas dos empreendimentos contratados na fase 1, por outro lado, também, observa-se novas frentes de expansão e novos produtos imobiliários, em especial, nas avenidas e localidades próximas as vias de ligação com o DF.

Já para a contratação de empreendimentos na faixa 3 observa-se um volume de contratação menor, se comparado aos números de contratação no faixa 2. Os municípios com maior volume foram Águas Lindas de Goiás, Valparaíso de Goiás e Luziânia. O município com menor volume de contratação na faixa 3 foi o município de Santo Antônio do Descoberto, com 31 unidades contratadas.

Em decorrência, de grande parte do banco de dados não está georreferenciado e a fragilidade de informações completas na prefeituras, desde planta urbana dos bairros e laudos urbanísticos dos empreendimentos não foi possível identificar com precisão as áreas de concentração voltadas para as faixas de maior renda comparando-as com as de menor renda do Programa.

Considerando o volume de contratações dos empreendimentos habitacionais vinculados ao PMCMV em suas duas fases em todos os munícipios integrantes da Ride-

\footnotetext{
${ }^{41}$ Essa informação foi confirmada pelas entrevistas. Não foi possível ter acesso aos dados nas secretárias municipais e estaduais que a confirmassem. No entanto, as entrevistas e os dados universais sustentam a afirmação.
} 
DF, a situação é semelhante a dinâmica identificada nos municípios integrantes da Área Metropolitana de Brasília (AMB), em relação ao elevado número de contratações de unidades habitacionais para o atendimento da faixa 2.

\section{Quadro 45: Execução do Programa Minha Casa, Minha Vida fases 1 e 2 na Ride-DF}

\begin{tabular}{|c|c|c|c|c|c|}
\hline Renda & Modalidade & Contratadas & Valor Total & \multicolumn{2}{|c|}{ Estágio de Execução } \\
\hline & Empresas (FAR) & 18.542 & 1.279 .687 .565 & 2.872 & 2.872 \\
\hline & Urbanização (FAR) & S/I & S/I & $\mathrm{S} / \mathrm{I}$ & S/I \\
\hline Faixa 1 & Entidades (FDS) & 1.509 & 18.148 .009 & 642 & S/I \\
\hline & Oferta Pública & 238 & 5.170 .000 & 60 & 29 \\
\hline & Rural & 1.164 & 16.054 .230 & 218 & 218 \\
\hline $\begin{array}{l}\text { Total } \\
\text { Faixa } 1 \\
\end{array}$ & & 21.453 & 1.319 .059 .804 & 3.792 & 3.119 \\
\hline Faixa 2 & $\begin{array}{l}\text { FGTS de R\$ } 1.600 \text { até R\$ } \\
3.275\end{array}$ & 80.813 & 6.755 .663 .812 & 65.414 & $\mathrm{~S} / \mathrm{I}$ \\
\hline Faixa 3 & $\begin{array}{l}\text { FGTS de } \mathrm{R} \$ 3.275 \text { até } \mathrm{R} \$ \\
5.000\end{array}$ & 16.004 & 1.299 .843 .250 & 12.362 & 6.628 \\
\hline & Total & 118.270 & 9.374.566.866 & 81.568 & 6.628 \\
\hline
\end{tabular}

Fonte: MCidades (2015). Org. Karla França

Em relação à espacialização das construtoras que executam os empreendimentos na faixa 2 e 3 observa-se uma regionalização na atuação delas. As construtoras Gontijo e MRV Engenharia são as maiores detentoras de volume de quantidades de unidades habitacionais construídas nos municípios de Valparaiso de Goiás e Águas Lindas de Goiás, em especial na produção dos empreendimentos vinculados à faixa de renda 3 . Na produção habitacional para a faixa de renda 2 observa-se maior número de construtoras, sobretudo de médio porte. Existe uma distribuição melhor de volume de unidades habitacionais construídas entre as construtoras, ainda que se destaquem o grupo Gontijo e a MRV Engenharia.

Esses empreendimentos, em sua maioria, apresentam a tipologia verticalizada, evidenciando uma mudança no padrão habitual das moradias nesses municípios, de casa térrea para prédios. Disso resultam um forte adensamento urbano em áreas não previstas para esse padrão, uma verticalização excessiva e a produção de novos bairros sem planejamento e integração com o transporte público e serviços urbanos e lazer. Mas, também, é possível notar empreendimentos com tipologia casa com atributos diferenciados, em que se notam espaços de varanda, de lazer, de festas, para atrair uma 
população de renda mais elevada. Observa-se uma produção dos empreendimentos tipo casa com atributos diferenciados mais recorrentes em Valparaiso de Goiás, Cidade Ocidental e Luziânia.

A produção habitacional nas faixas 2 e 3 nos municípios goianos reproduz a lógica de condomínios, com muros que separam as "moradias" do seu entorno. Isso gera, segundo Ferreira (2012, p. 16), "uma malha urbana segmentada, pouco fluida, e que vai aos poucos aniquilando a possibilidade de usos dos espaços públicos".

Ainda de acordo com Ferreira (2012), no ímpeto de o mercado imobiliário ampliar sua margem de lucro, associado à fragilidade de regulamentação do uso do solo dos municípios, que flexibiliza a legislação urbana ou não aplica as referidas leis, quando existentes, induz a uma produção de prédios desconectados das estratégias de planejamento e da demanda, que impactará na infraestrutura, quando existente, ou nos custos de ampliação ou provisão de novas infraestruturas. Trata-se, por exemplo, de suporte viário suficiente para os transportes motorizados particulares e públicos, sistemas de esgotamento e drenagem das águas, escolas, áreas de lazer, em sua maioria, não considerados nos recentes projetos aprovados e executados nos municípios visitados.

Em relação à tipologia dos empreendimentos voltadas para as faixas de renda $2 \mathrm{e}$ 3, nota-se uma variação de preço conforme a proximidade com a rodovia e acesso à infraestrutura. Os projetos apresentam diferenças nos atributos. Em alguns empreendimentos, nota-se a inclusão de espaços para prática de esportes, áreas projetadas para atividades voltadas para o público infantil e adolescente, mecanismos de segurança. Conforme a variação dos atributos nos projetos, se observa uma variação do preço. Para ilustrar, no município de Valparaíso de Goiás, foram destacados pelos gestores os apartamentos localizados no empreendimento Garden City ou no Anhanguera Garden II, com localização próxima ao Shopping Center de Valparaíso. Esses empreendimentos apresentaram valores e público com poder aquisitivo mais elevado, em comparação aos empreendimentos também voltados para faixas de renda superior a R \$ 1.600,00 localizados no bairro Valparaíso I, como, por exemplo, o Residencial Fiugar II. 
Figura 34 - Residencial Anhanguera Garden II

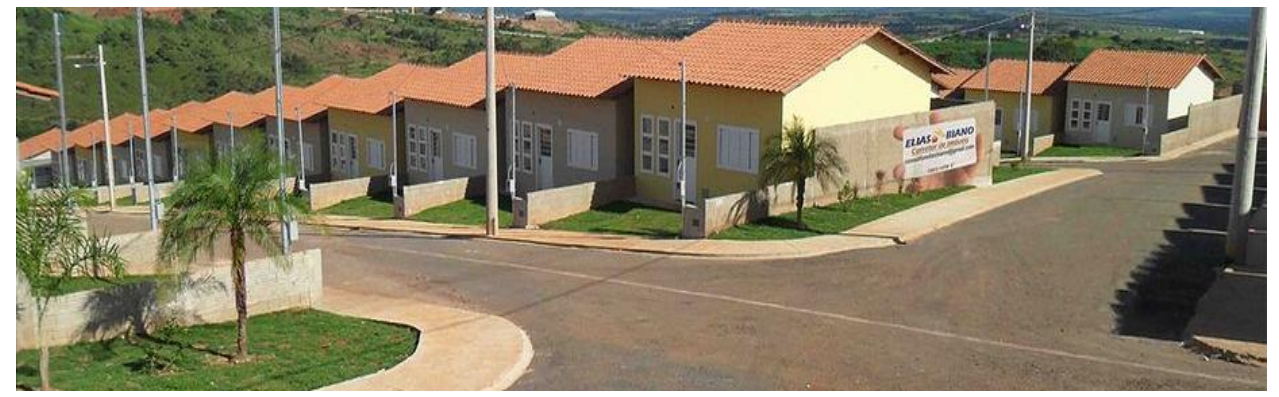

Fonte: Elias Biano, 2015.

Figura 35 - Residencial Fiugar

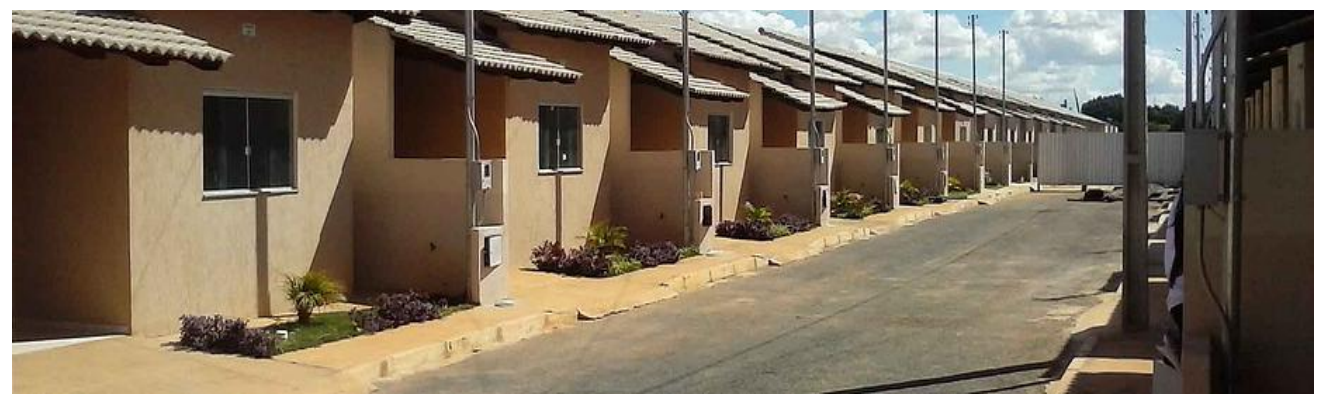

Fonte: Elias Biano, 2015.

O Residencial Fiugar II apresenta uma grande demanda, pelo fato de o valor das unidades ser mais baixo, se comparado aos empreendimentos localizados próximos às áreas centrais do Município. Em termos de valorização, foi notória, por parte dos gestores públicos, a alta valorização dos empreendimentos localizados no Bairro Valparaíso I, com acesso mais próximo à rodovia federal BR-040, que liga o município ao DF.

A partir dos dados da produção habitacional espacializados por município e faixas de renda, nota-se a discrepância entre os números de unidades financiadas pelo FAR (faixa 1) e pelo FGTS em todos os municípios. O volume de contratação de unidades para o atendimento das famílias enquadradas nas faixas de renda 2 e 3 , em alguns municípios, é superior ao déficit habitacional absoluto. Em metade dos municípios da AMB não houve contratação de empreendimentos via FAR ou para o atendimento da faixa de renda 1. 


\section{Quadro 48 - Déficit Habitacional versus Oferta de Unidades Habitacionais do PMCMV}

\begin{tabular}{|c|c|c|c|c|c|c|}
\hline & \multicolumn{2}{|r|}{ FGTS } & & FAR & TOTAL & \multirow{2}{*}{$\begin{array}{c}\begin{array}{c}\text { Déficit } \\
\text { 2007-2012 }\end{array} \\
\text { Total } \\
\end{array}$} \\
\hline & JH & $\%$ & $\mathbf{J H}$ & $\%$ & JH & \\
\hline Águas Lindas de Goiás & 14.094 & 84,8 & 1.403 & 8,4 & 16.620 & 5.304 \\
\hline Alexânia & 508 & 100,0 & 0 & 0,0 & 508 & 612 \\
\hline Cidade Ocidental & 4.899 & 100,0 & 0 & 0,0 & 4.899 & 1.858 \\
\hline Cocalzinho de Goiás & 1.479 & 100,0 & 0 & 0,0 & 1.479 & 341 \\
\hline Cristalina & 46 & 100,0 & 0 & 0,0 & 46 & 1.568 \\
\hline Formosa & 1.505 & 67,5 & 723 & 32,5 & 2.228 & 3.136 \\
\hline Luziânia & 5.567 & 91,8 & 499 & 8,2 & 6.066 & 5.535 \\
\hline Novo Gama & 1.038 & 100,0 & 0 & 0,0 & 1.038 & 3.588 \\
\hline Padre Bernardo & 1.219 & 100,0 & 0 & 0,0 & 1.219 & 648 \\
\hline Planaltina & 4.332 & 86,3 & 688 & 13,7 & 5.020 & 2.453 \\
\hline $\begin{array}{l}\text { Santo Antônio do } \\
\text { Descoberto }\end{array}$ & 2.578 & 100,0 & 0 & 0,0 & 2.578 & 1.736 \\
\hline Valparaíso de Goiás & 20.579 & 100,0 & 0 & 0,0 & 20.579 & 5.071 \\
\hline
\end{tabular}

Fonte: Caixa (2014). Organizado por Karla França (2015).

* Os dados da tabela foram atualizados em comparação aos dados utilizados para a produção das figuras 29,32 e 33.

Nos municípios goianos que apresentaram uma interação urbana e econômica mais próxima com o DF nota-se que a produção habitacional superou numericamente o déficit habitacional, por reposição de moradias nos municípios de Águas Lindas de Goiás, Cidade Ocidental, Cocalzinho de Goiás, Luziânia, Planaltina de Goiás e Valparaíso de Goiás. Entretanto, a maior parte dessa produção habitacional não foi destinada para a faixa de renda prioritária do déficit habitacional, isto é, a faixa 1. Ao contrário, destinouse para o atendimento da faixa de renda acima de três salários mínimos.

Essa produção de moradias cujo déficit habitacional é superado evidencia, de um lado, a transferência de produção habitacional para os municípios goianos com a finalidade de atender a uma população que reside no DF e que tem dificuldades de adquirir moradias, uma vez que o preço do solo urbano no DF é elevado, o que dificulta o acesso da população residente no DF às unidades habitacionais. De outro lado, amplia a escala de produção imobiliária do segmento econômico com novos lançamentos imobiliários focalizados para atender à classe média que busca adquirir um imóvel 
próprio com preços mais acessíveis em áreas próximas ao DF. Logo, as terras mais baratas dos municípios goianos e a flexibilização da legislação têm contribuído para a geração de um estoque de terras privadas para a produção de moradia em áreas de menor valor do preço da terra, em comparação com o DF, e reduzindo o estoque de terrenos para a produção de moradia social, ou empurrando esta produção para áreas distantes de infraestrutura urbana cujo terreno é mais barato.

Esse estoque de terras privadas, atrelado aos interesses do mercado imobiliário que atua na escala metropolitana, permite a expansão dos negócios imobiliários nos municípios goianos próximos ao DF, com a oferta de atributos diferenciados aos projetos para atrair o público do DF. Nas visitas aos órgãos municipais e nas entrevistas com os gestores públicos, prefeitos e a comunidade, foram recorrentes relatos da aquisição maciça de terras particulares localizadas nos municípios goianos pelos grandes grupos imobiliários, para alavancar a produção habitacional voltada para as faixas de renda 2 e 3.

Esse movimento do mercado privado produz novas configurações urbanas, acentuando e fragmentando as relações metropolitanas, sobretudo de moradia e trabalho entre o DF e os municípios goianos, assim como os processos de segregação social, ao expulsar a população de mais baixa renda para áreas mais distantes do acesso aos centros de emprego e da moradia. Isso se deve às mudanças nos valores dos aluguéis, inflacionados em função da alteração do perfil dos moradores. Por sua vez, os preços da venda de terrenos e imóveis elevaram-se, induzindo a expulsão da população de baixa renda das áreas próximas à implantação dos novos empreendimentos.

Restam a esta população de baixa renda as áreas precárias, do ponto de vista da infraestrutura urbana e social, inclusive quando atendidas pela política habitacional. Esses empreendimentos, em sua maioria, estão localizados em áreas sem ou com infraestrutura inadequada, uma vez que as áreas com padrão mínimo de infraestrutura e os estoques de terras adquiridos pelo setor privado nos municípios goianos têm como objetivo a valorização dessas áreas, para a implantação dos empreendimentos imobiliários voltados ao segmento econômico.

Embora não exista levantamento no âmbito do estado de Goiás e dos municípios de quanto o déficit habitacional do DF tem sido, em certa medida, atendido pela produção habitacional dos municípios goianos, foi unânime nas entrevistas com os gestores públicos o reconhecimento de que a população que vem adquirindo as unidades habitacionais voltadas para o atendimento da faixa de renda 2 em sua maioria exerce 
função laboral ou residência anterior no DF. Os dados do Quadro 48 confirmam que, do ponto de vista quantitativo, o volume de produção de unidades tem sido superior ao déficit absoluto dos municípios, o que evidencia o atendimento de necessidades habitacionais da população residente no DF.

Essa produção habitacional gerada na escala metropolitana provoca novas demandas de infraestrutura viária e urbanística, sobrecarregando as infraestruturas já existentes, no que diz respeito, por exemplo, ao transporte público, às vias de transporte entre o DF e esses municípios.

Portanto, a dinâmica habitacional e de mobilidade urbana nos municípios que integram a AMB necessita de instrumentos de planejamento integrados. Ao analisarmos a relação metropolitana no campo habitacional na AMB/Ride-DF, comprovamos que a produção habitacional não atende somente à dinâmica e às necessidades da escala municipal. Trata-se de um atendimento voltado à escala metropolitana, escala essa mais bem incorporada nas estratégias de atuação dos empreendedores imobiliários do que pelos gestores em suas várias escalas da Federação.

Logo, os problemas urbanos não podem ser resolvidos de forma setorial. De modo contrário, a amenização dos problemas urbanos requer articulações entre o planejamento urbano municipal e a escala metropolitana.

No entanto, os entraves para que se estabeleçam estratégias de aproximação para a promoção de ações articuladas são permeados por enormes desafios. Conforme alertam Motta et al. (2014), os problemas relacionados com a legislação e as fortes restrições institucional, técnica e burocrática transformam-se em verdadeiros obstáculos para a promoção de uma gestão do uso do solo e da habitação na perspectiva metropolitana.

\footnotetext{
A ineficácia e a inadequação dos instrumentos de planejamento e gestão urbana podem contribuir para o estabelecimento de padrões irregulares e informais de ocupação e urbanização, em especial dos segmentos mais pobres da população. Em alguns casos, ao propiciarem a supervalorização de imóveis em algumas áreas, podem incentivar - por omissão ou inadequação - um grande contingente da população pobre a ter apenas acesso a formas irregulares de ocupação e habitação. (MOTTA et al., 2014, p. 62).
}

Essas restrições, atreladas à incapacidade institucional dos municípios, contribuem para a elevação do preço dos terrenos e dos custos dos investimentos públicos e privados. Ao mesmo tempo, tal incapacidade ou insuficiência na criação e implementação dos instrumentos de planejamento e gestão urbana resulta em uma acelerada favelização e ocupação de novas áreas longínquas e com baixa capacidade de infraestrutura urbana no limite urbano-rural dos municípios goianos. 
Portanto, o acesso e a produção habitacional social são influenciados pelo ambiente regulador, fiscalizador e normativos nesses municípios. No caso do Programa Minha Casa, Minha Vida, são quase inexistentes ações de fortalecimento e de protagonismo municipal que articulem os investimentos do PMCMV com a política urbana municipal de mecanismos fundiários dos municípios integrantes da Área Metropolitana de Brasília/Ride-DF.

O posicionamento da Secretária Nacional de Habitação $(\mathrm{SNH})$, vinculada ao Ministério das Cidades a partir das entrevistas realizada para esta pesquisa indicou que os normativos do PMCMV em sua segunda fase prevê a contratação de um município para atender o déficit habitacional de outro município incluso em região metropolitana desde que seja comprovada a existência da dinâmica metropolitana e o déficit, entretanto, não existe nenhum projeto com essa especificidade.

Para a SNH, grande parte dos Municípios apresentam dificuldades de comprovação de atendimento do déficit habitacional de outro município que justifique a contratação. Vale ressaltar, que no próprio desenho da política habitacional há dificuldades, uma vez que nos estados não há um órgão com funções metropolitanas no desenho da habitação, onde possa existir estratégias de cooperação.

Sabe-se que o município é o ente responsável pela regulação do uso do solo. $\mathrm{Na}$ prática as administrações municipais e do Distrito Federal ao executarem suas estratégias de planejamento urbano e habitacional, realizam-na de forma setorial, ainda que reconheçam o fenômeno metropolitano existente.

Para Royer (2013), é inegável que a gestão da política habitacional exige outro olhar sobre a gestão do espaço, que não coincide com os limites políticos das fronteiras federativas, uma vez que a política habitacional é responsável pela geração de externalidades que extrapolam os limites dos municípios.

\footnotetext{
Não há, portanto, como compreender a dinâmica habitacional e de mobilidade urbana sem olhar para todo o conjunto da metrópole. Os limites municipais de há muito não são suficientes como lócus territorial das políticas públicas, pois o fato urbano é metropolitano, não municipal. Dessa forma os conflitos e problemas existentes nesse tecido urbano não têm como serem equacionados e resolvidos no âmbito municipal. (ROYER, 2013, p. XX).
}

Neste sentido, a gestão política habitacional demanda uma intervenção a partir de outras estruturas de governança que deve ser induzida pela União, para promover estratégias de produção de unidades habitacionais articulada ao desenvolvimento urbano e regional (DENALDI, 2012; ROYER, 2013; LOPES, 2014). 
Embora o município seja o ente federativo responsável pelo uso e ocupação do solo, sabemos que sua capacidade institucional é muito desigual e que é grande o "atraso" da sociedade brasileira relacionado com a herança patrimonialista. Não se pode atribuir apenas ao município tal responsabilidade. Cabe também à esfera federal induzir, por meio da capacitação, regulamentação e financiamento, uma adequada articulação da produção habitacional do PMCMV com as estratégias de desenvolvimento urbano e regional. (DENALDI, 2012, p. 16).

Embora se reconheça a inserção de uma parcela da população que estava fora do mercado formal e dos financiamentos antes da implementação do PMCMV nos municípios goianos pertencentes a $\mathrm{AMB}$ e do Programa Morar Bem/DF, é fato que não houve concertação das políticas habitacionais voltadas à escala do desenvolvimento urbano-regional. Acerca do assunto Klink e Rolnik (2011) afirmam que os investimentos habitacionais e de urbanização injetados remediaram as precariedades do modelo de cidades em curso, em vez de promoverem a produção de cidades inclusivas.

Nos municípios analisados, constatou-se que o volume de investimentos produziu novos bairros e novas configurações urbanas sem necessariamente estarem articulados à cidade. Logo, a produção habitacional, sem ações integradas, pressionou o acesso e a qualidade dos serviços e infraestrutura. Isso evidenciou a complexidade de provisão de infraestruturas em contextos metropolitanos para a resolução dos problemas urbanos que ultrapassam os limites municipais. Os municípios e o Distrito Federal não possuem capacidade de investimentos e programas para o fomento das infraestruturas de forma individual, sendo, por isso, necessário o desenvolvimento de políticas cooperadas entre os diferentes entes da Federação que atuam neste território - o Estado de Goiás, o Distrito Federal, os municípios e a União -, com a participação da sociedade.

Sabe-se que a cooperação entre os agentes do desenvolvimento, em âmbito metropolitano, já enfrenta dificuldades de ordem político-institucional relacionadas à autonomia dos governos locais, ou à repartição formal de atribuições entre os Entes da Federação, no que diz respeito à solução de problemas que se estruturam como de interesse coletivo. É ainda quase inexistente a implementação de mecanismos e instrumentos que ensejem a participação do setor privado ou da sociedade em ações de cooperação metropolitana (MOTTA et al., 2014). No recorte da AMB, a promoção de cooperação apresenta uma complexidade ainda maior, uma vez que o recorte Área Metropolitana de Brasília não existe institucionalmente, de modo que suas ações somente podem ser equacionadas na esfera da Ride-DF. 
Para o fomento de ações metropolitanas no âmbito desses municípios, o Art. $3^{\circ}$, do Decreto 7.469/2011, delimitou os serviços comuns na Ride-DF que demandam estratégias articuladas. Dentre esses serviços encontram-se o uso, parcelamento e ocupação do solo e a habitação social.

A delimitação desses serviços como funções públicas comuns no âmbito da escala da Ride-DF já é um avanço, em comparação ao regramento de diversas regiões metropolitanas instituídas e que ainda não delimitaram os serviços de interesse comum.

No entanto, desde o reconhecimento das funções públicas comum pouco foi realizado em termos de gestão e coordenação pelo Conselho da Ride-DF para o enfrentamento dos problemas urbanos. Neste sentido, o representante da SUDECO em entrevista concedida para a pesquisa afirmou que não existe para efeitos de ação das políticas elencadas para este espaço a priorização ou diferenciação dos municípios que apresentam uma forte dinâmica metropolitana com o DF dos que não apresentam. Embora, seja reconhecido pelo representante da SUDECO os problemas diferenciados e a necessidade de atuação específica para o enfrentamento dos problemas metropolitanos como proposto no documento Pró-Ride ${ }^{42}$. Destaca-se que no período entre 2014-2015, foram realizados reuniões com os representantes do Coaride que resultaram na criação de Grupos de Trabalhos. Como desdobramento dessas reuniões foram desenvolvidas propostas de aperfeiçoamento e estratégias de desenvolvimento integrada e meios de implementação.. Dentre as ações elencadas pelos grupos de trabalho destacaram-se as importantes sugestões de alteração do Decreto 7.469/2011 no que tange a ampliação das vagas de representatividade do poder público municipal.

Atualmente, a representação ${ }^{43}$ dos 22 munícipios no Coaride é realizada por um prefeito (a) indicado pela Associação dos Municípios Adjacentes de Brasília (AMAB). $\mathrm{Na}$ entrevista concedida foi reafirmado a sub-representação do poder local na estrutura da Ride-DF se comparado a alta representatividade do segmento Federal e a necessidade de maior diálogo na escala horizontal dentro do Coaride.

Ainda que a escala institucional da Ride-DF reconheça os serviços de interesse comum, inexistem ações para a construção de um marco regulatório ou estratégias de

\footnotetext{
42 Em 2001 foi elaborado o documento Pro Ride-DF, o qual previa uma regionalização para a atuação e fomento de política. Para tanto, foram delimitados círculos de muncípios metropolilizados, periurbanos e rurais. No entanto, o documento não foi implementado.

${ }^{43} \mathrm{Na}$ época de elaboração da pesquisa os municípios eram representados pela Prefeita de Valparaiso de Goiás.
} 
cooperação para a regulamentação de iniciativas ou programas que regulamentam políticas urbanas. Sobretudo, no que se refere a ações concertadas do uso e ocupação do solo e habitação social aplicada aos municípios e ao DF, além de normas, como planos de ação que poderiam reduzir a transferência de produção habitacional em andamento.

Do ponto de vista do planejamento da Sudeco, na entrevista realizada com o representante da Sudeco foi destacado que não existe nenhuma ação específica direcionado para o planejamento urbano, uso e ocupação do solo, bem como, habitação social. A única ação específica na tentativa de fortalecer as estratégias nas escalas regional-urbana foi o Programa 2029 ( Desenvolvimento Regional, Territorial Sustentável e Economia Solidária).

Foram ampliadas as estratégias regionais-urbanas nas ações do programa 2029 para o PPA (2016-2019). Outro destaque apontado pelo representante da Sudeco, foi o esforço do Ministério da Integração em elencar nas estratégias de definição do PPA as ações previstas na nova PNDR, ainda que a PNDR não esteja regulamentada por meio de lei federal. No entanto, não foram destacadas ações de planejamento estratégico e priorização de investimentos para o fomento ao desenvolvimento econômico da Ride-DF, embora tenha sido destacado a existência de projetos de fomento ao desenvolvimento produtivo as economias locais em parceria com a rede S (Sebrae, Senai, Sesi), por exemplo, artesanato local , apoio a gestão rural para os agricultores familiares.

No entanto, o cenário de crise que permeia a elaboração do PPA, somados aos cortes e contingenciamento gera preocupação para o fortalecimento das políticas regionais de desenvolvimento direcionadas para a Ride-DF.

Os desafios advindos da engenharia do arcabouço institucional recente para ações cooperadas em contextos metropolitanos tornam complexa sua aplicação no contexto da Ride-DF, uma vez que o arcabouço institucional prioriza as diretrizes para contextos metropolitanos que incidem em áreas de uma mesma unidade da Federação.

Trata-se da elaboração dos planos habitacionais em contextos metropolitanos ou da recente aprovação da Lei n. 13.089/2015, que instituiu o Estatuto da Metrópole, cujo artigo 19 recebeu veto presidencial, ao dispor em lei acerca de a possibilidade do Distrito Federal integrar uma Região Metropolitana. Isso viabilizaria institucionalmente o reconhecimento da AMB como a escala oficial metropolitana e permitiria a regulamentação e aplicação dos instrumentos de estratégias metropolitanas previstos na legislação que versa sobre Regiões Metropolitanas. No entanto, as justificativas da 
Presidência da República para que o Distrito Federal não integre uma Região Metropolitana foram explicadas no próprio veto, conforme se pode observar:

\begin{abstract}
Ao tratar de regiões metropolitanas, aglomerações urbanas e microrregiões, a Constituição faz referência, em seu art. 25, § 3oa a agrupamento de Municípios. Neste sentido, as inclusões no escopo do Estatuto da Metrópole de território de um único Município isolado e do Distrito Federal não encontrariam amparo constitucional. Em relação ao Distrito Federal, o instrumento de cooperação federativa adequado é a Região Integrada de Desenvolvimento Econômico RIDE, prevista no art. 43 da Constituição. Está já foi, inclusive, criada pelo Decreto n⿳⺈ 2.710, de 4 de agosto de 1998 - substituído pelo Decreto no 7.469 , de 4 de maio de 2011 - que regulamenta a Lei Complementar no 94, de 19 de fevereiro de 1998. (BRASIL, 2015).
\end{abstract}

O posicionamento da União no quesito das questões metropolitanas que envolvem

o Distrito Federal foi o de reconhecer que é a Região Integrada de Desenvolvimento Econômico - RIDE - o instrumento de cooperação federativa adequado para o tratamento das questões metropolitanas que envolvem os problemas entre o DF e o estado de Goiás. Neste sentido, o posicionamento da Secretária de Acessibilidade e Programas Urbanos do Ministério das Cidades em entrevista concedida para a pesquisa se posicionou acerca das possibilidades do enfrentamento da questão metropolitana na esfera da Ride-DF mediante veto do DF integrar Região Metropolitana:

Os instrumentos jurídicos que regulamentam as Regiões Integradas de Desenvolvimento Econômico e as Regiões Metropolitanas são distintos. As RIDES são arranjos que se situam em mais de uma unidade federativa, previsto na Constituição Federal e criadas por legislação federal específica. Têm como finalidade permitir a articulação da União sobre complexos geoeconômicos e sociais, com vistas ao desenvolvimento regional e à redução das desigualdades. As Regiões Metropolitanas são arranjos que abrangem o estado e seus municípios, regidos pela Lei 13.089/2015, com a finalidade de planejar, gerir e executar as funções públicas de interesse comum. A finalidade dos dois arranjos, portanto, não deve ser confundida.

Em relação ao veto presidencial, ainda que não exista possibilidade do Distrito Federal ser integrante de Região Metropolitana, tal fato não inviabiliza a participação do ente em outras formas de cooperação interfederativa como, por exemplo, na figura dos consórcios públicos, em especial na consecução das Funções Públicas de Interesse comum.

No âmbito da RIDE - DF, existe Conselho instituído para essa finalidade - O Conselho Administrativo da Região Integrada de Desenvolvimento do Distrito Federal e Entorno (COARIDE) - que conta com a participação de representantes da União (Ministérios da Integração Nacional, das Cidades, do Planejamento, Orçamento e Gestão e Ministério da Fazenda); o DiretorSuperintendente da SUDECO; um representante da Casa Civil da Presidência da República; bem como dos representantes dos Estados, Municípios e do Distrito Federal, indicados pelos respectivos Governadores. (Trecho da entrevista concedida pela SNAPU/MCidades)

Para Moura e Hoshino (2015), o veto presidencial acerca da possibilidade de o Distrito Federal integrar Regiões Metropolitanas representa um retrocesso em termos de concepção e prejudica os ajustes que poderiam ser operacionalizados na Ride do Distrito 
Federal, uma vez a atuação das Rides visa ao fortalecimento do desenvolvimento econômico-social em âmbito regional. Esta atuação, segundo os autores, não se sobrepõe nem dispensa a necessidade de ações no recorte de uma Região Metropolitana (Art. 25, $\S 3^{\circ}$ ), para a aplicação das Funções Públicas de Interesse Comuns (FPICs).

Embora, os vetos do DF integrar regiões metropolitanas e grande parte do regramento direcionado para as regiões metropolitanas impõem novos desafios e inovações para o enfrentamento dos problemas metropolitanos e, ao mesmo tempo, reafirma que as estratégias de fomento para a cooperação metropolitana se deve considerar o recorte da Ride-DF.

Logo, é essencial fortalecer o Coaride, uma vez que a função maior do consleho é a articulação das interinstitucionalidades e fomento aos arranjos institucionais.

Ainda que reconheçamos a importância de articulação das estratégias nas escalas regional e metropolitana, vale lembrar, que as políticas de desenvolvimento regional e os recortes prioritários de ações nem sempre consideram ações específicas para os territórios metropolitanos e pouco se tem avançado no diálogo cooperado das políticas regionais e de desenvolvimento urbano. 

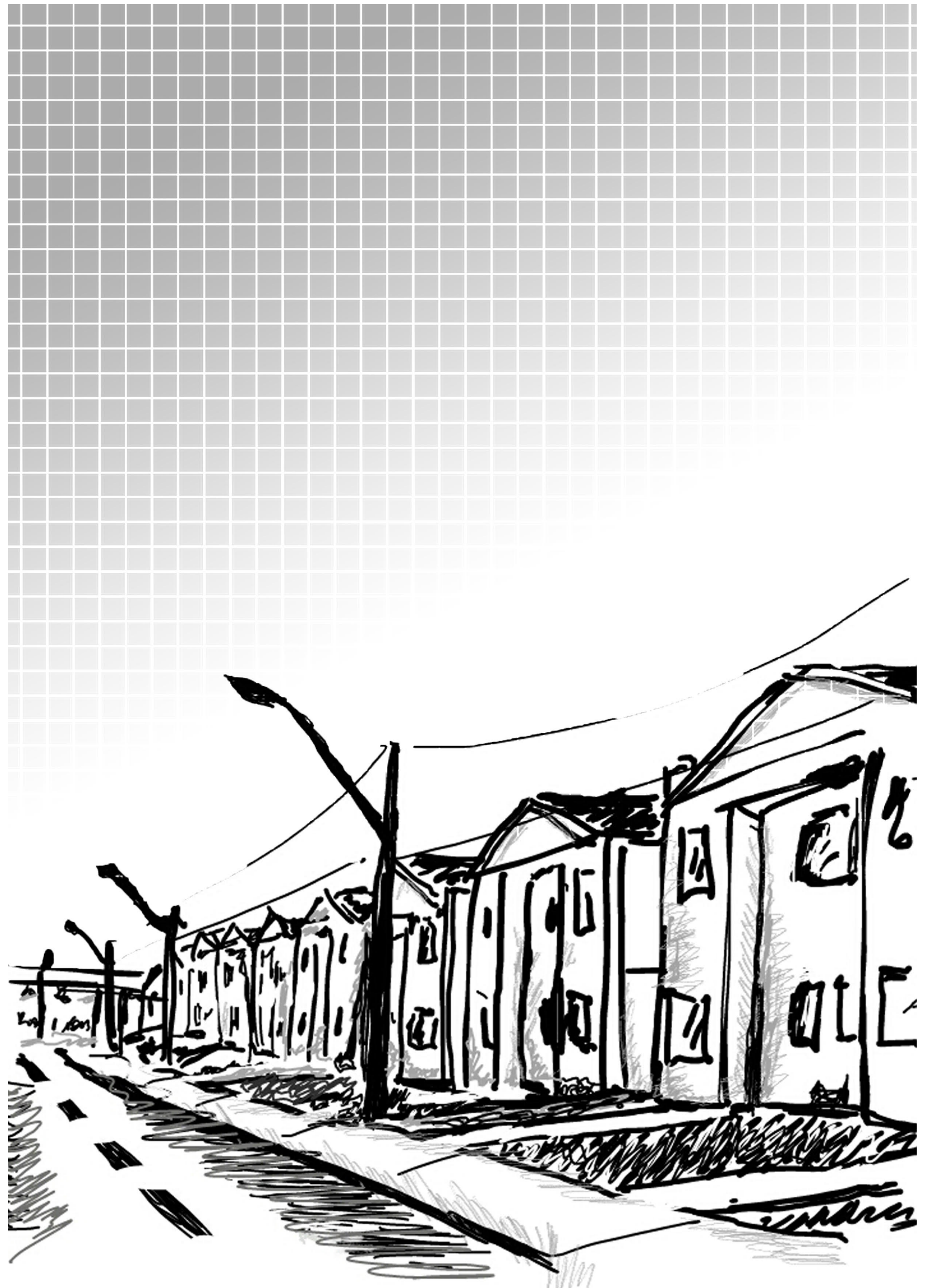
Considerações Finais 
O desenvolvimento de uma pesquisa que procurasse evidenciar as assimetrias das políticas habitacionais e as possibilidades para a implementação de políticas cooperadas de habitação de interesse social nos territórios metropolitanos brasileiros se revelou um enorme desafio do ponto de vista de delimitação do recorte espacial, ou seja, um recorte que não existe institucionalmente, mas pauta uma agenda de ações entre os governos distrital e dos governantes goianos e, também, concentra os problemas metropolitanos mais significativos das relações socioeconômicas estabelecidas entre a população que vivencia o cotidiano metropolitano existente no DF e nos municípios goianos inseridos na Área Metropolitana de Brasília (AMB).

Por vezes, os recortes Área Metropolitana de Brasília e Ride-DF evidenciaram o vácuo de um conceito que procurasse aglutinar a problemática da habitação numa perspectiva metropolitana. A indefinição de critérios, estudos técnicos e conceitos que procurasse legitimar e institucionalizar a complexidade dos fenômenos metropolitanos esteve presente ao longo desta tese.

Não menos importantes, revelaram-se problemáticos, do ponto de vista legal, para a implementação de estratégias metropolitanas, os regramentos nacionais, por vezes de difícil aplicação no contexto do recorte analisado e na Ride-DF e sem perspectivas de mecanismos para que possam ser aperfeiçoados para responder às demandas metropolitanas presentes.

Ainda que seja reconhecido pelos órgãos governamentais e universidades que o recorte da Área Metropolitana de Brasília (AMB) mais se aproxima de um território funcional metropolitano do que o desenho da Ride-DF, não existe seu reconhecimento legal. Portanto, assegurar a legitimidade política e institucional ao território metropolitano que envolve a AMB são ações importantes a serem construídas na esfera da Ride-DF.

A tese procurou evidenciar a relevância do planejar, executar e gerir estratégias que envolvem as questões habitacionais de forma concertada nos aglomerados metropolitanos. As ações de planejar, executar e gerir serviços ou funções públicas comuns se revelaram desafiantes do ponto de vista das materializações de ações, compromissos e corresponsabilidades para a pactuação de Agenda Metropolitana em anuência aos investimentos estaduais, federais e municipais.

O atual cenário pode evidenciar uma maior abertura para o desenvolvimento de estratégias, uma vez que se nota um amadurecimento dos institutos de pesquisa estaduais, distrital e federal na elaboração de pesquisas e diagnósticos acerca da relevância política, 
econômica e social dos aglomerados metropolitanos no Brasil, mas ainda são tímidas as propostas e ações para o incentivo de programas e financiamento para a promoção de ações concertadas para o fortalecimento de pactuações convergentes entre os entes da Federação, tanto em uma escala horizontal, como por exemplo entre União e Estado e Município, quanto na escala vertical, entre municípios. Pouco se tem avançado nas soluções para o fortalecimento do pacto Federativo e dos possíveis conflitos de interesses, capacidades institucionais e de autonomia.

De um lado, o discurso que mais ecoa trata-se da busca de soluções consorciadas entre os Entes. No entanto, inexistem os mecanismos que propiciem ações de governança metropolitana no atual ambiente federativo. Os consórcios públicos aparecem como a solução mais concreta. Mas ainda que relevantes, não abarcam a complexidade de respostas e ações necessárias para o estabelecimento de mecanismos indutores para a promoção de políticas articuladas.

Ao contrário, nos últimos dez anos o ambiente federativo e das políticas urbanas de forma geral induziu um desenho federativo entre a União e o município, o que tem contribuído para o fortalecimento de políticas e agendas locais desconectadas das agendas regionais e metropolitanas, reforçando as críticas à forte municipalização autárquica ou localismos.

De fato, são urgentes a construção e a execução de uma agenda regional que integre a dimensão metropolitana. Essas agendas regionais precisam ser construídas de baixo para cima e, em certa medida, se aproveitando das benesses da autonomia municipal, uma vez que essa autonomia possibilita uma construção colaborativa e plural de mecanismos de regulação e governança, acordos transjuridicionais para além da escala estado e município, e, mais importante, pode fortalecer a relevância das agendas de desenvolvimento com fundos e investimentos específicos.

Também é relevante uma retomada de articulação federativa dos programas urbanos, hoje inexistentes. Os atuais programas habitacionais são ótimos exemplos da execução de financiamento e infraestrutura sem a adoção de estratégias integradas. Se num primeiro momento os investimentos em habitação representaram a retomada de ganhos significativos de economia de escala, por outro lado, a ausência de mecanismos na política habitacional de estratégias de planejamento em ambiente metropolitano acabou por aprofundar as já existentes deseconomias de aglomeração na provisão e extensão dos serviços urbanos. 
Essas desconexões se estendem para além dos espaços dos empreendimentos, que em geral apresentam problemas de inserção urbana. Os seus impactos podem ser evidenciados nas limitações de estratégias de desenvolvimento urbano e responsabilidades na oferta de serviços urbanos, que acabam por pressionar os serviços urbanos de outro município, evidenciando os graves problemas de planejamento e estimativa de demanda de serviços acessados na escala metropolitana, porém executados e financiados na escala local.

As atuais pesquisas que versam sobre o processo de metropolização e a necessidade de arranjos de cooperação têm focado, prioritariamente, na necessidade de arranjos e novas institucionalidades nas regiões metropolitanas e nos aglomerados urbanos. Mas se revelam insuficientes para propor e articular ações que apontem caminhos para abarcar a diversidade de configurações espaciais que permeiam o processo de metropolização brasileiro, dentre eles as dinâmicas metropolitanas, que não se restringem a uma única Unidade da Federação, caso investigado nesta tese.

Esta pesquisa evidenciou os gaps de transferência de produção habitacional em território metropolitano. O arcabouço institucional da Ride-DF e a indução da União para a promoção do desenvolvimento urbano nas Rides não têm expressado ações e estratégias cooperativas no âmbito da política urbano-metropolitana. São quase inexistentes, por parte da União, adequações e ajustes no regramento nacional e em seus programas urbanos, que induzem os estados, municípios e o Distrito Federal a desenvolverem conjuntamente ações visando à resolução dos problemas comuns, como o caso da habitação, da mobilidade urbana, entre outros.

Do ponto de vista institucional, a lacuna desses regramentos quanto ao tratamento metropolitano na Ride-DF fragiliza e não estimula o fortalecimento de ações institucionais. Assim como afirmam Moura e Hoshino (2015, p. 12), “dificulta a extensão de infraestruturas e a oferta suficiente de serviços, terminando por ampliar o número de entes carentes de novos modelos de governança interfederativa".

A indução de estratégias concertadas traz a possibilidade de elaboração, ainda que mínimas e tímidas, de regras comuns para o uso e ocupação do solo nas áreas prioritárias a serem identificadas e mapeadas. Também contribuiria para o estabelecimento de pontos comuns nas leis regulamentadoras do uso e ocupação do solo, planos diretores e planos de habitação para a implementação de políticas de desenvolvimento urbano mais eficientes (MOTTA et al., 2014). 
Essas ações minimizariam a implantação de empreendimentos de forma espraiadas e sem provisão de infraestrutura, o que otimizaria os investimentos e as ações na escala metropolitana. No entanto, as possibilidades para o estabelecimento dessas ações necessitam da atuação contínua da União e dos Estados para o fortalecimento das capacidades político-institucionais, projetos de financiamentos e delimitação das corresponsabilidades para atraírem a iniciativa privada, uma vez que a capacidade fiscal e tributária dos municípios é heterogênea e, em sua maioria, insuficiente para a implementação de ações concertadas articulada à provisão de financiamentos.

Vale enfatizar que, em geral, os municípios que sofrem em graus diversos influência metropolitana, como, por exemplo, os municípios analisados nesta pesquisa, enfrentam graves problemas de geração de recursos, sobretudo geração de receitas próprias, baixa capacidade fiscal e de planejamento urbano. Assim, eles acabam por não conseguir, isoladamente, buscar as respostas adequadas para a demanda crescente de serviços urbanos advindos dos problemas metropolitanos e mais recentemente as demandas da população dos empreendimentos habitacionais.

As ações concertadas na esfera da habitação no recorte de pesquisa investigado exigem envolvimento e participação efetiva do Conselho Administrativo da Região Integrada de Desenvolvimento do Distrito Federal e Entorno (COARIDE) para a elaboração de um plano de ação, metas e implementação com foco na resolução dos problemas metropolitanos de forma integrada. Os atuais grupos de trabalho que integram o Coaride encontram-se desativados. Esses grupos devem ter um papel ativo de colaborar no fomento a pesquisas, projetos e ações mobilizadoras, junto aos gestores nas várias esferas da Federação, para a adequação das diretrizes, normas e ações.

Também se observa a dificuldade dos representantes da Sudeco em aprofundar o debate e ações partilhadas na esfera do planejamento metropolitano e uso do solo no âmbito do conselho e das câmaras temáticas. No que tange à questão urbana, a pauta mais relevante que demanda licitações e diálogos com o governo federal tem sido a questão do transporte semiurbano.

Em linhas gerais, observam-se ações pontuais e nem sempre articuladas com projetos e financiamentos. As ações pontuais que se destacam são projetos de infraestrutura e fortalecimento do parque produtivo. Já o desenvolvimento de ações para o enfrentamento da questão urbano-metropolitana parece não estar demandando reconhecimento técnico e investimentos consorciados no Coaride. 
Na esfera do Coaride, não há arranjos ou ações diretamente de gestão compartilhada para o planejamento e gestão dos serviços comuns. O que existe são iniciativas setoriais e investimentos realizados que não se articulam à esfera do Coaride. Dentre essas iniciativas consorciadas, tem se destacado o serviço de saneamento com três consórcios vigentes, além de estudos e diagnósticos que viabilizem a elaboração do plano regional de saneamento básico da Ride-DF, com financiamento do Ministério das Cidades. Essa ação ainda encontra-se em estágio inicial, e até o momento não tem dialogado com o Coaride.

Essas iniciativas setoriais e institucionalizadas demonstram a necessidade de ações consorciadas para a prestação e a gestão dos serviços urbanos, além de revelarem que a ausência de ações partilhadas pode afetar gravemente a prestação de serviço do outro ente federativo, o que impõe a necessidade de ações conjuntas.

Ainda que institucionalmente a habitação social e o uso do solo foram reconhecidas como funções públicas comuns na Ride-DF, na realidade existe uma série de limitações na elaboração de ações integradas no contexto metropolitano que envolve o Distrito Federal e os municípios goianos, pertencentes a outra unidade federativa. Por exemplo, os regramentos nacionais de parcelamento do uso do solo previstos na Lei Federal 6.766/1979 que podem ser aplicados aos contextos metropolitanos para melhor promoverem parcelamentos são alçados à competência do ente Estadual, para elaboração das diretrizes comuns. No caso da Ride-DF, essa engenharia somente seria viável com uma forte atuação do Estado de Goiás em articulação aos objetivos e metas pactuados com o Distrito Federal. Seria ineficiente uma pactuação do Estado de Goiás com os municípios sem considerar a legislação do uso do solo estabelecida no DF.

Um dos caminhos possíveis seria através de convênio, dada a viabilidade, sob o aspecto legal, da instituição de uma autoridade metropolitana para a análise e avaliação na emissão das anuências previas. Vale dizer que institucionalmente a Ride-DF não se caracteriza como uma região metropolitana e, portanto, até o momento não há na legislação mecanismos de ação integradas para o uso do solo no contexto da Ride-DF.

$\mathrm{O}$ fato de que parte do arcabouço institucional para a promoção de ações compartilhadas em regiões metropolitanas não encontre amparo legal para a implementação no contexto da AMB e da Ride-DF, por não se constituírem oficialmente em regiões metropolitanas, não impede uma indução do governo federal e dos entes em fomentar novas institucionalidades e convênios que viabilizem a elaboração de diretrizes e estratégias adequadas para a resolução dos problemas urbanos comuns. 
Por exemplo, os impactos dos recentes empreendimentos habitacionais, direta e indiretamente, trouxeram novas demandas de infraestrutura urbana, serviços, lazer para o Distrito Federal e de forma imediata para as prefeituras goianas. A implantação desses empreendimentos não foi planejado e sequer os planos e instrumentos previstos apontavam de forma clara a necessidade de respostas integradas a essas novas demandas. De forma setorial e inadequadas, as soluções atuais ainda são implementadas localmente, o que evidencia de forma urgente uma rediscussão das capacidades das estruturas institucionais do Estado, do Distrito Federal, dos municípios e da União para o estabelecimento de um planejamento estratégico em médio e longo prazo.

É recorrente o discurso de "falta de vontade política". A falta de vontade política não explica isoladamente as dificuldades no estabelecimento de mecanismos para uma governança que trate dos problemas metropolitanos partilhados diariamente entre o DF e os municípios goianos. Para além do discurso de "falta de vontade política", inexistem, como comprovado nesta pesquisa, estratégias e diretrizes da União, do Distrito Federal, do Estado de Goiás e dos municípios tanto do ponto de vista técnico, financeiro e de alinhamentos políticos que mobilizem gestores públicos e ampliem a participação da sociedade na busca de soluções inovadoras para uma melhor qualidade de vida para a população metropolitana.

Os atuais investimentos em habitação revelaram-se com baixa eficiência para o atendimento do déficit habitacional das famílias enquadradas na faixa de renda 1 . Por sua vez o déficit habitacional na faixa 1 foi o ponto central das diretrizes de planejamento da política de habitação em nível nacional, estadual, distrital e municipal. No entanto, a pesquisa revelou a desarticulação federativa entre as diretrizes e os programas contidos na política nacional de habitação e o planejamento e a execução pelos governos locais, seja de forma direta, na contratação dos empreendimentos para o atendimento da faixa 1 com financiamento do FAR, que foram baixos e distantes das áreas centrais, seja na forma de aprovação e emissão dos documentos pelos municípios para a implantação dos empreendimentos realizados pelo mercado privado, sem uma regulação efetiva pelo poder local.

Apesar de o governo federal ter ampliado e priorizado o volume de investimentos habitacionais nas regiões metropolitanas e na Ride-DF, estes não foram suficientes para a busca de uma solução integrada nos aglomerados metropolitanos. Se faz necessário articular as diretrizes de planejamento interfederativo às diretrizes de financiamento, para que os resultados sejam efetivos no território. Vale lembrar que a harmonia é 
fundamental. Caso contrário, tem-se uma centralização de investimentos e poder de decisão pela União sem convergência com os demais entes da Federação, como pode ser observado no volume prioritário de investimentos do PMCMV em municípios integrantes de regiões metropolitanas sem ações ou mecanismos de integração metropolitana.

Em relação às diretrizes de planejamento do DF que produziram uma série de legislações restritivas do uso e ocupação do solo do DF sem políticas de habitação social adequadas, gerou-se um padrão de ocupação informal no DF, além da indução da ocupação e fixação da população nos municípios goianos, o que é resultado de uma desintegração tanto das ações do planejamento local quanto regional.

Também foi constatada uma distribuição desigual de infraestrutura no território em relação à implantação dos empreendimentos habitacionais. Nos empreendimentos para o atendimento da faixa 1 foi recorrente o atraso na provisão de infraestruturas de saneamento, mobilidade e equipamentos públicos. Já para os empreendimentos contratados para o atendimento das faixas de renda 2 e 3, embora tenham sido identificados problemas de provisão de infraestrutura, estes foram menos comuns, em comparação ao tempo de ausência ou ao atraso para a implantação dos equipamentos, diante dos empreendimentos enquadrados na faixa 1.

É inviável estruturar mecanismos de governança voltados para ações concertadas no campo da habitação neste território se antes não forem revistos os mecanismos de gestão e regulação urbanas. Os mecanismos de gestão e regulação ancoram as diretrizes de governança a serem desenvolvidas para a elaboração de estratégias comuns para a regulação da oferta de terras nas franjas ou nas fronteiras administrativas, uma vez que esses mecanismos possibilitam os governos locais a identificar e intervir nas tendências de ocupação e demanda imobiliária, assim como auxiliam os governos locais a priorizar as zonas de intervenção metropolitana, as linhas de ação para potencializar os usos dos terrenos mais integrados e acessíveis, bem como ações estratégicas e comuns na escala regional.

A regulação e o desenvolvimento de novas institucionalidades são essenciais para compatibilizar o planejamento urbano municipal com as ações e diretrizes comuns para o território metropolitano e, também, para adoção de medidas para regular a ação do mercado imobiliário em prol dos interesses da coletividade. Eis, aqui, um dos maiores desafios de como equiparar capacidades e interesses difusos.

Os percalços são enormes para se avançar na promoção de mecanismos de concertação. Falta estrutura para o desenvolvimento de estratégias tangíveis de serem 
implementadas, pelas dificuldades de identificação, mapeamento, conhecimento técnico, uma vez que a maioria dos órgãos institucionais visitados não apresenta uma cultura de estrutura projetos integrada aos demais setores dentro das prefeituras, que dirá em uma escala metropolitana tão complexa.

Por sua vez, os próprios órgãos nacionais de desenvolvimento urbano, como o Ministério das Cidades, por exemplo, trabalha de forma setorial e não integrada. Os chamamentos públicos nacionais não convergem entre as secretárias ministeriais. Cada um ocorre em um período, e o próprio desenho e as exigências dos programas não otimizam recursos e não induzem fortalecimentos das institucionalidades.

Do ponto de vista político, a própria agenda política se mostra fragmentada, a começar pelas desconexões dos processos eleitorais nas esferas federal, estadual e municipal, que não ocorrem de forma sincronizada, provocando impactos $\mathrm{e}$ reconfigurações nas estruturas de planejamento, da destinação de prioridades nos PPAs e das próprias relações políticas. Soma-se a isso o desenho pouco claro do papel do Estado no fortalecimento da capacidade institucional no desenho da política habitacional.

Portanto, a execução da atual política habitacional, seja por meio do PMCMV ou das reduzidas ações na esfera do SNHIS, não tem contribuído para pensar estrategicamente o papel do território metropolitano de forma integrada. Inexistem projetos, política e ações que dialoguem e promovam novas institucionalidades para responder às demandas dos territórios metropolitanos.

O recorte da pesquisa analisado se revelou sui generis, ao buscar correlacionar o arcabouço institucional para a promoção de ações concertadas com a produção habitacional metropolitana para além dos recortes metropolitanos institucionalizados.

Ao mesmo tempo, as lacunas identificadas apontam caminhos para a construção de bases necessárias para se avançar em mecanismos de governabilidade, para que de fato as ações públicas direcionadas para este território sejam tangíveis para responder à dinâmica metropolitana em andamento.

As análises da operacionalização da política habitacional no DF e nos municípios goianos vinculados à Área Metropolitana de Brasília (AMB) permitiram identificar os avanços e as inflexões das políticas habitacionais e trouxeram a oportunidade de conhecer as distintas experiências de gestão municipal e a capacidade de tirar proveito com uma análise crítica que contribua para o melhoramento das políticas habitacionais. Políticas essas mais coesas no atendimento às necessidades habitacionais nas estruturas institucionais e socioeconômicas em anuência ao pacto federativo e autonomia municipal. 
Ao mesmo tempo, as análises trouxeram um aprendizado para a pesquisadora acerca das diretrizes alinhavadas nos espaços institucionais políticos e o que se efetiva no território. Enfim, conhecer as experiências alheias e delas tirar proveito, com uma visão crítica e atenta às condições em que ocorreram e à apropriação possível em outras realidades, é um aprendizado da maior importância para os(as) geógrafos(as). 


\section{Referências}

ABIKO, Alex Kenya; ORNSTEIN, Sheila Walbe. Inserção urbana e avaliação pósocupação (APO) da Habitação de Interesse Social. São Paulo: FAUUSP, 2002. (Coletânea Habitare/FINEP, v. 1).

ALMEIDA, Caliane Christie Oliveira de. Habitação social: origens e produção (Natal, 1889-1964). 2007. Dissertação (Mestrado) - Escola de Engenharia de São Paulo, Programa de Pós-Graduação em Arquitetura e Urbanismo, Universidade de São Paulo, São Carlos, SP, 2007.

ARAGÃO, José Maria. Sistema Financeiro da Habitação: uma análise sócio-jurídica da gênese, desenvolvimento e crise do sistema. Curitiba: Juruá, 1999.

ARRETCHE, Marta. Federalismo e igualdade territorial: uma contradição em termos? Dados, Rio de Janeiro, v. 53, p. 587-620, 2010.

AZEVEDO, Sérgio; ANDRADE, Luis Aureliano. Habitação e poder: da fundação da Casa Popular ao Banco Nacional da Habitação. Rio de Janeiro: Zahar, 1982.

AZEVEDO, Heloísa et al. Instrumentos urbanísticos, jurídicos e tributários para o desenvolvimento urbano: uma análise da sua implantação no Distrito Federal. Texto para Discussão, Rio de Janeiro: Ipea, n. 1.962, maio 2014.

BALBIM, Renato; BECKER, Maria Fernanda; COSTA, Marco Aurélio; MATTEO, Miguel. Desafios contemporâneos na gestão das regiões metropolitanas. In: LINHARES, Paulo de Tarso Frazão; MENDES, Constantino Cronemberger; LASSANCE, Antonio (Org.). Federalismo à brasileira: questões para discussão. Brasília: Ipea, 2012.

BARBOSA FERREIRA, Ignez Costa. Gestão do território e novas territorialidades. In: PAVINAI, Aldo (Org.). Brasília: gestão urbana, conflitos e cidadania. Brasília: Ed. UnB, 1999a.

BARBOSA FERREIRA, Ignez Costa. Espaço, poder e cultura na gestão do território. In: 
VASCONCELOS, Pedro (Org.). Novos estudos de Geografia urbana brasileira. Salvador: Ed. UFBA, 1999b.

BLANCO, Andrés et al. Procura-se casa para alugar: opções de política para a América Latina e Caribe. Washington DC: Banco Interamericano de Desenvolvimento, 2014.

BOLAFFI, Gabriel. Habitação e urbanismo: o problema e o falso problema. In: MARICATO, Ermínia (Org.). A produção capitalista da casa (e da cidade). São Paulo: Alfa-Omega, 1979.

BONDUKI, Nabil G. Do Projeto Moradia ao Programa Minha Casa Minha Vida. Teoria e Debate, v. 82, p. 1, 2009.

BONDUKI, Nabil. Origens da habitação social no Brasil: arquitetura moderna, lei do inquilinato e a difusão da casa própria. 5. ed. São Paulo: Estação Liberdade, 2011.

BONDUKI, Nabil. Planos Locais de Habitação: das origens aos dilemas atuais nas regiões metropolitanas. In: DENALDI, Rosana. Planejamento habitacional: notas sobre a precariedade e terra nos Planos Locais de Habitação. São Paulo: Annablume, 2013.

BOUILLON, César Patrício; MEDELLÍN, Nadin; BORUCHOWICZ, Cynthia. Portrait of a problem: the housing sector. In: BOUILLON, César Patrício (Ed.). Room for development: housing markets in Latin America and the Caribbean. Washington DC: Banco Interamericano de Desenvolvimento, 2012.

BRANCO, Maria L. G.; PEREIRA, Rafael Henrique M.; NADALIN, Vanessa G. Rediscutindo a delimitação das Regiões Metropolitanas. In: FURTADO, Bernardo Alves; KRAUSE, Cleandro; FRANÇA, Karla. Território metropolitano, políticas municipais: por soluções conjuntas de problemas urbanos no âmbito metropolitano. Brasília: Ipea, 2013.

BRASIL. Lei Federal no 4.380, de 21 de agosto de 1964. Diário Oficial [da] União, Brasília, 30 set. 1964. p. 15. 
BRASIL. Presidência da República. Constituição Federal do Brasil. 1967. Disponível em: 〈www.planalto.gov.br/ccivil_03/constituicao/Constituicao67.htm>.

BRASIL. Lei Federal nº 5.861, de 12 de dezembro de 1972. Diário Oficial [da] União, Brasília, p. 15, 12 dez. 1972.

BRASIL. Presidência da República. Constituição Federal do Brasil. 1988. Disponível em: <www.planalto.gov.br/ccivil_03/constituicao/Constituicao88.htm>.

BRASIL. Lei Federal no 5.107 de 13 de setembro de 1966. Diário Oficial [da] União, Brasília, p. 9, 14 set. 1966. Convertida na Lei nº 8.036, de 11 de maio de 1990.

BRASIL. Ministério das Cidades. Secretaria Nacional de Habitação. Plano Nacional de Habitação. Brasília: MCidades, 2009.

BRASIL. Programa Nacional de Habitação Urbana - PNHU. Brasília: MCidades, 2010.

BRASIL. Presidência da República. Casa Civil, Subchefia para Assuntos Jurídicos. Mensagem no 13, de 12 de janeiro de 2015. Brasília, 2015.

CAIADO, Maria Célia Silva. Estruturação intra-urbana e contrapartidas sociodemográficas: a diferenciação sócio-espacial da população na região do Distrito Federal e entorno. 2004. Tese. 295 f. (Doutorado em Demografia) - Instituto de Filosofia e Ciências Humanas, Universidade Estadual de Campinas, 2004.

CAMPOS, Neio. Brasília: a "capital” do capital incorporador. In: RIBEIRO, Luiz Cezar de Queiroz; AZEVEDO, Sérgio de (Org.). A crise da moradia nas grandes cidades: da questão da habitação à reforma urbana. Rio de Janeiro: Ed. UFRJ, 1996.

CARDOSO, Adauto Lucio. Mercado imobiliário e segregação: o caso do Rio de Janeiro In: O futuro das metrópoles: desigualdades e governabilidade. 1. ed. Rio de Janeiro: Revan/Observatório-IPPUR/UFRJ, 2000. v. 1, p. 319-350.

CARDOSO, Adauto Lucio. O Programa Minha Casa Minha Vida e seus efeitos territoriais. Rio de Janeiro: Letra Capital, 2013. 
CARDOSO, Adauto Lucio; ARAGÃO, Thêmis Amorim. Do fim do BNH ao Programa Minha Casa Minha Vida: 25 anos da política habitacional no Brasil. In: . $O$ programa Minha Casa Minha Vida e seus efeitos territoriais. Rio de Janeiro: Letra Capital, 2013.

CARDOSO, Adauto Lucio; NUNES Jr., Decio Rodrigues. Quando um direito vira produto: impactos do Programa Minha Casa Minha Vida na Cidade do Rio de Janeiro. In: SIMPÓSIO NACIONAL DE GEOGRAFIA URBANA, XIII., 2013. Anais... Rio de Janeiro: UERJ, nov. 2013.

CARIELLO FILHO, Orlando. As políticas federais de habitação no Brasil (1964 a 2002) e a reprodução da carência e da escassez da moradia dos trabalhadores. 2011. Tese (Doutorado em Arquitetura e Urbanismo) - Programa de Pós-Graduação da Faculdade de Arquitetura e Urbanismo, Universidade de Brasília, Brasília, 2011.

CARLOS, Ana Fani. A condição espacial. São Paulo: Contexto, 2011.

CARMO, Edgar Candido do. A política habitacional no Brasil Pós-Plano Real (19952002): diretrizes, princípios, produção e financiamento. Uma análise centrada na atuação da Caixa Econômica Federal. 2006. Tese (Doutorado em Economia) - Programa de PósGraduação do Instituto de Economia, Universidade Estadual de Campinas, Campinas-SP, 2006.

CASTELLS, Manuel. A sociedade em rede. São Paulo: Paz e Terra, 1999.

CAVALCANTI, Marcelo Antunes. A concepção e a atuação dos programas da Superintendência de Desenvolvimento do Centro-Oeste - SUDECO - no Território Goiano (1967-1990). 2009. Dissertação (Mestrado em Geografia) - IESA-UFG, Goiânia, GO, 2009.

CIDADE, Lúcia Cony. Planejamento, desconcentração e produção social do espaço no Distrito Federal. Espaço e Geografia, Brasília: UnB, v. 2, n. 1, p. 57-65, 1999. 
CODEPLAN. Pesquisa Metropolitana por Amostra de Domicílios. Brasília: Codeplan, 2013.

CODEPLAN. População, renda e ocupação nas unidades de planejamento territorial. Brasília: Codeplan, 2015.

COLELA, Patricia Maria Mach. O que não mudou na habitação popular: dos cortiços à comercialização de moradias em Brasília. 1991. 160 f. Dissertação (Mestrado em Planejamento Urbano) - Faculdade de Arquitetura e Urbanismo, Universidade de Brasília, Brasília, 1991.

COLLIN, Jean-Pierre; ROBERTSON, Mélanie (Dir.). Gouverner les metrópoles: enjeux et portraits des expériences sur quatre continents. Québec: Presses de l'Université Laval, 2007.

CONCIDADES - Conselho Nacional das Cidades. Apresentação [do] Balanço dos Programas de Habitação Social. Brasília, 2013.

COSTA, Ana Paula Mota. Gestão por meio de Planejamento Estratégico. In:

Programa de formação continuada-presencial para operadores do Sistema Nacional de Atendimento Socioeducativo. Brasília, 2013. Disponível em: 〈www.ceag.unb.br/sinase $>$. Acesso em: 21 fev. 2013.

COSTA, Everaldo Batista; PELUSO, Marilia Luiza. Territórios da memória candanga na construção da Capital do Brasil (1956-1971). In: SIMPÓSIO NACIONAL DE GEOGRAFIA URBANA, XIII., 2013, Rio de Janeiro. Anais... Rio de Janeiro, 2013.

CRUZ, Nuno Ferreira da; BERG, Sanford V.; MARQUES, Rui Cunha. Governança de serviços de infra-estruturas locais nos EUA. Revista Portuguesa de Estudos Regionais, n. 28, Portugal, 2011.

DIAS, Edney Cielici. Do Plano Real ao Programa Minha Casa, Minha Vida: negócios, votos e as reformas da habitação. 2012. Dissertação (Mestrado em Ciência Política) Programa de Pós-Graduação da Faculdade de Filosofia Letras e Ciências Humanas, Universidade de São Paulo, São Paulo, 2012. 
DUCCI, María Elena. Chile: el lado oscuro de una política de vivienda exitosa. Revista EURE, Santiago de Chile, v. XXIII, n. 69, jul. 1997.

EGHARI, Susan. Arranjo institucional, articulação governamental, gestão de recursos financeiros e planejamento na governança metropolitana: a referência de Montreal e a experiência brasileira. 2013. Tese. 254 f. (Doutorado) - Programa de Pós-Graduação da Faculdade de Arquitetura e Urbanismo, Universidade de Brasília, Brasília, DF, 2013.

FARAH, Marta Ferreira. Estado, previdência social e habitação. 1983. Dissertação (Mestrado) - Programa de Pós-Graduação em Sociologia, Universidade de São Paulo, São Paulo, SP, 1983.

FERREIRA, Ignez C. B. Brasília: mitos e contradições na historia de Brasília. In: PAVIANI, Aldo et al. (Org.). Brasília 50 anos: da capital a metrópole. Brasília: Ed. UnB, 2010 .

FERREIRA, Andrea Rosa. Programas de combate ao déficit habitacional brasileiro. Monografia (Graduação em Ciências Econômicas) - Departamento de Ciências Econômicas, Universidade Federal do Rio Grande do Sul, Porto Alegre, 2009.

FERREIRA, João Sette Whitaker. Produzir casas ou construir cidades? Desafios para um novo Brasil urbano: parâmetros de qualidade para a implementação de projetos habitacionais e urbanos. São Paulo: LABHAB; FUPAM, 2012,

FIRKOWSKI, Olga L. C. F. Metrópoles e regiões metropolitanas no Brasil: conciliação ou divórcio? In: FURTADO, Bernardo Alves; KRAUSE, Cleandro; FRANÇA, Karla. Território metropolitano, políticas municipais: por soluções conjuntas de problemas urbanos no âmbito metropolitano. Brasília: Ipea, 2013.

FIX, Mariana. Financeirização e transformações recentes no circuito imobiliário no Brasil. 2011. Tese (Doutorado) - Universidade Estadual de Campinas, São Paulo, 2011. 
FRANÇA, Karla Christina Batista de. Complexidade da região urbana GAB: o fragmento Alexânia-GO. Dissertação (Mestrado em Geografia). Programa de Pós-Graduação em Geografia - Universidade de Brasília, Brasília, DF, 2009.

FRANÇA, Karla; FURTADO, Bernardo. As experiências de governança metropolitana internacional: os casos dos Estados Unidos e Canadá. Texto para Discussão, Brasília: Ipea, n. 1.855, ago. 2013.

FRANÇA, Karla; PELUSO, M. L. . New ways of looking at old regions or old ways of looking at new regions: The Micro region of the Brasília s Surroundings. In: RSAI World Congress VIII World conference of the Regional Science Association International, 2008, São Paulo. CD-R Anais RSAI World Congress 2008.

FREITAS, Eleusina Lavôr Holanda de. Como qualificar conjuntos habitacionais populares. Brasília: Caixa Econômica Federal, 2004.

FRESCA, Tânia Maria. Uma discussão sobre o conceito de metrópole. Revista da ANPEGE, v. 7, n. 8, p. 31-52, ago.-dez. 2011.

FJP - Fundação João Pinheiro. Déficit Habitacional no Brasil 2010. Belo Horizonte: Fundação João Pinheiro, 2013.

GARSON, Sol. Regiões Metropolitanas: obstáculos institucionais à cooperação em políticas urbanas. 2007. Tese (Doutorado) - Programa de Pós-Graduação em Planejamento Urbano e Regional da Universidade Federal do Rio de Janeiro, 2007.

GARSON, Sol. Regiões metropolitanas: por que elas não cooperam? Rio de Janeiro: Letra Capital, 2009.

GONÇALVES, José Pereira. Acesso ao financiamento para a moradia pelos estratos de média e baixa renda: a experiência recente. In: Proyecto Regional Conjunto Cepal/Pnud Políticas Financieras para El Desarrollo Unidad de Financiamento D.C.I.T.F. Santiago do Chile: Cepal, 1997. (Serie Financiamento del Desarrollo). 
GONÇALVES, Maria da Conceição Vasconcelos. Favelas teimosas: lutas por moradias. Brasília: Thesaurus, 1998.

GONZÁLES, Suely Franco Netto. A gestão urbanística do espaço habitado: o objeto e o método no caso do Distrito Federal. In: PAVIANI, Aldo (Org.). Brasília 50 anos: da capital a metrópole. Brasília: Ed. UnB, 2010.

GOUVEA, Luiz Alberto. A capital da segregação e do controle social: uma avaliação da ação governamental na área da habitação. In: PAVIANI, Aldo (Org.). A conquista da cidade: movimentos populares em Brasília. Brasília: Ed. UnB, 1991.

GOUVEA, Luiz Alberto. A capital da segregação e do controle social: uma avaliação da ação governamental na área da habitação. São Paulo: Anablume, 1995.

GOUVEA, Luiz Alberto. Habitação e emprego: uma política habitacional de interesse social. In: PAVIANI, Aldo (Org.). Moradia e exclusão. Brasília: Ed. UnB, 1996.

GOUVEA, Luiz Alberto. Uma política habitacional de interesse social para o Distrito Federal. In: PAVIANI, Aldo (Org.). Brasília: gestão urbana, cidadania e conflitos. Brasília: Ed. UnB, 1999.

HARVEY, David. Condição pós-moderna. São Paulo: Loyola, 1992. . O enigma do capital e as crises do capitalismo. São Paulo: Boitempo, 2011.

HIRSCH, Joachim. Teoria materialista do Estado. Rio de Janeiro: Revan, 2010.

HOFFMANN-MARTINOT, Vicent; SELLERS, Jefferey. Politique et métropole: une comparaison internationale. Paris: CNRS, 2007.

IBGE. Censo Demográfico 1960.Rio de Janeiro: IBGE, 1960.

IBGE. Censo Demográfico 1970.Rio de Janeiro: IBGE, 1970.

IBGE. Censo Demográfico 1980.Rio de Janeiro: IBGE, 1980.

IBGE. Censo Demográfico 1991.Rio de Janeiro: IBGE, 1991 
IBGE. Censo Demográfico 2000. Rio de Janeiro: IBGE, 2000.

IBGE. Censo Demográfico 2010. Rio de Janeiro: IBGE, 2010.

IBGE. Região de influência das cidades: 2007. Rio de Janeiro: IBGE, 2008.

IBGE. Aglomerados subnormais: primeiros resultados. Rio de Janeiro: IGBE, 2010.

IBGE. Divisão urbano-regional. Rio de Janeiro: IBGE, 2013.

IBGE. Síntese de indicadores sociais: 2013. Rio de Janeiro: IBGE, 2014.

IPEA - Instituto de Pesquisa Econômica Aplicada. Infraestrutura social e urbana no Brasil: subsídios para uma agenda de pesquisa e formulação de políticas públicas. Brasília: Ipea, 2010. v. 2. (Série Eixos Estratégicos do Desenvolvimento Brasileiro; Infraestrutura Econômica, Social e Urbana; Livro 6).

IPEA - Instituto de Pesquisa Econômica Aplicada. Projeto Governança Metropolitana. Ipea: Brasília, 2012 (Série Rede Ipea).

IPEA - Instituto de Pesquisa Econômica Aplicada. Minha Casa Minha Vida, Nosso Crescimento: onde fica a política habitacional? Texto para Discussão, Rio de Janeiro: Ipea, n. 1853, ago. 2013a.

IPEA - Instituto de Pesquisa Econômica Aplicada. Estimativas do déficit habitacional brasileiro (2007-2011) por municípios (2010). Nota Técnica, n. 1, Rio de Janeiro: Ipea, $2013 b$.

LEFEBVRE, Henri. Espaço e política. Belo Horizonte: Ed. FMG, 2008.

LENCIONI, Sandra. Metamorfose metropolitana: dispersão espacial e fragmentação do urbano em Buenos Aires e São Paulo. In: . Argentina e Brasil: possibilidades e obstáculos no processo de integração territorial. 1. ed. São Paulo: Humanitas, 2011. p. 143-162. 
LOSADA, Paula Ravanelli. Potencialidades da cooperação intergovernamental para a gestão das regiões metropolitanas do Brasil. In: MAGALHÃES, Fernanda (Org.). Regiões metropolitanas no Brasil: um paradoxo de desafios e oportunidades. Brasília: Banco Interamericano de Desenvolvimento (BID), 2010.

KLINK, Jeroen J.; ROLNIK, Raquel. Crescimento econômico e desenvolvimento urbano: por que nossas cidades continuam tão precárias? Novos Estudos - CEBRAP, 2011, v. 89, p. 89-109.

KLINK, Jeroeen. Por que as regiões metropolitanas continuam tão ingovernáveis? Problematizando a reestruturação e $\mathrm{o}$ reescalonamento do estado socialdesenvolvimentista em espaços metropolitanos. In: FURTADO, Bernardo; KRAUSE, Ceandro; FRANÇA, Karla. Território metropolitano, políticas municipais: por soluções conjuntas de problemas urbanos no âmbito metropolitano. Brasília: Ipea, 2013.

LOJKINE, Jean. O Estado capitalista e a questão urbana. São Paulo: Martins Fontes, 1997.

LOW-BEER, Jacqueline Doris. Renda da terra: algumas noções básicas. Espaço \& Debates, São Paulo, v. 8, 1983.

MANGUEIRAL. Disponível em: $<$ http://www.jardinsmangueiral.com.br/\#>.Acesso em: jan. 2014.

MARICATO, Ermínia. Política habitacional no regime militar. Petrópolis: Vozes, 1987.

MARICATO, Ermínia. Política urbana e de habitação social: um assunto pouco importante para o governo FHC. 1998. Disponível em: http://www.usp.br/ fau/depprojeto/labhab/biblioteca/textos/maricato_politicaurbanafhc.pdf. Acesso em: 5 jul. 2013.

MARICATO, Ermínia. As idéias fora do lugar e o lugar fora das idéias. In: ARANTES, Otília; MARICATO, Ermínia; VAINER, Carlos B. (Org.). A cidade do pensamento único: desmanchando consensos. Petrópolis: Vozes, 2000. p. 121-192.

MARICATO, Ermínia. Brasil, cidades. Petrópolis: Vozes, 2008. 
MARICATO, Ermínia. Por um novo enfoque teórico na pesquisa sobre habitação. Cadernos Metrópole, São Paulo: PUCSP, v. 21, p. 33-52, 2009.

MARICATO, Ermínia. O impasse da política urbana no Brasil. Petrópolis: Vozes, 2011.

MARQUES, Eduardo; RODRIGUES, Leandro. O Programa Minha Casa Minha Vida na metrópole paulistana: atendimento habitacional e padrões de segregação. $R$. B. Estudos Urbanos e Regionais, v. 15, n. 2, nov. 2013.

MARTINS, Maria Lucia R.; RODRIGUES, Roberta M.; FERRARA, Luciana N. ; ANDRADE NETO, Gustavo Pires de. Política urbana e acesso à habitação social em regiões metropolitanas da América Latina e Europa. Revista Iberoamericana de Urbanismo, v. 3, p. 20-37, 2009.

MASSEY, Doreen. Pelo espaço: uma nova política da espacialidade. Rio de Janeiro: Bertrand Brasil, 2008.

MELO, Marcus André. Políticas públicas e habitação popular: continuidade e ruptura 1979-1988. RUA, Salvador, v. 2, p. 37-59, 1979.

MÉVELLEC, Anne; DOUAY, Nicolas. De La coopération intercommunale à la coopération métropolitaine: changement de paradigme dans l'aménagement du territoire á la française. In: Gouverner les metrópoles: enjeuex et portraits des éxperiences sur quatre continentes. Québec, Canada: Les Presses de l’Université Laval, 2007.

MONTE-MÓR, Roberto Luís de Melo. Planejamento metropolitano em Belo Horizonte: uma experiência universitária. Desafios ao planejamento: produção da metrópole e questões ambientais. 1. ed. Rio de Janeiro: Letra Capital, 2012. p. 95-112.

MONTE-MÓR, Roberto Luis de Melo. Macrozoneamento metropolitano: projeto em construção na Região Metropolitana de Belo Horizonte (RMBH). In: DRUMMOND, Maria Valeska Duarte (Org.). Pensar metropolitano: arranjos de governança nas regiões metropolitanas. 1. ed. Belo Horizonte: Fundação João Pinheiro, 2013. v. 1, p. 158-170. 
MORAR BEM. Disponível em:< http://www.morarbem.df.gov.br/>.Acesso em: jan.-fev. 2014.

MOURA, Andréa Mendonça de. Organização social do território e formas de provisão de moradia. In: RIBEIRO, Romulo José da Costa (Org.). Brasília: transformações na ordem urbana. 1. ed. Rio de Janeiro: Letra Capital, 2015.

MOURA, Rosa; HOSHINO, Thiago. Estatuto da metrópole, enfim, aprovado! Mas o que oferece à metropolização brasileira? Rio de Janeiro: Observatório das Metrópoles, 2015. Disponível em: $<$ http://www.observatoriodasmetropoles.net/download/estatuto_metropole_artigo_r osa.pdf>. Acesso em: fev. 2015.

MOURA, Rosa. A dimensão urbano-regional na metropolização contemporânea. EURE, Santiago, v. 38, p. 5-31, 2012.

MOURA, Rosa; GORSDORF, Leandro F. Questão metropolitana: panorama do saneamento básico no Brasil. Caderno Temático, n. 4. Brasília: Ministério das Cidades/Secretaria Nacional de Saneamento Ambiental, 2009.

MOTTA, Diana et al. A governança do uso do solo enquanto função pública de interesse comum na Região Metropolitana de São Paulo. In: COSTA, Marco; MARGUTI, Bárbara (Org.). Funções públicas de interesse comum nas metrópoles brasileiras: transporte, saneamento e uso do solo. Brasília: Ipea, 2014.

NASCIMENTO NETO, Paulo; MOREIRA, Tomás Antônio; SCHUSSEL, Zulma das Graças Lucena. Conceitos divergentes para políticas convergentes: descompassos entre a política nacional de habitação e o Programa Minha Casa, Minha Vida. R. B. Estudos Urbanos e Regionais, v. 1 4, n. 1, maio 2012.

OBSERVATÓRIO DAS METRÓPOLES. Níveis de integração dos municípios brasileiros em RMs, Rides e AUs à dinâmica da metropolização. Relatório de Pesquisa Observatório das Metrópoles. Rio de Janeiro, 2012. 
OECD - Organização para a Cooperação e Desenvolvimento Económico. Territorial reviews: competitive cities in the global economy. Paris: OECD Publications, 2006.

PAVIANI, Aldo. Periferização urbana. In: (Org.). Urbanização e metropolização: a gestão dos conflitos em Brasília. Brasília: Codeplan; Ed. UnB, 1987. p. 33-49. (Coleção Brasília).

PAVIANI, Aldo. A metrópole em crise: ensaios sobre urbanização. Brasília, DF: Ed. UnB, 1989.

PAVIANI, Aldo. Expansão metropolitana: a modernização com desemprego. In: LEMOS, Amalia Inés Geraiges de; ARROYO, Mónica; SILVEIRA, María Laura (Org.). América Latina: cidade, campo e turismo. São Paulo: CLACSO, 2006. p. 89-105.

PAVIANI, Aldo. Geografia urbana do Distrito Federal: evolução e tendências. Espaço \& Geografia, Brasília, v. 10, n. 1, p. 1-22, jan.-jun. 2007.

PASTERNAK, Suzana . Aspectos demográficos da região metropolitana de São Paulo. In: BÓGUS, Lúcia Maria Machado; PASTERNAK, Suzana. (Org.). Como Anda São Paulo. Rio de Janeiro: Letra Capital, 2009, v. 3, p. 11-38.

PEHIS/GO. Plano Estadual de Habitação de Interesse Social. Goiânia, Goiás, 2012.

PDOT; SEDHAB. Documento Técnico. Brasília, 2009. Disponível em: <http://www.sedhab.df.gov.br/>. Acesso em: fev.-abr. 2012.

PELUSO, Marília Luiza. O mercado imobiliário urbano na periferia do Distrito Federal: um estudo de caso - a Cidade Ocidental. 1983. 218 f. Dissertação (Mestrado em Planejamento Urbano) - Faculdade de Arquitetura e Urbanismo, Universidade de Brasília, Brasília, 1983.

PELUSO, Marilia Luiza. O morar na constituição subjetiva do espaço urbano: as representações sociais da moradia na cidade-satélite de Samambaia/DF. 1998. Tese. 196 
f. (Doutorado em Psicologia Social) - Departamento de Pós-Graduação em Psicologia Social, Pontifícia Universidade Católica de São Paulo, São Paulo, 1998.

PENNA, Nelba Azevedo. Política urbana: a ação do Estado no DF. 1991. Dissertação (Mestrado) - Faculdade de Arquitetura e Urbanismo da Universidade de Brasília, Brasília, 1991.

PENNA, Nelba Azevedo. Brasília: do espaço concebido ao espaço produzido - a dinâmica de uma metrópole planejada. 2000. Tese. 196 f. (Doutorado em Geografia Humana) - Faculdade de Filosofia, Letras e Ciências Humanas, Universidade de São Paulo, São Paulo, 2000.

PENNA, Nelba Azevedo. Empreendedorismo e planejamento urbano em Brasília: da máquina de morar à maquina de crescimento urbano. In: PEREIRA, Elson Manoel. (Org.). Planejamento urbano no Brasil: conceitos, diálogos e práticas. 2. ed. Chapecó: Argos, 2013. v. 1, p. 207-230.

RANDOLPH, Rainer. Expansão das metrópoles, descolamentos de suas fronteiras e reorganização regional em seu entorno: perguntas e caminhos. In: RANDOLPH, Rainer; SOUTHERN, Barbra Candice (Org.). Expansão metropolitana e transformação das interfaces entre cidade, campo e região na América Latina. São Paulo: Max Limonad, 2011.

RIBEIRO, Luiz Cezar de Queiroz (Org.). Metrópoles: entre a coesão e a fragmentação, a cooperação e o conflito. São Paulo; Rio de Janeiro: Editora Fundação Perseu Abramo/FASE - Federação de Órgãos para Assistência Social e Educacional, 2004.

RIBEIRO, Luiz Cezar de Queiroz; SANTOS JÚNIOR, Orlando Alves dos; AZEVEDO, Sérgio (Org.). Governança democrática e poder local: a experiência dos conselhos municipais no Brasil. Rio de Janeiro: Revan, 2004. v. 1.

RIBEIRO, Luiz Cezar de Queiroz; SANTOS JÚNIOR, Orlando Alves dos (Org.). As metrópoles e a questão social brasileira. 1. ed. Rio de Janeiro: Revan, 2007. 
RIBEIRO, Luiz Cesar de Queiroz; SANTOS JUNIOR, Orlando Alves. As grandes cidades e a questão social brasileira: reflexões sobre o Estado de exceção nas metrópoles brasileiras. In: CASTRO, Erika; WOJCIECHOWSKI, Maciej John (Org.). Inclusão, colaboração e governança urbana: perspectivas brasileiras. Vancouver, Canadá: The University of British Columbia; Rio de Janeiro: Observatório das Metrópoles; Belo Horizonte: Ed. PUC Minas, 2010. (Coleção Limites da Cidade).

ROLNIK, Raquel. Governar as metrópoles: dilemas da recentralização. Revista da Região Metropolitana do Rio de Janeiro (Rio URBANO), Rio de Janeiro, v. 1, n. 1, p. 76$83,1^{\circ}$ mar. 2002.

ROLNIK, Raquel. Novas perspectivas para a gestão metropolitana: o papel do governo federal: o desafio da gestão das regiões metropolitanas em países federativos. Rio de Janeiro: Bertrand Brasil, 2005. p. 50-51.

ROYER, Luciana. Financeirização da política habitacional: limites e perspectivas. 2009. Tese (Doutorado) - Universidade de São Paulo, São Paulo, 2009.

ROYER, Luciana. Municípios "autárquicos" e Região Metropolitana: a questão habitacional e os limites administrativos. In: FURTADO, Bernardo; KRAUSE, Cleandro; FRANÇA, Karla. Território metropolitano, políticas municipais: por soluções conjuntas de problemas urbanos no âmbito metropolitano. Brasília: Ipea, 2013.

RUPRAH, Inder J. The Housing Gap in Latin America: 1995-2015. Escritório de Avaliação e Supervisão. Washington, DC: Banco Interamericano de Desenvolvimento, 2009.

SAMPAIO, C. da S. et al. Arranjos institucionais de gestão metropolitana: o caso da Ride-DF. In: COSTA, M. A.; TSUKUMO, I. L. (Org.). 40 anos de regiões metropolitanas. Brasília: IPEA, 2013. (Série Rede IPEA. Projeto Governança Metropolitana no Brasil, v. 1).

SAMPAIO, C. da. et al. Saneamento Ambiental e Transporte na Ride/DF: Os desafios da gestão das Funções Públicas de Interesse Comum e o planejamento integrado. In: COSTA, M. A.; MARGUTI, B (Org.). Funções públicas de interesse comum nas 
metrópoles brasileiras: transportes, saneamento básico e uso do solo. Brasília: IPEA, 2014. (Série Rede IPEA. Projeto Governança Metropolitana no Brasil, v. 2).

SANTOS, Cláudio Hamilton M. Políticas Federais de Habitação no Brasil: 1964/1998. Texto para Discussão, n. 654, Brasília: Ipea, 1999.

SANTOS, Milton. A natureza do espaço: técnica e tempo, razão e emoção. 3. ed. São Paulo: Hucitec, 1999.

SARAVIA, Enrique; FERRAREZI, Elisabete. Políticas públicas. Brasília: ENAP, 2006.

SCHVASBERG, Benny. Habitação e urbanização popular: os recursos do trabalhador? Apropriação da fonte "Manon" em Brasília. In: PAVIANI, Aldo (Org.). Moradia e exclusão. Brasília: Ed. UnB, 1996.

SCHVASBERG, Benny. Políticas urbanas e regionais no Brasil. Brasília: UnB, Faculdade de Arquitetura e Urbanismo, 2011.

SEDHAB-DF - Secretaria de Estado de Gestão do Território e Habitação. Plano Distrital de Habitação de Interesse Social (PlandHis). Brasília. 2012. Disponível em: <http://www.sedhab.df.gov.br/>. Acesso em: abr.-dez. 2014.

SEIXAS, João; ALBET, M. (Ed.). Urban Gouvernance in Southern Europe: urban and regional planning and development series. England: Ashgate, 2012.

SILVA, Maria Ozanira da Silva. Política habitacional brasileira: verso e reverso. São Paulo: Cortez, 1989.

SILVA MIRANDA, Carmen Sinira Miranda. Programas habitacionais para famílias de baixa renda: o caso do Programa Socorro Social. Efetivação de um direito ou clientelismo? 2007. Monografia (Graduação Serviço Social) - Universidade de Brasília, 2007. 
VALLADARES, Licia. Repensando a habitação no Brasil. Rio de Janeiro: Zahar, 1982.

VARIZO CALVALCANTE, Claudia. Formação e transformação da centralidade intraurbana de Brasília. Dissertação. 196 f. (Mestrado em Geografia Humana) Universidade de Brasília, Brasília, DF, 2009.

VARON, Conceição de Maria Ferraz. E a história de repete... as vilas operárias e os conjuntos residenciais dos IAPs no Rio de Janeiro. 1988. Dissertação (Mestrado) Programa de Pós-Graduação em Arquitetura e Urbanismo, Universidade de São Paulo, São Paulo, SP, 1988.

WILSON, Robert H.; SPINK, Peter K.; WARD, Peter M. Governança metropolitana nas Américas. Cadernos Metrópole, São Paulo, v. 13, n. 25, p. 15-44, jan.-jun. 2011.

YARO, Robert; RONDEROS, Nicolas. International metropolitan governance: typology, case studies and recommendations. [S.1.]: The World Bank Group; Regional Plan Association, Sept. 2011. 
$\underline{\text { Apêndices }}$ 


\section{Apêndice A}

Roteiro de Entrevistas: Órgãos Governamentais e de representação Municipal

\section{Órgãos}

Prefeituras dos onze municípios integrantes da Área Metropolitana de Brasília

Companhia de Desenvolvimento Habitacional do Distrito Federal (Codhab)
Assunto

Identificar o planejamento e gestão do PMCMV

\section{Local}

Brasília-DF

E-mail

Município

Identificar as ações voltadas para a gestão da habitação e para a promoção do compartilhamento dos serviços, em

Brasília-DF especial a habitação.

Identificar as ações voltadas para a gestão da habitação e para a promoção do compartilhamento dos serviços, em Goiânia-GO especial a habitação.

Agencia Goiana de Habitação - AGEHAB -GO

Programas e ações que apresentam interface com a escala metropolitana, em especial as atividades para o compartilhamento de serviços públicos que foram definidos no decreto da Ride-

Brasília-DF

Ministério da Integração Nacional Superintendência do Desenvolvimento do Centro-Oeste (Sudeco) Diretoria de Planejamento e Avaliação DF como funções públicas comuns, como por exemplo a habitação de interesse social.

Agnaldo Moraes da Silva

Ministério das Cidades

Secretaria Nacional de Acessibilidade e

Programas Urbanos Departamento de Apoio à Gestão Municipal e Territorial
Identificar as ações e estudos em andamento que induzam estratégias de cooperação metropolitana.
Brasília-DF

Identificar as ações e estudos em andamento que induzam estratégias de cooperação metropolitana.
Brasília-DF

\section{Secretaria Nacional de Habitação}




\section{Apêndice B}

Roteiro de Entrevistas nas Prefeituras

Foco: Gerenciamento do Programa Minha Casa, Minha Vida e a capacidade de gestão urbana dos Municípios

Público-Alvo: Gestores

1. Quais os pontos positivos do Programa Minha Casa, Minha Vida em andamento no Município?

2. Em que o Programa Minha Casa, Minha Vida se diferencia das iniciativas anteriores para o enfrentamento do déficit habitacional?

3. Há uma política local de habitação do Município para além dos recursos do Programa Minha Casa, Minha Vida?

4. Como o Município tem contribuído para que a seleção de terrenos pelas construtoras não se dê em locais periféricos e desprovidos de infraestrutura?

5. O Município tem utilizado instrumentos urbanos para melhorar a localização dos empreendimentos habitacionais destinados para o atendimento das famílias enquadradas na faixa de renda 1 ?

6. Quais são as principais demandas geradas pelos empreendimentos vinculados ao PMCMV que requerem investimento em médio e longo prazo em serviços urbanos pela Prefeitura?

7. Quais são os principais vetores de expansão urbana do município? Há alguma relação com proximidade das vias de acesso ao DF?

8. Quais são as principais demandas geradas pelos empreendimentos vinculados ao PMCMV que requerem investimento em médio e longo prazo em serviços urbanos?

9. Quais as maiores dificuldades para a contratação dos empreendimentos do PMCMV pela Prefeitura?

10. Quais são as dificuldades técnicas do órgão que executa a política habitacional no Município?

11. Há alguma ação cooperada com outro Município ou o Distrito Federal na esfera habitacional?

12. $\mathrm{O}(\mathrm{A})$ senhor(a)? percebe algum impacto dos efeitos das políticas habitacionais de outro Município ou do Distrito Federal que traz dificuldades no planejamento e execução do programa em seu Município? Poderia citá-los? 


\section{Apêndice C}

Roteiro de Entrevistas na AGEHAB (GO)

Foco: Gerenciamento do Programa Minha Casa, Minha Vida e a capacidade de gestão urbana

Público-Alvo: Gestores

1. De que forma a AGEHAB tem apoiado o poder público municipal para a implementação dos instrumentos urbanos para melhorar a localização dos empreendimentos habitacionais destinados para o atendimento das famílias enquadradas na faixa de renda 1 nos Municípios goianos vinculados à Ride-DF?

2. Quais são as principais demandas geradas pelos empreendimentos vinculados ao PMCMV que requerem investimento em médio e longo prazo em serviços urbanos pelo Estado de Goiás?

3. Quais as maiores dificuldades para a contratação dos empreendimentos do PMCMV nos Municípios goianos vinculados à Ride-DF?

4. Quais as dificuldades técnicas da AGEHAB para a execução dos programas habitacionais nos Municípios goianos vinculados à Ride-DF?

5. Há alguma ação prioritária para estes municípios que apresentam problemas urbanos mais complexos?

6. Há alguma ação cooperada da AGEHAB com o GDF ou com o COARIDE na esfera habitacional?

7. Quais os instrumentos de planejamento e gestão habitacional existentes que devem ser aperfeiçoados para o enfrentamento dos problemas urbanos?

8. $\mathrm{O}(\mathrm{A})$ senhor(a)? percebe algum impacto dos efeitos ou da falta das políticas habitacionais integradas entre o DF e o Estado de Goiás nos Municípios integrantes da Ride-DF que traz dificuldades no planejamento e nos resultados da política habitacional executada pelo Estado de Goiás? Poderia citá-los? 


\section{Apêndice D}

Roteiro de Entrevistas na CODHAB (DF)

Foco: Gerenciamento do Programa Minha Casa, Minha Vida e a capacidade de gestão urbana

Público-Alvo: Gestores

1. Quais os pontos positivos do Programa Morar Bem Programa em andamento no Distrito Federal?

2. Em que o Programa Morar Bem se diferencia das iniciativas anteriores para o enfrentamento do déficit habitacional?

3. Há uma política local de habitação do GDF para além dos recursos do Programa Morar Bem? Quais os principais resultados?

4. Como o GDF tem contribuído para que a seleção de terrenos pelas construtoras não se dê em locais periféricos e desprovidos de infraestrutura?

5. O Poder Público tem utilizado instrumentos urbanos para melhorar a localização dos empreendimentos habitacionais destinados para o atendimento das famílias enquadradas na faixa de renda 1 ?

6. Quais são as principais demandas geradas pelos empreendimentos vinculados ao PMCMV que requerem investimento em médio e longo prazo em serviços urbanos pelo GDF?

7. Quais as maiores dificuldades para a contratação dos empreendimentos do PMCMV pelo GDF?

8. Quais as dificuldades técnicas da Codhab para a execução do Programa Morar Bem?

9. Há alguma ação cooperada do GDF com algum Município goiano integrante da Ride-DF na esfera habitacional?

10. $\mathrm{O}(\mathrm{A})$ senhor(a) percebe algum impacto dos efeitos ou da falta das políticas habitacionais nos Municípios integrantes da Ride-DF que traz dificuldades no planejamento e execução da política habitacional no GDF? Poderia citá-los? 


\section{Apêndice E}

Ministério da Integração

Superintendência do Desenvolvimento do Centro-Oeste

1. Quais as estruturas e arranjos que são mais relevantes no âmbito da RIDEDF para a articulação dos serviços públicos reconhecidos como comuns?

2. Quais os instrumentos de cooperação e concertação possíveis para o serviço comum da habitação de interesse social e do uso e ocupação do solo, reconhecidos no Decreto 7.469/2011?

3. Os estudos do IBGE, Ipea e da Codeplan têm apontado que o fato metropolitano está presente em apenas onze municípios da Ride-DF, fazendo com que as secretarias e órgãos do DF já delimitem uma Área Metropolitana de Brasília (AMB) sem amparo institucional. Qual a visão da Sudeco em relação aos problemas metropolitanos estarem presentes em alguns municípios da Ride-DF?

4. Há alguma ação prioritária para estes municípios que apresentam problemas uranos mais complexos?

5. Como ocorrem as estratégias e ações voltadas para a escala metropolitana na RIDE?

6. Existem diferenças nas estratégias de planejamento voltadas para os serviços urbanos (funções públicas) que apresentam características metropolitanas do planejamento na escala regional?

7. Como é realizado o planejamento das ações para a promoção de cooperação para os serviços comuns? Há alguma ação em desenvolvimento ou prevista?

8. Os instrumentos de cooperação e concertação são eficientes na estrutura da Ride-DF para o enfrentamento dos problemas metropolitanos, como mobilidade urbana, habitação social?

9. Quais os instrumentos de planejamento e gestão existentes que devem ser aperfeiçoados para o enfrentamento dos problemas urbanos?

10. Há orçamento destinado exclusivamente a RIDE-DF? Os recursos estão sendo aplicados de forma prioritária em que área?

11. Qual o percentual do orçamento foi executado e com que esforço

(elaboração de projetos, convênios, consórcios etc.?

12. Para a resolução dos problemas inerentes às funções públicas, como, por exemplo, a habitação social, quais os instrumentos e estratégias em andamento 
realizados com o Estado de Goiás, Municípios? Em sua maioria elas ocorrem na esfera do COARIDE?

13. Quais são os maiores avanços ocorridos no âmbito da RIDE-DF nos últimos cinco anos?

14. Quais são os maiores entraves ocorridos no âmbito da RIDE nos últimos dois anos? 


\title{
Apêndice F
}

\author{
Ministério das Cidades
}

Secretaria Nacional de Acessibilidade e Programas Urbanos

1. Quais as principais ações do Ministério das Cidades para o fortalecimento da cooperação interfederativa nas regiões metropolitanas?

2. Como o Ministério das Cidades percebe o impacto dos efeitos das políticas setoriais em contextos metropolitanos que trazem dificuldades no planejamento e gestão da habitação em aglomerados metropolitanos?

3. Quais medidas em andamento, adotadas pelo Ministério das Cidades, para fortalecer ações concertadas em contextos metropolitanos voltados para a habitação e mobilidade urbana? Existe na SNAPU alguma metodologia ou programa que procure integrar as ações programáticas nestas duas áreas?

4. Quais as principais ações e medidas a serem adotadas pelo Ministério das Cidades para a implementação do Estatuto da Metrópole?

5. Diante do veto presidencial de o Estatuto da Metrópole do Distrito Federal integrar região metropolitana, quais ações ou estratégias a serem desenvolvidas para o enfrentamento dos problemas metropolitanos na esfera da Ride-DF?

6. Existe algum diálogo ou parceria com o Ministério da Integração para a promoção de ações ou projeto que visem aperfeiçoar a estrutura de planejamento urbanoregional nas Rides? 


\section{Apêndice G}

Roteiro de Entrevistas: Ministério das Cidades

Secretaria Nacional de Habitação

1. Quais fatores estão dificultando a contratação de empreendimentos habitacionais pela modalidade FAR nos Municípios integrantes da Ride-DF?

2. Quais as principais dificuldades de execução do PMCMV nos Municípios goianos integrantes da Ride-DF, uma vez que já houve suspensão das contratações de financiamento habitacional, por exemplo, no ano de 2011 ?

3. Existe alguma ação que vise aperfeiçoar o desempenho do programa na Ride-DF, em especial a produção habitacional vinculada à faixa 1 ?

4. Quais são as medidas adotadas pelo Ministério das Cidades para enfrentar os problemas habitacionais em áreas com fortes dinâmicas metropolitanas?

5. Que instrumentos ou normativos podem ser aperfeiçoados para melhorar a localização dos terrenos nos empreendimentos destinados para a habitação social (faixa 1)?

6. Como o Ministério das Cidades pode aperfeiçoar a utilização de instrumentos urbanos na $3^{\text {a }}$ etapa do PMCMV?

7. Sabe-se que o Ministério das Cidades já prioriza os investimentos nas Regiões Metropolitanas e na Ride-DF, mas os recursos são dirigidos aos Entes de forma individual e nem sempre têm fortalecido as ações de governança metropolitana. Quais os limites e desafios do Ministério das Cidades em induzir ações e investimentos para a execução de políticas habitacionais de interesse comum nestes aglomerados metropolitanos?

8. Como o Ministério das Cidades percebe o impacto dos efeitos negativos das políticas habitacionais em contextos metropolitanos, em que a produção da habitação tem sido mais pujante nas franjas e periferias dos municípios adjacentes ao município polo das áreas metropolitanas?

9. Existe algum diálogo ou parceria da SNH para a promoção de ações ou projetos que visem aperfeiçoar a estrutura da política habitacional na esfera da Ride-DF? 
10. Quais são as medidas em andamento adotadas pelo Ministério das Cidades para fortalecer ações de governança intermunicipais e interfederativas em contextos metropolitanos voltados para a habitação? 


\section{Apêndice H}

Relação dos Empreendimentos Visitados

\begin{tabular}{|c|c|c|c|}
\hline Município & Empreendimento & $\begin{array}{l}\text { Faixa } \\
\text { de } \\
\text { Renda }\end{array}$ & UHs \\
\hline Distrito Federal & Paranoá Park & $1 \mathrm{e} 2$ & 6.240 \\
\hline Distrito Federal & Jardins Mangueiral & 2 e 3 & 8.000 \\
\hline Águas Lindas de Goiás & Residencial Bethel I & 1 & 199 \\
\hline Formosa & Jardim Planalto & 1 & 496 \\
\hline Valparaíso de Goiás & $\begin{array}{l}\text { Residencial Anhanguera Garden } \\
\text { II }\end{array}$ & 2 & 270 \\
\hline Valparaíso de Goiás & Residencial Fiugar & 2 & 177 \\
\hline
\end{tabular}




\section{Apêndice I}

Roteiro de perguntas realizadas aos moradores nas visitas aos empreendimentos listados no Apêndice G

1. Quais aspectos positivos você destaca em sua nova moradia se comparada à anterior?

2. Quais os aspectos negativos da nova casa?

3. Você precisou realizar algum tipo de reforma ou reparo antes de morar no empreendimento?

4. Como avalia a infraestrutura urbana básica do empreendimento?

5. No seu empreendimento, existem problemas de vazamento, rachaduras ou ele encontra-se em perfeitas condições?

6. Como avalia as condições de interação social, econômica e de mobilidade urbana no empreendimento? Você realiza atividades de lazer, faz compras nos bairro em que se localiza o empreendimento?

7. Você avalia como adequados os espaços de lazer existentes ou previstos? 


\section{Apêndice J}

Relação dos contatos realizados pela pesquisadora para obtenção de dados relativos ao quantitativos dos empreendimentos contratados, entregues, suas respectivas faixas de renda e localização nos órgãos Ministério das Cidades e na CAIXA.

\begin{tabular}{|c|c|c|c|c|c|c|c|}
\hline Ações & Protocolo & Órgào Superior & $\begin{array}{c}\text { Orgão } \\
\text { Vinculado }\end{array}$ & $\begin{array}{l}\text { Data de } \\
\text { Abertura }\end{array}$ & $\begin{array}{c}\text { Prazo de } \\
\text { Atendimento }\end{array}$ & Situação & $\begin{array}{l}\text { Nome do } \\
\text { Solicitante }\end{array}$ \\
\hline$\underset{\text { Detainar }}{\mathrm{Q}}$ & 23480018594201205 & $\begin{array}{l}\text { MCIDADES - Ministério } \\
\text { das Cidades }\end{array}$ & - & $\begin{array}{l}22 / 10 / 2012 \\
08: 14 \mathrm{~h}\end{array}$ & $26 / 11 / 2012$ & Respondido & Karla França \\
\hline Detahror & 80200000301201268 & $\begin{array}{l}\text { MCIDADES - Ministério } \\
\text { das Cidades }\end{array}$ & - & $\begin{array}{l}15 / 10 / 2012 \\
11: 03 \mathrm{~h}\end{array}$ & $05 / 11 / 2012$ & Respondido & Karla França \\
\hline Detainar & 80200000316201226 & $\begin{array}{l}\text { MCIDADES - Ministério } \\
\text { das Cidades }\end{array}$ & - & $\begin{array}{l}22 / 10 / 2012 \\
08: 27 \mathrm{~h}\end{array}$ & $12 / 11 / 2012$ & Respondido & Karla França \\
\hline Detahor & 80200000317201271 & $\begin{array}{l}\text { MCIDADES - Ministério } \\
\text { das Cidades }\end{array}$ & |- & $\begin{array}{l}22 / 10 / 2012 \\
08: 28 \mathrm{~h}\end{array}$ & $22 / 11 / 2012$ & Respondido & Karla França \\
\hline$\underset{\text { Detainor }}{\mathbf{Q}}$ & 80200000004201301 & $\begin{array}{l}\text { MCIDADES - Ministério } \\
\text { das Cidades }\end{array}$ & - & $\begin{array}{l}03 / 01 / 2013 \\
08: 39 \mathrm{~h}\end{array}$ & $23 / 01 / 2013$ & Respondido & Karla França \\
\hline Detahor & 80200000006201392 & $\begin{array}{l}\text { MCIDADES - Ministério } \\
\text { das Cidades }\end{array}$ & - & $\begin{array}{l}\text { 03/01/2013 } \\
09: 56 \mathrm{~h}\end{array}$ & $23 / 01 / 2013$ & Respondido & Karla França \\
\hline Detainer & 80200000254201333 & $\begin{array}{l}\text { MCIDADES - Ministério } \\
\text { das Cidades }\end{array}$ & - & $\begin{array}{l}03 / 05 / 2013 \\
11: 43 \mathrm{~h}\end{array}$ & $27 / 05 / 2013$ & Respondido & Karla França \\
\hline$\underset{\text { Detainar }}{\mathbf{Q}}$ & 80200000255201388 & $\begin{array}{l}\text { MCIDADES - Ministério } \\
\text { das Cidades }\end{array}$ & |- & $\begin{array}{l}03 / 05 / 2013 \\
11: 51 \mathrm{~h}\end{array}$ & $27 / 05 / 2013$ & Respondido & Karla França \\
\hline Detainar & 80200000168201410 & $\begin{array}{l}\text { MCIDADES - Ministério } \\
\text { das Cidades }\end{array}$ & - & $\begin{array}{l}16 / 03 / 2014 \\
20: 03 \mathrm{~h}\end{array}$ & $07 / 04 / 2014$ & Respondido & Karla França \\
\hline$\underset{\text { Detainar }}{Q}$ & 80200000169201456 & $\begin{array}{l}\text { MCIDADES - Ministério } \\
\text { das Cidades }\end{array}$ & - & $\begin{array}{l}16 / 03 / 2014 \\
20: 1 \mathrm{hh}\end{array}$ & $07 / 04 / 2014$ & Respondido & Karla França \\
\hline$\underset{\text { Detainer }}{Q}$ & 80200000356201430 & $\begin{array}{l}\text { MCIDADES - Ministério } \\
\text { das Cidades }\end{array}$ & - & $\begin{array}{l}\text { 09/06/2014 } \\
14: 44 \mathrm{~h} \\
\end{array}$ & $01 / 07 / 2014$ & Respondido & Karla França \\
\hline Detainar & 80200000572201485 & $\begin{array}{l}\text { MCIDADES - Ministério } \\
\text { das Cidades }\end{array}$ & - & $\begin{array}{l}08 / 09 / 2014 \\
14: 27 \mathrm{~h}\end{array}$ & $29 / 09 / 2014$ & Respondido & Karla França \\
\hline$\underset{\text { Detarner }}{\mathrm{Q}}$ & 80200000599201478 & $\begin{array}{l}\text { MCIDADES - Ministério } \\
\text { das Cidades }\end{array}$ & - & \begin{tabular}{|l|}
$16 / 09 / 2014$ \\
$11: 04 \mathrm{~h}$ \\
\end{tabular} & $06 / 10 / 2014$ & Respondido & Karla França \\
\hline$\underset{\text { Detainer }}{\mathbf{Q}}$ & 80200000013201556 & $\begin{array}{l}\text { MCIDADES - Ministério } \\
\text { das Cidades }\end{array}$ & - & $\begin{array}{l}05 / 01 / 2015 \\
16: 36 \mathrm{~h}\end{array}$ & $26 / 01 / 2015$ & Respondido & Karla França \\
\hline$\underset{\text { Detalnor }}{\mathbf{Q}}$ & 80200000037201513 & $\begin{array}{l}\text { MCIDADES - Ministério } \\
\text { das Cidades }\end{array}$ & - & $\begin{array}{l}13 / 01 / 2015 \\
15: 36 \mathrm{~h}\end{array}$ & $02 / 02 / 2015$ & Respondido & Karla França \\
\hline
\end{tabular}


Trecho de solicitação de dados realizada pela pesquisadora: Protocolo 80200000599201478

Em 16 de setembro de 2014.

Prezados,

Reitero a solicitação do pedido $\mathrm{n}^{\circ} 80200000572201485$.

Obtive resposta parcial, somente dos empreendimentos enquadrados na faixa 1.

Oportunamente, solicito as mesmas informações referentes às faixas 2 e 3 .

Solicito informações da produção habitacional relativa à construção de unidades do Programa Minha Casa, Minha Vida, fases 1 e 2, desde seu lançamento até o mês de agosto de 2014, conforme detalhado a seguir. As informações são para fins estritamente acadêmicos.

Dados dos Municípios Goianos: Águas Lindas de Goiás, Alexânia, Cidade Ocidental, Cocalzinho de Goiás, Cristalina, Formosa, Luziânia, Novo Gama, Padre Bernardo, Planaltina, Santo Antônio do Descoberto e Valparaíso de Goiás.

E do Distrito Federal.

Nome do Empreendimento

Quantidade de Unidades Habitacionais

Tipologia (se apartamento, casa, misto)

Data da contratação

Valor do empreendimento

Contrapartida

Data de entrega

Data de conclusão

Faixas de renda 2 ou 3.

\section{Resposta do MCidades}

Prezado (a) Senhor (a),

Em atenção ao seu pedido de acesso à informação, formulado com base na Lei $n^{\circ}$ 12.527/2011, regulamentada pelo Decreto $\mathrm{n}^{\circ} 7.724 / 2012$, informa-se que segue resposta anexa. Acrescenta-se que, em relação à contrapartida, a base de dados está sendo atualizada. E que o Ministério das Cidades não dispõe dos demais dados solicitados, além dos que foram informados.

Comunicamos a Vossa Senhoria que a apresentação de recurso a esta resposta, se for o caso, deverá obedecer ao disposto na Seção II do Capítulo III da Lei no $12.527 / 2011$ e na Seção IV do Capítulo IV do Decreto ${ }^{\circ} 7.724 / 2012$.

Atenciosamente,

Serviço de Informação ao Cidadão - SIC

Ministério das Cidades

sic@cidades.gov.br 


\section{Resposta CAIXA}

Prezada cidadã Karla França

1.Conforme solicitação através do E-SIC, site CGU, informamos que:

1.1. Diversas instituições financeiras, e não somente a CAIXA, atuam no MCMV, e portanto não é possível à CAIXA fornecer todos os dados solicitados.

1.2. Pelo exposto e considerando a abrangência da solicitação, orientamos a requerer tais informações no Ministério das Cidades, gestor do Programa Minha Casa Minha Vida.

2. Por fim, agradecemos o contato e esclarecemos que a CAIXA, na página www.caixa.gov.br/acessoainformacao, disponibiliza as informações corporativas em atendimento à Lei $12.527 / 2011$.

3. Informamos que a CAIXA mantém SAC para informações, reclamações, cancelamentos, sugestões, serviços e elogios, com atendimento 24 horas por dia, 7 dias por semana, pelo DDG 0800726 0101, e para reclamações não solucionadas no SAC ou denúncias, a CAIXA mantém canal de Ouvidoria com atendimento de segunda a sextafeira, das 08 às 18 horas, pelo DDG 08007257474 .

4. A CAIXA coloca-se à disposição através de seus canais de atendimento.

Atenciosamente,

CAIXA - Serviço de Informações ao Cidadão 


\section{Apêndice K}

Relação dos contatos realizados pela pesquisadora para obtenção de dados relativo aos quantitativos dos empreendimentos contratados, entregues, suas respectivas faixas de renda e localização na CODHAB-DF

\begin{tabular}{|c|c|c|c|c|c|c|c|}
\hline Açôes & Protocolo & Órgão Superior & $\begin{array}{c}\text { Orgão } \\
\text { Vinculado }\end{array}$ & $\begin{array}{l}\text { Data de } \\
\text { Abertura }\end{array}$ & $\begin{array}{c}\text { Prazo de } \\
\text { Atendimento }\end{array}$ & Situação & $\begin{array}{l}\text { Nome do } \\
\text { Solicitante }\end{array}$ \\
\hline$\underset{\text { Detalnar }}{\mathbf{Q}}$ & 00390000090201315 & $\begin{array}{l}\text { Secretaria de Estado da } \\
\text { Gestão do Temitório e } \\
\text { Habitação - SEGETH }\end{array}$ & $\begin{array}{l}\text { Companhia de } \\
\text { Desenvolvimento } \\
\text { Habitacional do } \\
\text { Distrito Federal- } \\
\text { CODHAB }\end{array}$ & $29 / 11 / 2013$ & $26 / 12 / 2013$ & Respondido & $\begin{array}{l}\text { Karla } \\
\text { Christina } \\
\text { Batista de } \\
\text { França }\end{array}$ \\
\hline Dctaingr & 00390000559201405 & $\begin{array}{l}\text { Secretaria de Estado da } \\
\text { Gestão do Território e } \\
\text { Habitação - SEGETH }\end{array}$ & $\begin{array}{l}\text { Companhia de } \\
\text { Desenvolvimento } \\
\text { Habitacional do } \\
\text { Distrito Federal - } \\
\text { CODHAB }\end{array}$ & 08/09/2014 & $29 / 09 / 2014$ & Respondido & $\begin{array}{l}\text { Karla } \\
\text { Christina } \\
\text { Batista de } \\
\text { França }\end{array}$ \\
\hline$\underset{\text { Dctainar }}{\mathrm{Q}}$ & 00390000021201573 & $\begin{array}{l}\text { Secretaria de Estado da } \\
\text { Gestão do Território e } \\
\text { Habitação - SEGETH }\end{array}$ & $\begin{array}{l}\text { Companhia de } \\
\text { Desenvolvimento } \\
\text { Habitacional do } \\
\text { Distrito Federal - } \\
\text { CODHAB }\end{array}$ & $05 / 01 / 2015$ & $26 / 01 / 2015$ & $\begin{array}{l}\text { Em } \\
\text { tramitação }\end{array}$ & $\begin{array}{l}\text { Karla } \\
\text { Christina } \\
\text { Batista de } \\
\text { França }\end{array}$ \\
\hline$\underset{\text { Detainar }}{\mathbf{Q}}$ & 00390000022201518 & $\begin{array}{l}\text { Secretaria de Estado da } \\
\text { Gestâo do Territónio e } \\
\text { Habitação - SEGETH }\end{array}$ & - & $05 / 01 / 2015$ & $26 / 01 / 2015$ & Respondido & $\begin{array}{l}\text { Karla } \\
\text { Christina } \\
\text { Batista de } \\
\text { França }\end{array}$ \\
\hline
\end{tabular}




\section{Apêndice L}

\begin{tabular}{|c|c|c|c|c|c|c|}
\hline & $\begin{array}{c}\text { Habitat Bid Urbanização de } \\
\text { Assentamentos Subnormais } \\
\text { (UAS) }\end{array}$ & $8.390 .323,95$ & 7.052 .517 .67 & $18 / 05 / 2004$ & $2.880 .428,62$ & $31 / 12 / 2011$ \\
\hline & \begin{tabular}{|c|} 
Urbanizacao de \\
Assentamentos precarios \\
Cidade Ocidental GO Bairro \\
Parque Araguari \\
\end{tabular} & $5.000 .000,00$ & $5.000 .000,00$ & $21 / 12 / 2007$ & $364.343,85$ & $31 / 08 / 2010$ \\
\hline & \begin{tabular}{|c|} 
Elaboracao ou Revisao do \\
Plano Habitacional de \\
Interesse Social \\
\end{tabular} & $58.591,05$ & $\begin{array}{c}\text { não } \\
\text { informado }\end{array}$ & $30 / 04 / 2008$ & $5.277,60$ & $31 / 12 / 2012$ \\
\hline & \begin{tabular}{|c} 
Implantacao ou melhoria de \\
obras de infra estrutura \\
urbana em municipios com \\
ate 100000 habitantes \\
\end{tabular} & $987.600,00$ & $\begin{array}{c}\text { não } \\
\text { informado }\end{array}$ & $31 / 12 / 2007$ & $74.885,97$ & $31 / 01 / 2012$ \\
\hline & \begin{tabular}{|c} 
Implantacao ou melhoria de \\
obras de infra estrutura \\
urbana em municipios com \\
ate 100000 habitantes \\
\end{tabular} & $975.000,00$ & $\begin{array}{c}\text { não } \\
\text { informado }\end{array}$ & $21 / 12 / 2007$ & $73.125,00$ & $31 / 01 / 2012$ \\
\hline & \begin{tabular}{|c} 
Implantacao ou melhoria de \\
obras de infra estrutura \\
urbana em municipios com \\
ate 100000 habitantes \\
\end{tabular} & $1.950 .000,00$ & $\begin{array}{c}\text { não } \\
\text { informado }\end{array}$ & $24 / 12 / 2007$ & $146.250,00$ & $31 / 01 / 2012$ \\
\hline & $\begin{array}{c}\text { Implantacao ou melhoria de } \\
\text { obras de infra estrutura } \\
\text { urbana em municipios com } \\
\text { ate } 100000 \text { habitantes }\end{array}$ & $487.500,00$ & $\begin{array}{c}\text { não } \\
\text { informado }\end{array}$ & $21 / 12 / 2007$ & $36.562,50$ & $31 / 12 / 2012$ \\
\hline & $\begin{array}{c}\text { Obras de infraestrutura } \\
\text { urbana em mumicípios de } \\
\text { médio ou grande porte } \\
\text { vinculado ao } \\
\text { desenvolvimento urbano }\end{array}$ & $146.250,00$ & $146.250,00$ & $29 / 12 / 2005$ & $10.968,75$ & $30 / 11 / 2007$ \\
\hline & $\begin{array}{c}\text { Elaboração ou revisão do } \\
\text { plano habitacional de } \\
\text { interesse social }\end{array}$ & $58.591,05$ & $58.591,05$ & $02 / 05 / 2008$ & $2.932,00$ & $31 / 12 / 2012$ \\
\hline & $\begin{array}{c}\text { Execução de obras de } \\
\text { infraestrutura e construção } \\
\text { de equipamentos } \\
\text { comunitários } 02 \text { quadras e } \\
01 \text { praças }\end{array}$ & $26.696 .336,00$ & $24.164 .800,84$ & $28 / 09 / 2011$ & 0 & $30 / 06 / 2014$ \\
\hline & $\begin{array}{l}\text { Urbanização de Águas } \\
\text { Lindas de Goiâs }\end{array}$ & $9.394 .099,93$ & $9.172 .012,73$ & $31 / 12 / 2009$ & $1.518 .349,15$ & $31 / 10 / 2014$ \\
\hline & $\begin{array}{c}\text { Construção de unidades } \\
\text { habitacionais }\end{array}$ & não informado & $\begin{array}{c}\text { não } \\
\text { infommado }\end{array}$ & $29 / 12 / 2006$ & $8.874,85$ & $31 / 12 / 2012$ \\
\hline Alexânia & $\begin{array}{c}\text { Implantação ou melhoria de } \\
\text { infraestrutura urbana em } \\
\text { municipios com até } 100 \\
\text { mil/hab }\end{array}$ & $126.750,00$ & $126.750,00$ & $16 / 08 / 2005$ & $6.971,25$ & $31 / 08 / 2006$ \\
\hline & \begin{tabular}{|c|} 
Implantação ou melhoria de \\
infraestrutura urbana em \\
municipios com até 100 \\
mil/hab
\end{tabular} & $487.500,00$ & $487.500,00$ & $30 / 12 / 2005$ & $26.812,50$ & $28 / 02 / 2007$ \\
\hline $\begin{array}{c}\text { Cidade } \\
\text { Ocidental }\end{array}$ & $\begin{array}{c}\text { Implantacao ou Melhoria de } \\
\text { Obras de Infra estrutura } \\
\text { Urbana em Municipios do } \\
\text { Estado de Goias que } \\
\text { Integram a RME DF GO } \\
\text { MG }\end{array}$ & $7.910 .600,00$ & $7.910 .600,00$ & $30 / 12 / 2008$ & $400.523,70$ & $31 / 12 / 2012$ \\
\hline
\end{tabular}




\section{Cont. Apêndice L}

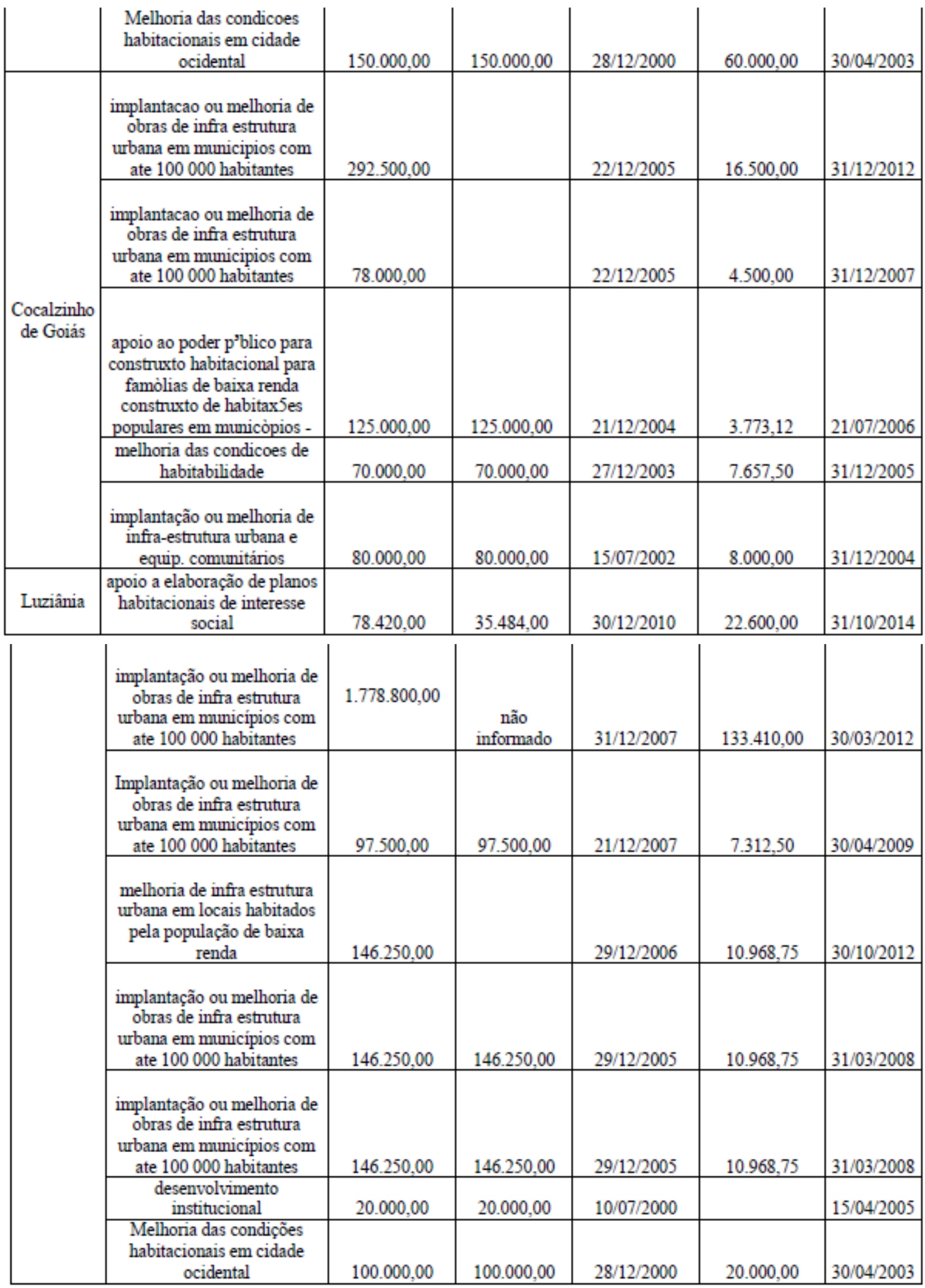




\section{Cont. Apêndice L}

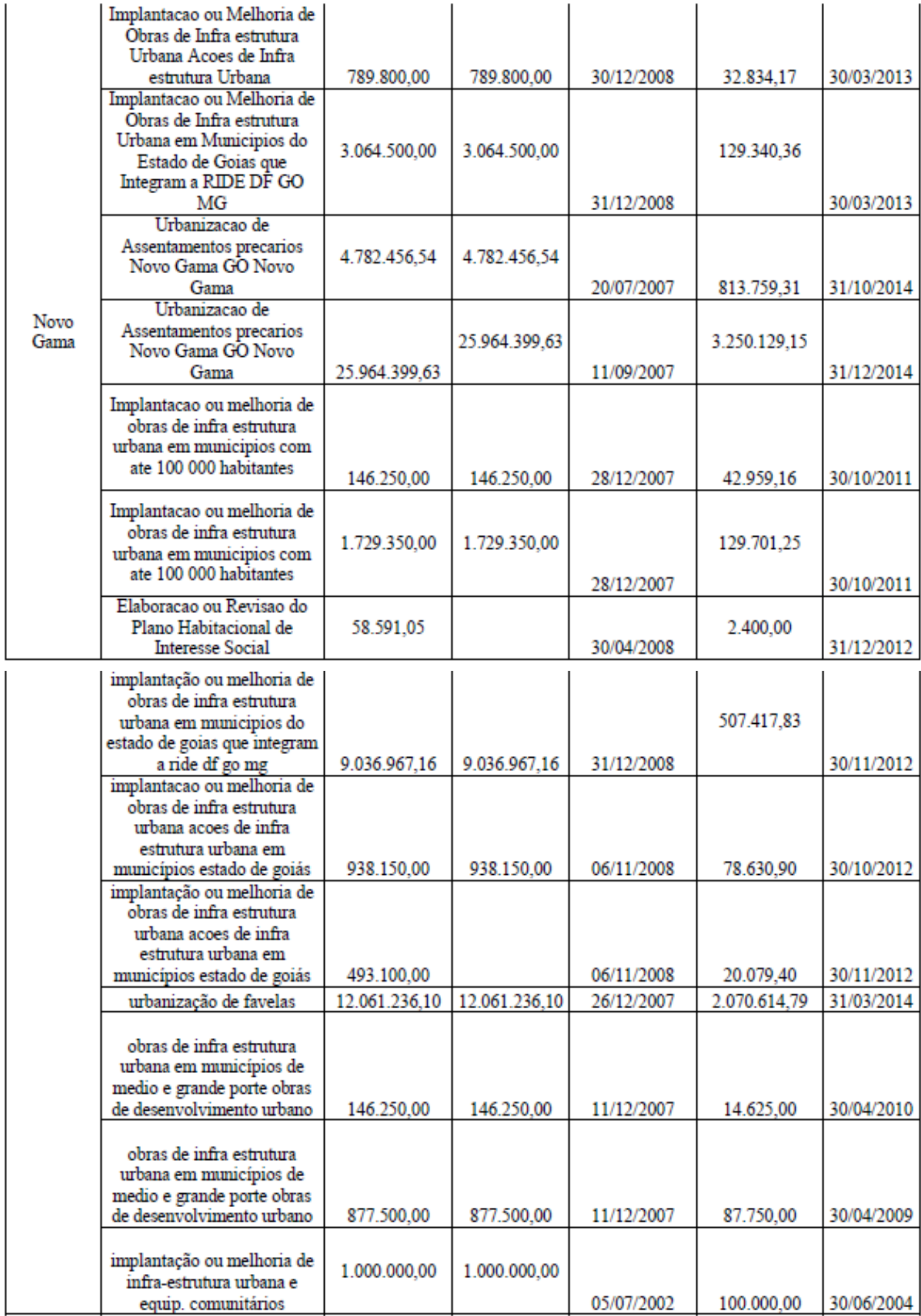




\section{Cont. Apêndice L}

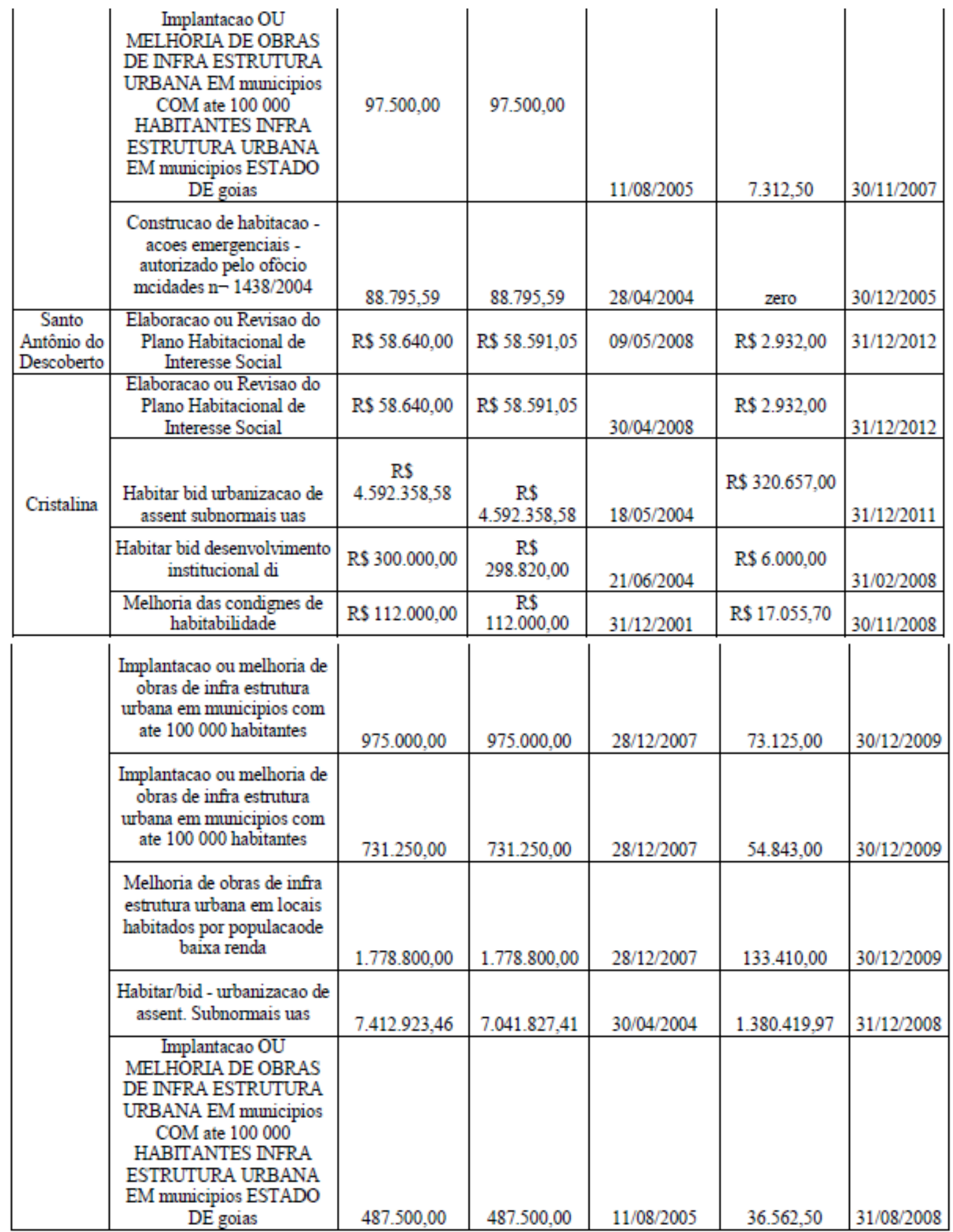




\section{Cont. Apêndice L}

\begin{tabular}{|c|c|c|c|c|c|c|}
\hline \multirow{7}{*}{$\begin{array}{l}\text { Novo } \\
\text { Gama }\end{array}$} & \begin{tabular}{|c} 
Implantacao ou Melhoria de \\
Obras de Infra estrutura \\
Urbana em Municipios do \\
Estado de Goias que \\
Integram a RDE DF GO \\
MG \\
\end{tabular} & $\begin{array}{l}\text { RS } \\
3.064 .500,00\end{array}$ & $\begin{array}{c}\mathrm{R} \$ \\
3.064 .500,00\end{array}$ & $31 / 12 / 2008$ & R\$ $129.340,36$ & $30 / 03 / 2013$ \\
\hline & \begin{tabular}{|c} 
Implantacao ou Melhoria de \\
Obras de Infra estrutura \\
Urbana Acoes de Infra \\
estrutura Urbana Novo \\
Gama GO \\
\end{tabular} & RS $789.800,00$ & $\begin{array}{c}\mathrm{RS} \\
789.800,00\end{array}$ & $31 / 12 / 2008$ & $\operatorname{R} \$ 32.834,17$ & $30 / 03 / 2013$ \\
\hline & \begin{tabular}{|c|} 
Urbanizacao de \\
Assentamentos precarios \\
Novo Gama GO Novo \\
Gama \\
\end{tabular} & $\begin{array}{c}\text { RS } \\
4.782 .456,54\end{array}$ & $\begin{array}{c}\mathrm{R} \$ \\
4.782 .456,54\end{array}$ & $27 / 12 / 2007$ & R\$ $813.759,31$ & $31 / 10 / 2014$ \\
\hline & $\begin{array}{c}\text { Melhoria de obras de infra } \\
\text { estrutura urbana em locais } \\
\text { habitados por populacaode } \\
\text { baixa renda }\end{array}$ & $\begin{array}{c}\text { RS } \\
1.778 .800,00\end{array}$ & $\begin{array}{c}\mathrm{RS} \\
1.778 .800,00\end{array}$ & $28 / 12 / 2007$ & R\$ $133.410,00$ & $30 / 12 / 2009$ \\
\hline & $\begin{array}{c}\text { Urbanizacao de } \\
\text { Assentamentos Precarios } \\
\text { diversos bairros }\end{array}$ & $\underset{25.964 .399,63}{\text { RS }}$ & $\begin{array}{c}\mathrm{R} \$ \\
25.080 .000,00\end{array}$ & $11 / 09 / 2007$ & $\begin{array}{c}\mathrm{R} \$ \\
3.250 .129,15\end{array}$ & $31 / 12 / 2014$ \\
\hline & $\begin{array}{l}\text { Habitar/bid - urbanizacao de } \\
\text { assent. Subnormais uas }\end{array}$ & $\begin{array}{c}\text { RS } \\
7.412 .923,46\end{array}$ & $\begin{array}{c}\text { RS } \\
7.041 .827,41\end{array}$ & $30 / 04 / 2004$ & $\begin{array}{c}\mathrm{R} \$ \\
1.380 .419,97\end{array}$ & $31 / 12 / 2008$ \\
\hline & $\begin{array}{l}\text { Construcao de habitacao - } \\
\text { acoes emergenciais - } \\
\text { autorizado pelo ofocio } \\
\text { mcidades n[ 1438/2004 }\end{array}$ & RS $88.795,59$ & R\$ $88.795,59$ & $28 / 04 / 2004$ & zero & $30 / 12 / 2005$ \\
\hline
\end{tabular}




\section{Anexos}

A pesquisadora acompanhou onze reuniões do Conselho Nacional das Cidades entre o período de agosto de 2012 e maio de 2015.

Entre a $34^{\mathrm{a}}$ e a $41^{\mathrm{a}}$, acompanhou as atividades do GT de Habitação na condição de ouvinte. A partir da $42^{\mathrm{a}}$ reunião, acompanhou as atividades do GT de Planejamento Urbano na condição de conselheira nacional, representando o Poder Público Municipal.

Anexo A - $34^{\mathrm{a}}$ Reunião do Conselho das Cidades.

Disponível em: http://cidades.gov.br/conselho-das-cidades/reunioes/118-conselhodas-cidades/reunioes-do-conselho-dasd-cidades/1643-34o-reuniao-do-conselhodas-cidades

Anexo B - $35^{\text {a }}$ Reunião do Conselho das Cidades

Disponível em: http://cidades.gov.br/conselho-das-cidades/reunioes/118-conselho-dascidades/reunioes-do-conselho-dasd-cidades/1642-35o-reuniao-do-conselho-das-cidades

Anexo C - $36^{\text {a }}$ Reunião do Conselho das Cidades

Disponível em: http://cidades.gov.br/conselho-das-cidades/reunioes/118-conselho-dascidades/reunioes-do-conselho-dasd-cidades/1641-36o-reuniao-do-conselho-das-cidades

Anexo D - $37^{\text {a }}$ Reunião do Conselho das Cidades

Disponível em: http://cidades.gov.br/conselho-das-cidades/reunioes/118-conselho-dascidades/reunioes-do-conselho-dasd-cidades/1640-37o-reuniao-do-conselho-das-cidades

Anexo E - $38^{\mathrm{a}}$ Reunião do Conselho das Cidades

Disponível em: http://cidades.gov.br/conselho-das-cidades/reunioes/114-conselho-dascidades/inicio/2703-38o-reuniao-do-conselho-das-cidades

Anexo F - 39 $\underline{\text { a Reunião do Conselho das Cidades }}$

Disponível em: http://cidades.gov.br/conselho-das-cidades/reunioes/118-conselho-dascidades/reunioes-do-conselho-dasd-cidades/2702-39reuniao

Anexo G $40^{a}$ Reunião do Conselho das Cidades

Disponível em: http://cidades.gov.br/conselho-das-cidades/reunioes/118-conselho-dascidades/reunioes-do-conselho-dasd-cidades/2956-40o-reuniao-do-conselho-das-cidades

Anexo H - $41^{\text {a }}$ Reunião do Conselho das Cidades

Disponível em: http://cidades.gov.br/conselho-das-cidades/reunioes/118-conselho-dascidades/reunioes-do-conselho-dasd-cidades/3051-41-reuniao-do-conselho-das-cidades

Anexo I - 42 $\underline{\text { a }}$ Reunião do Conselho das Cidades

Disponível em: http://cidades.gov.br/conselho-das-cidades/reunioes/118-conselho-dascidades/reunioes-do-conselho-dasd-cidades/3052-42-reuniao-do-conselho-das-cidades

Anexo J - $43^{a}$ Reunião do Conselho das Cidades

Disponível em: http://cidades.gov.br/conselho-das-cidades/reunioes/118-conselho-dascidades/reunioes-do-conselho-dasd-cidades/3463-43-reuniao-do-conselho-das-cidades 